Q

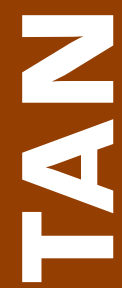

U

0

II

II

$E$

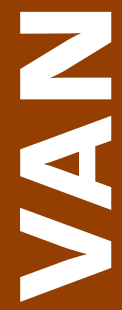

$z$

III

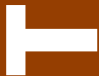

$\mathbf{I I}$

$\square$

$\checkmark$

14 



\title{
GENIETEN VAN WEERSTAND
}

\author{
PROEFSCHRIFT
}

ter verkrijging van de graad van doctor

aan de Universiteit Twente, op gezag van

de rector magnificus, prof.dr. H. Brinksma,

volgens besluit van het College van Promoties

in het openbaar te verdedigen op

vrijdag 27 april 2012 om 14.45 uur

Guido Willibrord Rijnja geboren op 28 april 1960 te Amsterdam. 
Dit proefschrift is goedgekeurd door de promotor, prof. dr. E.R. Seydel, en de assistent-promotor, dr. H.A. van Vuuren.

Voorzitter van de promotiecommissie:

prof. dr. K.I. van Oudenhoven - van der Zee.

Overige leden van de promotiecommissie: prof. dr. N.M.C. Aarts

prof. dr. M.D.T. de Jong

prof. dr. A.A. van Ruler

prof. dr. P.E.W.M. Tops

prof. dr. ir. P.P.C.C. Verbeek

prof. drs. J. Wallage. 
"Teleurstelling wordt als iets kwalijks gezien. Een ondoordacht vooroordeel.

Waardoor anders dan door teleurstelling, komen we erachter wat we hebben verwacht en gehoopt? En waardoor anders dan door die ontdekking zouden we tot zelfkennis moeten komen? Hoe zou iemand dus zonder teleurstelling helderheid over zichzelf kunnen verkrijgen?"

Pascal Mercier, 'Nachttrein naar Lissabon' (2006) 


\title{
Woord vooraf
}

\author{
Kroniek van een beleidsreparateur
}

25 Jaar geleden sta ik als pas aangetreden bestuursvoorlichter op het trottoir van het oude stadhuis aan de Dagelijkse Groenmarkt in Den Haag. De tekst die architect Daniel Marot in 1565 in een timpaan liet beitelen treft me: 'Ne Jupiter quidem omnibus' (vertaling 'zelfs Jupiter kan het niet iedereen naar de zin maken'). En ze verwondert: waarom plaatst de magistraat op de gevel een 'disclaimer' van dit formaat: met een krachtige verontschuldiging buigt het gemeentebestuur het hoofd. Geeft de Belastingdienst met de slagzin 'Leuker kunnen we het niet maken. Wel makkelijker' niet eenzelfde signaal af? Met een opmerkelijke toevoeging door de laatste twee woorden; die voegen een perspectief toe aan de verontschuldiging. De door Marot aangehaalde spreuk siert meer bestuurshuizen en er zijn ook moderne herauten van de negatieve aspecten van overheidswerk. Bestuurskundige Paul Frissen vestigt er aandacht op in publicaties, zoals in 'Gevaar verplicht' (2009), waarin hij de risico's van macht en de benodigde veiligheidspallen rond machthebbers beschrijft. Wie schaarse zaken verdeelt, ontmoet altijd kritiek, het is niet anders. De boodschap ontmoet soms meewarige blikken, zoals tijdens een debatbijeenkomst met ambtenaren bleek, toen Frissen uitriep: 'Wat jullie doen is leed bezorgen, erken dat nou eens' (Reuring Café, voorjaar 2008). Het is niet zo ingewikkeld, ademt de verzuchting van Barbara Czarniawska in een verhandeling over de verhalen die over organisaties de ronde doen (1997): 'Were the problems solvable, the public sector might well have ceased to exist'.

Moest uit die waarnemingen een proefschrift volgen? Overheidscommunicatie is een vak van verantwoording. Noblesse oblige. Onder de indruk van de geveltekst rijpte de behoefte aan verklaring. Welke betekenis moet worden toegekend aan de openlijke belijdenis van de negatieve aspecten van het overheidswerk? De kennismaking met grondslagen van de overheidsvoorlichting stuurde de verdieping, meer specifiek: de interpretatie van dit vakgebied door Chiel Galjaard (†2002), voormalig hoofd Voorlichting van de gemeente Den Haag, en oprichter van het onderwijs en de beroepsvereniging van overheidsvoorlichters.

Die kennismaking medio jaren negentig is bepalend geweest voor de serieuze verdieping in een gewetensvolle omgang met het fenomeen van negatieve beoordelingen. Gewetensvol, in die zin, dat deze vakvorser niet naliet te hameren op de morele keuzes die een ambtenaar kan én zal maken bij het hanteren van het eerder beschreven ongemak van de overheid. Hij positioneert de communicatie vanuit de overheid als een machtsaangelegenheid in een boekje dat hij kort voor zijn overlijden schreef ('Wie bekommert zich om de overheid', 1999, de cursivering is van de auteur): 'Het uitoefenen van macht gaat gepaard met veel sociale berekening. Die vindt vaak onderhuids, in de bliksemsnelle computer van de geest plaats, met veel antwoorden die er zijn nog voordat alle elementen van de berekening bewust zijn gemaakt. Maar niettemin, koele berekening: wie help ik, wie helpt mij, wat moet eerst, wat kan later, zal ik wachten. Zal ik toeslaan. Moet dat hard, om er clean een eind aan te maken, kan ik beter wachten op een gunstig ogenblik. Zal ik bars of vriendelijk zijn, laat ik mijn boosheid en macht zien of juist even niet. 
Moet ik masseren of dreigen, laat ik het sudderen of koken? Dat is echter alleen maar het technische of dienstbare onderdeel van het proces. De andere kant ervan is de communicatieve of de expressieve kant: Hoe komt wat ik zeg en doe op anderen over, zowel in de discussie over de macht als bij het uitoefenen ervan. Hoe ervaren zij mijn macht en mijn handelen als vertegenwoordiger daarvan, hoe maak ik het duidelijk, hoe kan het zo tot hun verbeelding spreken dat ze er graag in meegaan? Het verschil is duidelijk: aan de dienstbare kant werken de argumentatie en de tactiek, aan de expressieve kant werkt vooral de emotie die je teweegbrengt. Het gaat er bij dat laatste om of je mensen kunt aanspreken, op hun gevoel kunt werken. Of je beschikt over het gevoelige en tot de verbeelding sprekende taal- en beeldgebruik om het appèl op begrip te doen, om in te spelen op meegevoel, eensgezindheid, enthousiasme, angst of vrees. De twee kanten van de machtsuitoefening moeten in evenwicht zijn. Alleen de eerste betekent een conspiratieve, gevoelloze manipulator, alleen de tweede een onberekenbare en onverantwoordelijke agitator'. Dick Sijbrandij (+ 2001) hielp me eind jaren tachtig als chef deze en vele andere woorden te wegen en geen genoegen te nemen met eerste invallen (zoals Galjaard, die ook hij goed had gekend, dan verklaarde, 'Eerste antwoord, altijd fout. Niet omdat het niet goed is, maar omdat je er niet over hebt nagedacht.').

In gesprekken met Galjaard en andere vakbroeders, zoals Frank Regtvoort en Frits Lintmeijer - onder meer in het kader van een begeleidingscommissie voor een lesboek van zijn hand in de periode 1998 - 2002 - drong zich gaandeweg de vraag op: wie adresseert Galjaard eigenlijk in zijn teksten? De overheidsvoorlichter? Zeker, elke overheidsvoorlichter herkent de spagaat waarin je kunt komen te staan als het gaat om de keuzes die voorliggen voor de vormgeving van de macht in woorden en in plaatjes. Elke overheidsvoorlichter kent de betekenis die kan worden toegekend aan overheidsinformatie bij het ontwerp van een persbericht, folder of toespraak: welke accenten worden gelegd, welke elementen worden benadrukt of onderbelicht en welke sturing geven we aan betrokkenheid en inbreng?

Anne van der Meiden (2003), emeritus hoogleraar Public Relations onderstreepte in een betoog over morele aspecten van het ambt de bijna onvermijdelijke professionele dilemma's voor wie werkt met a) macht, b) waarheid en c) loyaliteit.

Een relevante ontwikkeling leek vanaf midden jaren tachtig van de vorige eeuw de kritische kanten van overheid iets af te vlakken. Een groot maakbaarheidsdenken maakten zich immers meester van de overheid. 'New Public Management' staat voor de opkomst van bedrijfsmatig denken, modellen, metingen, structuren en vergelijkingen ('benchmarks') in overheidsland. Mede gevoed door de opmars van audiovisuele media (de tv voorop) kon het ook voorkomen dat communicatieprofessionals zich als redders van maatschappelijke vraagstukken presenteerden. In die geest kon de overheidsvoorlichter groeien naar een 'beleidsreparateur' (De Bruijne \& Rijnja, 2007) die zwak of lastig beleid kon helpen 'verkopen'. Uitlopers van dit mechanistische denken vinden we ook nu nog bij spindoctors en campagne- en programmamakers. Maar onder deze ontwikkeling zwelde in de jaren negentig een belangrijke andere stroom aan. Kern van die stroming was de idee dat niet de beleidsreparatie maar de beleidspreparatie onder de loep moest worden genomen. Oftewel, niet de overheidsvoorlichter 
waakt over het communiceren van ongemakkelijke situaties, maar degene die beleid formuleert, besluiten voorbereidt en de uitvoering gestalte geeft. Het heeft een nog niet te stuiten trek naar voren opgeleverd: communicatieve kennis en vaardigheden komen eerder op tafel.

Wat we hier als een 'stroming' aanduiden, is in vele toonaarden beschreven. 'Interactieve beleidsvorming' en 'coproductie van beleid' staan vanaf het laatste decennium van de vorige eeuw voor een nieuwe kijk op de communicatie tussen overheid en samenleving in aan de hand van de vraag hoe beleidsvorming in een vroegtijdiger stadium al communicatief kon zijn. Met Robbert Coops leidde ik onze vakbroederlijke verwondering over de worsteling van de overheid met de mangel van publieke verwachtingen - je doet het nooit goed maar wie doet het dan? - naar een boekje, 'De overheid heeft het altijd gedaan' (2001a). Het verschijnen van dit boekje was de eerste gelegenheid dat Erwin Seydel de optie van een proefschrift suggereerde. Het contact met de bestuurskundige Pieter Tops en later Jouke de Vries opende deuren naar de bestuurskunde en beleidswetenschappen. De definitieve adressering van communicatie als opgave voor beleidsmakers mag op conto van de Commissie Toekomst Overheidscommunicatie worden geschreven (2001). Met de slagzin 'communicatie in het hart van het beleid' nagelden voorzitter Jacques Wallage en zijn commissieleden het belang van communicatie over keuzes in het algemeen belang, beslissingen en de uitvoering op de competentielijstjes van de mensen in het primaire proces: beleidsmakers. 'Communicatie is te belangrijk om aan communicatieprofessionals over te laten' werd een running gag in de vele bijeenkomsten die in communicatiekring over het rapport volgden: want zij voelden zich vooral aangesproken, meer dan beleidsmakers, laat staan politici....

De Academie voor Overheidscommunicatie bood vervolgens in 2002 een werkplek om de communicatieve dimensie van beleidsmakers systematisch te helpen versterken. Dymph van der Laan, vers aangesteld als coördinator bij dit nieuwe expertisecentrum in het Haagse, gaf me er gelegenheid nieuwe verbindingen te leggen in een gretige, enthousiasmerende setting. Wallage tekende er als voorzitter van het Comité voor begeleiding en advies voor een aanhoudend oog voor verbinding tussen theorie en praktijk. In 2003 ontstond het programma 'Factor C', dat inmiddels op vele plaatsen bij de rijksoverheid en andere bestuurslagen toepassingen en varianten kent. Met collega Paulijn de Bruijne grondde ik de methodiek die vervolgens als ' $\mathrm{K}_{3}$ ' het land door zou gaan: als beleidsmaker vergewis je je altijd van je krachtenveld, die kennis gebruik je voor een kernboodschap die aansluit bij kennis en verwachtingen en dat leidt tot een slimme kalender: de rangschikking van momenten en middelen van communicatie in - en dus niet alleen óver - beleid. Al die educatieve programma's focussen op de wens om de transactie tussen overheid en burger, dat ongemakkelijke mandaat, te versterken. Het begrip verwijst naar een vooronderstelling dat communicatie thuishoort in de rij primaire mechanismen waarvan een overheidsorganisatie zich kan bedienen, zoals wet- en regelgeving (juridische mechanismen, 'factor J') en subsidies en straffen en beloningen (financiële mechanismen, 'factor F') (RVD 2004).

De bemoeienis met professionalisering - leren en ontwikkelen - betekende een volgende aanjager in de verdieping van het eigene van de overheid en de rol van communicatie 
bij het hanteren hiervan. Onderwijs is iets anders dan communicatie, leerden we, onder meer dankzij ontmoetingen met andere academies en de stage van Maaike Glimmerveen (2007). Oog ontstond voor 'de factor T': de transfer van aangereikte kennis naar de praxis. Onder de titel 'Leren is een werkwoord' legden we in 2008 een visienota voor aan de Voorlichtingsraad - het samenwerkingsverband van departementale voorlichtingsdirecteuren - om het belang van leren tijdens het werken te onderstrepen. Ik zet deze gedachte op deze plaats aan, omdat de motivatie en de gelegenheid tot leren een uitgesproken troef is gebleken bij de verkenningen van de ambtelijke omgang met wat we hiervoor als 'ongemak' afficheerden. In het bijzonder doel ik dan op de rol van (ambtelijke) organisaties als de feitelijke werkplaatsen voor het eerdergenoemde herkennen en hanteren van publieke reacties. De ervaringen met het trainingsprogramma 'Factor C' - en in het bijzonder de kanteling van zorg voor de communicatieve kwaliteiten van het openbaar bestuur van louter de communicatiediscipline naar degenen die zich met beleidspreparatie bezighouden - zijn daarmee een belangrijke volgende aanjager geweest voor een studie naar wat beleidsmakers beweegt als het om overheidscommunicatie gaat.

Erwin Seydel vestigde de aandacht op de betekenis van werk en de keuzes die mensen kunnen en willen maken - ook als het gaat om verstoringen zoals angst, twijfel, verzet en woede. Hij stimuleerde een systematisch onderzoek naar de ambtelijke beslissing: wie of wat beweegt de beleidsmaker dan bij diens communicatieve handelen? Mark van Vuuren is thuis in dat domein en hielp de inzichten te ontbloten; wat heet: zonder zijn bemoeienis was de academische wereld nog steeds een moeras geweest. Samen oefenden ze druk uit om de laag te vinden onder 'ik vind...' en de bereidheid stap voor stap onderzoek te doen. Systematische inzichten uit de sociale psychologie waren hard nodig om een dominante focus in het communicatievak op bedrijfskunde en bestuurskunde aan te kunnen vullen. Bij die dominante focus hoorde immers een zwaar accent op intenties en capaciteiten van organisaties om te sturen en te beïnvloeden. Ik maakte kennis met de sociale psychologie als the other way around: hoe komen mensen (also known as 'doelgroep' en 'ontvangers') tot beslissingen in de context waar ze deel van uitmaken. Hoe vormen zich opvattingen, welke grondslagen liggen onder verwachtingen en kritiek? Kennismaking met heuristieken volgde, zoals de negativiteitsvertekening (negatief herinnert beter), de beschikbaarheid (waarschijnlijkheid lees je af van hoe makkelijk iets kan worden opgediept) en het mere-exposure effect van Zagoni: van waar je veel mee geconfronteerd worden, ga je van houden. Dat geldt ook voor wie je vaker ontmoet: je accepteert meer van iemand die je kent (Gray, 2003). Deze wenken hielpen kritiek op mensen en organisaties in proporties te zien. Wat betekent werk, hoe geven mensen betekenis aan informatie en welke manieren van omgang met weerstanden zijn er überhaupt? De gesprekken leidden naar een essay, dat in maart 2007 in Comma, tijdschrift voor de publieke sector werd gepubliceerd. Titel: 'Hoe gebruikt u uw teleurstelling vandaag'. Lead: 'Een overheid zonder teleurstellingen is als een vaas zonder bloemen. Wat doen we eigenlijk met die vreemde karakteristiek: overtroeven, wegwuiven of hanteren? Advies: toets plannen op teleurstelbaarheid (...). Sleutel: honoreer de publieke logica'. De reacties en commentaren zorgden voor een uitnodigende map. Dan ligt er voor je het weet een belofte om echt aan het werk te gaan. 
De ultieme aanjager voor de studie naar ambtelijke omgang met de ingebakken negatieve aspecten van het overheidseigene ontstond bij de doordenking van communicatie als één van de sturingsinstrumenten van de overheid. Dat was bij een studie voor een verkenning van de Wetenschappelijke Raad voor het Regeringsbeleid (WRR) in 2009, en een parallel traject voor de Voorlichtingsraad (Rijnja, Seydel \& Zuure, 2009, 2010) Steeds duidelijker werd dat de context waarin beleid gestalte krijgt bepalend is voor de slagkracht van beleidsverantwoordelijken: welke relaties doen er toe, en wat maakt dat deze relaties motiveren en gelegenheid creëren om in een gewenste richting iets voor elkaar te krijgen. Enkele grote projecten wezen de richting aan. Zoals het debacle van de campagne tegen baarmoederhalskanker en de dreigende griepepidemie in de zomer van 2009. Een massamediale campagne voor inenting van 12-jarige meisjes tegen baarmoederhalskanker probeerde via de traditionele media meisjes met rationele argumenten zover te krijgen zich te laten inenten. De meisjes en hun ouders informeerden zich echter via elkaar en eigen media over de mogelijke gevaren en nadelen van inenting. Het Rijksinstituut voor Volksgezondheid en Milieu (RIVM) onderkende te laat het effect van deze betekenisverlening en deed die af als fabels en per saldo onnodige kritiek. Daarmee werd echter de kracht van (alternatieve) betekenisverlening door de doelgroep zelf, onderschat. De dreigende griepepidemie onderstreept datzelfde jaar opnieuw het belang van een snelle en effectieve communicatie om de verspreiding van die ziekte zoveel mogelijk te voorkomen. De campagne ontblootte enkele veronderstellingen die we met Pol e.a. (2003) 'mythes' noemen, vanwege hun hardnekkige aanwezigheid in de overwegingen van campagnemakers, beleidsmakers en politici over het wel of niet starten van een campagne. De mythes roepen de schijn op dat communicatie wel even kritische drempels slecht.

Daar is ten eerste de mythe dat een boodschap met sterke argumenten altijd overtuigt: in de praktijk selecteren mensen echter sterk uit de vele boodschappen waarmee ze worden geconfronteerd. Overheidsargumenten geven daarbij zeker niet automatisch de doorslag. Ten tweede de mythe dat massamediale overheidscampagnes tot gedragsverandering leiden: in deze verkenning is al veelvuldig gebleken dat het overgrote deel van ons handelen helemaal niet voortkomt uit beredeneerd gedrag. Sommigen gaan ervan uit dat zelfs $95 \%$ van ons handelen automatisch gedrag betreft (Baumeister e.a., 1998, Dijksterhuis, 2007). Onderzoek leert ook dat advertentiecampagnes voor bijvoorbeeld frisdranken eerder bestaand bedrag c.q. consumptie bevestigen dan veranderen. Het is dus de vraag of louter massamediale overheidscampagnes voldoende zijn als de beleidsmaker gedragsverandering als doel heeft. Ten derde heerst de mythe dat de campagneboodschappen in de door de overheid betaalde zendtijd voldoende opvallen en opwegen tegen andere mediaboodschappen. Zodanig zelfs, dat ze een onderwerp niet alleen op de agenda kunnen zetten maar vervolgens ook de publieke opinie weten te sturen. Deze opvatting grijpt terug op een reeks klassieke theorieën over de macht van de media in de agendasetting: er wordt verondersteld dat kranten, radio en tv er voor kunnen zorgen dat ergens over wordt gesproken. Daarbij gaat het echter doorgaans om redactionele artikelen, en niet om reclame en advertenties, waartoe overheidsboodschappen min of meer behoren (Sears \& Kosterman, 1994). Kortom, mediaboodschappen van de 
overheid delven gemakkelijk het onderspit in een stroom van digitale berichtgeving en andere opiniestukken. Het voorbeeld van de inentingscampagne hielp duidelijk te maken dat de communicatie tussen een (overheids)zender en ontvangers niet los kan worden gezien van de interactie tussen ontvangers. Publieke houdingen (feiten én fabels) dienen serieus en vroegtijdig meegewogen te worden bij het ontwerp van het beleid. Communicatie verdient een inclusieve benadering. Wie vanuit de biotoop van beoogde publieksgroepen redeneert, kan aansluiten op de werkelijke beleving en betekenissen, had communicatiewetenschapper Cees van Woerkum zoveel malen zoveel zalen in zoveel toonaarden al voorgehouden, onder meer aan de hand van dit fraaie adagium: 'Argumenten zijn alleen interessant voor wie er naar op zoek is'.

In een studie naar het vertrouwen in de overheid spoot de Raad voor het Openbaar Bestuur (ROB, 2009) slagroom op de taart. De laatste prikkel voor een systematisch onderzoek naar de ambtelijke omgang met kritieke kanten van de overheid kwam tijdens de presentatie (en later de lezing) van 'Vertrouwen op democratie', het eerste onderzoek dat de ROB onder haar verse voorzitter Jacques Wallage presenteerde. Bezie de vergroting en de vervroeging van aandacht voor communicatieve aspecten bij beleidsvorming in de context van een toenemende 'horizontalisering', zo luidde de boodschap van het - ongevraagde - advies aan de minister van Binnenlandse Zaken en Koninkrijksrelaties (BZK): we nemen definitief afscheid van een situatie waarin de overheid 'verticaal' stuurt. In al dan niet duurzame netwerken komen mensen tot agendering, oordeelsvorming en ook besluitvorming. Al eerder is door onder andere Geert Teisman (1992) gewezen op de kentering van een 'unicentrisch' naar een 'pluricentrisch' perspectief: de overheid staat steeds minder boven de samenleving als probleemoplosser en steeds vaker tussen probleemoplossers in. Doelen worden pas in de loop van een proces en na onderlinge competitie helder, afhankelijk van haalbaarheid en beïnvloed door maatschappelijke opvattingen.

Deze ogenschijnlijk over elkaar buitelende waarnemingen versterkten mijn beeld dat we het omgaan met kritiek op de overheid door die overheid niet louter kunnen bezien als het topdown handelen met het ongemak, maar als het leren communiceren met de netwerken waarin (als de door Kingdon in 1994 beschreven 'policy windows') problemen en oplossingen bij elkaar kunnen komen (en ook weer divergeren). Wat gebeurt er tussen mensen en in hoeverre is de overheid deel van die publieke communicatie? Achter het woord 'overheid' rijpte vervolgens de variant 'tussenheid'. Interveniëren in de samenleving heeft onmiskenbaar en onontkoombaar communicatieve aspecten, en degenen die daarover beslissingen nemen kunnen niet vroeg genoeg zich vergewissen van de betekenis hiervan. Dat besef luidde uiteindelijk definitief de start van deze studie in. Wat beweegt die beleidsmakers om hun

\footnotetext{
1 Uitgesproken tijdens een lezing tijdens het voojaarscongres van de Vereniging Voor Overheidscommunicatie (VVO) in Leeuwarden in 1999. Dat wil zeggen, volgens mij. Op papier verscheen de zin nergens. Nadat ik in een interview naar aanleiding van zijn afscheid in november 2011 als hoogleraar aan de WUR de zin aanhaalde, bevestigde hij de mogelijkheid dat hij de zin zou kunnen hebben uitgesproken. Waarmee de bewering zichzelf bewees.
} 
ongemakkelijke, omstreden, kritiekzuchtige arbeid gezaghebbend te verrichten en hoe leren zij daarmee om te gaan in de specifieke context die de overheid kennelijk met zich meebrengt? Met Hans Wilmink greep ik deze vraag aan voor een studie, waarin de behoefte van het ministerie van BZK aan een scherpere aftekening van het eigene van de beleidsambtenaar en de zoektocht van deze promovendus elkaar konden versterken. Het resultaat was een publicatie en een studieochtend in augustus 2010, waarin een hartstochtelijk pleidooi naar voren kwam voor meer debat over ambtelijke spanningen (Rijnja \& Wilmink, 2010).

Het Centrum voor Arbeidsverhoudingen en Overheidspersoneel (CAOP) bood dat najaar een prachtige gelegenheid om naast de ambtelijke identiteit diens context te beschrijven: 'het eigene van de overheid'. De ettelijke weekenden die ik met Leon Klinkers wijdde aan het essay 'Waarden maken de overheid' (Rijnja \& Klinkers, 2011) hielpen het zicht te verdiepen op de kerntaken, maar vooral ook de kernwaarden die betekenis hebben voor mensen die de overheid beoordelen en om te beginnen van de mensen die er werken. We stelden vast dat niet het 'wat' van de overheid ter discussie staat, maar vooral het 'hoe'. Door de eeuwen heen zijn kerntaken als zorg voor de veiligheid, een basisbestaan en rechtsorde immers als onvervreemdbaar aan te merken; maar de inrichting van bestuurlijke en beleidsmatige processen staat aanhoudend ter discussie. En vaststaat dat het hoe in steeds grotere openbaarheid gestalte krijgt en dus speelbal is van velen. Oog voor de veranderende context is nodig om overheidshandelen te begrijpen en iets zinnigs te zeggen over de beslissingen van overheidshandelaars aan de voet van de $21^{\mathrm{e}}$ eeuw.

Was het professionele nieuwsgierigheid wat me in 2010 deed besluiten van de meer reflectieve modus bij de Academie naar de gemeente Rotterdam over te stappen? Van het strakke, gestileerde Ministerie van Algemene Zaken naar de op voorhand wispelturige praktijk van de gemeente, terug naar de biotoop die ik begin jaren negentig had gediend als woordvoerder. Toen vooral beleidsreparateur, nu meer preparateur? Met een flinke belofte ben ik aan de Coolsingel de confrontatie aangegaan met de praktijk van de overheid, de praktijk van het afwegen, keuzes maken, beslissen en dus ook het nee zeggen, teleurstellen, leedbezorgen. In een somber financieel klimaat stak een nieuwe wind op, en zo werd ik deelgenoot van een nieuwe publieke onderneming die intens de tanden zette in de vraag: welke overheid willen we en kunnen we zijn?

Dit is het decor waartegen deze studie in ongeveer vijf jaar gestalte kreeg. Velen leverden bijdragen, boden fora om verse inzichten te spiegelen of hielpen onafgemaakte aannames en bewerkingen te schragen. Zoals de waarnemende burgemeester van Almelo, James van Lith de Jeude, die in november 2009 na een lezing voor raadsleden uitriep: 'Wat u doet is Levinas!'. Hij verwees naar het verwonderende vermogen dat de joodse filosoof etaleerde om een ultieme poging te doen de Ander in het Gelaat te zien - en vanuit die waarneming tot oordelen te komen en de confrontatie aan te durven gaan. 'Hoe kan ik leven als ik niet begrijp waarom mensen achter Hitler aanlopen', poneert hij in meer dan één geschrift. In het gesprek met de raadsleden had ik een pleidooi gehouden om aan te sluiten op kritiek en 
die kritiek te benoemen, voordat je mooie vergezichten schetst. Aanleiding voor de bijeenkomst was een behoefte lokale lessen te trekken uit een uit de hand gelopen confrontatie tussen de gemeente en een horecaondernemer in 2008.

In deze motivatie voor het onderzoek zijn verscheidene mensen genoemd. Als het begrip 'vakvrienden' niet al bestaat is het bij deze gemunt: steeds weer zijn het collega's die me zo inspireren dat je ze niet alleen uit een beroepsmatige houding in de buurt wilt hebben en houden. Bedoeld en onbedoeld hebben ze me gestimuleerd om te leren en te begrijpen. In aanvulling hierop bedank ik ook enkele personen die bij uitstek dit proefschrift mogelijk hebben gemaakt. In alfabetische volgorde: Anouk Bosman, Sushrut Derks, Tom van Dijk, Jan Eberg, Henrik de Groot, Paul van Hal, Wim Ingenhoven, Anja de Jong, Lydia Jumelet, Ton König, Susan Lammers, Jan Mastenbroek, Ron Niessen, Ron Meijer, Vincent van Mastrigt, Hans Meijerink, Roelf Middel, Peter Noordhoek, Tom van Oosterhout, Betteke van Ruler, Kees van Schie, Jeroen Sprenger, Henny Strooij, Giovanni Timmermans, Bart de Vries en Vera de Witte. Zij gaven ieder betekenisvolle duwtjes, op vitale momenten. Bij de Dienst Publiek en Communicatie stimuleerde Jan Veenman mij in 2009 om de studie meer tijd te geven. Toen ik eind september 2010 het Ministerie van Algemene Zaken inwisselde voor de Bestuursdienst van de gemeente Rotterdam beschouwden ook Mark de Boer en Arjan van Gils het van meet af aan als vanzelfsprekend dat we de vanuit Den Haag getrokken lijnen in het Rotterdamse zouden doortrekken. Diverse malen boden opleidingsinstituten, communicatiekringen en collega's van departementen, gemeenten en het onvolprezen Genootschap van de Boodschap ruimte voor presentaties en discussies. Die ontmoetingen scherpten de overwegingen, aannames, afwegingen en conclusies. Steeds weer ontmoet ik mensen die me helpen een zaak van meer kanten te bekijken. Was het verwonderlijk dat burgemeester Havermans me bij mijn afscheid als gemeentewoordvoerder in Den Haag Simon Schama's 'Overvloed en onbehagen' (1989) cadeau deed? De auteur legt een link tussen de wens van Nederlanders om de zeeën te veroveren en de angst om door datzelfde water te worden verzwolgen. Wie uitersten ziet, kan wat daar tussenin ligt scherper waarnemen. Zo ook bleef Bram Peper begin jaren negentig als burgemeester zijn woordvoerder hinten op het zien van tegendelen (wat iets anders is dan tegenstellingen). Zoals de eerste keer dat hij een veronderstelde voorkeur voor linkse kwaliteitskranten pareerde met een suggestie aan de andere kant van het spectrum voor nieuws te zorgen. Keer het om, denk tegen. Zijn onverschrokken nieuwsgierigheid naar wat mensen echt beweegt, liet sporen na. Inderdaad, 'democratie is niet voor bange mensen': de oneliner doet recht aan de Januskop die de overheid zo kenmerkt. Dus past het wel dat ik in de naar deze Romeinse god vernoemde maand een punt zet achter een eindeloze zoektocht...

'Zul je er wel van genieten?' klonk het vanavond, toen ik naar de zolderkamer toog om de laatste hand te leggen aan het proefschrift: Annelies heeft de weg van de weerstand al eerder verkend. Ze gunde mij tijd er zelf achter te komen wat weerstand vermag. Zonder haar gezelschap had ik menig doorwaadbare plaats zomaar over het hoofd gezien. 


\section{Inhoudsopgave}

$\begin{array}{ll}\text { Woord vooraf } & 4\end{array}$

Inhoudsopgave $\quad 12$

1. Inleiding 15

$\begin{array}{ll}\text { 1.1. Inleiding } 15 & 15\end{array}$

1.2. Observatie: overheid als bron van kritiek 15

1.3. Diagnose: verklaringen in beeld 18

1.4. Probleemstelling en onderzoeksvragen 25

1.5. Opbouw van het onderzoek 28

1.6. Relevantie van het onderzoek 31

A. Theoretische verkenningen: overheid, werk en weerstand 34

2. Overheid als context voor werk 35

2.1. Inleiding 35

2.2. Waarom is er overheid? 35

2.3. Systeemkenmerken: context van ambtelijke arbeid 49

2.4. Beleid, of: het primaire proces van de overheid 53

2.5. Ambtelijke invloedssferen 56

2.6. Ambtenaren, makers van beleid 59

2.7. Ambtelijke systeemspanningen 62

2.8. Tot slot: de ambtenaar als verschilmaker 65

3. Werk als context voor weerstand 67

$\begin{array}{ll}\text { 3.1. Inleiding } & 67\end{array}$

3.2. Ambacht, vakmanschap, werk 67

3.3. De constructie 'werk' 69

3.4. Sensemaking: werkzame verhalen 75

3.5. Weerstand, een kwestie van perspectief 79

3.6. Beroepsgebonden weerstand 84

3.7. Tot slot: weerstand is zo gek nog niet 88

B. Empirie: work meaning en systeemspanningen 89 
4. De betekenis van ambtelijk werk 90

4.1. Inleiding 90

4.2. Sleutels van betekenis 90

4.3. Onderzoeksvragen 93

4.4. Onderzoeksopzet 94

4.5. Resultaten 96

4.6. Conclusies 114

$\begin{array}{ll}\text { 4.7. Tot slot: spelen met spanning } & 119\end{array}$

5. Onder de spanningsbogen 121

$\begin{array}{ll}\text { 5.1. Inleiding } & 121\end{array}$

5.2. Ambtelijke spanningen 121

5.3. Onderzoeksvragen 123

5.4. Onderzoeksopzet 123

5.5. Analysekader 124

5.6. Resultaten 125

5.7. Vijf strategieën 130

5.8. Conclusies 143

5.9. Tot slot: veiligheid 149

C. De ambtelijke beslisser: conceptueel model getoetst 151

6. De ontmoeting met weerstand 152

6.1. Inleiding 152

6.2. De ambtelijke arcade: contextuele spanningsbogen 152

6.3. Ambtelijke coping: een kwestie van stijl 155

6.4. Copingspectrum 158

6.5. Meebewegen: zoek de weerstand op 160

6.6. Invloedsfactoren: zes 'hefbomen' 170

6.7. Conceptueel model 179

6.8. Conclusies 180

7. De ambtelijke taxatie 182

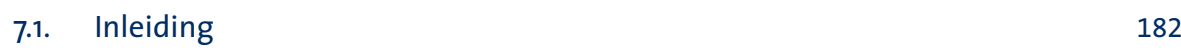

7.2. Onderzoeksvragen 182

$\begin{array}{ll}\text { 7.3. Onderzoeksopzet } & 187\end{array}$

7.4. Casestudy 1 - Een zachte landing 193

7.5. Casestudy 2-Een overtuigende opvang 208

7.6. Casestudy 3 - Een transparante bedding 227

7.7. Conclusies casestudies 243

7.8. Tot slot: reflectie 253 
8. Conclusies en slotbeschouwing 256

8.1. Inleiding 256

8.2. De betekenis van overheid als context van werk (vraag 1) 256

8.3. Ambtelijke vindingrijkheid: herkennen en hanteren van de specifieke context (vraag 2) 265

8.4. Toerusting voor weerstand: competenties van beleidsmakers (vraag 3) 271

8.5. Tot slot: van wie is de overheidscommunicatie? 276

$\begin{array}{ll}\text { Verantwoording } & 281\end{array}$

Bijlage I: $\quad$ Onderzoeksaanpak Work meaning 282

$\begin{array}{lll}\text { Bijlage II: } \quad \text { Onderzoeksaanpak Systeemspanningen } 285 & 25\end{array}$

$\begin{array}{lll}\text { Bijlage III: } & \text { Onderzoeksaanpak Casestudies } & 287\end{array}$

$\begin{array}{ll}\text { Literatuur } & 291\end{array}$

$\begin{array}{ll}\text { Samenvatting } & 321\end{array}$

$\begin{array}{ll}\text { Summary } & 328\end{array}$

$\begin{array}{ll}\text { Curriculum Vitae } & 335\end{array}$

Colofon 336 


\section{Inleiding}

Over kritieke tenten en venten

\subsection{Inleiding}

Beeld hem² in: een functionaris in een overheidsgebouw, die zich achter de oren krabt. Er ligt een tekst voor. Het kan een besluit van de volksvertegenwoordiging zijn, een voornemen uit een coalitieakkoord of een verzoek van een bestuurder. De tekst luidt een opgave in om te interveniëren, opdat een schaars goed kan worden verdeeld. Dat goed kan ruimte zijn, grond, geld, technische middelen of de inzet van mensen. Het kan veiligheid betreffen, duurzaamheid, volksgezondheid, welzijn, huisvesting of sport. De interventie noemen we beleid en dat kan regelgeving betreffen, een subsidie, een voorlichtingscampagne of een combinatie hiervan. Er kan druk op de ketel staan, mogelijk is het vijf voor twaalf. Maar er zal iets gebeuren, weet de orenkrabber. Die ook beseft dat welk besluit tot welke interventie ook, weerstand kan ontmoeten: angst bijvoorbeeld, twijfel, verdriet, boosheid, obstructie of woede. En dat dus de vraag prangt: wat doe ik met die gerede kans op tegenspel? Dit beeld van een worstelende professional is vele malen van stal gehaald bij een vraag naar het waarom van dit onderzoek. Het beeld verdient daarom een plaats aan de voet van deze inleiding, die uitmondt in de probleemstelling, centrale vragen en opbouw van het onderzoek.

\subsection{Observatie: overheid als bron van kritiek}

Kritiek op de publieke zaak is van alle tijden. Niet alleen in de media, ook in de literatuur zijn voorbeelden te vinden: De Balzac's 'Fysiologie van de ambtenaar' uit 1841 geniet herdruk na herdruk ('Vermorsing is: werkzaamheden laten verrichten die spoedeisend noch nodig zijn, monumenten bouwen in plaats van spoorwegen aanleggen, zich voorbereiden op een oorlog zonder te betalen') en ook Carmiggelt deed een duit in het zakje. Hij introduceerde een ambtelijk werkwoord: 'epibreren'. Dat staat voor 'niet anders aan te geven werkzaamheden verrichten (waarvan men de indruk wil geven dat ze belangrijk zijn, ook al stellen ze helemaal niets voor)' (Van Dale, 1999). Ook politici sparen hun biotoop niet; de republikeinse president Reagan lanceerde zijn zoektocht naar een bedrijfsmatiger benadering van de staat in 1981 met: 'Government is not the solution to our problem, government is the problem'. Voormalig PvdApartijleider Bos bood bij de laatste parlementsverkiezingen zijn geloofsbrieven aan met een boekje onder de titel 'Dit land kan zoveel beter'. Ook de Amerikaanse president Obama neemt bij zijn inauguratie begin 2009 publiekelijk een voorschot op de kritische houding, met, de boodschap dat hij geen perfecte president zal zijn, maar wel een eerlijke, en daar op afgerekend wenst te worden. Hertogh (2002) merkt op dat vooral de afgelopen twee decennia de categorie criticasters zich uitbreidde van burgers en ondernemers naar de binnenwereld van bestuurders en ambtenaren. Hij tekent ook aan dat de onmiskenbare kentering van autoritair bestuur

2 Om praktische redenen gebruik ik in de regel mannelijke verwijswoorden. 
naar horizontale vormen van besturing dit interne vuur niet heeft gedempt, maar juist heeft aangewakkerd. 'Burgers zijn goedkoper dan ambtenaren', kopt de Volkskrant naar aanleiding van een verkenning van het CDA over overheidsfinanciën (Gradus, 2009); in de bijdrage moet vooral de regeldrang van ministeries het ontgelden in combinatie met een oproep het aantal ambtenaren terug te dringen.

Kritiek: van alle tijden? Ergens, soms, resoneert de uitspraak van Plato dat je de deugden kunt ontdekken door de staat te bestuderen (Bierens de Haan, 1943). In de jaren '6o en '70 van de vorige eeuw kon Joop den Uyl nog leunen op brede steun voor de staat; zijn pleidooi voor spreiding van macht, kennis en inkomen werd bejubeld. Onder zijn opvolger Lubbers zwol de kritiek weer aan, onder klaroenstoten van verzakelijking; het zijn de jaren waarin economen met Reagan een andere staatsaanpak bepleiten en Osborne en Gaedler tot ver buiten de Verenigde Staten steun vinden voor hun 'Reinventing Government'. Ook in eigen land schieten dan bedrijfskundige modellen wortel, en verzelfstandigingen en privatiseringen maken duidelijk dat (maar vooral ook hoe) overheid op afstand kan worden gezet, vooral in de sectoren vervoer en woningbouw. Kabinetten onder leiding van premier Kok bedeelden de centrale staat weer een sleutelrol toe, waarbij het onderwijs en enkele grote infrastructurele projecten de toon zetten. Zo laat de geschiedenis welhaast wetmatig zien hoe onder sociaaldemocratische regeringen staat en overheid mogen ontwikkelen, om onder republikeinse respectievelijk liberale vlag weer in te binden. 'Ik ben steeds sterker gaan inzien hoe belangrijk gemeenten zijn geweest voor de ontwikkeling van de Partij van de Arbeid in de gemeenten, maar ook voor de wording van de partij überhaupt', verzuchtte de voormalige directeur van de Vereniging van Nederlandse Gemeenten, PvdA-fractievoorzitter in de Eerste Kamer en hoogleraar parlementaire geschiedenis Joop van den Berg, onder verwijzing naar stedenbouwers Wibaut (Amsterdam), Van der Ploeg (Rotterdam), Gietema (Groningen), Asselbergs (Amersfoort) en Duivesteijn (Den Haag) (Coops \& Rijnja, 2001b). Markant genoeg is het dezelfde Duivesteijn, die als voorzitter van een parlementaire onderzoekscommissie in 2005 de grote projecten de nek omdraait. Na een reconstructie van de besluitvorming over financiering van de Hoge Snelheidslijn en de Betuwerouten stelde de commissie vast dat bewindslieden op het ministerie van Verkeer en Waterstaat te lang te koppig aan grote projecten vasthielden. In Haagse kringen wordt achteraf van een 'paradigmawisseling' gesproken; spoedig wordt ook de voorbereiding van de Zuiderzeelijn en HSL Oost stopgezet. De geschiedenis laat wel vaker dergelijke scharnieren zien. De opeenvolgende kabinetten-Balkenende etaleerden vervolgens aanhoudende pogingen om de overheid dichter bij de burgers te halen. 'Meedoen' wordt het eerste woord in het kabinetsmotto in 2007 en de premier omarmt publiekelijk het pleidooi van de Wetenschappelijke Raad voor het Regeringsbeleid (WRR) voor 'sociale heroververing': 'We hebben allemaal een verantwoordelijkheid bij het versterken van vertrouwen en sociale binding', en hij haalt begeesterd de socioloog Ernest Geitner aan: 'No civil society, no democracy' (Balkenende, 2006).

leder kabinet legt een eigen accent, maar ondertussen klinkt steeds dezelfde grondtoon in de kritiek door: of overheid zich nu krachtig zelf aanbiedt, taken aan de markt 
toevertrouwt of samen met de gemeenschap in de slag gaat, het is niet goed of het deugt niet. De kritiek raakt het hele oeuvre overheidsprestaties:

a. De aanleiding voor overheidshandelen: de overheid is er niet als ze nodig is of te laat, en ze bemoeit zich met je op een moment dat je er niet op zit te wachten; het eerste slaat terug op crisissituaties en misstanden, waar de overheid zich moet laten zien om verstoorde stabiliteit aan te pakken, het laatste op handhavingsituaties. Populair gezegd: Waar waren jullie nou?

b. De werkwijze van de overheid: bereikbaarheid is een dankbaar onderwerp voor klachten, de ingewikkeldheid van besluitvorming, het vaak en nog openlijk oneens zijn (om te beginnen intern), tegenstrijdige en gestapelde regelgeving, en vele tussentijdse koersveranderingen. Wat werken ze vaak langs elkaar hen en wat is de taal vaak vaag en omzwachteld (Figee, 2001). Wat heb ik nou aan een 'inspanningsverplichting'?

c. De organisatie van de overheid: soms maak je met de ene ambtenaar een afspraak en weet een ambtenaar elders van niets. Of dan haalt een bestuurder of een politiek overleg eerdere afspraken onderuit, mensen weten vaak onderling niet van elkaars taken en werkzaamheden, het slurpt allemaal geld. De rol van Europa wordt steeds intensiever. Het geheel maakt een verwarde en gefragmenteerde indruk. Wat krijgen we eigenlijk voor onze belastingcenten?

d. De deskundigheid roept vragen op: hier lukt het niet een spoorlijn aan te leggen en daar strandt gratis schoolboeken in te voeren op de afgesproken datum. Ondertussen mogen ze wel besluiten om iedereen te laten inenten en jonge mensen naar gevaarlijke gebieden te sturen. Hoe kan $X$ eerst minister van A zijn en dan minister van $\mathrm{B}$ ? Wie zegt dat ze dit tot een goed einde brengen?

e. De gezichten van de overheid: bestuurders, beleidsambtenaren en uitvoerende ambtenaren. Wie gaat waarover en waarom hebben we met deze of gene te maken? Publiek-private samenwerking (PPS), op afstand geplaatste diensten en zelfstandige bestuursorganen (ZBO's) bevorderen het overzicht niet. Daar komt bij dat steeds meer nieuwe clubs en netwerken ontstaan die deels overheid zijn. Wie wie controleert is niet altijd duidelijk. 27 dienstverleners rond één pleegkind, moet dat echt?

f. De uitkomsten van overheidsinterventies: ze laten vaak lang op zich wachten en niet altijd is duidelijk hoe de uitkomst samenhangt met het oorspronkelijke doel. Vaak pakt het duurder uit, dan wordt het halverwege gestopt. Maar vaak ook niet, en dan vindt later verantwoording plaats, zoals bij de Noord-Zuidlijn in Amsterdam. Het proces lijkt wel eens belangrijker dan het resultaat. Gaat het bij het uitdiepen van de Westerschelde nou om scheepvaart of milieu? 
Een parafrase? Het is niet moeilijk om het containerbegrip overheid negatief te duiden. Kennelijk kost het weinig moeite om de kritische grondtoon aan te houden; het lukt in ieder geval niet makkelijk om de negatieve geluiden zachter te zetten. 'Complexe collectiviteiten worden vereenvoudigd tot vermeend concrete fenomenen', hekelde cultuursocioloog Zijderveld (2011) de generalisaties die rond grote instituten ontstaan: riskant, vooral wanneer ze een negatieve lading krijgen. Het pars pro toto-principe werkt snel, en dus is zorgvuldigheid geboden, ook bij een ogenschijnlijk voor de hand liggende interpretatie van 'overheid'. Ondertussen blijft 'de' overheid in mineur.

'Het ontbreekt aan een 'zorgvuldige diagnose' en aan 'collectief geheugen', verzucht de vicepresident van de Raad van State in zijn jaarverslag (2010) als hij de reeks vernieuwingen in de overheidsdienst de revue laat passeren. 'Met relatief gemak verschuiven opvattingen over het openbaar bestuur. Van de opvatting dat het bestuur een bedrijf is naar de opvatting dat het bestuur geen bedrijf is. Van de opvatting dat grootschaligheid vooral voordelen heeft naar de opvatting dat kleinschaligheid beter is. Van de opvatting dat uitvoerders op afstand moeten worden gezet naar de opvatting dat meer aandacht voor de professionele uitvoerders geboden is. Van de opvatting dat de rijksdienst beter is gaan functioneren naar de opvatting dat de rijksdienst beter aanzienlijk in omvang kan worden teruggebracht'. Er is volop discussie over de overheid, en dat is niet alleen te danken aan een terugkerend thema bij verkiezingen. Binnen bestuurshuizen vinden allerhande discussies plaats over taken, rollen, processen, interventies en structuren. Op vele plaatsen in de samenleving duiken vooronderstellingen op en aan teken- en knutseltafels met fraaie vergezichten geen gebrek. Bekker (2010) neemt een aanhoudende neiging waar om positieve onderzoeksresultaten over het functioneren van de overheid met negatieve te pareren. 'Beschouwingen van het Sociaal Cultureel Planbureau (SCP) en het Centraal Bureau voor Statistiek (CBS) dat het met de daling van vertrouwen eigenlijk wel meevalt, krijgen nauwelijks aandacht. Onheilsprofeten verdienen een goede boterham en ondertussen staat 'het Huis van Thorbecke' er nog steeds...'

\subsection{Diagnose: verklaringen in beeld}

De kritiek raakt dus een breed spectrum: aanleiding, ontwikkeling, uitkomsten en organisatie. In de literatuur zijn hiervoor diverse mogelijke verklaringen te vinden. Vooral onderzoek van het SCP en studies van adviesorganen als de ROB en de WRR bieden daarbij houvast. Op zoek naar begrip breng ik hieronder tien verklaringen voor ontstaan en voortbestaan van kritiek op de overheid in beeld:

1. Een zwak algemeen oordeel? Het Sociaal Cultureel Planbureau (SCP) meet op verzoek van het kabinet periodiek het oordeel van het publiek over de overheid in termen van vertrouwen. De uitkomsten spreken elkaar tegen. Enerzijds lezen we al enkele jaren dat het vertrouwen over de hele linie van de publieke sector laag is en sinds 2001 sterk afneemt (Dekker, 2006); Nederland is niet langer een high trust country, een begrip van Fukuyama (1995). Becker en Dekker (2006) wijzen op basis van onderzoek 
van het SCP echter op een door de bank genomen positief oordeel over overheid als het gaat om gemeenschappelijke voorzieningen en het democratisch stelsel, maar een negatief oordeel over parlement, de politieke partijen, de regering en bij specifieke gezagsdragers, wier onkreukbaarheid en competentie worden gelaakt. De Eurobarometer laat zien dat $55 \%$ van de ondervraagden vertrouwen heeft in de overheidsdiensten, en Nederland boekt een mooie $6^{\mathrm{e}}$ plaats na Oostenrijk, lerland, Luxemburg, Denemarken en Zweden. Bij de zogeheten Europese Waardenbarometer prijkt Nederland ineens op een $13^{\mathrm{e}}$ plaats, met slechts 37 procent vertrouwen in de overheid als geheel; alleen Italië en Griekenland doen het slechter (Dekker, Halman $\&$ Van der Meer, 2006). Vertrouwen impliceert dat verwachtingen afgestemd zijn en een relatie betrouwbaar is en is daardoor een goede graadmeter voor het toekennen van steun (Korsten \& De Goede, 2006). Fukuyama karakteriseert vertrouwen (1995) als het vermogen tot het realiseren van verbindingen ('associations') en een voorwaarde voor organisaties om relaties aan te gaan met afhankelijkheidsgroepen. Onderzoekers onderscheiden overigens sociaal vertrouwen van institutioneel (daarbinnen politiek vertrouwen), met volgens Putnam (1993) een correlatie: hoe meer sociaal vertrouwen, hoe meer politiek vertrouwen. Het 'vertrouwen' is dus betwijfeld, maar tegelijk kan niet worden gezegd dat Nederlanders hun overheid niet vertrouwen.

2. Slechte persoonlijke ervaringen? De Nationale Ombudsman voert bij herhaling aan dat burgers teleurstelling ervaren en dat die ervaringen aandacht behoeven (Jaarverslag 2007). Van der Walle (2006) noteerde echter na onderzoek naar de beoordeling van prestaties van besturen dat de meeste burgers redelijk tevreden zijn over het reguliere functioneren van gemeentelijke diensten en de rijksoverheid het 'redelijk tot goed' doet. Hij plaatst kanttekeningen bij ervaringen als imago-indicator, en wijst er daarbij op dat een groot deel van de ambtenaren zelden contact kan hebben met het publiek, zeker niet bij bestuurslagen buiten de gemeentelijke laag (provincie, rijk, waterschappen en veel zelfstandige bestuursorganen). Ook is niet duidelijk of en hoe een aantal goede ervaringen erin slaagt eerdere slechte teniet te doen. Het ontbreken van een eerder contact kan niettemin een drempel opwerpen voor de overheidsdienaar die rond een omstreden kwestie een beroep op iemand wil doen. Thompson en Alvesson (2005) stelden vast dat vertrouwen vooral aan de orde is bij gebrek aan voorspelbaarheid; als je niet op eerdere ervaringen kunt terugvallen, doet het er toe of je iemand je vertrouwen wel of niet gunt. Dit lijkt voor de overheid een relevant punt in het licht van de bevindingen van Van der Walle; vertrouwen is dan: 'the actor's belief that, at worst, others will not knowingly or willingly do him harm, and at best, that they will act in his interest (Newton, 2001). Volgens Hardin (2006) is vertrouwen alleen mogelijk als we personen die het voor het zeggen hebben kennen. Anderen beweren dat vertrouwen ook gebaseerd kan zijn op een combinatie van kennis van institutionele normen, de mogelijkheid om te (laten) controleren of men zich daaraan houdt, en de aanwezigheid van sancties voor het geval dat niet gebeurt (Dekker, 2006). Ervaring doet er dus toe, als het gaat om een oordeel en is als het om publieke dienstverlening gaat, niet per se onder de maat. 
3. Mediaberichtgeving vertekent? Wat is de betekenis van de periodieke uitvergroting van faux pas van bestuurders, een schandaal, crisis of ander incident in kranten en op radio en tv voor het overheidsimago? Onderzoeken (Elchardus \& Smits, 2002, Newton, 2006) maken duidelijk hoezeer de stroom aan negatieve berichten over conflicten, kritiek en incidenten een vertekend beeld geeft van de werkelijkheid: media berichten niet over 80 procent van het beleid dat steun heeft en aanvaard wordt, maar vooral over de 20 procent aan controverses, zoals asielzaken, bouwfraude, ruzies in kabinetten of scheve schaatsen van bestuurders. En ook is duidelijk hoezeer oorlogsmetaforen domineren zoals 'verdediging', 'onder vuur liggen', en ook vergelijkingen met racewedstrijden ('wie wint en wie legt het af'). Ze wakkeren een sensationele stemming aan. Maar dat is van alle tijden, en verklaart niet waarom de laatste jaren het vertrouwen sterk afneemt, zoals het SCP registreerde. Er is dan ook geen bewezen oorzakelijk verband tussen media-aandacht en publiek vertrouwen stellen Korsten en De Goede (2006). Een inhoudsanalyse van acht dagbladen, twee gratis bladen en twee televisierubrieken en een panelonderzoek tijdens de laatste verkiezingsperiode (De Ridder e.a., 2008) bevestigt dat kritiek op ministers of partijleiders geen effect heeft: 'De stelling dat waar rook is ook vuur zal zijn en dat in die zin kritiek een partij altijd schade berokkent, lijkt niet meer zonder meer houdbaar'. Ook blijkt dat bij mensen met veel politieke kennis mediaperformance nauwelijks invloed heeft, wat men onder meer verklaart uit een te gering inhoudelijk karakter van discussies. Die invloed is er wel bij mensen met minder politieke kennis, hetgeen de onderzoekers verklaren uit de mindere mate waarin men weerstand kan bieden aan de indrukken die hypes in het nieuws achterlaten. Bij mensen met weinig politieke kennis blijkt ook succes van personen en partijen een sleutelrol; men wijkt makkelijk uit naar favorieten. De media zetten onmiskenbaar een toon, maar het gewicht hiervan mag niet worden overschat.

4. Zwakke beleidsresultaten? We kennen een hoog niveau van onderwijs en een uitgebreid netwerk van sociale voorzieningen en toch overheersen berichten over hoge kosten, cynisme over resultaten en andere geringschattingen: doen we het nu goed of niet? (Dekker, 2006). Uitspraken over resultaten doen is niet eenvoudig, ondervond ook de Algemene Rekenkamer (2003) bij de beoordeling van de resultaten van een reeks uiteenlopende beleidsinspanningen. Louter de uitvoering van afspraken in het parlement bezien volstaat niet; resultaten zijn moeilijk meetbaar bij een organisatie die in het openbaar wikt en weegt, oordeelt en besluiten ten uitvoer legt, verklaart Ringeling (2004). Volgens Kirlin (1984) zou 'de besluitvormingscapaciteit van de samenleving' beter als beoordelingsmaatstaf kunnen gelden: maak duidelijk, steeds weer, hoe je als overheid conflicten in de samenleving aangaat, opzoekt, soms zelf veroorzaakt, is zijn oproep. De mate waarin je slaagt in het oplossen van die conflicten, daarop mag je beoordeeld worden; vertrouwen in het probleemoplossend vermogen van de overheid is betrouwbaarder dan vertrouwen in harde effecten, als het gaat om het imago (Coops \& Rijnja, 2001a). Easton (1965) concludeert dat burgers 
makkelijk 'diffuse' steun toekennen (aan instituties), terwijl hun 'beleidssteun' (aan beleidsprestaties) gering is. Dat helpt verklaren waarom burgers beleid kunnen accepteren, ook al hebben ze gering vertrouwen in de zittende regering. Hij verklaart deze houding door socialisatie en de betekenis van ervaringen over een langere periode. Neiging is volgens hem om ook bij geringe specifieke (beleids)steun op de lange duur diffuse steun te geven. En dus werkt het principe van commitment and consistency (Cialdini, 2006): mensen zijn geneigd een eenmaal gegunde instemming te bestendigen. De beleidsresultaten van de overheid worden dus in een relationele context bezien, waarbij andere maatstaven opgeld doen dan louter doelbereik of kostenefficiëntie.

5. Onbegrijpelijke beleidskeuzes? Akkerman (2006) signaleert juist op het punt van die duurzame steun een kentering naar een kritischer houding. Zij onderzocht de mate waarin burgers licht zien tussen verwachtingen en uitkomsten van specifiek beleid van achtereenvolgende regeringen, waaronder het sociale beleid. Ze noteerde een daling van het publiek vertrouwen in de overheid op dit terrein, onder verwijzing naar het onvermogen van achtereenvolgende regeringen om oplossingen te vinden voor hardnekkige opgaven op het terrein van het sociale beleid. Er is sprake van een toenemende aandacht van burgers voor de inhoud van de keuzes die de overheid maakt, en de wijze waarop zij daarbij betrokken zijn. Mensen spreken zich vooral uit over gevoerd beleid en imago van politici, als hun naar een beoordeling van de overheid wordt gevraagd; vertrouwen rust meer op die aspecten dan op algemene gevoelens van onbehagen en algemeen maatschappelijk wantrouwen (Becker \& Dekker, 2005). Beleidsvoorkeuren, evaluatie van de prestaties van de overheid en de economische situatie zijn belangrijke verklarende factoren voor vertrouwen in de overheid en naarmate overheid niet voldoende presteert zal het vertrouwen ook geringer zijn, registreerde ook Wuthnow (2002). Mensen zijn in mindere of meerdere mate actief bezig met het evalueren van de prestaties van de overheid en idem met het verbinden van oordelen daaraan. Onder die oordelen klinkt een bijzondere dissonant. Enerzijds spreekt uit de onderzoeken instemming met het fenomeen overheid, het stelsel van democratische besluitvorming, anderzijds melden burgers dat 'Den Haag besluit tot verslechtering van het leven'(SCP 2005). De belevingsmonitor van het kabinet Balkenende II bevestigde de SCPuitkomsten: in brede lagen van de bevolking begrijpt men niet waarom een keuze is gemaakt: waarom naar Uruzgan terwijl de ouderen pyjamadagen hebben en op de verpleeghuizen wordt gekort, waarom die al maar groeiende EU zonder een reflectie op voor- en nadelen, waarom al die marktwerking terwijl je de prijzen niet ziet dalen?' (Korsten \& De Goede, 2007). Tyler en Lind (1992) spreken van de theorie van de 'procedurele rechtvaardigheid': het oordeel over rechtvaardigheid van een ingreep stijgt naar gelang sprake is van a) inzicht in achtergrond van de resultaten, b) mogelijkheid tot vergelijken en c) heldere inspanningen. Begrip van de zaak is dus een relevant element in de publieke beoordeling. 
6. Ongenaakbare bestuurders? Vaak wordt teruggegrepen op de wijze waarop Fortuyn heikele thema's als wachtlijsten in de zorg en aanpak van het integratievraagstuk wist te benoemen: hij durfde de problemen bespreekbaar te maken, waar gevestigde bestuurders vooral oplossingen wilden bespreken (eenrichtingverkeer). Hij gaf burgers een 'thuis' en bood daardoor iets waarnaar burgers ook nu op zoek zijn: samenhang, registreert beleidsonderzoeker Van Dijk (2004, 2006), die 'ontheemding' waarnam bij het publiek. Het lukt veel bestuurders niet om mensen te binden aan politieke partijen, wier rol als emancipatiebewegingen lijkt te zijn uitgespeeld, zeker voor wat de gevestigde partijen betreft. 'Wederkerigheid' (Cialdini 2000) wordt als criterium steeds belangrijker en dat kan niet los worden gezien van de overgang van duurzame statische relaties naar kortdurende dynamische, informele netwerken. Dit proces is al enige tijd gaande, maar de overheid moet nog steeds wennen aan een 'pluricentrisch' perspectief in plaats van een 'unicentrisch' perspectief: publieke organisaties en politieke partijen zijn één van de spelers in het veld, waarin meer actoren een rol als spelverdeler kunnen claimen (Teisman, 1992, 2009). Bestuurders kunnen die nieuwe vormen van besluitvorming een gezicht geven, en uitgroeien tot iconen, ook al is dat met een op voorhand onzekere houdbaarheidsdatum. In de praktijk zijn ambtenaren vooral zichtbaar als de voorbereiders en uitvoerders van besluiten. Hun responsieve houding kan helpen de agenda's tussen samenleving en politiek meer gelijk te trekken (Derksen, 1996).

7. Onvermogen tot verbinden? Almond en Verba (1963) hebben de samenhang tussen vermogen tot vereniging en de houding ten opzichte van gemeenschappelijke afspraken en instituties onderzocht en een trend vastgesteld waarop nog regelmatig wordt teruggegrepen: leden van verenigingen hebben meer vertrouwen in de politiek dan mensen die niet aan verenigingen meedoen. Ook Rothstein (2002) signaleerde dat een groter vertrouwen in de medemens zich vertaalt in groter vertrouwen in instituties. Een voorname reden zou zijn dat deze aan organisaties of (tijdelijke) verbanden gebonden personen over meer informatie beschikken en toegang hebben tot meer bronnen, ook op toevallige momenten (Putnam, 2002). Breeman (2006) vraagt zich bij deze gegevens af of groepsdwang niet vertekent en haalt onderzoek aan waaruit naar voren kwam dat vertrouwen in de regel eindigt bij het bereiken van de toestand waarin een individu gunstige verwachtingen heeft (Mollering, 2001). Diverse auteurs noemen het wegkwijnen van vanzelfsprekende bindingen en het ontstaan van nieuwe 'lichte' gemeenschappen (o.a. Teisman, 1992, Van Gunsteren, 2006). Als virtueel startblok voor houdingen ten opzichte van de overheid wordt de afschaffing van de opkomstplicht bij verkiezingen in de jaren zestig genoemd: traditionele verbindingen zoals zuilbindingen zijn voor steeds kleinere kringen logisch, mensen shoppen langs netwerken waar ze deel van uit kunnen maken. Wie in die netwerken aanwezig is, kan helpen verbinden. Kennis en kunde om in nieuwe netwerken mensen te helpen verbinden wint aan betekenis. 
8. Opgeklopte verwachtingen? Burgers hebben 'teleurgestelde verwachtingen' (Ringeling, 2004). Dat fenomeen is op zich niet uniek voor overheid (ook een bedrijf kan je teleurstellen in je verwachtingen). Kettl (1988) noemt de hang naar verre, vage idealen tijdens verkiezingen: 'The public's perceptions of federal programs gone awry result not so much from poor government performance as from great expectations'. Frissen (1996) plaatst dit streven op één lijn met een 'mythe van bestuurbaarheid'. Die wordt niet alleen door bestuurders en ambtenaren gevoed, maar juist ook door het publiek; economische en bedrijfskundige motivaties jagen verwachtingen aan en die nodigen als het ware uit tot navenante teleurstellingen. Pol e.a. (2007) stellen op basis van vergelijking van massamediale overheidscampagnes vast dat campagnemakers, beleidsmakers en politici zelf hardnekkige mythes in stand houden, waaronder de veronderstelling dat een boodschap met sterke argumenten altijd overtuigt. Mertens (2003) stelt de vanzelfsprekendheid in de verwachtingen centraal in zijn analyse. 'Kenmerkend voor ons is dat wij veel zaken als probleem zien en dat wij daarbij vaak automatisch denken dat het opgelost kan en moet worden. Maar dat geldt voor ons als hedendaagse mensen. Ook hier werd vroeger gedacht dat honger, ziekte, overstroming en dood normale elementen van het alledaagse leven waren'. Postmoderne burgers stellen hogere verwachtingen dan de' modernisten' die hen voorgingen - hoger ook dan waargemaakt kan worden. Achterblijven van prestaties bij de eigen verwachtingen kan tot een imagodeuk van een organisatie of persoon leiden (Inglehart, 1999), een uitkomst die volgens anderen niet kan worden bewezen (Korsten \& De Goede 2007). Postmodernisten schenken vooral op een andere manier vertrouwen: je moet als instituut, bedrijf, autoriteit steun 'verdienen'. Verwachtingen hebben dus invloed en doen er in de context van de overheid toe, ze worden vooral aan politici gekoppeld.

9. Uitwaaierend burgerschap? Volgens de WRR spelen basishoudingen een rol bij de beoordeling van de publieke zaak, en waaiert in het postmoderne tijdperk de opvatting over burgerschap uit naar enkele typen houdingen ten opzichte van de overheid. Onderzoeksbureau Motivaction (WRR, 2005) schetst vier stijlen van burgerschap: afhankelijke burgers (26\%) kenmerken zich door een gezagstrouwe houding en risicomijding. Zij blijken ontvankelijk voor persoonlijk contact en hechten zeer aan toegankelijke informatie; afzijdige burgers (31\%) zijn gespitst op het eigen belang, wantrouwen het algemeen belang, tonen zich intolerant en een druk bestaan; het zijn zelfredzame zekerheidszoekers, die veel tv kijken, maar niet naar de publieke omroep; afwachtende burgers (23\%) zeggen de overheid niet nodig te hebben. Het zijn calculerende, opportunistische, jonge mensen, die beschikken over netwerken. Ze focussen op hun buurt, willen herkennen en herkend worden, en staan open voor inspiratie door anderen, waaronder de overheid. Actieve burgers (20\%) tenslotte kenmerken zich door een grote mate van vertrouwen in de overheid en staan ook open voor coproductie van beleid. Het gaat om tolerante mensen, die lid zijn van verenigingen, betrokken zijn bij wijk en buurt. 'Afhankelijke' en 'afzijdige' burgers 
zoeken zekere banden met wederzijdse rechten en plichten, terwijl 'afwachtende' en 'actieve' burgers hun weg zoeken in netwerken en zwakkere banden. Het eerste paar is uit op 'bonding', het tweede koppel op 'bridging' (Putnam, 2002), met bijbehorende voorkeurskanalen en oriëntaties, als het om overheid gaat. Afwachtende burgers hebben wel hun geloof in overheid als institutie, maar niet in democratie als zodanig verloren. Niet iedere burger wil en kan in het klassieke systeem van de civil society thuis komen. 'Afhankelijke' en 'actieve' burgers krijgen ondertussen vaak geen aandacht, omdat ze problemen hebben noch veroorzaken. Hun potentie als trekkers van sociaal initiatief wordt onbenut (WRR 1985). Van Gisteren (2010) bepleit een uiteenrafeling van onderscheidende relatiepatronen tussen overheid en burger. In de praktijk lopen 'verticale' en 'horizontale'ontmoetingen door elkaar: als gekozene en kiezer elkaar ontmoeten is van een ander contact sprake dan bij die tussen gezagsdrager en ingezetene, aanbieder en klant en besluitvormer en participant. Dat is in verkiezingstijd bij uitstek merkbaar en draagt al met al niet bij aan een overzichtelijke relatie. Meer relatiepatronen: dat vraagt om helderheid over wie waarvoor aanspreekbaar is, bestuurlijk en ambtelijk.

10. Geringe interne aandacht voor organisatiereputatie? Imagostudies zijn een belangrijk thema in corporate communication. Het begrip 'organisatiereputatie' - de weerslag van de aanwezigheid van een organisatie in de openbaarheid - wordt echter vooral gekoppeld aan private bedrijven. Dat hangt samen met de aanname dat onderscheid positioneren voor de meeste overheidsorganisaties niet van belang is: veel overheidsdiensten kennen een monopolie. De ontvankelijkheid neemt echter toe, vooral bij (op afstand geplaatste) diensten en zelfstandige bestuursorganen. Ilia en Lurati (2006) signaleren dat daarbij niet zozeer sprake is van een reputatie- als wel een relationele benadering: een 'narrow situational approach', gericht op opsporen van interpretaties en verwachtingen in de omgeving van de organisatie. Repelaer van Driel (2002) vulde daartoe een beproefd basismodel, het Reputation Quotiënt (Fombrun \& Van Riel, 2004), aan met het begrip 'communicatie'. Schoofs en Nelissen (2008) hebben de nieuwe schijf van zeven drijfveren getoetst bij stakeholders van drie zelfstandige bestuursorganen (ZBO's). Zij scoorden op het belang en de toepassing van: (1) aantrekkingskracht, (2) leiderschap, (3) maatschappelijke oriëntatie, (4) diensten en taken, (5) financiële verantwoording, (6) werkomgeving en (7) innovatie. 'Aantrekkingskracht' en 'Diensten en taken' bleken de grootste bijdrage aan de reputatie te leveren. Bij het wegen van toegekend belang en wat nu van toepassing is, sprong het kenmerk 'communicatie' naar voren, onder meer ook doordat juist hier een groot verschil bleek te bestaan tussen het toegekende belang en de mate van toepassing. Deze auteurs concludeerden dat - meer dan 'harde' reputatiedrijfveren zoals de uitvoering van de diensten en taken - 'zachte' drivers als 'dialoog' en 'verwantschap' een reputatie bepalen. Vergeet dus de idee dat een reputatie louter de identiteit van een organisatie reflecteert, aldus deze pioniers van non-profit reputatieonderzoek. Met communicatieve interventies kun je waarde toevoegen. 
Meer aspecten oefenen invloed uit op de publieke beoordeling van de overheid, zoveel is wel duidelijk. Uit de inventarisatie komen drie pregnante aanwijzingen naar voren:

I. Als het gaat om de publieke beoordeling van de overheid, is een overwegend negatieve houding onontkoombaar. Die negatieve houding leidt niet aanwijsbaar naar een tekort aan 'vertrouwen' in de overheid.

II. Procesmatige thema's domineren in de publieke beoordeling van de overheid, zoals persoonlijke ervaringen, verwachtingen over de bejegening en presentatie van inhoudelijke keuzes.

III. In een netwerkrijke samenleving is het zoeken en vinden van contact voor burgers én overheid complex. Het omstreden karakter van veel thema's op overheidsbordjes en uiteenlopende rollen doen niet alleen een extra appèl op de capaciteiten en kwaliteiten van bestuurders, maar ook op degenen die bestuurlijke besluiten helpen voorbereiden en uitvoeren.

\subsection{Probleemstelling en onderzoeksvragen}

Bij het adresseren van de negatieve connotaties door het publiek worden zowel het ongedefinieerde geheel ('de overheid') als bestuurders en ambtenaren door elkaar genoemd. Zowel persoonlijke ervaringen als indirecte beeldvorming (via de vrije media) spelen hierbij een rol. Er is sprake van een amalgaam van relaties en dat voedt onvermijdelijk een bonte reeks duidingen ('labels'), waarin enkele begrippen domineren - vertrouwen, kritiek, weerstand maar net zo makkelijk andere krachttermen aandacht vragen: kloof, cynisme, bureaucratie, stroperigheid. Ze raken aan de vraag of de staat 'in staat tot verbinding' is. Meer nog dan op inhoud maken mensen op het punt van relatie verbinding en wordt steun 'gegund'.

Bij het ontbreken van een een-voudige oriëntatie op de 'tent' is de 'vent' het (meest zichtbare en beschikbare) mikpunt van de (meervoudige) negatieve connotatie. Voor burgers (c.q. ondernemers) is de ambtenaar daarbij de meest concrete adressant: in de relatie met hem of haar wordt het publieke mandaat - de relatie tussen overheid en samenleving - tastbaar, behapbaar.

De ambtenaar. Hoe verstaat hij het appèl dat op hem wordt gedaan? Wat doet hij met zijn omgeving en wat doet die omgeving met hem? Dergelijke vragen wijzen in de richting van het begrip 'context': het systeem of de biotoop waarin iemand (amb(ach)telijk) handelt. We hebben te maken met een 'organisatiebiotoop' die kritiek oproept en met werknemers die weerstand kunnen ontmoeten. De Britse socioloog Sennett neemt in zijn studie van de geschiedenis van ambachtslieden (2008) waar dat werknemers bij de ontmoeting van ongemakkelijke situaties idealiter in staat zijn tot 'herformattering': in andere termen opnieuw verwoorden wat op je afkomt. In zijn studie naar de eigenheid van de overheid belichtte de bestuurskundige Berg (2006) de schaduwkant: wie zich geschaad voelt in zijn bronbelangen 
(Frijda, 2004) en zich daardoor niet veilig voelt, loopt het gevaar te vervreemden en dat leidt tot afhaken, inbinden of anderszins wegbewegen van de taakopvatting. Tussen enerzijds herformatteren en anderzijds wegbewegen ontvouwt zich een denkbare waaier vol handelswijzen om werkgerelateerde druk op te vangen. Dit leidt naar twee centrale onderzoeksvragen:

I. Welke betekenis heeft de specifieke context 'overheid'voor de beslissingen die ambtenaren nemen over het contact met het publiek? (verklaring)

II. Welke mogelijkheden heeft een ambtenaar om de context te herkennen en te hanteren bij het contact over omstreden beslissingen? (toepassing).

Ik veronderstel vaardigheden, strategieën om in een omstreden context te communiceren en te interveniëren. Maar, wat zet aan tot de ene of de andere benadering? Hoe komt de beoordeling van het handelen tot stand? Welke scenario's doen zich werkelijk in de praktijk voor? Hoe vangt de ambtenaar de kritiek op en doorbreekt hij de weerstand? In welke mate ervaren ambtenaren de beschikbare scenario's en een - samenhangend repertoire bewust en als wezenlijk? En indien sprake is van onbewust handelen, in welke mate herkennen ambtenaren de uitingen, beoordelen ze die en wat doen ze met die informatie, waarop baseren zij keuzes, welke acties vloeien hieruit voort en wat is het rendement? Is er daarbij zoiets als juist handelen te benoemen en zijn hierover generieke uitspraken te doen, of situationele uitspraken? En, wat is nodig om het handelen te ontwikkelen, laat staan borgen in een ambtelijke omgeving. Valt er überhaupt iets te 'leren', en waar vindt dat dan bij voorkeur plaats?

Wie bij de overheid werkt als ambtenaar, ontmoet vroeger of later weerstand bij publieksgroepen. Die weerstand kan vele gedaanten aannemen, van verwondering tot cynisme en woede. De uitkomst kan variëren van blijmoedig 'herformatteren' tot droefgeestig vervreemden. Het kan dus het product zijn van een directe ervaring, maar evengoed indirect via de media of netwerken rond beleid tot stand zijn gekomen. Het omstreden karakter van overheidsoptreden, de complexiteit van beleidsvormingsprocessen en maatschappelijke veranderingen maken duidelijk dat de interactie en in het bijzonder de transacties tussen beleidsmakers en het publiek steeds meer communicatieve vaardigheden vereisen.

De vaardigheden zijn moeilijk los te zien van de vele vaardigheden die in de samenleving worden ontwikkeld om meningen te manifesteren, te agenderen en invloed uit te oefenen en de snelheid, schaal en openheid waarmee dat gebeurt, met een schuin oog naar de sociale media. Meer dan 'omgaan met ongemak' is daarom sprake van 'omgaan met communicatie'. Deze omgang is in afnemende mate het 'alleenrecht' van de communicatiediscipline; degenen die in het primaire proces van beleidsvorming beslissingen nemen, besluiten over de communicatie met het publiek. Wet- en regelgeving en het treffen van voorzieningen dragen communicatieve componenten in zich en communicatie is niet iets wat je daar opplakt, maar wat er onderdeel van is: een voorschrift is net als een voorziening communicatief in zichzelf. 
De vaardigheid om die communicatieve dimensie van werk te hanteren begint met het herkennen en het erkennen van nut en noodzaak. Vanzelfsprekend maakt het hiervoor uit of je als ambtenaar een rol hebt bij de beleidsvoorbereiding of bij de uitvoering. Op dit punt maak ik een keuze in de studie, die samenhangt met de behoefte om het ontstaan van kritiek scherper in het vizier te krijgen. Ik stel daarom de beleidsmaker centraal en het moment waarop beleidsvorming een aanvang maakt: hoe vat hij de koe bij de horens, hoe wordt een opgave bij de aanvang ter hand genomen.

Met een knipoog naar de toepassing van het begrip management bij werkprocessen zou kunnen worden gesproken van het managen van teleurstellingen, of meer specifiek teleurstelbaarheid. Voor u ligt dan ook een studie naar deceptiemanagement, zoals ik in een verkennend essay in 2007 lichtvoetig beloofde (Rijnja, 2007). Immers, dát er vormen van kritiek de kop opsteken kan gezien de aanwijzingen over de aard van de taken die op het overheidsbord belanden, worden verondersteld. Beleidsambtenaren komen daarmee in beeld als primaire onderzoekspopulatie, eerder dan degenen die aan loketten of in andere executieve diensten de uitvoering van beleid ter hand nemen. In deze keuze ligt ook een pragmatische overweging besloten; we sluiten niet uit dat de verkenning van de beslissingen van ambtelijke beleidsmakers ook de praktijk van ambtenaren bij uitvoerende diensten helpt versterken. De aard van de kritiek laat zich bij die aanvang op voorhand niet beschrijven, in de zin van gegarandeerde publieke houdingen of gedragingen. Om deze reden is veeleer sprake van vermeende publieke houdingen en of gedragingen, waarmee men te maken kan hebben.

De keuzes die in de aanvangsfase worden gemaakt over de vermeende publieksreacties en de daarbij optionele beleidsmatige interventies zijn zelden het werk van louter één persoon, de omgeving waar de beleidsmaker deel uitmaakt is mede van invloed op de manier waarop iemand te werk gaat. Dat kunnen leidinggevenden zijn, directe collega's, en mogelijk anderen die bij de startfase een rol kunnen afdwingen. De wijze waarop beleidsambtenaren op dit terrein vragen stellen en weten te beantwoorden vatten we op als leerprocessen. Het expliciteren van opvattingen - aannames, ervaringen en hieraan ontleende inzichten - kan immers als een belangrijke component van de (ambtelijke) vaardigheid worden opgevat. Hiermee is ook de gedroomde vrucht van dit promotieonderzoek gegeven: een houvast voor beleidsmakers om te herkennen wat de eigen visie is op negatieve publieksreacties en wat de eigen opties zijn om met deze reacties om te gaan. Dat houvast adresseren we om te beginnen aan de beleidsmaker zelf, en vervolgens aan hen die in staat kunnen stellen om tot toepassing over te gaan. Dat kunnen collega's zijn, leidinggevenden of ondersteuners en opleiders. Op grond van het belang kennis over te dragen kan een derde centrale onderzoeksvraag worden toegevoegd:

III. Welke lessen kunnen worden ontleend aan de kennis over de beoordeling van kritiek op overheidshandelen door beleidsambtenaren, en de gedragingen die hiervan het gevolg zijn? 


\section{Samenvatting onderzoeksvragen}

I. Welke betekenis heeft de specifieke context 'overheid' voor de beslissingen die beleidsambtenaren nemen over het contact met het publiek? (verklaring)

II. Welke mogelijkheden heeft een beleidsambtenaar om de context te herkennen en te hanteren bij het contact over omstreden beslissingen? (toepassing)

III. Welke lessen kunnen worden ontleend aan kennis over de beoordeling van kritiek op overheidshandelen door beleidsambtenaren, en de gedragingen die hiervan het gevolg zijn? (toerusting)

\subsection{Opbouw van het onderzoek}

Het onderzoek is in drie delen opgebouwd.

A. Theoretische verkenningen. In de eerste - theoretische - sectie verken ik twee dragende begrippen uit de inleiding. In de eerste plaats belicht ik de overheid als context van werk: wat maakt de overheid als biotoop onderscheidend en wat betekent dit voor de werknemers, in het bijzonder de beleidsambtenaren? Het tweede thema dat in dat deel aan de orde komt is het omgaan met werkgebonden kritiek: wat karakteriseert werk en hoe gaat een werknemer hiermee om? Ik baseer deze verkenningen op literatuuronderzoek.

B. Empirisch deel. Vervolgens onderzoek ik twee kernthema's, die uit de theoretische verkenning oplichten. In het eerste onderzoek belicht ik de betekenisverlening aan werk. In deze studie naar 'work meaning' komt naar voren welke factoren een sleutelrol spelen bij het amb(ach)telijk handelen bij de overheid. In het tweede onderzoek staat de vraag centraal hoe beleidsambtenaren de in de theoretische verkenning gesignaleerde systeemspanningen herkennen en hanteren. Welke lessen kunnen worden ontleend aan de ambtelijke coping met de contextgebonden weerstand? Beide onderzoeken zijn kwalitatief van aard. Naast de uitkomsten van de theoretische verkenningen heeft aanvullend bronnenonderzoek in beide gevallen richting gegeven aan de onderzoeksvragen en de onderzoeksopzet. Vervolgens hebben semi-gestructureerde interviews plaatsgevonden.

C. Conceptueel model. Het onderzoek naar aanleiding van het theoretisch kader leidt naar een conceptueel model voor ambtelijke taxaties van (vermeende) weerstand. 
In dit model breng ik de verzamelde variabelen samen die de coping (omgang) met lastige opgaven kunnen bevorderen. Aan de hand van reconstructies van ambtelijke beslissingen toets ik de factoren die bij beleidsambtenaren het verschil kunnen uitmaken. Hiertoe zijn drie casestudies verricht. De geaggregeerde uitkomsten van deze studies en de data-analyse leiden naar het slothoofdstuk met conclusies over de centrale vragen uit paragraaf 1.4 .

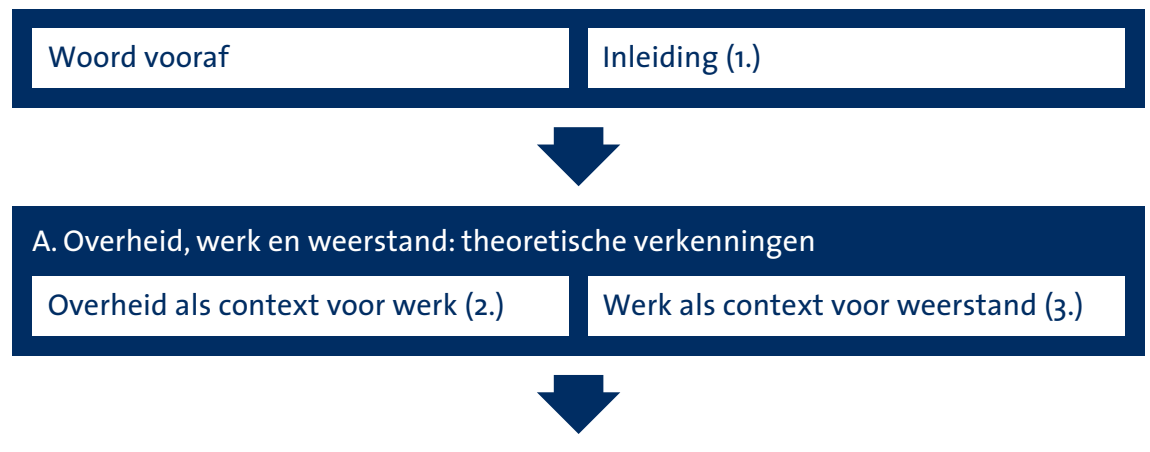

\section{B. Empirie: onderzoeken naar werk en systeemspanningen}

De betekenis van ambtelijk werk (4.) Onder de spanningsbogen (5.)

\section{De ambtelijke beslisser: conceptueel model getoetst}

De ontmoeting met weerstand (6.)

De ambtelijke taxatie: casestudies (7.)

Conclusies en aanbevelingen (8.)

\section{Figuur 1.1. Opbouw onderzoek}

Figuur 1.1. vat de opbouw van het onderzoek samen. De gekozen aanpakken van de diverse deelonderzoeken worden in de betrokken hoofdstukken (4, 5 en 7) nader toegelicht. Daarbij zal ik ook ingaan op de eigenschappen van de gekozen methoden. Vooruitlopend daarop wil ik aan de voet van dit proefschrift stilstaan bij de gekozen onderzoeksaanpak en in het bijzonder de keuze voor het verrichten van uitsluitend kwalitatief onderzoek.

Met dit onderzoek wil ik betekenissen en achtergronden van gedragingen exploreren. Miles en Huberman (1994) wijzen op de waarde van kwalitatief onderzoek voor het identificeren van bepalende interacties, processen, ervaringen, gedragingen en de variabelen die hierbij een rol spelen. Ik wil (nieuwe) theorieën genereren voor situaties waarvan ik meen dat weinig onderzoek is gedaan en waarvan we dus nog weinig weten: waarom leiden bepaalde processen en gedragingen tot bepaalde uitkomsten? In deze studie ben ik daarbij niet 
zozeer in een 'hoeveel' als wel in een 'hoe' geïnteresseerd: welke afwegingen en keuzes maken mensen in de context waarin zij werken? Hierbij passen kwalitatieve methoden. Ik realiseer me daarbij dat kwalitatief onderzoek zucht onder kwalificaties als 'vaagheid' (o.a. Boeije, 2005). De literatuur over kwalitatieve methoden laat echter een stevige focus op structurering zien, in het bijzonder van kernelementen als doelstellingen, conceptuele opbouw, formulering van onderzoeksvragen en organisatie van dataverzameling en - analyse (Miles \& Huberman (1994), Maxwell (1998) Boeije (2005). Aan iedere methode kleven overigens beperkingen.

In beschouwingen over kwalitatief onderzoek worden vooral betrouwbaarheid, validiteit en generaliseerbaarheid genoemd (Boeije, 2005, Miles \& Huberman, 1994, Tsoukas, 2009).

Die beperkingen onderken ik. Omwille van de betrouwbaarheid krijgt bij de deelonderzoeken de onderbouwing van procedures aandacht en vestig ik aandacht op het gebruik van protocollen voor dataverzameling, standaards voor scores van uitkomsten en het analyseren van de data. Ten aanzien van de validiteit of geldigheid van kwalitatief onderzoek voeren Miyata en Kai (2009) aan dat bij kwalitatief onderzoek niet alleen het ontwerp vooraf, maar ook de mogelijkheden tot interpretatie en bijsturing tijdens het onderzoek er toe doen. Meer dan validiteit is de betrouwbaarheid een punt van aandacht volgens deze auteurs; die wordt bevorderd door triangulatie van methoden en toetsing van de uitkomsten (bijvoorbeeld in feed back interviews en expertgesprekken). Het literatuuronderzoek, de interviews en de reflecties zijn nadrukkelijk gericht op het verkrijgen van inzicht in en onderbouwing van verschillende invalshoeken, meningen en visies. Juist door het samenbrengen van meer invalshoeken wordt betekenis gecreëerd (Swanborn, 2005). De generaliseerbaarheid tenslotte is bij kwalitatief onderzoek een spannende opgave. De onderzoekspopulatie is kleiner en de uitkomsten van gesprekken zijn voor meerdere interpretatie vatbaar dan cijfermatige metingen. Tsoukas (2009) meent dat juiste kwalitatieve (case)studies met een beperkt aantal onderzoeken gelegenheid bieden voor een oorspronkelijke en ook een fijnmazige bestudering van gedragingen en fenomenen. Hij stelt: 'The distinctive theoretical contribution of small-N studies stems from seeing particular cases as opportunities for further refining our hitherto conceptualization of general processes. Particular cases share family resemblances rather than an overarching feature'. Kwalitatief onderzoek biedt aldus ruimte om de diepte in een thema op te zoeken en specifieke thema's aan te lichten. Lincoln en Guba (1985) zijn van mening dat generaliseerbaarheid als doel bij kwalitatief onderzoek niet past; eerder gaat om 'transferability' en 'extrapolation': kun je de gegevens omzetten naar andere situaties.

Bij onder meer Miles en Huberman (1994) en Boeije (2005) vinden we tenslotte een voor dit proefschrift betekenisvol element in kwalitatief onderzoek, te weten de ruimte voor inbreng van de onderzoeker c.q. organisatie bij deze typen van onderzoek. De 'onderzoeksruimte' is in het geval van deze buitenpromovendus een relevant thema. Als onderzoeker sta ik immers in de onderzoeksomgeving, als ambtenaar heb ik een mate van toegang tot andere ambtenaren en hun casuïstiek waar wetenschappers van buitenaf niet of in ieder geval minder eenvoudig toegang toe hebben. Deze onderzoekspositie bood mij uitstek een gelegenheid om cases op te sporen, ambtenaren aan te spreken en dus te investeren in de netwerken die mogelijkheden die juist deze onderzoekende ambtenaar ten dienste 
staan. Tsoukas en Knudsen (2003) beschrijven de discussie dienaangaande waarbij ze drie hoofdstromingen onderscheiden. Aan de ene kant van het spectrum zie je een pleidooi voor (zo goed als) volledige objectiviteit, aan de andere kant een volledig subjectief standpunt. Alle verzamelde data worden dan gezien als beïnvloed door (het standpunt van) de onderzoeker. Hier tussenin vind je een benadering waarbij sprake is van 'genuanceerde objectiviteit'. Daarbij sluit ik aan vanuit het besef dat je een zekere subjectiviteit niet kunt uitsluiten (Boeije, 2005). Het is zeer de vraag of een objectivistische uitgangspositie houdbaar is; we zijn niet vrij van aannames met betrekking tot de overheid en ambtenaren.

Met verwijzing naar de voornoemde publicatie van Tsoukas en Knudsen onderstreep ik hier het belang van verduidelijking van deze uitgangspositie in het wetenschappelijk onderzoek én van het systematisch reflecteren op deze onderzoekspositie.

\subsection{Relevantie van het onderzoek}

Ik zie een maatschappelijke, een professionele en een wetenschappelijke betekenis voor het verrichten van dit onderzoek op dit moment.

De maatschappelijke relevantie schuilt in de aanhoudende behoefte aan duidelijkheid over de wijze waarop de overheid zich in haar dagelijkse handelen met de samenleving verhoudt. Het ambigue karakter van 'de' overheid maakt duidelijk dat dit handelen in de praktijk steeds minder zaak is van één 'vent' en één 'tent', maar uitwaaiert: zowel binnen overheidsorganisaties als in allerhande netwerken en publiek-private constellaties waar de overheid deel van uitmaakt. Uit een oogpunt van publieke verantwoording is er belangstelling voor de totstandkoming van het overheidsaandeel, en in het bijzonder de wijze waarop bestuurders en ambtenaren tot beslissingen komen ten aanzien van de bejegening door die overheid van het publiek. Dit onderzoek kan bijdragen aan een scherpere aftekening van de maatstaven waarop de overheid beoordeeld kan worden. Zoals door onder meer Ringeling (2004) is aangetoond kunnen overheidsprestaties zelden aan de hand van bedrijfsmatige maatstaven als effectiviteit en efficiency worden beoordeeld; wie handelt in processen - probleemoplossend vermogen - vraagt om beoordeling op basis van procesgerichte maatstaven als zorgvuldigheid, betrouwbaarheid en slagvaardigheid. Die processen worden ontworpen door actoren die bij het ontwerp van overheidsbemoeienis beslissingen nemen over de wijze waarop de samenleving tegemoet wordt getreden. Er is behoefte aan een anatomie van de sleutelmomenten waarop ambtenaren beslissen over de publieke bejegening.

Voor de professionele relevantie wijs ik op de geringe bekendheid die bestaat over de variabelen die er toe doen bij de totstandkoming van de - ambtelijke - bejegening van het publiek, zodra weerstand wordt verondersteld, erop wordt geanticipeerd of daadwerkelijk de kop op steekt. Veel is bekend over wat burgers beweegt, maar wat beweegt de ambtelijke beslisser? Hoe ziet hij de weerstand, hoe taxeert hij de betekenis ervan en wat voedt dan de keuzes om ermee om te gaan? Op allerlei manieren is aandacht voor het communicatief handelen van de overheid. Daarbij vervult de communicatiediscipline van oudsher een rol. 
Aanvankelijk vooral als de 'bezorger' van boodschappen aan doelgroepen en steeds meer als facilitator van gesprekken tussen de relaties die relevant zijn voor het succesvol samenkomen van problemen en oplossingen (zie: 'Factor C', het bewustwordingsprogramma om beleidsmakers sterker voor de dag te laten komen bij het beoordelen van het krachtenveld rond beleid, de boodschappen die worden overgedragen en de betekenis van de bewuste omgang met krachtenveld en boodschappen voor de communicatie in beleidsprocessen). Oogmerk van de studie is primair om de professionele ruimte van de beleidsmaker in kaart te brengen en de beschikbare handelingsperspectieven te duiden. Daarbij is en blijft de vraag aan de orde hoe de communicatiediscipline beleidsmakers hierbij kan ondersteunen, in ondersteunende zin, bij het leren communiceren tijdens beleidsvorming. Ik veronderstel hierbij een belangrijke waarde voor het welbevinden van beleidsambtenaren in een tijdperk waarin kritiek op de overheid en de ambtelijke dienst om zich heen grijpt. Er is sprake van 'bureaucrat-bashing' (Bekker, 2010b) en een toename van kritiek op de wijze waarop politici omgaan met het ambtelijke korps. Volgens voormalig minister De Vries 'is de overheid slecht voor haar eigen mensen' (2007). Met het boekje 'Lang leve de ambtenaar' heeft Wallage (2005) dit pleidooi kracht bijgezet: 'Wie een betere overheid wil, moet ophouden liefdeloos te spreken over de dienaren van diezelfde overheid. Zij zijn in potentie voor de verbetering zelfs bondgenoten', betoogt hij. De vorige vice-president van de Raad van State stelt in zijn jaarverslag over 2010 vast dat de aandacht voor 'bedrijfslogica' heeft geleid tot een onderwaardering van de ambtelijke professional. 'Wie een school of een zorginstelling ziet als een bedrijf, zal nooit recht doen aan de eigenheid van de taak van de daar werkzame professionals. Hij zal van de regen in de drup raken. leder van bovenaf opgelegd veranderingsproces voedt het verzet of de ontgoocheling van die professionals. De ziel van de school of de zorginstelling is de zelfstandige verantwoordelijkheid van de samenwerkende beroepsbeoefenaren' (Raad van State, 2010). Ook dat appèl versterkt de behoefte aan een anatomische les over de ambtelijke beslisser.

De wetenschappelijke waarde van dit onderzoek hangt direct samen met een roep om zicht op de variabelen die bij de ontmoeting van overheid en publiek in weerstandgerelateerde situaties verbindingen kunnen maken en breken. Het ontbreken van geëvalueerde praktijkervaringen bemoeilijkt het doen van gezaghebbende uitspraken over de mogelijkheden van beleidsmakers systematisch om te gaan met publieksreacties. Het ontbreken van die kennis staat een voortvarende toerusting van beleidsambtenaren in de weg. Dat legitimeert een studie naar de factoren die het verschil kunnen maken. Daar plukken de 'afnemers' van beleid vruchten van, maar om te beginnen de 'bezorgers' van (lastige...) boodschappen.

Het domein van deze studie beweegt zich hiermee in een driehoek overheid werk - leren. Kennis over ambtelijke beslissingen bij weerstand kan worden geput uit een op voorhand breed onderzoeksgebied. Ik benut inzichten uit diverse vindplaatsen binnen de sociale wetenschappen en kies daarbij een gecombineerd perspectief. Dat wil zeggen dat ik zowel op 'actor', 'structuur' als 'verandering' focus. De structuuroptiek richt zich op structuren, functies, regels, normen, instituties en hun invloed op en beïnvloeding door de sociale spelers; de actoroptiek gaat over de sociale spelers, individuen, groepen, organisaties, hun waarden, 
opvattingen en keuzes in relatie tot de spelregels en cultuur en de veranderingsoptiek belicht de dynamiek van dit sociale samenspel, verandering zelf, evolutie, brengt nieuwe verhoudingen tot stand, kritiek en reflectie leiden tot vernieuwing. De drie optieken omvatten het perspectief van sociale ontwikkelingen.

Ik heb voor deze studie nadrukkelijk de wetenschappelijke context van de communicatiewetenschap gekozen. De gedragswetenschappen richten zich bij uitstek op de totstandkoming, ontwikkeling en effecten van wat mensen doen. De ontmoeting met de faculteit Gedragswetenschappen van de Universiteit Twente maakte daarbij duidelijk in welke mate we hier kunnen putten uit bronnen van de sociale psychologie. Thema's als kennis, houdingen, percepties, verwachtingen, publieksreacties, beeldvorming en betekenisverlening gaan daardoor leven. De Universiteit Twente biedt daarmee een ideale omgeving om ervaringen en inzichten te scherpen en te slijpen. 


\section{A. Theoretische verkenningen: overheid, werk en weerstand}

Overheid als context voor werk (2.) Werk als context voor weerstand (3.)

Wat betekent het om te werken bij de overheid? De beantwoording van deze vraag gaat vooraf aan de tweede: wat betekent werken als het om weerstand gaat? Ik verken in hoofdstuk 2 - 'Overheid als context voor werk' - om te beginnen het eigene van de overheid. Over dat eigene bestaat een gemeenschappelijke notie: er is begrip voor de instandhouding van een systeem voor taken die vrije krachten in de samenleving te boven gaan. Zoals het waarborgen van de rechtsorde en het garanderen van een basisbestaan. Strijd ontstaat als het gaat om de manier waarop die taken worden overgenomen of overgedragen en vooral ook wie daarbij welke rol krijgt, vraagt of opeist. Daarmee heb ik de werkers binnen de overheid op de korrel genomen. Wat en wie zijn bepalend voor hun werkomgeving? Overheidsbemoeienis is a priori omstreden en de beleidsambtenaar komt dan in dat strijdperk naar voren als 'verschilmaker'.

Kritiek, ongemak en tegenspel zijn niet uitsluitend voorbehouden aan werken bij de overheid. In de tweede verkenning ontwikkel ik het fenomeen werk om de relatie van werk en weerstand in beeld te brengen. Het belang van werk verschilt van mens tot mens, maar wie bewust of onbewust - zich geroepen voelt om professioneel een bepaald doel te behalen is, zoals blijkt uit onderzoek, vaker geneigd grenzen op te zoeken en als het even kan te verleggen. Onder de titel 'Werk als context voor weerstand' komt in hoofdstuk 3 de vraag op tafel wat werk voor mensen kan betekenen en hoe werkers met betekenisverlening omgaan. Ik sta in het bijzonder stil bij werk met een 'vlekje': vuil werk, werk waarbij noodzakelijk kwaad moet worden toegepast of waar sprake is van omstreden besluiten. 


\title{
2. Overheid als context voor werk
}

\author{
Gezaghebbend nee zeggen
}

\subsection{Inleiding}

Hoe komt het dat aan de overheid aanhoudend wordt getwijfeld? Wat maakt dat kerntaken van de overheid zoals het waarborgen van de rechtsorde en het garanderen van een basisbestaan steeds weer moeten worden gelegitimeerd? 'Wie vindt den toon waarin deze dissonant zich oplost?' vroeg Johan Rudolph Thorbecke zich af. Dat was in 1848 , toen de kiel werd gelegd van de huidige organisatie van ons openbaar bestuur. Kennis van het eigene van de overheid is nodig om de bewegingsruimte en de bewegingen van beleidsambtenaren beter te kunnen duiden. In dit hoofdstuk breng ik de context in beeld die zo bepalend is voor wie werkt bij de overheid. Ik belicht daartoe de overheid aan de hand van specifieke kenmerken van het 'systeem' overheid en grondslagen van het ambtenaarschap. Om vervolgens in te kunnen zoomen op ambtelijke 'systeemspanningen' die op de weg komen van de beleidsambtenaar. Ik trek onze kijk op overheid op vanuit een historisch perspectief aan de hand van een kleine canon van de publieke zaak.

\subsection{Waarom is er overheid?}

De bescherming tegen natuurdreigingen leidde in het vroege Egypte al tot het aanstellen van burgers met speciale taken. Je zou hen de vroegste ambtenaren kunnen noemen. In de autocratie van het Heilige Romeinse Rijk was het vervolgens een erebaan voor de rijke elite, een voorrecht zelfs als je werd uitverkoren om een taak te vervullen waarbij je boven andere mensen werd geplaatst om bevelen uit te voeren waartoe het gezag besloten had.

Daar hoorde geen salaris bij. De Britse historicus Watson (2004) wijst de overgang van veeteelt naar landbouw aan als vertrekpunt voor het idee 'overheid; zodra mensen besloten niet langer te jagen en op één plaats te verblijven voor hun bestaan, ontstond de vraag naar verdeling van schaarste'. Overheid staat in essentie voor 'gezaghebbende toedeling van waarden in en ten behoeve van de samenleving' (Easton, 1965). Deze systeemtheoreticus focuste in een beschouwing over het eigene van de overheid op de fundamentele opgave te komen tot bindende besluiten over omstreden onderwerpen. Verschillende opvattingen bestaan over de wijze waarop deze essentie gestalte krijgt, maar niet of nauwelijks omstreden zijn vier behoeften die als repeterende kerntaken uit de geschiedenis van de overheid naar voren komen (Hoogerwerf, 1995):

1) Waarborgen van de rechtsorde: nationale grondwet, internationale afspraken, overlegvormen en instituties helpen om de gemeenschappelijke basis voor samenleven te bewaken. Veilig samenleven vergt onderhoud en dat vraagt om een stabilisator, die we in de rechtsstaat op een bepaalde manier hebben vormgegeven, met taken en rollen voor wetgevende, rechtsprekende en uitvoerende lichamen en voor het publiek. 
2) Garanderen van een basisbestaan: een dak boven je hoofd, onderwijs, gezondheidszorg en een mate van inkomen en werk en veiligheid; overheid helpt basisvoorzieningen te creëren, organiseren en beheren. Bij de sturing van deze maatschappelijke basis is de overheid soms coördinator, soms allocator en soms stimulator, maar altijd verantwoordelijk.

3) Bevorderen van het collectieve belang: de betrekkingen tussen overheid en samenleving en die tussen leden van de samenleving onderling vragen om onderhoud. Er is een coördinator nodig om 'onmogelijke opgaven' (De Vries \& Van Dam, 1998) in de samenleving op te kunnen pakken. Denk hierbij aan collectieve goederen die op grond van bedrijfseconomische criteria links gelegd worden zoals opvangvoorzieningen en de drugsproblematiek.

4) Compenseren van de markt: de financiële crisis heeft laten zien dat banken individueel noch in gezamenlijkheid in staat waren om tegenvallende resultaten tijdig op te vangen. Ingrijpen van de nationale banken en nationale regeringen was nodig om een systeem op te vangen. Preventieve voorzieningen, regels en toezicht helpen die taak te schragen. Overheid kan overgaan tot (tijdelijke) overname van verantwoordelijkheden, en neemt dan rol van stabilisator en coördinator op zich. In feite is dit ook aan de orde bij het bestrijden van klimaatproblemen en duurzaamheid: van wie is de lucht en wie gaat er over de luchtverontreiniging?

ledere selectie is aanvechtbaar, tegelijk is sprake van een beperkte strijd over wat overheid in de kern vermag. Natuurlijk, 'het garanderen van een basisbestaan' is een complexe aangelegenheid en 'compenseren van de markt' hint onbedoeld naar een suggestie alsof overheid markt aanvult, terwijl net zo goed kan worden gesteld dat het de publieke taak is om bedrijven in staat te stellen om ongelijke prestaties of oneerlijke voordelen te voorkomen of te doorbreken. Rutgers (2011) komt op grond hiervan tot een repeterend 'simpel uitgangspunt' dat de overheid de verantwoordelijkheid moet houden voor het algemeen belang en dat zij de bevoegdheid over de uitoefening van de soevereine macht niet kan uitbesteden. De overheid kan 'zorgen voor' (reguleren, zelf handelen) en 'zorgen dat' (faciliteren, anderen in staat stellen). De ontwikkeling van de overheid helpt verklaren hoe het denken over de toe-eigening en de toedeling van het vierluik van kerntaken gestalte kreeg en vooral ook hoe de vraag evolueerde wie waarvoor aan de lat staat.

De kleine canon van de overheid hierna is opgebouwd aan de hand van (twaalf) werkwoorden. De keuze voor juist werkwoorden hangt samen met de waarneming dat de overheid er zelden in slaagt om via robuuste eindtermen duidelijk te maken wat ze doet; ze moet steeds weer vertellen hoe ze het doet en waar ze staat. Hoe overheid werkendeweg wijzer wordt. Bij het openbaar bestuur is het proces belangrijker dan het resultaat. 


\section{Afspreken}

'De eerste, bij wie het opkwam een stuk grond te omheinen en te beweren: dat behoort mij toe, en die mensen vond, eenvoudig genoeg om hem te geloven, die was de eigenlijke stichter van de burgerlijke maatschappij'. De woorden van Rousseau in de tweede helft van de $18^{\mathrm{e}}$ eeuw raken aan de aanwijzing van Watson: wie eigendom claimt, lokt conflicten uit en die kunnen beteugeld worden, door afspraken te maken en toe te zien op de naleving ervan. Om daartoe te komen zijn drie dingen nodig: samenwerking, leiding en een doordachte aanpak van de gezamenlijke problemen. Je ziet deze trits in de ontwikkeling van overheid in allerlei gedaanten terug. Dit leidde in de middeleeuwen in Nederland tot de vorming van het waterschap als collectieve voorziening tegen het dreigende water en daarmee de systemen voor overheid zoals we die ook nu nog kennen. In Le Contrat Social spreekt Rousseau van 'het grondprobleem van de mensen' (1762): ‘Er moet een vorm van samenleven gevonden worden, die met alle gemeenschappelijke kracht de persoon en de goederen van iedere deelgenoot verdedigt en beschermt, en waardoor ieder, hoewel hij zich verenigt met allen, toch slechts aan zichzelf gehoorzaamt en even vrij blijft als tevoren'. Rousseau schrijft de tekst aan het begin van de Verlichting, waaraan hij met anderen als Diderot zo'n belangrijke bijdrage heeft geleverd: een beweging die op zoek is naar de vraag wie gezag draagt na de jaren waarin de kerkelijke overheid en, steeds meer, de adel zo'n belangrijke sturende rol had vervuld (Blom, 2010). Zienderogen wint de opvatting veld, dat het mogelijk moet zijn om gemeenschappelijke afspraken te maken, via communicatie verschillen te hanteren en geschillen te voorkomen of te smoren. Meer nog dan iets wat je kunt vastleggen is er sprake van een publieke communis opinio van 'collectiviteit' en het in handen leggen van een hoger 'systeem' (Bekker, 2011).

\section{Vastleggen}

Afspraken maken voor de gemeenschappelijkheid wordt al in de middeleeuwen steeds meer een kwestie van het smeden van verbonden en het neerslaan hiervan in documenten. Teksten helpen het gezag - vorsten en edelen, de kerk - 'het collectieve' uit te drukken. De Magna Carta uit 1215 is een vroege mijlpaal, vervolgens vinden we in de geschiedenis deze grondtoon terugkomen. De Declaration des droit de l'homme et du citoyen luidt in 1789 het 'maatschappelijk verdrag' in tussen burgers, waarbij de staat de soevereiniteit krijgt als bemiddelende en toezichthoudende instantie. Steeds weer zijn in de geschiedenis grote teksten - Fransen spreken van Textes Fondateurs - aanjagers om gemeenschappen te vormen. In deze lijn past ook de Universele Verklaring van de Rechten van de mens (1948). Pessers (2006) merkt op dat het hierbij niet om een onfeilbare, maar om een praktische wijsheid gaat, het vestigen van een 'norm van de goede trouw' als basis voor het dagelijks verkeer: tussen het private en het publieke domein, tussen markt en staat, kerk en staat. Dit patroon is ook herkenbaar in de macht(en)scheiding in de Trias Politica. Hebben deze documenten aanvankelijk een status van heilige, religieuze teksten, gaandeweg gaat het om door en met burgers gestelde normen, rationele afspraken om de sociale binding, communicatie in de letterlijke betekenis van gemeenschappelijk maken. 


\section{Ritualiseren}

Wie leggen die afspraken vast? In de late middeleeuwen proberen de Bourgondische en daarna de Habsburgse vorsten in de Nederlanden de macht te centraliseren. In tegenstelling tot de monarchieën in de omringende landen ontwikkelt de republiek zich naar een sterk gedecentraliseerd bestuur, met een nadruk op eigen belangen van de steden en wat we nu zouden noemen 'een polderistische bestuursstijl'. Deze beweging naar het vinden van aansprekende vormen voor het vastleggen van gemeenschappelijke wordt vooral van onderaf gevoed. In de praktijk is zelfs sprake van een reproductie van succesvolle stedelijke structuren voor overleg en besluitvorming (zoals commissies) naar gewesten en weer verder bottomup naar Den Haag. Van nauwkeurige planvorming is in die tijd geen sprake, wel van een behoorlijke 'bestuurlijke drukte', met een oplopende mate van complexiteit stad naar gewest naar de Unie. Diderot noteert na een journalistieke reis in 1773-1774 in zijn Encyclopedie: 'Sinds de Unie der Zeven Provinciën in 1579 in Utrecht tot stand is gekomen heeft de republiek ondanks gekrakeel in de algemene of bijzondere vergaderingen haar eenheid behouden. De aanhoudende externe druk (oorlog tegen Spanje, handhaving tussen andere grootmachten en de zeeoorlogen) en de instelling van een bestuurlijke elite worden als belangrijke redenen opgevoerd voor het aanhouden van polderen, netwerkvorming en pragmatisch bestuur. Het prille bestuur drijft boven alles op vertrouwen en vrijwillige vormen van samenspraak, samenwerking en rolverdeling. Niet zonder effect, want de Republiek staat voor een krachtige groei, die pas na tweehonderd jaar op grenzen stuit. De concurrentieslag op zee wordt verloren, het Europees financieel centrum van Amsterdam verhuist naar Londen, de druk van andere Europese grootmachten neemt toe. De bestuurlijke elite krijgt aristocratische trekken, en het 'praktische samenwerkingsverband van commercieel opererende stadsstaatjes' (Pleij, 2007) verliest zienderogen betekenis.

\section{IV. 'Organiseren'}

Te midden van deze 'bestuurlijke drukte' ontstaat specialisatie, waarvoor de prinsen en regenten meer en meer gespecialiseerde medewerkers in dienst nemen: beleidsmedewerkers in hedendaagse termen. De systematische start van deze vrijgestelden, de ambtenarij, vinden we bij de clerus (de weinige, echte geletterden) en de hofadel, waarvan falen immers onherroepelijk machtsverlies betekent, in de vorm van oorlog en materiële kosten. Sinds de late middeleeuwen is het gebruikelijk dat voor belangrijke functies, zoals thesaurier, pensionaris en stadsdokter, mensen worden aangetrokken met een juridische respectievelijk medische opleiding (mooi uitgewerkt op www.politiekcompendium.nl). Voor het overgrote deel van de functies wordt de deskundigheid opgebouwd als vrijwilliger ('volontair': zoals klerken) of in de vorm van wat we nu training-on-the-job zouden noemen (zoals op lokaal niveau de vorming van schoolmeesters en vroedvrouwen). De selectie van deze functionarissen vindt plaats op basis van persoonlijke relaties, het gaat in deze eerste stappen van de ambtelijke professie echt om vrijgestelden, die datgene doen waar de bestuurder niet aan toekomt. In de $18^{\mathrm{e}}$ eeuw zien we een doorontwikkeling gestalte krijgen, er is behoefte 
aan bewijsvoering, empirie, en aan verantwoorde, bestendige productie van beleidsrelevante kennis in de vorm van statistiek, staathuishoudkunde en demografie. De komst van de gespecialiseerde medewerkers is ook een prille voorbode voor een overgang van meer politieke georiënteerde naar meer ambtelijk georiënteerde besluiten. De formulering van beslissingen en de verkondiging ervan krijgt meer aandacht, getuige de formele sollicitatieprocedures bij schoolmeesters en vroedvrouwen (bekendmaking in kranten, selectiekandidaten, gesprekken met en bekwaamheidstest door kandidaten, aanstelling). De procedures leiden tot een opener vorm van werving en selectie, dat wil zeggen dat de rekrutering steeds minder afhankelijk is van persoonlijke contacten. Het rekruteringsdomein voor dit type functies is niet langer meer lokaal, maar regionaal. Voor ambtenaren-in-engere-zin ontstonden dergelijke procedures na het midden van de vorige eeuw. Voor hogere ambtelijke respectievelijk bestuurlijke functies in dorp, stad of gewest is over het algemeen bloedverwantschap en/of vriendschap met zittende functionarissen voldoende. Daarbij geldt echter wel dat voor de hoogste ambtelijke functies (griffier, raadspensionaris) in de gewesten over het algemeen een juridische opleiding noodzakelijk wordt geacht, terwijl enige bestuurlijke of andere relevante maatschappelijke ervaring bij rekrutering een streepje voor geeft. Lagere functies zijn te vergeven door politieke bestuurders. Door middel van het stelsel van politieke patronage verwerven deze steun. Zeker in de hogere geledingen is het onderscheid tussen politieke en ambtelijke functies nauwelijks te maken.

\section{Specialiseren}

Met de vestiging van het ambtenaarschap ontstaat een toenemende specialisatie in het denken over de rol van de overheid, die halverwege de $19^{\mathrm{e}}$ eeuw in Nederland culmineert in een grondwet en daarmee een belangrijke stroomlijning van het administratieve stelsel. Weber legt een verband tussen de kwantitatieve groei en de kwalitatieve uitbreiding van de bestuurstaken, techniek van organisatie en democratische betrokkenheid en de ontwikkeling van bureaucratie. Precisie, snelheid, eenduidigheid, het vermogen om zaken schriftelijk vast te leggen en de behoefte aan het voorkomen van wrijvingen voeden de aandacht voor het structuren van het bestuurlijke stelsel. Weber noteert een kanteling van traditionele, feodale gezagsverhoudingen ('Gemeinschaft') naar op rationele grondslagen gebaseerde, functionele gezagsverhoudingen ('Gesellschaft'). De latere rechtspositionele vertaling hiervan in een aparte 'ambtelijke status' is ontstaan omdat een speciale positie nodig en wenselijk werd geacht voor degenen die het gezag van de overheid bekleedden en uit publieke middelen werden gefinancierd. In de jaren 1800-1840 wordt benoeming op basis van patronage geleidelijk afgeschaft en een rangenstelsel met promotiecriteria ingevoerd. Verkoop van ambten, het meedelen in de inkomsten van boetes en andere tot dan toe geaccepteerde vormen van aanvulling op het inkomen verdwenen geleidelijk.

Deze ingrepen in de inkomsten van ambtenaren werden mogelijk door tegelijkertijd pensioenen en voorzieningen voor nabestaanden in te voeren. Zo kennen we in Nederland sinds 1804 een weduwen- en wezenpensioen en sinds 1814 een ambtenaren- en een gehandicaptenpensioen. Verdere ontwikkelingen in de late negentiende en vroege twintigste 
eeuw betreffen verfijning van dit stelsel en verdergaande professionalisering van het ambt middels opleidingsvereisten en specialisaties. Zo werden in de periode 1850-186o open competitie en toelatingsexamens ingevoerd. In de hausse aan primaire wetgeving die vanaf die jaren ontstaat is het niet verwonderlijk dat zoiets als een ambtelijke status ontstaat. Nederland krijgt een ambtenarenwet in 1929. Deze wet bracht de ambtelijke aanstelling in het veld. Die verzekert vooral dat het publieke belang wordt behartigd en dat ambtenaren ondergeschikt zijn aan 'de' politiek. Minstens zo belangrijk is dat de ambtenaar beschermd is tegen ontslag op politieke of religieuze gronden. Tegenover een inperking van burgerlijke vrijheden zoals medezeggenschap en vrijheid van meningsuiting en een gewoonlijk laag salaris staan zaken zoals (aanvankelijk) een grotere baanzekerheid en een betere pensioenvoorziening. Een paradox, die wellicht nog steeds op gaat, is dat hierdoor het verwerven van een ambtelijke baan gewild werd en dat tegelijkertijd ambtenaren verguisd werden.

\section{Uitbouwen}

De ontwikkeling naar een deskundiger ambtelijk apparaat heeft zich in de twintigste eeuw doorgezet. Hoogerwerf (1995) markeert kort na het midden van de negentiende eeuw een krachtige doorontwikkeling van de overheid. Vele zaken waarover tot dan toe alleen door individuele burgers, bedrijven, organisaties van het particulier initiatief werd beslist - of door blinde krachten, zoals de natuur en de demografische ontwikkeling - worden onderwerp van hoger gezag 'en dus van de politiek'. Het einde van de 19 e eeuw toont voorbeelden van de uitbouw van de zorg voor louter interne en externe veiligheid naar opbouwende taken. De nachtwakersstaat evolueert begin $20^{\mathrm{e}}$ eeuw naar de verzorgingsstaat, het welzijn en de gezondheid van de bevolking vragen indringend aandacht en de overheid claimt een rol om bij te dragen aan de economische ontwikkeling en de daarvoor benodigde economische infrastructuur en kennis (onderwijs). Vooral na de Tweede Wereldoorlog hebben overheidsinstellingen in toenemende mate specialisten aangetrokken. Gegeven de uitbreiding van het taken- en voorzieningenpakket in"nieuwe" beleidsterreinen in de twintigste eeuw, werden meer en meer beleidsambtenaren aangetrokken die een andere dan juridische opleiding hadden genoten (zoals onderwijskundigen, landbouwingenieurs, economen, bestuurskundigen, sociologen, planologen, politicologen). Hun invloed op de beleidsontwikkeling is onmiskenbaar.

Ter illustratie: het aantal overheidsambtenaren stijgt van 20.000 arbeidsjaren in 1850 tot 69.000 in 1901 en vervolgens naar ruim 224.000 pal voor het uitbreken van de Tweede Wereldoorlog. In 1900 telt het ministerie van Binnenlandse Zaken twaalf ambtenaren op de afdeling onderwijs, negen voor verkeer en waterstaat en zes voor landbouw en visserij. In 1981 staat de teller op totaal 549.200, met in de daaropvolgende dertig jaar een val naar 454.000 mensen in 2009 ( Rijk 120.000, Krijgsmacht 68.000, zelfstandige bestuursorganen (ZBO's) 46.000 , provincies 13.000 , gemeenten 174.000 , waterschappen 10.000 en gemeenschappelijke regelingen 23.000 . In de veiligheidssector tellen we 66.000 mensen $(63.000$ bij de politie en 3.000 bij de magistratuur). Worden ook het onderwijs en de wetenschap meegeteld dan 
noteren we 187.000 mensen in het basisonderwijs, 108.000 voor het voortgezet onderwijs, 56.000 in het middelbaar- en 39.000 in het hoger beroepsonderwijs, 50.000 bij universiteiten, 3.000 bij onderzoeksinstellingen en 60.000 bij universitair medische centra. In totaal komen we dan op 2,2 miljoen mensen, dat is $28,7 \%$ van de beroepsbevolking (BZK, 2009) ${ }^{3}$. Hoeveel mensen bij de overheid werken is overigens vooral afhankelijk van de taken die de overheid voor zich ziet weggelegd. Vanaf 1798 richt de nieuwe centrale overheid zich, behalve op een verbeterde organisatie van taken die al tijdens de Republiek tot het staatsbelang worden gerekend (financiën, buitenlandse zaken en defensie), vooralsnog op regelgeving en toezicht op de naleving. Vooral de lokale overheid werd aangesproken op de uitvoering, aangezien taken op het terrein van onderwijs, gezondheidszorg en maatschappelijke dienstverlening, waterstaat en dergelijke al eeuwen tot het takenpakket van het lokale bestuur behoorde. Een en ander betekende wel dat de betrekkingen tussen centraal en lokaal bestuur verder werden aangehaald.

Tussen 1820-1870 breidde het takenpakket zich uit, het betreft zowel een intensivering (uitbreiding/aanpassing van bestaande taken) als een extensivering van taken (opname van nieuwe taken) die niet alleen tot uitdrukking kwam in regelgeving, maar ook in - overigens niet sterke - stijging van het aantal overheidsfunctionarissen. Op lokaal niveau daalde het aantal functionarissen zelfs. Deze daling wordt veroorzaakt, omdat verschillende uitvoerende werkzaamheden worden geprivatiseerd of verzelfstandigd (openbare werken, reiniging). Voorts daalde het aantal functionarissen bij de lokale markten, eenvoudig omdat zij - gegeven de dalende betekenis van de markthandel - boventallig waren geworden. In de jaren 1850-1870 doet zich opnieuw een daling voor, en nu omdat de lokale financiën door de afschaffing van tollen en accijnzen (1852-1865) op geheel andere leest worden geschoeid. Rond 1850 lijkt het erop dat de overheid zich - zowel centraal als lokaal - heeft teruggetrokken op de traditionele taken van handhaving van openbare orde en veiligheid, financiën, buitenlandse zaken en defensie (uiteraard alleen centraal) en regelgeving. Overigens wijken de ontwikkelingen in Nederland niet af van wat elders in West-Europa gebeurde. De idee van overheidssturing wordt als verouderd beschouwd en bestuurders menen meer ruimte te moeten laten aan de particuliere sector. De ontwikkeling van de verzorgingsstaat wordt vooral gekenmerkt door de opbouw van zorgtaken. Heeft de centrale overheid de zorg om de kwaliteit van het bestaan gedurende enkele eeuwen overgelaten aan het particulier initiatief en het lokaal bestuur, nu neemt zij deze zorg op als haar verantwoordelijkheid. Vooral vanwege onvrede over de kwaliteit en/of de prijs van particuliere collectieve diensten (woningbouw, water-, gas- en elektriciteitsvoorziening) en het feit dat de

3 Van der Meer en Van der Berg (2011) merken op dat de verschillende definities van de personele omvang tot terughoudendheid manen. Vooral in nutsbedrijven, openbaar vervoer en academische ziekenhuizen is sprake van een krimp, bij de openbare orde en veiligheid, onderwijs en zorg is sprake van groei. Ze merken op basis van internationale vergelijking van het ambtelijk aandeel in de beroepsbevolking op dat Nederland over een relatief klein ambtelijk apparaat beschikt. Tegenover 'lijstaanvoerder' Groot-Brittannie $(4,66 \%)$ en Duitsland $(3,68 \%)$ steekt de 2,66 \% van Nederland bescheiden af. 
private sfeer onvoldoende antwoord biedt op de stijgende vraag naar diensten (armenzorg en de arbeidsbemiddeling). In een tijdsbestek van ongeveer 30 jaar (1870-1900) worden op initiatief van gemeentelijke overheden tal van voorheen geprivatiseerde taken (reiniging, openbare werken) en tal van nieuwe taken opgenomen (openbare nutsbedrijven). Daarnaast doen zich belangrijke taakuitbreidingen voor als gevolg van centrale wetgeving, bijvoorbeeld op het gebied van het openbaar onderwijs. Processen van ambtelijke specialisatie zetten zich inhoudelijk en kwantitatief verder door.

\section{Waarderen}

In toenemende mate ontstaat aandacht voor waarden als richtsnoer. Dit gebeurt in de vorm van compromissen, aanbrengen van nieuwe hiërarchie in vigerende waarden, het aanbrengen van differentiatie naar doelgroepen of toepassingen en in de vorm van wat Tropman (1981) een 'scheidsrechterlijke aanpak' noemt: het overdragen van de beslissing over de toedeling van waarden aan een rechter of een andere autoriteit. Die 'waardenoriëntaties' springen naar voren als - toenemende - pogingen om het eigene van de overheid om schaarse middelen te verdelen van toetsstenen te voorzien. Toetsstenen die zich, in de ontwikkelende context van ambtenaren als vrijgestelden van bestuurders, dus moesten lenen voor een discours met het publiek. Niet alleen voor oordelen binnenskamers, maar juist voor een maatschappelijke interactie en democratische toetsing. De tentakels van de Verlichting kruipen overal omhoog. Vrijheid, gelijkheid, tolerantie en verdraagzaamheid wortelen als dragende waardenoriëntaties. De opvatting van Rousseau in Le Contrat Social leest dan als een pleidooi voor oriëntatie van de rol van de overheid op het idee van gelijkheid. Naast gelijkheid komt het idee van vrijheid als dominante waarde naar voren in Montesquieu's De l'esprit des lois van 1748. Ook hij baseerde zich op de Engelse praktijk toen hij de trias politica ontwierp, de scheiding van de wetgevende, de uitvoerende en de rechterlijke macht. Andere richtinggevende oriëntaties betreffen de rol van tolerantie en verdraagzaamheid. De woorden van de liberale theoreticus John Stuart Mill uit 1859 worden dan aangehaald: 'Als de gehele mensheid met één uitzondering dezelfde opvatting had, terwijl die ene persoon een tegengestelde opvatting koesterde, dan zou de mensheid even weinig recht hebben om die ene persoon tot zwijgen te brengen als hij zou hebben om de mensheid het zwijgen op te leggen, als hij de macht had'. Meer auteurs wijzen op het samenkomen van vrijheid, gelijkheid en verdraagzaamheid als basale waarden onder democratie, en een daarbijhorende passende, evenwichtige besluitvorming.

Maar wie mag oordelen over deze waarden? In alle democratische staten in de $19^{\mathrm{e}}$ eeuw ontstaan bestuurlijke stelsels met vormen van indirecte of representatieve democratie. Met als sleutelbegrip de keuze voor 'vertegenwoordiging': het staan van een deel voor het geheel, het handelen voor en in naam van een ander. Centrale begrippen zijn hierbij 'lastgeving' (de volksvertegenwoordiger is zaakgelastigde die de wil van het de kiezers heeft uit te voeren) en 'machtiging' (er is niet zozeer sprake van een opdracht als wel van een volmacht van de kiezers). De grote wijziging die ten gevolge van de Nederlandse Grondwet in 1814 
gestalte krijgt is dat de vertegenwoordiging niet langer plaats zal hebben aan de hand van een 'verscheidenheidsmodel' (representatie op basis van standen en andere groepsbelangen), maar op basis van een 'eenheidsmodel' (het algemeen belang). In de loop van de $19^{\mathrm{e}}$ eeuw doet de (overigens nimmer grondwettelijk verankerde) partijvorming haar intrede, waarbij de volksvertegenwoordigers zich in de eerste plaats opstellen als 'lasthebber' en 'gemachtigde' (en in toenemende mate ook medewetgever, medebeleidsvormer en controleur) van achterbannen van hun partijen. De Grondwetswijziging van 1848 is een belangrijk moment voor de politieke democratisering, als ook in ons land rechtstreekse verkiezingen worden ingevoerd.

De betekenis van deze ontwikkelingsgang voor de ambtelijke kant van de overheid wordt vaak minder benadrukt. Het gaat vaak over de bestuurlijke dimensie, de inrichting van de politieke en bestuurlijke processen. Pessers (2006) onderstreept in een lezing de betekenis van waardenoriëntatie voor de legitimering in een bredere zin. Haar woorden zijn een pleidooi voor publieke verantwoording van allen die het openbaar bestuur gezicht geven. 'Nemen we de constitutionele waarden van het publiek domein die voor het openbaar bestuur de belangrijkste referenties zijn. Ambtenaren en professionals in de non-profit sector behoren onpartijdig, voorspelbaar, professioneel, dienstbaar aan en verantwoordelijk voor de publieke zaak te zijn. De burgers moeten erop kunnen vertrouwen dat de informatie van de overheid op juistheid berust, dat de regels fatsoenlijk zullen worden toegepast, dat ambtenaren in staat zijn hun discretionaire bevoegdheid weloverwogen uit te oefenen, dat ambtenaren geen persoonlijk belang hebben, en dat de waarheid wordt gesproken (...). Het publieke domein zou zijn sociaal integrerende functie verliezen indien burgers geen vertrouwen meer hadden in ambtenaren, in politieagenten, in rechters, in hulpverleners, in docenten of in wetenschappers'.

\section{Verankeren}

De voornoemde twee werkwoorden - specialiseren en waarderen - leiden eind $19^{\mathrm{e}}$ eeuw tot een divergerende beweging die in de $20^{\mathrm{e}}$ eeuw verder zou doorzetten. Op de ene uitloper van de denkbeeldige trechter is sprake van een ambtelijke specialisatie en bijbehorende groei van de categorie vrijgestelden, op de andere uitloper politieke specialisatie, gefocust op de betekenis van waarden voor het gezaghebbend beslissen in het algemeen belang. De politieke partijen komen op en de Antirevolutionaire partij bijt in 1879 het spits af. Vanaf dat moment raken we vertrouwd met de betekenis van de idealen als richtingaanwijzers voor politieke keuzes. Waarden worden gekneed tot idealen, het begrip 'beginselen' zal wortelen. Onder socialistische regeringsleiding zou de overheid verder groeien, klinkt het vooral uit het kamp van liberalen. Daar koestert men Smith's 'onzichtbare hand van de markt die tot harmonie leidt'. Thorbecke's uitspraak 'Kunst is geen regeeringszaak' wordt tot op de dag van vandaag bij tijd en wijle uit de kast gehaald. Het vrijheidsbeginsel vindt bij aanhangers van de VVD van oudsher wat meer steun. Omgekeerd vinden de beginselen van gelijkheid en solidariteit wat meer steun bij de PvdA. Aanhangers van het christendemocratische gedachtegoed verwijzen naar Kuyper, die de (protestantse) soeveriteit in eigen kring bepleit, met de eigen aard en taak van maatschappelijke kringen als gezin, school, bedrijf en kerk. In 
katholieke kring wordt opgeroepen tot het subsidiariteitsbeginsel, met een staat die aanvult waar het particulier initiatief tekort schiet. Voor een duiding van de rol van de overheid is de grondwetsherziening van 1848 in meerdere opzichten een scharnierpunt. De strijd tussen conservatieven die de macht van de koning willen handhaven en de liberalen die een vermindering van diens macht ten gunste van ministers nastreven culmineert in het verankeren van de ministeriële verantwoordelijkheid. Van betekenis is de Grondwet van 1848 vooral voor de vestiging van de rechtsstaat, waarin verhoudingen tussen overheid en samenleving worden afgetekend, op een wijze die tot in de huidige tijd doorwerkt. Met de verankering van de 'gecentraliseerde eenheidstaat' (in 1851 gevolgd door de Gemeentewet) wordt daarbij een stelsel bepaald waarin de overheid haar taken mag uitvoeren. Het 'Huis van Thorbecke' plaatst de gemeenten centraal in het ontwerp van de overheid. Wat de gemeente niet kan moet de provincie doen en wat het niveau van de provincie overstijgt komt het Rijk toe. Alberts (1986) signaleert vanaf de grondwetswijziging van 1848 een steeds vergaande differentiatie, waarbij er in feite niet twee maar drie uitlopers zijn: politieke macht, aangeblazen door het stelsel van politieke partijen, ambtenarenmacht en zoiets als publieke macht, de 'macht der onderdanen'. Het Huis van Thorbecke kent niet lang een leeg erf.

\section{Zorgdragen}

Ik geef deze processen van uitdijing hier extra aandacht omdat ze zo betekenisvol zijn voor de positie van de ambtenaar. Die positie moet aanvankelijk vooral rekening houden met de samenhang met of het onderscheid van bestuurders; steeds meer is ook de vraag aan de orde wat het publiek kan doen als het gaat om 'de publieke zaak'. Staan in de $19^{\mathrm{e}}$ eeuw overheid en samenleving tegenover elkaar, in de eerste helft van de $20^{\mathrm{e}}$ eeuw bemoeien ze zich steeds meer met elkaar en raken daardoor meer met elkaar vervlochten. Deze vermaatschappelijking komt tot uiting in de uitbreiding van het kiesrecht, de komst van politieke partijorganisaties en een gestage verandering in de samenstelling van volksvertegenwoordigingen uit alle lagen van de bevolking. In het begin van de $20^{\mathrm{e}}$ eeuw maken ook adviesorganen een opmars. Op de vermaatschappelijking van de staat volgt een verstatelijking van de maatschappij, opkomst van de 'verzorgingsstaat'. Het welzijn en de gezondheid van de bevolking vragen indringend aandacht en de overheid claimt een rol om bij te dragen aan de economische ontwikkeling en de daarvoor benodigde economische infrastructuur en kennis (onderwijs). Het initiatief ligt bij gemeenten, met enkele duidelijke accenten. Van 1851-1870 ligt de nadruk op onderwijs in armenzorg, in 1870-1891 krijgt huisvesting en gezondheid veel aandacht, in 1918-1940 ligt de nadruk op economische dienstverlening en sociale zorg. De focus op infrastructurele voorzieningen, huisvesting, stadsvernieuwing en welzijn dateert van na de oorlog (19451985): er is sprake van een forse toename in het aantal geschreven rechtsnormen. Naarmate de overheid zich meer met de samenleving bemoeit, gaat de samenleving zich ook meer met de overheid bemoeien. Publieke debatten voedden discussies over en vooral ook besluiten tot nieuwe overheidsmaatregelen, waarbij naast de politieke partijen en het parlement, belangengroeperingen en individuele burgers een steviger stem in het kapittel opeisten. De media roerden zich in dit proces, vooral aangeblazen door de afschaffing van het 
dagbladzegel in 1869. Dat besluit stimuleert het gebruik van dagbladen en andere kranten en daarmee de mogelijkheden voor communicatie over en weer. Met media als versterkers, een proces dat maar door- en doorzet in de loop van de eeuw: aanvankelijk vooral door de vrije media en vanaf de dertiger jaren met eigen tijdschriften en andere typen massamediale uitingen van belangenorganisaties, zoals demonstraties en congressen. Deze 'megafoon'functie van de media maakt een belangrijk verschil mogelijk bij het hanteren van spanningen, als we in de historie enkele grote revoluties de revue laten passeren. Spanningen tussen het politieke en het maatschappelijke systeem en tussen waarden binnen de politieke cultuur leiden met de opkomst van de massamedia tot steeds snellere en steeds fellere mobilisatie. Het democratiseringsstreven in de jaren zeventig en het politieke onbehagen in de jaren negentig (met het jaar 2002 als kristallisatiepunt) laten een aanzienlijk snellere acceleratie zien.

Holtslag (2011) neemt waar dat gaandeweg vorige eeuw de overheid het zicht verloor op zijn eigenlijke verplichtingen (waaronder hij het bieden van adequaat onderwijs en het garanderen van adequate zorg rekent). Zorg en onderwijs behoorden tot de civil society - de maatschappelijke organisaties tussen overheid en markt - en het was juist de bedoeling dat het geen centrale bestuurstaken maar zelfbestuurstaken zouden zijn en blijven. Met toezicht als een publieke veiligheidsklep voor de deugdelijkheid van het onderwijs en de kwaliteit van de medische beroepsuitoefening. Na de ontzuiling werd de staat de facto echter steeds meer gezien als de eigenaar van de zorg- en onderwijsinstellingen, en verdween het civil societyidee uit beeld. Of markt óf overheid lijkt de vereenvoudigde, dominante zienswijze in de tweede helft van de $20^{\mathrm{e}}$ eeuw. Aan het begin van de $21^{\mathrm{e}}$ eeuw (kabinetten-Balkenende) wordt getracht de civil society weer meer in beeld te brengen (o.a. met behulp van de Amerikaanse socioloog Etzioni). Holtslag meent echter dat de overheid vooral in eigen kring ging onderzoeken hoe de maatschappelijke problemen konden worden getackeld. Die behoefte aan vaardigheid in eigen kring leidde tot de opkomst van protocollen, ketensturing, samenwerkingsafspraken, convenanten en allerhande andere beheersmatige ingrepen. Tilburg maakte furore met 'het Tilburgse model' waaruit een enorme ambtelijke vaardigheid en geloof in eigen kunnen sprak.

\section{Ondernemen}

De $20^{\mathrm{e}}$ eeuw ontvouwt zich als een etalage met uitdijende profilering op alle drie de genoemde uitlopers politiek, ambtenarij en publieke bemoeienis, met de media als versterker. Als ik in deze kleine canon inzoom op de ambtenaar komt een naar verhouding dominante doorontwikkeling in beeld. Dat wil zeggen: méér dan de politieke partijen nemen ambtenaren en adviseurs steeds meer initiatief in de vormgeving van de natie in de jaren van wederopbouw. Diverse auteurs wijzen erop dat de groei van de verzorgingsstaat de deuren opent naar een meer bedrijfsmatige oriëntatie op de overheid, de 'managementstaat' (De Vries, 2008, Ankersmit \& Klinkers, 2008). Saillant genoeg helpt de publieke druk op de overheid daarbij een handje. In de jaren tachtig komt het draagvlak voor de verzorgingsstaat steeds meer onder druk te staan, en dat kan niet alleen geweten worden aan een economische terugval, en een toename van werkloosheid. Er is behoefte aan een andere overheid, die sneller werkt, boter 
bij de vis levert en doorpakt. Er is steeds meer kritiek ook op de groei van de rijksuitgaven. Van een begroting van 154 miljoen in 1900, naar ruim 5 miljard in 1950, ruim 9 miljard in 1960 en bijna 30 miljard in 1970, quo vadis? Het begrip 'beleidseffecten' wint aandacht, en gesteund door allerhande mogelijkheden om internationale luiken te openen stromen nieuwe inzichten binnen over doelmatigheid en doelgerichtheid van besturing. Premier Thatcher in Groot-Brittannië en de Amerikaanse President Reagan winnen de harten van velen door uit te spreken dat de overheid kleiner en bedrijfsmatiger kan werken. Als in 1993 Osborne en Gaebler een miljoenenpubliek aan hun voeten krijgen met de bestseller 'Reinventing government' is duidelijk dat de verzakelijking aanslaat. Nederland vindt vertalingen in de vorm van planning and control, prestatie-indicatoren en criteria voor outputsturing. 'New Public Management' staat voor de zienswijze dat overheidsgezag geen vanzelfsprekendheid is, dat gezag moet worden verdiend en wel via het realiseren van aansprekende, tastbare prestaties. Beleidsvorming en uitvoering kunnen in dat beeld het beste worden gescheiden. Afrekenen op resultaat is het devies, want burgers hebben recht op goede waar voor hun belastinggeld. Niet door wat de overheid is of uitstraalt, maar door wat ze aan goede werken verricht verschaft de overheid zichzelf 'outputlegitimiteit', weet de politicoloog Scharpf (1999). De voormalige vice-president van de Raad van State, Tjeenk Willink, hekelt de afgelopen jaren aanhoudend het denken in termen als 'klant' en 'producten' en plaatst forse vraagtekens bij 'een bureaucratischbedrijfsmatige logica' (Rob, 2009, Jaarverslag, 2010). Stond overheid niet aan de lat voor het gezaghebbend toedelen van waarden aan de mensen en geledingen die er toe doen? Komt het er niet op aan problemen en hun oplossingen in samenspraak met probleemhebbers, professionele uitvoerders, instellingen van de burgersamenleving en burgers op hun merites te analyseren en onderzoeken? In plaats hiervan worden (nog steeds) vraagstukken als het ware in een mal gegoten die beantwoordt aan de standaardeisen van de op bedrijfsmatige leest geschoeide bureaucratie: financiële haalbaarheid, effectiviteit, efficiency en controle: 'De beleidsvorming krijgt een eigen dynamiek en wordt naar binnen gericht'. Innovatie wordt spaarzaam toegelaten.

Waartoe leidt het idee van de ondernemende overheid als het gaat om de ambtelijke vrijgestelde? Beleidswetenschapper Trommel (2009) merkt op dat publieke taken aan het begin van de $21^{\mathrm{e}}$ eeuw de facto steeds minder als een taak van publieke organisaties worden gezien. Competitie en marktwerking leiden ertoe dat 'maatschappelijke organisaties, marktpartijen maar ook individuele burgers worden ingelijfd bij een hedendaags vreemdelingenlegioen van publieke taakuitvoerders' aldus Trommel: 'Omdat het gezag van de overheid niet meer vanzelfsprekend is, moet ze laten zien dat ze presteert, om zo de loyaliteit en de trouw van de burgers te versterken. Maar omdat het om de prestatie gaat, doet het er steeds minder toe wie die levert (cursivering door mij, GR). New Public Management betekent dat burgers, maatschappelijke organisaties, private en commerciële organisaties worden ingezet voor de publieke zaak. Het is een uitbreiding van het leger van publieke functionarissen'. Holtslag signaleert dat na een periode van een goed gevoel over de overheid (accent: verzorgingsstaat) een 'populaire cultuur van slecht bestuur' de overhand heeft gekregen. 


\section{Herwaarderen}

Hoe kun je, pal na het eerste decennium van de $21^{\mathrm{e}}$ eeuw deze kleine ambtelijke canon afronden? Ik neem waar dat sprake is van een verwatering van wie waarover gaat. Bestuurders, vrijgestelde ambtenaren, lobbyisten, publicisten en minder gedefinieerde beïnvloeders vormen een amalgaam, gelegenheidscoalities, en er is een oplaaiend debat over het eigene van de overheid (CAOP, 2011). Platforms als De Publieke Zaak en Reuring Café blijken thuishavens voor bedrijfskundigen én bestuurskundigen én publicisten én ambtenaren:fuzzy structures, die bepleiten om de toedeling van overheidstaken verder te enten op slimme coalities: tijdelijk als dat kan, duurzaam als dat moet is het parool. Daarbij hoort dat de overheid niet klein genoeg kan zijn (Van Twist, 2011), het politieke meer omvat dan politici kunnen overzien laat staan claimen (Frissen, 2009) en een nieuwe taal wordt gezocht om het hybride samenkomen van bestuurlijke, politieke, maatschappelijke en ambtelijke krachten onder woorden te brengen. Het begrip civil society en ook 'gemeenschapszin' herleeft. Voor de aanpak van maatschappelijke problemen moet de overheid zich naar de samenleving buigen. Het gaat om 'het heroveren van het publieke domein', met kerntaken voor 'buurtregisseurs', 'stadsmariniers' en andere beroepsbeoefenaren met de poten in de klei. Marcel de la Haije is 'stadsmarinier' in Rotterdam: 'De overheid is voor de gewone burger geanonimiseerd. In het kader van schaalvergroting en efficiencyoperaties is het doen van meldingen gecentraliseerd en ondergebracht in grote callcenters. Terwijl vroeger bij een telefoontje aan het wijkbureau van deelgemeente of politie een half woord genoeg was, moeten bewoners nu voor hun gevoel een kruisverhoor ondergaan alvorens ze hun feitelijke melding kwijt kunnen. Terwijl de medewerker van de callcenter keurig zijn script of protocol afwerkt, voelt menig burger zich niet serieus genomen. Een tweede oorzaak van de teleurstelling van bewoners ligt in het gebrek aan terugkoppeling. Het komt te weinig voor dat bewoners na een melding horen wat 'de overheid' heeft ondernomen. Daar waar die terugkoppeling automatisch verloopt, wil dat nog wel eens misgaan. Ik sprak al veel burgers die een kaartje in de bus kreeg waarop stond dat hun probleem was verholpen, terwijl dat voor hen helemaal nog niet het geval was. Een derde oorzaak van de teleurstelling is de gebroken belofte die bewoners in zulke stadswijken keer op keer hebben gehoord van elkaar opvolgende bestuurders en ambtenaren' (Klinkers \& Van Vliet, 2010).

De eenzijdige focus op het bedrijfsmatig denken wordt minder blind nagejaagd dan in de jaren van de ontdekking van New Public Management, maar overheidswatcher Tjeenk Willink is niet gerust op het zelfreinigend vermogen van de ambtelijke dienst. In de inleidende beschouwing van het jaarverslag van de Raad van State over 2010 dient hij het risico op 'dat staatkundige instituties per saldo aan betekenis inboeten', doordat het vermogen om gezaghebbend met waarden om te gaan wegkwijnt.'Instituties zijn historisch gegroeid en vertegenwoordigen waarden. Die waarden komen tot uiting in het geheel van de staatsrechtelijke regels en gemeenschappelijke omgangsvormen die instituties intern en tegenover elkaar in acht nemen. Instituties worden onderdeel van de heersende bestuurscultuur en worden in toenemende mate gereduceerd tot louter doelorganisaties. 
Het gezag van en het respect voor instituties nemen af. Het eigen karakter van de Nederlandse staatkundige instituties wordt niet meer beseft'. Hij verwijst hierbij onder meer naar het gegeven dat de privatisering en verzelfstandiging in Nederland de afgelopen twee decennia vaak verder ging dan de Europese Unie strikt genomen eiste, en verder dan in bijvoorbeeld Frankrijk of Duitsland werd gerealiseerd. Dat kan moeilijk los worden gezien van de reactie op het ineenstorten van het verzuilde maatschappelijk middenveld en de financieringsproblemen bij publieke diensten in de nadagen van de verzorgingsstaat. Er moest een snelle reactie komen, in de vorm van een terugtredende overheid met als voorbeeld het concept New Public Management. De staat droeg in een snel tempo taken over en ging zich als een bedrijf gedragen: 'het besef vervaagde dat de verhouding tussen staat, markt en burgersamenleving en de verhouding tussen wetgever, bestuur en rechter meer in de Europese culturele traditie staan dan in de Angelsaksische'. Trommel (2009) oppert de terugtreding van de overheid in klassieke zin en de tred vooruit van de samenleving om losser van de overheid te functioneren als een uitgestoken hand te zien. Hij spreekt van een herovering van het publieke domein, 'new social governance'. Er ontstaat een focus op de netwerken waar de overheid deel van uitmaakt. Ging bij de verzorgingsstaat de aandacht vooral uit naar van bovenaf geregisseerde zorg, en in de managementstaat tot de organisatie van de bureaucratie, in de 'weefselstaat' ziet het politieke bestuur zich als de organisator van sociale verbanden. Prachtwijken, Centra voor jeugd en gezin, product- en bedrijfschappen en zelfs vredesmissies ('the Dutch Approach') komen in het teken te staan van het helpen organiseren van nieuwe, hanteerbare verhoudingen tussen overheid en samenleving. Dat vraagt wel om de erkenning dat we makkelijk kunnen doorslaan in nieuwe vormen van 'gulzig bestuur': in het nieuwe open veld van tijdelijke en duurzame, formele en informele, reële en virtuele combinaties als Don Quichottes strategieën uit de kast halen om de werkelijkheid te (be)grijpen en invloed te doen gelden. Trommel adresseert bestuurders, maar ook ambtenaren kunnen zich aangesproken voelen bij de oproep om te helpen herwaarderen waar de overheid voor staat, en waarvoor niet.

\section{Aansluiten (tot slot)}

Met dit werkwoord eindigt de reeks werkwoorden van deze kleine canon. Die begon met afspreken en vervolgens leidde langs vastleggen, ritualiseren, organiseren, specialiseren, uitbouwen, waarderen, verankeren, zorgdragen en ondernemen naar herwaarderen. Aansluiten is thans het parool, en wel op nieuwe configuraties waarin maatschappelijke vraagstukken worden opgedist, geadopteerd, gearticuleerd, geagendeerd, beoordeeld, in de politieke arena worden besproken en naar besluitvorming worden gebracht en uitvoering gestalte krijgt. En geëvalueerd... Ik maak uit de geschiedenis op dat de kern van overheid - zoals gekarakteriseerd aan de hand van Easton en Hoogerwerf aan het begin van deze paragraaf - niet zozeer in het geding is. Verschil en ook geschil ontstaan bij de vraag naar de wijze waarop de toedeling van waarden gestalte krijgt. De ambtenaar is daarbij geëvolueerd van een soort erebaan naar die van vrijgestelde rechterhand, specialist op inhoud en vervolgens besturing naar vooruitgeschoven post thuis is op inhoud, proces en rol van de overheid. Die ten behoeve van het bestuur signaleert wat gaande is, contacten onderhoudt, interventies bedenkt, besluiten 
voorbereidt en de uitvoering begeleidt en ook praktisch gestalte geeft. De vormgeving van deze interactie veronderstelt een steeds communicatievere ambtenaar, of het nu gaat om het signaleren, onderhouden, bedenken, voorbereiden, besluiten en uitvoeren. Er is inmiddels een nieuwe overheid ontstaan, die anders is dan de uitdijende, managende wederopbouwende overheid van de afgelopen halve eeuw; er is inmiddels een nieuwe ambtenaar, die meer en meer zal bewijzen hoe de overheid in staat is effectief aan te sluiten op het moment dat in de samenleving onvoldoende capaciteit beschikbaar is om schaarse mensen en middelen toe te delen, vangnetten te spannen waar dat naar de zin van volksvertegenwoordigers en andere vertegenwoordigers van het volk niet goed gebeurt en talenten aan te spreken. Was dat dan niet altijd al de bedoeling? Ongetwijfeld. Maar meer nog dan ooit maken netwerken - de menselijke, de technologische, de virtuele - het mogelijk om oplossingen te zoeken en te vinden. Wat de overheid rest is niet een nederige rol-hoewel een omdoop in 'nederheid' wel wat ongemak zou kunnen weghalen - maar een verdere verzwaring van de oorspronkelijke opgave om te doen waartoe de samenleving niet zelf in staat is. En dus 'boven' de samenleving te staan, in het volle besef van de complexiteit die dat met zich meebrengt en het ongemak en lastige duidbaarheid die dat met zich meedraagt. Misschien dat andere landen daarom geen equivalent van ons begrip 'overheid' gebruiken. Zo gaat het Engelstalige debat gaat over 'government' en 'administration'. Geen wonder dat de waardering voor overheid zo lastig te beargumenteren is, stelt bestuurskundige Rutgers (2011), aan wie ik deze verwijzing ontleen.

\subsection{Systeemkenmerken: context van ambtelijke arbeid}

Omwille van de eerder geschetste trits samenwerking, leiding en een doordachte aanpak van de gezamenlijke problemen, is dus nauwelijks van een scherpe afbakening van het domein 'overheid' te spreken. Het idee overheid heeft fluïde trekjes, en er zijn er die letterlijk van verwatering spreken. Pikant detail is in dat opzicht dat de meest zichtbare voorbode van onze huidige besturen de waterschappen zijn. Het waterschap is de voorloper van wat soms prozaïsch samengevat wordt met het begrip 'Huis van Thorbecke', de in 1848 ontvouwen 'gedecentraliseerde eenheidsstaat' van een liberale staatsman. Sindsdien fungeren gemeenten als basis van bestuur, aangevuld met provincies voor taken die de gemeentelijke capaciteiten te boven gaan en de rijksoverheid voor wat het provinciale probleemoplossend vermogen overstijgt. Dat is overheid in enge zin, de praktijk toont de hybride situatie die we in de vorige paragraaf beschreven, met een keur aan openbare en semiopenbare 'lichamen' - diensten, organen, instituten - en een gestaag uitdijend patroon van constellaties waarin publieke en private taken en rollen zijn samengebracht (zie www.overheid.nl voor een staalkaart van het openbaar bestuur). Meer dan de structuur biedt een systeembenadering houvast voor het duiden van de context waarin de ambtenaar zijn of haar weg vindt. Ik zoom verder in op het systeem overheid aan de hand van (elf) 'systeemkenmerken'. Op basis van Hoogerwerf (1995), Galjaard (1999) en Berg (2004) ontstaat de volgende karakteristiek:

a) Subjectieve grondslag: oordelen op basis van waarden voedt kleuring van keuzes. Een politieke uitspraak om een vraagstuk op te pakken is vaak het vertrekpunt, 
waarbij doelstellingen vaag en ambigu (Lipsky, 1980) worden geformuleerd en niet altijd sprake is van objectieve controleerbare gegevens. Politici in verkiezingstijd 'agenderen' deze subjectieve grondslag steeds opnieuw, door telkenmale grootse intenties en vergezichten neer te leggen. Ringeling (2004) legt een verbinding met het juridisch karakter van overheidsbemoeienis, waardoor inherent ondoelmatigheid is ingebakken: je moet je indekken, er zijn aanhoudende checks and balances; dat voedt het gebruik van omschrijvingen als 'inspanningen', 'bevorderen' en 'taakstellingen'. Dit wordt versterkt door de grote mate van symboliek en dramatisering (de 'dramademocratie' van de Vlaamse socioloog Elchardus, 2002) en het uitbundig gebruik van metaforen: bestuurskundige Van Twist (1994) brengt de hervormingsvoorstellen voor de vorming van zogeheten kerndepartementen terug tot een staaltje 'verbale vernieuwing'. Keuzes zijn primair op waarden gebaseerd, waardoor er eerder sprake is van 'waardenrationeel handelen' dan 'doelrationeel handelen' (Van Dam \& De Vries, 1998).

b) Fundamenteel omstreden: bij democratische besluitvorming over die waardentoedeling geeft een meerderheid de doorslag, en dus zijn er altijd 'verliezers': zij die zich moeten voegen in het besluit van de meerderheid. Individuele belangen leggen het af tegen 'algemeen belang' en dit kan conflicteren met directe eigen belangen en waarden. De overheid (her)definieert een vraagstuk en creëert daarmee nieuwe werkelijkheidsdefinities: 'beleidsontwikkeling is het maken van een gezamenlijk kader, waarbinnen zorgen, belangen en ambities zinvol kunnen worden gethematiseerd' (Wagemans, 1998). Habermas (1984) spreekt van 'koloniseren van de leefwereld', Foucault waarschuwt voor 'disciplinering' en 'dresseren' (Van den Hove, 2011).

c) Leveringsplicht: de overheid is eraan gehouden diensten te leveren, zodra hiertoe is besloten en kan zich dan niet verschuilen achter marktmechanismen. Zij kent dan een 'inspanningsverplichting' en die plicht vraagt om voortdurend onderhoud. Dit leidt ertoe dat de overheid een uitgebreid assortiment aan diensten en voorzieningen kent, en een apparaat moet onderhouden om de diensten te kunnen leveren. Het assortiment is op voorhand groot, de apparaatskosten op voorhand hoog. Tegelijk staat vast dat de overheid taken moet oppakken omdat ze bedrijfseconomisch niet rendabel worden geacht: eerste opvang van vluchtelingen en reparatie van beschadigde openbare voorzieningen. Totdat het tegendeel bewezen is; vuurtorens en ook het loodswezen werden geprivatiseerd toen bleek dat ook reders wilden bijdragen aan veilig bereikbare havens en beheer van zwembaden verdween als overheidstaak toen woningen standaard met badkamers werden gebouwd. Subsidie op schoolzwemmen resteerde.

d) Beperkte vrijwilligheid: de burger is zelden echt 'klant', doordat overheidsdiensten een monopolie kennen. Dit geldt voor transacties als vergunningen en documenten, maar 
ook voor de 'afname' van besluiten. Tijdens verkiezingen staat de staatsburger even boven 'zijn' overheid, daarbuiten is hij onderdaan. Er zijn dan ook slechts in beperkte mate logische, zichtbare koppelingen tussen betalen van diensten en het genieten ervan. Voor een deel van de diensten geldt ook dat de burger wel meebetaalt via belastingen, maar er geen directe vrucht van heeft.

e) Macht: de overheid heeft de unieke mogelijkheid om haar gezag kracht bij te zetten en burgers en ondernemers voorzieningen op te leggen. Dit komt ook tot uiting in de instrumenten van de overheid. Het klassieke instrumentarium van regelgeving komt in allerlei vormen tot de bevolking, steeds vaker in combinatie met de twee andere typen instrumenten: voorzieningen en voorlichting. Tot de toebedeelde macht hoort het monopolie om geweld toe te passen ('zwaardmacht'). Het 'gezag' ontleent zijn 'macht' aan het vermogen om gezaghebbend nee te zeggen (Tops, 1999). Het wedijveren over conflicten is volgens de Spaanse wijsgeer Savater (1998) per saldo de bestaansreden voor politiek; ten onrechte wordt de overheid aangezien als veroorzaker van conflicten, terwijl ze juist zorgt voor het kanaliseren ervan: 'Politiek verhindert dat conflicten uitgroeien tot een kankergezwel dat de samenleving kan vernietigen'.

f) Lekenbestuur en ambtelijke specialisten: bij bestuurders zoals bewindslieden staat geen vakkennis voorop, daarvoor vallen ze terug op vakdeskundige ambtenaren en adviseurs. Bestuurders zijn voor een beperkte tijd aangesteld, ambtenaren voor langere duur. Dit zijn wezenlijke elementen om het samenspel tussen bestuurders en ambtenaren te begrijpen, en vooral ook de spanningen die ontstaan als politiek respectievelijk maatschappelijk draagvlak en korte respectievelijk lange termijn elkaar ontmoeten. Dilemma's hebben betrekking op de focus op korte termijn versus lange termijn, loyaliteit aan politici versus aan publieke organisaties en openbaren van informatie versus 'beleidsintimiteit'. Een reeks onderzoeken ontbloot spanningen en strategieën (Nieuwenkamp, 2001, Breed, 2008, Van Twist, 2010, Rijnja \& Wilmink, 2010)

g) Openbaarheid: de overheid kent vele wettelijke grondslagen voor openheid, zoals de Wet openbaarheid van bestuur regelt dat alle informatie die onder bestuursorganen berust openbaar is, tenzij enkele uitzonderingsbepalingen van toepassing zijn.

Dit stimuleert verschillende formele en informele vormen van bekendmaking van informatie aan doelgroepen via eigen en via vrije media. Kranten, radio en tv beschouwen het als hun taak om tegenwicht te bieden aan de overheid (en markt): informerend, opinievormend en als forum, maar vervullen die rol in steeds mindere mate in door klakkeloos informatie over te nemen en de oren te laten hangen naar boodschappen van overheidsvoorlichters (Tjeenk Willink, 2009). De invloed van het internet is hier zichtbaar. Opereren in een glazen huis stimuleert ook oppervlakkigheid en vraagt van bestuurders om te kunnen gaan met het etaleren van mislukkingen (Ringeling, 2004). 
h) Beperkte beheersbaarheid: wie in openbaarheid voorbereidingen treft voor het aanpakken van omstreden vraagstukken en zich daarbij beroept op subjectieve grondslagen, kan niet altijd een lineaire doel-middel planning volgen. Tijdsdruk, publieke en politieke verantwoording en mogelijkheden voor beroeps- en bezwaarprocedures kunnen verder bijdragen aan lastige of niet beheersbare processen van beleidsvorming en -uitvoering. Een dominante hang naar overleg, overeenstemming en draagvlak hangt rechtstreeks samen met de lage ligging van ons land: je kunt elkaar maar beter in de peiling houden, meent de historicus Frijhoff (Spiering, 1999) en ook Hofstede laat zich in deze zin uit (1999). Accepteren dus: consensusvorming, conflictbeheersing, onderhandeling en compromisvorming zijn in de Nederlandse publieke context geen hindernissen maar voorwaarden (Toonen, 1987). Veel tijdelijke oplossingen zijn het gevolg (Ringeling, 2004). 'Muddling through' is van een ervaring een dominante methode geworden (Lindblom, 1979). Kingdon (1984) introduceerde het begrip 'policy windows': 'beleid' ontstaat steeds vaker doordat problemen, alternatieven en politiek als onafhankelijke stromen samenkomen en dan 'beleidsramen' openen: het probleem wordt herkend, de oplossingen zijn voorhanden en de politiek is er rijp voor. Allerhande vormen van flexibeler inspelen op gebeurtenissen komen op, maar ook 'street level bureaucrats' kunnen geen ijzer met handen breken (Lipsky, 1980).

i) Verscheidenheid in eenheid: steeds weer blijkt hoe lastig 'eenheid' is in het openbaar bestuur. In Nederland vormen altijd coalities de besturen en deze gelegenheidscombinaties zijn geen stimulans voor gezamenlijk optreden. Rationeel gezien is er steun voor de behoefte van burgers aan helderheid en consistentie (één loketgedachte), maar het blijkt in de praktijk een moeilijke opgave. De Nationale ombudsman bombardeerde de verdergaande versnippering en gebrekkige samenwerking in ketens in 2006 tot sleutelthema van zijn jaarverslag. Vooral in symboliek (één logo, één huisstijl, één corporate story, gezamenlijke werkbezoeken van de bewindslieden) worden regelmatig pogingen gedaan om een streven naar eenheid kracht bij te zetten, maar het gedrag laat al te vaak zien hoe moeilijk het is om rijen gesloten te houden. Het is een publiek geheim dat bewindslieden bij interdepartementaal voorbereide onderwerpen vrijdag na de ministerraad - en als het even kan daarvoor... proactief de glorie voor besluiten in de media claimen. En ook bij andere bestuurslagen zoals gemeenten, zijn hiervan voorbeelden aan te wijzen.

j) Zelfbinding: de overheid is voorzien van 'veiligheidskleppen': beroeps- en bezwaarprocedures en verantwoordingsvormen. Staatsrechtgeleerde Scheltema (1989) onderstreept de context van de rechtsstaat; vier beginselen markeren de randen van het speelveld: het rechtszekerheidsbeginsel (waaronder de eis van individuele rechtsbescherming), het gelijkheidsbeginsel (waaronder de scheiding van wetgevende uitvoerende en rechtsprekende macht), het democratiebeginsel en het 'beginsel van de dienende overheid' (waaronder de eis van officieel erkende 
grondrechten). Zie de hoge colleges van staat als de Raad van State (onder andere advies bij voorgenomen wetsvoorstellen voorafgaand aan behandeling in de Tweede Kamer), de Algemene Rekenkamer (onder andere toetsing van effectiviteit en efficiency) en de Nationale Ombudsman (beoordeling van klachten over bejegening) in dit licht. Specifieke wetten als de Wet openbaarheid van bestuur en de Algemene wet bestuursrecht en integriteitsregels hebben een functie op dit punt. Ook kent de overheid voor publieke verantwoording verscheidene momenten (Prinsjesdag, Verantwoordingsdag). Publieke organisaties hebben verantwoording af te leggen over de resultaten, maar ook over de wijze waarop deze zijn behaald (De Vries \& Van Dam, 1998). Wie bij de overheid gaat werken legt een eed of belofte af, waarmee werkgever en werknemer het vertrouwen in elkaar uitspreken de bijzondere, morele dimensie te bewaken. 'Ik zweer (beloof) dat ik mij zal gedragen zoals een goed ambtenaar betaamt, dat ik zorgvuldig, onkreukbaar en betrouwbaar zal zijn en dat ik niets zal doen dat het aanzien van het ambt zal schaden' (zie o.a. www. overheid.nl).

k) Uitvergroting: 'Publieke dienstverlening is naar haar aard een dissatisfier: als het goed gebeurt, beschouwt iedereen dat vrijwel aanstonds als normaal. Wie maar even onder de zelf aangebrachte meetlat blijft, kan spoedig zijn opwachting maken bij tv-programma's als 'Ook dat nog', sneerde Van den Berg (2001). De overheid is bij uitstek gevoelig voor de drie primaire criteria van nieuwswaardigheid bij journalisten: conflict, verantwoordelijkheid en human interest (Kleinnijenhuis e.a., 2003). Er is een neiging tot symboliek en dramatisering ('dramademocratie' muntte de Vlaamse socioloog Elchardus de ontwikkeling in 2002) en media doen aan scripting en casting: ze plaatsen nieuws in dwingende verhaallijnen incluis van tevoren bedachte rollen (Van Twist e.a. 2010). Publieke woordvoerders op hun beurt proberen deze hang naar dramatische uitvergroting te pareren door zelf informatie te framen (inkaderen) en publieksgroepen te primen (voorbewerken) (Pol e.a., 2007, De Bruijn, 2010).

Elf kenmerken helpen het eigene van de overheid in beeld te krijgen. Ze wijzen daarbij naar enkele specifieke spanningen die het functioneren van dat systeem met zich meebrengt. Die kunnen op meerdere manieren worden uitgelicht. Vanuit het perspectief van burgers en ondernemers bijvoorbeeld, vanuit dat van het politiek bestuur en vanuit ambtenaren. Vooral naar de eerste twee invalshoeken is veel onderzoek verricht. In mijn studie richt ik de blik op het ambtelijk handelen. Vanuit dat perspectief kom ik tot een nadere duiding van ambtelijke 'systeemspanningen'. Eerst een tussenstap: waar staat de ambtenaar in het 'systeem' overheid?

\subsection{Beleid, of: het primaire proces van de overheid}

Bij de toedeling van taken door de overheid duiken naast 'publiek' de woorden 'politiek' en 'beleid' steeds weer op. Beide begrippen worden vaak door elkaar gehaald, maar kennelijk heeft dat een functie, lezen we bij De Graaf en Hoppe (1996). Zij spreken van een 'semantische ontsnapping' van 'politiek' naar 'beleid', waarbij het tweede begrip vooral 
zakelijkheid, deskundigheid en objectiviteit is gaan uitstralen en 'politiek' steeds meer is komen te staan voor controverse, partijdigheid en manipulatie. 'Politiek is strijd om beleid' vatten De Graaf en Hoppe hun verkenning samen, en Frissen (2009) spreekt van een toenemende neiging om maar te spreken van 'het politieke' als de spil waarom overheidshandelen draait. De geschiedenis laat zien hoe bewegingen van 'politisering' afgewisseld worden door uitgesproken 'depolitisering' en ook 'ontpolitisering', waarbij de taak en de rol van de overheid wordt teruggedrongen of verdwijnt. Dat kan zowel betrekking hebben op de rol van het bestuur als op het beheer, op gedeeltelijke of gehele overdracht of juist toe-eigening van verantwoordelijkheid en op decentralisatie en centralisatie van taken. Het woord is al enkele malen gevallen. Wat de overheid maakt noemen we beleid. Wat is beleid? Een licht verwonderde Pieter Winsemius muntte als verse minister van Volkshuisvesting, Ruimtelijke Ordening en Milieubeheer (VROM) vrij rap na zijn aantreden de 'beleidslevenscyclus' (1990): bij beleidsvorming, hoe grillig ook, is sprake van probleem(h)erkenning, formulering van oplossingen, een besluit, uitvoering en beheer. Veel beleid is niet eenvoudig cyclisch of lineair, maar eerder en vaker meervoudig en complex; de karakteristiek hielp echter rollen en patronen te verhelderen: er is altijd een begin, een besluit en een stadium van uitvoering. Er is ook een andere manier om naar beleid te kijken in de zin van sturingsvormen. Dan gaat het om drie typen interventies. De zweep staat voor wet- en regelgeving, of juridische bepalingen die helpen om gewenst gedrag op te leggen. Onder de categorie zweep scharen we veel verplichtingen en regels voor bijvoorbeeld veilig verkeersgedrag. De peen staat voor economische interventies, waarbij de overheid de burger met behulp van een bevorderende of belemmerende maatregel verleidt tot ander gedrag. Voorbeelden hiervan zijn er zowel positieve zin (subsidie, scholen, openbaar vervoer, condooms, statiegeld, glasbakken) als negatieve zin (verkeersdrempels, accijnzen, beprijzing, boetes).

De tamboerijn (anderen prefereren het allitererende begrip 'preek') omvat de communicatieve interventies die gericht zijn op het vergroten van kennis en bewustzijn over een vraagstuk. Voorbeelden van de tamboerijn zijn informatie in de vorm van tv-spotjes, billboards of andere vormen van campagne voor milieuvriendelijk gedrag, gezonde voeding en een gezonde leefstijl.

Deze populaire kenschets steunt op een indeling die al langer in bestuurs- en beleidswetenschappen wordt gebruikt. Van Manen (1990) onderscheidt zes typen beleidsinstrumenten: influenceren (informatie, sociaal-psychologische beïnvloeding), faciliteren (fysieke voorzieningen), stimulering (subsidies), repulsiveren (heffingen, statiegeld, aansprakelijkheid), limiteren (fysieke beperkingen, quotering, bonnen), en commanderen (verbodsbepalingen, strikte voorschriften). Natuurlijk is hier sprake van een versimpeling. Ik gebruik de populaire drieslag, omdat ze voldoende houvast biedt voor het palet waarvan de politicus, bestuurder en beleidsmaker zich - bewust of onbewust- bij een voorliggend probleem bedient. Het drieluik vertoont interessante parallellen met de drieslag die Habermas (1984) voor strategisch handelen definieerde: niet alleen organisaties, maar ook individuen kiezen voortdurend voor het toepassen van macht, het aangaan van een ruil of het investeren in socialisatie. Onder 'macht' breng ik de juridische bepalingen onder, onder 'ruil' de economische interventies en onder 'socialisatie' de communicatieve beleidsinstrumentaria. 
Een andere verwantschap met de drieslag biedt een typologie van Bennis, Benne en Chin (1985). Zij onderscheiden drie verschillende strategieën voor het teweegbrengen van veranderingen.

De empirisch-rationele strategieën waarbij de rationele mens het uitgangspunt is. Volgens deze strategie is de mens bereid om een bepaalde handelswijze te volgen als hij ervan overtuigd is dat dit in zijn eigen belang is. Veel voorlichting is primair gericht op dit eigen belang. Bij de normatief-reëducatieve strategieën wordt het individu gezien als iemand die actief op zoek is naar oplossing van problemen, en die dus 'in' is voor vormen van transactie. De overheid kan hierbij helpen door advies te geven en ondersteunende, bijvoorbeeld educatieve middelen in te zetten. Tenslotte, de machts- of dwang strategieën betreffen politieke en economische sancties bij uitoefening van macht. Politieke macht is gebaseerd op de wet en op sancties tegen individuen en groeperingen die de wet overtreden. Nelissen (1989) onderzocht de werkingsduur van de drie instrumenten. $\mathrm{Hij}$ stelde het volgende vast: juridische instrumenten focussen op gehoorzaamheid en sorteren vaak een kortetermijneffect, economische instrumenten helpen de identificatie te versterken en hebben een middellange termijn effect, en instrumenten van socialisatie (en dus communicatie) helpen bij internalisatie en danken hun populariteit aan een lange doorwerkingtermijn. Als ik deze diverse typologieën bijeenbreng ontstaat een spectrum (tabel 2.1.):

Tabel 2.1. Spectrum beleidsinstrumenten

\begin{tabular}{|l|l|l|l|l|l|l|}
\hline Instrument & Mechanisme & Strategie & Activiteit & Brongebied & Effect & Werkingsduur \\
\hline Zweep & Macht & $\begin{array}{l}\text { Dwang/ } \\
\text { macht }\end{array}$ & $\begin{array}{l}\text { Wet- en } \\
\text { regelgeving }\end{array}$ & $\begin{array}{l}\text { Juridisch- } \\
\text { bestuurlijk }\end{array}$ & $\begin{array}{l}\text { Gehoorzaam- } \\
\text { heid }\end{array}$ & Korte termijn \\
\hline Peen & Ruil & $\begin{array}{l}\text { Normatief- } \\
\text { reeducatief }\end{array}$ & $\begin{array}{l}\text { Voor- } \\
\text { zieningen }\end{array}$ & Economie & Identificatie & $\begin{array}{l}\text { Middellange } \\
\text { termijn }\end{array}$ \\
\hline $\begin{array}{l}\text { Tamboerijn } \\
\text { (preek) }\end{array}$ & Socialisatie & $\begin{array}{l}\text { Empirisch- } \\
\text { rationeel }\end{array}$ & Voorlichting & $\begin{array}{l}\text { Sociale } \\
\text { psychologie }\end{array}$ & Internalisatie & Lange termijn \\
\hline
\end{tabular}

De beleidspraktijk laat zien hoe in de verschillende fasen van beleidsvorming gezocht wordt naar kansrijke benaderingen, op basis van de drie typen sturingsinstrumenten.

Met de nesteling van communicatie 'in het hart van het beleid' (Kabinetsstandpunt Commissie Toekomst Overheidscommunicatie, 2001) blijkt steeds duidelijker dat jarenlang gescheiden, verkokerde trajecten zijn bewandeld. Per saldo is sprake geweest van eenzijdigheid en een rem op innovatie en synergie: de diverse brongebieden van wetenschap en de vloed aan ervaringen met interventies bieden vele variaties, en dagen uit tot geïntegreerde benaderingen. In eigen land, maar ook bij internationale vergelijking groeit het besef dat we jarenlang onszelf en vooral ook het publiek tekort hebben gedaan als het gaat om mogelijke combinaties tussen penen, zwepen en tamboerijnen, c.q. regels, ruilen en voorlichtingsacties. Bijvoorbeeld: de overheid kan besluiten de fietsindustrie te subsidiëren (peen) om tweewielers standaard dusdanig uit te rusten, dat in het donker de fietsverlichting automatisch aanfloept. In ons land werd primaat toegekend aan regels en handhaving (zweep), in combinatie met uitbundige 
nationale campagnes (preek: 'fiets als een vorst, fiets verlicht'). Later werd dit aanbod aangevuld met lokale acties om in een periode gratis je fiets na te laten kijken (peen). Er is sprake van een duidelijke verschuiving, waarbij steeds meer naar verbindingen wordt gezocht tussen de (te) onderscheiden typen beleidsinterventies. Scheidend directeur-generaal De Goeij van VWS preludeert in een bundel over de opbrengsten van zogeheten leefstijlcampagnes (Bouman e.a., 2009) op de omslag van 'campagnes' naar 'programma's', waarin de preferenties van publieksgroepen samenhangend worden opgespoord, begrepen en aangesproken. 'Beleid is communicatie' is een slagzin die sindsdien regelmatig door wisselende smaakmakers in de mond wordt genomen.

\subsection{Ambtelijke invloedssferen}

Het diffuse karakter van het systeem dat we met het begrip overheid aanduiden maakt het er allemaal niet eenvoudiger op; traditionele verticale verhoudingen zijn aangevuld en deels opgelost in of overgenomen door horizontale relaties (WRR, 2006, ROB, 2010). Ik orden het systeem waarin de ambtenaar functioneert daarom aan de hand van een schema met drie specifieke invloedssferen: het politieke bestuur, de ambtelijke bureaucratie en de maatschappelijke omgeving. Tussen deze domeinen of arena's is sprake van zowel bilaterale als multilaterale verhoudingen, en navenante typen van conflicten. Juist de verbondenheid van de arena's karakteriseert de unieke context van het openbaar bestuur. Het is aan de beleidsambtenaar om bij een opgedist of veroorzaakt vraagstuk de opvattingen en verwachtingen te kennen, begrijpen en de zetten op de drie speelborden te bedenken, helpen voorbereiden of uit te voeren. In figuur 2.1. zijn de samenhangende ambtelijke arena's samengebracht.

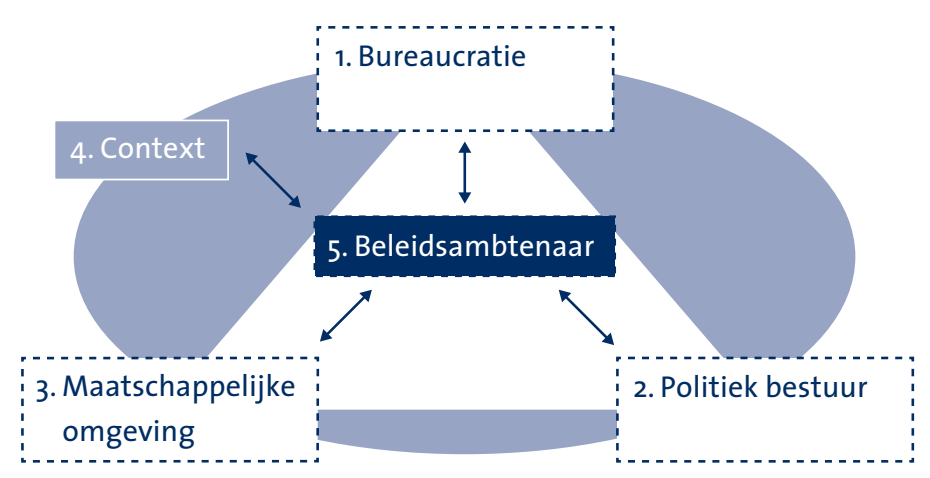

Figuur 2.1. Ambtelijke arena's

Deze ordening helpt om zowel het onderscheid als de samenhang van onderdelen aan te geven. De beleidambtenaar staat in het midden om de focus op zijn opgave kracht bij te zetten: hij moet de verwachtingen en handelingen van de drie typen arena's herkennen en hanteren. Die duiding kan nog fijnmaziger worden uitgewerkt. Gesprekken met 
beleidsmedewerkers en hun leidinggevenden (Nelis, 2008) brachten immers in totaal zes domeinen in beeld, als we ook het wetenschappelijk domein (kennisverantwoordelijkheid) en het internationaal domein (onderhandelende verantwoordelijkheid) meerekenen.

Ik heb de beleidsmaker in dit schema in het midden geplaatst, in het volle besef dat die centrumpositie in een netwerksamenleving de werkelijkheid geen recht doet. In deze dissertatie staat evenwel de beleidsambtelijke praxis centraal. De beleidsambtenaar heeft met een 'stapeling' van de verwachtingen en handelingen van de drie arena's c.q. van drie typen processen - politiek, maatschappelijk en bureaucratisch - te maken. Meer dan louter het dienen van (minstens...) drie heren, dan wel het scherpstellen van drie zichtlijnen, gaat het vanuit het oogpunt van de beleidsambtenaar om het hanteren van de context en de wijze waarop hij hieraan betekenis verleent: hoe verbindt hij kennis, ervaring en inzicht. Een beleidsambtenaar speelt aldus op drie borden tegelijk:

De bureaucratie (1) staat voor de ambtelijke dienst, die begint bij het bestuursorgaan waar de ambtenaar te werk is gesteld, maar strekt zich vervolgens uit naar interdepartementale contacten en overleggen. Samenspel tussen dat bestuursorgaan, diensten, op afstand geplaatste bestuursorganen en inspecties vraagt aandacht. Hier wordt dossierkennis verwacht, ervaring op een of meer specifieke terreinen en toegang tot netwerken in en om de overheidsorganisatie. Traditioneel scoren ten opzichte van de (politieke) focus op korte termijnsuccessen en aandacht in de media hier meer het oog voor de lange termijn en de vakinhoud. Onder druk van bedrijfsmatig denken (New Public Management) is in de afgelopen twee decennia steeds meer aandacht uitgegaan naar de meetbaarheid en controleerbaarheid van werkzaamheden. Beleidsambtenaren hebben steeds meer vrijheid gekregen om namens het bestuur (interactief) beleid te maken en netwerken te vinden, te creëren en daarbinnen afspraken te maken. Het begrip 'regie' steekt hierbij de kop op en in het verlengde hiervan plaats ik de aandacht voor communicatieve interventies. De relationele dimensie van besturen en beleid maken wordt steeds meer onderkend.

Het politiek bestuur (2) verwacht ondersteuning bij de herkenning, agendering, oplossing, besluitvorming en uitvoering. Voorbeelden van strategische beleidsdiensten zijn beleidsbrieven en strategische nota's, op operationeel vlak wordt de voorbereiding van beantwoording van vragen vanuit de volksvertegenwoordiging en overleggen, bestuurlijke beraden en maatschappelijke contacten aan. Meer korte dan lange termijn, meer bestuurlijke dan vaktechnische argumentatie, meer snelheid dan volledigheid tekenen de focus. De politieke bestuurder wil in stelling worden gebracht. De traditionele media volgen vanuit de stapeling van aandacht voor conflict, human interest en verantwoordelijkheid (Kleinnijenhuis e.a., 2003) op een eigen manier de bestuurlijke verrichtingen, waarbij in vervolg op wat Elchardus (2002) de dramademocratie noemde, populisme de kop opsteekt: doorgeschoten vereenvoudiging van de complexiteit die overheidshandelen kenmerkt, in de vorm van beelden, soundbytes en metaforen. Concurrentie tussen de media - de betaalde en de gratis, publieke en commerciële en in toenemende mate ook de gevestigde en de sociale media - versterkt de omslag naar een snelle, compacte aanpak. 
De maatschappelijke omgeving (3) staat voor wat zich ooit louter als 'afnemers' aandiende (behoudens de vierjaarlijkse verkiezingsinbreng) en zich thans ook in meer of mindere mate als meeweter, meedenker en meebeslisser op 'het politieke' richt. De 'producten' hiervan zijn divers en omvatten directe en indirecte contacten over voornemens, besluiten, regelingen, convenanten, projectorganisaties en diensten. Korte termijnopbrengsten prevaleren, maar ook consistentie wordt veel waarde toegekend. Burgers, ondernemers, maatschappelijke organisaties en instellingen en belangenorganisaties verwachten dat 'hun' overheid knelpunten tijdig, alert en behoorlijk oppakt, oplost en laat neerdalen in voorzieningen. Verwachtingen worden uitgelokt, opgedist, opgeklopt en voeden per saldo een gevarieerde en variabele reeks houdingen, waarin teleurstelling voorkomt, maar ook cynisme, woede, expliciet verzet en vervreemding. De uitzonderlijke positie van de overheid wordt wellicht het meest voelbaar op die momenten, dat de overheid haar burgers aan regels bindt. In de literatuur komt dan de betekenis van de zogenoemde gezaghebbende toedeling van waarden naar voren en het fenomeen van het opleggen van plichten, door die overheid. Hoggett (2006): 'Citizens therefore project onto government all that they cannot contain within themselves. It follows that part of the authority invested in government, is citizens' own disowned authority". Een probleem is dat de burgers deze projectie vaak niet bewust uitvoeren en veelal niet als zodanig herkennen. In de praktijk blijkt het voor politici, bestruurders en ambtenaren niet altijd eenvoudig om duidelijk te maken dat de overheid boven de partijen en staat én van ons allemaal is. Welke logica schuilt achter dit systeem waarvoor we allemaal betalen, dat plichten oplegt én rechten verschaft - om van tijd tot tijd te bepalen hoe en met wie het verder moet, als het om overheid gaat?

Het samenkomen van bestuur, beleid en samenleving 'veroorzaakt' aldus een unieke context (4): overheid brengt een specifieke interactie met zich mee, waarvoor het begrip 'identiteit' tekort schiet; dit is immers aan een organisatorische eenheid gekoppeld, terwijl het gaat om de 'interactie' waarin een of meer actoren met elkaar 'verschil maken'. Ook het begrip 'organisatiecultuur' dekt de lading niet; het gaat eerder om het stapelen van culturele processen. Deze processen vinden deels los van elkaar plaats, maar haken gevraagd en ongevraagd in elkaar. Het is evident dat zich hierbij positieve en negatieve ervaringen voordoen, vanuit de invalshoek van alle drie de arena's. Die kunnen te maken hebben met de beoordeling van de legitimiteit en de kwaliteit van bemoeienis met een vraagstuk, de totstandkoming van oordelen en beslissingen en de aanpak van wat hieruit naar voren komt. Er is als het ware sprake van een voortdurende afrekening op mate van 'deugbaarheid': mag het, kan het en laten we dit toe?

De beleidsambtenaar (5) wordt geacht de onderscheiden arena's in de peiling te houden en de interactie in de context te articuleren: niet naar één of twee, maar naar alle drie de arena's. De (elf) systeemkenmerken helpen om in te zoomen op enkele specifieke systeemspanningen. De duiding hiervan is nodig om de bewegingen van beleidsambtenaren - en meer specifiek de ruimte die zij nemen en krijgen om spanningen te herkennen en te hanteren - goed te begrijpen. Voordat we de zoomlens hanteren, werpen we nog wat extra licht op het fenomeen 'ambtenaar', in het bijzonder de beleidsmaker bij de overheid. 


\subsection{Ambtenaren, makers van beleid}

'Door ambtenaar te worden ben je ingetreden in de grote gemeenschap van hen, die geroepen zijn, met inzet van al hun krachten, het algemeen belang te dienen; binnen de sfeer van recht en wet hun medeburgers te helpen; mede te werken aan een maatschappelijke organisatie, waar binnen groter menselijk geluk, groter algemeen welzijn mogelijk zal zijn dan in de tegenwoordige'. De woorden zijn afkomstig uit het Vademecum voor de jonge ambtenaar. Dat werk dateert van 1957. De bestuurskundige en voorman van bestuurskundig onderwijs Van Poelje schreef de tekst om uitdrukking te geven aan het eigene van het ambtenaarschap. Met 'roeping' dus als een centraal begrip: werken voor de overheid, dat doe je niet zomaar. Met de ambtelijke eed wordt het bijzondere karakter van het werken in dienst van de democratie nog steeds leven gehouden. Van tijd tot tijd wordt het als archaïsch fenomeen afgedaan, maar ondertussen blijkt het een cruciaal symbool: de beëdigde ambtenaar krijgt als vertegenwoordiger van de staat, bij de rechter meer vertrouwen dan de gewone burger, stelt Rutgers (2011), die hierbij aantekent: 'Zou dat niet zo zijn, dan kon de overheid de rechtsorde uiteindelijk niet handhaven. De fictie en de verplichting dat een ambtenaar het algemeen belang moet laten prevaleren boven het eigen belang, is hier cruciaal. Het betekent dat aan ambtenaren hoge eisen moeten worden gesteld'.

Volgens bestuurskundige De Vries is de beleidsambtenaar bij de overheid idealiter (1) inhoudelijk deskundig, (2) politiek loyaal en neutraal, (3) adviseur op basis van feiten en wetenschappelijke kennis, (4) bedenker van beleidsalternatieven en (5) kan zich verplaatsen in de gedachtewereld van politieke bestuurders (plaatsvervangend denken). In deze karakteristiek komt de Duitse overheidsdenker Weber naar voren. Die stelde dat ambtenaren moesten beschikken over Fachwissen en Dienstwissen. Niessen (2003) onderstreept het bijzondere karakter van de laatste kwaliteit: het toe-eigenen van 'ambtelijk verantwoordelijkheidsbesef'. De roep om een nieuw-Weberiaanse staat wordt internationaal aangeblazen door een internationale bestuurskundige alliantie. Bouckaert en Pollit (2004) roepen op tot een staat die 'krachtig integrerend' aanwezig is, waarin medewerkers weten op welk politiek bestuurlijk niveau een vraagstuk het beste kan worden aangepakt - en met welk besluitvormingsmechanisme ('governance kan niet zonder scherp beeld van 'government'). Opleidingen voor ambtenaren moeten zorgen voor toerusting omtrent normatieve politieke vraagstukken, economische keuzevragen, constitutioneel recht en filosofie. Systematische bespreking hiervan helpt bij het verwerven van Fingerspitzengefühl: voor de selectie van informatie, het voorbereiden van keuzes en in- en extern informeren bestaat geen vastomlijnde organisatiestructuur, daarvoor heb je ervaring nodig (Niessen, 2003).

Karsing en Niessen (2008) hebben op grond van onderzoek en bijdragen aan opleiding en training van beleidsmedewerkers en leidinggevenden tien standaarden voor ambtenaren gedefinieerd: (1) toewijding aan de publieke zaak; (2) deskundigheid, (3) vakbekwaamheid; (4) onafhankelijkheid en onpartijdigheid; (5) democratisch besef; (6) rechtsstatelijk besef; (7) politiek-bestuurlijke gevoeligheid; (8) flexibiliteit; (9) omgevingsgerichtheid (dienstbaarheid 
of responsiviteit), en (10) resultaatgerichtheid en samenwerkingsbereidheid. Als een soort bijsluiter bij hun typologie onderstrepen ze het begrip 'roeping' en halen de eerdergenoemde woorden van Van Poelje uit diens ambtelijk vademecum aan. Deze roeping zou volgens de auteurs niet moeten worden gezien als iets dat vanuit een hogere macht buiten de ambtenaar indaalt, maar als een kwaliteit die van binnen uit moet nestelen. Niet te fanatiek: 'Bezieling, beroepstrots en beroepseer zijn een vorm van egobevrediging. Maar is dat erg? Wel als die leidt tot egoïsme, zelfvoldaanheid, ijdelheid, zelfbewieroking, arrogantie, zelfgenoegzaamheid. Dat staat immers de taak van de ambtenaar in de weg: het publieke belang te dienen. Applaus voor jezelf is niet erg, zolang je maar niet vergeet dat je dit applaus wel moet verdienen, dat applaus voor je zelf hand in hand moet gaan met applaus van de burger. Dan is bezieling niet alleen een belangrijke motivator, maar ook terecht'. Sociologe Tonkens (2008) spreekt van 'de logica van het professionalisme' als de wens om 'vanuit een seculiere roeping, een transcendente waarde zoals gezondheid of welzijn, zo goed mogelijk te delen'. Niet wat de klant wil, maar wat de klant nodig heeft staat centraal, en dit moet spreken uit de ambtelijke prestaties. Ambtelijk besef, daarmee begint het.

De Vries (2008) waarschuwt voor de opmars van 'procesarchitecten', die zich tussen bestuurders en professionals opdringen: 'inhoudsloze ambtenaren die staats- en bestuursrechtskennis missen'. De komst van steeds meer niet vakinhoudelijk toegeruste maar bestuurs- en bedrijfskundig geschoolde ambtenaren heeft tot gevolg dat het rijk medewerkers kreeg met weinig kennis van normatieve politieke en juridische vraagstukken, meent hij: 'voor managers die resultaat willen boeken, is het recht een sta in de weg'. Specialisten moeten wijken voor 'publieke ondernemers, publieke managers en politieke managers, communicatiedeskundigen, spindokters en politieke ambtenaren - een ring, maar niet van ijzer, omdat zij zeer mobiel zijn'. De Vries signaleert een reeks dreigende tekortkomingen: niet alleen de overheid maar ook de rechterlijke macht zal steeds minder serieus worden genomen, inhoudsloze managers zullen zich niet staande weten te houden in de lastige onderhandelingen die de gefragmenteerde netwerken van vandaag met zich meebrengen, en die focus op processen verstoort de onvermijdelijke gezagsverhoudingen tussen bestuurder en (top)ambtenaar. De kritische geluiden suggereren een ideaaltypische kern van ambtenaarschap.

Deze en andere kritische geluiden hebben het ministerie van Binnenlandse Zaken en Koninkrijksrelaties aangezet tot een beschrijving van de kern van de beleidsambtelijke professie (Nelis, 2008). De beleidsmedewerker moet thuis zijn in het politiek bestuur, de bureaucratie en de maatschappelijke context. Gesprekken met beleidsmedewerkers en hen leidinggevenden hebben zes 'domeinen' in beeld gebracht waar een beleidsmedewerker in thuis moet zijn a) het politiek domein (verantwoordelijkheid voor adviseren over lange termijn en politieke besluitvorming), b) het maatschappelijk domein (verantwoordelijkheid voor functioneren van systemen, stelsels en sectoren en beleidsverantwoordelijkheid), c) het wetenschappelijk domein (kennisverantwoordelijkheid), d) het bestuurlijk domein (besturingsverantwoordelijkheid voor de uitvoering), e) het ambtelijk domein (coördinerende verantwoordelijkheid) en $\mathrm{f}$ ) het internationaal domein (onderhandelende 
verantwoordelijkheid). Het onderzoek grijpt de zogeheten beleidslevenscyclus (Winsemius, 1990) aan om de rollen van beleidsmedewerkers te duiden en de bijbehorende kerntaken, producten en competenties. De beleidsmedewerker komt hieruit naar voren als iemand die afwisselend onderzoeker, strateeg, expert, procesregisseur, organisator, vakman, relatiebeheerder en stimulator moet kunnen zijn. Het type vraagstuk en ook de aard van het departement bepalen uiteindelijk de benodigde inzet. De hoofdlijnen worden verder uitgewerkt in 'loopbaanlijnen', opdat bij instroom van nieuwe medewerkers en bij professionalisering systematisch binnen de rijksdienst kennis en ervaringen kunnen worden doorgegeven.

Een terugkomend thema is de rechtspositionele vertaling van de ambtelijke eigenheid. Lange tijd is de ambtelijke werknemer qua rechtspositie en arbeidsvoorwaarden een aparte status toegekend. Eind jaren zeventig van de vorige eeuw laaide het debat over deze 'ambtelijke status' op, onder meer onder druk van allerhande nieuwe wetgeving voor ondernemingsraden, Arbo en pensioenen. In 1984 leidde dit debat naar een besluit van overheidswerkgevers en de ambtenarenbonden; het 'Grand Design' (Becking, 2001) betekende een vergaande toepassing van diverse regels op de genoemde terreinen. Deze gelijktrekking is nooit volledig tot stand gekomen. Zo kan de Wet op de ondernemingsraden worden overruled door het politieke primaat, waardoor tijdens een recente kabinetsformatie twee ministeries konden worden samengevoegd zonder inbreng van de ondernemingsraden. Het dossier 'ambtelijke status' kent een wat schokkerige aandacht en kent slechts in kleine kring urgentie. Ambtenaren kennen er zelf weinig status (...) aan toe; onderzoek naar het arbeidsmarktimago leerde dat het ook geen kwestie is voor toetreders tot de arbeidsmarkt (DPC, 2008). Volgens Niessen (2003) is het rechtspositionele onderscheid tussen overheid en markt ook geen relevante indicator voor de bijzondere positie van een overheidsdienaar in relatie tot het fenomeen van de waardentoedeling en dus de politiek-bestuurlijke context: 'niet de ambtenaar is een bijzondere werknemer, maar de overheid is een bijzondere werkgever. In die zin dat zij naast werkgever overheid is en blijft, en als zodanig gebonden is aan bepaalde normen en waarden'. Bekker pleit als hoogleraar Arbeidsverhoudingen (2009a, 2011) voor een versterking van de positie van ambtenaren en wijst vooral op zichtbaarheid van de beleidsmaker. De ambtelijke status is hem daarbij een doorn in het oog, doordat de oorspronkelijke bedoeling niet meer aan de orde is, meent hij. De status was er immers gekomen om de ambtenaar te beschermen tegen politieke willekeur. Nu die willekeur niet of nauwelijks in alle beslotenheid kan worden uitgeoefend, kan de speciale status verdwijnen. Naast efficiencyvoordelen ontstaat er meer ruimte om te profiteren van de grotere flexibiliteit van de particuliere arbeidsverhoudingen. Er is steeds meer ruimte om het ambtelijk domein en ambtelijk vakmanschap zelfstandig te ontwikkelen van de politieke biotoop. In plaats van aandacht voor rechtspositionele thema's zou het beter zijn te focussen op 'een herbezinning van de arbeidscapaciteit' met vragen als: kan de ZZP-er bij de overheid dezelfde plaats krijgen als in de rest van de maatschappij? Het ambt van de ambtenaar zou in lijn met deze opvatting veel minder als kluif voor de politiekbestuurlijke arena moeten worden beschouwd. Een abstractieniveau hoger luidt dan de vraag: hoe kun je de kwaliteit van alle overheidsdienaren - politieke en ambtelijke dus - verhogen? 


\subsection{Ambtelijke systeemspanningen}

Het schema in figuur 2.1. biedt houvast bij het in beeld brengen van enkele pregnante systeemgerelateerde spanningen.

In de relatie met politiek bestuur ontmoeten ambtenaren de betekenis van het leerstuk van de bestuurlijke (voor het rijk: ministeriële) verantwoordelijkheid. Zij werken onder een functionaris, die onder democratische controle staat van de volksvertegenwoordiging. Deze constitutionele grondslag betekent dat alles wat op of vanuit een ministerie (provincieof gemeentehuis) gebeurt, kan worden toegeschreven aan de functionaris die de politieke leiding heeft. Diverse gebeurtenissen, vooral incidenten hebben afgelopen jaren laten zien dat een bewindspersoon niet alles kan weten wat er op een departement gebeurt, maar daar dus wel op kan worden aangesproken en uiteindelijk ook deze 'verantwoordelijkheid moet nemen' ten overstaan van de volksvertegenwoordiging. Deze 'afspraak' houdt ook in dat een bewindspersoon kan worden aangesproken op misstanden die onder een voorganger zijn begaan. Niessen (2003) merkt op dat de ministeriele verantwoordelijkheid soms gelijk getrokken wordt met aftreden; ten onrechte, meent hij: 'Alles aan één functionaris toerekenen is niet hetzelfde als alles aan die functionaris 'aanrekenen, laat staan: die functionaris op alles afrekenen'. Bekend zijn die situaties waarin een minister moest aftreden omdat hij het liet gebeuren dat hem niet op tijd de juiste informatie werd aangereikt. Het begrip 'Carringtondoctrine' verwijst naar de Britse minister die aftrad omdat bleek dat hij niet door zijn departement op de hoogte was gesteld van het ontstaan van de Falklandoorlog. Ik onderstreep dit thema vanwege de betekenis voor het democratisch besef en de politiek-bestuurlijke verhoudingen: de beantwoording van de vraag welke informatie de bestuurder moet hebben behoort tot de meest essentiële vaardigheden van een beleidsambtenaar. De focus op de ondersteuning van bestuurders bij hun politiek-bestuurlijke leiding roept regelmatig vragen op over de relevantie van verwantschap van de ambtenaar met de politieke kleur van de bestuurder en de vraag in hoeverre de ambtenaar 'zijn' principaal bijstand mag/moet verlenen bij partijpolitieke werkzaamheden. Spanningen kunnen ook ontstaan waar bewindspersonen voor een kortere termijn meer beleidsvoornemens willen effectueren dan de ambtelijke leiding van een departementsonderdeel nodig acht. 'Als de bewindspersonen verstandig zijn, concentreren zij zich op hun kernprogram, als de ambtelijke top zijn vak verstaat, blijft daar de blik op de wat verdere toekomst gericht', stelde Wallage (2005) in een verhandeling over de spanning tussen 'actualiteit en toekomstbestendigheid'. Ook Bekker (2011) bepleit een eigenstandige ontwikkeling van ambtenaren in plaats van voortdurend te focussen op het tot elkaar veroordeeld zijn: 'Waar politici zich te veel afzetten tegen de ambtelijke dienst, bestaat bij de ambtelijke dienst soms te veel cynisme en afschuw over de mediagedreven waan van de dag. Verbetering van begrip van en voor elkaars rollen zou een belangrijk aandachtspunt moeten zijn'.

In relatie met de 'eigen' bureaucratie kunnen ook specifieke spanningen ontstaan. ledere ministerie en iedere provinciale en gemeentelijke organisatie kent de gelaagdheid 
van een bestuursdienst (departement, provinciehuis, enzovoort) en uitvoerende diensten, waarbij soms sprake is van een derde laag in de vorm van toezichthoudende organen en één of meer sectorale inspecties. Deze drie-eenheid valt geheel onder de bestuurlijke verantwoordelijkheid: de diensten voeren uit wat aan beleid is overeengekomen en de inspecties stellen de bestuurder in staat om over de uitvoering verantwoording af te leggen aan de volksvertegenwoordiging. In relatie tot eerdere opmerkingen over fragmentering van arbeidsorganisaties merken we op dat onder de noemer 'diensten' een waaier aan baten- en lastendiensten en zogeheten zelfstandige bestuursorganen is ontstaan. Op het rijksniveau zijn beleidsmedewerkers op de departementen door de locatie van hun werkzaamheden primair op de ambtelijke leiding (secretaris-generaal en directeuren-generaal) en de politieke leiding (bewindspersonen) gericht. Medewerkers bij de diensten dienen in de eerste plaats hun dienstdirecteuren c.q. de inspecteuren-generaal. Het samenspel tussen departementen, diensten en inspecties, onderling zowel als horizontaal, is een prominent onderdeel van de operatie die in 2007 in gang is gezet onder de noemer Vernieuwing Rijksdienst. Bij wijze van prelude stak het kabinet-Balkenende in 2007 in het regeerakkoord de loftrompet over de medewerkers die prompt 'frontsoldaat' werden gedoopt: 'Leraren, artsen, agenten, hulpverleners en andere professionals zijn van onschatbare waarde en verdienen onze volle steun en vertrouwen'. Uit 'Beroepstrots', het onderzoeksproject van het Ministerie van Binnenlandse Zaken en Koninkrijksrelaties en de Stichting Beroepseer (Van den Brink e.a., 2009) kwam naar voren dat de mannen en de vrouwen van de uitvoering 'regeldruk' als belangrijkste 'Iast' ervaren en van departementen vaker en eerder interactie verwachten over de mogelijke impact van beleid, waarover zij immers het directe contact met het publiek hebben. Winsemius (o.a. in Huibregtsen e.a. 2009) signaleert in toenemende mate spanningen tussen 'witte boorden' (beleidsmakers op vooral departementen) en 'blauwe boorden' (medewerkers bij uitvoeringdiensten). Deze spanningen hebben in het bijzonder betrekking op vier typen vragen: 1) de mate van differentiatie (maatwerk versus rechtsgelijkheid en efficiënte uitvoering), 2) de reikwijdte van aanpak (één-loketdrang bij burgers versus specialisaties), 3) bestuurlijk initiatief (betrokkenheid vergroten en coproducties aangaan of regels en voorzieningen opleggen) en 4) bestuurlijke afstand (ruimte laten voor initiatief onderop of juist straf leiding geven).

In het contact met de maatschappelijke omgeving ontwikkelt zich een diversiteit qua typen relaties, overeenkomsten en werkwijzen. Dit hangt nauw samen met de onthiërarchisering, individualisering, internationalisering en informatietechnologie. Van een 'unicentrisch' perspectief ontwikkelt de overheid zich naar een 'pluricentrische' focus, registreerde Teisman al in 1992, waarbij in wisselende samenstellingen problemen worden geagendeerd, oplossingsrichtingen worden geformuleerd, besluitvorming tot stand komt en de uitvoering (en handhaving of beheer) gestalte krijgt. Deze ontwikkelingen stellen eisen aan de beleidsmedewerkers, zowel voor wat de interne werkprocessen betreft als de inrichting van het contact met andere bestuursorganen, de departementale diensten en maatschappelijke instellingen en het publiek. Van een focus op louter interne beleidsvorming zijn de afgelopen jaren (en worden nog steeds) stappen gezet naar interactieve beleidsvorming, overdracht van taken en bevoegdheden, afstoting van werkzaamheden, aansluitingen op 
maatschappelijk initiatief en organisatie van nieuwe programmatische en projectmatige werkvormen zoals publiek private samenwerkingsvormen. Deze veranderingen leiden tot een reeks vernieuwingen, die hoe dan ook de klassieke Weberiaanse 'bureaucratie' relativeert, en zoals we uit het commentaar van bestuurskundige De Vries en vicepresident Tjeenk Willink van de Raad van State zagen, mogelijk verzwakt. Oftewel, hoe borgen we in de nieuwe netwerken democratische fundamenten als rechtsstatelijkheid, rechtsgelijkheid en integriteit? Het beroep van beleidsambtenaar vraagt dus naast inzicht in hiërarchische verhoudingen ook veel know how over het herkennen en hanteren van wensen en verwachtingen in de samenleving. Anders gezegd: hoe kan je als beleidsmaker meelevend zijn maar ook iedereen gelijk behandelen? Deze 'double bind' tekent de fundamentele eigen opgave van de beleidsmaker; Rutgers (2011) spreekt van de 'flippo-paradox': toen één persoon stikte door een stuk speelgoed in een chipszak, werd direct geroepen om regelgeving voor dit soort merchandising. Ook het discours rondom het rookverbod in horeca-instellingen laat het patroon zien: nieuwe regels, meer controleurs, hogere kosten maar ook weer meer regeldruk en controles en tenslotte zelfs afwijken van duidelijke regels.

Maakt ook het type overheidsorganisatie veel uit, in dit verband? Wilson komt in een studie tot een verdeling van organisaties naar de mate dat prestaties en resultaten bekend zijn (1989):

Tabel 2.2. Typen overheidsorganisaties (Wilson, 1989)

\begin{tabular}{|c|c|c|}
\hline & Effecten van activiteiten bekend & Effecten van activiteiten onbekend \\
\hline Prestaties bekend & $\begin{array}{l}\text { Productiediensten } \\
\text { (Dienst Uitvoering Onderwijs) }\end{array}$ & $\begin{array}{l}\text { Procedurele diensten } \\
\text { (Defensie) }\end{array}$ \\
\hline Prestaties onbekend & $\begin{array}{l}\text { Craft organisaties } \\
\text { (Staatsbosbeheer) }\end{array}$ & $\begin{array}{l}\text { Coping organisaties (scholen, welzijns- } \\
\text { werk, Centrum voor Werk en Inkomen) }\end{array}$ \\
\hline
\end{tabular}

Bij een 'productieorganisatie' - waar zowel de prestaties als de resultaten bekend is, zoals bij het verstrekken van studiebeurzen - zou dan sprake kunnen zijn van minder ongemakkelijke relaties dan bij een 'copingorganisatie', waar prestaties en uitkomsten niet of moeilijk meetbaar zijn. Zoals van leraren globaal bekend is wat ze doen, maar uitslagen van centrale examens niet duidelijk maken of de prestaties van de leerlingen een gevolg zijn van hun inzet of de specifieke kwaliteiten van de leerlingen. Uit een studie van Korsten ('Mensgerichte organisaties', ongedateerd artikel), die de typologie aanhaalt, kan ook worden afgeleid dat bij een combinatie van heldere prestaties en heldere uitkomsten sprake kan zijn van een complexe situatie. Zo kan bij uitkeringsinstanties (in de typologie een productieorganisatie) sprake zijn van een grote omvang van de vraag en dito aantal vragers in combinatie met vage doelstellingen, veel beleidsvrijheid van de ambtenaren en een veelvormig relatiepatroon met publieke partners. Het type overheidsorganisatie tekent zich daarbij dus niet af als een richtinggevend en 'uitsluitend' houvast. 
Deze verkenning van de overheidscontext brengt per saldo negen 'systeemspanningen' voor de ambtenaar in beeld. Het zijn de bijzondere kenmerken die de ambtelijke beleidsmaker op zijn weg kan vinden en waarvan het de vraag is of en hoe hij deze kan herkennen en hanteren:

I. Algemeen belang en individueel belang.

II. Hoge verwachtingen en beperkt draagvlak.

III. Beperkte beheersbaarheid en complexe processen.

IV. Efficiency en maatschappelijk commitment.

V. Democratisch verkregen macht en maatschappelijk commitment.

VI. Openbaarheid en zelfbinding (rechtsstatelijkheid).

VII. Lekenbestuurder en ambtelijke professional.

VIII. Korte termijn en lange termijn.

IX. Ondergeschiktheid aan een principaal en eigen verantwoordelijkheid.

\subsection{Tot slot: de ambtenaar als verschilmaker}

In een meer complexe beleidsomgeving doen steeds meer partijen mee die een inbreng hebben bij de vorming van beleid. Dit komt tot uiting in spanningen tot en tussen de geschetste typen relaties waarmee de beleidsmedewerker te maken heeft: de externe partners (burgers, maatschappelijke organisaties en collega-departementen), de politiek en de interne omgeving (collega beleidsmedewerkers en facilitaire diensten). Daarbij vraagt een complexere beleidsinhoud aandacht: wat op een overheidsbord wordt genomen of gelaten is, vormt steeds vaker een maatschappelijk gezien lastige dan wel onrendabele opgave. Door de vele partners met wie beleidsmakers rekening moeten houden wordt ook meer informatie verzameld; de verschillende partijen geven aan deze informatie ook weer verschillende betekenissen en dat maakt het onoverzichtelijk. Wie beleid maakt ontmoet kritiek, of maakt in ieder geval een grote kans daarop; de praktijk laat zien dat een beleidsmaker leert de spanningen herkennen en hanteren (Rijnja \& Meuleman, 2004). De vraag is hoe die betekenisverlening in de context van werk verloopt. Die betekenisverlening beschouw ik als een communicatief proces (bij een letterlijke vertaling van communicatie als: 'vergemeenschappelijken'). Kennis van en ervaring met het ontstaan van en het omgaan met verschillen is voor wie de overheid dient minder een keuze dan een aan zekerheid grenzende waarschijnlijkheid. 
Dit vraagt om een verdieping van de 'verschilvolle ontmoetingen' en dus van de aard van de confrontaties. 'Toen we de kritiek honoreerden, ging er pas iets veranderen', merkte de toenmalige secretaris-generaal van het ministerie van Verkeer en Waterstaat op in 2008, bij het hernemen van de interactie met het publiek over de uitbreiding van luchthaven Schiphol. Dit ambtelijk inzicht mag zijns inziens tijdens de beleidsvorming eerder langszij komen, en begint bij het aanspreken en ook tegenspreken van de ambtelijke en politieke top van de organisatie (Kuijken, 2008). Ook de Wetenschappelijke Raad voor het regeringsbeleid (WRR) onderstreept bij een studie over 'beleidsleren' bij de overheid (2006) de betekenis van ambtenaren als weerstandbewuste, zo niet weerstandbeluste medewerkers: 'de praktijk heeft uitgewezen dat loyaal zijn en kritisch tegenspel bieden goed te combineren zijn en juist het wezenskenmerk moeten vormen van de professionele ambtenaar van deze tijd'. Op grond van studie naar communicatie met sleutelfiguren bij ruimtelijke projecten signaleert Scholten (2009) een ontwikkeling naar 'daring democracy', waarin ook gedurfde planning, gedurfde besluiten en gedurfde ambtenaren nodig zijn: 'Risk seems to be the denotating element in the concept. Daring decisions always have an element of risk, whether they are controversial, innovative, having a high impact or a combination of the three other elements'. De auteur stelt vast dat veel aandacht uitgaat naar de technieken van beleidsvorming, besluitvorming en interactie en te weinig naar de individuele kwaliteiten van de ambtenaar, die hij bijna liefkozend 'beleidsondernemer' doopt: 'Their will to effect change, their skills, resources and strategies are vital in exercising their role as policy entrepreneur'. 


\section{Werk als context voor weerstand}

De 'losse koppeling' waaraan mensen betekenis ontlenen

\subsection{Inleiding}

Wat betekent 'werk' bij het ontmoeten van spanningen, zoals de weerstand van burgers of ondernemers tegen (voorgenomen) beleid? Na de verkenning van overheid als context voor werk, zoom ik in dit hoofdstuk in op werk als de context voor de omgang met weerstand. Daartoe belicht ik om te beginnen het fenomeen 'werk', de werknemer. Aandacht gaat uit naar de betekenis die mensen toekennen aan werk ('work meaning'): wat doet werk met jou en wat doe jij met werk? Vervolgens onderzoek ik het fenomeen 'weerstand' in de context van werk. Als object van onderzoek gaat de aandacht daarbij niet zozeer uit naar de vorming van de weerstand bij het publiek, maar naar de 'coping' ermee door beroepsbeoefenaren bij de overheid. Kennis van weerstand helpt de functie ervan te duiden: wat is het eigene van weerstand als reactie? Weerstand zegt iets over wat iemand niet wil, maar is dat louter negatief? Inzichten over beroeps- en functiegebonden weerstand brengen mogelijke interventies in beeld.

\subsection{Ambacht, vakmanschap, werk}

'Een goede metselaar kan, als hij een tas steenen ziet staan, direct zeggen, welk soort het is, voor welk doel ze gebruikt worden. Mooi materiaal, die steenen, zegt vader De Rooy en men ziet aan hem, dat hij van zijn materiaal houdt. Hij is een expert in 'steenenkunde' en betreurt het, dat van de 100 metselaars er 80 de steenen, die zij gebruiken, niet van elkaar kennen. Er zijn, meent hij, onder de metselaars te weinig vaklieden; het lijkt of zij geen ambitie hebben gehad in hun vak; steenen sjouwen, specie ertussen smeren en dat een aantal uren per dag, daarmee zijn ze tevreden. Dat is evenwel het vak niet. Zoo'n man kan geen schouwtje maken, ze hebben geen zicht op hetgeen gebouwd wordt en waar zijzelf aan meebouwen (...) zij weten niets van een porring en voor het maken van een gewelf staan ze als onmachtigen'. Op verzoek van de Vereeniging ter Veredeling van het Ambacht bundelde J. Spaan in 1941 zijn krantencolumns over 'vakbekwaamheid' tot de bundel 'De glorie van het ambacht'. Het geschreven portret van metselaar De Rooy toont enkele karakteristieken van een vakman: materiaalkennis, ambitie, oog voor context en ook trots.

De vertelling wijst ook op een grens, namelijk die tussen de ambachtsman - die louter een taak verricht - en de vakman, die iets goed wil doen omwille van het werk. Het onderscheid raakt aan een repeterend thema in teksten over vakmanschap. 'Hand' en 'verstand' strijden al eeuwenlang om de eer. Die tweedeling staat ook voor de spanning tussen de aanhangers van het 'hoe' en die van het 'waarom', tussen een focus op produceren in enge zin of het dienen van de gemeenschap en tussen je willen onderscheiden van anderen of verbindingen willen aangaan. Arendt verkoos het om onderscheid te maken: de Animal laborans is de werkezel die 
zich verdiept in zijn taak en de buitenwereld op afstand houdt: werk is een doel op zichzelf en de Homo faber verdiept zich in de context waarin zijn werk plaatsvindt; hij is niet zozeer de collega van de Animal laborans als wel diens meerdere. Is de Animal laborans gefixeerd op de vraag 'hoe', voor de Homo faber staat de 'waarom'-vraag centraal. Volgens Sennett (2008) suggereert dit onderscheid dat praktijkgerichte mensen niet kunnen denken; waarom kan Animal laborans niet als gids van Homo faber fungeren? Immers: 'om te leren van de dingen moeten we belang hechten aan de kwaliteit van stoffen of de juiste manier om vis te pocheren; aan de hand van fraaie stoffen en goed bereid voedsel kunnen we ons bredere categorieën van 'goed' voorstellen'.

Louter beschikken over kennis is dan ook ontoereikend; praktijkervaring is nodig om expliciete en onbewuste kennis te gebruiken. De vakman is bij Sennett een verbinder, demioergos (samenstelling van publiek (demios) en productief (ergon)). Hij is eerder uit op verbinden (coöperatie) dan op onderscheiden (concurrentie). Zo blijken organisaties waar vakgerichte doeners focussen op meetbare doelen en processen (gesloten kennissystemen), bij tegenstand minder veerkracht te hebben dan 'open kennissystemen': daar werken gebruikers mee bij het 'gemeenschappelijk' ontwerpen, produceren én toepassen van kennis. Het zijn de gilden waarin dit 'vergemeenschappelijken' tot een kunde wordt verheven: het gildesysteem gaat immers uit van systematische overdracht van kennis en vaardigheden langs de drietrapshiërarchie leerling, gezel en meester. Slaagde de leerling erin te ontwikkelen door imitatie, de gezel weet dat hij binnen de werkplaats - en vervolgens daarbuiten - inzicht en leiderschap moet tonen. De meester beschikte vervolgens over een - onaantastbaar - oordeel; hij verenigde in zich autoriteit en autonomie. Dat leidde soms tot gezelschappen met wel wat veel meester-ego's, maar ondertussen verdiepte en verbreedde de kennis zich in en door die gemeenschappen. Het gezag van de meester kwam zowel in vaardigheid van het ambacht als vaardigheid in het netwerk tot uiting. Dat was althans de bedoeling; tot de schrijnende voorbeelden van meesters die maar één van beide troeven ontwikkelden behoort de beroemde vioolbouwer Stradivarius. Sennett verhaalt hoe de zoons Stradivari na hun vaders dood de werkplaats moesten opdoeken, doordat pa zijn geheim in het graf meenam; onbekend is of hij bewust bang was voor het uitlekken van zijn werkwijze of onbewust een schat verborg. Kan vandaag de dag met analyse van het vernis en klankonderzoek een vrijwel gelijke kopie van een viool worden gemaakt, toen was de beschikbare hand van de meester een must. Stradivarius faalde in het delen van de veelheid aan bewuste - maar zeker ook onbewuste kennis die in zijn werkplaats werd opgebouwd. Ach, dat was voor de Verlichting, zeggen we nu; toen in de $18^{\mathrm{e}}$ eeuw het motto sapere aude (heb de moed om je eigen verstand te gebruiken) ingang vond, wisten werkgevers maar vooral ook werknemers wat hun te wachten stond. Verlichtingsvoorman Diderot meldt in 'zijn' Encyclopédie (1771-1751) na gesprekken met Parijse vaklieden hoe het inzicht de ronde doet dat werknemers moeten kunnen leren van ervaringen: blootstellen aan de praktijk helpt onvermogen onder ogen te zien en rekening te houden met beperkingen. 
De sociale component wordt in de loop van de geschiedenis steeds meer waarde toegedicht. Het fenomeen 'werkplaats' kreeg door de industrialisatie een nieuwe dimensie, waarbij machines het beeld gingen bepalen en het begrip 'arbeider' wortelde. We zijn vertrouwd geraakt met 'systemen' om werk te kunnen organiseren en 'management' is niet meer weg te denken: sturing van alles wat komt kijken bij het vinden, verdiepen en verbreiden van human resources. Ambachtsman, vakman, arbeider, leerling, meester, gezel, arbeider, manager: een steeds verdere arbeidsdeling voedde de nesteling van het containerbegrip 'werk', wat voor sommigen niet meer of minder dan een 'baan' was. De toenemende aandacht voor persoonlijke ontwikkeling bracht vervolgens de 'loopbaan' in beeld. In oud-Engels betekende een 'carrière' overigens een goed aangelegde weg en een 'job' een berg kolen of een stapel hout; in die betekenissen resoneert iets van vakmanschap en van per saldo langzame en sociale processen van denken én doen, weten én ervaren en individuele presteren én de gemeenschap dienen.

\subsection{De constructie 'werk'}

In deze korte schets lichten diverse kenmerken van werk op. Wat karakteriseert het verrichten van werk? Negen kernbegrippen helpen de betekenis van werk samen te vatten.

1. Persoonlijke eigenschappen. Voor het identificeren hiervan zijn meer meetmethoden beschikbaar waarvan de Myers-Brigges Type Indicator (MBTI) en de Big Five typologie als meest gebruikte kaders worden getypeerd (Robbins \& Judge, 2008). Gramsbergen e.a. (2005) wijzen op het samenkomen van enkele individuele kenmerken in arbeidssituaties. Het Big Five model onderscheidt vijf 'dimensies' 1) extraversie introversie (is iemand teruggetrokken of sociabel), 2) vriendelijkheid-vijandigheid (beschikt iemand over inlevingsvermogen, geduld ook), 3) zorgvuldigheid-slordigheid (kan iemand zich concentreren en doorzettingsvermogen tonen, bij Robbins en Judge (2008) 'plichtsgetrouwheid' gedoopt), 4) emotionele stabiliteit- neurotisch (toont iemand incasseringsvermogen, zekerheid) en 5) open-begrensd (hoe is het gesteld met de ontvankelijkheid om te ontplooien en oordeelsvermogen te tonen, Gramsbergen (2005) spreekt hier van 'intellectuele autonomie'). Er is discussie over de vraag in hoeverre deze eigenschappen aangeleerd kunnen worden. Volgens door hen aangehaald onderzoek van Bloemers en Hagedoorn (2001) suggereert genetisch onderzoek dat minimaal $60 \%$ van ons gedragsrepertoire en onze persoonlijkheid wordt verklaard uit genetische factoren ( maar ontbreken metingen die voor harde bewijzen kunnen zorgen).

2. Persoonlijke vaardigheden. Sennett (2008) schuift drie typen vaardigheden van vakmanschap naar voren. Je kunt een medewerker de maat nemen naar de mate dat hij in staat is tot 1 ) lokaliseren (specificeren waar iets belangrijks plaatsvindt en dit leiden naar een concreet voornemen), 2) bevragen (vermogen om door te dringen tot de kern, ontbloten van eigenschappen), en 3) uitbreiden (de ontdekte betekenis vergroten, openstaan voor nieuwe, andere werkwijzen). lemand die zijn vak verstaat 
heeft als belangrijke kwaliteit om (mensen te helpen) verder te kijken dan louter verschillen en tegenstrijdigheden (cognitieve dissonanties, Festinger, 1957). Dat lukt als hij kan 1) 'herformatteren': een bestaand instrument of geldende denkwijze op een andere wijze kan helpen bezien, 2) koppelen: twee onvergelijkbare domeinen bij elkaar brengen, zoals de vondst om radio en telefonie te verbinden, de mobiele telefoon voortbracht; 3) verwonderen: onbewuste kennis ophalen naar je bewustzijn om de koppelingen te maken, en het laten 4) Ianden: een idee vormgeven, met beide benen op de grond staan. Je zou dit ook 'constructieve nieuwsgierigheid' kunnen noemen.

3. Persoonlijke drijfveren. Galjee en Lazeron (2009) melden dat persoonlijke scores van werknemers over het rendement van hun vermogens steeds belangrijker worden. De vraag 'wat doe ik' legt het af tegen 'wat zet ik in'. Mensen meten de waarde van het werk af aan de mate waarin sprake is 1 ) van een gevoel van verbinding met de omgeving, 2) een beroep op eigen talenten, 3) erkenning van de eigen richting, 4) gevoel van een rechtvaardige behandeling, en 5) het gevoel dat het werk er voor iemand zelf toe doet: 'de centrale vraag is: hoe spreken de verschillende leidinggevenden mensen aan op de eigen zingevingsvragen en hoe verbinden zij deze vragen met de organisatie. (...) Als werk niet bijdraagt aan de eigen betekenis dan liggen fragmentatie en zinloosheid op de loer. (...) Als mensen zich als passanten zien is dat een gevaar voor organisaties. Er is een verlangen naar verbinding dat de welvaart ontstijgt: van welvaart naar welzijn naar welbevinden'. Grondslagen van dit denken zien we ook bij andere auteurs. Volgens Hackman en Oldman (1980) zijn mensen intrinsiek gemotiveerd als ze 1) zich persoonlijk verantwoordelijk voelen voor de kwantitatieve en kwalitatieve resultaten van het werk (autonomie), 2) hun werk als zinvol ervaren (als ze ervaren dat hun bijdrage een duidelijk toegevoegde waarde heeft) en 3) de feitelijke resultaten van hun spanningen kennen. Van Vuuren en Dorenbosch (2011) reiken het onderscheid tussen broodwinning, carrière en roeping aan. Deze trits is niet een ladder van 'goed' naar 'beter'; mensen met de derde werkoriëntatie uit de voornoemde reeks zijn vaker enthousiast en minder vaak ziek. De driedeling helpt de vraag te beantwoorden wat je eigenlijk van werk verwacht.

4. Sociale expertise. De aandacht gaat steeds meer uit naar de context waarin werk gestalte krijgt. Gardner (2002) noemt het belang om als medewerker te beschikken over 'sociale expertise': kennis waardoor je verder kunt kijken dan de elementen van een techniek, naar het hogere doel en de samenhang ervan. De (richtinggevende) normen van de vakman voor goed werk moeten voor de leek toegankelijk en begrijpelijk zijn en dat begint met het systematisch overdragen van informatie hierover binnen de organisatie. Kernberg $(1975,1999)$ signaleert een spanning bij experts om niet onopgemerkt te blijven, volgens hem is er sprake van een aanhoudend risico op 'zelfbewuste demonstratie' en narcisme. De goede vakman opent juist deuren; hij kent het belang van een schets, staat open voor onvoorziene gebeurtenissen en beperkingen, maar vooral: hij zingt zich niet los van zijn omgeving. 
5. Collegialiteit. Dit thema ligt in het verlengde van het voorgaande.

De wetenschappelijke aandacht voor dit thema (Nijhof e.a., 2002, Robbins, 2003, Gramsbergen e.a. 2005) leert dat sociale ondersteuning van collega's negatieve effecten van werkdruk en stressvolle situaties kan verminderen. Mensen met goede sociale contacten hebben minder last van zogenaamde burnout-verschijnselen dan mensen die in hun eentje hoge eisen en werkdruk trachten te weerstaan. Indicatoren van collegialiteit zijn: 1) belangstelling tonen, ook voor zaken die buiten de werksfeer liggen; 2) uit eigen beweging hulp en advies bieden en er om kunnen vragen, en 3) conflicten niet uit de weg gaan, maar doorspreken en bemiddelend kunnen optreden (Robbins, 2003). Bandura (1986) registreerde dat het waarnemen van een bepaalde aanpak bij anderen en het resultaat van die aanpak leidt tot de wens om dit gedrag te imiteren (bij een positief resultaat), of juist niet (bij een negatief resultaat). Hoe meer degene die het voorbeeldgedrag vertoont op ons lijkt (qua leeftijd, geslacht, enzovoort), des te groter is de kans dat we dat gedrag als modelgedrag voor onszelf accepteren. 'Our interactions, for example, with colleagues, clients, managers and employees, are the means by which we continually negotiate the shared 'contour lines of relevance' (Guevera \& Ord, 1996).

6. Leren en ontwikkelen. De meester motiveert, hij verleent de gezel en de leerling ambitie en ook ruimte: om te onderzoeken, ervaren, ontmoeten en creëren. 'Spelen' noemt Huizinga dat. In Homo Ludens (1938) zette hij uiteen dat in het premoderne Europa ouders en kinderen zelfde typen spelletjes deden, en hoezeer spelletjes doen helpt grenzen te zien en te beoordelen. De industriële revolutie zorgde ervoor dat volwassenen hun speelgoed wegdeden: nuttigheid werd belangrijker, maar het was fnuikend voor de nieuwsgierigheid, die kan optreden als je het speelveld betreedt, en het vermogen om met elkaar grenzen op te sporen en daarover afspraken te maken. Architect Van Eyck liet zien hoe belangrijk speelplaatsen in wijken zijn voor alle leeftijden: peuters in de zandbak, pubers met de bal en volwassenen die een oogje in het zeil houden. Zo ook kunnen werkplaatsen arena's zijn om te ervaren, te oefenen, te herhalen, en aan te passen. Spelregels helpen om te verstarren noch te verzanden; consistentie en complexiteit vragen en krijgen zo het broodnodige onderhoud. Grenzen maken het spel juist zo betekenisvol, schreef Huizinga al in de genoemde verhandeling uit 1938: 'Wij spelen, en weten, dat wij spelen, dus wij zijn meer dan enkel redelijke wezens, want het spel is onredelijk'. Leren is een werkwoord met een lange adem. Levitin (2006) berekende dat tienduizend uur een gebruikelijke norm is voor de tijd die nodig is om een expert te worden; dat komt neer op tien jaar lang drie uur per dag oefenen of bij de leerling in het middeleeuwse gilde zeven jaar lang ongeveer vijf uur per dag werken. Aldus verkrijg je 'ritme' en bereik je de 'routine' die nodig is om aanvankelijk ingewikkelde handelingen tot een bestendigende, vloeiende beweging te maken (Sennett, 2008). Weggeman (2007) ziet een terugkerend patroon in de geschiedenis - mensen ontwikkelen zich van 'trainee' naar 'ster', worden dan 'productietijger' en uiteindelijk 'verteller'. Hij noemt het belangrijk 
de doorontwikkeling van medewerkers te monitoren; de cyclus kan zich namelijk meermalen in een loopbaan herhalen. Een ervaren 'meester' kan ook weer een zoekende 'leerling' nieuwe ontwikkelingen helpen ontdekken. Ook Kolb (Prein, 2001) onderstreept het belang van ervarend leren: mensen werken beter zodra het 'wiel' van 1) concreet ervaren (voelen), 2) observeren (reflecteren), 3) theoretiseren (denken) en 4) actief experimenteren (handelen) in beweging wordt gehouden. Op basis van Kolb's leerfasen koppelde Weggeman (2007) basale oriëntaties van medewerkers aan kansrijke benaderingswijzen, waarmee hij een gedifferentieerde benadering binnen de complexiteit voorstelt. Hiermee ontstond het volgende beeld (vetgedrukt de oriëntaties en cursief de benaderingen):

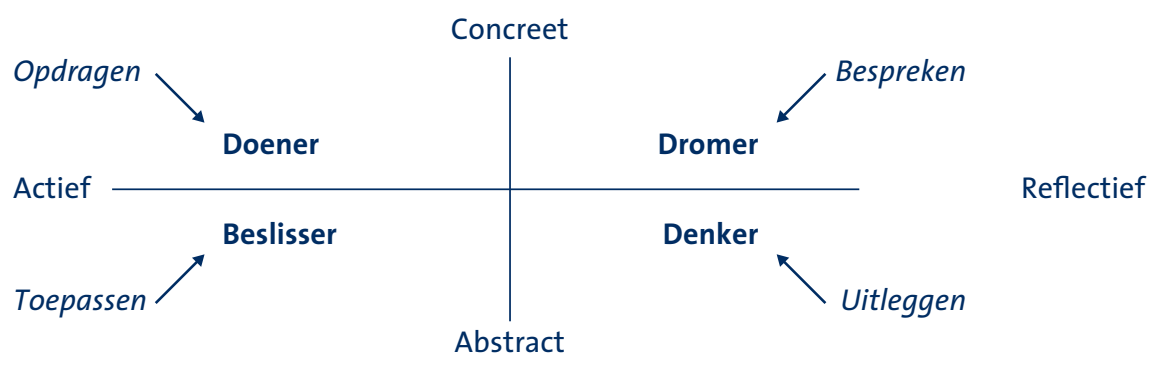

Figuur 3.1. Leeroriëntaties (Weggeman 2007)

7. Identificatie met de organisatie. Smidts e.a. (2001) bevroegen medewerkers van een nutsbedrijf, een non-profit dienstverlener en een grote bank over hun vereenzelviging met de organisatie. Daaruit kwam naar voren dat er twee belangrijke drijfveren zijn voor de mate waarin iemand zich wil identificeren met een organisatie, namelijk het 'communicatieklimaat' en het 'perceived external prestige': het interne beeld van de externe reputatie. Het klimaat wordt gevoed door de optelsom van twee deelbeoordelingen, namelijk de beschikbaarheid en bruikbaarheid van: 1) informatie over de organisatie ('inhoud') en 2) openheid door de top, persoonlijke steun en betrokkenheid bij belangrijke beslissingen ('rol'). Dat bevestigde de hypothese dat medewerkers die kennis kunnen reproduceren over doelstellingen, (product) ontwikkeling en toekomstplannen aanmerkelijk zekerder van hun zaak zijn en betere ambassadeurs (zie ook Dutton e.a., 1994). De identificatie wordt versterkt als medewerkers denken dat buitenstaanders positief over de organisatie oordelen: 'members may feel proud of being part of a well-respected company, as it strengthens their feelings of self-worth to 'bask in reflected glory'. Daarbij kan het gaan om krantenberichten, maar ook om informele verhalen. Het onderzoek laat overigens niet zien of het omgekeerde ook het geval is; leidt een negatief perceived external prestige tot een zwakkere identificatie? Carmeli (2009) maakte uit onderzoek (in Israëlische instellingen voor gezondheidszorg) op dat deze gepercipieerde beeldvorming buitenshuis vooral van betekenis is voor hechting ('affective commitment') aan de 
organisatie: ze blijven bij een organisatie omdat ze dat willen en niet omdat ze het gevoel hebben dat het moet. Qua inhoud werden uitspraken over het prestige uitgesplitst naar oordelen over bedrijfsmatige en sociale/relationele prestaties; het laatste type werd door de medewerkers meer betekenis toegedicht, als het gaat om de identificatie met de organisatie.

8. In- en extrinsieke baanaspecten. We plaatsen deze invalshoek bewust aan het slot van deze korte rondgang. Een goed salaris, baanzekerheid en interessant werk blijken de belangrijkste work values van werknemers (Ester e.a., 2004). Deze factoren komen voor de beoordeling van het management, de werkwijze van de organisatie en het beeldvorming vanuit de buitenwereld. Extrinsieke aspecten als salaris en carrièremogelijkheden blijken bij werknemers in de private sector zwaarder te wegen (Houston, 2000), terwijl intrinsieke aspecten als de inhoud van het werk en de mate van zelfstandigheid en verantwoordelijkheid bij werknemers in de publieke sector prevaleren (Lyons, 2006). Dit laatste komt ook naar voren in onderzoek van Steijn en Lensink (2007) naar de Public Service Motivation (PSM) van rijksambtenaren: 'aantrekkelijkheid van beleid en politiek' en 'betrokkenheid bij de publieke zaak' zijn de sterkste motivatoren. Voor de eerstgenoemde dimensie bleek ook nauwelijks verschil tussen sectoren te bestaan, bij het dienen van de publieke zaak vallen waarderingen bij 'harde' sectoren als politie, defensie en het openbaar bestuur hoger uit dan bij 'zachte' sectoren onderwijs en gezondheidszorg. Instromers noemen over de hele linie baanzekerheid en salaris belangrijker dan dat uitstromers aangeven; die kennen op hun beurt het management en de organisatie meer betekenis toe (Knies \& Leisink, 2008). Het externe imago van de werkgever speelt geen onbelangrijke rol (zie ook hiervoor), maar wel een ondersteunende, in zoverre dat bij de selectie van een baan de kenmerken van het werk meer betekenis wordt toegedicht dan de waardering die men toekent aan een organisatie (Ester e.a., 2004).

9. Psychologisch contract. De persoonlijke elementen die iemand in werk inbrengt krijgen betekenis in de 'interpersoonlijke contexten' (Weick, 1995), die 'organisaties' zijn. Intrinsieke factoren wegen daarbij zwaarder dan extrinsieke, vooral in de publieke sector. Volgens organisatiepsychologe Rousseau (1989) maken werknemers en organisaties naast een - formele, juridische - arbeidsovereenkomst ook een 'psychologisch contract' op. Dit betreft de - informele, beleefde - wijze waarop werknemers de 'ruilrelatie' met hun werkgever aangaan: wat belooft de werkgever hun, wat doen zij daarvoor terug? Het contract legt een basis: arbeidsorganisaties slagen er in mindere of meerdere mate in om drie noodzakelijke componenten van gedrag tot hun recht te laten komen: motivatie, capaciteit en gelegenheid (Triademodel, Poiesz, 1999). Dit heeft een persoonlijke dimensie, maar vanzelfsprekend ook een collectieve: organisaties met sterke psychologische contracten (ervaren veiligheid en zekerheid) kennen ook sterkere collectieve reacties bij reorganisaties (Nauta, 2007). De Caluwé en Vermaak (2004) wijzen op het 
fenomeen van de 'koppeling': medewerkers verbinden in een psychologisch contract gedrag en opvattingen. De mate waarin dat lukt, hangt in belangrijke mate af van de ervaren veiligheid om feedback te krijgen of te geven, of men daadwerkelijk iets over het eigen gedrag wil leren en of men over de vaardigheden beschikt om van en met elkaar te leren.

\section{Tussenbalans: werk}

Negen begrippen helpen duidelijk te maken hoe in werk persoonlijke aspecten (hulpbronnen, vaardigheden en drijfveren), sociale aspecten (de rol van collega's en de ruimte voor ontmoeting en reflectie) samenkomen. Bij dat samenkomen kan sprake zijn van 'contracten', in ieder geval is sprake van koppelingen die betekenis verlenen. Het betrekkelijke irrationele karakter van organisaties maakt het er daarbij niet makkelijker op te sturen of te reguleren: 'Organisaties houden de mensen van de straat, vormen een alibi voor vergaderen, vereenvoudigen sociaal contact, maar verder hebben ze niet veel te bieden'. Aldus Weick in 1969, toen hij de theorie van de 'losse koppeling' lanceerde. Hij verwijst daarin naar het lastige, ambigue karakter van organisaties waarin immers vele opvattingen en gedragingen samenkomen. Over deze - al dan niet losse - koppelingen tussen persoonlijke en sociale aspecten bestaan uiteenlopende opvattingen. De aan Weick toegeschreven theorie staat bijvoorbeeld op gespannen voet met de visie op organisaties als doelgerichte, bewust ontworpen machines, waar alles op elkaar is afgestemd. De Caluwé en Vermaak (2002) volgen Weick: 'Een organisatie is een verzameling keuzemomenten (cursivering door mij, GR) die een probleem vereist, onderwerpen en gevoelens die zoeken naar situaties waarin ze gelucht (geuit) kunnen worden, oplossingen die naar onderwerpen of problemen zoeken waarop ze een antwoord kunnen zijn en beslissers die naar werk zoeken'. Bij een eerdere beschrijving van de ontwikkeling van (externe) beleidsprocessen van de overheid kwam ook een dergelijke benadering naar voren. Een voorbeeld is Kingdon's (1984) signalering dat beleidsvorming steeds meer trekken heeft van 'policy windows': het zelden geplande samenkomen van problemen, oplossingen en krachten die oplossing mogelijk maken. Staveren en Boonstra (2007) menen dat 'lerende organisaties' erop gericht zijn om personen tot hun recht te laten komen in de voorkomend coalities c.q. losse koppelingen. Vooral publieke organisaties streven volgens hen naar 'waardecreatie'. Deze opvatting ziet bestuurslagen als 'waardecreërende systemen' waarin organiseren, veranderen en communiceren leerprocessen zijn van betekenisgeving en interactie. Een lerende organisatie maakt het mogelijk een 'oerconflict' (Hanson, 1996) als het ware te dempen: aan de ene kant willen medewerkers immers sturing en beheersing vermijden, aan de andere kant willen leidinggevenden beheersen en veranderingen te sturen. Hanson stelde vast dat conflicten tussen domeinen kunnen worden opgelost als (1) partijen zich bewust zijn van het conflict, (2) elkaars domein respecteren en daar niet op willen ingrijpen, (3) de afhankelijkheid van elkaar (willen) zien, (4) er een forum voor overleg (communicatie) is en (5) er overeenstemming is over procedures voor overleg met een wederzijds gelegitimeerde coördinatie van de besluitvorming. Is er, met andere woorden, een 'kritisch overgangsgebied', waarin verwachtingen en opvattingen worden uitgewisseld? De kwaliteit van de 'ontmoeting' 
van het individuele domein van professionals en dat van leidinggevenden is essentieel voor de ontwikkeling van professionele organisaties.

Deze duidingen leiden naar de vraag hoe individuen binnen dat complex komen tot duiding, ordening en dus 'koppeling' (betekenisverlening, 'sensemaking', Weick, 1995). Op basis van onderzoek naar veranderingsprocessen binnen organisaties stelde Weick vast dat werknemers bij de veelheid van (nieuwe) informatie die op hen afkomt in eerste instantie teruggrijpen op ervaringen of routines, maar als dit niet lukt pas in staat tot duiden en besluiten wat te doen, als de informatie die op hen afkomt, aansluit bij de context waarin zij verkeren. Dat maakt de betekenisverlening tot een uiterst relevant aanknopingspunt voor het begrijpen van werk en daaraan gekoppelde gedragingen.

\subsection{Sensemaking: werkzame verhalen}

Hoe geven mensen betekenis, of: hoe werkt het proces van sensemaking?

Wrzesniewski e.a. (2003) wezen als startpunt op een directe of subtiele verstoring. Weick (1995) etaleerde dat moment nadrukkelijk als een soort kansrijke verwarring; 'complexiteit' is een bevorderende factor voor een medewerker om over de betekenis van werk na te denken: 'I suspect that turbulence throws people back on whatever heuristics for noticing they know best'. Aandacht voor betekenis van werk ontstaat bij uitstek als mensen worden geconfronteerd met een moeilijk te dichten kloof en als die kloof ertoe doet. Oftewel, een vakman wordt pas wakker als hij een probleem ziet en moet handelen. Weick: 'The combination of a lack of clarity and multiple interpretations produce a shock that engages sensemaking'. Deze invalshoek biedt een interessant houvast voor het theoretisch kader voor de ambtelijke omgang met (vermeende) weerstanden in dit onderzoek.

Volgens Pratt and Asforth (2003) begint het proces van betekenisgeving op het werk met twee typen kernvragen: 1) persoonlijke vragen naar de eigen rol ('wat doe ik?) en 2) organisatiegerichte vragen ('waar behoor ik toe?'). Het antwoord op deze vragen leidt naar een oordeel over de betekenis van het werk: 'daarom ben ik hier'(waarbij ook het zelfbeeld een vraag toevoegt, dus 3) 'wie ben ik?'). Wrzenieswski e.a. (2003) maakten uit onderzoek op dat de persoonlijke vragen per saldo zwaarder wegen dan vragen over de plek in de organisatie: alles begint bij de plaats die werk in je leven inneemt. Ook is het niet zozeer een individueel als wel een interpersoonlijk afwegingsproces. Dat ligt niet per se voor iedereen gelijk. Eerder onderzoek naar arbeidsmotivaties (Wrzesniewski e.a., 1997) bracht drie dominante 'oriëntaties' op werk in beeld, die vooral zicht bieden op het gewicht dat mensen überhaupt aan de zingeving van werk toekennen. Ziet iemand zijn werk als 'baan' ('Job'), carrière ('Career') of als roeping ('Calling')? Bij de eerste categorie is werk louter een middel om geld te krijgen waarmee je buiten het werk leuke dingen kunt doen. Wie een loopbaan belangrijk vindt kijkt naar beloning, prestige en status, en dus de ontwikkelingsmogelijkheden. We herkennen in beide typen de ambachtsman van Sennett (2008). Hoewel roepingen van oudsher aan religieuze dienstbaarheid worden gekoppeld, gaat het bij de categorie 'Calling' om mensen 
die gefocust zijn op het werk in zichzelf en de bijdrage aan een groter geheel en een betere wereld. Niet alleen de inhoud doet er in verschillende mate toe, ook en vooral de intensiteit waarmee men verwacht dat een baan helpt persoonlijke doelen te verwezenlijken. In oplopende mate kan dus bij de drie typen oriëntaties sprake zijn van een intense 'meaningfullness', en een dito gevoeligheid voor werkgerelateerde signalen of cues (Weick, 1995). Uit onderzoeken naar motivaties van beleidsambtenaren kwam deze laatste drijfveer pregnant naar voren (BZK, 2008, RVD/DPC, 2009) $)^{4}$.

Wrzesniewski e.a. (2003) introduceerden het begrip 'workmeaning 'voor de wijze waarop medewerkers betekenis verlenen aan hun werk. Centraal in deze uitleg van de manier waarop mensen hun werk waarderen, prijkt de persoonlijke optelsom van drie dimensies binnen 'werk': job meaning verwijst naar de betekenis die een individu toekent aan activiteiten en taken, role meaning betreft de betekenis van je positie in de organisatie, en selfmeaning staat voor wat de baan iemand leert over zichzelf. Medewerkers turen als het ware - vaker onbewust dan bewust - door twee lenzen naar het trio baan, hun rol en zichzelf; door het ene glas monsteren ze de inhoud ('wat is hier gaande?') en door het andere evalueren ze het rendement ('wat is dit waard?'). Dit denken wordt geactiveerd door een signaal: dat kan een mondelinge vraag zijn, een mail of een andere gebeurtenis. Deze cue (Weick, 1985) zorgt ervoor dat naast bovengenoemde twee lenzen, ook een waardeoordeel wordt gegenereerd: bevestigt dit mij in mijn functioneren of verstoort het de facto (Wrzesniewski: is er sprake van 'affirmation resp.'disaffirmation')? Deze denkstappen in betekenisgeving leiden naar gedachten en uitspraken over de baan, de eigen rol en persoonlijke gevolgen, en dat mondt uit in een oordeel, maar vooral ook in handelingen: laat je het er bij zitten, kom je in actie, wat ga je doen? De energie die deze betekenisgeving geeft, heeft belangrijke opbrengsten. Cartwright en Holmes (2006) rapporteren dat een 'hoge' workmeaning kan leiden tot een verbetering van de prestaties van een organisatie, het behouden van medewerkers, effectief management van veranderingen, een groter commitment van de organisatie en betrokkenheid van medewerkers. En 'lage' workmeaning kan navenant leiden tot lossere banden met de organisatie, cynisme en vertrek.

Uit studies blijkt het dominante sociale karakter van dit proces; work meaning kan dan ook worden opgevat als een interpersoonlijke vorm van sensemaking. Zo toetsen medewerkers persoonlijke 'waarderingen' van hun werk in mindere of meerdere mate aan anderen; de conversaties over deze 'evaluaties' nemen een belangrijke plaats in (Hackman \& Oldham, 1980). Er is sprake van een actief proces, en niet alleen indien de eerste cue een bevestigende, positieve lading heeft. Integendeel, zodra de signalen een negatieve lading hebben is de drang collega's te benutten groter (Dutton, 2003). Medewerkers romen de markt af voor kansen om te informeren, consulteren en samenwerken: 'Our perspective also assumes that employees seek out

4 We vinden een verwijzing terug in diverse bestuurshuizen. In glas in lood roept een raam in de hal van het stadhuis van Alkmaar de binnenkomende ambtenaren toe: 'Indien 't gemeen U roept besorght het als uw eigen'. Joost van de Vondel (1579-1687) gebruikte de spreuk naar verluidt toen hij Cornelis Pieterszoon Hooft, burgemeester van Amsterdam, karakteriseerde. 
social situations in which their view of the meaning of their job, role, and selves is reinforced by the cues they are likely to receive in those settings or interactions' (Wrzesniewski, 2003).

Work meaning blijkt dus naast een actieve aangelegenheid in hoge mate een sociale constructie. Terzijde kan worden opgemerkt dat dit ook logisch is, gezien het feit dat de meeste ervaring met werk ook op het werk wordt gemaakt. Het gaat daarbij echter niet louter om de uitwisseling van informatie maar om conversatie: het contact met anderen stuwt de ervaring, waarneming of oordeel in een vorm, een vertelling. Zoals bij een onderzoek naar werkbeleving onder chirurgen bleek: 'Until recently, I wasn't sure how meaningful my work was. I had doubts. A surgeon does a really beautiful job. That's meaningful to him immediately. But it's not the kind of sustaining thing that makes a job meaningful. It must concern the relationship that you have with the people you work with' (Terkel, 1972). Deze conversaties kunnen bepalend zijn voor de prestaties van een organisatie, doordat de verhalen niet alleen informatie en conversatie in zich dragen over wat iemand (be)denkt, maar ook interpretaties en evaluaties over wat iemand doet (Quinn \& Dulton, 2005). Verhalen maken concrete voorstellingen van zaken die een communicatieve waarde vertegenwoordigen: ze worden doorverteld en bieden aanknopingspunten voor nieuwe ervaringen, interpretaties en evaluaties (Weick, Sutcliffe \& Obstfeld, 2005). Ook Czarniawska onderstreept in haar studie van verhalen in organisaties (1997) het interactieve karakter: 'we are never the sole authors of our own narratives; in every conversation a positioning takes place (...) which is accepted, rejected or improved upon by partners in the conversation'. De kracht van die verhalen schuilt in het begrijpen van verstoringen, 'its openness for negotiating meaning', en de betekenis hiervan neemt dus toe naarmate meer sprake is van verstoringen in de context van het werk.

Fairhurst en Sarr (1996) stelden hierbij vast dat het gebruik van metaforen, jargon, contrast en een spin (voordelen benadrukken) als hulpmiddelen fungeren. Complexe informatie kan aldus worden voorzien van een 'frame' en in een concrete voorstelling om worden gezet. Voorop in dit lijstje staat de metafoor, die vooral blijkt te helpen als je bestaande gegevens in een nieuw licht wilt (helpen) plaatsen. Gabriel (2000) onderzocht vele organisatieverhalen en stelde vast dat in alle vertellingen dominante stijlmiddelen naar voren kwamen:

1) verantwoordelijkheid, 2) motief, 3) emotie, 4) eenheid/uitsluiting, 5) agency/agendasetting en 6) causale relatie. Gesprekspartners verwerven met één of meer van deze middelen aandacht, interesse en contact. Framing kan helpen om in complexe situaties zaken naar voren te halen of juist 'backstage' te positioneren: 'From this perspective, framing refers to using a particular 'repertoire' of categories and labels to bracket and interpret ongoing expereience and inform action. In other words, it refers to the communicative processs through witch people forground or background certain aspects of experience and apply a set of categories and labels to develop 'coherent stories of what is going on' and make decisions about 'what should be done given [those] unfolding stor[ies]' (Weick, 1999).

Ook structuur helpt een boodschap te laten landen, waarbij meerdere invalshoeken effectief blijken. Boodschappen komen over als ze de 'So what-proof' (Rijnja \& De Witte, 2007) doorstaan: wie vraagt me wat? > waarom moet ik dit weten? > kan ik het volgen? > wat moet 
ik ermee? > wat gaan we doen? Op corporate niveau geldt dat mission statements en corporate stories meer effect sorteren als ze de trits bevatten: waar komen we vandaan? > waar gaan we naar toe? > en waar staan we nu? (Van der Jagt, 2004). Klassieke heldenverhalen kennen een basisstructuur die ook teruggevonden kan worden in moppen en small talk: kwestie > held > weerstand > overwinning > perspectief (Rijnja, 2004). Greimas (1988) filterde uit organisatieverhalen vier 'narratieve fasen', er is altijd sprake van: een inbraak die aandacht vraagt ('manipulation'), een competitie waarin voorstellen en argumenten worden uitgewisseld ('competence'), een concluderende verbinding ('performance') en een afsluitende moraal ('sanction'). 'Narratieven' is het verzamelbegrip voor 'verhalen' waarvan steeds duidelijker wordt hoe ze mensen helpen ervaringen, oordelen en evaluaties te delen met anderen. Quinn en Dalton (2005) stelden na een gespreksanalyse vast dat in groepen het effect van deze opbouw toeneemt naar mate sprekers erin slagen om anderen bij een conversatie te betrekken: 'Thus, both the narrative's goal and the perspective from which the narrative is 'told' affect the energy people feel and the degree to which people create collective subjects that generate high-energy interactions.' In verhalen vinden betekenissen dus vaak een vorm, en dat is in hoge mate een interpersoonlijke aangelegenheid. Complexiteit van de context waarin die betekenis wordt verleend, is een relevante en stimulerende factor. Door de vertellingen (narratieven) zijn mensen beter in staat om in een organisatie een verstoring of verandering aan te pakken en te hanteren. De context van het werk, voorop de werkplaats en de collega's doen er daarbij in hoge mate toe, vooral omdat ze er zijn en dus mee kunnen interpreteren en evalueren. Als een pendant van de perceived external prestige ontpopt zich dus ook een belang voor een perceived internal prestige. En vice versa, want we hebben te maken met een toenemende openheid: het onderscheid tussen binnen- en buitenwereld vervaagt. Czarniawska (1997): 'What traditional politicians may have difficulty in grasping, but what the officials understand well, is that in postmodern times the notion of 'backstage' vanishes'. Voorgrond en achtergrond, werkelijkheid en spel vermengen en leiden in tal van vakgebieden tot wonderlijke vermengingen van professionals en amateurs, hoofd- en bijrolspelers.

\section{Tussenbalans: sensemaking}

Binnen de 'losse koppeling' die werk heet zijn mensen dus op zoek naar betekenissen. Zodra persoonlijke factoren als eigenschappen, vaardigheden en ook drijfveren worden aangesproken kan worden gesproken van leerprocessen. Daarbij zijn als het om werk gaat meerdere lagen te ontdekken, omdat medewerkers de taak, hun rol en de betekenis van interacties met anderen - bewust en onbewust - mee laten wegen. Naast de waargenomen oordelen van de buitenwereld spelen de waarnemingen van collegiale oordelen ook een rol: het perceived internal prestige. Werkgevers kunnen deze processen onderkennen en er dan actief ruimte voor bieden. Persoonlijke herkenning van dergelijke processen is hoe dan ook wezenlijk voor het begrip van de context waarin je als werknemer beslissingen neemt. Verstoringen helpen daarbij om bewust te zijn van de keuzes waarvoor je in je werk gesteld kan worden. Organisaties kunnen ervoor kiezen om de verhalen van die verstoringen te beschrijven en als expressies van de organisatie-identiteit levend te houden. 


\subsection{Weerstand, een kwestie van perspectief}

De ambtelijke omgang met negatieve publieke houdingen worden hier gekoppeld aan het begrip 'weerstand'. Wat is weerstand, hoe doet weerstand zich voor in werksituaties en hoe herkennen en hanteren werknemers die situaties?

Weerstand is een verzamelbegrip, met alle risico's van onnauwkeurigheid van dien. In de organisatiekunde bestaat hiervoor veel aandacht. Een vroege vindplaats is Lewin (1948): 'een opeenvolging van acties om grote veranderingen tegen te gaan'. Maure (1996) spreekt van 'een kracht die beweging vertraagt of stopt'. Het ontmoeten van weerstand in het werk is op zichzelf een normaal sociaal gegeven en dat geldt ook voor daarbij optredend ongemak. Weerstand is ook niet bepaald eigen aan het verrichten van werk, ons hele doen en laten is ervan doorspekt. Ongemak hoort er dan ook bij, maar kan ons ondertussen danig uit balans brengen. In de literatuur is de nodige aandacht te vinden voor het streven om die onbalans uit de weg te gaan en eigen overtuigingen en acties zoveel mogelijk met elkaar in verband te willen brengen (Festinger, 1957). Mensen en organisaties kunnen kleine schommelingen absorberen, maar grote schommelingen leiden, als ze niet kunnen worden genegeerd, naar verzet (Lewin, 1948).

Van conflicten is bekend dat zij niet statisch zijn, maar zich dynamisch ontwikkelen in een sociale context. Dat kan zichtbaar zijn, maar ook sluimeren. Noelle-Neuman (1980) maakte uit onderzoek ook op hoe bij weerstand tegen verandering individuen onbewust of deels bewust 'ondergronds' gaan als hun stem niet wordt gehoord, en ze onvoldoende macht ervaren om gehoord te worden of een gewenst doel te bereiken. Escalatie is in dit verband een relevant fenomeen. Kim (2004) stelde vast dat bij een toename van harde strategieën, het uitgroeien van kleine kwesties en toename van kwesties of betrokkenen een 'conflictspiraal' in werking kan treden. Glasl (1990) typeert de gefaseerde doorontwikkeling als een doorgroei van win-win (met pogingen tot samenwerking, toenemende polarisatie en uiteindelijk een appèl op het geven van hom of kuit; 'geen woorden maar daden') via win-verlies (waarin zich competitie voordoet, coalitievorming plaatsvindt en men uiteindelijk ijvert voor het voorkomen van gezichtsverlies) naar verlies-verlies (waarin het 'sanctiepotentieel' van de ander wordt vernietigd of verkleind, getracht wordt de tegenpartij te versplinteren en uiteindelijk uitmondt in (zelf)vernietiging). Eeuwema en Wild (2006) signaleren daarbij dominante oriëntaties van mensen, waarbij het toegekende belang richting geeft. Competitieve mensen houden van conflict en zien eerder strijd, willen winnen, terwijl mensen met een coöperatieve instelling eerder tegenstelling aanvoelen en dan harmonie nastreven en een oplossing zoeken.

Voor het ontstaan van weerstand wijzen Eidelson en Eidelson (2003) op de essentiële betekenis van een persoonlijke ervaring, waarbij vijf 'aanjagers' zijn te onderscheiden: superioriteit, onrechtvaardigheid, wantrouwen, kwetsbaarheid of hulpeloosheid. Giebels en Eeuwema (2006) wijzen op de werking van een 'wig' tussen rolopvattingen en rolverwachtingen. Uit onderzoek maken ze op dat rolonduidelijkheid, roloverlading en 
rolconflicten de meest voorkomende oorzaken zijn bij conflicten in de context van organisaties. Bij weerstand van derden is sprake van afhankelijkheid, (psychologische) ervaring, spanning; een raakvlak tussen een interpersoonlijke en een intrapersoonlijke beleving, een serie opeenvolgende gebeurtenissen (Giebels \& Eeuwema, 2006 met verwijzing naar Van der Vliert, 1997). De auteurs merken op dat sprake kan zijn van een eenzijdige houding en relativeert het 'persoonlijke' karakter: er kan ook sprake zijn van terugvallen op opinies van anderen. In zijn studie van emoties (1993) heeft Frijda de ontwikkeling van emotionele reacties beschreven. lemand voelt (a) een plotselinge verandering in gedrag, (b) een fysiologische reactie en (c) een persoonlijke evaluatieve beleving (Frijda, 1993). Deze meer affectieve (gevoel) dan cognitieve (denken) reactie (Ajzen, 2002) heeft een relevante functie, namelijk om de eigen zogeheten 'bronbelangen' te beschermen, bewaken en bevredigen - en het eigen handelen weer op het spoor te zetten. Hij noemt zes typen 'bronbelangen'. Zodra die geraakt worden kan een emotionele reactie veroorzaken: nieuwsgierigheid, spanning zoeken, nabijheid en samenhang, vertrouwdheid en oriëntatie, beheersbaarheid en waarden. Van der Pligt en Damen (1998) wijzen erop dat de inschatting van consequenties voor de eigen centrale waarden een belangrijk criterium is voor een weloverwogen beslissing (positief óf negatief); zij verbinden hieraan de stelling dat publieksreacties niet louter als emoties of angstgedreven reacties kunnen worden weggezet. Dekker (2005) registreerde in metingen naar publiek vertrouwen ook een toename van aandacht voor rationele, inhoudelijke keuzes van kabinetten bij het publiek. Simon acht het blijkens zijn studie over besluitvorming in organisaties onmogelijk om rationeel te kiezen (1966): 'Rationaliteit vereist volledige kennis en anticipatie van de consequenties die volgen op iedere keuze. In feite is echter kennis van consequenties altijd fragmentarisch. Omdat deze consequenties in de toekomst liggen, moet de verbeelding het gemis aan ervaring in het waarderen daarvan aanvullen. Men kan zeer onvolledig op waarden anticiperen. Rationaliteit vereist een keuze uit alle gedragsalternatieven die mogelijk zijn. Bij feitelijk gedrag komen slechts enkele van deze mogelijke alternatieven in gedachten'.

Metselaar en Couzijnsen (1997) hekelen de overwegend negatieve uitleg van het begrip. In hun studie wordt weerstand uiteengetrokken als een botsing met normen en waarden van een groep (sociaal perspectief), een verstoorde balans tussen stabiliteit en verandering (psychologisch perspectief) en een conflict tussen partijen (politiek perspectief). Volgens Merron (1993) is het beter om te spreken van 'veranderingsbereidheid', teneinde niet tegenkrachten centraal te stellen, maar datgene waar iemand naar zoekt. Cuppen heeft naar aanleiding van onderzoeken naar weerstand bij CO2 opslag (2009, 2011) vastgesteld dat meer dan van tegenkrachten sprake is van perspectieven van mensen: 'Sommige mensen voelden zich een proefkonijn, terwijl anderen vreesden voor de waarde van hun woning (...) maar alle tegenstanders werden op één hoop geveegd'. Merron (1993) spreekt in het kader van organisatieverandering over weerstand als 'een verzameling uiteenlopende ideeën over hoe de organisatie eruit moet gaan zien'. Hoe nemen mensen een nieuwe ontwikkeling waar, hoe percipieert men de verandering die voorligt, daar draait het om. Daarbij kan sprake zijn van niet durven (angst, schroom en schaamte), niet willen (twijfel, verzet, boosheid) en niet kunnen (onvermogen, verlamming) met allerhande tinten op een denkbeeldig spectrum daartussen 
(zoals woede, cynisme, afkeer en afhaken) (Metselaar 2002). Het onderscheid naar willen, kunnen en durven komt voor in de basistheorieën van Ajzen (2002) en Fishbein (1967) naar veranderbereidheid en hun gezamenlijke theorie van beredeneerd gedrag (1975). Keuzegedrag wordt gestuurd door eigen waarden en normen ('wil ik dit wel'), de omgevingsinvloed ('durf of mag ik dit wel') en de eigen effectiviteit ('kan ik dit wel').

Diverse auteurs wijzen op het bewuste en beredeneerde karakter van gedrag in relatie tot weerstand (o.a. Gramsbergen, 2005, Dijksterhuis 2007, Pol e.a. 2007); Moeskops (2006) wijst op zogeheten 'projectieve processen': de onbewuste overdracht van emoties op een ander, die zich in iedere relatie voordoen. Ze kunnen zich ook voordoen als afweer van onaangename of beangstigende gevoelens, en in hevige vorm tot identificaties leiden. Het gaat dan om wel ervaren maar niet nader geduid ongemak. Als dat bestendigt ('doorzeurt') kan 'collusie' ontstaan: een dergelijke onbewuste spanning leidt dan tot afstand, die niet eerder wijkt eer één van de gesprekspartners in staat is de spanning te benoemen. Ook de zogeheten 'motivationele vertekeningen' worden onbewust uitgevoerd: behoefte aan zelfbescherming en zelfverheerlijking leidt makkelijk tot vertekening. Eigen succes schrijven we toe aan onszelf, mislukkingen aan anderen (Frank \& Gilovich, 1988). Succes van anderen wordt toegeschreven aan externe oorzaken en mislukking aan interne factoren. Hier wordt ook gesproken over 'fundamentele attributiefouten'. Schultz Von Thun (2004) noemt het samenkomen van emotionele en rationele aspecten bij de ontvangst van boodschappen. ledere boodschap kent een zakelijk aspect (komt de boodschap helder over), een expressief aspect (kloppen getoonde emoties met de inhoud), een relationeel aspect (wat 'zegt' de boodschapper over een ander) en een appellerend aspect (welk beroep doet iemand). Als zich ergens weerstandgedrag voordoet is altijd sprake van een samenkomen van rationele factoren (aard en inhoud van een verandering), procesfactoren (inrichting van een aanpak) en persoonlijke, in het individu gelegen factoren. De typen zijn in afnemende mate te identificeren en stuurbaar (Horn, 1998).

Ford (1999) noemt de betekenis van ervaring van weerstand en karakteriseert dit als een 'tweede orde werkelijkheid'. Ervaring werkt als een attributie die ontstaat op basis van een andere gebeurtenis, en die daardoor beter hanteerbaar is dan de feitelijke oorzaak of veroorzaker. Weerstand is dus een ervaring van een ervaring, een interpretatie, een vorm van framing van de situatie die zich voordoet. Eysink Smeets (2008) maakte uit onderzoek naar publieke percepties van overlast en veiligheid op dat bij het ontbreken van een eigen ervaring beelden van buiten (waaronder die van de media) de rol van de eigen ervaring kunnen overnemen en voor een forse vertekening kunnen zorgen. Weerstand kan dus ontstaan uit een eigen ervaring en, bij ontbreken daarvan, uit vervangende beelden. Eysink Smeets registreerde bij directe ervaring een milder of positiever oordeel dan bij de indirecte beeldvorming. Ook Zeelenberg en Pieters (2006) wijzen op de betekenis van 'ervaring' voor het funderen van een oordeel. Een negatief oordeel over een situatie is het product van een ervaring met het handelen van anderen, die in strijd is met een verwachting over dat handelen: 'Disappointment is felt in situations where others are responsible for the bad experience' (Zeelenberg \& Pieters, 2006) en 'disappointment stems from disconfirmed expectancies', Zeelenberg, 1998). 
Dit oordeel kan betrekking hebben op individuele personen en op organisaties. Studies naar de werking van teleurstelling bij aankoop van producten wijzen op een hefboomwerking en dus de mogelijkheid van verscherping van het oordeel. 'The experience of disappointment involves feeling powerless, feeling a tendency to do nothing and get away from the situation, actually turning away from the event, and wanting do to nothing' (Zeelenberg, 1998). De Nationale ombudsman concludeerde op basis van eigen onderzoeken dat bij het ontbreken van contact met einddoelgroepen (burgers bijvoorbeeld) een grotere kans ontstaat dat ambtenaren mechanistisch en afstandelijk te werk gaan. Hij hekelde in dat verband het 'opknippen' van werkzaamheden (jaarverslag 2007). Eerdere ervaringen vergroten de kans op weerstand dan wel het voorkomen ervan. De 'beschikbaarheidheuristiek' doet zich dan voor: de neiging om de waarschijnlijkheid van een gebeurtenis af te leiden uit hoe je gemakkelijk meer voorbeelden uit het geheugen kunt oproepen. Ook enkele andere klassieke vuistregels in de sociaal-psychologische literatuur wijzen op een correlatie tussen een geschiedenis die mensen hebben met een ander of een organisatie en de kans op weerstand. Relevant is de werking van de 'confirmatievertekening': de neiging om informatie te verzamelen, te interpreteren en te scheppen, in overeenstemming met gangbare opvattingen en de hiermee verwante 'confirmatiezucht': mensen kennen meer gewicht toe aan informatie die hun overtuigingen bevestigt. Hier ligt een verwantschap met de ook eerder geïdentificeerde betekenis van leren en ontwikkelen. De 'negativiteitsvertekening' leert dat indrukken die zijn gevormd op basis van negatieve termen, extremer doorwerken dan indrukken op basis van even positieve termen (onder anderen in verzamelwerken als Gray, 2003); ook de dominantie van het 'conflictframe' (Kleijnnijenhuis, 2003) bij de formulering van wat nieuwswaardig is bewijst de aandacht voor het negatieve: weerstand $=$ verzet $=$ slecht... . Negatief herinnert beter en heeft een hogere conversatiewaarde zoals ook geruchten bewijzen: deze negatief getoonzette verhalen hebben als prominent kenmerk dat velen ze snel kennen terwijl ze zelden op papier staan. In de Chinese taal wordt het begrip 'crisis' gesymboliseerd door de samentrekking van 'gevaar' en 'kans'. Ook conflictexpert Kenneth Cloke (2006) onderstreept de kwaliteiten van het bieden van weerstand. Boos maken geeft ook energie, met een vijand verschaf je jezelf een identiteit, het schort eigen tekortkomingen op en het bespoedigt resultaten als je een bureaucratische molen tegenkomt: 'it forces others to heed us, especially faceless bureaucrats, clerks, and 'service representatives', who only seem to respond to our requests or do what we want when we yell at them'. In een soms hilarische verhandeling komt hij uit op de conclusie: weerstand bieden is vooral een signaal afgeven.

\section{Tussenbalans: weerstand}

Naast een dominante negatieve uitleg is een andere duiding van dit verzamelbegrip mogelijk, waarbij wordt uitgegaan van een ondernemende instelling van een persoon of populatie, waarbij sprake is van bereidheid om een uitweg of doorgang te vinden. De definitie van Merron spreekt aan. Hij positioneert weerstand als meervoudige perspectieven op een situatie. Deze benadering sluit aan bij bevindingen uit onderzoek van Weick (1995). Hij stelde op basis van onderzoek in organisaties vast dat mensen streven naar de meest positieve 
opbrengst, het belonings- of utiliteitsprincipe (bijvoorbeeld in de vorm van waardering of bewondering vanuit de directe sociale omgeving) en actief aan de slag gaan om de ongestructureerde en soms chaotische werkelijkheid te begrijpen en daaraan betekenis te verlenen. Zodra de nieuwe informatie aansluit bij de mechanismen die binnen die context werkzaam zijn, kan het individu de situatie op voor hem zinvolle wijze duiden en daarmee ook zicht krijgen op hoe men zich moet gedragen. Het gaat er om de betekenis van de situatie voor de burger of groepen burgers te leren begrijpen en waar mogelijk bij te sturen om vervolgens een handelingsperspectief voor alternatief gedrag te bieden (Seydel 2009).

Een saillante opgave voor de verdere ontwikkeling van weerstand in relatie tot werk is het deels bewuste, deels onbewuste karakter (van reacties op verstoringen). Dat maakt de beschreven aandacht voor het ervaren en het benoemen van weerstand in interacties relevant. Het herkennen van weerstand is aan de ene kant eenvoudig te noemen, als we focussen op symptomen (een standpunt, een demonstratie, een ziekmelding, afhaakgedrag etc.). Wie weerstand wil begrijpen en vervolgens ook wil aangrijpen voor een adequate interventie, zal onder de symptomen moeten zoeken naar determinanten die er toe doen. Daarbij helpen inzichten over de determinanten van gedrag en betekenisverlening. Rijnja, Seydel en Zuure (2009) hebben determinanten voor een contextuele benadering van communicatie beschreven waarop kan worden aangesloten:

a. De verwachtingen of attitudes van individuen. Welke 'uitkomstverwachtingen' heeft een individu of groep over wat het uitvoeren van het gedrag in kwestie zal opleveren? (Bandura, 1986). Deze zijn niet alleen gebaseerd op logische redeneringen en verstandelijke overwegingen, maar ook op diepgewortelde gewoontes en 'irrationele' overtuigingen.

b. De sociale omgeving. Wie doen er werkelijk voor mensen toe, hoe wordt deze sociale omgeving aangesproken bij voorgenomen handelingen en de evaluatie ervan en welke rollen zijn te onderscheiden bij de verspreiding van boodschappen? Welke beloning doet ertoe en tot welke navolging van gedrag zetten de contacten aan?

c. Zelfeffectiviteit (wilskracht). Hoe schat men de eigen mogelijkheden in om voorgenomen gedrag daadwerkelijk uit te voeren dan wel na te laten? Bij die inschatting spelen vroegere ervaringen vaak een belangrijke rol, omdat mensen op basis van deze ervaringen schatten hoe moeilijk of makkelijk het voor hen is om het bewuste gedrag te wijzigen.

d. Emoties. Pin (2009) laat zien dat betrokkenheid de basis vormt voor acceptatie van nieuwe informatie maar dat emotie uiteindelijk bepalend is voor het effect. Het succes van acceptatie van nieuwe informatie wordt mede bepaald door de mate waarin organisaties erin slagen contact te maken met emotionele onderstromen van het publiek. 
e. Vertrouwen. Vertrouwen in de zender vormt een van de belangrijkste factoren voor effectieve communicatie. Voor een betekenisvolle communicatie is het effectiever om gericht na te gaan wie of wat er op een bepaald moment vertrouwd wordt en wat de drijfveren daarachter zijn. Wederkerigheid doet er toe: burgers en consumenten hechten er veel waarde aan om op een reële wijze gehoord te worden. Met waardigheid en respect terugkoppelen kan soms het verschil maken tussen steun en afhaken.

De resultante van deze determinanten is steeds een persoonlijk perspectief op de ontwikkeling die zich aandient (c.q. een verzameling daarvan). Ten overvloede wellicht teken ik daarbij aan dat er niet sprake kan zijn van een eenvoudige route in het brein van mensen, noch dat gedrag geheel voorspelbaar is op basis van een afgetekende set beginselen. Daarvoor lopen persoonlijke hulpbronnen teveel uiteen, affecties en waarden idem dito, en gooien de hoge mate van onberedeneerdheid van gedrag en de automatismen in het gedrag, roet in het eten. Niet wat mensen zeggen, maar wat mensen doen biedt houvast: action speak louder than words (John Locke).

\subsection{Beroepsgebonden weerstand}

'Krijgt een trap van een paard tegen zijn hoofd als hij 9 is. Loopt een baan bij de wetgevende macht mis als hij 23 is. Liefje sterft als hij 26 is. Heeft een zenuwzinking als hij 27 is. Keert terug in de politiek en loopt een zetel mis in de Senaat als hij 46 is. Loopt opnieuw een zetel mis als hij 50 is. Wordt tot president van de Verenigde Staten gekozen als hij is 51 is. Ra ra wie is dat?, daagt columniste Februari (2009) de lezer uit. De opmerkelijke weerstandsdrang van Lincoln staat voor de kunst van 'mislukken, falen, van je paard vallen en weer opstaan (...) niet God willen spelen maar bescheiden beginnen, en bereid zijn faliekant te mislukken. Dat is dan ook uiteindelijk onze opdracht'. Personen kunnen uitgroeien tot helden als ze hebben getoond een tegenslag te overwinnen, weet narratoloog Ramzy (2002), onder verwijzing naar klassieke heldenverhalen en leiderschapsgeschiedenissen. We hadden hier ook een tekst over Roosevelt, Reagan of Clinton kunnen plaatsen: je rijpt door tegenslagen en wint mensen voor je als je aan het pareren van de tegenslag een nieuw perspectief kunt knopen. Biografieën van leiders bevatten steevast verhalen waaruit spreekt dat juist door een crisis of juist door een conflict leiderschap tot ontwikkeling kwam. Een tegenslag hoeft niet per se samen te vallen met (ervaren) weerstand, maar biedt volgens de vertellingen wel aanknopingspunten voor het duiden in termen van meervoudige perspectieven op gebeurtenissen.

Aan bepaalde beroepen kleeft als het ware weerstand. Ashforth en Kreiner (1999, 2002) onderzochten de wijze waarop werknemers zich gedragen die te maken hebben dirty work: beroepen met een stigma of smet ('taint'), waaronder mijnwerkers, lijkschouwers, maar ook taxichauffeurs. De theorievorming hierover biedt houvast voor het begrijpen van de weerstand die ambtenaren ontmoeten, waar het de opinie over het werk als domein betreft. Een tweede onderzoeksterrein dat wenkt is dat van necessary evils ('noodzakelijk kwaad', dat 
we onder meer in de medische sector zien, bij het (communiceren over) het toedienen van injecties en het verrichten van ingrepen). Het is onvermijdelijke arbeid vaak, weten Molinsky en Margolis, die hiernaar onderzoek deden (2005), en daardoor ook een interessante bron voor het verwerven van zicht op het 'kwaad' dat overheidsfunctionarissen een samenleving toe kunnen dienen.... 'Professionals must sometimes do harm in order to do well'. Maar ook beroepssport kent weerstand. Wie niet tegen zijn verlies kan, komt niet ver. Een 'rondje langs de velden' helpt de betekenis van deze schaduwkanten mee te wegen bij onze zoektocht naar aanknopingspunten voor de wijze waarop (beleids)ambtenaren betekenis verlenen aan hun werk.

Dirty work. Dit begrip werd midden vorige eeuw gemunt door Hughes en is vooral bekend geworden door het werk van Ashforth en Kreiner $(1999,2002)$. Het gaat om werk met een fysiek stigma (lijkschouwers), een sociaal stigma (taxichauffeurs) of een moreel stigma (tweedehandsautoverkopers). De onderzoekers onderstrepen (1999) dat de 'dirtiness' steeds een sociale constructie is: het is minder een directe verklaring van het werk dan een associatie van anderen. Met ongemak als resultaat: 'If dirty workers look to others they are likely to be frustrated; yet, if they do not look for affirmation, their sense of a workplace self may remain somewhat tenous (...) An individual's ability to negotiate a taint is therefore essential to improving important individual and organisational outcomes' (Ashforth, Kreiner, Clark \& Fugate, 2007). De onderzoekers bepleiten een samenhangende benadering van twee aspecten: het zelfbeeld en de sociale validatie van het werk. De sleutelvraag is 'how are they able to see themselves as good people doing dirty work or better, good people doing good work' (Ashforth \& Kreiner 1999). Dirty workers moeten daartoe een 'esteem-enhancing social identitity' creëren met het oog op een heilzame persoonlijke ontwikkeling en de kwaliteit van de sociale cultuur op en om het werk: hoe je anticipeert op eerzin en weerstand en vervolgens deze ook pareert begint in de collegiale context. Een stevig zelfperspectief helpt om in eigen kring en daarbuiten 'een verhaal' te hebben.

Necessary evils. Molinsky en Margolis (2005, 2008) spitsen de blik op 'vuil werk' in feite verder toe, door hun onderzoek naar omstreden handelingen, de zogeheten 'necessary evils'. Dit fenomeen komt vooral voor in de medische sector, waar artsen en verpleegkundigen gevoelige verrichtingen (zoals injecties en operatieve ingrepen) moeten verrichten, maar ook bij politieagenten en in de verslavingszorg. 'Tasks in which a person must knowingly and intentionally cause emotional or physical harm to another human being in the service of achieving some perceived greater good or purpose. (...) To do them well, performers of necessary evils must be capable of treating victims with interpersonal sensitivity and compassion' (2008). Beide onderzoekers haalden een set dimensies van het verrichten van 'noodzakelijk kwaad' naar voren, die in mindere of meerdere mate aandacht vragen van de professional (2005). In de eerste plaats is sprake van taakgebonden aspecten: is iemand in staat (1) om te gaan met complexiteit en (2) de kans op terugkerende frequentie. Vervolgens telt de persoonlijke rol, waarbij drie dimensies worden belicht: (3) de a priori kritische blik naar de uitvoerder, (4) de intensiteit van iemands betrokkenheid en (5) de mate waarin de legitimiteit 
van de handeling kan worden aangetoond. Als het gaat om de impact tenslotte gaat het om de mate waarin de ingreep iets concreets oplevert (6) en een ruimere betekenis heeft in de zin van (7) menswording en van (8) fundamentele rechten. Deze auteurs noemen het voortdurend samenhangen van positieve en negatieve beoordelingen 'onvermijdelijk problematisch' (2005) en hameren op een goede doordenking (en training) van vier aspecten: hoe ervaren en beoordelen beroepsbeoefenaren (a) verantwoordelijkheid, (b) (gepercipieerde) rechtvaardigheid, (c) moeilijkheidsgraad van de taak en (d) de daadwerkelijke verrichting. Vooral het vierde element ('palpability') blijkt cruciaal voor de kwaliteit van de prestatie en de wijze waarop iemand hierover rapporteert. Vier aspecten - ervaring met de handeling, de ervaren ernst van de ingreep, de zichtbaarheid ervan en de persoonlijke relatie - voeden de mate waarin iemand er een positieve (trots, tevredenheid) of een negatieve (schuld, spijt) beoordeling aan verbindt. In de literatuur over dirty work en necessary evils komen beleidswerk en overheidsinterventies niet expliciet aan de orde.

Beroepssporters. Wie een wedstrijd speelt kan verliezen. Sportclubs melden de afgelopen jaren vaker de aanstelling van sportpsychologen; onder de kop 'Voetballer mag moeite hebben met zijn rol' wijst Ajax' sportpsycholoog Keizer op de mentale belasting van de profvoetballer: 'In een seizoen staan rond de vijftig wedstrijden gepland, je moet continu gefocust worden (...) Het is zaak om goed om te gaan met teleurstellingen, bijvoorbeeld als je niet opgesteld bent of geblesseerd raakt, en ook met de kansen die je krijgt'. De aanhoudende media-aandacht voert de druk op. 'Veel talent hebben en snel succesvol zijn is misschien wel leuk, maar juist door met tegenslag om te leren gaan word je mentaal sterker' (Vooren, 2009). De zelfmoord van een prominente Duitse keeper voedt najaar 2009 ook weer de aandacht voor de kwetsbare kanten. Sportverslaggever Van Holland (2008) schreef eerder in een opinieartikel zijn verwondering over de eenzijdige focus op winnaars al eens van zich af: 'Verliezers zijn lastig en verstoren ons comfortabele leven. Met winnaars kun je feestvieren, met verliezers moet je huilen'. Kort na de Olympische Spelen stelde hij vast: 'Leren kun je van verliezen, misschien wel meer dan van winnen. In boeddhistische termen: een nederlaag is een moment van bezinning'. Knight, MacNeill en Donelly (2005) vergeleken hoe de media waren omgegaan met de verliezen van de teams van Canada en Nieuw Zeeland tijdens en na de Spelen van 2000. Ze analyseerden dat successen een belangrijke bevestigende functie bleken te hebben voor de nationale identiteit, maar dat de duiding van teleurstellingen er steviger inhakte: er was sprake van een dubbele functie: berichten over verliezen leverden een maatschappelijke reflectie op over topsport en een verdieping van de nationale waarden. Ook stelden ze vast dat teams die bij de aanvang van het toernooi verwachtingen temperden en publiekelijk de kans op verlies incalculeerden, op meer begrip konden rekenen dan teams die na hoge verwachtingen ook navenant teleurstelden. Persoonlijke uitingen van teleurstelling en excuses geven geen garanties voor begrip, maar vrij en openlijk tonen van verschillen in opvatting wordt positiever ontvangen dan krampachtig één geluid tonen. Louter 'Gloria' voedt argwaan.

Ambtenaren. De publieke sector kent nauwelijks gerichte aandacht voor het omgaan met weerstand. Een uitzondering kan worden gemaakt voor de zorg om fysiek en verbaal 
geweld tegen de uitvoering. De rijksoverheid bekommert zich nadrukkelijk om de bejegening van agenten, loketpersoneel en andere overheidsfunctionarissen met een publieke taak. Er zijn diverse handreikingen (websites, trainingen, protocollen, zie www.minbzk.nl/publieketaak) beschikbaar gesteld. Eind 2011 ging een campagne van de Stichting Ideële Reclame (SIRE) van start. Wat de weerstand betreft die beleidsmakers ontmoeten wordt vooral het perspectief van de burger en de samenleving ruimschoots in beeld gebracht. De samenleving als slachtoffer geniet onverschrokken aandacht. Als over weerstand in relatie tot de overheid wordt geschreven overheerst het verwijt: de overheid roept weerstand over zichzelf af, moet zich bewust zijn van de schade die ze toedient en de risico's die monopolie op geweld en macht met zich meebrengt. Ik verwijs hier kortheidshalve naar hoofdstuk 2 voor enkele gezaghebbende bronnen uit - vooral bestuurskundige - hoek. In 2008 bood de Vereniging van Bestuurskunde tijdens haar jaarcongres de vloer aan de Amerikaanse politicoloog en antropoloog Scott. Die hekelde eerder in 'Seeing like a state' (1998) uitbundig de neiging van overheden om met grootse ordeningsplannen de facto natuurlijke patronen en houdingen in gemeenschappen om zeep te helpen. Scholten (2009) signaleerde een toename in het aantal 'gedurfde besluiten' ('daring decisions') van de overheid (in onderzoek toegesneden op ruimtelijke projecten). Controverse, innovaties, en grootschalige impact zijn vaak de aanjagers voor - per saldo risicodragende besluiten.

De WRR belichtte in 2006 dit thema in een onderzoek over de wijze waarop de overheid omgaat met hardnekkige, 'ongetemde' problemen. Onder de titel 'De lerende overheid' riep de adviesraad op tot 'beleidsleren': lering trekken uit fouten. De raad stelde vast dat de omslag van een verticaal naar een (ook) horizontaal bestuur het ambtelijk apparaat in een complexere context plaatst. Opvattingen en verwachtingen over processturing en politieke gevoeligheid sporen niet altijd in het verkeer tussen bestuurders, ambtenaren en in interbestuurlijke contacten. De professionele ambtenaar zal volgens Mertens (1996) moeten investeren in systematische reflectie. Daaronder valt wat hem betreft het vermogen om, voorbij de eigen voorkeuren, vigerende waarden en wisselende preferenties op te sporen en te doorgronden. Geef je rekenschap van de kans op een wijzigende tijdshorizon, denk aan meer dan één oplossing en durf buiten geïnstitutionaliseerde paden durven treden, voegt hij hier aan toe. Een beleidsmaker zal volgens hem voortdurend moeten helpen ervaringen, oordelen en wensen te articuleren en te verzamelen. Beleidsambtenaren zullen daarom steeds vaker zelf kennis opdoen, zelf slaagkansen moeten onderzoeken, en de confrontatie aangaan, zo lezen we in dit WRR-rapport. 'Hun werk veronderstelt aan de ene kant puzzling: het zoeken naar passende oplossingen voor problemen, en aan de andere kant gaat het om powering: het sluiten van politieke deals en verwerven van voldoende politieke steun voor oplossingen. De ambtelijke beroepsgroep gonst steeds meer van vragen als (Hemerijck, 2005): werkt het (instrumenteel), past het (institutioneel), mag het (rechtmatigheid) en hoort het (maatschappelijk aanvaardbaar). En bestuurskundige In 't Veld (1995) somberde: 'Beleidsconstructie is au fond een tragische activiteit, elk beleid is namelijk ten dode opgeschreven, dankzij het samenspel van de wet van de afnemende beleidseffectiviteit en de wet van de beleidsaccumulatie. Een kritisch publiek is door de omstreden aard van overheid 
een gegeven. Publieksgroepen reageren steeds sneller en slimmer op wat op hen afkomt (de eerste wet) en de beleidsmakers passen, geconfronteerd met de publieksreacties hun beleid weer aan, waarna de eerste wet weer in werking treedt'. Ringeling, (2004) nam in een studie naar het imago van de overheid een verwant standpunt in: ambtenaren moeten leren uitgaan van het a priori omstreden karakter van overheid en dus investeren in procesgerichte waarden zoals zorgvuldigheid, betrouwbaarheid en rechtmatigheid. Wat de overheid idealiter biedt is probleemoplossend vermogen, ze is dus altijd deel van een proces, een netwerk of een keten (Coops \& Rijnja, 2001). De afgelopen jaren neemt de aandacht voor het thema van de ambtelijke bejegening toe, waarbij de vorige vicepresident van de Raad van State en de Nationale Ombudsman als uitgesproken aanjagers fungeren. Zij wezen aanhoudend op het belang van zorgvuldig en fatsoenlijk contact vanuit de overheid en tonen ook oog voor ondersteuning van en ruimte voor professionals (Jaarverslag NOM, Raad van State 2009, 2010). Het CAOP greep de kritiek op de overheid en op ambtenaren aan voor een verkenning van 'het eigene van de overheid' en stelde in een slotdocument vast dat de druk op de professional naar verhouding te weinig aandacht geniet, om te beginnen bij politieke bestuurders, die weinig zorg voor de vaardigheid van hun medewerkers en hun vaardigheid om het eigene en kritieke karakter van de overheid te hanteren, ten toon spreiden (CAOP, 2O11).

\subsection{Tot slot: weerstand is zo gek nog niet}

Uit de literatuur kan een waaier aan opvattingen worden opgemaakt voor het (h)erkennen van de perspectieven die mensen kunnen hebben op een verstoring of andere barrière op hun weg. Daarbij is kennis van verwachtingen, emoties, sociale omgevingsinvloed, wederkerigheid en eigen effectiviteit (wilskracht) basiskapitaal. Inzichten over beroepsgebonden weerstand maken duidelijk dat in bepaalde werksoorten de kans op het 'lezen' van die perspectieven stevig in opleiding of reguliere taakuitoefening is vervlochten, maar dat het ook voorkomt dat er minder systematisch aandacht aan wordt gegeven. Die aandacht kan verschil maken tussen de idee dat je werk 'goed' is en jij een 'goed mens'(Ashforth \& Kreiner, 1999) of niet. Van Vuuren en Dorenbosch (2011) wijzen op het belang van die (zelf)evaluaties voor de professionele identiteit. 'Weerstand' opvatten als louter een lastige, negatieve publieke reactie is dan ook te makkelijk: het kan zowel een teken van afkeer zijn als van energie en bereidheid om iets te onderzoeken. Ook de pionier van een waarderende manier van onderzoeken (appreciative inquiry), Cooperrider, propageert een positieve benadering van onderwerpen die zich als 'probleem' aandienen (Masselink e.a., 2008). Voor een werkdefinitie van weerstand biedt de uitleg van Merron (1993) houvast. In de context van organisatieverandering definieerde hij weerstand als 'een verzameling uiteenlopende ideeën over hoe de organisatie eruit moet gaan zien'. Vertaald naar de overheidscontext hebben we dan te maken met: 'een verzameling uiteenlopende perspectieven op een overheidsopgave'. 


\section{B. Empirie: work meaning en systeemspanningen}

De betekenis van ambtelijk werk (4.) Onder de spanningsbogen (5.)

In het maken van overheidsbeleid ligt weerstand als het ware besloten, zoveel is wel duidelijk na de verkenningen hiervoor. De context waarin beleidsmakers hun werk doen is omstreden en de aard van hun taken is van dien aard dat we te maken hebben met lastige opgaven die vrije krachten in de samenleving niet zelf hebben kunnen oplossen. In welke mate beleven beleidsambtenaren deze context en welke factoren zijn van betekenis bij de keuzes die zij maken om problemen te signaleren, oplossingsrichtingen te duiden, partijen te vinden en binden en beslissingen voor te bereiden? In hoofdstuk 4 komen onder de titel 'De betekenis van ambtelijk werk' overheidsdienaren aan het woord. In dit onderzoek staat work meaning centraal: hoe kennen ambtenaren betekenis toe aan hun arbeid - en in het bijzonder aan de interactie met anderen.

In een tweede onderzoek zoom ik in op de in hoofdstuk 2 gesignaleerde 'systeemspanningen' van de overheid. Opereren in een krachtenveld met politieke, ambtelijke en maatschappelijke belangen, voorkeuren en mores betekent schaken op meerdere borden tegelijk. Maar in welke mate herkennen beleidsmakers die spanningen en welke strategieën ontwikkelen zij hierbij om doelstellingen te behalen. Het onderzoek in hoofdstuk 5 - 'Onder de spanningsbogen' - focust op de wijze waarop beleidsmakers in hun primaire proces - het beleidsproces - de specifieke context van de overheid herkennen en hanteren. 


\section{De betekenis van ambtelijk werk}

Wat en wie maakt werk zinvol?

\subsection{Inleiding}

Wat leert de praktijk over de werkbeleving van beleidsambtenaren? In dit hoofdstuk krijgt de theoretische verkenning van work meaning uit het vorige hoofdstuk een verdieping aan de hand van ervaringen bij beleidsmedewerkers. Hoe verloopt het proces van betekenisgeving (sensemaking) bij de man of vrouw die dagelijks voor de opgave staat om een publiek vraagstuk aan te pakken? Hoe beleeft de ambtenaar de ruimte waarin zijn of haar handelen, ontstaat en beleid tot ontwikkeling komt? Centraal staan de ervaring met de interacties die het werk met zich meebrengt, de rol van beelden en verhalen over het werk en de wijze waarop men in staat is tot ambachtelijke aanpassingen, bijvoorbeeld bij de ontmoeting van verstoringen.

\subsection{Sleutels van betekenis}

In paragraaf 3.4. is de betekenisverlening aan werk als thema geïntroduceerd. Wrzesniewski, Dutton en Debebe (2003) hebben aangetoond dat twee typen factoren invloed uitoefenen, namelijk extrinsieke factoren (zoals taakverscheidenheid, belang van de taken en interactie met anderen: collega's, klanten, leidinggevenden of ondergeschikten) en intrinsieke factoren (zoals de waarden die mensen aan hun werk ontlenen). Ander onderzoek van Wrzesniewski, Cauley, Rozin en Schwartz (1997) leerde dat de dominantie van deze factoren samenhangt met de vraag of mensen werk als een baan zien (focus op financiële beloning), als een carrière (focus op eigen vooruitgang) of als een roeping (focus op zingeving). Dit is relevant waar eerder de roeping (Karssing, 2007, zie hoofdstuk 2) als een drijfveer voor indiensttreding bij de overheid naar voren kwam. In hoofdstuk 3 is de betekenisverlening aan werk toegelicht aan de hand van het begrip work meaning. Wrzesniewski (2003) meent dat drie samenhangende aspecten hierbij van belang zijn, te weten job meaning (wat betekenen activiteiten en taken), role meaning (wat ontleen ik aan de positie binnen de organisatie) en self meaning (wat leert dit werk mij over mezelf). Het belang van kennis over de betekenisverlening heeft een waarde voor een werknemer, maar Cartwright en Holmes (2006) hebben aangetoond dat een 'hoge' work meaning van werknemers kan leiden tot een verbetering van de prestaties van de organisatie, het behouden van belangrijke werknemers, effectief veranderingsmanagement en een groter commitment aan de organisatie?

Uit de theoretische verkenningen komt naar voren dat drie thema's bij dit proces van betekenisverlening de toon zetten. Dit zijn de interacties die het werk met zich meebrengt, de invloed van beeldvorming over het werk op ambtenaren en de job crafting oftewel de ambachtelijke omzetting van de betekenisverlening: wat wil je en wat doe je met wat je waarneemt? Een toelichting op deze drie 'sleutels'. 


\section{Sleutel I: Interacties; de rol van gesprekken}

Cartwright en Holmes stellen dat de relatie tussen de interne wereld van het individu en de externe context van de werkplaats een belangrijke voedingsbodem is voor de work meaning. Werknemers vormen die betekenis met behulp van drie relationele vragen: a) waar behoor ik toe, b) hoe verhoud ik mij tot anderen, en c) wat is mijn bijdrage aan anderen? De signalen hiervoor komen binnen in de vorm van gedragingen en acties van collega's, klanten en leidinggevenden (Wrzesniewski e.a., 2003). Mensen hebben de neiging om deze signalen te interpreteren als positief of negatief bedoeld was en wat iemand bedoeld kan hebben met het signaal. Quinn en Dutton (2005) geven aan dat de conversaties die mensen op hun werk hebben bepalend kunnen zijn voor de prestaties van een organisatie. Zij geven aan dat de verhalen die mensen op het werk met elkaar delen worden geïnterpreteerd.

Deze interpretatie komt volgens Quinn en Dutton voort uit wat er letterlijk gezegd wordt en uit het non verbale gedrag. De interpretaties van conversaties hebben vervolgens een invloed op het energieniveau van een medewerker. Dit energieniveau bepaalt vervolgens hoe iemand verder communiceert en de moeite die mensen willen steken in de activiteiten op hun werk. Door de interacties die mensen hebben worden situaties omgezet in taal, waardoor de situatie concreet wordt. Wanneer de situatie concreet is, is dit de basis voor een handeling om met de situatie om te gaan. Quinn en Dutton maken duidelijk dat de interacties die mensen op hun werk hebben bepalend zijn voor de interpretaties van situaties en de inspanningen die zij willen leveren voor de activiteiten in hun werk. Hiermee kan de communicatieve dimensie van de betekenisverlening worden onderstreept. Aarts (2008) noemt de toegekende waarde aan interacties wezenlijk voor het vermogen strategisch te communiceren in en vanuit organisatie. 'Het gaat om een voortdurend afstemmen tussen wat extern en intern gebeurt, tussen formele en informele communicatie, tussen bedoelde boodschappen en onbedoelde signalen, en vooral om de wijze waarop deze zaken op elkaar inhaken'. Er is sprake van een niet geheel onvrijwillige aangelegenheid, stelt zij met verwijzing naar onder meer Elias (1982: 'Uit deze vervlechting, uit de interdependentie van mensen ontstaat een ordening van heel specifieke aard, een ordening die dwingender en sterker is dan de wil en het verstand van de afzonderlijke mensen die deze vervlechting vormen'.

\section{Sleutel II: Perceived prestige: beeldvorming van de beeldvorming}

Smidts, Pruyn en Van Riel (2001) wijzen op de invloed van de gepercipieerde percepties in de buitenwereld op de identificatie van werknemers met de organisatie. Wanneer een organisatie bijvoorbeeld veelvuldig positief in het nieuws komt, dan voelen de werknemers zich trots en versterkt dit hun gevoel van eigenwaarde. Zij zullen zich dan meer verbonden voelen met de organisatie. Het tegenovergestelde kan echter ook het geval zijn. Aanhoudende negatieve boodschappen kunnen deuken veroorzaken die de interacties raken. Dit perceived external prestige kan beïnvloed worden door de meningen van referentiegroepen, publiciteit, informatie die door de organisatie zelf naar buiten wordt gebracht en interne communicatie tussen medewerkers over hoe de organisatie door buitenstaanders wordt gezien. Hierbij gaat het om de rol van vermeende en werkelijke verhalen van journalisten en publieksgroepen voor de beeldvorming over de overheid. Dat maakt de vraag relevant hoe ambtenaren zelf aankijken 
tegen de beeldvorming en in het bijzonder de betekenis ervan voor taak, baan en zelfbeeld aankijken. Op grond van de veel aangehaalde vergelijking overheid-bedrijfsleven kan daarbij een functie worden verondersteld voor de duiding van speciale categorieën. Het perceived prestige of an external party vraagt dan aandacht. We vinden hiervoor aanwijzingen bij Ashforth en Mael (1989), die wijzen op het fenomeen dat mensen graag indelen in sociale categorieën. Dat gebeurt enerzijds omdat dit helderheid schept met betrekking tot de sociale omgeving en anderzijds omdat dit het individu helpt om zichzelf te kunnen plaatsen in die sociale omgeving (sociale identificatie). Ashforth en Mael stellen verder dat mensen bij het indelen in sociale categorieën vaak gebruik maken van in groups en out groups. Alleen al de aanwezigheid van een out group zorgt er volgens Ashforth en Mael voor dat mensen zich meer verbonden voelen met de groep waar ze toebehoren. Elsbach \& Bhattacharya (2001) geven daarnaast aan dat mensen het vaak makkelijker vinden om aan te geven waar ze niet toe behoren dan waar ze wel toebehoren. Een cognitieve scheiding maken met betrekking tot een groep waar je niet toebehoort wordt door hen ook wel aangeduid als disidentification. Elsbach \& Bhattacharya geven aan dat mensen vaak begrijpen wie ze zijn door te omschrijven wat ze niet zijn. In lijn met deze theorie maken de ambtenaren dus een vergelijking met het bedrijfsleven om voor zichzelf duidelijk te maken wat het werken voor de overheid voor hen betekent. Walsh en Gordon (2008) ondersteunen dit door te stellen dat wanneer mensen zich vergelijken met out groups het voor hen zelf duidelijker wordt wat er van hun verwacht wordt en wat ze van anderen kunnen verwachten.

Naast de externe beeldvorming kan ook een interne pendant worden verondersteld: welke rol spelen interne verwachtingen over oordelen en beelden? Volgens Fuller, Hester, Barnett, Frey, Relyea en Beu (2006) is het vooral de gepercipieerde status die betekenis geeft. Er is sprake van perceived internal respect. Die hangt samen met de zichtbaarheid van de werknemer binnen de organisatie, de waargenomen waardering en ontwikkelingsmogelijkheden en de mogelijkheid om invloed uit te oefenen op beslissingen die binnen de organisatie worden genomen. Dit nodigt uit ook het perceived internal prestige te onderzoeken. Carmeli (2005) verbindt op basis van onderzoek de betekenis van 'percepties van percepties' aan de mate van binding met een organisatie. Affective commitment is in zijn waarneming de hoogste vorm van binding die een werknemer kan hebben met een organisatie; werknemers met een sterke neiging op dit punt blijven binnen een organisatie omdat ze dat willen en niet omdat ze dat moeten. Dit beïnvloedt vervolgens de mate waarin werknemers gedrag vertonen dat positief is voor de organisatie en dat buiten hun formele functiebeschrijving valt. Het perceived prestige dat werknemers ervaren heeft dus een sterke invloed op de mate van hechting van medewerkers met een organisatie. Wat prikkelt is de vraag hoever de invloed hiervan strekt: is een sterk beeld ook een indicator van voorgenomen handelen? Werknemers percipiëren percepties en de betekenisverlening doet ertoe. Voor henzelf, maar ook voor de communicatie met anderen. Wat doet iemand zodra betekenis wordt toegekend aan interacties en beeldvorming? Dit leidt naar de betekenis van de derde sleutel in ons onderzoek: welke grenzen komen in beeld en wat kan uit deze observaties worden opgemaakt over de intenties om denkbare veranderingen te concretiseren? 


\section{Sleutel III: Job crafting: ambachtelijke aanpassing}

Wrzesniewski en Dutton (2001) introduceerden het begrip job crafting. Hiermee worden de fysieke en cognitieve veranderingen bedoeld die individuen maken binnen de taak- of relationele grenzen van hun werk. Dat is bijvoorbeeld aan de orde bij verstoringen, ten positieve en ten negatieve. De 'ambachtelijk aanpassing' komt tot uiting in cognities, taakuitoefening c.q. aanpassingen en relationele instellingen. Bij het veranderen van de taakgrenzen kan het gaan om het veranderen van de vorm of het aantal activiteiten dat iemand uitvoert. Cognitieve veranderingen hebben betrekking op hoe iemand de baan ziet. Het veranderen van de relationele grenzen kan betekenen dat iemand ingrepen doet in de interacties binnen de baan. Dat is een hybride proces: mensen kunnen hun werk op een andere manier bekijken doordat zij hier voor een deel een eigen invulling aangeven. Dat is dus voor persoon en organisatie van belang. Wzresniewski en Dutton registreerden dat als job crafting in lijn met de organisatiedoelen gebeurt, het een positieve invloed kan hebben op de prestaties van de organisatie. Er kan dus een wisselwerking worden verondersteld tussen de toegekende betekenissen op grond van interacties en workmeaning en daaraan te ontlenen aanpassingen in het beoordelen van het werk. Mensen zijn tot jobcrafting geneigd om drie typen redenen (Wrzesniewski \& Dutton, 2001): 1) controle houden over je werk, 2) verbinden met anderen die er voor het werk toe doen en 3 ) een positief zelfbeeld opbouwen, waardoor je zelf lekker in je vel zit maar ook - eerder - actie kan ondernemen als je een negatief ervaren situatie wilt veranderen. In het kader van onze probleemstelling intrigeert de toegekende waarde aan deze laatste drijfveer in hoge mate. Volgens Lyons (2008) is voor een positief zelfbeeld een drieeenheid verantwoordelijk: de beschikbare cognitieve capaciteit, het zelfbeeld, de waargenomen controle en het open staan voor veranderingen. Ambachtelijk aanpassen heeft een sterke persoonlijke component, maar de rol van de omgeving - directe interacties en invloeden via beeldvorming - is evident. Boonstra en Van Staveren (2007) wijzen erop dat 'denkomslagen' in organisaties die een sterke interactieve context kennen - 'waardecreërende systemen' - het karakter van leerprocessen hebben. 'Het gaat daarbij om een subjectieve aanpak die in dialoog gestalte krijgt (...) communiceren en organiseren vallen samen'. We sporen in de job crafting daarom ook de leerbehoeften op.

\subsection{Onderzoeksvragen}

De centrale vraag in dit onderzoek luidt: welke betekenis verlenen ambtenaren aan hun werk en welke rol speelt communicatie in dit proces? Om de centrale vraag te kunnen onderzoeken zijn een aantal deelvragen opgesteld, waarin de betekenis van de genoemde 'sleutels' wordt onderzocht:

(1): Welke invloed hebben de interacties die ambtenaren gedurende hun werkzaamheden hebben op de betekenis die zij aan hun werk verlenen?

(2): Wat is de invloed van de gepercipieerde beeldvorming op de betekenis die ambtenaren aan hun werk verlenen? 
(3): Welke rol speelt job crafting (ambachtelijke aanpassing) bij de betekenis die ambtenaren aan hun werk verlenen?

In schema:

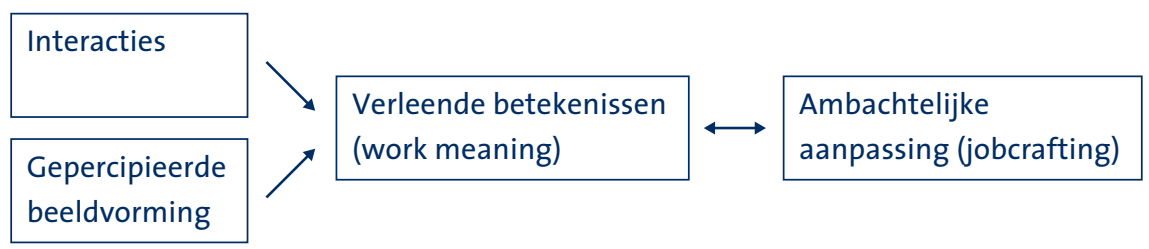

\subsection{Figuur onderzoeksvragen}

\subsection{Onderzoeksopzet}

Vanwege het verkennende karakter van de onderzoeksvragen heb ik gekozen voor kwalitatief onderzoek in de vorm van interviews. 'Een interview kan worden gezien als een gespreksvorm waarin de interviewer zich bepaalt tot het stellen van vragen over gedragingen, opvattingen, houdingen en ervaringen ten aanzien van bepaalde sociale verschijnselen, aan één of meer deelnemers of geïnterviewden, die zich voornamelijk beperken tot het geven van antwoorden op die vragen' (Boeije, 2005). Patton (1990) geeft aan dat er bij kwalitatief onderzoek meer op de percepties en gevoelens van de geïnterviewde kan worden ingegaan en beter persoonlijke belevingen worden achterhaald dan met kwantitatief onderzoek mogelijk is. Daarnaast geeft Patton aan dat met kwalitatieve methoden meer de diepte kan worden ingegaan en dat er meer ruimte is om stil te staan bij details. Binnen het onderzoek is een keuze gemaakt voor het houden van semi-gestructureerde interviews. Bij een semi-gestructureerd interview zijn wel de onderwerpen bepaald die aan bod moeten komen, maar staan de vragen niet vast. Hierdoor kan ingespeeld worden op de antwoorden van de geïnterviewde. Voorafgaand aan de interviews is er een globale vragenlijst opgesteld. De leidraad van dit gesprek was om rijksambtenaren over hun werk te laten vertellen. Onderwerpen die hierbij aan bod kwamen waren: de waardering van het werk, de beleving van de interacties die ze gedurende hun werkzaamheden hebben, het beeld dat buitenstaanders van de overheid hebben en communicatie van beleid. Daarbij is gebruik gemaakt van de critical incident techniek. 'In general terms, the technique is used to gather observations of human behavior and to determine the competencies required of members from a specific profession of group' (...) 'For each event mentioned, a predetermined set of questions is asked about what exactly happened, who were involved, and what the consequences of the incident were. In the data analysis phase, the incidents are used to identify underlying structural patterns regarding the strength and weaknesses of the internal communication of the organization'. (Zwijze \& De Jong, 2005). In de interviews is het begrip (ambtelijk) 'sleutelmoment' gebruikt, als focus voor het identificeren van de omgang met (vermeende) kritiek van de buitenwereld op (voorgenomen) 
werkzaamheden. De veronderstelling luidt dat vanuit een concrete gebeurtenis een gesprek makkelijker tot stand komt dan vanuit een abstracte onderzoeksvraag.

Voor het onderzoek zijn 32 interviews gehouden. De geïnterviewden waren allen werkzaam binnen de Rijksoverheid. Bij de ministeries is een verdeling tussen bestuursdepartementen (focus op interacties met voorwaardenscheppende taken) en vakdepartementen (specifieke taakgebieden) nagestreefd. De geïnterviewden waren werkzaam bij één van de volgende ministeries: Binnenlandse Zaken en Koninkrijksrelaties en Justitie (bestuursdepartementen) en (voorheen) Landbouw, Natuur en Voedselkwaliteit en Verkeer en Waterstaat (vakdepartementen). Voorts is onderscheid gemaakt tussen ministeries en uitvoerende diensten om de relevantie van het werken bij bestuurs- en uitvoeringsgerichte onderdelen te kunnen wegen. Voor de uitvoerende diensten zijn medewerkers aangezocht van de Dienst Justitiële Inrichtingen (Justitie), de Inspectie Verkeer en Waterstaat (Verkeer en Waterstaat), de Belastingdienst (Financiën) en de Voedsel en Warenautoriteit (Landbouw, Natuur en Voedselkwaliteit). Via een mail werden contactpersonen benaderd met de vraag vijf medewerkers voor te stellen om mee te werken aan het onderzoek. Om een beeld te krijgen van verschillende groepen rijksambtenaren werd gevraagd rekening te houden met twee criteria: spreiding in leeftijd en spreiding in aantal jaren ervaring binnen de organisatie. Daarnaast werd de voorkeur gegeven aan rijksambtenaren die een zelfstandige verantwoordelijkheid hadden voor één of meer beleidsdossier(s). Vervolgens werd telefonisch of via de mail contact gezocht met de personen die bereid waren om mee te werken. De context werd hierbij vaag gehouden om niet teveel sturing te geven ('onderzoek naar werkbeleving'). Voor alle interviews werd afgesproken op het werk van de geïnterviewde. Het onderzoek vond plaats in de periode februari - oktober 2009. Dit hoofdstuk is gebaseerd op de uitkomsten van het onderzoek en vooral de transcripties van de interviews. Van de 32 interviews die zijn gehouden, is bij 31 interviews toestemming verleend om het gesprek op te nemen op een recorder.

De lengte van de interviews varieerde van 35 tot 90 minuten. Na het afnemen van de interviews zijn de gesprekken woordelijk uitgeschreven. Vervolgens werden de interviews gecodeerd aan de hand van een schema. Een aantal interviews werd ook gecodeerd door een tweede codeur om intersubjectiviteit te waarborgen. Zie bijlage I voor het onderzoeksprotocol en het codeerschema. Tabel 4.1. vat de opzet samen (paragrafen tussen haakjes). 
Tabel 4.1. Schema onderzoek work meaning

\begin{tabular}{|l|l|}
\hline Interacties op het werk (4.5.1.) & $\begin{array}{l}\text { Belangrijkste interacties } \\
\text { Positieve interacties } \\
\text { Negatieve interacties }\end{array}$ \\
\hline Perceived external prestige (4.5.2.) & $\begin{array}{l}\text { Perceived external prestige } \\
\text { Perceived internal prestige } \\
\text { Perceived prestige of an external party }\end{array}$ \\
\hline Work meaning (4.5.3.) & $\begin{array}{l}\text { Job meaning } \\
\text { Role meaning } \\
\text { Self meaning }\end{array}$ \\
\hline Job crafting (4.5.4.) & $\begin{array}{l}\text { Cognitieve crafting } \\
\text { Taak crafting } \\
\text { Relationele crafting } \\
\text { Leerbehoeften }\end{array}$ \\
\hline
\end{tabular}

\subsection{Resultaten}

Bij de presentatie van de bevindingen komen achtereenvolgens interacties, perceived prestige, work meaning en jobcrafting aan bod, de factoren uit het model in figuur 4.1.

\subsubsection{Interacties}

Na duiding van de belangrijkste interacties komt de waardering (positief en negatief) aan bod.

De meest genoemde interacties tijdens het werk zijn bij de ondervraagde rijksambtenaren de contacten met collega's. Sommigen noemen als reden dat dit de personen zijn waarmee ze het meest samen moeten werken. Anderen geven aan dat ze het soms fijn vinden om steun te vinden of hun hart te luchten bij collega's wanneer ze in een moeilijke situatie zitten. Als het er op aankomt, is de collega bij de hand. Een inhoudelijke betrokkenheid is daarbij niet per se noodzakelijk, belangrijker is de beschikbaarheid en de persoonlijke 'klik' als het er op aankomt.

- "Ik kan het ook heel goed delen met diegene waarmee ik heel nauw samenwerk. En die kent die situatie ook, dan kan je gewoon even je hart luchten, maar we beuren elkaar dan ook wel weer op van wij gaan gewoon door."

- "We zijn hier heel erg gewend om maar weer met z'n allen te praten als het lastig wordt."

- "Je hebt nu eenmaal collega's waar je het beter mee kunt vinden. Zelfde universiteit, kennis uitwisselen."

- "Ik zie het hier echt wel als mijn veilige thuisbasis, ik bedoel ik kan hier mopperen en hier 
kan ik boos zijn en hier mag ik roepen dat ik het even niet meer weet maar ik dat ik dat niet naar buiten kan doen, dus hier moet een plek zijn en die mensen zijn er dus."

Vervolgens wordt de leidinggevende vaak genoemd. Vaak is dit contact functioneel om afstemming te bereiken over datgene wat gedaan moet worden. Sommige respondenten geven ook aan de waardering van hun leidinggevende over hun werkzaamheden belangrijk te vinden:

- "Binnen de directie stem ik veel af met mijn beleidsmanager, dat is het teamhoofd en zij is inhoudelijk verantwoordelijk voor het werk wat het team doet."

In de derde plaats komt de directeur/een MT aan bod. Ook hierbij speelt afstemming van de werkzaamheden weer een belangrijke rol. Enkele ondervraagden noemen de steun van het hogere management belangrijk bij beslissingen die veel consequenties hebben voor anderen.

- "Dus op een gegeven moment moet het ook zo zijn dat je op tijd stukken door kan krijgen, dus dat je MT goedkeuring geeft maar ook als sparring partner even kan meepraten; ik denk dat het zo moet maar denk jij ook dat etcetera."

Bij ministeries noemen de geïnterviewden vaak de bewindspersoon (minister of staatsecretaris) hun belangrijkste contact, aangezien die de uiteindelijke beslissingen neemt:

- "Als de minister zegt 'spring door een hoepel' dan springen we door een hoepel."

Een categorie die veel wordt genoemd zijn interdepartementale relaties.

- "Dat je daar dus heel veel tijd voor moet uittrekken omdat mensen vanuit verschillende ministeries een andere achtergrond hebben en dus ook een heel andere manier van denken."

- "Samenwerken met andere departementen is onvermijdelijk natuurlijk. Maar dat vraagt wel een lange adem."

Externe relaties (c.q. publiek, burgers) worden zelden spontaan als eerste genoemd. Werk begint binnenshuis. De buitenwereld is moeilijk te vatten. Veel contact verloopt via koepels en andere bestuursorganen in den lande:

- "In Limburg zit een beetje afwachten in de cultuur, in Gelderland was het erg persoonsafhankelijk."

- "Nou in eerste instantie heb ik te maken met een kenniscoöperatie, dat is een samenwerkingsverband van scholen en die proberen het contact met het bedrijfsleven te leggen (...) soms ga ik ook wel eens naar scholen toe maar meestal heb ik daar geen tijd voor." 


\subsubsection{Positieve interacties}

Voor veel ambtenaren is het belangrijk dat contacten snel resultaat genereren.

- "Waar ik energie uithaal is als ik zie dat iets e toe doet en als er iets is wat ik van de minister moet iets doen of er moet iets in de Kamer en dat moet acuut voorbereid worden, nou dat is belangrijk en dat moet gebeuren."

- "Waar ik bijvoorbeeld heel veel voldoening uit kan halen zijn coachingsgesprekken, omdat ik dan merk, dan ben je anderhalf uur met iemand in gesprek en je ziet gewoon echt een verschil tussen het begin en het einde van een gesprek."

Een aantal geïnterviewden geeft aan het als positief te ervaren als ze verschillende belangen samenbrengen. Hierbij gaat het bijvoorbeeld om bijeenkomsten waarbij verschillende partijen uit de branche aanwezig zijn en deze partijen met elkaar in gesprek gaan:

- "De eerste bijeenkomst georganiseerd en daar allerlei partijen voor uitgenodigd en dat was echt zo vreselijk leuk. Daar zag je ook dat mensen met elkaar in gesprek gaan, fietsenbond en de ouderenbond met elkaar in gesprek gingen, die bleken nog nooit met elkaar gesproken te hebben."

- "Dat is mooi. Dan is er een concept hier intern geregeld en dan moet je naar de directeuren om instemming te vragen en kan het naar buiten toe. En dan is er een maatschappelijke confrontatie, dan komt het op de website, het wordt naar maatschappelijke organisaties gestuurd om te vragen wat vinden jullie van dit beleid?"

De wens maatschappelijke bijdragen te leveren komt in meerdere varianten naar voren:

- "Ja, dus dat je sowieso met je werk afhankelijk bent van mensen daarmee hangt samen dat je dus met ze moet samenwerken, overleggen, een bepaald doel wilt bereiken, ja dat je gezamenlijk probeert te bereiken en daarin te sturen. Ja".

Waardering is een volgende factor. Om te beginnen van collega's. Eén ambtenaar noemt als voorbeeld een bijeenkomst die een minister had georganiseerd voor de medewerkers die de meeste Kamervragen hadden beantwoord. Vervolgens ging de minister in gesprek met hen:

- "Ik bedoel je kan een bonus krijgen, maar dit is veel leuker, wat zij doet is dus vragen aan jou van wat vind je ervan? (...) Door gewoon het gesprek aan te gaan, gedurende drie kwartier met een borrel aan het eind, dat zijn de dingen waar je ook energie van krijgt."

In contact blijven met de maatschappij wordt in dit verband ook genoemd. Door zelf langs te gaan bij de brancheorganisaties of door voorlichtingen te geven over hun onderwerp op scholen. Een dialoog aangaan met de samenleving speelt hierbij een belangrijke rol. Vaak halen beleidsambtenaren hier ook weer input uit voor hun beleidsonderwerp:

- "Ik merk dat ik gevoed wordt door de dingen die om mij heen gebeuren." 
- "Ik kan het zelf wel belangrijk vinden, maar als er geen weerklank heeft dan...nee".

\subsubsection{Negatieve interacties}

Waar bij de positieve interacties het zien van een resultaat een rol speelt, is bij de negatieve interactie uitblijven van het resultaat van belang. Vaak hangt dit samen met strijdige belangen.

- "Het verlengde van bureaucratie is dus dat je minder snel effecten merkt. Het duurt soms vrij lang voordat je resultaten ziet van wat wat je in gang zet."

- "Ja, bij sommige ideeën die zijn al honderd keer gedaan, dat hoef je niet te proberen, nou dat werkt niet motiverend".

Wanneer in een interactie een andere partij een ander belang heeft en hierin niet tegemoet wil komen verliezen veel rijksambtenaren hun energie. Hierbij worden veel voorbeelden met brancheorganisaties genoemd. Wantrouwen heerst nogal eens bij de brancheorganisaties ten opzichte van de overheid. Vooral een eenzijdig negatieve houding blokkeert. Vooral als de andere partij alleen maar de negatieve kanten van een onderwerp kan zien, maar zelf geen inhoudelijke bijdrage levert:

- "Nou dat is echt mijn energie killer als mensen op de rem gaan staan en zeggen het kan allemaal niet."

- "Nou ik liet duidelijk merken dat ik daar niet zo blij mee was. En ik merkte dat ook andere partijen aan tafel het niet eens waren met deze persoon dus dat sterkte mij weer"

- Toen eigenlijk de hele sector de kont tegen de krib gooide en eigenlijk ook moeilijk aanspreekbaar was, daar hadden we eigenlijk geen zin meer in. Dan heb ik het gevoel dat ik een beetje leeg gezogen wordt (...) nou dan kom je op dat moment niet verder".

Een complicerende factor die ook wordt genoemd is als andere partijen (buiten henzelf) tegenstrijdige belangen hebben. Zij geven aan dat zij het lastig vinden om deze belangen dan samen te brengen om uiteindelijk gezamenlijk een doel te bereiken. Eerder werd al aangegeven dat situaties waarin waardering wordt getoond voor de werkzaamheden van de ambtenaar als positief worden ervaren. Omgekeerd kan het ook negatief uitpakken als je het gevoel hebt niet gewaardeerd te worden.

- "Toen was er een persoon en die trok het belang helemaal in twijfel en dat ontnam mijn energie, omdat $i k$ dacht (...) we delen het risico dat er iets moet gebeuren en je gaat het in twijfel trekken?"

Veel respondenten noemen de bureaucratie als grootste ergernis binnen de organisatie. De interne communicatie binnen de rijksoverheid wordt vaak als slecht ervaren en hierdoor duurt het lang voordat er besluiten worden genomen. Enkelen geven echter aan dat de bureaucratie niet alleen kenmerkend is voor de overheid, maar dat het ook voorkomt in het bedrijfsleven bij grote organisaties. De bureaucratie ontneemt soms energie: 
- "Door de bureaucratische processen die hier lopen kunnen zaken met maatschappelijk belang zo vier weken blijven liggen doordat ze toevallig niet op de agenda kwamen in die vergadering"

\subsubsection{Perceived prestige}

In welke mate vraagt beeldvorming over het werk aandacht van beleidsambtenaren?

\subsubsection{Perceived external prestige}

Een groot deel van de ambtenaren neemt waar dat buitenstaanders geen positief beeld hebben van de overheid. De klassieke (voor)oordelen over de overheid komen naar voren, namelijk de bureaucratie, inefficiëntie, logheid en langdurige processen:

- "Ik denk wel dat mensen over het algemeen een beeld van inefficiëntie hebben bij de overheid. Als je ziet van wat zij kunnen weten van de overheid, dan is het heel vaak dat het heel lang duurt."

Een enkele respondent geeft aan dat buitenstaanders het vaak wel goed vinden dat de overheid er is, aangezien de overheid zich bezig houdt met maatschappelijk relevante zaken:

- "Nou ik denk over het algemeen dat mensen over de overheid redelijk positief denken in de zin van die doen dingen die nodig zijn."

Het functioneren van de overheid wordt volgens de ambtenaren alleen niet zo goed beoordeeld. Voorkennis van taken en rollen wordt ter nuancering aangevoerd:

- "Ik denk dat het heel erg verschilt. Ook gewoon wat ze zelf net hebben meegemaakt en of ze het ook zien als één grote eenheid of verschillende onderdelen. Ik bedoel als iemand net een afwijzing heeft gekregen van een verblijfsvergunning van zijn aanstaande vrouw en hij denkt dat ligt aan Justitie of diegenen die al weten dat er een verschil is tussen IND en Justitie, die benaderen mij op dat moment al anders."

Volgens de ondervraagde medewerkers spelen de media een grote rol bij de beeldvorming over de overheid. Reden: de overheid komt vooral in het nieuws wanneer er dingen mis (kunnen) gaan:

- "Nou de media zitten er bovenop, want het is interessant hè? Alles wat niet lukt is leuk"

Een aantal van hen geeft aan dat de overheid door buitenstaanders vaak als een ivoren toren wordt gezien. Er wordt een grote afstand ervaren tussen de overheid en de burger:

- "Nee, ik denk dat ze vinden dat we te traag zijn, te log, een heleboel mensen waarvan zij het idee hebben van wat doen die eigenlijk allemaal?" 
Grapjes over het stereotype ambtenaar komen velen tegen, binnens- en buitenshuis:

- "Ik denk dat bij iedereen wel het cliché naar voren komt van een ambtenaar die lekker zijn krantje zit te lezen. Een vriend mij zegt in elk gesprek, nou succes met die katern."

- "Een vriend van mij die werkt in het bedrijfsleven en er is een onderzoek gedaan naar de raamambtenaar. Dus laatst ging mijn telefoon en dat was die vriend van mij en die zei, zit je weer uit het raam te kijken?"

- "Mijn broer zegt dat ik iedere dag een stropdas om heb die ik zo tussen mijn bureaula kan stoppen dat, als ik in slaap val, ik niet achterover val."

- "Dus als ik vertel dat ik ambtenaren flexibeler wil maken, nou dan gaan mensen natuurlijk erg hard giechelen van die stoffige ambtenaren die ineens uit hun kamer moeten en ontheemd aan het rondkijken zijn."

Hoewel het beeld van de overheid en de ambtenaar volgens de ondervraagden vaak slecht is, wordt het werk van de ambtenaar door buitenstaanders vaak wel als relevant gezien. De meeste respondenten geven aan positieve reacties te krijgen als ze vertellen waar ze zich mee bezig houden. Wanneer rijksambtenaren met buitenstaanders over hun werk praten, proberen ze dit vaak zo concreet mogelijk te maken. Hiermee helpen ze de buitenstaanders de relevantie van hun werk te zien. Omgekeerd geeft één medewerker aan niet vaak over haar werk te vertellen, omdat het vaak te abstract is:

- "Nou ik merk en dat komt ook omdat het een zodanig abstract project is wat ik nu doe, dat ik het er heel vaak maar bij laat zitten" (...) Ja, soms heb ik ook wel eens het gevoel dat je daarmee bevestigt dat het allemaal heel vaag is wat je als ambtenaar doet."

Het onderwerp waar de ambtenaar zich mee bezig houdt is ook van invloed op het beeld van buitenstaanders. Het ministerie van Justitie en de Dienst Justitiële Inrichtingen hebben een spannend imago, waardoor buitenstaanders nieuwsgierig worden. Dit genereert bij de medewerkers zelf ook een bepaalde trots:

- "Als je op een verjaardag bent is iedereen geïnteresseerd in wat je doet, iedereen vindt dat leuk. ledereen heeft er ook een opvatting over en iedereen heeft er ook een mening over en iedereen is nieuwsgierig."

De actualiteit speelt daarbij ook een rol. Geïnterviewden zeggen het leuk te vinden dat de onderwerpen waar zij zich mee bezig houden vaak in de kranten terug te vinden zijn. Op feestjes halen ze dan ook vaak voorbeelden uit de actualiteit aan wanneer ze vertellen over hun werk:

- "lk merk wel dat mensen dat altijd wel interessant vinden, omdat die bestrijding van die dierziektes is wel iets waar veel mensen een beeld bij hebben en dat is toch belangrijk dat dat goed gebeurt." 
Beleidsambtenaren doen dus hun best om hun werk voor anderen interessant te maken en in de meeste gevallen slagen zij hier ook in. Het werk belangwekkend maken voor anderen heeft niet alleen betrekking op het perceived external prestige, maar is ook een essentieel onderdeel van het werk van een beleidsmaker. Veel ambtenaren geven aan dat het belangrijk is om draagvlak te creëren voor een beleidsstuk. Dat begint met aandacht voor het beleidsonderwerp:

- "Dus hoe kan je dan als je daar beleid op maakt dat laten landen of dingen veranderen, bijvoorbeeld als mensen zich daar niet eens mee bezig houden of dat belangrijk is en waarom dat belangrijk is."

Voor het verkrijgen van belangstelling voor een beleidsonderwerp speelt de actualiteit van het onderwerp weer een rol. Daarnaast is het van belang of mensen in hun directe omgeving met het onderwerp te maken hebben. Wanneer dit niet het geval is en het onderwerp niet actueel is geven een aantal gesprekspartners aan dat het lastig is om de toegevoegde waarde van het beleidsstuk duidelijk te maken aan de maatschappij.

- "En dat kan ertoe leiden dat stromingen in de maatschappij sommige dingen niet belangrijk vinden, die je als ministerie wel belangrijk vindt."

- "Over die communicatie van de rapportages betreft, het blijft gewoon heel erg lastig om te communiceren dat het relevant is voor de consument."

\subsubsection{Perceived internal prestige}

Waardering voor het werk telt, en dat begint bij collega's.

- "Ik denk dat 80\% van de ambtenaren die je spreekt zegt ik vind het belangrijk dat er een maatschappelijk doel aan verbonden is en ik denk dat dat het is wat ons verbindt en dat dat ook mensen heel erg betrokken maakt. En dat tast het arbeidsethos niet aan".

Eén persoon geeft aan dat ze het gevoel had dat het onderwerp waar zij mee bezig is, voor de minister niet zo belangrijk was. Dit heeft vervolgens een invloed op haar identificatie met het ministerie:

- "Nou weet je, de taken die wij hebben, die zijn niet echt BZK eigen en er zit ook niet heel erg veel liefde van onze bewindspersoon in. (...) Vandaar dat ik me waarschijnlijk ook niet heel erg BZK'er voel of zo."

Daarnaast gaven veel ondervraagden aan dat ze het belangrijk vinden om binnen de organisatie gewaardeerd te worden voor hun werk.

- Als ze vragen kom wat drinken en vertel eens hoe je dit of dat hebt geregeld, nou dat zijn dingen waar je ook energie van krijgt. Dus natuurlijk complimentjes krijgen is fijn". 


\subsubsection{Perceived prestige of an external party}

Uit de interviews kwam naar voren dat de beleidsmedewerkers niet alleen een inschatting maken van het beeld van buitenstaanders, maar dat zij zelf ook op een bepaalde wijze aankijken tegen andere partijen. Vooral de vergelijking overheid bedrijfsleven komt dan naar voren.

- "Nee, ja er zijn altijd voor- en nadelen van een overheid. Kijk van de andere kant je hoort ook wel eens verhalen dat het in het bedrijfsleven niet zo heel erg veel beter is. En je bent toch wel met maatschappelijke problemen bezig en dat vind ik nog altijd leuker dan dat je... weet ik veel, ingrediënten voor verf aan het maken bent."

- "Wat ik heel leuk vind aan werken bij de overheid is, dat is mijn primaire drijfveer om bij de overheid te willen werken, is dat ik het idee heb dat de wereld een beetje mooier kan maken. Ik wil heel graag dienend aan de samenleving mijn werk verrichten, dus ik zie mezelf ook niet snel overstappen naar het bedrijfsleven of zo."

- "Je realiseert je: natuurlijk kunnen dingen anders, overheid is ook af en toe gewoon echt wel overheid met 100 keer toestemming vragen en lange lijnen en niks kan snel, het is niet dat je hier wat kan verzenden en dat het morgen gedaan kan zijn. En ik heb wel het idee dat dat in een commercieel bedrijf wel kan maar dat weet ik ook niet, want ik heb nooit dus in het bedrijfsleven gezeten."

Daarnaast komt de burger ook als categorie naar voren - een massa die naar hun idee een gebrek aan kennis hebben over de overheid: hoe ze functioneert of waar ze zich mee bezighoudt:

- "Het is natuurlijk een enorme illusie om te denken dat de gemiddelde burger snapt hoe Den Haag werkt en een ministerie, ja je hebt er zoveel en je hebt zoveel ministers en laat staan staatssecretarissen. Een gemiddeld iemand, die een beetje ver van Den Haag afstaat, die heeft geen flauw idee."

Naast het gebrek aan kennis over de overheid noemt ook een deel dat de burger geen goede maatschappelijke kennis bezit. Vaak wordt aangegeven dat er door de media een vertekend beeld wordt gegeven van maatschappelijke zaken en dat dit door de burger wordt overgenomen:

- "Dus er is een hele grote spagaat van wat de burger vindt en hoe het in de werkelijkheid is."

Een deel van de ambtenaren geeft aan dat in de loop der jaren burgers kritischer zijn geworden ten opzichte van de overheid. Zij geven aan dat de burger veel vaker zijn mening wil geven over maatschappelijke zaken dan vroeger. Ook geven respondenten aan dat veel burgers de overheid pas benaderen als er iets mis is en dat er daardoor een negatief beeld ontstaat van de overheid:

- "Nou dat is op zich goed, dat de burger in elk geval veel meer veeleisend is geworden ten opzichte van de overheid, alleen het slaat vaak door. De overheid wordt voornamelijk wanneer mensen het niet zint benaderd en dan kom je als overheid eigenlijk altijd op achterstand te staan, van ik vind dat je het niet goed doet." 


\subsubsection{Work meaning}

Waartoe leiden de toegekende betekenissen over interacties en interne en externe beelden van beelden van anderen? Wat zeggen de duidingen van interacties en beeldvorming per saldo over de workmeaning van de beleidsambtenaar bij de rijksoverheid?

\subsubsection{Jobmeaning (de overheid in beeld)}

Er zijn maar weinig geïnterviewden die expliciet aangeven dat het beeld van buitenstaanders van de overheid opweegt tegen invloed heeft op de betekenis die zij zelf aan hun werk geven. Het werk doet er immers toe:

- "Of de overheid nou een positief of negatief imago heeft, ik ben trots dat ik een bijdrage kan leveren aan deze maatschappij en als we een negatieve ervaring hebben dan denk $i k$ er is nog veel werk aan de winkel en als we een positieve ervaring hebben dan denk ik er is nog steeds veel werk aan de winkel."

Anderen noemen negatieve beelden vooral een hinderlijke bijkomstigheid. Zij praten dan over het beeld van de overheid dat in de media naar voren komt, in het bijzonder bij mensen die niet tot de inner circle behoren: collega's, vrienden en familie:

- "Uiteindelijk zeggen we allemaal dat we het doen voor de maatschappij en als de maatschappij ons iedere keer een smak om de oren geeft en zegt nee weer niet, nou op een gegeven moment heb je wel eens zoiets kan ik me voorstellen, dat heb ik ook wel eens, pff het kan ook nooit goed zijn hè?"

De behoefte aan zichtbaarheid van relevantie is duidelijk. Welke bijdrage moet de overheid leveren:

- "Als je maar iets kan doen wat door de buitenwereld maar een beetje opgemerkt wordt."

\subsubsection{Rolemeaning (aanpak van taken)}

Het is lastiger om over de overheid als geheel te spreken dan over de taken en rollen:

- "De verkeersveiligheid kunnen ze zich helemaal niks bij voorstellen. En dan vertel ik dus over de APK, de kentekens, motorfietsen en dan over alcohol en het rijbewijs. (...) Dus dat maakt het heel concreet en concreet is voor heel veel mensen toch ook wel weer leuk."

Het onderscheid met de politiek doet er ook toe. Hun rol is anders...Bij de houding ten opzichte van de politiek is sprake van twee groepen. De ene groep geeft aan dat de overheid teveel reageert op de publieke opinie. Vervolgens moeten er vanuit de politiek maatregelen worden doorgevoerd, die de medewerkers naar hun mening afhoudt van wezenlijke zaken:

- "Ja, je wordt er toch ingezogen en wij hebben nog wel zoiets van: die mensen hebben daar potverdorie helemaal geen verstand van, die roepen maar wat, maar je ziet dan wel waar het toe leidt via de media en de Kamervragen, want de Kamervragen 
komen heel vaak uit de media voort. En vervolgens kunnen wij hier die vragen gaan beantwoorden."

De andere groep ondervraagden meent dat de politiek meer moet kijken naar wat er in de maatschappij leeft. Deze groep heeft te maken met maatregelen die door de politiek worden besloten, maar waarvan zij zien dat deze in de praktijk niet werken:

- "Vaak heeft de politicus die de vraag heeft gesteld geen idee hoe het er eigenlijk aan toe gaat. Die heeft ergens iets horen luiden, maar stelt dan vragen waarvan ik denk van nou volgens mij moet je je maar eens verdiepen in het werk voordat je die vragen überhaupt gaat stellen."

Een scherpe rolaftekening is nodig, en een belangrijke kwaliteit is dan om zo objectief mogelijk te blijven en o.a. verschillende partijen te raadplegen.

- "Dat is de grote opdracht van ambtenaren: zo objectief mogelijk je bewindspersoon adviseren."

Naast de objectiviteit geven meerdere ondervraagden aan dat ze ook rekening moeten houden met de wijze waarop de minister zich presenteert.

Een beleidsmedewerker werkzaam bij een ministerie geeft aan dat het dus niet alleen om de inhoudelijke advisering gaat, maar ook om de toonzetting van een beleidsstuk:

- "En dan is het zaak om in een niet al te lange brief neer te zetten wat het standpunt is van de minister, wat ze ervan vindt en met de toonzetting die daarbij past van is het positief, is het niet positief, is ze gematigd enthousiast, wat straalt het uit. Dus het is niet alleen technisch, de inhoudelijke boodschap, maar ook de manier waarop je het brengt en past dat bij haar."

\subsubsection{Selfmeaning (het eigen aandeel)}

De eigen bijdrage aan de samenleving komt ook hier naar voren:

- "Nou het belangrijkste is dat ik graag de wereld een beetje mooier wil maken. Dat geeft mij nog steeds de energie".

Het hebben van leuke collega's wordt gezien als een belangrijk aspect van hun baan. Steun vinden bij collega's of je hart luchten in moeilijke situaties helpt harde beelden te verzachten. Vaak heffen deze positieve interacties de negatieve interacties weer een beetje op, waardoor er voldoende energie overblijft om de werkzaamheden verder op te pakken:

- "Dus je moet niet teveel situaties hebben die alleen maar energie vragen en die situaties zijn er wel geweest. Dus dan heb je af en toe ook echt nodig dat iemand tegen je zegt van nou het gaat goed." 
Waardering speelt een belangrijke rol bij (positieve) interacties en dit komt in de work meaning tot uiting. Dit kan zowel waardering van binnen de organisatie zijn als waardering van externe partijen:

- "Ja, dat werkt voor mij wel heel erg als een katalysator. Dat is wel heel erg stimulerend, van nou dat streelt je ego wel als ambtenaar."

- "Ja, ik word altijd door iedereen wel heel hard gepest over het ambtenaarschap en ik probeer mensen er wel van te overtuigen dat er wel heel veel mensen aan het werk heel hard aan het werk zijn, en er zitten ook mensen tussen, echt het klassieke type ambtenaar, maar ik neem aan in het bedrijfsleven ook types hebt die nou ja...(...)mijn vriendinnen die allemaal advocaat of wat dan ook zijn verdienen een godsvermogen maar die werken er ook tachtig uur voor en in het weekend. Hier heb je gewoon een mooi salaris met prettig werktijden, een goede werkgever die een hoop secundaire arbeidsvoorwaarden geeft en een hoop verlof".

Affiniteit met het onderwerp ligt in het verlengde hiervan. Voor veel rijksambtenaren geldt dat de waarden waar het ministerie of de uitvoerende dienst voor staat in lijn moeten liggen met persoonlijke waarden:

- "Ik zou niet naar Defensie gaan bijvoorbeeld of... er zijn een aantal dossiers waarvan ik denk van nee dat past niet. (...) Dus in die zin is het onderwerp en het ministerie wel van belang."

- "Justitie heeft wat dat betreft voor mij iets, dan denk ik: ja rechtsstaat. (...) Waar Justitie voor staat daar sta ik achter, daar werk ik graag aan mee."

Weten waartoe wat je doet leidt, en ook wie er wat mee opschiet vinden diverse gesprekspartners een betekenisvolle zaak. Wie werkzaam is bij een uitvoerende dienst geeft dit ook expliciet aan. Hiermee bedoelen ze dat ze dicht bij de maatschappij staan en zichtbare resultaten boeken:

- "lk vind het ook nog steeds heel erg leuk om dicht bij de uitvoerende kant te zitten, want het geeft gewoon altijd weer een bepaalde dynamiek."

- Het leukste is als iets blijvend effect heeft, maar dat weet je niet altijd".

Er zijn ook ondervraagden die aangeven dat ze graag direct voor de minister werken. Wanneer ze iets moeten voorbereiden voor de minister krijgen ze hier meestal veel energie van:

- "En waar ik energie uit haal is als ik zie dat het er toe doet en als er iets is van de minister moet iets doen of er moet iets in de Kamer en dat moet acuut voorbereid worden, nou dat is belangrijk en dat moet gebeuren."

- "lk wil ook een nuttige bijdrage leveren en nu realiseer ik me dat één van de dingen die ik in mijn werk gewoon goed moet doen is iedere keer scherp krijgen van wat is nou die nuttige bijdrage en dat is ook onderdeel van mijn werk om dat te kunnen doen." 


\subsubsection{Job crafting: ambachtelijk aanpassen}

Hoe verloopt het identificeren van de vormen van job crafting - de fysieke en cognitieve veranderingen die individuen maken binnen de taak- of relationele grenzen van hun werk?

\subsubsection{Cognitieve crafting (denken over de overheid)}

Veel ambtenaren noemen het duiden van het maatschappelijk belang van hun functie meer nog dan van de overheid. Wanneer dit belang van hun werk niet direct zichtbaar is, zoek je het op:

- "Ik weet niet of je wel eens dat voorbeeld hebt gehoord dat er een schoonmaker werkt in een grote fabriek en dat mensen dan vragen wat doe jij hier nou, nou ik help de mensen hier om een goede auto te produceren, weet je wel? Nou dat gevoel. Dat je meehelpt om de veiligheid te waarborgen. Dat vind ik wel belangrijk."

- "Als je met iets bezig bent, een onderwerp, en dan toch proberen er iets van te maken, dus de maatschappelijke relevantie daarvan te ontdekken en om te kijken of je dan een bijdrage kunt leveren om het openbaar bestuur beter te laten functioneren."

Het leggen van causale relaties (en daarmee concretiseren) is daarbij een van de mogelijkheden:

- "Dan zeg ik vergeet niet dat ik als Nederlands staatsburger ook met de overheid te maken heb. (...) En jij en ik krijgen niet uitgelegd dat een bouwvergunning zes maanden kan duren, met andere woorden, stel je bent bakker en je moet brood leveren dan bestel jij meel en dan ga je zeggen ja het graan moet eerst gezaaid worden en zo."

- "Maar dan moeten ze eerst ophouden met zeiken. Dat we gewoon denken van we hebben overheid, een relatief gezien klein, niet corrupt, best wel efficiënt, we hebben een van de beste verzorgingsstaten van de wereld, ergens doen we het dus best wel goed".

Vergelijken met het bedrijfsleven helpt dan ook, vooral als je kunt laten zien dat er in het bedrijfsleven ook wel eens wat mis gaat. Door een 'benchmark' te maken met het bedrijfsleven ervaren sommigen hun eigen werk als meer zinvol. Veel ambtenaren verdedigen zich ook voor (het werken voor) de overheid:

- "Ja, er zijn altijd voor en nadelen van de overheid. Kijk van de andere kant je hoort ook wel eens verhalen dat het in het bedrijfsleven niet zo heel erg veel beter is."

- "En soms heb ik wel eens wat last van de bureaucratie waarin we werken, maar dat heeft niet zozeer met het ambtenaarschap te maken want mijn vrouw die werkt in een bedrijf waar 120.000 mensen werken en dat is net zo bureaucratisch, nog bureaucratischer dan waar ik werk. Dus het heeft niet te maken of je bij het bedrijfsleven werkt of bij de overheid maar het heeft wel te maken dat je bij een grote organisatie werkt."

- "Ja, omdat je iets doet wat. het is volgens mij veel moeilijker dan het bedrijfsleven omdat je met veel meer belangen tegelijkertijd te maken hebt en op de een of andere manier moet je die toch met elkaar verenigen. Bij het bedrijfsleven ga je voor het 
product dat je maakt en ga je voor winst maken, dat is je focus. En dat vind ik totaal niet interessant. En alleen als je ambtenaar bent kun je er iets aan veranderen. Het is het enige vak waarin je maatschappelijk iets kunt veranderen. In alle andere vakken ben je gewoon onderdeel van de maatschappij en je kunt erover klagen maar je verandert zelf helemaal niks."

- "En ik vind ook dat, mijn vrouw is daar nog best wel vaak jaloers op, als het gaat om de secundaire voorwaarden dan zijn er ongelooflijk veel mogelijkheden, ik ben bijvoorbeeld in Rome geweest voor mijn werk en als je ziet wat ze in mij investeren als manager in opleidingen en zo nou dat is gewoon, kunnen ze echt een puntje aan zuigen in het bedrijfsleven. Daar kunnen ze niet tegen op. Zij krijgen weliswaar een dikke leasebak en een laptop van de zaak, dus vooral die financiële zaken dat is allemaal uitstekend geregeld daar, niets aan te klagen maar het ontbreekt vooral aan het investeren in de ontwikkeling van mensen."

Besef van de ambtelijke positie speelt voor velen een duidelijke rol:

- "De burger heeft de Kamer gekozen dus we mogen uitgaan van dat datgene wat de minister en de Kamer doet. En als de burger tegen mij zegt ik wil $A$ en de minister ik wil $B$ dan is het $B$ want de minister maakt de afweging en die is ook ingehuurd om dat besluit te nemen en de burgermening telt wel maar die kiest de Kamer en de Kamer bepaalt wat ze doet met wat de regering zegt (...) Als ik het daar niet mee eens ben, jammer dan voor mij, dan moet je geen ambtenaar worden"

Maar ook kan een weerzin blijven hangen. Je mort wat:

- "Ja, zo'n moment denk ik wel eens: jongens kom op. Ik ben heel resultaatgericht en ik houd er ook van om daar hele duidelijke afspraken over te maken. En dat lukt niet altijd hier".

\subsubsection{Taak crafting (taakuitoefening)}

'Ruimte nemen' komt in diverse toonaarden naar voren:

- "Je kunt niet zonder een krachtenveldanalyse of weten wie hoe ergens in zit".

- "lk kan me voorstellen dat dit voor nieuwe medewerkers lastig is. Want dan verwacht je misschien dat er een stem van boven klinkt die zegt hoe iets moet gebeuren. Ik ben er achter gekomen dat een van de dingen die ik moet doen is iedere keer scherp krijgen van wat is nou die nuttige bijdrage en wat voeg ik aan wie of wat toe".

- "Ik krijg heel veel vrijheid in het hoe en om te onderzoeken wat ik leuk vind qua aanpak".

- "Persoonlijk krediet, het is allemaal persoonlijk krediet".

De rol van de politiek als opdrachtgever komt in vrijwel alle gesprekken aan bod.

De kijk die ambtenaren op de politiek ontwikkeld hebben is een indicator voor de manier waarop iemand in staat is om met een ambtelijke positie om te gaan. Speel het spel mee, klinkt dan als boodschap door: 
- "Ik noem het ook echt politiek spel, want dat is het ook een beetje. Ik beschouw het als een spel, ik neem het niet te serieus, dat moet je ook niet doen want dan wordt je niet gelukkig in onze omgeving. Want ja je verliest ook wel eens en als je dan het spel heel serieus neemt, dan kun je daar een slecht gevoel aan overhouden en dat probeer je te voorkomen."

- "Werken aan de samenleving vind ik echt belangrijk maar het politieke spel vind ik echt leuk, daar geniet ik van. En ik ga ook wel eens gewoon naar een Kamerdebat omdat ik dat leuk vind".

- "Het is wel echt een spel geworden tussen de Tweede Kamer, de bestuurders van de brancheorganisaties en het ministerie, de top van het ministerie en. nou dan wordt het heel lastig om het uit te leggen aan je buurman, je moeder, je vader, noem het maar op."

- "Je moet ook in de gaten blijven houden, wat is nou het spelletje dat hier wordt gespeeld? Wat is het politieke spel? Wat zijn de belangen van mensen?"

Het spel moet meegespeeld worden, en het heeft geen zin om op de stoel van de politicus, de uiteindelijke beslisser te gaan zitten. Ken je rol en de spelregels, het ambtelijk besef ten voeten uit:

- "Er worden heel vaak keuzes gemaakt waarvan je denkt, hoe kunnen zij het bedenken? (...) Nou dat kun je één keer roepen, dat kun je twee keer roepen en dan moet je draaien. Dan moet je denken, okay, dat is dan de realiteit."

- "Wij weten ook van, de politiek vindt nu de administratieve lastenverlichting heel erg belangrijk, maar die ondernemer die zegt dat maakt niet uit als ik wat meer lasten heb als ik maar een goede dienstverlening heb en op een schip terecht kan en dan wil ik nog wel een aantal formuliertjes extra invullen. Dus de Kamer weet ook niet goed wat de sector of wat de maatschappij wil en dat weten wij wel."'”

- "Je probeert je ambtelijke en politieke leiding uit de wind te houden. Dat is onze taak".

Voor sommige rijksambtenaren levert de crafting op basis van de taak een bijdrage aan hun persoonlijke ontwikkeling. Eén van hen gaf ook aan extra taken op te pakken waarbij ze sneller resultaat kon zien dan bij haar reguliere beleidswerk. Hierbij geven extra taken c.q. afwisseling zoeken weer energie om bezig te gaan met formele taken:

- "En ik merk nu dat ik heel blij ben met de afwisseling die ik nu heb, want ik heb dat project eigenlijk als hoofdtaak, maar daarnaast ook andere dingen waarvan je het einde in zicht ziet."

We zien hier ook de relevantie voor het type organisatie als variabele naar voren komen. Mensen kiezen bewust voor hun plaats in de (beleids)ketens:

- "Toen ik bij de gemeente werkte toen dacht ik op een gegeven moment, ja ik vind het wel leuk om eens een keer aan het begin van de keten van het Rijk te staan. Want de gemeente heeft heel vaak afgeleid beleid, dus we bedenken hier in Den Haag iets en uiteindelijk gaan we dat uitvoeren en daar kwamen heel vaak dingen voorbij waarvan ik dacht, wie heeft dát bedacht? (...) Nou toen dacht ik dan ga ik eens een keer aan het 
begin van de keten staan om eens gewoon te kijken of het me lukt om iets uitvoerbaars te maken."

- "Voor mij was dat een reden om naar een uitvoeringsorganisatie te gaan. Om te denken ik moet zelf ook een keer gaan waarmaken van wat ik altijd heb geroepen, namelijk het uitvoeren. Het uitvoeren is belangrijker dan abstracte beleidsplannen maken, je kunt plannen maken wat je wilt maar als de uitvoering het niet doet gebeurt er niks.

En daarom ben ik overgestapt".

Loyaliteit voedt verantwoordelijkheid, komt nadrukkelijk naar voren:

- "De baan is wat ik er van maak, als ik ga zitten wachten achter mijn bureau en denk: ik wacht wel tot er iets leuks op me afkomt, ja dan wordt het niks en dan is het niet leuk."

- "Als die sector niet wil en boos wordt (...) ja daar ben ik wel eens moedeloos van en daarna ook iedere keer weer bellen van dat gaat niet...ja...dan moet ik me echt bij elkaar rapen en denken: welke rol heb ik, welke rol hebben zij, kan ik er wat aan doen, want $i k$ voel me wel verantwoordelijk voor dingen waar ik misschien helemaal niet voor verantwoordelijk ben en dat zijn dingen waar ik geen energie van krijg, daar word ik doodmoe van".

Sommige rijksambtenaren geven aan dat het beeld van buitenstaanders een extra stimulans voor hen is om foute of onvolledige beelden tegen te gaan. Dit doen ze door zelf harder te gaan werken of door zich anders op te stellen in de externe contacten:

- "Ja, bijvoorbeeld als ik gebeld wordt door iemand die van het kastje naar de muur is gestuurd, dat ik dan zeg van kom op zeg, ik ga zelf wel even kijken wie u moet hebben. Dus als ik contact heb met buiten dan denk ik wel: dit bevestigt natuurlijk alleen maar dat beeld. En ja, dat is ook niet goed, dus ga ik kijken of het anders kan."

110

Maar evengoed klinkt de relativering:

- "Die beelden zijn er ook niet voor niets. Ik merk het ook wel als er iets onverwachts gebeurt en ik denk oh en dan moet ik om mezelf lachen, alsof ik het ooit wel onder controle had. Wat een idioot idee. Maar dat is vaak wat van ambtenaren wordt verwacht. Dat ze hun minister uit de wind houden en zorgen dat alles exact beheersbaar en controleerbaar verloopt. Dat kan helemaal niet. De maatschappij is niet onder controle dus laat staan dat de overheid daar controle op kan uitoefenen. En dat vinden mensen wel weer grappig als je dat met voorbeelden kunt benoemen".

- "Ja zeg: 'Wow'verwacht ik ook weer niet".

Opschalen is een optie: een aantal ambtenaren geeft aan hun werkzaamheden over te dragen aan iemand anders als een bepaalde situatie te ingewikkeld wordt. Dit kan aan een collega zijn of aan een leidinggevende. Die heeft dan meer status of ervaring waarop men terug kunnen vallen.

- "Soms kunnen mensen best statusgevoelig zijn dus als mijn directeur contact opneemt met iemand en zegt van joh, ik wil je even iets voorhouden en een medewerker van 
mij die wil met je praten, wat vind je ervan dan komt dat anders binnen dan als $i k$ bijvoorbeeld rechtstreeks een medewerker benader en zeg ik wil dit eens met je afstemmen".

- "Als ik vind dat de ander gewoon geen gelijk heeft, dat hij het gewoon niet snapt, dan wil ik wel eens kijken dat zet ik bijvoorbeeld mijn afdelingshoofd in omdat die sterker is dan zijn afdelingshoofd".

Een zekere mate van onrust moet kunnen:

- "Het is wel een beetje raar product: gevangeniswezen. Ik vond het heel spannend maar $i k$ vind het ook eng. Ik vind de bezoeken die je doet heel gaaf, maar ik ben ook wel heel blij als ik weer gewoon buiten sta. Dus het is een beetje een haat-liefdeverhouding. Ik werk hier vijf jaar, dus ik denk dat dat ook wel een indicatie geeft van hoe je er zelf in staat".

\subsubsection{Relationele crafting (communicatief handelen)}

Een deel van de rijksambtenaren geeft aan moeizame interacties te vermijden:

- "Nou ja bij dat soort overleggen waarbij ik verwacht dat er allemaal problemen op tafel worden gelegd die vermijd ik wel eens een beetje."

In informele situaties kan het ook helpen te ridiculiseren:

- "Gewoon die stereotype beelden wat uitvergroten zo van, druk weekend gehad maar gelukkig ben ik ambtenaar en kan ik de hele week bijkomen van het drukke weekend."

Een ander deel van de rijksambtenaren kiest er in moeizame interacties voor om de confrontatie aan te gaan. Dit kan in de vorm van een terugkoppeling geven aan de minister als ze het niet eens zijn met een besluit. Maar dit kan ook plaatsvinden bij een moeizame interactie met een brancheorganisatie. Wie voor deze strategie kiest vindt het belangrijk om contact te houden met de andere partij:

- "De enige manier is toch om constant met elkaar in contact te treden, dus niet dat je denkt van daar wil ik niets mee te maken hebben, want dat gaat toch niet, maar wel dat opzoeken."

Er zijn ook ambtenaren die met betrekking tot de minister ervoor kiezen om in eerste instantie een terugkoppeling te geven, maar uiteindelijk toch overstag gaan. Zij geven hierbij aan dat je uiteindelijk toch loyaal moet zijn naar je minister. Wanneer de beleidsmedewerkers ervoor kiezen om de confrontatie aan te gaan met brancheorganisaties is er een aantal tactieken, dat ze gebruiken. Namelijk: aandacht geven aan de relatie, benoemen van de weerstand en zoeken naar een gemeenschappelijk belang. Met aandacht geven aan de relatie wordt bedoeld dat er eerst gewerkt wordt aan een goede relatie met de andere partij om vervolgens een functioneel doel te bereiken. Dit werken aan de relatie betekent voor veel ambtenaren 
dat ze het belangrijk vinden om vroegtijdig verschillende partijen te betrekken bij het beleidsproces.

- "Ik heb er bewust voor gekozen om de strategie te beginnen met een conceptverhaal, niet een open bijeenkomst van laten we allemaal maar eens wat roepen, maar wel zeggen die is onze insteek, schiet er asjeblieft op en als je helemaal niks aanspreekt ook prima maar ik hou er niet van nou ja roept u maar".

- "Gewoon het feit dat je mensen betrekt, dat mensen zich serieus genomen voelen, dat je terugkoppelt, dat je mensen warm houdt... Ik denk dat als de relatie goed is dan komt de inhoud vanzelf wel".

Ook kan het betekenen dat de rijksambtenaren soms op een aantal punten iets moeten inleveren om uiteindelijk een hoger doel te behalen:

- "Je moet altijd wat inleveren. Het poldermodel is een typisch Nederlandse uitvinding, maar het is de enige manier waarop je met mensen samen kunt leven. Als iedereen maar zijn eigen verhaal vasthoudt, ja dan heb je ook geen gesprek."

Een enkele ambtenaar geeft aan de weerstand van de andere partij te benoemen. Het doel hiervan is om openheid te creëren, waardoor de ambtenaar ook inzicht krijgt in de belangen van een andere partij. Deze tactiek wordt overigens niet alleen gebruikt in moeizame interacties met brancheorganisaties, maar ook in moeizame interacties met collega's:

- "Terwijl ik zoiets heb van als ik merk dat er geen energie in een gesprek zit, dan moet je het zo snel mogelijk bespreekbaar maken, van hoe is het voor jou en voor jou, ok."

Veel geïnterviewden geven aan in moeizame interacties te zoeken naar een gemeenschappelijk belang. Ze peilen naar eigen zeggen bij voorkeur eerst het belang van de andere partij en proberen hierop in te spelen.

- "Je moet gewoon benadrukken wat de gezamenlijke kansen zijn en proberen die angsten die erachter zitten te ontkrachten."

Dat kan betekenen dat je verbindingen legt die anderen niet zien:

- "Door de bureaucratische processen die hier lopen kunnen zaken met maatschappelijk belang zo vier weken blijven liggen doordat ze toevallig niet in de agenda kwamen in die vergadering."

- "De Partij van de Dieren bijvoorbeeld praat heel vaak over dezelfde dingen en probeert de minister ook wel uit te lokken en dat is ook goed voor het debat. Dus je merkt dat we heel vaak technische antwoorden geven, dus heel erg feitelijk. (...) Dat je puur en alleen antwoord geeft op de vraag en alles vermijdt wat tot vragen kan leiden. En het is ook de vraag of je daar niet wat stelliger in kunt zijn zodat je ook een boodschap hebt richting de Kamer en dat je in die zin wel eens aan kunt geven wat je standpunten zijn en dat is wel eens lastig." 
We zien op dit punt ook de grote betekenis van het vinden van interne relationele steun van collega's. Dit kan zijn om hun hart te luchten, maar ook om advies te vragen over een bepaalde situatie. Er zijn ook rijksambtenaren die aangeven bondgenoten te zoeken in het geval van moeizame interacties. Ze zoeken dan mensen binnen de organisatie die een zelfde mening toegedaan zijn als zijzelf en proberen zo sterker te staan tegenover de andere partij:

- "Ja, meestal zoek ik inderdaad mensen die er wel open voor staan en daar ga ik dan een keertje mee van gedachten wisselen van goh hoe zie jij dat dan en wat zijn daar de voordelen van en soms vraag ik dat wel eens, van hoe zou jij dat dan willen verkopen aan je collega's?"

- "Ja, ik zoek altijd bondgenoten, managers of inspecteurs, mensen die er wel open voor staan en dan ga ik daar een keer mee van gedachten wisselen van goh hoe zie jij dit en hoe zou jij dat verkopen aan jouw collega's, weet je wel?"

En krijg je de handen niet op elkaar dan is lef een competentie, durf om een eigen weg in slaan.

- "Ja, ik verzet me daar wel tegen en dat betekent dat ik wel heel kritisch ben naar mijn omgeving. Maar ook niets schuw en daar is wel wat lef voor nodig ben ik achter gekomen om gewoon tegen je leidinggevende of tegen de top van het ministerie een goede discussie te voeren."

- "Nou om op het interne debat te reageren is niet zo moeilijk, maar om er daadwerkelijk resultaten uit te halen."

\subsubsection{4.}

Wat doe je als je tekortkomingen in het handelen van jou of je organisatie ziet? Expliciet gevraagd naar 'leren' geeft een aantal aan niet te weten wat of hoe:

- "Dat is een beetje moeilijk want je weet niet wat het aanbod is, ik weet niet zo goed wat ik mis".

- "Nieuwe mensen zeg ik ook dat het echt een vak is, dat je zeg maar vanuit een leeg blad probeert onbevooroordeeld een bewindspersoon te adviseren, om met die lijn het veld in te gaan zitten en dan zo objectief mogelijk adviseren op de pro's en contra's van wat hij wil en daarna ga ik helpen om zijn besluit te verdedigen in de Kamer en dat is echt een vak, een ontzettend leuk vak".

Maar mogelijkheden om te leren van ervaringen - vooral negatieve - worden verwelkomd:

- "lk vind het als mensen met verschillende meningen bij elkaar zitten hoe je daar handig mee omgaat en ik weet dat mensen vinden dat ik dat wel redelijk goed kan en ik vind mezelf altijd wat zacht, maar volgens mij hadden we best een stapje verder kunnen komen als ik wat steviger was geweest" 
- "Nou als anderen in een conflictsituatie zit vind ik dat minder lastig dan dat ik er zelf in zit, hoe kan ik dat beter doen".

- "lk heb gemerkt dat het heel belangrijk is juist achteraf te kijken hoe iets is gelopen. Het gaat soms zo grillig, hoe leer je daar dan van?"

- We hebben die managers laten praten met een coach erbij en mensen gingen onderling elkaar tips geven over hoe dat nou moest als mensen gingen klagen en wat je dan zelf kon doen"

- "We moeten steeds meer nadenken over hoe we boodschappen formuleren maar of het goed valt weet ik eigenlijk vaak niet en zou ik wel eens willen leren

Sommigen koppelen leren nadrukkelijk aan loopbaanontwikkeling:

- "En ik ben 41 dus ik heb nog wel even te gaan en je moet natuurlijk fris blijven, dus je wilt blijven leren en een van de dingen waar ik me graag op wilde ontwikkelen was de managementlijn".

- "Ik geloof sterk in geleidelijke ontwikkeling"

- "Ik ben gewoon een soort HR-manager van mensen en mensen hebben dus problemen of ze worstelen met dingen, ik ben heel erg aan het coachen natuurlijk of mensen aan het begeleiden".

- "Ik denk dat het wel te maken heeft men een stukje senioriteit dus het is misschien ook ja misschien gewoon credits opbouwen doordat je gewoon veel ervaring hebt met allerlei onderwerpen".

\subsection{Conclusies}

In deze paragraaf worden de centrale vraag en de deelvragen beantwoord.

4.6.1. Deelvraag 1: welke invloed hebben de interacties die ambtenaren gedurende hun werkzaamheden hebben op de betekenis die zij aan hun werk verlenen?

De belangrijkste interacties die ambtenaren tijdens hun werk hebben zijn de contacten met collega's, interdepartementale overlegsituaties en vervolgens met leidinggevenden of (indirect) de minister. Deze interne contacten worden duidelijk meer gewicht toegekend dan die met het publiek en/of organisaties. Positieve interacties kenmerken zich door - snel - resultaat, vermogen om tegenstrijdige belangen samen te brengen en waardering voor geleverde inspanningen. Korte afstand tot c.q. feedback van bewindslieden scoort hoog. Negatieve interacties kenmerken zich door uitblijven van zicht op resultaat, onvermogen tegenstrijdige belangen te overbruggen en bureaucratie. De invloed van interacties op de betekenis van het werk wordt over het algemeen groot geacht. Heldere rollen (ten opzichte van de politiek bijvoorbeeld) komen als troef naar voren, alsook de mogelijkheid om 'het spel' mee te kunnen spelen. Daarnaast vragen persoonlijke factoren aandacht zoals de behoefte aan waardering, het vermogen tot durf en de match tussen eigen en organisationele waarden. 
4.6.2. Deelvraag 2: wat is de invloed van het perceived external prestige op de betekenis die ambtenaren aan hun werk verlenen?

Over het algemeen bestaat volgens de ondervraagden geen positief beeld van de overheid en de ambtenaar. Het werk dat de individuele ambtenaar doet wordt volgens hen meestal wel positief gewaardeerd door buitenstaanders. Naast het perceived external prestige spelen ook het perceived internal prestige en het perceived prestige of an external party een rol. Het negatieve beeld dat er heerst bij buitenstaanders van de overheid en de ambtenaar draagt bij aan een bepaalde weerstand die rijksambtenaren ervaren vanuit organisaties of burgers waar ze mee te maken hebben. Genoemd worden vooral geringe voorkennis bij buitenstaanders en een niet altijd begrepen achterdocht bij belangenorganisaties ten opzichte van overheidsbemoeienis. Veel ondervraagde ambtenaren geven aan moeite te hebben om soepel met deze 'signalen van weerstand' om te gaan. De media dragen voor een groot deel bij aan de beeldvorming die het publiek heeft van de overheid. Een aantal ambtenaren geeft aan dat de overheid vooral in het nieuws komt als er dingen mis gaan. De overheid is een organisatie die een plicht heeft om transparant te zijn en wordt dus op de voet gevolgd door de media. Voor rijksambtenaren is dit soms lastig omdat zaken waar zij nog mee bezig zijn vroegtijdig in de belangstelling komen. Ook geven sommige rijksambtenaren aan dat het lastig is om in te schatten welke ruimte ze hebben, bijvoorbeeld in welke fase ze in de openbaarheid kunnen treden met hun beleid. Vaak zijn ze voor deze beslissingen afhankelijk van personen die hoger in de organisatie zitten. Tegenover de nadelen van het negatieve beeld staan echter de ervaren belangstelling voor de spannende opgaven die op het overheidsbord komen. Tegelijk wordt de invloed van de beeldvorming over het algemeen niet heel hoog geschat; er is veel relativering, onder meer door het ervaren besef dat de overheid er als zodanig toe doet. Ook speelt de interne beeldvorming mee, collega's die steunen verzachten harde woorden van buitenaf.

\subsubsection{Deelvraag 3: welke rol speelt job crafting bij de betekenis die ambtenaren aan werk} verlenen?

Alle drie de vormen van job crafting komen voor binnen de rijksoverheid.

Er zijn binnen de overheid dan ook voldoende mogelijkheden om aan job crafting te doen. Door middel van crafting proberen de ambtenaren lastige situaties in hun werk hanteerbaar te maken. De drie vormen van job crafting hebben dus op hun beurt ook weer invloed op de work meaning.

\section{Invloed work meaning op job crafting}

Uit het onderzoek komt naar voren dat de betekenis die ambtenaren op grond van de interacties en de beeldvorming aan hun werk verlenen een duidelijk waarneembare invloed heeft op hun job crafting. Velen van hen craften hun werk cognitief om het maatschappelijk belang goed voor ogen te kunnen houden. Daarnaast proberen de ambtenaren door middel van cognitieve crafting goed het doel van hun werkzaamheden voor ogen te houden. Dat uit zich ook in de jobcrafting, waarbij het nemen van ruimte, het zoeken van afwisseling en de metafoor spel (zie ook hierna) naar voren komen. Bij de taakuitoefening komt een scala aan 
strategieën naar voren, zoals vermijden, relativeren, confronteren, weerstand benoemen, aandacht geven, slimme verbindingen aangaan en benadrukken van gemeenschappelijke of hogere belangen. Een terugkerend motief is de - overwegend gelaakte - bureaucratie en daarbij voorkomende procedures en regelgeving, die heldere beeldvorming en oordeelsvorming bemoeilijkt. Grosso modo spreekt uit de interviews op dit punt de nodige ambtelijke vindingrijkheid. Dat blijkt ook uit de luchtige betekenisverlening aan grapjes en vooroordelen over ambtenaren.

Invloed job crafting op work meaning

Uit de resultaten van het onderzoek kan vervolgens worden opgemaakt hoe job crafting invloed kan hebben op de work meaning van rijksambtenaren. De zogeheten cognitieve crafting helpt om je werk op een andere manier te bekijken, waardoor het werk voor zinvoller wordt of waardoor ze beter met moeilijke situaties om kunnen gaan.

Daarbij spelen onder meer de gelegde causale relaties met processen en arbeidsvoorwaarden in het bedrijfsleven een rol. Ook leiden beoordelingen van publieke kennis en houdingen naar een relativering. Pregnant komt naar voren dat het helpt om je werk te zien aan de hand van de metafoor 'spel'. Dit wordt zowel in een waarderende betekenis uitgelegd als in een vorm van wegbewegen van de werkelijkheid: een hulpmiddel om niet te snel teleurgesteld te raken. Door relationele crafting proberen rijksambtenaren op een bepaalde manier met hun relaties om te gaan, waardoor hun werkbeleving zo min mogelijk ten koste gaat van de moeizame interacties. Taak-crafting wordt gehanteerd om meer variëteit aan te brengen in het takenpakket, de eerdergenoemde stijlen waarin lastige situaties worden geïnterpreteerd, of de wijze waarop de eigen ontwikkeling kan worden versterkt, wat ook weer een positieve invloed heeft op de work meaning.

4.6.4. Centrale vraag: welke betekenis verlenen ambtenaren aan hun werk en welke rol speelt communicatie in dit proces?

Uit het onderzoek blijkt dat vooral de interacties een grote rol spelen bij de betekenis die ambtenaren aan hun werk verlenen. Die rol blijkt bij de vorming van de workmeaning, maar vervolgens ook uit de omzetting hiervan in werk en de terugslag daarvan weer op de duiding van de opgaven in het werk als beleidsmaker. De betekenis van het perceived (external) prestige komt minder sterk naar voren, maar oefent wel invloed uit, door het openbare karakter en de voortdurende drang om verantwoording van publiek en media. Dat bevestigt in welke mate het werk van de beleidsambtenaar een communicatieve aangelegenheid is. Welke centrale conclusies zijn mogelijk op basis van deze verkenning van ambtelijke betekenissen?

\section{Een unieke, spannende mangel van belangen}

Ambtenaren geven blijk van een voortdurende aftasting van wat hun positie kan zijn ten opzichte van drie - verbonden - krachtenvelden: de maatschappelijke arena, het politiek bestuur en de bureaucratie. Vanuit de drie hoeken wordt druk uitgeoefend in die zin dat zowel interacties als beeldvorming aandacht opeisen, beelden veroorzaken en aanpassingen 
genereren die op hun beurt weer de workmeaning beïnvloeden. Verkeren tussen de drie categorieën blijkt regelmatig spanningen te genereren, maar het is ook onvervreemdbaar in die zin dat het samenhangt met het wezen van ambtelijke beleidsvorming. Zelden waait de wind uit louter één hoek. Wat de politiek-bestuurlijke hoek betreft komt uit de interviews met de rijksambtenaren naar voren dat naar hun mening de wil van de politiek niet altijd ten goede komt van het maatschappelijk belang. Dat geeft een ongemakkelijk gevoel. Aan de ene kant moeten ze voldoen aan de wil van de politiek, maar aan de andere kant menen ze soms dat dit niet altijd de beste keuze is voor het maatschappelijk belang. De rijksambtenaar meent dichter bij de maatschappij te zitten en beter te weten wat er speelt, maar hij kan er naar zijn mening niets mee doen omdat hij de wil van de politiek moet uitvoeren. Daarbij komt naar voren dat in de politieke arena verschillende belangen een rol spelen. Voor rijksambtenaren is het belangrijk om deze belangen te doorzien, zodat zij op een objectieve, professionele basis hun minister kunnen adviseren en maatschappelijke en departementale verwachtingen recht kunnen doen. Alleen de minister uit de wind halen of houden volstaat misschien even, maar is nooit een lang leven beschoren. Alleen de burger beschermen of anderszins dienen kan ook niet als in de politieke arena gezaghebbende keuzes over schaarse goederen moeten plaatsvinden. Tussen de oriëntaties van de maatschappelijke arena en de bureaucratie kan het evenzeer erom spannen. Wat de bureaucratische hoek betreft geven de ondervraagden er blijk van te beseffen dat niet alleen de politiek, maar ook de departementale top ijzers in het vuur legt. Om aandacht te krijgen voor hun beleidsstuk moeten rijksambtenaren niet alleen extern een draagvlak creëren, maar ook intern 'weten hoe de hazen lopen'. Rijksambtenaren moeten binnen de organisatie belangstelling weten te krijgen voor hun beleid bij de juiste personen. Het spelen van het interne spel is volgens sommige rijksambtenaren lastig, omdat er volgens hen veel 'positiespel' wordt gespeeld binnen de rijksoverheid. Daarmee bedoelen zij dat de inhoud van het beleid soms ten koste gaat van (het behoud van) de status of positie van iemand. Een rijksambtenaar geeft aan vaak tegen een blokkade aan te lopen wanneer hij bepaalde veranderingen wil doorvoeren binnen de organisatie. Hij geeft aan zelf wel het initiatief te nemen om dingen aan te kaarten, maar dat er vaak niet naar hem wordt geluisterd. Ook voor de maatschappelijke arena telt dat belangen een eigen functie kan worden toegekend. Dat is bijvoorbeeld het geval als individuele of deelbelangen aandacht vragen. Het samenkomen van de arena's brengt hoe dan ook een ongemakkelijk gevoel voor de rijksambtenaar met zich mee. Dat geldt in het bijzonder wanneer andermans en eigen opvattingen - en in het bijzonder onderliggende waarden - niet bij elkaar kunnen worden gebracht. Maar ook speelt voortdurend een behoefte aan verantwoording mee: de beleidsmaker wil zijn werk graag uit kunnen uitleggen aan buitenstaanders. Bij die betekenisverlening en de omzetting ervan in handelen komt een oeuvre aan strategieën naar voren, die scherper afgetekend moeten worden, zoals de neigingen tot vermijden of juist confronteren, het honoreren van weerstand of juist streven naar gemeenschappelijke belangen. 


\section{Resultaat telt, vooral procesresultaat}

Uit de gesprekken blijkt de ambtelijke wil om resultaten te kunnen definiëren, zicht op resultaten te houden en die resultaten zelf zichtbaar te kunnen maken. Dit punt komt vooral scherp naar voren door de moeite die wordt toegekend aan de typen resultaten die mogelijk zijn: vaker processtappen dan harde en meetbare uitkomsten. Bij zowel het persoonlijke welbevinden als de verantwoording naar anderen telt dat mee: wat levert het op? Zo maken we uit de beoordeling van de interacties op dat beleidsambtenaren een positieve workmeaning ontlenen aan de inschatting om een maatschappelijk belang te kunnen dienen. Wanneer dit omgekeerd niet lukt door de beoordeling van bureaucratie of het politieke proces van meningsof besluitvorming, is sprake van een negatieve impact op de workmeaning. Bij het perceived external prestige komt naar voren dat rijksambtenaren duidelijk willen kunnen maken op welke wijze ze bijdragen aan het maatschappelijk belang. Indien dat lukt, heeft dat een positieve invloed op de workmeaning. De bureaucratie blijkt door de bank genomen een factor met een negatieve invloed op de beeldvorming van de overheid en de ambtenaar. Rijksambtenaren proberen het werk cognitief te craften om zelf het maatschappelijk belang voor ogen te houden in het bureaucratische systeem van de overheid. Voor rijksambtenaren werkzaam bij een ministerie (ten opzichte van die bij diensten) is de politiek een belangrijke factor om rekening mee te houden bij het opstellen van beleid. Zij geven hierbij aan dat je voorafgaand aan het opstellen van beleid rekening moet houden met hoe het beleid kan vallen in de politiek. Een beleidsmedewerker geeft aan soms voor een dilemma te staan over in hoeverre hij in zijn beleidsstukken zijn eigen visie en argumenten kan laten doorschemeren. Dat wordt vooral moeilijk als het gesprek hierover niet direct met de bestuurder kan worden gevoerd. Daarnaast kwam er nog een aantal andere aspecten naar voren zoals het toegekende belang van het werk in iemands leven, basishoudingen ten opzichte van politiek, de verwantschap met het beleidsonderwerp en de - beschikbare - nabijheid van de eindgebruiker.

\section{Spel helpt; vindingrijkheid alom}

Ambtenaren tonen vindingrijkheid als het gaat om het omgaan met de spanningen die hun werk met zich meebrengt. Dat leidt tot een scala aan houdingen om (potentiële) confrontaties aan te gaan. Taal is belangrijk om lastige opgaven te duiden en 'speaking terms' te vinden en relaties te kunnen bestendigen. Balans vinden vraagt om die vindingrijkheid, velen zijn zich we van bewust dat ze soms niet duidelijk kunnen zijn en dan irritaties oproepen. De metafoor 'spel' dringt zich in dit onderzoek op. Het begrip komt het meest naar voren in relatie tot de politiek. Gewezen wordt dan op de grilligheid van besluitvorming en de soms geringe transparantie van motieven, belangen en 'agenda's'. Maar spel doet zich ook binnenshuis voor, waar sprake kan zijn van bureaupolitiek en uitruil van afspraken. Een aantal rijksambtenaren wijst er ook op dat belangenorganisaties vaak goed in staat zijn om hun kaarten voor de borst te houden en te timen wanneer ze welke troeven uitspelen. Er is een neiging waar te nemen het spel dat men bij de overheid speelt als anders te zien dan dat in het bedrijfsleven, waarbij in het oog springen als onderscheidende kenmerken: de maatschappelijke relevantie, de persoonlijke inzet om een hoger belang te dienen en de 
uitdagingen om tegenstrijdige of uiteenlopende belangen te verbinden. Deze spelmetafoor doet zich voor op het snijvlak van interacties en beeldvorming, dat wil zeggen dat de beleidsambtenaar bij het hanteren van de spanningen die het werk met zich meebrengt toont een eigen taal te kunnen gebruiken om een spanningsveld te herkennen en te hanteren. Daarbij valt op dat de duiding in termen van een spel als een bevrijdende uitingsvorm naar voren komt: spel helpt. Het helpt om de ruimte te identificeren die iemand tot zijn beschikking heeft om als het ware op drie borden tegelijk te kunnen schaken, met de politiek-bestuurlijke, de bureaucratische en maatschappelijke tegenspelers die zich onvermijdelijk aandienen. Is hier niet sprake van compensatie of afscherming? De aard van het spel verdient nadere studie. Zo komen meerdere opvattingen voor over rollen, speelruimte en spelregels. Er is ook sprake van belangstelling en bereidheid om op dit punt iets te leren.

\section{De kracht van collega's}

Een vierde conclusie verwijst naar de publieksgroepen die de ondervraagden primair naar voren schuiven als degenen die er bij de interactie toedoen. Uit de gesprekken komt de betekenis van - directe - collega's naar voren. Dat blijkt uit de sociale steun die wordt toegekend aan collega's in lastige situaties, maar ook uit de rol die zij spelen bij de beeldvorming over de overheid, taken en het eigen ambtelijke handelen. Collega's worden genoemd vóór leidinggevenden en hoger management en ook vóór bewindslieden. Opvallend is het relatieve belang dat wordt toegekend aan buitenstaanders en in het bijzonder het publiek; burgers komen eigenlijk nergens in beeld als belangrijke relaties. Dit roept ook vragen op: in welke mate is sprake van een bewuste keuze en waardoor is deze ingegeven: de blik naar binnen als ontwijk-optie? Daarbij komt naar voren dat de beschikbaarheid van collega's veel waarde toe wordt gekend: het feit dat er mensen zijn die het werk kunnen helpen duiden, hobbels kunnen helpen nemen en het werkplezier kunnen helpen vergroten is belangrijker dan de inhoudelijke verwantschap van iemand met de opgave waar de beleidsmaker voor staat. Dit zou betekenen dat de sociale dimensie van de arbeid van de beleidsmaker een belangrijke indicator is voor het hanteren van de spannende driehoek, het vinden van resultaten en het (leren) spelen van het spel. Deze contacten kunnen ook als leerbehoeften worden gezien. Het betreft dan vragen als: hoe verkrijg ik extern belangstelling voor mijn beleidsonderwerp, hoe ga ik om met weerstand, hoe ga ik om met de media, hoe knoop ik verschillende belangen aan elkaar, hoe zorg ik ervoor dat ik zo objectief mogelijk mijn minister adviseer, hoe tref ik bij boodschappen de juiste toon, hoe speel ik het (politieke, maatschappelijke en bureaucratische) spel?

\subsection{Tot slot: spelen met spanning}

Bij zowel ambtenaren die werkzaam zijn bij een ministerie als zij die werkzaam zijn bij een uitvoerende dienst kwam vaak naar voren dat ze het leuk vinden om met hun werk dicht bij het vuur te zitten, omdat dit een bepaalde dynamiek met zich meebrengt. Voor degenen die werkzaam zijn bij een ministerie wordt met dit vuur de politieke besluitvorming bedoeld en voor de rijksambtenaren die werkzaam zijn bij een uitvoerende 
dienst is dit vuur de maatschappij. Enkele rijksambtenaren die bij een uitvoerende dienst werken gaven aan dat ze nooit bij een ministerie zouden willen werken, omdat ze graag direct resultaat willen leveren aan de burger. Andersom zeggen sommige departementsambtenaren dat ze graag bij een ministerie werken omdat ze daar een directe invloed kunnen hebben op de beslissingen die er genomen worden. We zien in de verzamelde uitspraken vooral naar voren komen dat spanning van betekenis is voor werk, soms afgedaan met relativeringen, maar vaker met de nodige begeestering gekoppeld aan de metafoor spel.

Hebben we met deze ambtenaren van doen met een apart slag werknemers? Wat maakt die hang naar spelen met spanning zo manifest? Karssing (2006) wijst er in zijn studie naar integriteit en dus de morele aspecten van arbeid op dat 'kenniswerkers' (waartoe hij beleidsmakers rekent) onmiskenbaar een andere oriëntatie hebben dan mensen die in hun dienstverlening op spierkracht of handvaardigheid terugvallen. Namelijk ideeën, begrippen, modellen en informatie staan voorop. Hij karakteriseert hun biotoop raak met de woorden van (Freidson, 1994, 2001): 'the kind of work they do is esoteric, complex and discretionary in character: it requires theoretical knowledge, skill and judgment that ordinary people do not possess, may not wholly comprehend, and cannot readily evaluate. Furthermore, the kind of work they do is believed to be especially important for the well-being of individuals or of society at large, having a value so special that money cannot serve as its sole measure: it is also Good Work'. 'Ervaring' vormt hen en er is sprake van een 'seculiere roeping' en een belangeloze of zelfs altruïstische houding: dienstbaarheid aan degenen die zij dienen. In die uitleg is professionele dienstverlening van beleidsmakers op te vatten als een 'geloofsproduct' in de woorden van Nooteboom (2002) en als zodanig te onderscheiden van zoekproducten en ervaringsproducten. 'Bij zoekproducten kan men de kwaliteit vooraf beoordelen, bij ervaringsproducten alleen tijdens gebruik en bij geloofsproducten zelfs na gebruik niet. Voorbeelden van zoekproducten zijn huizen, auto's en apparaten voor hen die er voldoende verstand van hebben. Voorbeelden van ervaringsproducten zijn concerten, restaurants en vakanties. Voorbeelden van geloofsproducten zijn advisering en medische hulp'. Adviezen, mondeling en schriftelijk, vormen een belangrijk bestanddeel in de beschrijvingen in dit hoofdstuk, met dus een focus op de belangen van anderen. De ontmoeting van de uiteenlopende belangen is iets dat de beleidsmakers, althans volgens de tot dusver vergaarde casuïstiek, allesbehalve omzeilen, ze zoeken het op. Sennett (2008) maakt onderscheid tussen ambachts- en vaklieden. 'De vakman is een meer omvattende categorie dan de ambachtsman; hij of zij vertegenwoordigt in ieder van ons het vermogen om werk goed te doen omwille van het werk'. Dat kan niet anders dan spanningen opleveren, stelt hij vast, op basis van bestudering van de geschiedenis van vakmanschap: 'de werkelijkheid op de werkvloer is dat mensen die vakwerk willen afleveren depressief zijn, genegeerd worden of verkeerd worden begrepen door sociale instellingen'. Een somber perspectief, in het licht van de geschetste 'spannende' context waarin mensen het beleidsvak bij de overheid kiezen? 


\title{
5. Onder de spanningsbogen
}

\author{
Werken met ambtelijke dilemma's
}

\subsection{Inleiding}

Werken voor de overheid brengt enkele 'systeemspanningen' met zich mee. Er is sprake van een specifiek systeem door het samenkomen van meervoudige belangen vanuit de publieke, bureaucratische en politieke arena's - en enkele specifieke kenmerken van de overheid, zoals openbaarheid, rechtmatigheid en beginselen van behoorlijk bestuur. Een beleidsambtenaar vindt als het ware onder een arcade van spanningsbogen een weg en dat vraagt vaardigheden om dilemma's te herkennen en te hanteren. In hoofdstuk 2 is met een schets van de ontwikkeling van de overheid verkend hoe de overheidscontext de beleidsruimte van een ambtenaar kan beperken, maar evengoed kan uitdagen tot nieuwe verbindingen en resultaten. In dit hoofdstuk volgen we beleidsambtenaren bij hun confrontatie met deze spanningen. De verkenning beoogt factoren in beeld te brengen die bijdragen aan het omgaan met de lastige contacten die zo inherent zijn aan het ambtelijk bestaan. 'It is perhaps the one place where questions of technique ('what works') and questions of value stand a chance of being integrated'. (Hoggett, 2006).

\subsection{Ambtelijke spanningen}

In hoofdstuk 2 zijn negen 'systeemspanningen' geïdentificeerd die in de ambtelijke beleidspraktijk naar voren komen.

I. Algemeen belang en individueel belang.

II. Hoge verwachtingen en beperkt draagvlak.

III. Beperkte beheersbaarheid en complexe processen.

IV. Efficiency en maatschappelijk commitment.

V. Democratisch verkregen macht en maatschappelijk commitment.

VI. Openbaarheid en zelfbinding (rechtsstatelijkheid).

VII. Lekenbestuurder en ambtelijke professional.

VIII. Korte en lange termijn.

IX. Ondergeschiktheid en verantwoordelijkheid. 
Deze spanningen hangen samen met het samenkomen van de drie velden waarmee de beleidsmaker te maken heeft: het politiek bestuur, de bureaucratie en de publieke arena. De (spaarzame) evaluaties van grootschalige overheidsprojecten laten zien dat ervaringen en inzichten toenemen afhankelijk van de kwaliteit van het spel op de drie speelborden. Zo leert de introductie van het nieuwe zorgstelsel dat het - onbewust! - realiseren van 'dilemmabestendige arrangementen' als belangrijkste aanjager kan worden gezien voor de acceptatie en de effectiviteit van omstreden voorzieningen (De Bruijn e.a., 2008). 'Procesmanagement' komt op als domein met steeds vaker lessen en aanwijzingen. De beleidsmedewerker komt naar voren als iemand die afwisselend onderzoeker, strateeg, expert, procesregisseur, organisator, vakman, relatiebeheerder en stimulator is (Winsemius, 1998).

Er zijn eerder pogingen gedaan om te beschrijven hoe de ambtenaar omgaat met deze spanningen. Zo is gepleit voor een ambtenaar die over de competenties FORS beschikt: Flexibel, Open, Resultaatgericht en Samenwerkingsgericht. In de literatuur is deze benadering als 'nogal steriel' betiteld (Noordergraaf, Van der Steen \& Frissen, 2006). Een andere benadering komt van bestuurskundige Frissen (2009), die een aantal 'bijzondere deugden' onderscheidt. Hij motiveerde die insteek met te wijzen op het belang van maatvoering voor wie met macht werkt en van verdraagzaamheid voor wie onder druk werkt. (Zie ook de passage over zelfbinding in hoofdstuk 2). Hij bepleit zes 'vakvereisten': prudentia ('verstandigheid'), proportionaliteit, bescheidenheid, oordeelsvermogen, tolerantie en kosmopolitisme ('de kwaliteit om de eenheid van de wereld in zijn gebrokenheid en differentiatie te aanvaarden als uitgangspunt voor het politieke handelen'). Kingdon (1984) wees in een poging tot het formuleren van 'criteria voor goede beleidsconstructie' op een reeks inspanningen die de acceptatie van beleid moeten helpen borgen. Hij noemde overigens om te beginnen als criterium 'een gematigd ambitieniveau': wie bij de overheid beleid maakt moet zich op voorhand niet rijk rekenen. Vervolgens formuleerde hij naast technische en financiële haalbaarheid als maatstaven voor de goede beleidsambtenaar, dat hij of zij moet zorgen dat wat geconstrueerd wordt acceptabel is voor de drie arena's: het politiek bestuur, het publiek en de bureaucratie. Aristoteles stelde dat het hanteren van een deugd een mens niet veel verder brengt, tenzij we bij iedere deugd ook meteen het tegenovergestelde ervan in ogenschouw nemen. De uitdaging voor het handelen is vervolgens om tussen de uitersten verantwoorde keuzes te doen. Er moet een balans worden gevonden in de spanning tussen de uitersten, waarbij begrippen als evenwicht en proportionaliteit om de hoek komen kijken. Op de uitersten zelf is sprake van disproportionaliteit, in termen van de bestuurskundige Klinkers (2009) een 'uitwas'. Dat geldt bijvoorbeeld voor de krachtterm 'flexibiliteit' uit de reeks van FORSdeugden. Als die leidt tot verlies van iedere continuïteit, dan is flexibiliteit bepaald niet meer nastrevenswaardig maar disproportioneel geworden; een uitwas. Een ander voorbeeld: om de veel gehoorde ambtelijke competentie 'politieke sensibiliteit' tot een leidraad voor ambtelijk professioneel handelen te maken moeten we - in navolging van de oproep van Aristoteles de spanning opzoeken tussen twee uitersten. Dat is enerzijds het te veel tegenspreken (tegen de politiek) enerzijds, waardoor die als een hindermacht kan worden ervaren, en anderzijds de te kritiekloze onderschikking. Volgens Steijn (2009) is overigens prudentie op zijn plaats 
als het gaat om het definiëren van competenties. 'Een groot gevaar van het gebruik van competentiemanagementsystemen is dat ze vervallen tot een rituele dans'. Als dat gebeurt dan helpen ze niet om vaardiger te worden in het omgaan met dit type spanningen, maar worden ze juist gebruikt om dit type spanningen te verhullen of te omzeilen. Steijn bepleit daarom aandacht voor aandacht aan de dilemma's in de dagelijkse praktijk. Onderzoek naar de ambtelijke omgang met de systeemgerelateerde spanningen zou dan ook niet alleen inzicht in louter competenties moeten geven, maar ook in de praktische toepassing met die competenties.

\subsection{Onderzoeksvragen}

De centrale vraag in dit onderzoek luidt: wat is de betekenis van het eigene van het ambtenaarschap bij de rijksoverheid voor de professionele toerusting van beleidsambtenaren? Deze centrale vraag is toegespitst naar drie specifieke deelvragen:

1) Hoe komen de bijzondere kenmerken van de overheid tot uiting in het dagelijks werk van de beleidsambtenaar bij de rijksoverheid?

2) Hoe gaat de beleidsambtenaar om met de spanningen die dat oplevert, in het bijzonder zodra verschillende arena's elkaar raken?

3) Welk (nieuw) licht werpt dit op zowel de vraagstukken rond de verhouding tussen ambtenaren en hun omgeving (politiek, publiek, interdepartementaal) als op het streven naar verdere professionalisering van de ambtelijke dienst?

\subsection{Onderzoeksopzet}

Het onderzoek is gehouden in de zomer en het najaar van 2009 en bestond uit gesprekken met negen ambtenaren. Hierbij is gestreefd naar spreiding over verschillende taakgebieden en departementen binnen de rijksdienst. De respondenten zijn in uiteenlopende domeinen van de rijksoverheid werkzaam: gezondheidsbeleid, primair onderwijs, infrastructuur, werkgeverschap, inburgering en integratie, internationale betrekkingen. Eén respondent is op strategisch niveau werkzaam in een van de uitvoeringsorganisaties van het Rijk; één heeft de rijksdienst verlaten en treedt als ZZP'er nog op als opdrachtnemer voor het Rijk. Deze gesprekken concentreerden zich op een door de respondent gekozen 'ambtelijk sleutelmoment': een gebeurtenis of dossier waarin naar hun eigen oordeel de essenties van hun ambtelijk werk goed naar voren kwamen. Hierbij is evenals bij het onderzoek in hoofdstuk 4 gebruik gemaakt van de 'critical incident'- methode (Zwijze \& De Jong, 2005). Van deze gesprekken zijn transcripties gemaakt, op basis van een geluidsband. Alle gesprekken zijn (met instemming van de respondenten) woordelijk uitgeschreven. Vervolgens is een inhoudsanalyse uitgevoerd, waarbij het analysemodel werd geconfronteerd met de uitspraken in de interviews. Dat heeft geleid tot een selectie van 109 citaten, die zijn ingedeeld in thema's (interventies) en 
clusters van systeemkenmerken. Deze zijn verwerkt in twee tussenrapportages, gevolgd door reflecties met de respondenten op uitkomsten (en de daaraan te hechten betekenissen). Er zijn twee bijeenkomsten geweest met de respondenten: in december 2009 en in februari 2010. Daar zijn de uitkomsten en het gebruik van de citaten getoetst en er is met de respondenten gereflecteerd op de interpretaties. Tot slot zijn enkele experts geconsulteerd die richting kunnen geven aan de professionalisering van de rijksambtenaar in de rijksdienst (het directoraat-generaal Organisatie en Bedrijfsvoering Rijk (OBR) en de Algemene Bestuursdienst, $A B D)$. Uiteindelijk zijn conclusies en enkele voorstellen geformuleerd en aan een aantal betrokkenen op het terrein van professionalisering gepresenteerd.

\subsection{Analysekader}

De interviews werden gehouden aan de hand van een raster, dat tevens diende als checklist voor de gesprekken en als hulpmiddel bij de inhoudsanalyse. Het raster werd niet van tevoren aan de gesprekspartners getoond. De 'systeemspanningen' zijn in dit model uitgewerkt naar mogelijke rolopvattingen en gedragingen en voorzien van een 'startvraag'.

Bij de samenstelling werd gebruik gemaakt van gegevens uit de eerder theoretische verkenningen. In schema (tabel 5.1.):

Tabel 5.1. Analysekader onderzoek systeemspanningen

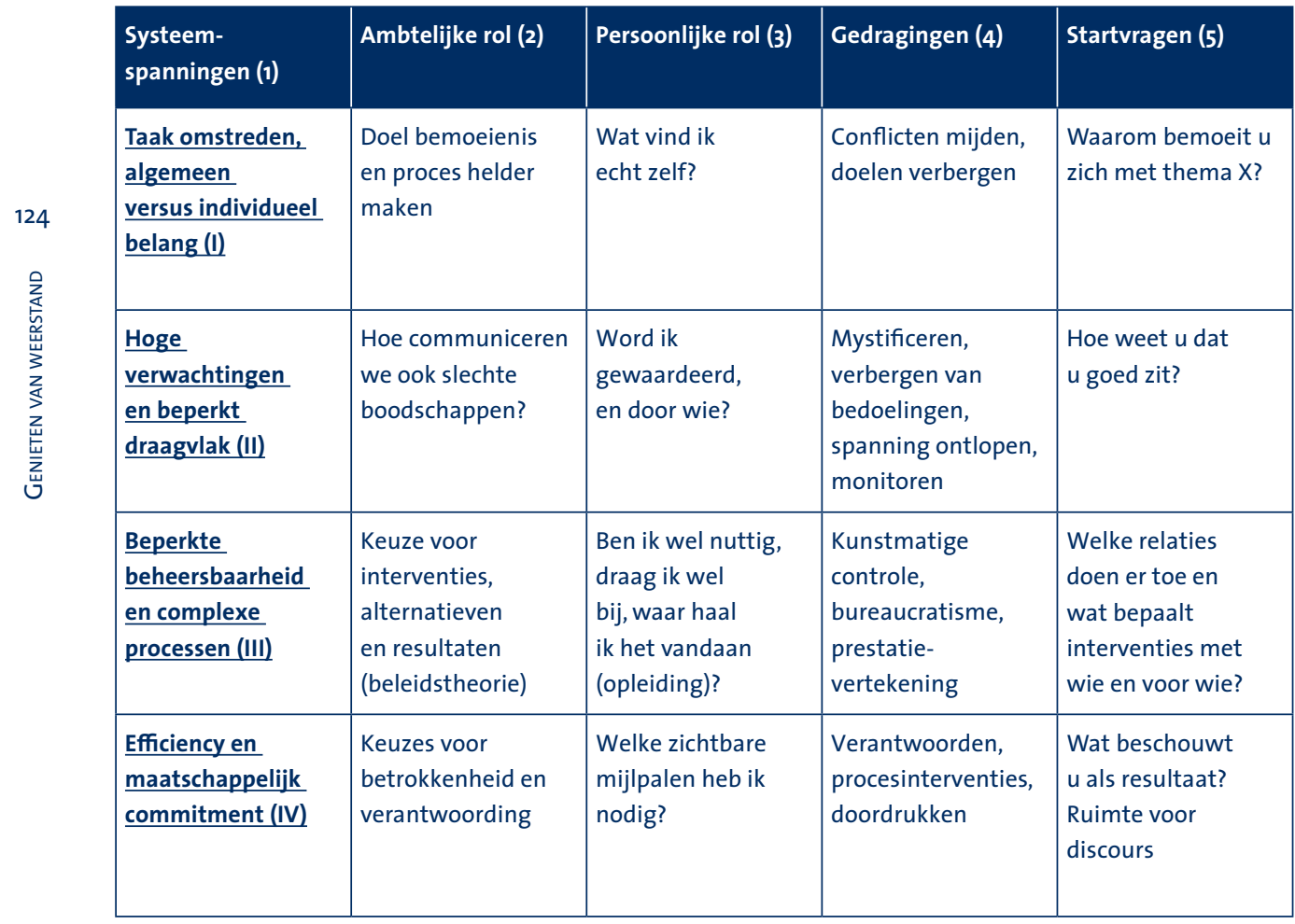




\begin{tabular}{|c|c|c|c|c|}
\hline $\begin{array}{l}\text { Systeem- } \\
\text { spanningen (1) }\end{array}$ & Ambtelijke rol (2) & Persoonlijke rol (3) & Gedragingen (4) & Startvragen (5) \\
\hline $\begin{array}{l}\text { Democratisch } \\
\text { verkregen macht } \\
\text { en maatschappelijk } \\
\text { commitment (V) }\end{array}$ & $\begin{array}{l}\text { Expliciteren van } \\
\text { politieke grondslag }\end{array}$ & $\begin{array}{l}\text { Vind ik mijn eigen } \\
\text { morele standaarden } \\
\text { terug (waarden en } \\
\text { normen)? } \\
\text { Is het moreel } \\
\text { acceptabel als 51\% } \\
\text { (meerderheid) een } \\
\text { voorstel steunt? }\end{array}$ & Ontkenning & $\begin{array}{l}\text { Hoe gaat/ } \\
\text { ging u om met } \\
\text { (omstreden) } \\
\text { politieke besluiten? }\end{array}$ \\
\hline $\begin{array}{l}\text { Open(baar)heid } \\
\text { en zelfbinding } \\
\text { (rechtsstatelijk- } \\
\text { heid) (VI) }\end{array}$ & $\begin{array}{l}\text { Openbaarheid, } \\
\text { verantwoording }\end{array}$ & $\begin{array}{l}\text { Is dit een eerlijk, } \\
\text { oprecht en correct } \\
\text { overheidsoptreden? } \\
\text { Kan ik het zelf } \\
\text { rechtvaardigen? }\end{array}$ & $\begin{array}{l}\text { Geen slechte } \\
\text { boodschappen, } \\
\text { mystificeren }\end{array}$ & $\begin{array}{l}\text { Welke rol speelt de } \\
\text { relatie met burgers/ } \\
\text { veld in uw werk }\end{array}$ \\
\hline $\begin{array}{l}\text { Lekenbestuurder } \\
\text { en ambtelijke } \\
\text { professional (VII) }\end{array}$ & $\begin{array}{l}\text { Objectieve } \\
\text { mogelijkheden/ } \\
\text { alternatieven } \\
\text { expliciteren } \\
\text { (beleidstheorie?) }\end{array}$ & $\begin{array}{l}\text { Kan ik mijn kunnen } \\
\text { hier kwijt? }\end{array}$ & $\begin{array}{l}\text { Tunnelvisies, } \\
\text { eenzijdig } \\
\text { opschrijven wat } \\
\text { politiek verlangd } \\
\text { wordt, cynisme }\end{array}$ & $\begin{array}{l}\text { Hoe hebt u het } \\
\text { contact met uw } \\
\text { bewindspersoon } \\
\text { georganiseerd? } \\
\text { Ruimte voor } \\
\text { discours vanwege } \\
\text { politieke leiding, } \\
\text { expliciet of impliciet } \\
\text { gegeven? }\end{array}$ \\
\hline $\begin{array}{l}\text { Korte en lange } \\
\text { termijn (VIII) }\end{array}$ & $\begin{array}{l}\text { Consistenties en } \\
\text { inconsistenties } \\
\text { blootleggen }\end{array}$ & $\begin{array}{l}\text { Krijg ik de ruimte } \\
\text { om dit bloot te } \\
\text { leggen? }\end{array}$ & $\begin{array}{l}\text { Conflict mijden, } \\
\text { spanning ontwijken, } \\
\text { confronteren, } \\
\text { argumenteren }\end{array}$ & $\begin{array}{l}\text { Stelling: politici } \\
\text { streven naar } \\
\text { korte termijn, } \\
\text { ambtenaren naar de } \\
\text { lange. } \\
\text { Een kwestie in uw } \\
\text { werk? }\end{array}$ \\
\hline $\begin{array}{l}\text { Ondergeschikt- } \\
\text { heid en eigen } \\
\text { verantwoordelijk- } \\
\text { heid (IX) }\end{array}$ & $\begin{array}{l}\text { Binnen eigen } \\
\text { verantwoordelijk- } \\
\text { heid werken }\end{array}$ & $\begin{array}{l}\text { In hoeverre ben ik } \\
\text { verantwoordelijk } \\
\text { (technisch en } \\
\text { moreel/ethisch)? }\end{array}$ & $\begin{array}{l}\text { Verantwoordelijk- } \\
\text { heid afdwingen, } \\
\text { ontkennen, steun } \\
\text { zoeken }\end{array}$ & $\begin{array}{l}\text { Hoe bent u } \\
\text { omgegaan met } \\
\text { de ambtelijke } \\
\text { hiërarchie? } \\
\text { Ruimte voor } \\
\text { discours van } \\
\text { ambtelijke leiding, } \\
\text { impliciet of expliciet } \\
\text { gegeven? }\end{array}$ \\
\hline
\end{tabular}

\subsection{Resultaten}

Uit de interviews kwam naar voren dat de tien 'systeemspanningen' konden worden teruggebracht tot drie typen spanningen. Het aan de theorie ontleende onderscheid bleek de facto neer te komen op drie 'spanningsbogen' die als het ware de dagelijkse gang van een beleidsambtenaar overkappen: 
a. Belangenafweging in het besef van rechtsstatelijkheid. Deze formulering stelt het fenomeen belangentegenstelling centraal. Hieronder vallen de spanning tussen algemeen belang en individueel belang (I) en tussen hoge verwachtingen en beperkt draagvlak (II). Bij de laatste bleek immers een duidelijke relatie met rechtsstatelijk handelen. Ook kon de spanning tussen de wettelijk verankerde openbaarheid en zelfbinding (VI) hier aan worden gehaakt; rechtstatelijk handelen kan spanning oproepen tussen vroegtijdige openheid en 'beleidsintimiteit's.

b. Beheersbaarheid in democratische context. Beheersbaarheid van complexiteit is vooral aan de orde in relatie tot formele en informele democratische processen. Hieronder vallen de eerder onderscheiden spanningen tussen beperkte beheersbaarheid en complexe processen (III), die tussen democratisch verkregen macht en maatschappelijk commitment (V), waarin immers de politieke oordeels- en besluitvorming tot uiting komt en efficiency en maatschappelijk commitment (VI). De laatste bleek overigens vrijwel samen te vallen met spanning III.

c. Vakmanschap onder ministeriele (bestuurlijke) verantwoordelijkheid. Deze spanningsboog omvat de relatie tussen de ambtenaar en de bestuurder. Hieronder plaatsen we de spanningen lekenbestuurder en ambtelijke professional (VII), korte en lange termijn (VIII) en ondergeschiktheid en eigen verantwoordelijkheid (IX).

Deze vaststelling leidde bij de gegevensverwerking tot een ordening van de resultaten in een drieluik.

\subsubsection{Eerste spanningsboog: belangenafweging in het besef van rechtsstatelijkheid}

126

Omdat de overheid bij uitstek een rol moet vervullen waar strijdige belangen en waarden aan de orde zijn, zijn de overheidstaken uiteindelijk gebaseerd op politieke keuzes; ze hebben dus een subjectieve grondslag. Daarmee zijn ze fundamenteel omstreden en is machtsuitoefening en dwang door de overheid onontkoombaar. Om misbruik daarvan te voorkomen wordt de overheid zelf ook gebonden aan eisen van rechtsstatelijkheid, rechtmatigheid en openbaarheid. Daarvoor zijn binnen departementen de 'checks and balances' georganiseerd in de vorm van juridische onderdelen en procedures. Vervolgens zijn nadrukkelijk voorzieningen getroffen waardoor vanuit de samenleving kan worden getoetst en geïntervenieerd. Uit de vraaggesprekken:

- 'Met subsidies moet je altijd kunnen legitimeren dat ze het algemeen belang dienen. En daar letten ook allerlei collega's op. Het is heel goed dat er een directie Juridische

5 Dit begrip is door de Commissie Toekomst Overheidscommunicatie (2001) naar voren gebracht in een pleidooi om ambtenaren in de gelegenheid te stellen in een vroegtijdig stadium ideeën te kunnen ontwikkelen en bespreken zonder dat deze openbaar gemaakt hoeven te worden. 
Zaken is en een financiële afdeling die met je mee kijkt.'

- 'Als je als beleidsambtenaar door allerlei discussies in de verleiding zou komen om te veel in bijzondere belangen te treden, zijn er allerlei mechanismen die dat verhinderen. Je kunt alleen maar subsidiëren binnen wettelijke kaders. Anders moet je gaan aanbesteden'.

- 'Toen heb ik de Algemene wet bestuursrecht voor de neus van de DG gelegd en heb ik gezegd: dáár staat het. We moeten dát doen; zo niet, dan ga je geweldig nat.'

- 'Een bewindspersoon kan zeggen: "Daar moet een oplossing voor komen; ik wil ook mijn partijgenoot ter wille zijn". Je kunt je voorstellen dat de ministers zoiets willen; aan de andere kant moet je ook rekening houden met gelijkheid, het beginsel van behoorlijk bestuur en al die soort dingen. Ik neem uiteindelijk die beslissing niet, maar ik moet wel adviseren en ik moet ook op de risico's wijzen en de mogelijke gevolgen.'

- 'Dat vond ik zakelijk een onverstandige beslissing. Maar het raakte niet mijn ziel. Als ik het verzoek krijg om er aan mee te werken dat moslims het land uit worden gezet die hun fietslicht niet laten branden, dan denk ik dat ik een andere functie ga zoeken. En wel per direct.'

- 'De instructie is nu: beslis oplossingsgericht. Men krijgt geen werkinstructies meer, we regelen de uitvoering niet meer dicht. Er is beslisruimte, daarbij wordt het kader aangegeven maar wat nog belangrijker is: het doel van de regel. Uitvoering moet zijn eigen ruimte opeisen.'

- 'Ja, als de minister wat meer tijd had gehad, waren we eruit gekomen. Ik heb het afgeraden, omdat dat juridisch niet verder te rechtvaardigen viel.'

\subsubsection{Tweede spanningsboog: beheersbaarheid in democratische context}

Het feit dat de taak èn de uitoefening ervan fundamenteel omstreden zijn maakt ze vaak ook tot een nogal ondankbare opgave. De negatieve uitgangspositie levert ongemak op: moet ze benoemd worden, en vooral: hoe moet ze worden benoemd, wat wordt benoemd en wie, in welke rol en met welke verantwoordelijkheid? De eerder genoemde subjectieve grondslag maakt het uitvoeren van de taak bovendien vaak complex. Een recht-toe-recht-aan doel-middelplanning voldoet niet; de relatie met burgers, belangengroepen en de voor de overheid zelfbindende regels, is gecompliceerd. De slagzin 'Van A naar Beter' van het ministerie van $V \& W$ suggereert eenvoud, maar kan niet verhullen dat files, oponthoud en moeilijke bereikbaarheid juist de aanleiding zijn voor aanhoudende zorg van de overheid.

Het maatschappelijk onderhandelingsproces kenmerkt zich doordat relaties, overeenkomsten en werkwijzen steeds diverser worden. De overheid ontwikkelde zich van een 'unicentrisch' naar een 'pluricentrisch' perspectief (Teisman, 1992). Daarbij worden in wisselende samenstellingen problemen geagendeerd, oplossingsrichtingen geformuleerd, besluitvorming tot stand gebracht en uitvoering (en handhaving of beheer) gestalte gegeven. Deze ontwikkelingen stellen eisen aan de beleidsmedewerkers, zowel in de interne werkprocessen als in het contact met andere bestuursorganen, departementale diensten, maatschappelijke instellingen en het publiek. Was er in het verleden een focus op louter interne 
beleidsvorming, de afgelopen jaren zijn (en worden nog steeds) stappen gezet naar interactieve beleidsvorming en overdracht van taken en bevoegdheden. Ook worden werkzaamheden afgestoten, wordt aansluiting gezocht met maatschappelijk initiatief en manifesteren zich nieuwe programmatische en projectmatige werkvormen. Overheid en burgers komen elkaar in meerdere rollen tegen. Als 'kiezer' staat de burger - even - boven de overheid, als 'staatsburger' er naast, zoals bij de consultatie over afwegingen. Als 'onderdaan' en als 'klant' echter, is sprake van een ondergeschikte rol. De media en vooral internetfora werken hierbij als een katalysator van agendering en debat, maar ook van hypes en misverstanden. Hoe borg je als ambtenaar in die nieuwe context democratische fundamenten als rechtsstatelijkheid, rechtsgelijkheid en integriteit? In de context van dit hoofdstuk kunnen we minimaal vaststellen dat het beroep van beleidsambtenaar naast inzicht in hiërarchische verhoudingen, ook veel know how vraagt om wensen en verwachtingen in de samenleving te herkennen en te hanteren.

De hierdoor veroorzaakte beperkte beheersbaarheid kan op zichzelf geen reden zijn om dan maar van de taak af te zien. Voor de overheid geldt immers een leveringsplicht, terwijl over de taakuitoefening in het openbaar verantwoording moet worden afgelegd. Dit spanningsveld tussen resultaat willen boeken (beheersbaarheid), draagvlak houden bij burgers en belangengroepen, en de openbare verantwoording, wordt geïllustreerd door de volgende ervaringen van de geïnterviewden:

- 'Schrijnende individuele gevallen zijn vaak de reden dat het in de publiciteit komt en de reden om het beleid in zijn totaliteit ter sprake te brengen. Dan moet aan het parlement of aan de pers worden uitgelegd, hoe het zo gegaan is, en moet je daar al heel snel mee aan tafel. Dan praat je al heel snel mee over hoe dit zo is gekomen en hoe dit kan worden veranderd.'

- 'Als de ministers met de Tweede Kamer hebben afgesproken "we gaan met de partijen praten", dan probeer ik dat zo snel mogelijk te organiseren zodat we meteen weer richting de Kamer kunnen zeggen wat besproken is.'

- 'De minister had een heel goed politiek gevoel: zij voelde heel goed aan van 'dit project moet niet aan mij blijven plakken'. Ze wilde zich niet te veel vereenzelvigen met het project. Zij had zichzelf dus al losser gemaakt van het project toen zij eraan begon.'

- 'Ik vind eigenlijk dat je je niet kunt opstellen als louter "dienaar" van één minister. Dat heeft met de eenheid van het kabinet te maken; je moet als ambtenaar zorgen dat het naar buiten toe één stem is, hoe frustrerend het ook is.'

\subsubsection{Derde spanningsboog: vakmanschap onder ministeriële (bestuurlijke)}

verantwoordelijkheid

De democratische rechtsstaat bedient zich van gekozen bestuurders, die voor een bepaalde tijd (hun democratisch mandaat) zijn aangesteld. In dat verband brengen we het leerstuk van de ministeriële verantwoordelijkheid onder de aandacht. Ambtenaren werken onder een functionaris, die onder democratische controle staat van de volksvertegenwoordiging. Deze constitutionele grondslag betekent dat alles wat op een 
ministerie gebeurt, kan worden toegeschreven aan de functionaris die de politieke leiding heeft. Diverse gebeurtenissen, vooral incidenten, hebben de afgelopen jaren laten zien dat een bewindspersoon niet alles kan weten wat er op een departement gebeurt, maar daar dus wel op kan worden aangesproken en uiteindelijk ook deze verantwoordelijkheid moet nemen ten overstaan van de volksvertegenwoordiging. Deze 'afspraak' betekent ook dat een bewindspersoon kan worden aangesproken op misstanden die onder een voorganger zijn begaan. Niessen (2003) merkt op dat de ministeriële verantwoordelijkheid soms gelijk getrokken wordt met aftreden, ten onrechte: 'Alles aan één functionaris toerekenen is niet hetzelfde als alles aan die functionaris aanrekenen, laat staan: die functionaris op alles afrekenen. Bekend zijn die situaties waarin een minister moest aftreden omdat hij het liet gebeuren dat hem niet op tijd de juiste informatie werd aangereikt. De beantwoording van de vraag welke informatie de minister of staatssecretaris moet hebben, behoort tot de meest essentiële vaardigheden van een beleidsambtenaar'. Deze karakteristiek verwijst expliciet naar ambtenaren bij de rijksoverheid maar kan ook voor beleidsambtenaren bij provincies en gemeenten worden toegepast. $\mathrm{Er}$ is aan het eind van de dag altijd sprake van 'politiek primaat' (Nieuwenkamp, 2001). De benoemde bestuurder wordt ondersteund door professionele ambtenaren; dit betekent dat zij dit beroepsmatig doen, los van politieke kleur of voorkeur en voor langere (meestal onbepaalde) duur zijn aangesteld. Die relatie tussen lekenbestuur en professionele ambtenarij wordt beïnvloed door de verschillende oriëntaties tussen de twee. We noemen er enkele.

In de eerste plaats de oriëntatie op de lange termijn (ambtenaar) versus de korte termijn (bestuurder). Spanningen kunnen ontstaan als bewindspersonen beleidsvoornemens voor een kortere termijn willen effectueren dan de ambtelijke leiding van een departementsonderdeel - bijvoorbeeld vanuit overwegingen van continuïteit - nodig of wenselijk acht. Ten tweede: de waardenoriëntatie.

De bestuurder is primair georiënteerd op de waarden 'legitimiteit' en 'politieke steun'; voor de ambtenaren zijn de waarden 'deskundigheid' en 'doelmatigheid' dominanter (Van der Wal, 2006). Regelmatig rijzen er vragen over de relevantie van verwantschap van de ambtenaar met de politieke kleur van de bewindspersoon, en in hoeverre de ambtenaar 'zijn' bewindspersoon bijstand mag verlenen bij partijpolitieke werkzaamheden. Ten derde: de bestuurder is weliswaar niet de normale hiërarchische baas van de ambtenaar, maar bij hem of haar ligt de invulling van de eerder genoemde subjectieve grondslag. De bestuurder bepaalt immers uiteindelijk welke taken worden uitgeoefend en met welk doel. Uit de interviews:

- 'Dat wij hier een bepaalde politieke sensitiviteit hebben ontwikkeld om te weten welke zaak op welk beleidsterrein of wat dan ook zou kunnen leiden tot het in gevaar brengen van die bewindspersoon.'

- 'Onze directie werkt voor beide ministers. We lopen via de DG's naar de ministers. Dat is nog eens extra lastig. We moeten onze nota's op beiden afstemmen. Dus we geven opties: voor u zou dit een goede optie zijn, en voor u dat. We belichten dus wel van alle kanten de dingen die ze hebben gezegd of toegezegd. Ze krijgen beiden een 
gelijk verhaal, maar bij de ene slaat de weegschaal naar die kant uit en bij de andere naar de andere kant.'

- 'We hebben die nut- en noodzaakdiscussie nog een keer gedaan met als uitkomst dat het project er niet moest komen. Maar dat vond ook niemand erg meer, want het doel was veranderd voor ons. Het was in die tijd dat grote projecten uit waren. Toen besloot dus een minister niet haar lot eraan te verbinden. Dat is politiek.'

- 'Je moet ook als grote uitvoerder de minister confronteren met consequenties van de eigen wensen. Wat we doen is zeggen, dat kunnen we wel of dat kunnen we niet en dat kunnen we pas op die termijn, want dat leidt tot de uitvoering van $x$ soortgelijke gevallen. Ik neem uiteindelijk de beslissing niet, maar ik moet wel adviseren en ook op de risico's wijzen en de mogelijke gevolgen. Een goede minister ziet daar altijd het eigen belang van in, ook voor zijn eigen functioneren.'

- 'Een deel van de ambtelijke professie is vooruitdenken met het hoofd van de minister. Dus, wat gaat hij of zij ongeveer willen en wat moet hij of zij daarvoor weten, en ook wat niet.'

- 'Wat in deze sector wel moet, is Kamerleden uitleggen van tevoren hoe technisch een wetsvoorstel in elkaar zit en ik zou willen dat je dit of dat zou doen.'

\subsection{Vijf strategieën}

Deze arcatuur van spanningsbogen tekent het pad en is daarmee wezenlijk voor het ambtelijk presteren. De spanningen zijn vooral in hun samenhang van betekenis voor de publieke sector, afzonderlijk komen ze in enige vorm mogelijk in de private sector ook voor. Ze bepalen de bijzondere context van het overheidshandelen, ze geven er de specifieke dimensies aan. Ze vragen om erkenning, herkenning en hantering in het dagelijkse werk. Sennett (2008) stelt in (zijn eerder aangehaalde) cultuurhistorische studie over vakmanschap vast dat de kern van het 'vakmanschap' lastig expliciet kan worden gemaakt; veel speelt zich in het onbewuste af. Mede hierom verdient de vakman ruimte voor ontwikkeling en leren. Ook de redacteuren van een bundel over 'beroepstrots' (in de publieke sector) breken hier een lans voor. Zij bepleiten een dialoog en debat onder beroepsbeoefenaren waarbij de balans tussen vier groepen waarden hernieuwde aandacht krijgt. Het gaat hen daarbij om de professionele, rechtsstatelijke, bedrijfsmatige en humane beginselen (Van den Brink, Janssen \& Kole, 2009). Teisman noemt in een analyse over de ambtelijke 'spagaat', de noodzaak voor ambtenaren om 'flexibel [te] schakelen, opportuun te zijn en verschillende talen tegelijkertijd te spreken' (in een inspiratiecollege voor P\&O-ambtenaren bij het Rijk in mei 2009). In de gesprekken komen vijf typen interventies - strategieën - naar voren waarmee de betrokkenen zijn omgegaan met de spanningsbogen:

1. Gebruik de bureaucratie, zonder je er buiten te plaatsen;

2. Breng de politiek in stelling, zonder door te schieten; 
3. Help de maatschappelijke omgeving te werken, zonder het politiek primaat te vergeten;

4. Erken de complexiteit, zonder eigen verantwoordelijkheid te schuwen;

5. Neem het heft in eigen hand, zonder beginselen van behoorlijk bestuur uit het oog te verliezen.

De eerste drie thema's hebben betrekking op de drie arena's waarmee de beleidsambtenaar te maken heeft: de politiek-bestuurlijke processen, de ambtelijkbureaucratische processen en maatschappelijke onderhandelingsprocessen. Ze zijn in de onderstaande figuur door de driehoek verbonden. De beide andere thema's verwijzen naar de context waarin werk gestalte krijgt (waarmee alle actoren te maken hebben) en de 'integrerende' betekenis van de persoonlijke eigenschappen en vaardigheden die nodig zijn om zich staande te houden. Tabel 5.1. brengt de strategieën in beeld:

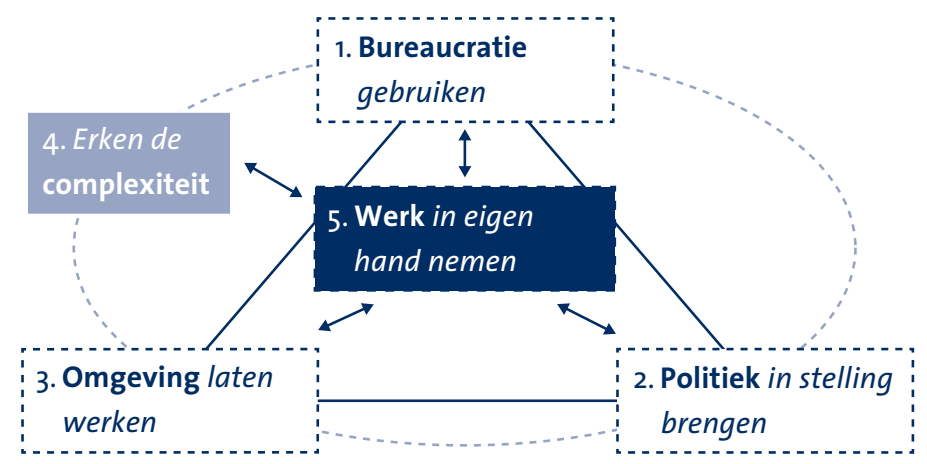

Figuur 5.1. Ambtelijke strategieën

De negen verhalen zijn geordend naar deze vijf interventietypen. Dat illustreer ik hierna aan de hand van de uitspraken van de geïnterviewden. Zij geven aan hoe men in de besproken situaties gehandeld heeft, of welke lessen men uit de vertelde praktijk voor zichzelf heeft getrokken. Het zijn dus zowel feitelijke uitspraken (over het eigen handelen) als normatieve uitspraken van de betrokkenen zelf (richtlijnen, lessen uit de eigen praktijk). Ze beschrijven hoe de intrinsieke spanningen in het werken bij de overheid kunnen worden overwonnen door eigen (professioneel) optreden. Bij elk interventietype worden hierna citaten uit de gesprekken weergegeven.

5.7.1. Strategie 1: Gebruik de bureaucratie, zonder je er buiten te plaatsen

De bureaucratische context brengt tal van belemmeringen met zich mee. Zo wijzen respondenten op de afscherming van de politieke leiding via ambtelijke tussenlagen 
en structuren. Hier en daar lijkt die afscherming de laatste tijd verder toe te nemen:

- ' 'k kom nu zelden of nooit meer met de minister in aanraking. Het is allemaal zo ingepakt. Er is een heel bureau BSG opgetuigd. Het is een industrie geworden.'

Die context kan de individuele ambtenaar niet ontlopen, maar die hoeft hij of zij ook niet passief te ondergaan. Daar getuigen de volgende drie uitspraken van.

- 'Wat ik niet begreep was dat werken in de ambtelijke hiërarchie en dan dat "opschalen", alles afstemmen. Ik had toen collega's die ook een soort gezonde tegenzin hadden tegen de gebruikelijke ambtelijke structuur. Zij leerden mij het als een spel te zien waar je iets mee kan. Toen kreeg het wel iets leuks.'

- 'De uitvoeringstoets werkt bij ons zo goed door de korte lijnen. Als ik collega's van andere departementen vertel dat ik als uitvoerder wel drie of vier keer per week bij de minister zit dan vallen ze van hun stoel.'

- 'Je moet verifiëren of degene die het [een ambtelijke nota die een tegengeluid bevat] tegenhoudt gelijk heeft, of dat anderen die meer kennis hebben dan jij, er hetzelfde oordeel over hebben.'

Ook brengt het interdepartementale verkeer diverse spanningen met zich mee, die nog worden versterkt door het instellen van de programmaministeries in het kabinet Balkenende IV dat op het moment van de interviews functioneert. De programmaministeries zijn ingesteld om de beleidsvorming beter dan binnen de sectorale kokers, te laten aansluiten op de meervoudige problematiek (wijken en integratie) of op een specifieke doelgroep (jeugd). Omdat de rest van de overheidsorganisatie daar niet op is ingericht vergt dat vaak extra afstemming: meer coördinatie en langere lijnen.

- 'I $k$ vind het op zich prachtig dat het kabinet horizontaal werkt, zodat al die onderwerpen met al die invalshoeken worden bekeken. Alleen die lijnen zijn zo verschrikkelijk lang. Misschien moet je wel horizontale departementen gaan maken.'

Die langere lijnen en extra coördinatie kunnen averechts werken indien ze leiden tot veel overheid - intern gedoe en daardoor een geringe doorlaatbaarheid van nieuwe ervaringen van buiten. Een respondent heeft daar met zijn team een tegenwicht tegen gevormd:

- 'We zijn opgehouden om tegen de andere departementen aan te praten en zo te proberen hen mee te krijgen. We zijn buitenom gaan werken en hebben nieuwe ervaringswerelden van buiten binnengebracht. Daar hebben we hen mee geconfronteerd. Op ongewone plaatsen, zoals in een kroeg waar we mensen hadden uitgenodigd uit de betrokken groep die heel goed over hun bestaan konden praten. Dat bracht hen en ons in beweging.'

Een gevaar van ambtelijke coördinatie is de neiging om bij de ambtelijke afstemming die dat vergt, genoegen te nemen met de grootste gemene deler in plaats van samen 
uit te komen op een verder gaande ambitie. Een respondent formuleert vanuit zijn ervaring de volgende gedragsregel die daar tegenwicht tegen kan bieden:

- Je moet gemeenschappelijke ambities ontwikkelen maar dat is iets geheel anders dan je neerleggen bij andermans' ambities als die te laag zijn. En je moet elkaar aanspreken op de afgesproken ambities.'

De verhalen laten dus zien hoe de ambtelijke organisatie de neiging heeft de ambtenaar af te schermen van de politieke leiding en van invloeden van buiten. Het werk dreigt daarmee - ook waar er programmaministers zijn ingesteld - te veel op de interne overheid gericht te raken. De verhalen getuigen er echter ook van dat deze druk kan worden weerstaan. Natuurlijk zijn daarbij de inzet en de persoon van de ambtenaar essentieel. Daar komen we nog op als we de vijfde interventiestrategie behandelen, aan het eind van deze paragraaf. Men wijst daarnaast op het belang van drie randvoorwaarden op het niveau van de interne organisatie, wil de ruimte voor de persoon en diens professionaliteit voldoende tot zijn recht komen. Deze drie zijn: (a) voldoende (interne) ambtelijke steun, (b) een zekere interne continuïteit; en (c) voortdurende interne feedback. Over interne ambtelijke steun en vertrouwen en de meer rechtstreekse en open verhoudingen die nodig zijn:

- 'Steun van leidinggevende en vieren van successen zijn een belangrijke stimulans.'

- 'Ik gaf zelf wel aan als ik het verstandig vond als hij (mijn ambtelijk meerdere) ernaar keek. Dat deed hij dan ook.'

- 'Daarom heeft dat ook te maken met een cultuuromslag. Nu zijn mensen nog bang om afgerekend te worden. Als je dan vraagt, noem maar eens iemand die ontslagen is omdat hij een verkeerde beslissing heeft genomen? Nou, er is niemand ontslagen. Daar hebben ze nooit een voorbeeld van. Waarom doe je het dan niet? Waarom ben je dan zo bang om een beslissing te nemen? Dat heeft te maken met vertrouwen.'

Ook komt de noodzaak naar voren om een zekere continuïteit in de ambtelijke leiding te hebben:

- 'Maar van belang is ook dat de directeur en het afdelingshoofd in de tussentijd zijn gewisseld. Dat geeft geen continuïteit. Deze directeur heeft een andere ambitie met het programma.'

Wellicht moeten we hier preciezer zijn: als er wisseling is van de leidinggevenden is het van belang dat zij oog hebben voor de continuïteit van de lopende programma's, zeker als de politieke leiding met wie ze zijn afgesproken, er nog zit. Dat is kennelijk niet altijd het geval.

Ten slotte kwam het belang van een voortdurende interne feedback aan bod.

De collegiale contacten en de collegiale uitwisseling worden als noodzakelijk ervaren om het eigen vermogen tot het oplossen van problemen en spanningen te kunnen ontwikkelen. 
- 'Meer dilemmatrainingen en trainingen in oplossingsgericht beslissen leidden tot minder verloren cases bij de rechter en tot efficiëntere uitvoering.'

- 'Tijdens interne bijeenkomsten - zeepkistbijeenkomsten-praten we wel over dit soort zaken of vertel ik over de voortgang van het dossier aan collega's.'

- 'Dus ik vind hier een paar extra ogen die er verstand van hebben, verstandig. Dat is een professioneel oordeel.'

5.7.2. Strategie 2: Breng de politiek in stelling, zonder door te schieten

De beleidsambtenaar dient de bewindspersoon met kennis en bijstand, onder meer ten overstaan van de volksvertegenwoordiging waaraan de minister en staatssecretaris verantwoording verschuldigd zijn. Hier komen begrippen aan de orde als de ministeriële verantwoordelijkheid, politieke sensitiviteit en ook interpersoonlijke verhoudingen, 'Fingerspitzengefuhl' en weten hoe de hazen lopen. Dergelijke begrippen worden vaak aangehaald om de complexiteit van de politieke processen te (be)grijpen. Het gaat dan om het dienen van de bewindslieden, maar ook daarbij geeft men aan dat men niet wil volstaan met een puur volgende opstelling. Het gaat ook over de wijze waarop bestuurders (pro)actief door de ambtenaar in stelling kunnen worden gebracht. Daarbij is het van groot belang maar ook erg moeilijk, om een goede balans te vinden. De ambtenaar die gaat 'spindokteren' voor zijn minister, waarbij de ambtenaar actief en mogelijk manipulatief een waarheid schept in het belang van de bewindspersoon, stelt zich weliswaar actief op maar veronachtzaamt de objectiviteit en onafhankelijkheid die van een professionele ambtenaar mogen worden verwacht.

De ambtenaar die de minister volgt en uitsluitend ' $h$ is masters voice' verwoordt, doet hetzelfde maar dan op een passieve manier. De ambtenaar die de minister voortdurend met de ambtelijke visie en aanpak confronteert, ook als de minister zijn politieke keuze al heeft gemaakt en uitgesproken, neemt weliswaar een grote onafhankelijkheid in acht, maar zal door de minister als een hindermacht worden ervaren. Er zijn voor die balans tussen enerzijds actief en anderzijds terughoudend, en tussen meedenken enerzijds en vanuit onafhankelijkheid opereren anderzijds, geen eenvoudige wegwijzers. De volgende accenten worden door de respondenten aangegeven.

Een eerste element van professionele onafhankelijkheid is dat een ambtenaar een engagement inbrengt. Dat engagement betekent ook dat de blik niet alleen binnen de overheid is gericht, maar ook op de maatschappelijke buitenwereld. Er moet ruimte zijn (worden opgeëist) om ook onafhankelijke bronnen aan te boren om de inspiratie en kennis op te doen die nodig is:

- 'Ik denk dat je als ambtenaar een bovengemiddelde maatschappelijke betrokkenheid hebt. Merk ik ook bij mijn mensen. Daarnaast ook een ambtelijke loyaliteit richting de minister. Die twee dingen komen af en toe met elkaar in conflict. Voor mij is dat wat gemakkelijker, want ik kijk toch meer naar de hoofdlijnen.'

- 'De dienstbaarheid aan het publiek belang is me eigenlijk met de paplepel ingegoten.'

- 'Er is een beroemde notitie van Eichmann over de Endlösung. Die is zo opgesteld zoals wij dat als ambtenaren ook nog te vaak doen: in verbloemde taal opschrijven wat de opgave is.' 
Een tweede element is de taak om bij de voorbereiding van een programma of project verschillende visies en invalshoeken mee te nemen; juist voor de overheid is immers een zorgvuldige belangenafweging essentieel. Het is steeds minder mogelijk om zelf vanachter het bureau de relevante invalshoeken goed genoeg te overzien. Het is dan zaak dit te regisseren en meerdere partijen bij elkaar te brengen. Ook tijdens de uitvoering van een programma of project kunnen zich verschuivingen voordoen: nieuwe visies, ontwikkelingen in de samenleving of in de belangenverhoudingen en - soms als gevolg daarvan - wijzigingen van de politieke opvattingen. De ervaring leert dat zulke verschuivingen vaak geleidelijk gaan en niet altijd voor de verschillende spelers even helder zichtbaar zijn. Dan is het aan de ambtelijke ondersteuning om die helderheid te scheppen:

- 'De minister bleek geneigd mijn adviezen over te nemen, tot ik merkte dat ze wat losser ging staan van mijn adviezen. Toen dacht ik: het gaat niet goed. Toen zei een oude baas van me: je hebt gelijk, maar krijgt het nooit. Je hebt maar één keus: zelf de draai maken. Anders wordt die draai voor je gemaakt. Dat heb ik toen gedaan.'

- 'Men was gewoon tegen het project. Grote projecten waren uit. Niemand had zin in een megalomaan project.'

- 'Ik werd wakker geschud. Het was gevoel. Dan ga je praten. Dat heb ik als les meegenomen. Je moet continu bezig zijn met je oogkleppen wegmanagen, zodat je toch die brede blik blijft houden. Toen we die discussie opnieuw gingen doen, heb ik een commissie ingesteld die dat voor mij ging regelen, het critical review team (...)

En daardoor waren wij ook in staat om een vraagstuk van alle kanten te zien. En dat team werd onze grootste supporter in de besluitvorming.'

- 'Het was uitvoeringstechnisch een slecht wetsontwerp. Dat de minister dat niet ziet.... maar zij heeft dat destijds doorgezet, heeft ze wel genoeg tegenwerpingen gehad? Er zit gewoon een aantal mensen dat zijn werk niet goed doet. Er had een uitvoeringstoets op moeten zitten.'

Een derde element is de plicht om goed te weten wat de bewindspersoon wil en wat dat betekent voor de ambtelijke inzet. In de volgende uitspraken beginnen de ambtenaren niet bij de details, maar op een hoger abstractieniveau. Wat is de stijl, de stijl van redeneren, de 'ankerlijn' van de minister?

- 'Ik verdiep me altijd zeer in de stijl van ministers. [Deze minister] stelt zulke hoge eisen. Eigenlijk verlangt hij van zijn directe ambtenaren wat hij van zichzelf verlangt en dat is bijzonder veel. Hij ziet dat het moeilijk gaat, maar het ministerie wint daarmee wel aan kwaliteit. Het heeft even geduurd, maar door die hoge eisen gaat de kwaliteit enorm omhoog (...) hij is superpolitiek.'

- 'Hij heeft één basis, een soort ankerlijn, bij ieder project waarvan hij weet: daar draait de politieke discussie om.'

- 'Ik heb niet zo veel met goed en kwaad. Er zijn gewoon dingen die beter zijn dan andere dingen. Je moet ermee kunnen omgaan dat bestuurlijke bazen kunnen wisselen.' 
Vaak is het zo dat meerdere bestuurders een verantwoordelijkheid hebben voor hetzelfde onderwerp. Een beleidsambtenaar is gewoonlijk slechts aan één minister tegelijk verantwoording schuldig. Op ministeries waar er een programmaminister naast een gewone vakminister zetelt, komt het voor dat een ambtenaar de facto beide ministers tegelijk moet dienen, terwijl die ook nog van verschillende partijen zijn. Dan wordt het extra gecompliceerd om te bepalen hoe de ambtelijke inzet zo goed mogelijk de ministeriële verantwoordelijkheid kan dienen:

- 'Ze praten heel veel met hun eigen departement en met hun partij. Als je dan ook nog heel druk moet zijn met collega-bestuurders van andere partijen, dat is bijna een onmogelijke taak, om dat allemaal te doen. Het kan wel eens zijn dat we in de Kamer komen en dat ze zeggen, [ambtenaar] wil je me nog even informeren, en de ander ook. En dan komt [naam derde minister]er weer tussen. Ik zit wel eens te denken, misschien moet de SG eens kijken naar een andere structuur.'

- 'De ene minister was het eigenlijk niet eens met regels, wil zo weinig mogelijk regulering. En de andere minister wil, omdat zelfregulering niet werkt, een wettelijk instrument. Over één zinnetje in die nota is wel vier weken met de ministers gediscussieerd. Of het woord "regulering" erin moest worden gezet. Toen kwam dat andere departement daar ook nog bij.'

Het is in zo'n geval ook voor de helderheid van de verhouding tussen de ambtelijke en ministeriële verantwoordelijkheden van belang om goede afspraken te maken over wie wat doet. Dat is in een politieke context echter niet eenvoudigweg een zaak van papier:

- 'We hebben mooie lijsten gemaakt met onderwerpen, wie waar verantwoordelijk voor was. [Onderwerp X] hadden we aan [naam B]toebedeeld. Maar dan zie je als het er echt om gaat in de praktijk, dan stelt dat paraafje helemaal niets voor. Want dan gaat hij daar toch op een andere manier mee om. Les voor mij: dat heeft dus geen zin, lijsten waar iemand wel of niet over gaat.'

Maar wat kan de ambtenaar hier (bij het bedienen van twee bewindslieden op één departement dus) bijdragen om te voorkomen dat dit tot verwarring, gebrek aan actie en voortgang dan wel conflicten leidt? De verschillen die er zijn tussen de ministers worden expliciet gemaakt voor beide bewindslieden.

Het vierde element is als een randvoorwaarde. Het is de fundering onder de ambtelijke rol ten opzichte van de verantwoordelijke minister: voor de Nederlandse ambtenaar is onafhankelijkheid en onpartijdigheid een erezaak.

- 'We proberen toch vooral zo goed mogelijke verhoudingen te houden. Dat niet een van beiden politiek nat gaat. En we proberen zo snel mogelijk een overleg te organiseren. Dat werkt ook. Je hoopt dat er dan beweging komt in de Kamer. Maar het is niet zo dat $i k$ de illusie heb dat ik kan bemiddelen in de zaken waar echte frictie zit. Dat werkt niet goed in het systeem. Ze kunnen goed met elkaar opschieten. Wat we wel proberen is het 
bij DG's neer te leggen. Beide ministers hebben ook echt vertrouwen in DG's. Dat is ook heel prettig.'

- 'Op dat moment is het een compromis tussen minister A en minister B. Maar we gaan wel met partijen praten. Op dat moment is de opdracht aan ons: maak een stappenplan hoe je toch denkt te komen tot [politiek opgegeven doelstelling in het dossier]. Dat lijkt een duidelijke opdracht. Naar aanleiding van dat [geschilpunt tussen de ministers] zaten we aan tafel. [Minister B]zegt dan, oké, ik begrijp dat je dat niet wilt, maar laten we dan met de partijen gaan praten, wij samen [minister A en minister B]en dan wil ik van jou [ambtenaar]dat stappenplan om naar [politieke doelstelling] te komen.'

- 'Je moet wel voor iedere minister [van verschillende politieke signatuur]zorgen, dat ieder zijn verhaal heeft. Je schetst voor elke minister ook de positie van de andere minister.'

Het fundament onder de genoemde elementen van dienen enerzijds en kritisch onafhankelijk blijven anderzijds, is het vertrouwen tussen bestuurder en ambtenaar. De ambtenaar moet de ruimte (veiligheid) hebben om 'tegen te denken' of andere visies in te brengen en is dus niet de onderdanige dienaar van de minister. Maar hij dient nooit een ander dan de minister, laat staan een ander politiek belang.

- 'De minister zat achterin de dienstauto, niemand had nog een mobiele telefoon, maar de auto had wel een telefoon; hartstikke uniek. Tussen Rijswijk en de Tweede Kamer besprak hij de hele wereld. Daar zit je bij en dat hoor je niet. Je weet werkelijk niet waar het over gegaan is, laat staan wie hij gesproken heeft. Dat is een vorm van wederzijds vertrouwen; ethiek.'

- 'Je moet als ambtenaar zorgen dat het naar buiten toe één stem is, hoe frustrerend het ook is.'

5.7.3. Strategie 3: Help de maatschappelijke omgeving te werken, zonder het politiek primaat te vergeten

Departementen komen uit een periode waarin een rechtsstatelijke kijk op overheidsprocessen domineerde. Steeds meer krijgen zij te maken met netwerken en organisaties, die mede knelpunten agenderen, oplossingsrichtingen aandragen en besluiten uitvoeren. 'Aansluiten' is een veel gehoord werkwoord. Hiermee wordt gedoeld op mogelijkheden om een sector te helpen organiseren en iets toe te voegen aan een complexe problematiek. Maatschappelijke processen staan centraal in dit thema: welke wensen en mogelijkheden doen zich voor als je met 'het veld', instellingen en einddoelgroepen te maken krijgt? Enkele decennia geleden kon vaak nog worden volstaan met de consultatie van het middenveld, dat voor de grote onderwerpen een vast relatiepatroon had met de politiek en de departementen. De beleidsambtenaar heeft met steeds meer complexe netwerken te maken en moet daarin creatief zijn en keuzes kunnen maken; allereerst moet hij/zij voeling krijgen met die netwerken en hun woorden en beelden. Nieuwe werkwijzen dienen zich dus aan, die kunnen schuren met bestaande. Soms zijn er nieuwe spelregels nodig, 
maar nog vaker gaat het er om dat de oude, bestaande spelregels ruimte bieden voor nieuwe vormen en nieuwe toepassingen. Nadrukkelijk gaat het niet om per se honoreren van alle invalshoeken of de pleitbezorgers hiervan, maar wel om het wegen van hun betekenis, mogelijke rollen en invloed in de politiek-bestuurlijke context. Waar het er om gaat ten behoeve van de beleidsvorming de maatschappelijke omgeving naar binnen te halen, moet soms nog een stap verder worden gezet. Dan moeten de verschillende invalshoeken vaak nog worden gearticuleerd en geformuleerd, en een weg vinden in de voorbereiding. Dat vergt het uiterste aan ambtelijke activiteit en creativiteit. Ook is een combinatie van vaardigheden nodig op zowel het inhoudelijke vlak (welke vraagstukken zijn aan de orde, hoe kunnen we die tot leven brengen ) als het procesmatige vlak (hoe organiseer ik een inbreng van anderen zodanig dat ik er ten behoeve van de minister iets mee kan):

- 'Ik had ook wel bij dit onderwerp het idee dat dit op een groot draagvlak moest kunnen rekenen, een gezamenlijkheid. Sommigen vinden dat natuurlijk vreselijk ouderwets, polderen en gezeur om sociale partners erbij te betrekken. Maar voor mij was het toch eigenlijk wel vrij kardinaal dat dat ook gedragen zou worden door sociale partners en de politiek zou raken (...) Die hadden nog nooit met elkaar in één gebouw vergaderd over [...] Dat klikte enorm goed. Dat is goed neergeslagen in die adviezen aan de minister. Dat vind ik dan leuk. Dan denk ik: het is toch wel goed en handig geweest en dat is geregisseerd.'

- 'Tja, het is ook een beetje redeneren vanuit de positie van de [burger - belanghebbende] zelf. Want als je achter je bureau zit, is het droogzwemmen en zo. Je kunt wel een juridische regeling in elkaar timmeren, maar we wisten eigenlijk verdomd weinig van die [doelgroep]. Er is een 'dark number', maar hoe groot dat is? Wat wij hebben gedaan... gedurende de rit is ook de groep [belanghebbenden]zelf betrokken geweest bij de beleidsvorming.'

Het komt voor dat de verschillende invalshoeken niet voor het oprapen liggen en zeker niet bij de geijkte belangengroepen en overleggen. Dan moeten andere bronnen worden aangeboord en dan moet er naar nieuwe oplossingen worden gezocht. Dan krijgt ook het maatschappelijk engagement van de ambtenaar zelf een kans:

- 'Het klinkt heel stom, maar ik denk dat het gewoon een handigheid is. (...) Ik ben in [wereldstad X] geweest en daar hebben ze een format ontwikkeld waarmee je ingrijpt op de hele omgeving van het kind. Dus de ouders, de school, de wijk, de kantine, enz. Ze verspreiden een heel integraal pakket aan maatregelen om [probleem, onderwerp dossier] te bestrijden en dat bieden ze aan, aan de gemeente. Dit moet de focus worden. Ik was heel enthousiast, ik herken dan echt dingen die goed zijn. Daar ga ik dan mee de boer op richting de bewindslieden en ik laat ook de mensen die enthousiast zijn vanuit het veld richting de Kamer erop reageren.'

- 'Een van de dingen die we hebben gedaan is dat we een expertgroep hebben ingesteld. Je kunt die [kwestie in beleidsdossier]op twee manieren bekijken. Dat zie je op alle fronten terug, ook bij de experts.' 
- 'Naast de expertgroep was er ook een groep met scholen. Die bestond ook uit verschillende geledingen, zoals een leerkracht, begeleider, schoolleider, enz. Ook hebben we een sessie gehad met ouders van de doelgroep. Daar hebben we misschien wel het meeste aan gehad. We hebben dus de ouderorganisaties in de gelegenheid gesteld om hun achterban naar voren schuiven.'

Maar de ambtenaar moet die invalshoeken altijd confronteren met de politieke wil. Het probleem is echter, dat ook die politieke wil veelal niet kant-en-klaar beschikbaar is. We hebben in de vorige paragraaf uitvoerig behandeld hoe de ambtenaar ook bij de articulatie van die politieke wil (uiteraard voor zover het eigen dossier betreft), een taak heeft.

- 'Het klinkt allemaal heel theoretisch. Wat ik ook probeer, is om te luisteren naar de taal van de ministers en wat ze ook zeggen. Bijvoorbeeld [naam minister] heeft het steeds over parallellie van belangen. Vandaar dat we nu heel veel energie steken in een convenant, waar je juist al die partijen hebt, maar waar je ook wilt dat partijen duidelijk doelstellingen afspreken, waaraan het gemeten kan worden. Dat het zeg maar SMART gemaakt wordt.'

- 'Redelijk overzichtelijk vond ik het wel, maar beheersbaar, ook in de zin van je eigen voorkeuren erdoor krijgen en zo, daar is natuurlijk geen sprake van. Maar binnen mijn ambtelijke professie weet ik natuurlijk dat als de minister bepaalde dingen wil en bepaalde voorkeuren heeft, dat we daar dan heel serieus naar kijken en daar dan op doorborduren.'

- 'Er zijn misschien wel tachtig verschillende wegen daar naartoe. En niet al die wegen liggen de ministers even goed. Welke weg is nu voor deze minister goed, welke wil hij verdedigen in de Kamer?'

- 'Bij mij was het toch wel een overtuiging, dat wil je dit dossier per se verder brengen, dan moet je, daar wat je wat kunt in alle bescheidenheid - het zijn maar hele kleine knopjes waar je aan kunt draaien, ook wat moet doen (...) Maar voor deze kabinetsperiode werkt die step-by-step-policy heel goed. Daar moet je dan ook maar tevreden mee zijn. Want politiek was het verder toch niet hoger schaalbaar. Ook de sociale partners zelf willen niet veel meer dan dit.'

Vergelijkbare kwesties spelen er ook als we het hebben over het ambtelijk werk voor de uitvoering. Dat geldt zeker voor de meer strategische functies binnen die uitvoeringsorganisaties en ook bij de uitvoering van maatschappelijk zeer gevoelig beleid. Ook in de uitvoering moet niet alleen een politieke doelstelling worden gerealiseerd, maar ook een maatschappelijke problematiek worden opgelost. Daardoor is ook daar een dynamische relatie tussen politieke wil (en rechtsregels) enerzijds en maatschappelijke werkelijkheid anderzijds, waarin de ambtenaar een actieve rol vervult:

- 'Kan het niveau van de dienstverlening omhoog binnen de regels die er gemaakt worden en heeft de uitvoering voldoende ruimte om zelfstandig beslissingen te kunnen nemen? Met andere woorden: is de wet niet zo dichtgetimmerd dat wij geen oplossingen voor 
de zaken die we op ons bureau krijgen, kunnen vinden? (...) Je kunt je voorstellen, als het een heel strak wettelijk stramien is, dat de bijzondere gevallen niet in dat vluchtluik te duwen zijn. Dat weten we uit het verleden. (...) Inmiddels is er ruimte gegeven aan de uitvoering om tot oplossingen te komen, om zaken van tafel te krijgen en binnen de regels maatwerk te vinden voor het behandelen van aanvragen (...). Het is mijn rol om dat ook over te brengen op het departement, dat veel verder staat van die klant.'

- 'Waar het op aan komt is, het van buiten naar binnen kijken, over de hele linie, wat we niet voldoende doen. Een van de mooiste momenten was een DG die een stuk schreef over hoe zijn moeder werd behandeld door een dienst. Zo zijn er een heleboel dingen waar beleid op beleid gestapeld is en mensen er niet mee uit de voeten kunnen.'

- 'Dus wij zitten vaak bij de bewindspersoon om te vertellen als je dit wil dan kan het wel of kan het niet. Wij hebben een onderzoeksafdeling die wordt gevraagd: als dit het voorgenomen beleid is, zoeken jullie dan uit wat de uitvoerbaarheid is en waar loop je tegenaan als dit al de dagelijkse praktijk zou zijn qua kosten, qua doorlooptijd, qua sturing, neveneffecten. In die context zit ik. We hebben een motto: 'De klant centraal'. Zorgen dat de klant goed bediend wordt. Dat hij snel weet of hij mag komen. Dat is het thema dat we continu proberen in te brengen bij deze beleidsvorming. (...) Kan het op een snelle, zorgvuldige manier?'

5.7.4. Strategie 4: erken de complexiteit, zonder verantwoordelijkheid te schuwen

Beheersbaarheid van de ambtelijke opgave is een terugkerend thema in veel gesprekken. Valt er iets te beheersen dan, of juist niet en maakt dat het werken dan zo bijzonder en soms ook aantrekkelijk? In de vorige paragrafen is uitvoerig besproken hoe essentieel het is voor de ambtelijke professie om verschillende invalshoeken in te brengen en altijd een onafhankelijke positie in te nemen. Dat zal in veel gevallen ook van een medewerker in het bedrijfsleven worden verlangd, maar voor de ambtenaar ligt dit zwaarder door de bijzondere context waarin hij werkt. Dat wil zeggen: onder politieke leiding, werkend aan taken die fundamenteel omstreden zijn omdat ze altijd een keuze vergen tussen verschillende belangen van individuen en groepen. Ook opereert een ambtenaar binnen rechtsstatelijke regels die extra eisen stellen op het punt van openbaarheid, controleerbaarheid, zorgvuldigheid en integriteit. Wat kun je als ambtenaar met de complexiteit die daaruit voortkomt? Begrippen als realisme, pragmatisme komen aan de orde, en per saldo de ruimte die een beleidsambtenaar heeft (neemt). Complexiteit kan een belemmering vormen om tot een (beheersbaar) resultaat te komen en om het beleid algemeen aanvaard te krijgen. Het is echter vaak juist ook de reden van (gevraagde) overheidsbemoeienis en het kan een dynamo zijn die energie levert voor het probleemoplossend vermogen. Soms is er dus geen andere weg dan de complexiteit for granted nemen, en maximaal inzichtelijk te (helpen) maken welke betekenisvolle verbanden er toe doen.

- 'Het hebben van het overzicht daarover is een heel belangrijk punt. Als leidinggevende moet je dus flexibel zijn. Maar dat geldt dus ook voor medewerkers. Dan heb ik een 
aantal, dat in dat [beleidsterrein] zitten die zeggen, vorig jaar moesten we dat en dat en nu moet alles anders. Die kunnen het gewoon niet volgen. Dat zijn degenen die ik wat minder hard nodig heb (...) Ik bedoel het meer van, je moet ook flexibel zijn in je resultaatdefinitie.'

Soms neemt de ambtenaar ruimte door het vraagstuk te (re)framen: in een nieuwe context van betekenissen plaatsen. Wat is er eigenlijk aan de hand en langs welke benadering gaan we aan een beleidsoplossing werken? Soms, als de oplossing van een vraagstuk geforceerd onder een heersende visie wordt gebracht, kan het presenteren van een nieuw interpretatiekader een vorm van manipuleren of beheersen zijn. Het kan echter ook nieuwe openingen bieden, als er nieuwe beelden en betekenissen worden toegevoegd die het ook voor betrokkenen nieuwe perspectieven geeft.

- 'Toen ik de klus kreeg had ik er niets mee. Maar de gesprekken met die kinderen waren dus heel belangrijk. Als je de direct betrokkenen spreekt, is dat niet allemaal niet zo eenduidig. Als het eenduidig was, was het probleem al lang opgelost.'

- 'Je kunt die kwestie op twee manieren bekijken. Dat zie je op alle fronten terug, ook bij de experts. Je weet op een gegeven moment dat bepaalde experts het als zorg zien. Je hebt ook hoogleraren, die zien het als talent waarmee op de universiteit promotieprijzen kunnen worden gewonnen. Er zit een kracht dat we die hebben verenigd.'

Een andere manier om de complexiteit te lijf te gaan is het vraagstuk te ontleden en tot hanteerbaarder proporties terug te brengen.

- 'Ja, maar het komt ook aan op realiteitszin. Als je dingen wilt bereiken, dat die incrementele weg meestal toch de beste is. Ik heb mijn neus gestoten met het hele verhaal met [ander, minder leuk dossier]. Daarbij ben ik stad en land afgegaan, bij allerlei vakbonden presentaties gehouden, enz. Als een soort discipel mijn verhaal vertellen. Niemand had het licht gezien, kan ik je zeggen. En daarbij hadden wij een Big Bang idee.... De minister dacht, hoe kan ik nog een beetje die angel eruit halen. Er is toen een roerende brief naar de Kamer gestuurd [.... De ene keer schuif je die argumenten naar voren en de andere keer die argumenten. Nu kwam dat zo uit, om dat op een bijzondere manier te gaan benadrukken. En daarmee was de kous dan af. Maar er is geen draagvlak voor dat thema. Versnellen, dat is ook zo'n kreet. Als je in de politiek snel resultaat wilt en blijkt dat je toch wel in een moeras van actoren zit met wie je zaken moet doen, dan moet je anders werken.'

Het complexe karakter van de uitvoering van overheidsbeleid kan worden gekarakteriseerd als een 'draaischijf', waarbij verschillende beleidsmatige, politieke en bedrijfsmatige eisen als het ware kunnen worden verbonden.

- 'Goede uitvoering laat de uitvoeringsconsequenties van een voorgenomen maatregel zien, maar ook de consequenties van een maatregel voor het geheel. Uitvoering zit op de draaischijf: continuïteit van beleid, wensen ten aanzien van een specifiek geval, uitvoerbaarheid.' 
5.7.5. Strategie 5: Neem het heft in eigen hand, zonder beginselen van behoorlijk bestuur uit het oog te verliezen

Bij de beleidsmaker zelf komen alle lijnen samen: wat heeft hij of zij in huis om de processen in de diverse arena's te herkennen en te hanteren? Vandaar dat we deze vijfde interventie in het centrum van de figuur hebben geplaatst. Hier komt alles samen; in zekere zin is deze persoonlijke inzet de spil waar het geheel om draait. Het is ook steeds de grondtoon geweest bij de in de vorige paragrafen behandelde onderwerpen. Wij halen uit de gesprekken een sterk pleidooi voor wat je zou kunnen noemen een 'activistisch ambtenaarschap'. De ambtenaar neemt zoveel mogelijk het heft in eigen hand. Hij legt zich niet bij voorbaat neer bij weerstand in de organisatie. $\mathrm{Hij}$ laat de omgeving niet op zich af komen. Hij ondergaat de politiek niet passief. Actief ambtenaarschap betekent niet alleen gevraagd in beweging komen (op gezag van een meerdere of de politieke leiding) maar ook uit eigen initiatief beweging maken. Niet alleen de eigen invalshoek volgen maar zélf zorgen voor de inbreng van anderen, zelf sturing geven aan de ordening van informatie en de toerusting van de ambtelijke hiërarchie, de politieke leiding en maatschappelijke actoren. De ambtelijke polsstok is lang, maar het gebruik vereist ambtelijk verantwoordelijkheidsbesef: vóór alles rechtsgelijkheid, legitimiteit en zorgvuldigheid.

- 'Zolang de Kamer niet kikt denken ze [de ambtelijke leiding en de collega's] "het komt wel, het ligt op de plank". Maar ik vond de regeling die we tot dan hadden een schaamlap. Dat vond ik persoonlijk.'

- 'We hebben de neiging om heel veel dingen nogal te institutionaliseren, terwijl de persoonlijke discussie wel degelijk erg van belang is voor het succes van de dingen.'

Daarbij blijkt het essentieel om grenzen te zien en in acht te nemen: geen puur persoonlijk gewin. Waar die grenzen liggen, daarover vonden we bij onze respondenten geen kant en klare recepten. Ze vroegen er ook niet om, wellicht omdat ze weten dat die niet bestaan? Ook in de literatuur vonden we ze niet.

Het vaker aangehaalde Fingerspitzengefuhl komt ook in Sennett's analyse naar voren: vakmanschap kan niet goed in algemene regels kan worden uitgelegd; het wezen ervan is impliciet. De vakman kan worden herkend aan zijn innerlijke drive om de dingen goed te willen doen omwille van het werk. Dat is dus iets anders dan persoonlijk gewin. Die beleving vonden wij terug in onze gesprekken. Het is Tonkens' (2008) 'logica van het professionalisme', de wens om 'vanuit een seculiere roeping een transcendente waarde, bijvoorbeeld gezondheid of welzijn, zo goed mogelijk te delen'. Niet wat de klant wil, maar wat de klant nodig heeft staat centraal, en dit moet spreken uit de prestaties:

- 'Onderdeel van diezelfde vrijheid is wel dat je de drive hebt om dingen goed te doen, te laten "deugen".' 
- 'Als mensen niet meer zien dat het niet om hun eigen ding gaat maar om de organisatie die ze vertegenwoordigen, dan gaat het mij tegenstaan.'

- 'Een meegaand karakter werkt dus niet. Als je handelt volgens eigen winst etcetera moet je niet de publieke zaak willen dienen. Nee, het enige ijkpunt is als je de volgende morgen wakker wordt en je denkt, zou ik het vandaag weer zo doen, ja. Of je kijkt in de spiegel, en denkt: die moet niet alleen geschoren worden maar het ook beter doen als gisteren.'

- 'Het is inderdaad dat vingertoppengevoel. Dat is niet van, als het niet goed gaat krijg ik op mijn kop, maar meer van, ik wil niet dat het niet goed gaat.'

- 'Het is heel goed om [ook] mensen uit bedrijfsleven te halen. Bij bedrijven is ook veel bureaucratie, maar commercieel werken heeft wel met duidelijkheid te maken. Direct iemand aanspreken en helder zijn over wat je wilt. Mensen die ik van buiten haal en uit het bedrijfsleven haal, die hebben dat gewoon. (...) Gewoon aanspreken. Er wordt soms tegen een ambtenaar heel lang niets gezegd en dan opeens worden de poten onder je stoel weggezaagd.'

Dit element van de persoonlijke inbreng, de actieve opstelling, is niet alleen van toepassing op de vorming, maar ook op de uitvoering van beleid. Uit het onderzoeksproject van het ministerie van BZK en de Stichting Beroepseer, 'Beroepstrots' (Van den Brink e.a., 2010), kwam ook naar voren hoezeer ambtenaren in de uitvoerende diensten 'regeldruk' als belangrijkste 'last' ervaren. Van de bestuurskernen verwachten zij vaker en eerder interactie over beleid, waarover zij immers het directe contact met het publiek hebben:

- 'Eenheid van beleid is gebaat bij ruimte in de uitvoering. Te veel uitvoeringsregels, protocollen en werkinstructies leiden tot beslisangst: trage uitvoering, achterstanden en veel procedures bij de rechter.'

- 'Hoe erg is het om een keer een verkeerde beslissing te nemen in vergelijking met de situatie dat er te weinig beslissingen worden genomen?'

\subsection{Conclusies}

Na de deelvragen komt de centrale vraag aan de orde.

5.8.1. Deelvraag 1: Hoe komen de bijzondere kenmerken van de overheid tot uiting in het dagelijks werk van de beleidsambtenaar bij de rijksoverheid?

\section{- Belangenafweging in het besef van rechtsstatelijkheid}

Het omstreden karakter van de overheid kruipt door alle kieren en gaten naar de werkvloer van de beleidsmaker. Wat de overheidstaak zo bijzonder maakt is dat de afweging altijd in het openbaar moet kunnen worden verantwoord en daardoor een speelbal is van allen die de kritiek willen uiten, aanblazen of versterken. Daarbij vraagt een 'web van veiligheidspallen' steeds aandacht. Door procedures, checks and balances 
en ook externe partijen die kunnen toetsen en controleren zal de belangenafweging niet alleen kritisch gevolgd worden maar kan ook altijd worden geïntervenieerd.

- Beheersbaarheid in democratische context.

De subjectieve grondslag die democratische besluitvorming met zich meebrengt $(50 \%+1$ is een meerderheid) versterkt het omstreden karakter: er zijn altijd verliezers, er is altijd kans op gedoe. Dat maakt besluitvorming bij de overheid tot een werkelijk bijzondere opgave. Planning van werkzaamheden is lastig en het - publiek vaak verlangde zicht op scherpe doelen en klare resultaten kan vaak niet worden geboden. Tegelijk is de overheid(sdienaar) gehouden aan een leveringsplicht, waar linksom of rechtsom beslissingen (openbaar) gemaakt moeten worden. De 'spagaat' van Teisman wordt ook als 'draaischijf' uitgelegd.

- Vakmanschap onder ministeriële (bestuurlijke) verantwoordelijkheid. Het politieke primaat verleent de bestuurder een bijzonder type leiderschap. Hij of zij is altijd de baas doordat hij of zij ten overstaan van de volksvertegenwoordiging verantwoording moet afleggen. Niet de (beleids)ambtenaar. Die positie kan schuren met vakinhoudelijke overwegingen over wat goed of fout is in probleemsituaties. Zo ook komen schuringen voor tussen de kortere termijn van de bestuurder en de langere tijdshorizon van een beleidsambtenaar. De bestuurder bepaalt, maar in welke mate samen met de ambtenaar? Objectiviteit en verantwoordingszin komen scherp naar voren.

\subsubsection{Deelvraag 2: Hoe gaat de ambtenaar om met de spanningen die dat oplevert, in het} bijzonder zodra verschillende arena's elkaar raken?

Drie typen interventiestrategieën komen naar voren, gericht op respectievelijk de politiek-bestuurlijke, de maatschappelijke en de ambtelijk-bureaucratische arena. Daarnaast kan aan de interviews een contextuele strategie worden ontleend die zich richt op het hanteren van complexiteit. Uiteindelijk focust dit onderzoek op de vraag: wat heeft de beleidsmaker per saldo in huis om op de drie (vier) borden te kunnen spelen en de interactie tussen de borden te benutten? Per interventietype staan in een schema de hoofdpunten die aan de orde komen. Hierbij wordt steeds per strategie gekeken naar: (a) wat zijn valkuilen (wat kun je beter niet doen?), (b) welke kansen doen zich voor (wat helpt?), (c) welke randvoorwaarden komen aan het licht (bevorderende en belemmerende factoren) en (d) welke competenties spreken uit de verhalen (wat heb je in huis?). Dit leidt naar de conclusies (tabel 5.2.): 
Tabel 5.2. Conclusies

\begin{tabular}{|c|c|}
\hline \multicolumn{2}{|c|}{ 1: Gebruik de bureaucratie, zonder je ervoor af te sluiten } \\
\hline Valkuilen & $\begin{array}{l}\text { - Afschermen van politieke leiding } \\
\text { - Geringe doorlaatbaarheid ideeën } \\
\text { - Coördinatie = genoegen met de grootste gemene deler }\end{array}$ \\
\hline Kansen & $\begin{array}{l}\text { - Korte lijnen } \\
\text { - Verifiëren bij anderen buiten directe lijn } \\
\text { - Nieuwe ervaringswerelden mobiliseren } \\
\text { - Gemeenschappelijke ambities ontwikkelen }\end{array}$ \\
\hline Randvoorwaarden & $\begin{array}{l}\text { - Interne ambtelijke steun, vertrouwen, autonomie } \\
\text { - Continuïteit (van afspraken) } \\
\text { - Interne feedback, debat en dialoog }\end{array}$ \\
\hline Standaardcompetenties & $\begin{array}{l}\text { - Vakbekwaamheid, deskundigheid } \\
\text { (Dienstwissen, Verfahrenswissen: weten 'hoe de hazen lopen') }\end{array}$ \\
\hline \multicolumn{2}{|c|}{ 2: Breng politici in stelling, zonder door te schieten } \\
\hline Valkuilen & $\begin{array}{l}\text { - De minister passief volgen, his masters voice } \\
\text { - Spindoctoring } \\
\text { - Als hindermacht worden ervaren door de minister }\end{array}$ \\
\hline Kansen & $\begin{array}{l}\text { - Eigen engagement inbrengen } \\
\text { - Verschillende invalshoeken inbrengen } \\
\text { - Ministeriële wil helder krijgen }\end{array}$ \\
\hline Randvoorwaarden & $\begin{array}{l}\text { - Onafhankelijkheid en onpartijdigheid } \\
\text { - Veilige organisatiecultuur }\end{array}$ \\
\hline Standaardcompetenties & $\begin{array}{l}\text { - Politiek-bestuurlijke gevoeligheid } \\
\text { - Toewijding aan de publieke zaak }\end{array}$ \\
\hline \multicolumn{2}{|c|}{ 3: Help de maatschappelijke omgeving te werken, zonder het primaat te vergeten } \\
\hline Valkuilen & $\begin{array}{l}\text { - Onbekendheid met partners en met wat zij willen } \\
\text { - Onbekendheid/vaagheid over wat minister wil }\end{array}$ \\
\hline Kansen & $\begin{array}{l}\text { - Zich verplaatsen in positie burgers, belanghebbenden } \\
\text { - Experts binnenhalen } \\
\text { - 'Reframen' van vraagstukken } \\
\text { - Scherp stellen van verschil tussen wil politiek en betrokkenen }\end{array}$ \\
\hline Randvoorwaarden & - Ruimte om oplossingen te zoeken (autonomie) \\
\hline Standaardcompetenties & $\begin{array}{l}\text { - Deskundigheid, bekwaamheid (Fachwissen) } \\
\text { - Omgevingsgerichtheid (dienstbaarheid en responsiviteit) }\end{array}$ \\
\hline
\end{tabular}




\begin{tabular}{|c|c|}
\hline \multicolumn{2}{|c|}{ 4: Erken de complexiteit, zonder verantwoordelijkheid te schuwen } \\
\hline Valkuilen & - Alleen doen wat beheersbaar is, complexiteit miskennen \\
\hline Kansen & $\begin{array}{l}\text { - Flexibiliteit, meebewegen } \\
\text { - 'Reframen' van vraagstukken en oplossingen: nieuwe contexten } \\
\text { en betekenissen aangeven } \\
\text { - Ontleden van vraagstukken }\end{array}$ \\
\hline Randvoorwaarden & - Ruimte en tijd om andere invalshoeken in te brengen \\
\hline Standaardcompetenties & $\begin{array}{l}\text { - Deskundigheid en vakbekwaamheid (Fachwissen) } \\
\text { - Resultaatgerichtheid en samenwerkingsgerichtheid }\end{array}$ \\
\hline \multicolumn{2}{|c|}{ 5: Neem het heft in eigen hand, zonder beginselen van behoorlijk bestuur uit het oog te verliezen } \\
\hline Valkuilen & $\begin{array}{l}\text { - Alleen iets doen als het gevraagd wordt } \\
\text { - Vervreemden, werk los van persoon }\end{array}$ \\
\hline Kansen & $\begin{array}{l}\text { - Zelf beleid initiëren } \\
\text { - Persoonlijke drive het goed te doen } \\
\text { - Eigen verantwoordelijkheid nemen }\end{array}$ \\
\hline Randvoorwaarden & $\begin{array}{l}\text { - Ruimte voor risico's, fouten maken } \\
\text { - Toewijding }\end{array}$ \\
\hline Standaardcompetenties & $\begin{array}{l}\text { - Rechtsstatelijk besef } \\
\text { - Democratisch besef }\end{array}$ \\
\hline
\end{tabular}

5.8.3. Deelvraag 3: Welk (nieuw) licht werpt dit op zowel de vraagstukken rond de verhouding tussen ambtenaren en hun omgeving (politiek, publiek, interdepartementaal) als op het streven naar verdere professionalisering van de ambtelijke dienst?

De verhalen maken duidelijk hoe beleidsambtenaren steeds weer proberen juist niet af te haken of af te schermen en ook in het beperkt beheersbare werk zelf de spil willen en kunnen blijven. De negen respondenten vertellen in feite een verhaal van een actieve, oplossingsgerichte ambtenaar. Die als het moet alle ambtelijke vaardigheden uit de kast wil en kan halen. In zekere zin zijn het dus 'ideaaltypische' verhalen over het ambtenaarschap geworden, maar ze raken wel aan wat de kern van het ambtenaarschap in die praktijksituaties is. Gewezen werd hierbij ook op de situaties in de ambtelijke dienst die van tijd tot tijd naar voren komen en dan ontbloten hoe raderen verstopt kunnen raken als de match van de arena's niet goed uitpakt. Het rapport van de Commissie-Davids (2010) naar de besluitvorming over de inval in Irak (dat verscheen na afronding en verwerking van onze interviews) bevat enkele 
kritische passages over het functioneren van ambtenaren. De commissie geeft aan hoe soms kritische ambtelijke adviezen een te lange weg door de ambtelijke hiërarchie moesten gaan en wel eens inhoudelijk werden geherinterpreteerd - foutief of eenzijdig - zonder terugkoppeling met de stellers. Opvallend is ook de wijze waarop de commissie oordeelt over een ontstane ambtelijke tweespalt binnen een ministerie. De tweespalt werd schadelijk doordat betrokkenen zich volgens de commissie 'in een veel te laat stadium met elkaar verstonden'.

In een politiek gevoelige kwestie mag een ambtenaar - hoog of laag in de hiërarchie - dus niet passief afwachten. Eerder in dit hoofdstuk kwamen ook deze lessen naar voren: overwin de belemmeringen van de bureaucratie, en ontloop niet de persoonlijke verantwoordelijkheid die je daarbinnen hebt. Zie ook de in paragraaf 2.6. aangehaalde ideaaltypische karakteristieken van De Vries (1998, 2008) en Niessen en Karssing (2008).

Zowel de theoretische benaderingen als de uitspraken in het voorliggende onderzoek onderstrepen de betekenis van de ideaaltypische kenmerken van het ambtenaarschap. Daarbij valt iets anders op. In de theoretische benaderingen over de ambtelijke professie gaat het overwegend over 'standaarden' en 'competenties'. Aan het belang daarvan doen we niets af, maar uit onze verhalen uit de praktijk komt een ander accent naar voren en dat is het fenomeen 'dilemma's'. Beleidsambtenaren ontmoeten de spanningen en ontdekken de interventies doordat ze dilemma's herkennen en willen oplossen. Tijdens de bespreking van de bevindingen met de respondenten kwam ook deze waarneming naar voren, met de verzuchting dat men belangstelling heeft voor bespreking en duiding van de omgang met de dilemma's. Hier gaat de suggestie van uit dat dialogen en debatten op de werkvloer kunnen helpen om het vakmanschap en de professionalisering van de ambtenaar te trainen en een lerende organisatie te kunnen maken. Dit sluit ook aan op de eerder aangehaalde pleidooien voor professionalisering zoals de bundel 'Beroepstrots' (Van den Brink e.a., 2008) en de oproep van de secretarissen-generaal in februari 2010 om meer aandacht voor het rechtsstatelijk besef van ambtenaren. Dan is er nog de Algemene Bestuursdienst, die als essentie van het vakmanschap van de ambtenaar, aan dit rechtsstatelijk besef het democratisch besef heeft toegevoegd, het integriteitsbewustzijn en het burgerbewustzijn.

De beschikbaarheid van leersituaties - dicht op het werk - komt daarmee als bevorderende factor naar voren. Het is echter de vraag in welke mate de behoefte aan leren expliciet aanwezig is. De respondenten gaven aan geen bewuste strategie te hanteren. Hoewel de toegewezen valkuilen en kansen en de opgetekende randvoorwaarden en competenties niet werden ontkend werd duidelijk dat sprake is van veel impliciete kennis of tacit knowledge, waarvan men zich niet altijd bewust wordt en die ook niet licht wordt overgedragen. 


\subsubsection{Centrale vraag: wat is de betekenis van het eigene van het ambtenaarschap bij de rijksoverheid voor de professionele toerusting?}

Tot slot enkele algemene conclusies op basis van dit onderzoek.

I. De vindingrijke ambtenaar staat op

De verhalen van de respondenten vormen een etalage van vindingrijkheid. Ze laten zien wat het beroep kan inhouden en welke eisen dat stelt. Het biedt - aan de hand van de theorie èn de praktijk - een ideaaltypische beschrijving: zo ziet een ambtenaar eruit als alle kwaliteiten voor het vervullen van een taak uit de kast moeten èn kunnen worden gehaald. Dit is een stimulerende constatering om op voort te borduren. Ambtenaren zijn gedreven door resultaten - in de wetenschap dat die een lange adem en de nodige relativering vragen -, waardering - die begint in de binnenring van collega's en leidinggevenden - en probleemoplossend vermogen: gefocust op het vinden van verbindingen, gemeenschappelijke oriëntaties en belangen. Er zijn duidelijk drijfveren aanwezig om op een positieve oplossingsgerichte, waarderende manier om te gaan met de vele kanten van het eigene van de overheid. Voor deze activistische, vindingrijke ambtenaar blijft een dienstbare opstelling de kern, maar dat is voor hem het tegengestelde van passief of afwachtend. Hij neemt zoveel mogelijk het heft in eigen hand. Hij legt zich niet bij voorbaat neer bij weerstand die van de organisatie uitgaat. Hij laat de omgeving niet op zich af komen. Hij ondergaat de politiek niet passief. Hij ijvert voor objectiviteit, het leggen van verbindingen en publieke verantwoording. Dit actieve ambtenaarschap betekent niet alleen gevraagd in beweging komen (op gezag van een meerdere of de politieke leiding) maar ook uit eigen initiatief beweging maken. Niet alleen de eigen invalshoek volgen maar zélf zorgen voor de inbreng van anderen, zelf sturing geven aan de ordening van informatie en de toerusting van de ambtelijke hiërarchie, de politieke leiding en maatschappelijke actoren. De ambtelijke polsstok is lang, maar het gebruik vereist ambtelijk verantwoordelijkheidsbesef: vóór alles rechtsgelijkheid, legitimiteit en zorgvuldigheid.

\section{Bespreken van spanningen}

In de gesprekken - maar vooral ook daarbuiten - komt naar voren dat beleidsambtenaren het op prijs stellen te reflecteren op hun handelingen, de keuzes en de aannames daarbij. Dan komen vragen op als: hoe vul je als ambtenaar de beïnvloedbare ruimte in, hoe krijgen beleidsregels vorm bij te behandelen praktijkgevallen en wat leer je van jouw keuzes om dilemma's en spanningen te hanteren? Voor het ontwikkelen en onderhouden van het vakmanschap zijn binnen de eigen werkkring mogelijkheden, waarbij naast trainingen ook bijeenkomsten worden genoemd om successen te vieren. Vooral aan collegiale feedback wordt veel waarde toegekend. Enkele respondenten wezen op de mogelijkheden om dilemma's in het overheidwerk uit te wisselen en te oefenen met de strategieën. 


\subsection{Tot slot: veiligheid}

Negen positieve, oplossingsgerichte verhalen mogen geen leidraad zijn voor een beoordeling van de beleidsambtelijke slagkracht. Er zijn ook situaties denkbaar waarin ambtenaar op een of meer van de fronten belemmeringen ondervindt en daardoor minder tot interventies en initiatieven komt. Die leiden er toe dat ambtenaren terughoudender en 'meer afwachtend [worden] in plaats van activistisch' (Bekker, 2009). Bijvoorbeeld omdat zij afgeschermd worden van de politieke leiding, geacht worden mee te werken aan eenzijdige positieve beeldvorming, niet de ruimte krijgen voor 'tegendenken' of zelf niet de ruimte durven opeisen die daar voor nodig is. In dit verband is de discussie over de ambtelijke status ook relevant. Ik voer dit thema hier in de conclusies op om het belang aan te geven van de onafhankelijke beroepsuitoefening door de ambtenaar, in het bijzonder de bescherming van zijn grondrechten en de bescherming tegen (politieke) willekeur. Het is vooral van belang dat de ambtelijke top die bescherming heeft omdat die vooral op het scharnierpunt tussen politieke leiding en ambtelijk apparaat moet functioneren. Het is in het belang van het ambtelijk vakmanschap om de bijzondere rechtspositie op dit punt te herijken: voor wie is de bijzondere rechtsbescherming precies nodig, hoe moet die eruit zien en hoe werkt dat uit op de borging van de ambtelijke onafhankelijkheid in de praktijk? Uit onderzoek blijkt ook dat ondermaats presteren bij de overheid vaker wordt gedoogd en minder snel leidt tot ontslag dan in het bedrijfsleven. Dat schaadt ook de kwaliteit van de beroepsuitoefening. Op dit punt moeten de overheidsmanagers strakker worden, en de 'activistische' ambtenaren kunnen hen daarin krachtig steunen. Ambtenaarschap vraagt veel van de persoonlijke professionele presentatie. Duidelijk is dat de vindingrijkheid - bewust en onbewust - groot is, soms tegen oprukkende elementen. Zoals: de aanhoudende druk van bedrijfsmatige logica, de politieke preferenties voor korte-termijnsuccessen en publiek ongeduld. De kern van de rolopvatting van de ambtenaar - mogelijk maken van gezaghebbende afwegingen in het algemeen belang ten dienste van de politieke leiding - staat onder druk. Dan doelen we niet zozeer op de van oudsher vaak negatieve of eenzijdige benadering van overheid en overheidsdienaren door burgers. Hoewel die in het ergste geval gepaard gaat met bedreiging, en geweld ook zorgen baart, zien we in de kritische benadering door burgers niet direct een bedreiging voor de ambtelijke beroepsuitoefening. Constructief wantrouwen past bij de openbare lichamen die delen van publieke verantwoordelijkheden voor korte of langere tijd overnemen. Een groter probleem wordt wellicht de geringe steun die uit programma's van politieke partijen spreekt als het gaat om de ambtelijke medewerkers die politieke beloftes helpen nakomen en democratisch besloten maatregelen helpen uit te voeren. Het verband tussen politieke ambities en ambtelijke werklast werd nergens expliciet gelegd in die programma's. In tijden van crisis - maar niet alleen dan - krijgt de zorg om de kwaliteit van ambtenaren bitter weinig aandacht.

De kanttekening in de openingszin van deze slotparagraaf maakt een beperking van dit onderzoek duidelijk. De vraag prangt of we hier te maken hebben met een te rooskleurig beeld? De uitkomst is wellicht verklaarbaar omdat we de deelnemers vroegen de praktijk te 
vertellen van een opdracht die zij als het meest kenmerkend en beslissend voor hun ambtelijk bestaan beschouwden. Dat heeft geleid tot een selectie door de respondent. Ook kan het type respondenten een rol spelen: we hebben mensen ondervraagd met een zelfstandige verantwoordelijkheid voor een beleidsdossier, dus geen starters of ondersteunende medewerkers. Hoewel het niet allemaal succesverhalen zijn - één project moest voortijdig worden gestopt en een ander werd niet naar bevrediging afgerond - maken de respondenten duidelijk dat het wel om uitdagende ervaringen gaat waarvoor alles uit de kast moest worden gehaald en dat dit tot op zekere hoogte ook kón. 


\section{De ambtelijke beslisser: conceptueel model getoetst}

De ontmoeting met weerstand (6.)

De ambtelijke taxatie: casestudies (7.)

Conclusies en slotbeschouwing (8.)

De twee theoretische verkenningen en de twee onderzoeken leiden naar een conceptueel model: hoe werkt de ambtelijke taxatie van een lastige opgave? In dit deel komen de inzichten uit de omgang met omstreden werk samen met de kennis over de specifieke context waarin ambtenaren beleid maken. Hoofdstuk 6 heet 'De ontmoeting met weerstand' om uiting te geven aan het relationele aspect in het herkennen en hanteren van aarzeling, twijfel, kritiek of anderszins voorkomend tegenspel. In de kwaliteit van het contact ligt veel besloten, als het gaat om de 'coping' van de ambtenaar. Aan de eerdere onderzoeksdelen ontleen ik enkele dominante stijlen om bij vermeende weerstand weg-, tegen- of juist mee te bewegen. Dit 'meebewegen' wordt als krachtige opening voor de beleidsmaker uitgewerkt, waarbij enkele uitgesproken bevorderende factoren worden geïdentificeerd.

In hoofdstuk 7 spiegel ik het conceptueel model aan de praktijk. 'De ambtelijke taxatie' volgt drie beleidsmakers op de voet bij hun ontmoeting met de weerstand. Op welke wijze herkenden zij de mogelijke weerstand, hoe verliep het contact en wat waren de consequenties voor hun wijze van 'ambtelijke coping' voor het uiteindelijke doelbereik. In hoofdstuk 8 volgen tenslotte conclusies over de (werkers aan de)'Weg van de meeste weerstand'. 


\title{
6. De ontmoeting met weerstand
}

\author{
Conceptueel model voor ambtelijke coping
}

\subsection{Inleiding}

Hoe verloopt de ambtelijke taxatie van het handelen bij (vermeende) weerstand? Het conceptueel model in dit hoofdstuk is het resultaat van de theoretische verkenningen en de onderzoeken naar werkbeleving en omgang met systeemgerelateerde spanningen bij het maken van overheidsbeleid. Wie als beleidsmaker problemen helpt oplossen die vrije krachten in de samenleving niet zelf kunnen verhelpen, kan niet heen om tegenspel, die in vele gedaanten zich kan aandienen. Bij het aangaan van die ontmoeting staan de beleidsmaker meerdere 'copingstrategieën' ten dienste. Over die strategieën en de factoren die invloed uitoefenen op de taxatie welke strategie gevolgd zal worden, gaat dit hoofdstuk.

\subsection{De ambtelijke arcade: contextuele spanningsbogen}

Er is overheid omdat en zolang steun bestaat voor de opvatting dat vrije krachten in de samenleving niet in staat zijn collectieve waarden naar tevredenheid toe te delen (Easton, 1965). Een algemeen belang overvleugelt een individueel belang en daarmee begint de kans op verschil van mening over de aanleiding, de aanpak en de uitkomsten van 'overheidsbemoeienis'. Een reeks checks and balances beoogt een (juridisch gezien) legitieme en (maatschappelijk gezien) acceptabele context te bevorderen voor de inmenging, beleidsvorming, besluitvorming en de uiteindelijke uitvoering van beslissingen in dat algemeen belang. Zoals: een wettelijk verankerde openbaarheid, regulering van procedures, borging van beginselen van behoorlijk bestuur en verantwoording van voornemens en uitgaven. Deze voorzieningen helpen de overheid om in eigen kring rekenschap te geven van het omstreden karakter en bieden afnemers van overheidsdiensten - in hun verschillende rollen als onderdaan, klant, staatsburger en kiezer - instrumenten om invloed uit te oefenen. Maar ze nemen het omstreden eigene van overheidsbemoeienis en daarmee de kans op weerstand - het uiteenlopen van perspectieven op de mogelijke interventies - niet weg. Contextueel gezien is sprake van een gegeven, en dat is een belangrijk vertrekpunt voor onze studie naar de wijze waarop de beleidsambtenaar deze specifieke context hanteert. Deze contextuele eigenheid is een belangrijk gegeven voor onze studie: systeemkenmerken oefenen invloed uit op de wijze waarop ambtelijke medewerkers hun beslissingen taxeren en daaraan uitvoering geven.

We vinden hiervoor steun bij o.a. Zimbardo (2010) op basis van onderzoek naar gedragingen van gevangenispersoneel in de afgelopen decennia. Staub (1989) weet: 'Deel uitmaken van een systeem creëert zienswijzen, het beloont adhesiebetuigingen aan dominante zienswijzen, en het maakt dat afwijken hiervan psychologisch veel vergt en moeilijk is'. Het is relevant te weten hoe mensen dan tot zienswijzen en beslissingen komen. 
De publieke weerstand in deze systemische context kan de aanleiding van de bemoeienis betreffen, maar ook de processtappen die hierop volgen en/of de uiteindelijke uitkomst. In ons onderzoek nemen we in het bijzonder de startfase van beleidsvorming op de korrel. Dan immers maakt een beleidsambtenaar voor het eerst een taxatie van wat of wie op zijn of haar weg kan komen. In de startfase is sprake van een ontwerp, een expliciete stellingname om gefaseerd en/of gedoseerd te werk te gaan. Dan ook ontmoet de ambtenaar de perspectieven op de kwestie, de oplossingsmogelijkheden en de overheidbemoeienis bij de publieken die er toe doen. Een tweede toespitsing betreft de focus op de beleidsambtenaar. De geschiedenis van de overheid leert dat gekozen (en benoemde) bestuurders bij het toedelen van schaarse waarden ertoe overgingen medewerkers vrij te stellen voor de beleidsvoorbereiding en de uitvoering van besluiten. Beleidsambtenaren staan centraal in onze studie, niet hun bestuurlijke bazen en ook niet hun publieke afnemers: burgers en ondernemers en hun organisaties.

Beleidsambtenaren bewegen zich per saldo in een uniek systeem, waarin drie typen arena's aanhoudend druk uitoefenen: het politieke bestuur, de bureaucratie en het publieke domein, de samenleving. Het samenkomen van de arena's leidt - ten opzichte van medewerkers in het bedrijfsleven of instellingen of het vrije beroep - tot enkele specifieke typen opgaven. In de eerste plaats speelt de beleidsmaker de subjectieve grondslag parten: rechtsstatelijkheid (regels voor zorgvuldig, rechtmatig, behoorlijk bestuur) in een context van politiek-bestuurlijke belangenafweging. Een tweede spanningsboog betreft de omgang met beheersbaarheid van een vraagstuk in een context van democratische besluitvorming, waarbij meerderheidsbesluiten en juridische interventies voor vertragingen en omleggingen kunnen zorgen. Tenslotte is sprake van ambtelijk vakmanschap onder bestuurlijke verantwoordelijkheid, waarbij behoefte aan zichtbare resultaten op korte termijn en duurzame en consistente uitvoering elkaar raken. Een beleidsmaker bij de overheid vindt zijn of haar weg onder deze arcatuur van drie spanningsbogen.

Er is alle reden om aan te nemen dat de impact van deze systeemgerelateerde spanningen sterker wordt. Dat heeft om te beginnen te maken met een herijking van de organisatie van overheid - een proces met de focus op de interne organisatie van overheid - en een zich vernieuwende externe context. Wat de organisatie van overheid betreft is aan de voet van de 21e eeuw sprake van een ingrijpende verkleining. Op alle niveaus is sprake van afstoting van taken en overdracht van taken aan private partijen. Dit proces is in de jaren negentig van de vorige eeuw in gang gezet. Meer en meer is bedrijfsmatig denken in overheidskringen toegepast, waardoor efficiency en financiële motieven meer en meer gewicht werden toegekend (New Public Management, o.a. Tjeenk Willink, 2010). Een toegenomen managerial denken zet niet alleen druk op de capaciteit van de overheid om taken op te pakken, afwegingen te maken en uitvoering in gang te zetten; het verandert ook de aandacht voor waardentoedeling, participatie van belanghebbenden en professionaliteit van de ambtelijke beleidsondersteuner. De druk op ambtenaren is groot om duidelijk te maken waar de overheid voor kan staan en gaan in de hybride constellaties waarin de overheid geheel of gedeeltelijk 
taken op zich neemt - of moet nemen omdat niet zelden de constellaties van buitenaf worden gecreëerd.

Naast de interne hervormingen vragen de toenemende snelheid en schaal van openbare communicatie aandacht. De sociale media versnellen en verruimen de mogelijkheden om gevoelens te articuleren en mensen te mobiliseren (Bekkers e.a., 2009). Deze trend maakt duidelijk dat steeds minder sprake kan zijn van een klassieke overheid die 'verticaal' bestuurt en uit-legt op haar moment, via haar kanalen, in haar woorden wat haar goed dunkt. In een 'horizontaliserende' samenleving (ROB, 2009) met tal van kortstondige al dan niet elektronische netwerken en coalities wordt overheidsbeleid steeds meer 'powering en puzzling' (Heclo, 1974). 'Inhaken' en 'aansluiten' zijn de sleutelbegrippen. De media spelen een belangrijk rol bij het registreren en uitvergroten hiervan vanwege hun focus op conflict, verantwoordelijkheid en human interest (Kleinnijenhuis e.a., 2003), evenals de krachtige rol van belangenorganisaties en andere influentials (ook bekend als de vijfde en zesde macht, ná de duiding van de ambtenarij als vierde macht). Niet alleen de vrije media maar vele sociale media vragen en verwerven dus invloed op menings- wils- en besluitvorming, waarvoor ooit de besturing bij het openbaar bestuur berustte. Allerhande sociale en - al dan niet gejuridiseerde - werkvormen laten zien hoe de communicatie van organisaties steeds belangrijker is geworden. Aan begrippen geen gebrek: coördinatie, consultatie, regie, co-creatie; ze illustreren het ontstaan van overgangsgebieden, waardoor meer dan van 'overheid' van 'tussenheid' gesproken kan worden.

Wie bij de overheid werkt, is zich volgens onderzoeken in meer of mindere mate bewust van maatschappelijk relevante opgaven, lastige problemen en politiek omstreden beslissingen. Sterker nog, de ontmoeting van deze opgaven blijkt per saldo een unique selling point voor afstuderenden die voor een overheidsbaan opteren (in het bijzonder beleidsambtenaren op HBO- en academisch niveau, BZK, 2007). Het vermogen tot omgaan met weerstand hoort erbij, als je voor de overheid als werkgever kiest (onderzoek work meaning, hoofdstuk 4).

'Weerstand' wordt in deze studie nadrukkelijk opgevat als 'een verzameling uiteenlopende perspectieven op een overheidsopgave'. Louter benadrukken van de negatieve publieke reactie zou geen recht doen aan de betekenisgeving van alle betrokkenen - voorop burgers en ondernemers en hun organisaties - bij een overheidsopgave. We sluiten hiervoor aan bij in hoofdstuk 3 aangehaalde opvattingen van Merron (1993) en ook die van Cooperrider (Masselink, 2008) over veranderingsprocessen in organisaties. Zij stellen tegenover het negatieve model een positieve benadering voor, waarin - ook! - de vraag wordt beantwoord waar mensen naar zoeken. Weerstand is in deze opvatting veeleer een kwestie van actieve betrokkenheid bij een zaak, waarin meerdere en uiteenlopende rollen, belangen en inzichten ertoe kunnen doen. 


\subsection{Ambtelijke coping: een kwestie van stijl}

Het omgaan met de systeemgerelateerde spanningen en daarvan af te leiden vormen van publieke weerstand (in allerlei gedaanten, van verwondering tot verzet) is niet uniek voor overheidsfunctionarissen; weerstand kan ook op de weg komen van medewerkers in vrije beroepen en in het bedrijfsleven, zoals het ook in privésituaties voorkomt. Wel biedt het systeem waarin ambtenaren hun werk doen - met de in de vorige paragraaf samengevatte arcatuur van spanningsbogen - een gerede kans op herhaling van de weerstand. Juist dat patroonmatige karakter voedt mogelijkheden om een beroepshouding te vormen ten aanzien van het voorkomen van (dus mogelijke, vermeende) weerstand. Uit de normalisatiestudies van o.a. Margolis en Molinksy $(2005,2008)$ komt naar voren hoe in 'onvermijdelijk problematische' situaties de persoonlijke beoordeling van de denkbare rol aan de orde is: vooral vier factoren worden dan professioneel gewogen; verantwoordelijkheid, rechtvaardigheid, moeilijkheid en de daadwerkelijke verrichting. Deze patronen komen bij uiteenlopende werksoorten met problematische aspecten aan de orde, waarbij genoemd worden medisch specialisten, agenten c.q. personeel met geweldsinstructies en ook beroepssporters. In deze beroepsgroepen krijgen grondslagen uit de sociale psychologie zoals het fenomeen van de cognitieve dissonantie (Festinger, 1957) dus een bijzonder accent: wat doet iemand die beroepshalve en onvermijdelijk met weerstand in aanraking komt?

Lange tijd werden daarbij vier typen omgangsstijlen dominant geëtaleerd (Gramsbergen, 2005): 1) Ontlopen (als je het onderwerp onbelangrijk acht, als uitstel baat, en als je schat dat de ander beter kan handelen), 2) Forceren (snelheid is geboden, beslissen is belangrijk en de ander is niet voldoende gemotiveerd te bewegen en beschikt niet over voldoende machtsmiddelen), 3) Toegeven (als je ongelijk hebt, je inschat toch te zullen verliezen, als de ander meer baat heeft dan jij bij de uitkomst en je harmonie wilt bewaren) en 4) Confronteren (als sprake is van een complex probleem, als je iets wilt leren, er tijd en voldoende motivatie beschikbaar is). In de literatuur over conflicthantering vinden we een toenemende aandacht voor het uitstellen of ontkomen aan de confrontatie. Prein (2005) onderscheidt dan respectievelijk: 1) Vermijden (indien confrontatie uit de weg kan worden gegaan), 2) Forceren (mogelijk bij stevige machtsbasis en hoge druk), 3) Toegeven (als een ander gelijk heeft en je los kunt laten), 4) Probleem oplossen (indien beide partijen over tijd, energie, motivatie en creativiteit beschikken) en 5) Compromis zoeken (water bij de wijn doen, als beide partijen daartoe bereid zijn en dus willen of kunnen 'middelen'). Figuur 6.1. brengt de stijlen van Prein in beeld. 


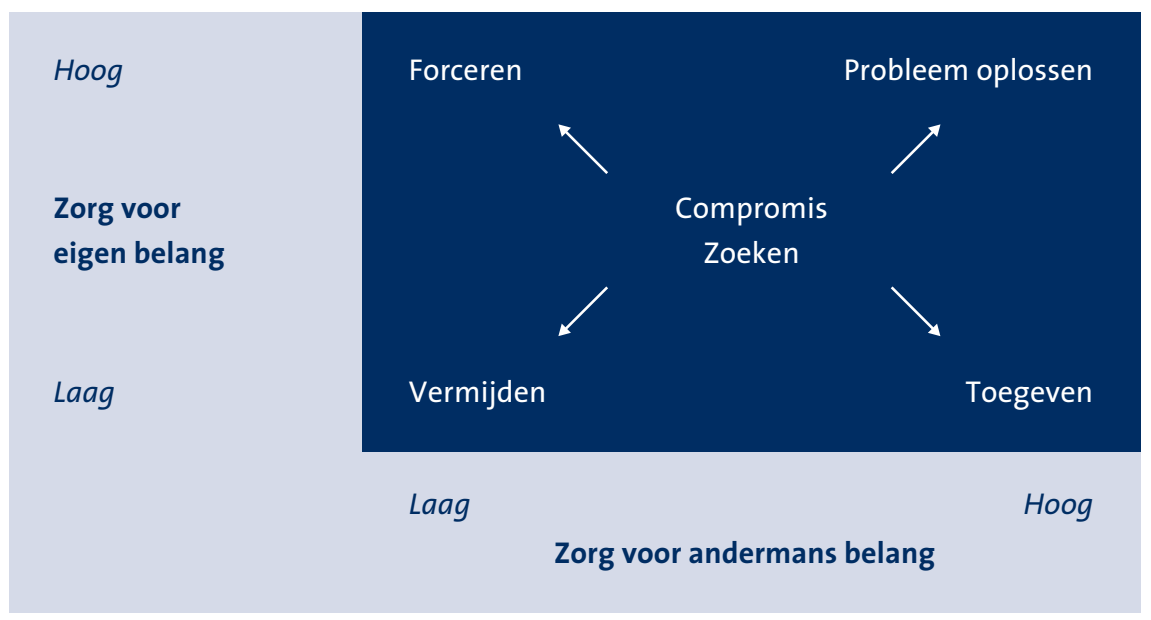

Figuur 6.1. Conflicthantering Prein (2005)

Ik haal dit schema naar voren, vanwege de focus op het element 'belang' en vooral het zoeken en vinden van het gedeelde belang. Eeuwema en Wild (2006) stellen dat grofweg de helft van de mensen van nature meer gericht is op samenwerking en dus rekent houdt met anderen, harmonie waardeert en oplossingsgericht is. Tegenover deze 'coöperatieve' instelling staat een 'competitieve' instelling, waarin conflict wordt omarmd en winnen als belangrijker wordt ervaren. Deze basisinstellingen maken het soms moeilijk elkaar te begrijpen en leiden eenvoudig tot botsingen. Er zijn verscheidene tests (o.a. op het internet) beschikbaar om persoonlijke voorkeuren voor het omgaan met conflictueuze situaties te testen. Zie o.a. de Thomas Kilmann vragenlijst, waarin de zorg voor eigen dan wel andermans en gezamenlijk belang getest kan worden; Leary ontwierp op basis van onderzoek naar patronen van gedragsbeïnvloeding een systematiek die als 'De roos van Leary' bekendheid geniet. Deze benadering gaat uit van twee dimensies: in welke mate is iemand op symmetrie ('samen-'versus 'tegen'-gedrag) en op complementariteit ('onder'- versus 'boven'-gedrag) gericht? De hieraan te ontlenen diagnoses helpt de primaire oriëntatie te verduidelijken: zet je in beginsel in op eigen, andermans en gezamenlijke belangen?

Coping is 'de manier waarop iemand zowel gedragsmatig, cognitief als emotioneel, reageert op de aanpassing vereisende omstandigheden' (Lazarus \& Folkman, 1987). Copingstrategieën zijn vooral in de sociaal-pedagogische zorg veelvuldig aan te treffen: hoe bieden mensen het hoofd aan verleidingen of andere verstoringen. Genoemde auteurs onderscheidden daarbij 'probleemgericht' en 'emotiegericht' copen, bij de eerste staat een inhoudelijke aanpak voorop, bij de tweede de gevoelens bij een lastige situatie. Bij een probleemgerichte benadering staat het oplossen van een probleem voorop, zoeken mensen informatie en staan ze open voor sociale steun, op zoek naar een positieve zelfmotivatie. De emotiegerichte strategieën tonen echter eerder vermijdingsgedrag, afleiding zoeken en mogelijkheden voor emotionele expressie. Onderzoek van Fields en Prinz (1997) leert dat 
de emotiegerichte copers vaker in stresssituaties belanden, terwijl de probleemgerichte aanpak mensen helpt 'op te zadelen', toe te rusten om een weerstand te hanteren. Geerts e.a. (2006) tekenen aan dat sprake is van stuk voor stuk bewuste mechanismen, waarbij zich ook een 'ladder' van strategieën heeft ontwikkeld: 1) Passiviteit of negativisme, 2) Rekken van procedures, 3) Meerdere einddoelen formuleren, 4) Netwerken opbouwen en instrumenteel inzetten en 5) Duurzame verbindingen opbouwen. Compas e.a. (2001) onderscheiden copingstrategieën naar positieve benaderingen - (1) probleem oplossen, (2) cognitieve herstructurering en (3) positieve herwaardering van de 'stressor' - en negatieve aanpakken: 4) gedragsvermijding, 5) sociale terugtrekking, 6) niet accepteren, 7) wishful thinking, 8) zelfkritiek en 9) emotionele uitbarsting.

We zien deze 'handelingsladders' ook terug bij Giebels' 'De tafel van tien' (2002): een set strategieën voor het hanteren van lastige situaties, waarvan de uitsplitsing naar relationele en inhoudelijke focus relevant is, met een primaire hoop op het kunnen realiseren van relationele opbrengst. De eerste drie strategieën uit de reeks zijn hierop gericht, de daarop volgende benaderingen gaan uit van een minder relationele als wel inhoudelijke opbrengst: 1) Aardig zijn, 2) Gelijkwaardigheid tonen, 3) Geloofwaardigheid inbrengen, 4) Emotioneel appel (met behulp van waarden, emotie), 5) Intimidatie (waarschuwen, vertrouwensvraag stellen), 6) Beperking opleggen (schaarste, tijdlimiet), 7) Directe druk (herhalen), 8) Legitimeren (regels noemen), 9) Ruilen (wederkerigheid: iets bieden of door-in-the-face: groter voorstellen en dan terugkrabbelen, waarna de tegenstander iets wil terugdoen) en 10) Rationeel overtuigen (argumenteren, voet tussen de deur: iemand gaat eerder in op tweede groot verzoek na klein eerste verzoek). Bij de toepassing blijkt dat het type partij dat weerstand biedt, het repertoire beperkt: voor emotionele conflictpartijen biedt aardig zijn, het doen van emotioneel appel, legitimeren en ruilen soelaas, bij ideële partijen zet geloofwaardig zijn en legitimeren zoden aan de dijk en tref je antisociale partijen, zet dan in op gelijkwaardig zijn, geloofwaardigheid en directe druk. Ashforth e.a. (2007) spreken bij een uitwerking van deze stijlen in de beroepsmatige context van een patroon om 'normalisatiestrategieën' te ontwikkelen. Ze onderscheiden drie categorieën van benadering, door de betekenis van het beroep en de cliëntrelatie te benadrukken, respectievelijk de afweer te organiseren. Bij de eerste categorie - de beroepsgerichte benadering - gaat het om presentatie van de inhoud. Hiertoe behoren: 1) Reframing (positieve aspecten werk aanzetten), 2) Perspectief wisselen, op andere schaal bezien, 'recalibrating'), 3) 'Refocussing' (andere aspecten benadrukken, zoals zorgverlof bij overheid) en 4) 'Social buffers' (sociale steun van de beroepsgroep benadrukken). De tweede categorie richt zich op interveniëren in de relatie met gebruikers: 5) Confronteer de cliënt of het publiek (via de media bijvoorbeeld) serieus of humoristisch met de grote en onmisbare waarde van het werk of 6) idealiseer het contact en benadruk verwantschap. Categorie drie bestaat uit defensieve tactieken: 7) Vermijden, 8) Galgenhumor, 8) Accepteren, 10) Afzetten tegen anderen, 11) Criticasters kritiseren (media, andere beroepsgroepen), 12) Cliënten de schuld geven en 13) Persoon en rol scheiden (je voert maar uit...). 


\subsection{Copingspectrum}

Deze opstellingen kunnen worden samengebracht in drie typen reacties. Er zijn twee uitersten op een spectrum, met aan de ene kant de taxatie om je van de weerstand af te wenden en aan de andere kant de weerstand te breken. Daartussen zit een middenweg, waarin je beïnvloedbare ruimte kunt zoeken en deelbare belangen - kunt vinden. We brengen de verzamelde inzichten samen in drie categorieën benadering voor de omgang met (vermeende) weerstand in de context van overheid 6 .

De eerste categorie wijst op de mogelijkheid tot 'wegbewegen'. In het oog springende verschijningsvormen zijn: ontlopen (gedragsvoorbeelden: vermijden, afschuiven, bagatelliseren) en ritualiseren (in vorm laten oplossen, procedures aanbrengen om op te knippen, op te schalen en te apaiseren). $\mathrm{Er}$ is weliswaar niet één beste manier van omgaan met conflictueuze situaties, benadrukken experts (Giebels \& Eeuwema, 2005), maar duidelijk is dat 'vermijden' vooral voor de korte termijn effect heeft, op de lange duur betekent dit een kans op oplopende weerstand met alle gevolgen die escalatie kan hebben. In de studie van Berg naar het eigene van de overheid (2008) wordt het ontlopen van directe confrontaties als een begrijpelijke neiging binnen de context van het systeem overheid gepositioneerd. De in hoofdstuk 2 aangehaalde 'systeemkenmerken' brengen tot uiting dat een stapeling van 'systeemspanningen' (hoofdstuk 5) met zich mee kan brengen dat een medewerker 'systeemdwang' ervaart: het eigen gedrag wordt dan als vreemd ervaren en men kan dichtklappen (en wegbewegen) of juist in de contramine schieten en tegenbewegen, overtuigen (= meer zeilen bij zetten dan de elementen vragen). 'Vervreemding' is een risico voor overheidsdienaren dus: gedrag dat de facto op gespannen voet staat met wat iemand eigenlijk zou willen. Frijda (1993) wijst erop dat vervreemding kan ontstaan als individuen taxeren dat wezenlijke 'bronbelangen' onder een te grote druk komen te staan. Het gaat dan in het bijzonder om het toegekende belang aan nieuwsgierigheid, vertrouwdheid, nabijheid en oriëntatie. Andersom zou ook sprake kunnen zijn van een grotere weerbaarheid zodra de bronbelangen in situaties-onder-druk - tijdig kunnen worden bekrachtigd of versterkt. Metafoor: de 'struisvogel' die zijn kop in de grond steekt en de werkelijkheid ontkent. Johnson (2010) gebruikt voor dit type gedrag het begrip 'vluchten'.

De categorie'tegenbewegen' bevindt zich aan de andere kant van het denkbeeldige spectrum. Niet mijden, maar drammen is nu het parool. Stijlvormen waarin dit tot uiting komt zijn confronteren (beperkingen opleggen, overtuigen, schaarste suggereren) en forceren (opleggen, emotioneel appel, intimideren). Uit de onderzoeken naar normalisatiestrategieën van Milgram kwam naar voren hoe bij het opvoeren van druk de autonomie en het eigen onafhankelijk oordeelsvermogen van individuen werd aangetast, en de bereidheid verminderde

6 De weerstand is vermeend, omdat er sprake is van een taxatie, die niet per se daadwerkelijk voorkomt of ervaren wordt. 'Het is niet de werkelijkheid die u stoort, maar het is de betekenis die u eraan geeft' (Wild en Euwema, 2006) 
om het eigen gedrag kritisch te herwaarderen (Zimbardo, 2010). Men ging over tot drie vormen van jobcrafting: 1) opdeling van de actie (het opknippen van de verantwoordelijkheden), 2) geleidelijk opvoeren van de druk in elkaar opeenvolgende acties en 3) het creëren van een sterk hiërarchische, autoritaire context. Spierballen tonen is dan het parool. Aan het slot van bestuursperiodes willen bestuurders nog wel eens opdracht geven aan de ambtelijke organisatie om resultaten te inventariseren en als het ware prijzenkasten op te trekken. Tonen wat je wel doet of hebt gedaan kan de aandacht helpen wegnemen van wat er misgaat of niet lukt. Metafoor: de olifant die de porseleinkast doordendert. Bij Johnson (2010): 'vechten'.

Deze beide categorieën wijzen de facto op het uit de weg gaan van wederkerig contact met de persoon of partij waarvan weerstand wordt verondersteld. Beide oriëntaties blokkeren daarmee de taakuitvoering zodra een lastige boodschap voorligt. Weick (1985) maakte uit onderzoek onder medewerkers van een gezondheidsorganisatie echter op dat bij - reële en dreigende - verstoring bereidheid bestaat om alternatieve routes te verkennen. In ons onderzoek naar de ambtelijke omgang met systeemspanningen (hoofdstuk 5 ) registreerden we: geconfronteerd met beroepsgebonden weerstand blijkt - deels onbewust - sprake van een vindingrijkheid. Tussen weg- en tegenbewegen is daarmee sprake van een copingcategorie die uitzicht helpt bieden op de taakuitoefening en die focust op contact - teneinde de lastige boodschap te bezorgen en daarmee de denkbare deceptie te managen. Een kenmerkende houding hierbij is het onderzoeken van de perspectieven die zich aandienen. Beleidsmakers tonen dan nieuwsgierigheid naar die perspectieven en bereidheid om bruggen te vinden of te bouwen, met uitgesproken fanatieke uitschieters daartussen zoals we in het empirische deel hebben kunnen zien. Daarbij kwam ook de metafoor 'spel' meermalen naar voren: een passie om een doorwaadbare plaats te vinden waar mensen vertwijfeld zijn over mogelijkheden om tot een vergelijk te komen. Een ander kenmerk is 'inhouden van de teugels': het uitstellen van de eerste zet om een ander op de proppen te laten komen met een woord of een daad. Bij dit 'meebewegen' zien we stijlen die getuigen van inleven, overeenkomen, vertragen en expliciteren van de twijfel. Hiertoe rekenen we ook de judo- of jezuïtische techniek, waarbij gezocht wordt naar de ontvankelijkheid van de andere partij om mogelijk een draai te kunnen maken. Aan de hand van deze redeneerlijn licht tussen de opties 'vluchten' (voor het wegbewegen) en 'vechten' (voor 'tegenbewegen') het begrippenpaar 'v(ertr)ragen' op voor meebewegen. Kenmerk van deze strategie is dat nieuwe perspectieven worden gevonden, een nieuw licht op de zaak kan ontstaan waardoor een omslag mogelijk is. Als metafoor gebruiken we de spin, die het krachtenveld kent, kansen opzoekt en een nieuw web van mogelijkheden spant, een nieuwe context voor de dialoog. Tabel 6.1. toont het Copingspectrum: een drieluik, dat verder is uit te vouwen naar zeven stijlen en een waaier aan verwante gedragsvoorbeelden: 


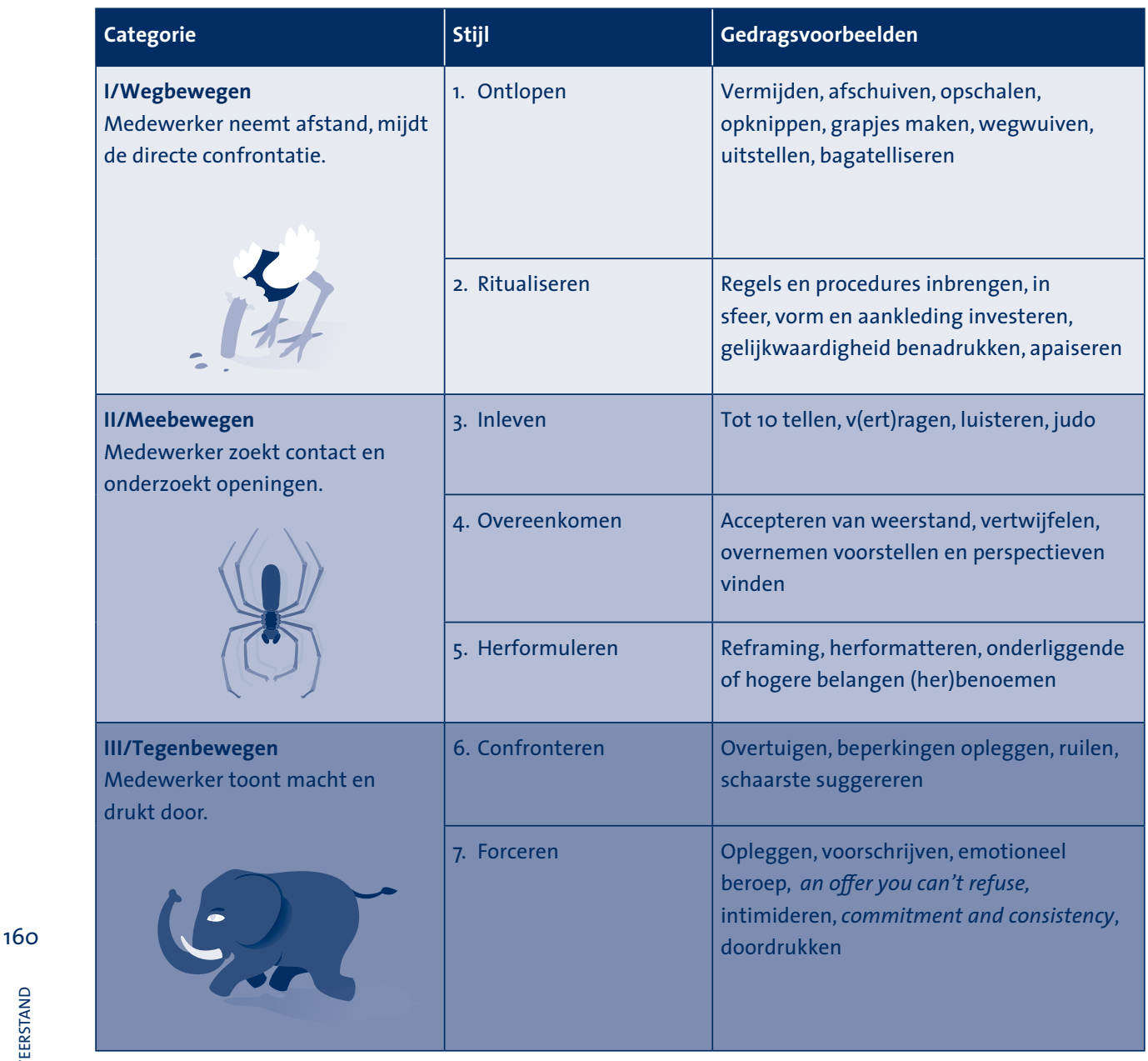

\subsection{Meebewegen: zoek de weerstand op}

We werken de optie 'meebewegen' verder uit: wat maakt deze weg begaanbaar en kansrijk voor beleidsmakers die met weerstand te maken kunnen krijgen? Sennett (2008) zet drie bakens neer in een beschouwing over de omgang met complexe opgaven. Je kunt 1) 'herformatteren', in andere termen voorstellen wat voorligt, 2) geduld betrachten, als iets meer tijd kost dan je had verwacht, er niet langer tegen strijden en gedrag aanpassen, en 3) je kunt je identificeren met de weerstand, dat wil zeggen: niet eerst de grote kluiven aanpakken en dan pas de details uit de weg ruimen, maar andersom. Je concentreert je dan op kleine, meegevende elementen. Volgens Sennett kan de complexiteit van een moment waarin spanning ontstaat als een 'ontwerpinstrument' fungeren: door toegevoegde complexiteit 
ontstaat meer betrokkenheid: mensen gaan op meer elementen letten. Het is in feite het omarmen van frustratie. Hij wijst daarbij op de betekenis van de fysieke en sociale context, en vooral de grensgebieden, 'waar gefilterd wordt, dat zijn actieve plaatsen. Zie de rol van stadsmuren: die grenzen zijn grensgebieden geworden; 'het probleem is dat we beter zijn in grenzen dan grensgebieden'. Bij druk richten mensen zich vaak op centra, terwijl de kansen in de periferieën liggen, 'plaatsen voor afscheiding, maar ook voor uitwisseling'. Hij trekt hier de vergelijking met de speeltuintjes die architect Van Eyck in grote steden hielp aanleggen: vrijplaatsen en afscheidingen, die per saldo de nieuwsgierigheid stimuleerden, mensen uitdaagden om met ambiguïteit om te gaan, elkaar op te zoeken en toe te laten een gemeenschappelijk domein te creëren. Zoek de speelruimte op...

Ook andere auteurs wijzen op de betekenis van het vergroten van de eigen beïnvloedbare ruimte. Giebels en Eeuwema (2006) noemen: 1) Tijd laten werken, 2) Toepassen van een GRITstrategie (Graduated Reciprocation in Tension, publieke verontschuldiging bijvoorbeeld, waarna ander meebeweegt, 3) Humor en 4) Herframen via (a) een overkoepelend doel of gezamenlijke vijand, b) een ander (mede)verantwoordelijk maken en dan gezamenlijke kluif maken), partijen of kwesties splitsen (kleinere deelproblemen maken) of d) door procedureafspraken maken. De auteurs halen Ury aan die vijf stappen onderscheidt: 1) Tel tot 10 (stel even uit), 2) Ontwapen door naast de ander te gaan staan (actief luisteren, zoek gezamenlijke oriëntatie), 3) Verander het spel (ander kader aanreiken, vragen naar waarom en onderliggende belangen), 4) Bouw een brug (visualiseer kleine uitkomst, help ander gezichtsverlies te voorkomen) en 5) Maak het lastig om nee te zeggen door negatieve consequenties van voortduren huidige situatie inzichtelijk, help idee te krijgen dat keuze vrijwillig is, leg vast). Uit deze benaderingen spreekt ook de optie van relativering, een theatrale strategie, met toepassingen als bagatelliseren ('alle sectoren over een kam scheren lukt niet'), diskwalificeren ('onderbouwing deugt niet') en dramatiseren ('hiermee gaan we terug naar de vorige eeuw').

Vermaak (2009) focust op een opbouw, waarbij eerst getracht wordt bij een ander aansluiting te vinden, eer men doorpakt naar meer sturende interventies. In zijn proefschrift over 'taaie vraagstukken' in de context van organisatieverandering presenteert hij op basis van onderzoek bij enkele overheidsdiensten het concept van 'paradoxaal interveniëren'. Centraal in deze benadering staat een dosering van de druk, in de veronderstelling dat je niet dieper moet ingrijpen dan nodig is. Van licht naar zwaar: 1) Vertragen, met luisteren als belangrijkste kwaliteit, ruimte scheppen voor 'gesputter' dus; 2) Twijfel expliciteren verwijst naar het openlijk en samen zoeken naar positieve gezichtspunten, 3) Ambities herevalueren is vervolgens als optie mogelijk, teneinde te bezien wat de ander nodig heeft om iets in zijn omgeving te veranderen (als in het kaderen van Ury, hiervoor genoemd) en 4) Voorschrijven resteert als je er op de eerdere niveaus niet uitkomt. Vermaak voegt hieraan het woord 'symptoom' om aan te geven dat het vanuit jouw gezichtspunt geen ideale oplossing kan zijn maar dus wel een laatste houvast. Tabel 6.2. toont in schema de opbouw van wat Vermaak 'paradoxaal interveniëren' noemt: 
Tabel 6.2. Paradoxaal interveniëren (Vermaak, 2009)

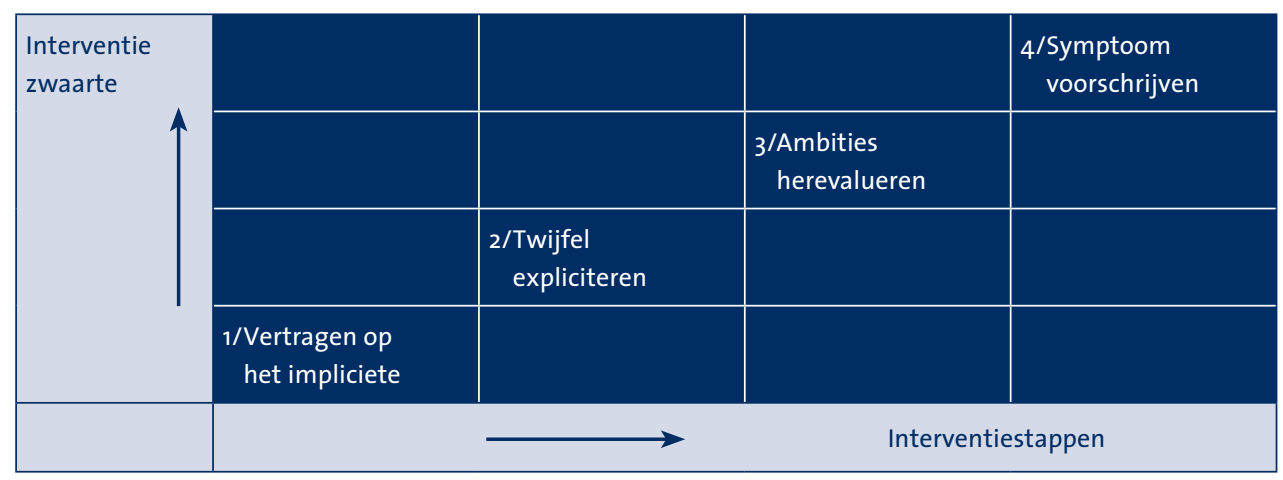

Vermaak ontleende zijn inzicht aan organisatieveranderingen. Hij onderstreept hierbij de betekenis van 'bezig zijn' voor motivatie en begeestering, waardoor een verbinding ('engagement') kan ontstaan. We zien het concept van aansluiten, luisteren en vertragen ook terug in andere disciplines. Zoals in de klassieke ordening van fasen van verwerking van de Amerikaanse psychiater Kubler-Ross (1969). Haar werk heeft nadrukkelijk betrekking op situatie waarin eindigheid van het leven aan de orde is, maar is ook in veranderkundige kringen overgenomen om duidelijk te maken hoe mensen lastige boodschappen verwerken. $\mathrm{Na}$ 1) de schok volgt 2) ontkenning en isolering, 3) woede, 4) onderhandelen over alternatieven, 4) depressie/treuren, en 5) al dan niet volledige aanvaarding van de verandering. De auteur tekent aan dat het model minder lineair is dan mogelijk overkomt; essentie is dat de gesprekspartner deze 'denkstappen' van de ander herkent - en het eigen tempo! - en erop inspeelt. In de eerste fasen is het inleven, vertragen en meebewegen van groot belang, en leidt wegbewegen (bagatelliseren) of tegenbewegen (hoop inblazen) eerder averechts dan bemoedigend. Ontneem mensen hun verdriet (teleurstelling, consternatie) niet en omarm de twijfel, het ongemak, luidt de boodschap. Figuur 6.2. geeft de fasen van verwerking weer. 


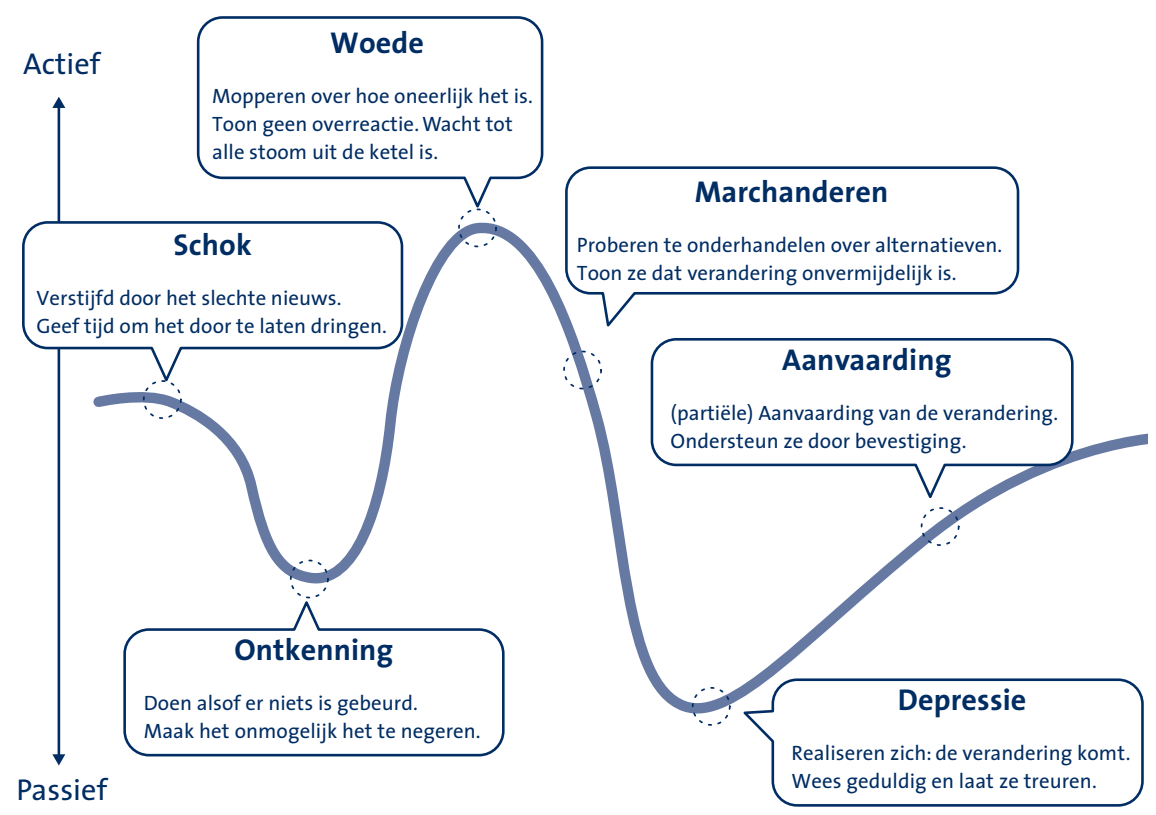

Figuur 6.2. Verwerkingscyclus Kubler-Ross (1969)

De Britse dichter Keats muntte in 1818 in een brief het begrip 'negative capability': a state in which a person is capable of being in uncertainties, mysteries, doubts. Without any irritable reaching after facts and reason'. 'Negative' verwijst hier naar het vermogen om niet te handelen, om de tendens om in actie te schieten te weerstaan. Wanneer spanningen langer worden weerstaan, het 'niet weten' langer kan worden verdragen is het mogelijk om een emotionele en mentale ruimte te creëren waarin nieuwe gedachten naar voren kunnen komen. In tegenstelling dus tot snelle besluiten nemen en complexiteit negeren. Gelb (1998) haalt in een studie naar beginselen van Da Vinci het principe van 'Sfumato' (letterlijk vertaald met: in rook opgaan) naar voren: 'een bereidheid om dubbelzinnigheid, paradoxen en onzekerheid te verwelkomen'. De grote kunstenaar was steeds gericht op ontdekking, stelde aanhoudend vragen en toonde interesse voor de kleinste details om maar over meerdere visies te kunnen beschikken. Met de Mona Lisa als ultieme expressie, de paradoxale en mysterieuze schoonheid waarin je nieuwe perspectieven kunt blijven ontdekken.

Het weloverwogen inzetten op 'vertragen' en 'vertwijfelen' is ook in andere maatschappelijke domeinen aan te wijzen. Zoals in de judosport, in 1882 ontwikkeld door de Japanner Jigoro Kano. Judo betekent letterlijk 'de zachte weg'. Kenmerk van de sport is dat de deelnemers elkaar met respect benaderen en behandelen. Het is de bedoeling om te winnen, maar nooit om de ander door verwonding uit te schakelen. Nathans nam de 'Judostijl' op in haar trainingsboek over adviseren (1992). Het gaat dan om vergaand bevestigen van de claims van een betrokkene en toedelen van zoveel verantwoordelijkheid, zodat de geadviseerde aarzeling openbaart. Dat kan door uitvergroten van een standpunt, terugtrekken van de 
gespreksleider en rondspelen van problemen en oplossingen. De 'Judo-stijl' wordt vooral geschikt geacht als mensen baat hebben bij behoud van bestaand gedrag of als er problemen zijn op betrekkingsniveau. De gespreksleider doet een beroep op een ander deel van de persoonlijkheid dan het deel dat weerstand heeft, namelijk dat deel dat wil veranderen en ontwikkelen.

Geul (1998) haalt in een studie naar beleidsstijlen de Jezuïtische methode naar voren als techniek om bij weerstand mensen eerst te bevestigen in hun weerstand en al bevestigend te zoeken naar een moment van twijfel, op basis waarvan een draai kan worden gemaakt. Vernoemd naar de orde die de Spanjaard Ignatius de Loyola in 1534 stichtte. Een negatief waas hangt over de toepassingen - men spreekt ook van een Jezuïetenstreek die in de kern neerkomt op een vorm van manipulatie. Door bevestiging en bewondering te tonen wordt een bestaande voorstelling van zaken aangepast zodat een acceptabel perspectief ontstaat. De beleidsmaker zoekt dan dus naar openingen bij de ander en of het honoreren van deelwensen de ontvankelijkheid kan vergroten om toch mee te gaan in een verandering. Volgens Van Schendelen komt dat overigens vaak neer op afwentelen, uitstellen, zoethouders en doorverwijzingen (1989): 'men bedenkt, construeert en hanteert variabelen die het probleem verkleinen, onschadelijk maken, verplaatsen, vertragen of anderszins minder hinderlijk maken'.

Meebewegen kan dus ook betekenen dat de meebewegende partij de gemoedstoestand en de taal van de ander omarmt. In de Verenigde Staten bestaat een traditie op dit punt: een grootschalige bomenkap werd door een Republikeinse gouverneur geframed als 'Healty Forests Plan' om Democratische affiniteit met gezondheid te prikkelen (Luntz, 2009). Weerstand duidt immers op betrokkenheid en een hoog energieniveau: wie dan luistert, begrip toont, laat zien hoe hij of zij worstelt met de situatie en mensen helpt om afscheid te nemen van een oude situatie en het perspectief te zien van de nieuwe, kan meters maken (Vermaak, 2009). We zien dit communicatieve koppel van erkenning en perspectief ook terug bij de slagzin van de Belastingdienst 'Leuker kunnen we het niet maken. Wel makkelijker'. Hier wordt de erkenning van een pijnlijke interventie gekoppeld aan een perspectief, dat boven alles relevant is voor de beoogde publieksgroep, de belastingbetaler. De Belastingdienst kon hier toe komen ${ }^{7}$ door het vermogen om zich in te leven in de dominante houdingen van belastingbetalers. Focusgroeponderzoek leerde de dienst in 1992 in welke hoge mate sprake was van bereidheid van het publiek zich te voegen naar de verplichting belasting te betalen ('compliance', bereidheid zich te plooien): 'Ik draag iets bij als mijn buurman ook betaalt', kwam uit kwalitatief onderzoek naar voren, alsook een basale waardering voor de deskundigheid van de Belastingsdienst. Ondervraging van het publiek naar de grondslagen van weerstand gaf vervolgens zicht op de kansrijke interactie: belastingbetalers willen vooral snel en eenvoudig aan hun verplichting kunnen voldoen. De slagzin 'Leuker kunnen we het niet maken.

7 Aldus een toelichting van Dick Geurts, communicatieadviseur, in een gesprek met hem en collega Harrie van Rooij (november 2011) over de totstandkoming van de slogan van de Belastingdienst en de communicatiestrategie die hieraan ten grondslag ligt. 
Wel makkelijker' zat bijna letterlijk in de briefing aan het reclamebureau: in het samenspel tussen reclamebureau, de opdrachtgevers bij de communicatiedirectie en de betrokken leiding van de Belastingdienst werd de betekenis van de slagzin geïdentificeerd. Maar ook de combinatie van communicatie en de bijbehorende bewijsvoering - vereenvoudiging van de aangifte - kwam in het vizier. En is sindsdien niet meer losgelaten, getuige ook het jongste Beleidsplan communicatie van de dienst (november 2011). Tegenover de korte termijnoriëntatie van het politieke bedrijf - het departement - slaagt de dienst er per saldo in om een lange termijnrelatie met de burger gaande te houden, waarin niet de politieke strijd, maar de repeterende agendering van de naleving van een kennelijke sociale norm (belasting betalen hoort erbij) in combinatie met een simpel handelingsperspectief de toon zet: zo gaan we met elkaar om....

De vrucht van meebewegen is dan ook vaak een nieuwe ordening van gegevens, een nieuwe talige werkelijkheid, een nieuwe agenda die daarbij als gemeenschappelijk wordt beoordeeld. Zo wordt het Nederlandse poldermodel geroemd vanwege de hefboomfunctie van het continue articuleren van de bereidheid om tot overeenstemming te komen ('agree to disagree') bij vakbeweging, werkgeversorganisaties en overheid (Lendering, 2005). Volgens Frijhoff (vraaggesprek met Spiering, NRC Handelsblad, 1999) is hier sprake van een typisch Nederlands kenmerk: het vermogen om steeds weer te zoeken naar 'draagvlak' en overleg heeft de facto de waterschappen en daarmee de democratisch gelegitimeerde bestuurscultuur in Nederland gefundeerd. Taal en in het bijzonder het stijlmiddel eufemisme spelen hierbij een belangrijke rol, zoals het gebruik van begrippen als inspanningsverplichting (voor doelstelling) en nulgroei (voor bezuinigingen).

In een studie van enkele ongemakkelijke, meerpartijdige conflicten in de ruimtelijke ordening stellen Brummans et al. (2008) vast hoe partijen die qua standpunten ver van elkaar verwijderd zijn een nieuwe gemeenschappelijke werkelijkheid kunnen creëren door een situatie te creëren waarin iedereen de kans krijgt om eigen voorkeuren (frames) als het ware naar de voorgrond te verplaatsen. Er ontstaat dan een (nieuwe) ordening en betekenisgeving waardoor mensen in staat worden gesteld tot een gemeenschappelijke definitie van een situatie. 'From this perspective, framing refers to using a particular 'repertoire' of categories and labels to bracket and interpret ongoing experience and information action. In other words, it refers to the communicative process through which people foreground and background certain aspects of experience and apply a set of categories and labels to develop 'coherent stor[ies] of what is going on' and make decisions of 'what should be done given those unfolding stor[ies]' (Weick, 1999)'. Kern van deze benadering is dat bestaande verschillen niet worden geëlimineerd, maar naar de achtergrond worden geschoven ten gunste van gedeelde opvattingen. De gemeenschappelijke winst schuilt dan in de gedeelde visie op wat er aan de hand is: 'an intractable multiparty dispute can be seen as a symbolic arena in which disputants framing reportoires differ from and frequently oppose each other for extended periods of time. Er is sprake dan van een agree to disagree met een product dat Brummans c.s. 'commonality's' noemen: systeemovereenkomsten. Een verwante opvatting over het schuiven met gedeelde en uiteenlopende opvattingen zien we 
bij de onderwijskundige benadering van gemeenschappelijk leren van Fiol (1994).

Hij deed onderzoek naar de wijze waarop gedeeld begrip ontstond bij het aanreiken van nieuwe en diverse feiten en stelde vast dat om te komen tot gemeenschappelijk begrip het bieden van ruimte aan convergentie én divergentie baat heeft. Wijs omgaan met deze tegenpolen bleek te bestaan uit het benadrukken van de convergentie als dat kan en ruimte bieden aan uitwaaierende opvattingen als dat moet. De psycholoog Miyake (1991) benadrukt op basis van onderzoek onder studenten dat het samen handelen als een hefboom kan fungeren: door die gedeelde ervaring is het mogelijk gedeeld begrip te creëren: 'Even after an hour long joint comprehension activity that resulted in a subjective feeling of complete sharing, members of dyads [= duo's van studenten, GR], when individually queried, gave very different explanations'. Essentieel bij deze benadering is het besef dat door Isaacs (1999) onder woorden werd gebracht: je kunt dialoog niet afdwingen, maar wel de gunstige condities creëren die bevorderen dat de dialoog ontstaat (o.a. in de titel van zijn boek 'Dialogue and the art of thinking together'). Van den Bos (2009) zet 'procedurele rechtvaardigheid' - waargenomen rechtvaardigheid van de bejegening - af tegen 'distributieve rechtvaardigheid' (rechtvaardiging van de uitkomst(en)). Uit onderzoek maakte hij op dat burgers meer waarde toekennen aan de waarneming van rechtvaardigheid, eerlijkheid, respect en vriendelijkheid dan de bevrediging van een uiteindelijk resultaat. Een belangrijke verklaring ligt volgens hem bij informatieonzekerheid: burgers willen een oordeel kunnen vormen over de mogelijke uitkomst en percipiëren de procedure dan bij wijze van toetssteen.

'Meebewegen' ontpopt zich hiermee als allesbehalve een geforceerde neiging om tot verzoening te komen ('het compromis om het compromis'), maar juist om met behoud van verschillen 'on speaking terms' te geraken. We vinden dit fenomeen ook bij de Frans-joodse filosoof Levinas. Hij bleef vrij lang in gesprek met zijn leermeester Heidegger, ook toen bleek dat deze er nazisympathieën op nahield. Hij zocht naar de verbindingen en de verschillen tussen hen beiden. Levinaskenners onderstrepen dat deze houding diens werk aanzienlijk heeft verrijkt: door je in de weerstand te verdiepen - er dwars doorheen te kijken - kun je sterker voor de dag komen (Keij, 1993). 'Je moet dus juist in gesprek gaan met degenen die diametraal tegenover je staan', concludeert hoogleraar christelijke filosofie Van Riessen (Hamelink, 2010). Levinas bepleit meer in het bijzonder het omarmen van 'meervoudigheid', 'afhankelijkheid' en 'kwetsbaarheid', registreert Keij; Levinas kiest dus bewust voor de ambivalentie, de 'dubbelwaardige' mens. We onderstrepen deze inzet hier, omdat ze de massieve staat van weerstand helpt openbreken: het is niet iets wat tegenover je staat, maar wat deel uitmaakt van de contextuele werkelijkheid en daarom gekend moet worden. Wie de ambivalentie toelaat gaat voorbij het zwart-wit denken en gunt zichzelf een onderzoekende houding naar meerdere invalshoeken en zienswijzen. In aanvulling op het begrip 'de derde weg' (waarbij bij conflicten wordt uitgegaan van een verzoening, het samenbrengen van uiteenlopende inzichten en opvattingen), opent Levinas als het ware de mogelijkheid van 'de vierde weg' (Keij 1993). Probeer het onderscheid niet op te heffen, maar benoem het, zoals de Belastingdienst feitelijk ook presteerde met de slagzin 'Leuker kunnen we het niet maken. Wel makkelijker': per saldo immers een fors aangezette omarming van gemakzucht. Focusgroepen met belastingbetalers 
hadden duidelijk gemaakt dat die luiheid geen doel in zich was, maar wel om erkenning smeekte. Overigens waren de belastingplichtigen zich er terdege van bewust dat belasting betalen erbij hoort. Deze 'compliance' kon alleen ontstaan door een echt gesprek aan te gaan, de doorwaadbare plaatsen te zoeken en in 'weerwoord' een nieuw perspectief te ontdekken. Van der Riessen (1991) spreekt van het toelaten van 'schroom': de bereidheid om elke visie op het goede niet van het zelf uit vorm te geven, maar aan te passen aan de situatie en de vraag van de ander' (cursivering van mij, GR). Van der Ven ontleent aan een studie naar de filosofie van Levinas een pregnant kenmerk van de ontmoeting met weerstand: schaamte (2008). Hij signaleert bij professionals het voorkomen van 'rationaliteitsschaamte': een moment waarop iemand zich teruggefloten weet, geraakt en zich in mindere of meerdere mate bewust is van 'een niet doordachte weerstand'. Ook deze auteur neemt afstand van een hang naar rationaliteit bij de ontmoeting met kritiek of de veronderstelling hiervan. Onderwerp van zijn studie zijn interne veranderingsprocessen in organisaties. Een fixatie op rationele processen ontneemt managers de kans om 'de Ander' te zien - het begrip dat zo'n centrale plaats heeft in Levinas' filosofie. Twee andere leidende begrippen in die filosofie zijn 'nabijheid' en 'gelaat'; het vermogen om de ander écht te zien en 'de morele impuls in mij los te maken en te voorkomen dat ik de ander geweld aan zal doen'. Niet codes en reglementen, maar eerlijke verkenning van de relatie, met de bijbehorende tegenstellingen, daar gaat het om. Veel 'managerial' concepten zijn echter gericht op het krampachtig en 'manipulatief' bijeenbrengen van medewerkersbelangen en bedrijfsbelangen, aldus Van der Ven, die een 'totaliserende' en 'inkapselende' werking van rationaliteit waarneemt: uit angst voor de echte ontmoeting wordt gevlucht in een eigen logica van meten en behalen van targets.

Ten Bos (2004) gebruikt de metafoor van de weg als aanduiding voor het dwingende karakter dat uitgaat van rationele benaderingen: 'De mens is in de organisatie altijd een spookrijder'. We zien versterking van dit geluid bij pleitbezorgers van de chaostheorie (Weggeman, 2008). Zij hekelen de reïficatie of het toekennen van een 'dingkarakter' aan begrippen als 'individu', samenleving' en 'organisatie'. Verbinding met anderen vinden degenen die de confrontatie opzoeken, dilemma's niet willen gladstrijken, maar ruimte willen bieden aan verschillen. De Jong (1997) onderscheidde in dit verband een onderscheid tussen 'instrumenteel rationeel handelen' en 'waarderationeel handelen'. Bij het eerste begrip draait het om het bereiken van efficiënte inzet van mensen en middelen, terwijl bij de tweede vorm voortkomt uit de overtuiging dat een handeling een intrinsieke waarde kan hebben, ongeacht het nut. Deze invalshoek helpt ons om onderscheid aan te brengen tussen het weloverwogen en onderbouwde sturen van handelen bij (het aan zien komen) van weerstand en het ontvankelijk en open tegemoet treden van de (vermeende) situatie waarin je terecht komt. We nemen een dominante neiging waar om 'binnen vastgestelde categorieën het ongelijke gelijk [te] maken' (Van der Ven, 2003) en daarmee weg te bewegen van de kansen die een confrontatie biedt om een eigen(standige) beoordeling van een situatie te maken, een ervaring te hebben voor de betekenisverlening, het gesprek écht aan te gaan. Met de auteur deel ik de opvatting dat het ontnemen van een zicht op de gesprekken bij die mensen het gevaar van 'misleiding' en ook 'uitsluiting' of 'blindheid' met zich meebrengt. 
Mogelijke oplossingen die in de ontmoetingen en gesprekken en dus in de weerstand besloten liggen, worden nodeloos op afstand gehouden.

Diverse studies naar gesprekken en discoursanalyses noemen de betekenis van het niet-expliciete karakter van gesprekken die mensen met elkaar voeren. Mensen bevinden zich in tijden van crises of risico's in een dilemma en de autoriteit die een dergelijke situatie herkent - en erkent - kan contact maken en daadwerkelijk communiceren. Aldus Klarenbeek (2011), die voor haar promotieonderzoek gesprekken van ouders bij de campagne van het RIVM voor het inenten van meisjes tegen baarmoederhalskanker in 2009 onderzocht. $\mathrm{Bij}$ een tweede campagne in 2010 trok het instituut lering uit de - genegeerde - gesprekken bij de eerste campagne het jaar ervoor. In uitingen werd bewust de weerstand van ouders en meisjes uitgelicht ('Is het wel veilig?', 'Wat betekent dit voor seks?' etcetera). Flyvbjerg, die onderzoek deed naar kostenoverschrijdingen bij grote infrastructurele projecten, spreekt over 'strategische misrepresentatie'. Overheidsorganisaties doen vaak de relatie met burgers geweld aan door 'overoptimistische' berichten de wereld in te sturen. Hieraan ligt de misvatting ten grondslag dat het volk zichzelf niet gerust kan stellen. Maar, 'de lijn tussen optimisme en misrepresentatie is zo dun dat burgers op basis van ervaringen uit het verleden de overheid vaak per definitie wantrouwen'. En: 'Goednieuws-shows en absolute garanties wekken vooral achterdocht'. (De Boer, 2011). Ook mediatrainer Wieringa (2011) bespreekt hoe overheidstaxaties hun voedingsbodem vinden in misinterpretaties over hoe mensen met informatie om zullen of kunnen gaan. In een artikel naar aanleiding van de brand met een chemiebedrijf in Moerdijk wijst hij op de 'informatieparadox': hoe meer informatie, hoe meer onzekerheid. Autoriteiten stoeiden duidelijk met de vraag of ze eerst alle gegevens op een rij moesten hebben of alles openbaar op het internet moesten plaatsen. 'Meer informatie is dus niet de goede oplossing. De kunst is om te zoeken naar de goede informatie', weet mediatrainer Wieringa, die de variant 'meer over minder' voorhoudt: analyseer welke informatie er voor wie toe doet. Of: welke informatie schraagt het vertrouwen? Wie op basis van die kennis de zorgen én bedenkingen van sleutelfiguren 'adresseert', communiceert 'van buiten naar binnen in plaats van andersom'. In het concrete geval van Moedrijk had de boodschap kunnen luiden: 'We meten geen schadelijke stoffen, maar toch zeggen we u dat u ramen en deuren moet sluiten Dat klinkt inderdaad strijdig, maar dat doen we voor alle zekerheid'. Niet verhullen dus waar het je om te doen, je kaarten open op tafel leggen en perspectief bieden. Wieringa: 'Krakkemikkige eerlijkheid overtuigt meer dan gelikt theaterspel'. 'Mensen hebben niet zo zeer hekel aan veranderen, maar aan veranderd worden' stelt Horn (1998). Hij wijst op twee dominante mechanismen bij (dreigende) weerstand. Enerzijds is het van belang zorg te dragen voor reductie van onzekerheid en anderzijds voor het verhogen van onzekerheidstolerantie. Zie tabel 6.3.: 
Tabel 6.3. Omgaan met onzekerheid (Horn, 1998)

\begin{tabular}{|l|l|}
\hline Reduceren van onzekerheid & Verhogen van onzekerheidstolerantie \\
\hline $\begin{array}{l}\text { Heldere informatie over de inhoudelijke } \\
\text { achtergronden van veranderingen }\end{array}$ & $\begin{array}{l}\text { Aandacht voor individuele beleving door intensieve } \\
\text { interactie }\end{array}$ \\
\hline Serieus nemen van vooroordelen & Zo exact mogelijk gepland proces \\
\hline Voortschrijdende besluitvorming & Voortdurende procesinformatie \\
\hline Beperken van alternatieve scenario's & Betrokkenheid bij uitwerken van modaliteiten \\
\hline $\begin{array}{l}\text { Vastleggen van zo veel mogelijk essentiële } \\
\text { zekerheden voor het individu }\end{array}$ & $\begin{array}{l}\text { Faciliteren van proces en van medewerkers die } \\
\text { veranderingen ondersteunen }\end{array}$ \\
\hline Gefaseerde implementatie & $\begin{array}{l}\text { In een vroeg stadium opleidingsplannen ontwikkelen } \\
\text { en opleidingen starten }\end{array}$ \\
\hline Afsluiten van veranderingen en evaluatie & Zorgzame cultuur doorzetten na het proces \\
\hline
\end{tabular}

We vestigen tot slot van deze bespreking van de meebeweeg-strategie de aandacht op de beschikbaarheid van opties voor verandering. Hoggett en Simon (2009) wijzen hier bijvoorbeeld op in een verhandeling over de omgang met dilemma's in de context van werk. Ze onderscheiden twee typen uitgangssituaties. Ten eerste de situaties waarin tegenstellingen ontstaan waarbij er geen andere uitweg is dan te kiezen voor één van een aantal opties. Je komt tegemoet aan één optie, waarde of criterium en schiet daarmee tekort ten opzichte van de andere optie(s). Het tweede type situaties kent tegenstellingen waarbij het juist onmogelijk is te kiezen voor één van de alternatieven, het tekortschieten gebeurt ten opzichte van alle opties. Uit een studie naar de juridische functie bij de rijksoverheid maakten Mens, Mul en Van den Kieboom (2010) op dat taak (aard van het werk, helderheid over stappen en resultaten), territorium (waar ga je over en niet), rol (wie doet wat en wat doe ik) en tijd (wanneer werken we eraan en wanneer niet (meer)) de belangrijkste begrenzingen zijn die je kunt aanbrengen.

\section{Tussenbalans: de potentie van meebewegen}

Wie werkt in de context van de overheid maakt onmiskenbaar een kans dat zijn of haar geestelijke of emotionele vrijheid onder druk komt te staan: de contextgerelateerde prikkels kunnen het gedrag dat door de eigen wil wordt opgeroepen overvleugelen. Persoonlijke eigenschappen kunnen hindernissen opleveren bij het aangaan van lastige contacten. Het ontbreken van een constructieve interactie met collega's en ruimte voor reflectie kunnen ook het handelen flink belemmeren. Vervreemding en wegbewegen van de kritische situatie zijn dan een logische consequentie van de belemmerende factoren die de overheidscontext met zich meebrengt. Evenzeer maken onze verkenningen en onderzoeken duidelijk dat de beschikbaarheid van collegiale contacten, ruimte voor reflectie in combinatie met ambtelijk besef en zicht op resultaten als bevorderende factoren kunnen worden opgevat 
voor het hanteren van de systeemkenmerken van overheid. Naast de 'weg van de minste weerstand' en 'overtuigen' lonkt daarom de optie mee te bewegen met de (vermeende) weerstand een te beïnvloeden keuze is bij de ambtelijke taxatie van een lastige kluif en per saldo voor het bereiken van een bevredigende ambtelijke taakuitoefening. Uit het onderzoek naar de omgang met systeemspanningen (hoofdstuk 5 ) kwam al met al een flinke dosis ambtelijke vindingrijkheid naar voren, een ontvankelijkheid om te zoeken naar manieren om 'mee te bewegen'. Daarbij stelden we vast dat het ambachtelijk handelen (job crafting) in belangrijke mate op onberedeneerd gedrag leunt; desgevraagd maken beleidsmedewerkers duidelijk moeilijk te kunnen ver(ant)woorden waar ze hun handelen op baseren.

Deze bevinding relativeert de opvatting dat bij coping sprake zou zijn van bewust, gecalculeerd gedrag (Geerts, 2000) en sluit aan bij andere onderzoeken (Dijksterhuis, 2007, Pol, 2006). Maar alles begint bij het vermogen om contact te leggen en vanuit contact het verschil te herkennen en erkennen. Dit is de kern van wat meebewegen betekent in de spannende, tegenstrijdige context waarin de beleidsmaker overheidsbemoeienis (re)presenteert.

\subsection{Invloedsfactoren: zes 'hefbomen'}

Meebewegen veronderstelt het willen en kunnen aangaan van een wederkerig contact, waarin dus enkele werkende elementen oplichten. Zoals: geduld en aanpassing (Sennett), twijfel en vertraging (Vermaak) eerlijkheid en waardigheid (Levinas), bescherming van verschillen (Brummans) en meervoudige perspectieven (Merron). Vanuit dat contact kunnen volgende stappen worden gezet, waarbij 'inleven', 'overeenkomen' en 'herformuleren' als dominante stijlen zijn geïdentificeerd. Wat bepaalt de bagage van de beleidsmaker om aan die copingstrategie gestalte te kunnen geven? Aan de verkenningen en onderzoek ontlenen we zes beïnvloedende factoren: (1) persoonlijke hulpbronnen, (2) professionele drijfveren, (3) ambtelijk besef, (4) sociale steun, (5) zicht op resultaat en (6) ruimte voor reflectie. We lichten deze 'hefbomen voor meebewegen' hierna toe.

Ad.1. In de eerste plaats doen persoonlijke hulpbronnen ertoe. Wat neem je aan eigenheid mee als het er op aan komt? Het belang van de identificatie van persoonlijkheidskenmerken is aanleiding geweest voor diverse modellen en meetinstrumenten. De Myers Briggs Type Indicator (MBTI) geniet weliswaar veel bekendheid, maar krijgt ook kritiek op de validiteit van metingen (o.a. Capraro \& Capraro, 2002) en het beperkte bewijsmateriaal in werksituaties (onder andere uitgewerkt in Robbins \& Judge, 2008). In het model worden persoonlijkheidstypen gekarakteriseerd aan de hand van de termen extravert versus introvert, sensitief versus intuïtief, denkende versus gevoelsmensen en 'beoordelaars' versus 'ontvankelijken'. We grijpen de vijf basisdimensies van de Big Five typologie aan om in de context van dit onderzoek de bagage aan persoonlijke hulpbronnen te karakteriseren. Gramsbergen e.a. (2005) grijpen de betekenis van deze dimensies aan voor het karakteriseren van basiseigenschappen: 
I. Extravert (versus introvert): voelt iemand zich op zijn gemak in gezelschap van anderen, is hij of zij assertief en sociaal dan wel teruggetrokken;

II. Inschikkelijk (versus vijandig) ${ }^{8}$ : is iemand geneigd zich te richten op anderen, vertrouwen te geven, getuigt hij/zij van inlevingsvermogen;

III. Zorgvuldig (versus slordig): is iemand verantwoordelijk, ordelijk, volhardend: een eenmaal gesteld doel zet je niet zomaar weg;

IV. Emotioneel stabiel (versus neurotisch): iemand is niet voor één gat te vangen, blijft kalm, toont zich zeker;

V. Open (versus begrensd): geeft iemand blijk van nieuwsgierigheid, intellectuele autonomie, durf, om proactief en origineel voor de dag te komen.

Bales (1955) wijst (in de context van relaties in kleinere gemeenschappen waaronder families) op de betekenis van het expliciteren van deze eigenschappen. Hij registreerde dat mensen minder moeite hebben om een uitdaging aan te gaan als ze vooraf uitspreken hoe ze iets willen aanpakken; ze zijn juist uitgesproken over de werkgerelateerde spanningen. Mensen met een proactieve persoonlijkheid tonen initiatief, ondernemen actie en creëren ruimte voor verandering (Seibert e.a., 2001). Wat betreft het meten van deze persoonlijkheidskenmerken merken Doppler en Lauterberg (1996) op dat scoringslijsten beperkt houvast bieden. Naar aanleiding van het Stanford Prison Experiment stelde ook Zimbardo (2010) vast dat de betekenis van persoonlijke veerkracht vooral in interacties betekenis krijgt en registraties van waarnemingen meer houvast bieden. We brengen deze eigenschappen als indicatoren voor persoonlijke eigenschappen samen in tabel 6.4.

Tabel 6.4. Persoonlijke hulpbronnen

\section{Factor 1: Persoonlijke hulpbronnen}

Indicatoren:

- Extraversie

- Inschikkelijkheid

- Zorgvuldigheid

- Emotionele stabiliteit

- Openheid, proactiviteit

8 We verkiezen het woord 'inschikkelijk' uit de bewerking van Robbins en Judge (2008) boven het wat algemenere begrip 'vriendelijk', dat we in een bewerking van Gramsbergen (2005) aantroffen. Inschikkelijkheid brengt krachtiger onder woorden wat ook vriendelijkheid vermag: bereidheid er voor een ander te zijn. 
Ad.2. Vervolgens onderkennen we de betekenis van professionele drijfveren. Hierbij draait het om de invloed van de ambitie van een medewerker om in de context van de organisatie waar hij of zij werkt eigen talenten te verzilveren, erkenning van de eigen richting te zoeken, gevoel van maatschappelijke relevantie te beproeven. We kunnen ook ten aanzien van deze factor enkele specifieke indicatoren onderscheiden. In tabel 6.5. brengen we deze indicatoren samen.

- Om te beginnen maken we gebruik de driedeling van Sennett (2008): baan, carrière en roeping. Deze drie oriëntaties op werk kunnen worden gezien als sporten op een ladder. Sennett stelt vast dat bij het klimmen van die ladder meer en meer sprake is van engagement.

- Van den Brink (2009) spreekt van beroepstrots als een aanjager van initiatief en professioneel lef; het is niet verwonderlijk dat in het mede door hem geredigeerde boek over ambtelijke trots werknemers uit de publieke sector aan het woord komen die er blijk van geven regels aan hun laars te lappen en buiten de gebaande paden te treden.

- Niet zelden valt daarbij ook het begrip 'spel': werknemers willen dan 'spelen' met beïnvloedbare ruimte en 'spelregels' benutten of herinterpreteren, waarbij de verschillende deelnemers 'rollen' vervullen.

- Uit de interviews in de onderzoeken komt bij motivaties om voor de overheid te (gaan) werken nadrukkelijk de zorg voor de publieke zaak, belangstelling voor maatschappelijk relevante opgaven en lastige uitdagingen naar voren.

- Politieke betrokkenheid en engagement met kritische groeperingen komt ook vaak voor in de verhalen. Hier telt ook het nemen van verantwoordelijkheid, waarbij idealen of dromen aansporen. We zien deze kenmerken terug bij uitgesproken helden in de geschiedenis, waarbij gewaagde doelen, heldhaftigheid, opoffering voor een grotere zaak, wijsheid en rechtvaardigheid tot de centrale kenmerken behoren.

- Tot slot bieden waardenoriëntaties houvast. Waarden staan voor de fundamentele en duurzame overtuiging dat een specifieke gedragswijze of na te streven manier van leven persoonlijk of sociaal te verkiezen is boven een tegengestelde gedragswijze of manier van leven (Rokeach, 1973). De begrippen persoonlijkheid en waarden zijn nauw verwant; bij 'waarden' staat meer het handelen voorop, waardoor we dit bij deze tweede factor onderbrengen. Kennis over eigen en andermans waarden kan helpen inzicht te geven in wat iemand drijft om te werken aan de gezaghebbende toedeling van waarden ook bekend als overheid. Hoe waarden-vol handelt iemand? 
Factor 2: Professionele drijfveren

Indicatoren:

- Roeping (i.r.t. baan of carrière); engagement

- Beroepstrots; spel

- Publieke opgaven; politieke betrokkenheid

- Gewaagde doelen; reis volbrengen

Waardenvol

Ad.3. Wie staat voor zijn of haar zaak en gedreven is er wat van te maken kan doorpakken in het systeem dat overheid heet. Daarbij helpt de derde onderscheidende factor: ambtelijk besef. Dit begrip vatten we hier samen met vaardigheid in het herkennen en hanteren van het eigene van de overheid. Tabel 6.6. brengt de indicatoren samen.

- In hoofdstuk 5 is een arcatuur van drie systeemgebonden spanningsbogen geïntroduceerd en getoetst? Dit is de eerste dimensie. Ben je in staat tot herkennen van systeemspanningen van a) vakmanschap versus bestuurlijke verantwoordelijkheid, b) beheersbaarheid in een democratische context en c) belangenafweging in besef van rechtsstatelijkheid (Rijnja en Wilmink, 2010).

- Vervolgens komt het aan op het hanteren van 'ambtelijke strategieën'. Gemeenschappelijk kenmerk in de te onderscheiden benaderingen is 'in stelling brengen' van anderen, waaronder we verstaan dat spelers hun rol kunnen spelen. We hebben vijf strategieën onderscheiden (hoofdstuk 5). In de eerste plaats komt het erop aan politieke bestuurders gelegenheid te bieden om korte termijnsuccessen te boeken en bij 'hun' volksvertegenwoordiging goed beslagen ten ijs te komen; zij zijn het die verantwoording afleggen en breng hun dus daarvoor optimaal in stelling. Dat vraagt in de woorden van Weber Dienstwissen en Verfahrenswissen: 'weten hoe de hazen lopen'. Kennis van de beginselen van behoorlijk bestuur is dan van betekenis, maar vooral het hanteren van de dilemma's die zich hierbij voordoen, zoals openbaar maken van afwegingen en voornemens en rechtmatig omgaan met schaarse middelen, ruimte, waarden. In de tweede plaats: ten opzichte van de samenleving komt het aan op het kunnen faciliteren van de dialoog, het bieden van mogelijkheden om mee te - blijven - denken, mee te werken en mee te beslissen. In de afgelopen vijftien jaar is de discretionaire of beslisruimte van de beleidsambtenaar aanzienlijk verruimd, wat slim afstemmen met de politieke en bestuurlijke beslissers maar ook en vooral met publieke spelers vraagt. Een vaardige ambtelijke professional kan slimme coalities smeden en publieke partijen in stelling brengen om rollen te vervullen die ooit onwrikbaar bij de overheid werden neergelegd of door de overheid werden geclaimd. In de derde plaats komt het ten opzichte van de bureaucratie aan op het 
vermogen om die bureaucratie te laten werken. 'Gebruik de bureaucratie, zonder je ervoor af te sluiten', concludeerden we op basis van de interviews met ambtenaren die lastige kluiven op hun bord hadden weten weg te werken. De bureaucraat kan als een 'draaischijf' fungeren tussen enerzijds uitvoeringsorganisaties en partijen in de samenleving en anderzijds de politiek-bestuurlijke arena. Het gaat ook om weten hoe en wanneer bestuurders informatie moeten hebben en hoe in het verkeer tussen ambtelijke diensten belangen kunnen worden geïdentificeerd en interne partijen kunnen worden meegenomen bij opgaven. Organiseren van interne feedback behoort ook tot de vermogens van de beleidsambtenaar. 'Erken de complexiteit, zonder verantwoordelijkheid te schuwen' is het vierde element: het verwijst naar het vermogen om meervoudige werkelijkheden te kunnen herkenen en op meerdere borden te kunnen schaken.

- In het bijzonder hebben we het vermogen om in te spelen op deze meervoudige biotoop geaccentueerd. Hier komt de beschreven vaardigheid in het '(her)framen' onder meer naar voren: lukt het om een kwestie dusdanig te presenteren dat meerdere, rivaliserende partijen zich eraan verbinden. Tot slot komt het aan het bij al deze strategieën op het vermogen om het heft in eigen handen te nemen, een activistische opstelling.

Je zou hier met een speelse verwijzing naar de emotionele intelligentie (EQ, Goleman, 1996) ook van een ambtelijk quotiënt voor de intelligentie ('AQ') kunnen spreken?.

Tabel 6.6. Ambtelijk besef

\section{Factor 3: Ambtelijk besef}

Indicatoren:

- Herkennen van systeemspanningen: vakmanschap in samenspel met bestuurlijke verantwoordelijkheid, beheersbaarheid in een democratische context en in staat tot belangenafweging in besef van rechtsstatelijkheid (openbaarheid, zorgvuldigheid etc.)

- Hanteren van strategieën: politiek in stelling brengen, bureaucratie gebruiken, complexiteit erkennen en de maatschappelijke omgeving laten werken

- Inspelen op bij politieke, publieke en maatschappelijke arena's passende taal en frames (w.o. herframen, front- en backstaging van argumenten, beelden)

Deze set van drie invloedsfactoren leidt naar de veronderstelling van een ideaaltypische procesgang voor een beleidsambtenaar die bij een opgave een gerede kans op weerstand (A) taxeert (B). De trits van persoonlijke en ambtelijke factoren voedt dan het vermogen tot 'meebewegen' (C):

9 We werken dit thema hier niet verder uit, leent zich wel voor vervolgonderzoek. 


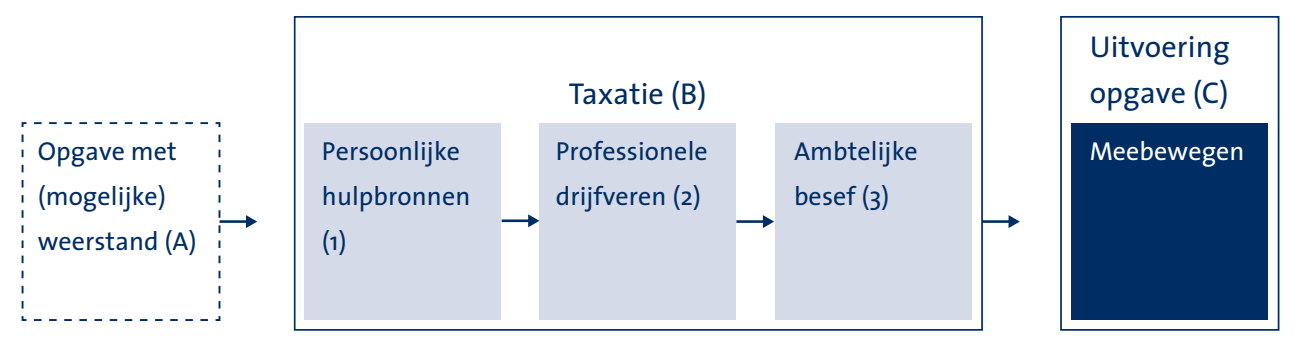

Figuur 6.3. Primaire beïnvloedende factoren

In de onderzoeken naar work meaning (hoofdstuk 4) en systeemspanningen (hoofdstuk 5) zijn enkele specifieke factoren naar voren gekomen, die het ambtelijke handelen kunnen helpen versterken, naast de voornoemde drie factoren. De drie volgende factoren zijn van een tweede orde, ze faciliteren de voornoemde ideaaltypische route:

Ad.4. Factor 4 betreft de kwaliteit van de interacties op het werk, specifiek: de betekenis van sociale steun. Primair kijken we dan naar de rol van interactie met collega's. In tabel 6.7. zijn de indicatoren samengebracht.

- Nabijheid en beschikbaarheid van anderen is een eerste indicator. De beschikbaarheid van collega's kan volgens de beschrijvingen in hoofdstuk 4 onzekerheid reduceren en zekerheid verhogen c.q. spanning helpen opvangen en eigen effectiviteit helpen vergroten. Daarbij werd ook vastgesteld dat minder dan inhoudelijke (vak) verwantschap empathie telt. Stroebe e.a. hebben de invloed van direct beschikbare netwerken voor sociale steun in stressvolle situaties onderzocht (Stroebe e.a., 1996).

- Voor het identificeren van typen sociale steun benutten we de door Van Sonderen (1991) beschreven zes vormen van sociale steun: a) alledaagse ondersteuning (beschikbaarheid), b) emotionele ondersteuning, (c) waarderingssteun, (d) instrumentele ondersteuning, (d) social companionship (elkaars gezelschap zoeken) en (e) informatieve ondersteuning (m.b.t. het gedrag van betrokkene). Aan de hand hiervan kunnen we de aard van de steun beschrijven: is er sprake van een kameraadschappelijke terugvaloptie of een inhoudelijke vorm van ondersteuning?

- Ook het beeld van collega's over de beeldvorming (perceived internal prestige) kwam in de theorie als aspect hierbij naar voren bij de beoordeling van werkgebonden weerstand. De externe bekrachtiging (media o.a.) is vooral van betekenis bij de bevestiging van opvattingen en keuzes (Carmeli, 2009). In het onderzoek in hoofdstuk 4 bleek deze invloed gering; in hoofdstuk 5 bleek vervolgens dat externe druk en verantwoording onlosmakelijk aan het ambtelijk handelen zijn verbonden.

Metselaar en Cozijnsen (1997) wijzen op de samenhang tussen 'zelfcontrolefactoren' - de kennis van en ervaringen met eerdere processen - en 'externe controle factoren': wat stelt de organisatie iemand ter beschikking om te handelen? Naast middelen, tijd en mankracht gaat het dan ook om de ervaren steun van anderen. 


\section{Factor 4: Sociale steun}

Indicatoren:

- Nabijheid, beschikbaarheid van sociale steun op de werkvloer

- Vormen van steun: alledaagse, emotionele, instrumentele en informele steun en waardering); idem in persoonlijke levenssfeer

- Perceived internal prestige (waargenomen beeldvorming in eigen werkomgeving); media-aandacht

Ad.5. Vervolgens komt naar voren hoe het zicht op resultaten invloed uitoefent, of: welk beeld heeft men van de impact van werkzaamheden. Daarbij onderscheiden we de volgende indicatoren (samengevat in tabel 6.8.).

- Hoe concreter het onderwerp, hoe grotere de kans op zelfverklarend beleid; goede wijn behoeft geen krans. Een maatregel of voorziening die geen of weinig toelichting behoeft, vraagt geen vertaalslagen (of: 'beleidsreparatie' (De Bruijne \& Rijnja, 2007) door of met behulp van de communicatieafdeling.

- Snelheid van handelen vergroot de kans dat medewerkers contact kunnen maken en kunnen identificeren welke gevoelens, kennis, verwachtingen en perspectieven een rol spelen. Dit doet zich voor al voor bij complexe organisaties waarin medewerkers schakels van ketens vormen.

- Voor het inzicht in impact is de (letterlijke) afstand tussen beleid en uitvoering relevant. Wie geen einddoelgroep ontmoet neemt anders waar dan als de uitkomsten direct en mogelijk vis-à-vis worden af-, toe- of aangerekend: heb je kans om iemand in het gezicht te zien (Levinas)? Is het gedefinieerde resultaat een ingevuld formulier, een interne beslisser of een externe tussenpersoon of einddoelgroep? (Nationale Ombudsman, 2008).

- Volgens Mens en Mul (2010) is vooral helderheid over taak (aard van het werk, helderheid over stappen en resultaten), territorium (waar ga je over en niet), rol (wie doet wat en wat doe ik) en tijd (wanneer werken we eraan en wanneer niet meer) belangrijkste indicatoren bij het maken van keuzes over omstreden taken. In feite gaat het hier om 'begrenzers'; zo maakt onduidelijkheid over het tempo niet zelden dat mensen aandacht verliezen of afhaken, zoals bij reconstructie van de Betuweroute werd vastgesteld (Boom \& Metze, 1997),

- Verborg (2003) wijst op de betekenis van de concrete ervaring bij oordeelsvorming. Een beslisser is zich vaak niet bewust van de ervaringsregels die hij of zij gebruikt, maar zodra dat het geval is, kan hij hiervan afwijken. Hoe moeilijker een opgave, hoe meer uniek, hoe moeilijker het is om ervaringsregels op te bouwen. 
Factor 5: Zicht op resultaat

Indicatoren:

- Concreetheid van de opdracht

- Snelheid van de vervulling (versus stroperigheid)

- Inzicht in impact (afstand tot resultaat)

- Helderheid over taak/territorium/tijd/rol

- Ervaring met soortgelijke opgaven (hoe complexer hoe relevanter)

- Feedback van directe leidinggevenden/bestuurders/influentials (relatie met factor 4: sociale steun).

Ad.6. Ruimte voor reflectie kan deuren openen. Is sprake van een lerende omgeving? 'Vakmensen zijn het meest trots op vaardigheden die rijpen', schreef Sennett (2008):

'Wie zich blootstelt aan de praktijk, het durft te doen, moet dus niet zozeer vergissingen maar onvermogen doorzien, rekening houdend met een beperkte vaardigheid waar hij of zij nets aan kan doen'. Kunnen en mogen er fouten (bij Sennett: 'heilzame mislukkingen') worden gemaakt en welke voorzieningen zijn in de arbeidsomgeving beschikbaar? Tabel 6.9. vat de laatste set indicatoren samen.

- Schön (1983), spreekt van de ideaaltypische situatie waarin werknemers als 'reflective practitioners' worden gezien, die kritisch en bekwaam de eigen verantwoordelijkheden serieus nemen. Dit veronderstelt een omgeving (cultuur) van verantwoordelijkheid waarin professionals elkaar ondersteunen en collegiaal corrigeren door middel van collegiale toetsing en consultatie in plaats van door van bovenaf opgelegde regelgeving en afschrikkingsmechanismen (Karssing, 2006). Dan kunnen mensen een koppeling maken tussen gedrag en leren (Vermaak, 2009). Hoe diffuser en complexer een taak, hoe belangrijker de mate waarin organisaties ruimte bieden om te leren en te reflecteren op aannames, opvattingen, voornemens en bevindingen binnen de context van de eigen werkomgeving.

- Naast visie gaat het om programmatische bewijzen. We nemen waar dat onmiskenbaar belangstelling en bereidheid aanwezig is om dilemma's te bespreken, te reconstrueren en te bezien hoe aan 'weerstandpreventie' kan worden gedaan, maar is er ook sprake van tastbare (reguliere) programma's voor introductie, vorming en toerusting (Boonstra, 2000, Weggeman, 2007)? Organisaties kunnen hun medewerkers in mindere of meerdere mate in staat stellen om medewerkers uit te nodigen tot leren. Zwartkijksessies hielpen het ministerie van VWS bij de invoering van het nieuwe zorgstelsel (De Bruijn e.a., 2007), vreemde ogen dwingen.

- In welke mate ervaren medewerkers vrijheid, gelijkheid en zingeving (Berg, 1999, 2008) om effectief en met plezier hun werk te kunnen verrichten?

- Medewerkers op hun beurt kunnen de ervaringen die ze opdoen benutten voor 
overdracht aan anderen. Hoe stollen ervaringen? Dat kan bijdragen aan het institutioneel geheugen van de organisatie, van een afdeling of een discipline. Met Bikker (2006) heb ik eerder gepleit voor de vorming van 'communisprudentie': een communicatieve variant van de functie van gezaghebbende uitspraken over wetgeving bij juristen. De overdracht van gezaghebbende uitspraken over communicatie kan bijdragen aan beroepsvorming en de omgang met omstreden kwesties. Karssing (Niessen \& Karssing, 2008) heeft op soortgelijke gronden gepleit voor de vorming van 'moresprudentie' over ethische dilemma's in organisaties.

Tabel 6.9. Ruimte voor reflectie

\section{Factor 6: Ruimte voor reflectie}

Indicatoren:

- Koppeling tussen gedrag en leren

- Programma's voor introductie, intervisie, e.d.

- Ervaren vrijheid, zingeving en gelijkheid

- Agendering van de ervaren verantwoordelijkheid, rechtvaardigheid/moeilijkheid in dagelijks werk

- Vorming van institutionele kennis; moresprudentie

De mate waarin één of meer van deze drie - secundaire - factoren kan worden aangesproken, beïnvloedt het vermogen van een beleidsambtenaar tot 'meebewegen' of het komen tot een taakuitoefening waarin (vermeende) weerstand tegemoet zal worden getreden en lastige boodschappen zullen worden overgedragen. De beschikbaarheid van deze hefbomen maakt het dan mogelijk dat medewerkers niet of minder snel geneigd zijn tot wegbewegen (ontlopen) over te gaan dan wel tegen te bewegen (forceren), zodra zich weerstand aandient. 


\subsection{Conceptueel model}

Zes beïnvloedende factoren ontlenen we aan onze verkenningen: ze kunnen fungeren als hefbomen voor 'meebewegen' met weerstand. Dat leidt naar het volgende conceptueel model:

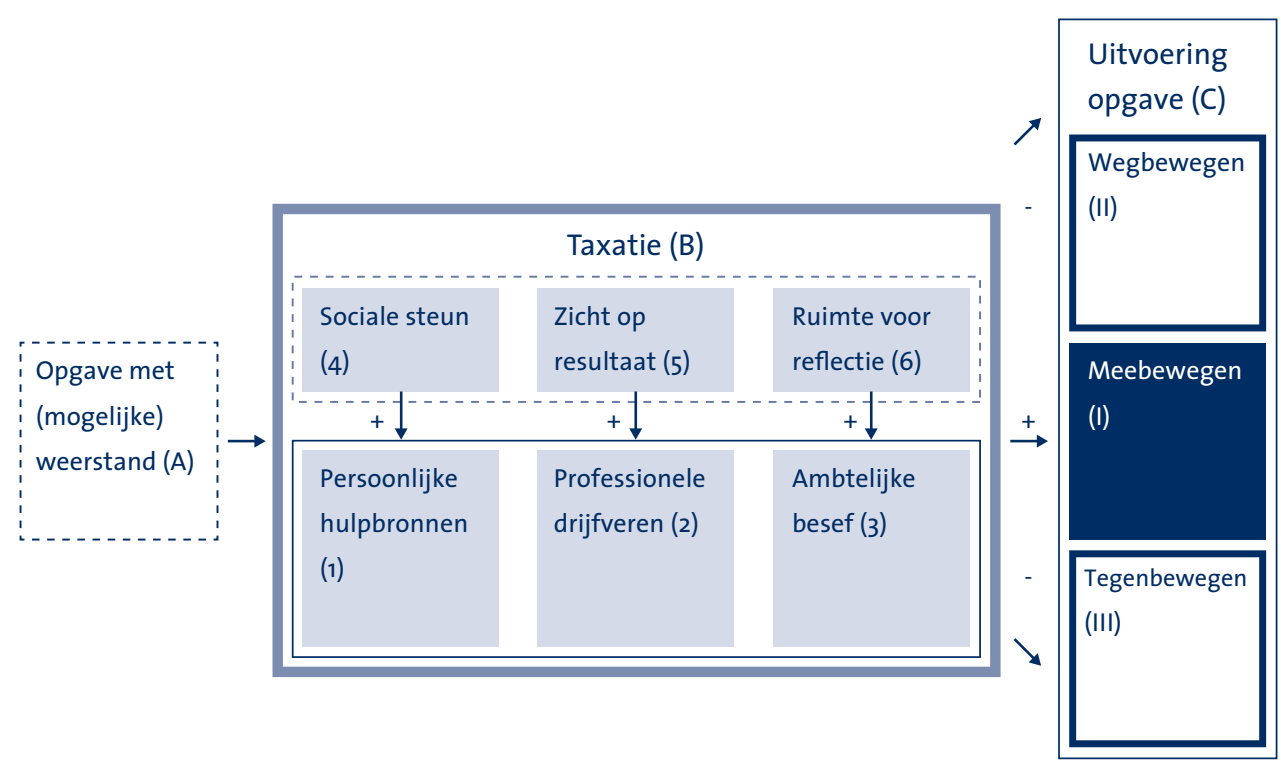

Figuur 6.4. Conceptueel model

Toelichting: geconfronteerd met een opgave met (mogelijke) weerstand (A) maakt de beleidsambtenaar een taxatie (B).Bij deze taxatie worden ideaaltypisch drie primaire

invloedsfactoren aangesproken, te weten persoonlijke hulpbronnen (1), professionele drijfveren (2) en ambtelijk besef (3). De beschikbaarheid hiervan fundeert het vermogen om 'mee te bewegen' met de ander, opdat contact wordt gemaakt om de weerstand te hanteren (C). Drie secundaire invloedsfactoren bevorderen de benutting van de trits hulpbronnen, drijfveren en ambtelijk besef. Door sociale steun van collega's (4), zicht op resultaten van het werk (5) en beschikbare ruimte voor reflectie (6) neemt de kans toe dat beleidsambtenaren de opgave met (mogelijke) weerstand aan gaan c.q. meebewegen (I).Een beperkte beschikbaarheid van deze (zes) invloedsfactoren vergroot de kans dat de beleidsambtenaar niet zal meebewegen.

Dit kan zich manifesteren in wegbewegen van uitvoering van de taak/opgave (II, vluchten) of juist tegenbewegen (III, vechten). 


\subsection{Conclusies}

Beleid maken bij de overheid is 'powering and puzzling' (Heclo, 1974) en die combinatie is niet zelden omgeven met sombere blikken en twijfel over succes. 'The motto of profit-oriented companies is optimism; they thrive on action, energy and growth. The public sector is by definition pessimistic', schreef Brunsson (Czarniawska, 1998) nadrukkelijk zonder cynisme, om vervolgens aan te geven dat verstoringen en onderbrekingen niet vrolijk stemmen, maar tegelijk een enorme potentie hebben voor interactie. Werken voor de overheid vraagt bereidheid en het vermogen om tegenstrijdigheden te ontmoeten en open te staan voor nieuwe inzichten, die dan kunnen ontstaan: 'An interruption stops the flow of routinezed action, of received ideas; it leads ambiguity, which calls for reflection, and reveals paradoxes which, in an organizational context, call for deparadoxification'(Czarniawska, 1998). Tegenstrijdigheid als leidraad voor een ambtelijke professional? In deze paradox schuilt mogelijk de sleutel van het probleemoplossend vermogen van de overheid, als we afgaan op het omstreden karakter van overheidsbemoeienis, het 'onmogelijke' karakter van de vragen die de samenleving aan de overheid overlaat of in haar schoot legt en het ongewisse van de uitkomst van overheidsbemoeienis. Uit onze verkenningen en het onderzoek komt echter naar voren dat kansrijke benaderingen in conflictueuze situaties vragen om niet te snel heil te zoeken in het verzoenen van meningen of de woorden en beelden die mensen gebruiken. Juist in het verkennen van meervoudige werkelijkheden schuilt een kans op de openbaring van nieuwe en deelbare inzichten, die houvast kunnen bieden bij een gemeenschappelijk vervolg. Hierbij kan sprake zijn van naar de voor- of achtergrond schuiven van als relevant aangemerkte betekenissen. Daarbij spelen woorden en beelden een belangrijke rol, maar het zijn per saldo gezaghebbende transacties (afspraken, handelingen) die verschil maken: niet louter communicatie, maar communicatief beleid.

De in de interactie ontdekte (nieuwe) gemeenschappelijke frames hebben bij het communiceren van beleid niet alleen betrekking op inhoudelijke argumenten, maar vaak op processen, afspraken over manieren van communiceren. Waarbij een belangrijk kenmerk is dat verschillen worden toegelaten, het is mogelijk om to agree to disagree. We spreken dan van communicatieve confrontaties (en misschien is 'comfrontaties' wel een mooie samentrekking). Dit vraagt ambtelijk leiderschap, vermogen om te copen met de situaties waarin belangen uiteenlopen en dus via nieuwe verbindingen verrassend kunnen samenlopen. De kansrijke copingstrategie vatten we in dit hoofdstuk samen met het begrip 'meebewegen', als een weg tussen wegbewegen (vluchten) en tegenbewegen (vechten). In dit hoofdstuk hebben we zowel dit perspectief van een bedding voorzien door stijlen en gedragsvoorbeelden te benoemen, als de factoren geïdentificeerd die een beleidsmaker kunnen helpen bij het vinden van de doorwaadbare plaatsen als zich een ogenschijnlijk onbegaanbaar moerasgebied voordoet. Naar voren is gekomen dat het kunnen openstaan voor verschillen, stappen zetten naar de ander, vermogen om te vertragen en in gesprek komen over onderliggende belangen en wat mensen (wel) willen belangrijke kwaliteiten zijn om mee te bewegen met (vermeende) weerstand. Daarbij hebben we de betekenis onderkend van het bestaan van meervoudige perspectieven op een situatie en dat die meervoudigheid allesbehalve hoeft te verhinderen dat nieuwe, gedeelde 
perspectieven ontstaan. Of mogelijk al aanwezig waren en door de interactie als het ware worden uitgepakt. Want: 'cruciale actoren zijn in staat tot het slechte, maar bereid tot het goede', aldus bestuurskundige Teisman (Van Rooy, 2009).

Het conceptueel model dat we op grond van onze verkenningen in dit hoofdstuk neerleggen vraagt om spiegeling aan de praktijk. We volgen daartoe drie ambtelijke beleidsmakers die in hun praktijksituatie weerstand het hoofd wisten te bieden. De casestudies beogen inzicht te geven in de werking van de copingstrategie en in de bijdragen van de zes beïnvloedende factoren: wat maakt het verschil in ambtelijk handelen?

In 1999 introduceerde bestuurskundige Tops de uitdrukking 'gezaghebbend nee zeggen' voor bestuurlijk handelen waarin ook bij tegengestelde opvattingen beslissingen als legitiem worden beoordeeld. We presenteren met ons conceptueel model een ambitie om boter bij de vis te leveren voor wat betreft ambtelijk handelen. 


\section{De ambtelijke taxatie}

De vindingrijkheid van meebewegers

\subsection{Inleiding}

Bezuinigingen, omstreden opvangvoorzieningen, ingrepen in wijken: bij het bezorgen van lastige boodschappen kunnen beleidsmakers wegbewegen (vluchten, ontwijken), tegenbewegen (vechten, forceren) en meebewegen (weerstand opzoeken).

Die laatste 'copingstrategie' heeft vele voordelen, zo maakten we op uit literatuur en onderzoek, doordat in de interactie nieuwe perspectieven besloten kunnen liggen of kunnen ontstaan. Zes factoren zijn als bepalend geïdentificeerd voor de taxatie van de geschetste gedragopties, ze fungeren als 'hefbomen' voor de gepresenteerde voorkeur. Deze uitkomsten van onze verkenningen en onderzoeken vragen om spiegeling aan praktijkervaringen. Dit gebeurt in de vorm van drie casestudies naar de werking van de copingstrategie 'meebewegen'. We volgen drie professionals bij de taxatie van een specifieke opgave. In het bijzonder onderzoeken we de manifestatie van het 'meebewegen' en de werking van de zes invloedsfactoren. De cases zijn reconstructies: we ploegen met de betrokken ambtenaren terug hoe hun keuzes tot stand zijn gekomen en welke actoren, perspectieven en interventies daarbij van betekenis zijn geweest. Na een introductie van de onderzoeksopzet en de onderzoeksvragen volgen de afzonderlijke casebeschrijvingen en conclusies: welke lessen kunnen worden ontleend aan de drie praktijkvoorbeelden van ambtelijke omgang met lastige opgaven.

\subsection{Onderzoeksvragen}

De centrale vraag in dit deelonderzoek luidt: hoe komen beleidsambtenaren succesvol tot de copingstrategie 'meebewegen' indien er sprake is van vermeende weerstand. Deze vraag wordt aan de hand van twee specifieke onderzoeksvragen onderzocht:

1) Hoe manifesteert de copingstrategie 'meebewegen' zich ten opzichte van de optie om weg- en tegen te bewegen?

2) Hoe oefenen de (zes) factoren invloed uit op de ambtelijke taxatie bij (vermeende) weerstand - ieder voor zich en in samenhang? 
In het conceptueel model dat in paragraaf 6.7. (figuur 6.4.) werd gepresenteerd (figuur 7.1.) komen de copingstrategien en factoren samen:

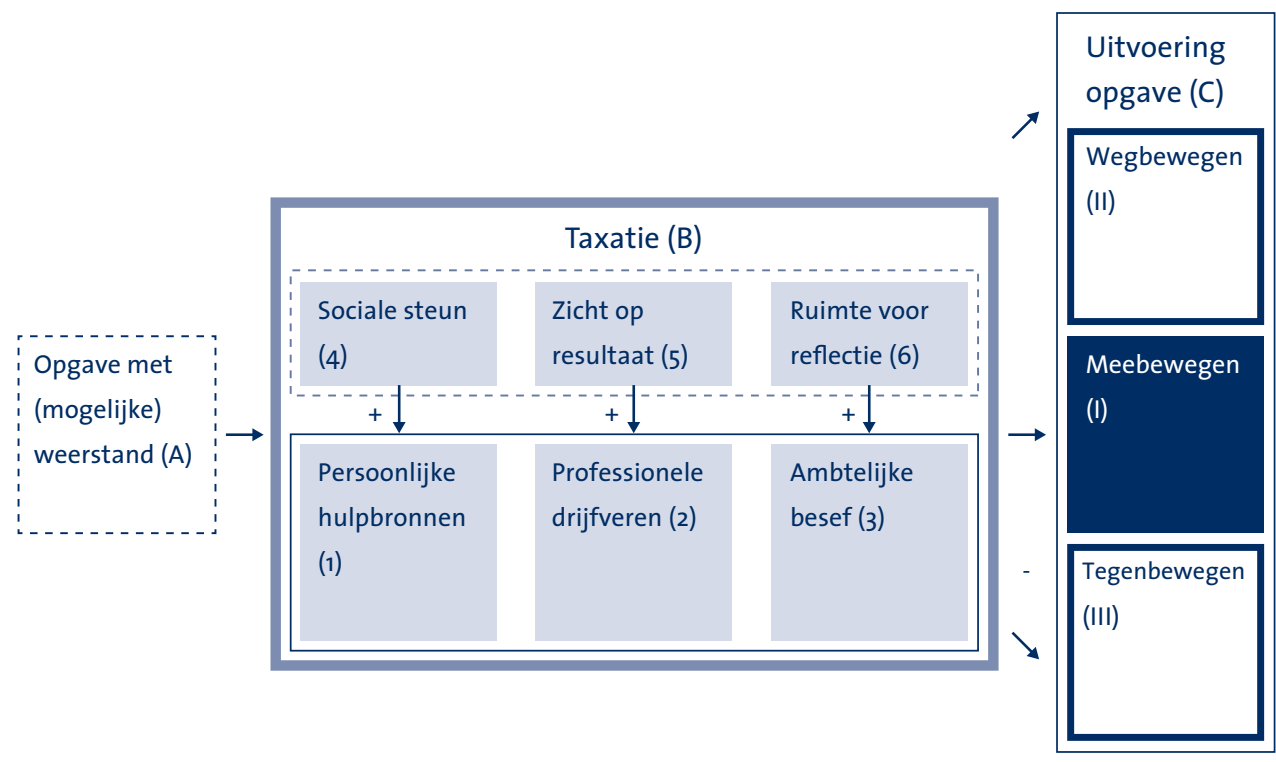

Figuur 7.1. Conceptueel model

Toelichting: geconfronteerd met een opgave met (mogelijke) weerstand (A) maakt de beleidsambtenaar een taxatie (B). Drie copingstrategieën liggen dan voor. Hij of zij kan wegbewegen (vluchten, II) van de uitvoering van de taak (C), tegen bewegen (III, vechten) en meebewegen (I), waarbij contact wordt aangegaan en sprake kan zijn van een communicatieve confrontatie ('comfrontatie'). NB. De functie van het conceptueel model is ordening; Wester (1991) wijst op de betekenis van een conceptueel model om onderzoekseenheden duidelijk maken, zowel afzonderlijk als in hun onderlinge relaties. 
Per typen copingstrategie zien we enkele dominante stijlen; een toelichting is te vinden in de paragrafen 6.4. ('Copingspectrum') en 6.5 ('Meebewegen: zoek de weerstand op'). Tabel 7.2. vat per copingstrategie de geïdentificeerde stijlen en toepassingen (gedragsvoorbeelden) samen. In het onderzoek willen we de werking van deze stijlen en gedragingen expliciteren, in het bijzonder de stijlen en gedragsvoorbeelden die in de als middelste (gearceerd) weergegeven categorie naar voren komen. We onderzoeken hoe de beleidsmaker tot de taxatie komt om van deze strategie gebruik te maken. De copingstrategie 'meebewegen' is uitgewerkt naar een aantal gedragsvoorbeelden, die we - evenals de andere twee onderscheiden stijlen - doorvertalen in specifiekere toepassingen (gedragsvoorbeelden).

Tabel 7.2. Copingstijlen per strategie

\begin{tabular}{|c|c|c|}
\hline Wegbewegen & Meebewegen & Tegenbewegen \\
\hline Ontlopen: & Inleven: & Confronteren: \\
\hline $\begin{array}{l}\text { Vermijden, afschuiven, } \\
\text { opschalen, opknippen, grapjes } \\
\text { maken, wegwuiven, uitstellen, } \\
\text { bagatelliseren }\end{array}$ & $\begin{array}{l}\text { Tot } 10 \text { tellen, v(ert)ragen, } \\
\text { luisteren, judo }\end{array}$ & $\begin{array}{l}\text { Overtuigen, beperkingen } \\
\text { opleggen, ruilen, schaarste } \\
\text { suggereren }\end{array}$ \\
\hline Ritualiseren: & Overeenkomen: & Forceren: \\
\hline $\begin{array}{l}\text { Regels en procedures inbrengen, } \\
\text { in sfeer, vorm en aankleding } \\
\text { investeren, gelijkwaardigheid } \\
\text { benadrukken, apaiseren }\end{array}$ & $\begin{array}{l}\text { Accepteren van weerstand, } \\
\text { vertwijfelen, overnemen } \\
\text { voorstellen en perspectieven } \\
\text { vinden }\end{array}$ & $\begin{array}{l}\text { Opleggen, voorschrijven, } \\
\text { emotioneel beroep, an offer } \\
\text { you can't refuse, intimideren, } \\
\text { commitment and consistency, } \\
\text { doordrukken }\end{array}$ \\
\hline & $\begin{array}{l}\text { Herformuleren: } \\
\text { Reframing, herformatteren, } \\
\text { onderliggende of hogere belangen } \\
\text { (her)benoemen, of op de voorgrond } \\
\text { plaatsen (front-staging) }\end{array}$ & \\
\hline
\end{tabular}

Drie primaire factoren oefenen invloed uit op de taxatie van de klus die voorligt: persoonlijke hulpbronnen, professionele drijfveren en ambtelijk besef. Het conceptueel model veronderstelt dat naast deze drie primaire factoren drie invloedsfactoren een secundaire en ondersteunende rol kunnen spelen: de beschikbaarheid van sociale steun, de mate waarin men zicht heeft op resultaat (impact) van beslissingen en de ruimte in de organisatie voor reflectie en leren. Aan de voorgaande verkenningen en onderzoeken ontlenen we per factor enkele specifieke indicatoren, die in paragraaf 6.6. ('Invloedsfactoren: zes hefbomen') zijn toegelicht; bij wijze van leeswijzer vatten we deze (zes) factoren en de onderscheidende indicatoren samen in tabel 7.3. Bij de factoren zijn de indicatoren op basis van paragraaf 6.6. van een toelichting voorzien. 


\begin{tabular}{|c|c|}
\hline Primaire factoren & Toelichting \\
\hline $\begin{array}{l}\text { 1. Persoonlijke hulpbronnen } \\
\text { Indicatoren: } \\
\text { - Extraversie } \\
\text { - Inschikkelijkheid } \\
\text { - Zorgvuldigheid } \\
\text { - Emotionele stabiliteit } \\
\text { - Openheid, proactiviteit }\end{array}$ & $\begin{array}{l}\text { De vijf persoonlijkheidseigenschappen van de ‘Big } \\
\text { Five'-typologie worden als graadmeters gebruikt voor } \\
\text { de mate waarin iemand geneigd is bij (vermeende) } \\
\text { weerstand contact aan te gaan. Ze indiceren de } \\
\text { gerichtheid op anderen, de openheid, wijze van } \\
\text { bejegening en de volharding bij een gekozen aanpak. }\end{array}$ \\
\hline $\begin{array}{l}\text { 2. Professionele drijfveren } \\
\text { Indicatoren: } \\
\text { - Roeping (i.t.t. baan of carrière); engagement } \\
\text { - Beroepstrots; spel } \\
\text { - Publieke opgaven; politieke betrokkenheid } \\
\text { - Gewaagde doelen; reis volbrengen } \\
\text { - Waarden-vol }\end{array}$ & $\begin{array}{l}\text { Wie zijn werk opvat als een roeping, zal eerder } \\
\text { geneigd zijn een uitdaging op te zoeken bij mogelijke } \\
\text { weerstand dan wie werk louter als een baan ziet of } \\
\text { een stap in een carrière. } \\
\text { Hij of zij spreekt eerder van 'spel', trots en het } \\
\text { nastreven van een gewaagd doel ('reis') en oog } \\
\text { voor publieke misstanden of juist kansen in de } \\
\text { samenleving. } \\
\text { Een andere professionele indicator is de aandacht } \\
\text { voor (processuele) waarden en streven naar } \\
\text { betrokkenheid, meedoen. }\end{array}$ \\
\hline $\begin{array}{l}\text { 3. Ambtelijk besef } \\
\text { Indicatoren: } \\
\text { - Herkennen van systeemspanningen } \\
\text { - Hanteren van strategieën } \\
\text { - Inspelen op bij rollen en belangen door passende } \\
\text { frames in woord en beeld }\end{array}$ & $\begin{array}{l}\text { Wie 'weet hoe de hazen lopen' (h)erkent eerder } \\
\text { spanningen: tussen vakmanschap en bestuurlijke } \\
\text { verantwoordelijkheid, tussen beheersbaarheid } \\
\text { en democratische besluitvorming en tussen } \\
\text { belangenafweging en rechtsstatelijkheid. } \\
\text { Hij of zij kan: de politieke arena in stelling brengen, } \\
\text { de bureaucratie gebruiken, complexiteit erkennen en } \\
\text { de maatschappelijke omgeving laten werken. } \\
\text { Tot slot scoren we op vaardigheid in het ordenen } \\
\text { van informatie, argumenteren en creëren van } \\
\text { gemeenschappelijke beelden. }\end{array}$ \\
\hline
\end{tabular}




\begin{tabular}{|c|c|}
\hline Secundaire factoren & Toelichting \\
\hline $\begin{array}{l}\text { 4. Sociale steun } \\
\text { Indicatoren: } \\
\text { - Nabijheid, beschikbaarheid van sociale steun } \\
\text { op de werkvloer } \\
\text { - Vormen van steun: } \\
\text { - Perceived internal prestige }\end{array}$ & $\begin{array}{l}\text { Wie doen ertoe als het gaat om de sociale omgeving: } \\
\text { collega's, gesprekspartners en het thuisfront. } \\
\text { Daarbij onderzoeken we de vorm van de steun: } \\
\text { welke vorm doet zich voor: alledaagse, emotionele, } \\
\text { instrumentele en informele steun en waardering); } \\
\text { idem in persoonlijke levenssfeer. } \\
\text { De waargenomen beeldvorming (bijvoorbeeld media- } \\
\text { aandacht) kan ook steun geven (of wegnemen). }\end{array}$ \\
\hline $\begin{array}{l}\text { 5. Zicht op resultaat } \\
\text { Indicatoren: } \\
\text { - Concreetheid van de opdracht } \\
\text { - Snelheid van de vervulling (versus stroperigheid) } \\
\text { - Inzicht in impact (afstand tot resultaat) } \\
\text { - Helderheid over taak/territorium/tijd/rol } \\
\text { - Ervaring met soortgelijke opgaven } \\
\text { (hoe complexer hoe relevanter) } \\
\text { - Feedback van directe leidinggevenden/ } \\
\text { bestuurders/influentials (relatie met factor 4) }\end{array}$ & $\begin{array}{l}\text { Hoe kleiner de afstand tot de effecten van } \\
\text { werkzaamheden, hoe groter de kans dat de } \\
\text { beleidsmaker de impact van werkzaamheden } \\
\text { ontmoet. } \\
\text { De kennis en vooral de ervaring van de ontmoeting } \\
\text { telt, wie vanachter een bureau oordeelt handelt } \\
\text { anders dan degene die tussen de mensen in staat. } \\
\text { Die afstand is bepalend voor terugkoppeling en } \\
\text { bijsturing. } \\
\text { Helderheid over processen is een andere indicator, } \\
\text { hoe langer een proces duurt, hoe groter de kans dat } \\
\text { vertekeningen plaatsvinden. }\end{array}$ \\
\hline $\begin{array}{l}\text { 6. Ruimte voor reflectie } \\
\text { Indicatoren: } \\
\text { - Koppeling tussen gedrag en leren } \\
\text { - Programma's voor introductie, intervisie, e.d. } \\
\text { - Ervaren vrijheid, zingeving en gelijkheid } \\
\text { - } \text { Agendering van de ervaren verantwoordelijkheid, } \\
\text { rechtvaardigheid/ moeilijkheid in dagelijks werk } \\
\text { - Vorming van institutionele kennis; moresprudentie }\end{array}$ & $\begin{array}{l}\text { De aanwezigheid van een lerende omgeving schept } \\
\text { voorwaarden om te bespreken wat niet liep als } \\
\text { beoogd, om fouten te maken ook. } \\
\text { In welke mate is in de organisatie ruimte ingebouwd } \\
\text { om te leren en te reflecteren, gevraagd en } \\
\text { ongevraagd? } \\
\text { Naast vormingsgerichte activiteiten gaat ook } \\
\text { aandacht uit naar de mate waarin sprake is van } \\
\text { duurzame aandacht voor (borgen van) lessen van } \\
\text { medewerkers. }\end{array}$ \\
\hline
\end{tabular}




\subsection{Onderzoeksopzet}

In deze paragraaf worden de onderzoeksmethoden toegelicht.

\section{Casestudies}

De casestudy is: 'an empirical inquiry that investigates a contemporary phenomenon within its real life context; when the boundaries between phenomenon and context are clearly evident; and in which multiple sources of evidence are used' (Yin, 1984). Volgens Huttner, Renckstorf en Wester (1995) biedt een casestudy bij uitstek de mogelijkheid om op één eenheid een groot aantal aspecten of kenmerken in relatie tot elkaar te onderzoeken. De terminologie van Czarniawska spreekt daarbij aan, die van 'window studies' rept: 'a researcher opens an arbitrary window and describes all that can be seen through it' (1989). De onderzoeker bestudeert verschijnselen in een natuurlijke situatie met inbegrip van hun brede context en gebruikt daarbij meerdere gegevensbronnen naast elkaar. Bovendien kunnen waarden en betekenissen, die weliswaar in een specifieke context tot stand zijn gekomen, getransformeerd worden naar een breder begrijpen van de sociale wereld om ons heen (Tsoukas \& Knudsen, 2003). We hebben in onze aanpak daarom meerdere bronnen naast elkaar benut en in verband gebracht met elkaar ('triangulatie', Yin, 1994). We volgend daarbij de uitwerking van Miles en Huberman (1994) die vier typen methoden onderscheiden: (a) interviews, (b) documentanalyse, (c) observaties en als variant op het laatste (d) gecreëerde waarnemingssituaties.

De casestudy kan daarbij gebruikt worden voor het gedetailleerd beschrijven van een 'critical case' (Flyvbjerg, 2006) teneinde vast te stellen of een theorie opgaat, Zijns inziens geldt dit vooral als verhalen een substantieel element zijn. Hij onderstreept de betekenis van de 'intuïtie' van de onderzoeker en opent hartstochtelijk de weg naar 'participerende observatie' als onderzoeksvorm voor de casestudy. In de inleiding hebben we de betekenis onderstreept van het onderzoeken vanuit het netwerk van de onderzoeker: hierdoor is sprake van een laagdrempelige toegang van de onderzoeker tot de respondenten en de context waarin zij hun werk doen. Eisenhardt (1989) merkt overigens op dat de invloed van subjectiviteit bij deze onderzoeksvorm te veel gewicht wordt toegekend en Flyvbjerg voert aan dat subjectiviteit een gegeven is voor alle studies. Hij meent dat het juist de betrokkenheid van de onderzoeker bij het onderzoeksobject is, die het mogelijk maakt tot echte waarnemingen te komen: 'If one assumes that reserarch, like other learning processses, can be described by the phenomenology for human learning, it then becomes clear that the most advanced form of understanding is achieved when researchers place themselves within the context being studied. Only in this way can researchers understand the viewpoints and the behaviour, which characterizes social actors'. Dit is in het bijzonder aan de orde bij het voeren van vraaggesprekken. Het betekent de facto dat niet alleen het perspectief van de onderzoeker ruimte krijgt maar er ook ruimte is 'om aan te sluiten bij de behoefte van de participant om bij sommige zaken iets langer stil te staan, door met interesse te luisteren en door hem zijn verhaal te laten afmaken'. Boeije (2005), die hierop wijst, maakt ook attent op de betekenis van één groot interview 
ten opzichte van langdurige aanwezigheid in een casus-omgeving. In het laatste geval kan gewenning en aanpassing ontstaan bij zowel onderzoeker als onderzochte ('reactiviteit'). Omwille van de betrouwbaarheid, validiteit en overdraagbaarheid (in paragraaf 1.5.is uiteengezet waarom aan dit begrip voorkeur is gegeven boven het begrip generaliseerbaarheid) is naast het ontwerp van het interviewprotocol de keuze voor de O-sort methode en de terugkoppeling van onderzoeksgegevens van belang.

\section{Critical incident methode}

We vlechten in deze aanpak de critical incident methode, vanwege de krachtige betekenis van 'sleutelmomenten' bij de ervaring en bewustwording van de impact van persoonlijk professioneel handelen. De methode is als eerste uitgebreid beschreven door Flanagan in 1954 (Zwijze-Koning \& De Jong, 2005) en werd in eerste instantie gebruikt om taakomschrijvingen te maken, die gebaseerd waren op daadwerkelijke observaties uit het werkveld. In het onderzoek bepaalt de respondent wat een gebeurtenis 'kritiek' maakt. Het is immers zijn of haar houding en interpretatie die onderzocht wordt. Zwijze-Koning en De Jong hebben de betekenis van de methode voor de communicatie van organisaties onderzocht. De waarde schuilt om te beginnen in het doordringen binnen een specifieke beroepsgroep. De methode blijkt van alle beschikbare methoden bij uitstek houvast te bieden bij het helpen zien van wat iemand als wezenlijk ervaart. Concrete alledaagse gebeurtenissen worden door de explicitering van individuele keuzes voorzien van feedback, suggesties, waarde-oordelen en alternatieven. Dat maakt de methode ook als vorm van leren in organisaties interessant. Aan de hand van situaties uit de praktijk kunnen abstracties als bijvoorbeeld 'bejegening' of 'weerstand' worden geconcretiseerd. Voor het onderzoek betekent dit dat we de geïnterviewden vragen om aan de hand van een 'sleutelmoment' hun verhaal te doen.

\section{Q-sort methode}

Voor het expliciteren van de copingstrategieën hebben we aan het slot van de interviews een controle ingevoegd om de respondent zelf de gehanteerde copingstrategie te laten benoemen. De Q-sort methode bestaat uit het voorleggen van een aantal beweringen. Deze beweringen worden door de respondent in een rangorde geplaatst, aan de hand van een schaal (zeer eens tot zeer oneens). De schaal is gespiegeld, wat betekent dat scores kunnen worden gemaakt op basis van een mate van instemming of juist afwijzing. De Q-sort is in dit onderzoek nadrukkelijk aan het slot van het vraaggesprek toegepast, om geen richting te geven aan de uiting van copingstrategien. Het ordenen van de beweringen biedt de respondent gelegenheid om gedragsvoorkeuren expliciet te maken die in de voorafgaande bespreking naar voren werden gebracht. Volgens Ten Klooster, Visser en De Jong (2008) is een belangrijk voordeel van de methode dat het directe inzichten verschaft in aannames van mensen ten aanzien van vraagstukken. In de onderzoeksopzet is bij de Q-sort iedere respondent ook gelegenheid meegegeven feedback te geven op keuze uit de beweringen. De beweringen zijn geënt op de onderscheiden drie copingstijlen en gedragsvoorbeelden (zie de samenvatting in 7.2.). 
Tabel 7.4. Q-sort: beweringen per copingstrategie

\begin{tabular}{|c|c|c|c|}
\hline Copingcategorie & Bewering & Nummer & $\begin{array}{l}\text { Corresponderend } \\
\text { gedragsvoorbeeld }\end{array}$ \\
\hline Wegbewegen & $\begin{array}{l}\text { Dit hoort niet op mijn bordje } \\
\text { Er zijn ergere dingen in de wereld } \\
\text { Hier zijn gelukkig procedures en } \\
\text { commissies voor }\end{array}$ & $\begin{array}{l}\text { I } \\
\text { II }\end{array}$ & $\begin{array}{l}\text { Vermijden, afschuiven, opschalen } \\
\text { Wegwuiven, grapjes, bagatelliseren } \\
\text { Ritualiseren }\end{array}$ \\
\hline Meebewegen & $\begin{array}{l}\text { Weerstand maakt nieuwsgierig } \\
\text { Zoeken naar een gedeeld belang } \\
\text { of waarde } \\
\text { Wat kan wel? }\end{array}$ & $\begin{array}{l}\text { IV } \\
\text { V } \\
\text { VI }\end{array}$ & $\begin{array}{l}\text { Inleven, twijfel expliciteren, } \\
\text { v(ert)ragen } \\
\text { Herformuleren, herbenoemen } \\
\text { Overeenkomstig belang of } \\
\text { waarde vinden }\end{array}$ \\
\hline Tegenbewegen & $\begin{array}{l}\text { Zonder bluf ben je nergens } \\
\text { Soms moet je doorduwen } \\
\text { We kunnen niet bezig blijven }\end{array}$ & $\begin{array}{l}\text { VII } \\
\text { VIII } \\
\text { IX }\end{array}$ & $\begin{array}{l}\text { Intimideren } \\
\text { Emotioneel beroep } \\
\text { Doordrukken }\end{array}$ \\
\hline
\end{tabular}

De beweringen zijn ongesorteerd en ongemarkeerd aan het slot van interviews voorgelegd. Na afloop zijn ze van de hierboven aangegeven arcering voorzien. In de weergave van de casestudies zien we de arcering terug. Zie voor de codering bijlage III.

\section{Aantal cases}

Over het optimale aantal te onderzoeken cases lopen opvattingen uiteen. Casestudypionier Yin (1994) werkt een 'single cases embedded design' uit en erkent de beperkingen voor generaliseerbaarheid van uitkomsten. Eisenhardt (1989) wijst op de betekenis van extreme voorbeelden. Zij haalt Pettigrew (1988) aan voor de stelling dat it makes sense to choose cases as extreme situations and polar types in which the proces of interest is 'transparantly observable'. In feite is dat aan de orde in dit onderzoek, doordat we op zoek zijn gegaan naar situaties waarin achteraf bezien sprake was van één specifieke copingstrategie, namelijk 'meebewegen. Flyvbjerg (2008) noemt het een misvatting dat op basis van één case geen generaliseerbare conclusies kunnen worden getrokken. Volgens deze auteur zijn er geen theorieën in de sociale wetenschappen die gezaghebbend voorschrijven dat je meer dan één case moet bestuderen. Hij wijst daarbij op een overdrijving van feitenonderzoek ten opzichte van de betekenis van adequate waarnemingen. Ook bij Huttner, Renckstorf én Wester (1995) vinden we een relativering van de vraag of het één of meer casestudies betreft ondergeschikt aan de vraag of de studie houvast biedt om de onderzochte aspecten of 
eenheden te bestuderen. Opgemerkt wordt ook dat een casestudy is op te vatten als meerdere onderzoeken ineen: 'Het is geen techniek, maar een type onderzoek'. Tegelijk is het evident dat bij het doormeten van individuele prestaties en meerdere factoren - zoals in het voorliggende onderzoek - het voor de hand ligt meerdere vergelijkende studies een rijker beeld verschaffen. Tsoukas (2009) heeft in het bijzonder onderzoeken met een gering aantal casestudies onderzocht ('small-N-studies') en weerspreekt de kritiek dat hierbij sprake is van een beperkte waarde uit oogpunt van generaliseerbaarheid. Sterker nog, de klassieke hang naar generalisatie doet de werkelijkheid geweld aan, meent hij: 'It is not so much analytical generalization that small-N studies aid, as analytical refinement (of heuristic generalization). By doing so the craving for generality is not the craving for subsuming particular instances under general laws or mechanisms, but the craving for a clearer view - higher elucidation'. Hij haakt bij Flyvbjerg aan; casestudies met een beperkt aantal cases onderzoekers bieden 'a better chance to be creative since proximity to reality and feedback from the object of study forcxe researchers to test analogically derived conceptions of what is going on'. In de goede traditie van kwalitatief onderzoek bieden de casestudies meer houvast voor het observeren van de betekenis van de context waarbinnen mensen waarnemen, overwegen, handelen - en daarop te reflecteren. Casestudies leveren volgens Tsoukas bij uitstek een bijdrage aan gesprekken in organisaties, hetgeen aansluit op onze onderzoeken naar ambtelijke gedragingen. 'Small $\mathrm{N}$-studies do not present a map but a portrait of the world that acts as an aid to perception'.

\section{Caseselectie}

We hebben in drie casestudies individuele beleidsambtenaren bevraagd over hun taxatie van een lastige beleidsopgave. Dit aantal biedt op voorhand voldoende gelegenheid voor vergelijking van gegevens. De cases zijn geselecteerd aan de hand van zes criteria: (a) complexiteit (aard en omvang van het krachtenveld); (b) controversialiteit (intensiteit van tegenstellingen); (c) motivatie van betrokken beleidsmedewerkers en hun leidinggevenden om mee te werken; (d) focus op de aanvangsfase van een beleidsopgave; (e) respondent heeft een bepalende verantwoordelijkheid voor het dossier en ( $f$ ) een achteraf als bevredigend gekwalificeerde uitkomst. Dit onderzoek is daarmee nadrukkelijk gericht op best practices, teneinde de werking van de copingstrategie 'meebewegen' en de beïnvloedende factoren in beeld te brengen. Dat is ons doel. Dit betekent dat cases zijn geselecteerd op basis van aanwijsbare weerstand en een beschikbare beoordeling dat de betrokken beleidsmakers die weerstand niet uit de weg zijn gegaan, maar hebben opgezocht (in de vorm van mediaberichten of documenten). De cases werden geselecteerd bij één bestuurlijke organisatie om over vergelijkbare onderzoeksgegevens te kunnen beschikken; de focus op Rotterdam hangt samen met de motivatie om lessen te trekken uit dit onderzoek voor de praktijk bij de eigen werkgever. Dit heeft geleid naar drie casestudies, die we in tabel 7.5. kort introduceren. 
I. Bezuiniging op subsidie diergaarde Blijdorp: 'Een zachte landing'

Op 7 oktober 2010 presenteert de gemeente Rotterdam de Begroting voor 2011. Bij die gelegenheid wordt een reeks bezuinigingen op gemeentelijke subsidies bekendgemaakt. Daartoe behoort het voorstel aan de gemeenteraad om de jaarlijkse bijdrage aan Diergaarde Blijdorp af te bouwen. De korting behoort tot de zwaarste ingrepen op de gemeentelijke rol. In vijf jaar tijd zal de subsidie worden teruggebracht van $€$ 4,3 miljoen naar $€ 800.000$ per jaar. Teleurstelling volgt bij de leiding en medewerkers van de grootste attractie van Rotterdam en de grootste dierentuin van het land. Kritische geluiden steken de kop op, er volgt een gesprek met de gemeente, een demonstratie en inspraak in de gemeenteraad. Die stemt in met de voorgenomen bezuiniging, op voorwaarde dat sprake zal zijn van 'een zachte landing'. We volgen de gemeenteambtenaar die leiding geeft aan de voorbereiding van de bezuinigingsvoorstellen en de uitvoering van het raadsbesluit ${ }^{10}$. Hij is tevens directeur van de dienst Sport en Recreatie.

II. Opvang voor ex-prostituees: 'Een omstreden opvang'

In 2002 besluit een nieuw college van B\&W in Rotterdam, bestaande uit CDA, VVD en Leefbaar Rotterdam de 'tippelzone' aan de Keileweg te sluiten. Voor de opvang van de ex-prostituees worden deelgemeenten benaderd en besluit het college uiteindelijk om in de wijk Katendrecht de opvang te realiseren. Dat besluit wordt na veel verzet teruggedraaid, waarna de deelgemeente Feijenoord opvang in een pand aan de Oranjeboomstraat voorstelt. Op 16 februari belegt de deelgemeente een bewonersavond. De uitnodiging leidt naar een drukbezochte en emotionele uitbarsting: protesten en verwijten domineren in de plaatselijke Persoonshal. De bewonersorganisatie voert het protest aan: waarom zijn ze in het besluit niet eerder betrokken, waarom moeten er zoveel vrouwen worden opvangen en waarom is de voorziening pal naast een kinderdagverblijf gepland? Het deelgemeentebestuur likt zijn wonden en besluit dan tot een andere aanpak. Er komt een gespreksronde langs instellingen en groeperingen die een gemeenschappelijke oriëntatie op het vraagstuk oplevert en uiteindelijk tot de opening van de opvangvoorziening. We volgen de deelraadsvoorzitter, tot kort daarvoor gemeenteambtenaar. Na de bestuursperiode krijgt hij, weer ambtenaar, opnieuw met een complex opvangproject te maken. We betrekken deze overstap bij onze beschrijving, vanwege de doorwerking van inzichten en ervaringen in Feijenoord.

\footnotetext{
${ }^{10}$ Alle personen zijn in dit onderzoek met een initiaal van de voornaam aangeduid.
} 


\section{Watercompensatie vanwege bouw parkeergarage: 'Een transparante bedding'}

Voorjaar 2009 besluit de gemeente Rotterdam om een parkeergarage te bouwen in Kralingen. Voor de bouw van de garage moet water worden onttrokken aan de grond en volgens de geldende wetgeving dient die onttrekking elders in de directe omgeving gecompenseerd te worden. Een projectleider van het ingenieursbureau van de dienst Gemeentewerken krijgt de opdracht om een inrichtingsplan voor te bereiden. Hij vormt een planteam en start de planontwikkeling voor 'de Groene Corridor': een naam die het project dankt aan de functie van de langgerekte ecologische verbindingszone voor flora en fauna, waar de watercompensatie zal worden gerealiseerd. We volgen de projectleider bij de realisatie van zijn opgave.

De respondenten zijn benaderd met de vraag om mee te werken zonder voorafgaande uiteenzetting van de copingstrategien en de (zes) beïnvloedende factoren. In de uitnodiging is meegedeeld dat het onderzoek betrekking heeft op 'de omgang met lastige opgaven' en uitgaat van de veronderstelling dat hen dit in het genoemde dossier is gelukt. In alle gevallen heeft een voorbereidend gesprek plaatsgevonden waarin werkwijze en de verwerving van secundaire bronnen (documenten, mail en mediaberichten) centraal stond". De interviews vonden plaats in de periode april-juni 2011.

\section{Analyse en verwerking}

'Analyseren is de uiteenrafeling van de gegevens overeen bepaald onderwerp in categorieën, het benoemen van deze categorieën met begrippen, en het aanbrengen en toetsen van relaties tussen de begrippen in het licht van de probleemstelling' (Boeije, 2005). Alle vraaggesprekken zijn op de band opgenomen en volledig uitgewerkt in transcripties. leder interview werd gevoerd aan de hand van een semi-gestructureerde vragenlijst. In bijlage III zijn de vragen- en scorelijsten te vinden. Deze zijn gebaseerd op de in paragraaf 7.2. weergegeven kenmerken van copingstijlen (tabel 7.2.) en beïnvloedende factoren (tabel 7.3.). De analyse van de resultaten is gestart met een codering van transcripties en andere brondocumenten (notities, verslagen en knipsels) aan de hand van een voorgestructureerde indeling op basis van de copingstijlen en beïnvloedende factoren. Voor de coping-analyse heeft codering plaatsgevonden aan de hand van kleuren (zie ook tabel 7.4.). Op deze manier heeft er terreinverkenning plaatsgevonden en is het begrippenkader in de tabellen 7.2. en 7.3. verder

\footnotetext{
11 Aan het reconstructiegesprek voor casestudy I nam ook de beleidsadviseur deel, die P. bij dit dossier ondersteunde, R. Ten behoeve van de dataverzameling voor casus II is ook een achtergrondgesprek gevoerd met een communicatieadviseur, met wie W. samenwerkte, J.
} 
aangescherpt. Vervolgens zijn de gegevens uitgewerkt, om te beginnen in een chronologisch feitenrelaas en vervolgens in een beschrijving van achtereenvolgens de geïdentificeerde coping en onderliggende gedragsvoorbeelden en de werking van de beïnvloedende factoren en onderliggende indicatoren. Met oog op de betrouwbaarheid zijn strikt de beschreven factoren en onderliggende gedragsvoorbeelden respectievelijk indicatoren aangehouden, in het volle besef overigens dat het hier een kwalitatief onderzoek betreft en dientengevolge minder gestandaardiseerd gewerkt kan worden dan bij kwantitatieve metingen. De aandacht hiervoor maakt het mogelijk dit onderzoek te herhalen c.q. uit te breiden over meerdere cases. 'Door een juiste verantwoording kan er worden nagegaan of er vertrouwen bestaat in de uitkomsten van het onderzoek' (Boeije, 2005). Ook de Q-sort bood in ieder vraaggesprek ruimte voor een terugkoppeling en aanvullende reflecties. Deze zijn ook op de band opgenomen en in de casebeschrijvingen verwerkt. Na individuele cases zijn de uitkomsten geaggregeerd. Aan het eind van de gegevensverwerking heeft een terugkoppeling plaatsgevonden van de bevindingen. De conceptteksten van de hierna uitgewerkte casebeschrijvingen evenals de conclusies zijn aan de respondenten voorgelegd. Hierbij is gelegenheid gegeven om uitspraken te nuanceren en toevoegingen te plaatsen.

Tot slot een opmerking over de validiteit. 'Validiteit heeft betrekking op de beïnvloeding van het onderzoek door systematische fouten. Wanneer de onderzoeker dan ook meet of verklaart wat hij daadwerkelijk wil meten of verklaren, wordt dat opgevat als validiteit' (Boeije, 2005). Onderdeel van het onderzoek was dat de respondenten niet voorafgaand aan het onderzoek inzage kregen in de copingstrategien en beïnvloedende factoren. Beschrijving van de codering, transcripties van de interviews en de Q-sort evenals de terugkoppeling aan de respondenten dragen bij op dit punt. Het overeenkomen van casebeschrijvingen en $\mathrm{O}$ sort versterkten de validiteit van het onderzoek op basis waarvan de uitspraak kan worden gedaan dat sprake is van representatie van de werkelijkheid.

In schema ziet de onderzoeksaanpak er als volgt uit:

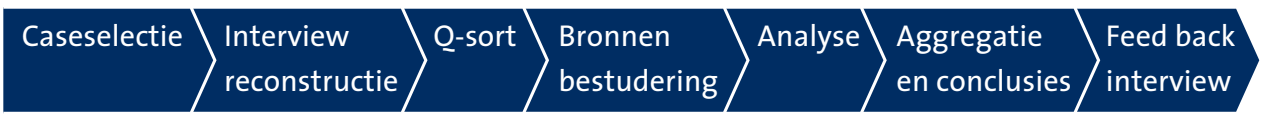

Figuur 7.2. Onderzoeksaanpak casestudies

\subsection{Casestudy 1 - Een zachte landing}

\subsubsection{Kroniek van het proces}

In deze paragraaf zetten we de casussituatie uiteen; tabel 7.6. vat het feitenrelaas samen. Bij het aantreden van een nieuw Rotterdams college van B\&W in mei 2010 wordt duidelijk dat de gemeente fors zal gaan bezuinigen. Uit het coalitieakkoord kan worden opgemaakt welke bakens worden verzet. Zo zal op het vlak van sport en recreatie voorrang 
worden gegeven aan sportstimulering en -participatie. Op 24 juni stuurt de gemeente naar alle gesubsidieerde instellingen een brief. Het college van B\&W roept op tot terughoudendheid bij het aangaan van nieuwe verplichtingen en idem bij de vervulling van externe vacatures. De brief bevat ook de uitnodiging 'alvast concreet na te denken over mogelijke besparingen'. Als later de zomer de directeur van de Diergaarde een kennismakingsgesprek heeft met de nieuwe wethouder volgt een bevestiging van de kritieke financiële situatie, die de in dat gesprek aangekondigde uitbreidingsplannen helpen dempen. Het college besluit bij de bespreking van de begrotingsvoorstellen eind september 2010 tot een presentatie van de directeur Sport \& Recreatie over de gevolgen van een korting in de B\&W-vergadering. Een overweging hierbij is het beeldbepalende karakter van de stedelijke attractie en de jarenlange relatie tussen gemeentebestuur en diergaarde. De Diergaarde heeft sinds 1948 een subsidierelatie met de gemeente. Sinds 1988 kent de stichting een Raad voor Toezichtmodel, waarbij ze op grotere afstand van de gemeente is komen te staan. In deze raad hebben prominenten uit de samenleving zitting, waaronder een lid van de Koninklijke familie en een vertegenwoordiging van het Rotterdamse bedrijfsleven en de universiteit. De gemeente heeft het recht om één lid van de raad voor te dragen maar maakt hiervan geen gebruik. Het college oordeelt naar aanleiding van de presentatie door de dienst dat de diergaarde zichzelf kan bedruipen en met een aanzienlijk lagere subsidie kan volstaan. Kostenbesparingen zijn mogelijk, evenals tariefsverhoging en er zijn mogelijkheden voor het genereren van meer externe gelden (sponsoring). De focus van de gemeentelijke bijdrage zou kunnen komen te liggen op educatieve activiteiten en behoud van uitstervende diersoorten. Het besluit tot subsidievermindering wordt opgenomen in de begroting.

Op de ochtend van 7 oktober worden de gemeenteraad, de media en om te beginnen alle betrokken instellingen ingelicht. In een gemeentelijk draaiboek is opgenomen dat op basis van de grootte van de korting de wethouder dan wel de verantwoordelijke dienstdirecteur de tijding zal brengen. Ook zijn gemeenschappelijke kernboodschappen voor de bewijsvoering aangereikt die het financiële knelpunt van de gemeente onderstrepen - 'het geld is op' -, de procesgang incluis bezwaarmogelijkheden en een inhoudelijke afweging per beleidsonderdeel toelichten, zoals bij sport en recreatie de focus op sportparticipatie. De verantwoordelijke wethouder belt die ochtend met de directeur van de diergaarde over het collegevoornemen en kondigt de brief aan waarin de korting en de verdere procedure worden toegelicht.

Het is een bijzondere samenloop van omstandigheden, dat juist die middag de feestelijke opening plaatsvindt van een hernieuwde poort van de diergaarde. Lang voor het bepalen van deze datum is echter de 7e oktober geprikt om de gemeenteraad over het volle pakket bezuinigingen te informeren; de mondelinge mededeling vergt dus geen uitstel. De wethouder en de directeur van de gemeentelijke dienst Sport en Recreatie bezoeken de bijeenkomst. Uit de gesprekken die dag blijkt de teleurstelling - bij allen; de een jaar eerder vertrokken voorganger van de huidige directeur van de diergaarde spreekt tegenover P. van een zwarte dag voor Nederland. 
De brief van 7 oktober refereert aan de 'winstwaarschuwing' van 24 juni en bevat een staatje waaruit kan worden opgemaakt hoe de jaarlijkse subsidie zal worden afgebouwd. De diergaarde krijgt de gelegenheid haar zienswijze kenbaar te maken, ook schetst de brief de bestuurlijke stappen: een inspreekmoment op 25 oktober in de raadscommissie en de begrotingsbehandeling op 11 november. De diergaarde gaat in op de uitnodiging voor een 'Zienswijzegesprek'. Op 13 oktober maakt de directie van de dierentuin duidelijk hoe zwaar de boodschap is gevallen en welke risico's ze ziet voor de bedrijfsvoering en het voortbestaan. Lopende verplichtingen kunnen mogelijk niet worden afgelost. Ze appelleert aan de betekenis van de diergaarde voor Rotterdam en vraagt vooral aandacht voor de snelheid waarmee bezuinigd zal worden. De diergaarde besluit tot een demonstratieve optocht naar het stadhuis op de dag dat ook de commissievergadering plaatsvindt. Daar houden de directeur van de diergaarde en een vrijwilliger begeesterde betogen. Naast de historische banden tussen stad en diergaarde wijzen ze op het maatschappelijk belang van de topattractie voor het lokale imago, de betekenis voor Rotterdammers en de werkgelegenheidseffecten. Berichten in de media maken duidelijk hoezeer Rotterdammers de diergaarde in hun armen hebben gesloten. Dat blijkt ook als op de 7 november, enkele dagen voor het raadsdebat over de begroting een gratis open dag wordt belegd. Een massale toestroom van 46.500 bezoekers is het gevolg. Er worden 107.000 handtekeningen verzameld, die voorafgaand aan de raadsvergadering aan de burgemeester worden aangeboden.

Als op 11 november de gemeenteraad over de begroting 2011 spreekt, worden twee moties aangenomen die 'een zachte landing' van de bezuiniging vragen: de wethouder krijgt de opdracht om samen met de diergaarde naar mogelijkheden te zoeken om de kortingen op te vangen. Die uitkomst is voor de directeur van de dienst Sport en Recreatie aanleiding voor een initiatief. Op 18 november formuleert hij een lijstje met 11 'actiepunten'. Ze betreffen de liquiditeitspositie, de kostenstructuur, de onderhoudsaanpak, de prestatie-indicatoren voor de subsidiebeschikking, duurzaamheid, werkgelegenheid, arbeidsvoorwaarden, fokprogramma's, verhogen van de inkomsten en de bestemming van een geschenk van de gemeenteraad (een bedrag van $€ 4,5$ miljoen bij het 150 jarig bestaan voor renovatie van de Rivièrahal). Hij nodigt de directeur van Blijdorp uit voor een bespreking. Vanaf 2 december zal aan de hand van de actiepuntenlijst tweewekelijks samen worden vergaderd om de voortgang te bespreken. Er vinden zes gesprekken plaats waarin gaandeweg opgaven van oplossingen worden voorzien. Aan de gesprekken neemt een vaste kern deel; vanuit de dienst zijn dat de directeur, een beleidsadviseur en de controller, vanuit de diergaarde de directeur, diens controller, hoofd communicatie en hoofd personeel en organisatie. De gemeentelijke dienst betrekt diverse specialisten van gemeentelijke diensten bij de expeditie, zoals experts op het gebied van monumenten, personeel en organisatie en financiën. Aldus komen nieuwe perspectieven op tafel. Zoals de aanbesteding van het onderhoud, de overgang van een overheids- naar een CAO die past bij de leisuresector, de berekening van tarieven voor de toegang en de horeca en de gebruikmaking van mantelcontracten van de gemeente. Via de dienst Sport en Recreatie wordt binnen de gemeente beschikbare expertise aangeboord en gedeeld met de diergaarde. Zes gesprekken vinden plaats. Op tafel ligt steeds een voortrollende actielijst waarin per 
actiepunt de verantwoordelijke 'actiehouder', deadline en status. De gemeenschappelijke probleemoplossing resulteert eind april 2011 in een concept-raadsvoorstel, waarin uiteen wordt gezet hoe op alle genoemde punten voorzieningen kunnen worden getroffen en 'de zachte landing' naar de mening van diergaarde en gemeente bewaarheid kan worden. De uitkomsten worden betrokken bij de voorjaarsretraite van het college. De gemeenteraad ontvangt op 17 juni een raadsbrief met de verzamelde voorstellen en het verzoek om akkoord te gaan met afdoening van de moties. We beëindigen onze oriëntatie op deze casus op dat moment.

\section{Tabel 7.6. Feitenrelaas casestudy I}

\begin{tabular}{|c|c|}
\hline \multicolumn{2}{|l|}{ Feitenrelaas } \\
\hline 28 april 2010 & Coalitieakkoord nieuw college van B\&W \\
\hline $27 \mathrm{mei}$ & Installatie nieuw college van B\&W \\
\hline 15 juni & College stelt Kaderbrief vast (beleidsmatige en budgettaire kaders begroting 2011) \\
\hline 24 juni & $\begin{array}{l}\text { Brief aan gesubsidieerde instellingen met vooraankondiging bezuinigingen } \\
\text { ('winstwaarschuwing') }\end{array}$ \\
\hline 16 september & Briefing wethouder over berichtgeving (schriftelijk) \\
\hline 5 oktober & Presentatie directeur S\&R van gevolgen subsidiekorting in B\&W vergadering \\
\hline 7 oktober & $\begin{array}{l}\text { Mondeling bericht bezuiniging, persconferentie begroting, gevolgd door brief, } \\
\text { opening nieuwe entree }\end{array}$ \\
\hline 7 oktober & Start zienswijze procedure \\
\hline 13 oktober & Zienswijzegesprek Diergaarde en gemeente (ambtelijk) \\
\hline 25 oktober & $\begin{array}{l}\text { Inspraakbijeenkomst raadscommissie met inbreng Diergaarde } \\
\text { (directeur en vrijwilliger) }\end{array}$ \\
\hline 27 oktober & $\begin{array}{l}\text { Behandeling begroting in raadscommissie, voorafgegaan door demonstratieve } \\
\text { tocht naar Coolsingel }\end{array}$ \\
\hline 7 november & Gratis open dag Diergaarde \\
\hline 11 november & $\begin{array}{l}\text { Raadsbehandeling, aanname twee moties: 'zachte landing bezuiniging' met } \\
\text { einddatum } 1 \text { april } 2011\end{array}$ \\
\hline 12 november & Afgeven definitieve beschikking bezuiniging \\
\hline 18 november & $\begin{array}{l}\text { Startgesprek Diergaarde-gemeente voor uitvoering motie; inventarisatie van } \\
\text { de gemeenschappelijke agenda ( } 11 \text { puntenlijstje) }\end{array}$ \\
\hline 2 december & $\begin{array}{l}\text { Start gespreksronde aan de hand van gemeenschappelijke agenda } \\
\text { (eens per } 2 \text { weken) }\end{array}$ \\
\hline 29 april 2011 & Gemeente (ambtelijk) en diergaarde stellen rapportage aan de gemeenteraad vast \\
\hline 17 juni & Raadsbrief met afdoening moties. \\
\hline
\end{tabular}




\subsubsection{Coping met korting}

Wat maakt de handelwijze van ambtenaar P. bij de bezorging van de bezuiniging op Blijdorp een illustratie van de copingstrategie 'meebewegen'? We grijpen hiervoor terug op de beschrijving van de copingstrategie voor het 'meebewegen' (samengevat in 7.2.); hierbij onderscheidden we drie dominante stijlen: inleven, overeenkomen en herformuleren. Per stijl zijn gedragsvoorbeelden aangegeven, aan de hand waarvan het handelen geïdentificeerd kan worden. De beschrijving van stijlen is een leidraad bij onze beschrijving van het ambtelijk handelen in de cases.

We zien in deze casus wat 'inleven' in de situatie van een getroffen instelling vermag. Dat betreft om te beginnen de dag dat de wethouder de bezuinigingsboodschap bezorgt. Dan blijkt het belang voor erkenning van de belevingswereld van door kortingen getroffen instellingen:

- De wethouder en ik hadden een taakverdeling gemaakt, dat zij de echt grote bezuinigingen zou bellen, en ik de kleinere. Maar ja, kleine is al betrekkelijk, want als je maar 100.000 Euro subsidie krijgt en je krijgt niets meer, en je bent Rotterdam Topsport en je had 1,5 miljoen subsidie en je krijgt nog maar 1,3. Dat laatste is een wat makkelijker boodschap dan dat je die ene meneer moet bellen die sinds jaar en dag subsidie krijgt van de gemeente en waarbij het niet opkomt dat de subsidie zal eindigen.

Het Wijktheater bijvoorbeeld, dat zijn mensen, die met hart en ziel ergens aan werken: 'Dus ik krijg niets meer?'.

Wrang genoeg staat diezelfde dag de feestelijke opening van de poort staat gepland. De aanpak getuigt van het vermogen om te vertragen, dat wil zeggen: anderen in de gelegenheid te stellen om de boodschap tot zich te nemen:

- Ik vond dat wij een goed verhaal hadden, en dat vind ik nog steeds. Maar op dat moment is jouw verhaal niet meer zo interessant, dat wordt toch niet gewaardeerd, geloofd of ontvangen. Dus ik heb ervoor gekozen om de mensen gewoon hun verhaal aan mij te laten vertellen, voor zover ze daar behoefte aan hadden.

Soortgelijke uitingen zijn er bij vervolgstappen in het proces. Dit geldt bijvoorbeeld voor het omgaan met politiek-bestuurlijke betekenisverlening (door zichzelf af te vragen wat de gevolgen zijn voor de wethouder), de omgang met ambtelijke voorkeuren elders in de organisatie (bij de collega's van de Bestuursdienst bijvoorbeeld, waar men primair gericht is op de bestuurlijke besluitvorming en minder op de gevolgen voor de getroffen instellingen). En om te beginnen in de omgang met de getroffen instelling (directeur en medewerkers van de diergaarde). Je moet je plaats weten en helder zijn over je rol:

- Het aantal fokprogramma's, daar moet je als gemeente helemaal niets van willen weten. Anders dan dat het waarde heeft.(...) Hij [directeur diergaarde, GR] is ook wel weer ondernemer genoeg om kansen en mogelijkheden te zien. 
$\mathrm{Na}$ (ast) het 'inleven' komt aan de hand van die hefboom het 'overeenkomen' uit de trits stijlen in deze casus herkenbaar in beeld. Een belangrijke functie is hier weggelegd voor het 11-puntenijstje: de set afspraken die voortvloeien uit de raadsmotie dat 'een zachte landing' nodig is voor de bezuiniging op de instellingssubsidie. Dit lijstje, het hieraan gekoppelde tweewekelijks overleg over de voortgang en de schriftelijke verslaglegging groeien in deze casus uit tot de gemeenschappelijke agenda, datgene wat gemeente en diergaarde bindt. P. toont daarbij zorg en initieert contact. Hij betrekt ook andere geledingen uit de gemeentelijke organisatie bij het proces: expertise op het vlak van bedrijfsvoering, personeelszaken en inkoop. Het product is gezamenlijke onderneming:

- Er is gaandeweg veel respect voor elkaars standpunten gegroeid.(...) Consensus hebben we niet over de bezuinigingen, maar je kiest voor een coöperatiemodel, cocreatie, hoe noem je dat, noem het even coöperatie, dus coöperatief met elkaar op weg. En dat coöperatiemodel was niet het enige, maar wel het model dat ik kon bedenken voor dit geval, wat dienend zou zijn voor de motie als wel voor de dierentuin zelf, want dat is ook waar hij voor staat: een gigantische klus als het gaat om modernisering van zijn organisatie.

Het faciliteren van het gesprek verschaft deze beleidsmaker gaandeweg het proces dan ook autoriteit, in de betekenis van een optreden als gezaghebbende zender van informatie, als verbindingsofficier en als organisator van processen. Op basis van de gemeenschappelijk gegenereerde kennis van verwachtingen en belangen is het mogelijk om toekomstbestendige trajecten in gang te zetten. Er komen nieuwe perspectieven op tafel en daardoor ontstaat zicht op een resultaat. Er is dan ook sprake van herformuleren van de opgave, zoals in de beschrijving van de copingstrategie naar voren komt: het gaat in het overleg tussen gemeente en diergaarde steeds minder om louter een bezuinigingsoperatie en steeds meer om het toerusten van de diergaarde voor een gezonde toekomst. Het gezamenlijke programma (11 puntenlijstje) om de per motie afgedwongen 'zachte landing' te bevorderen heeft daarbij dus een belangrijke functie. De interventie is niet van symboliek gespeend. Om te beginnen 'intern', dat wil zeggen voor het discours tussen gemeente en diergaarde: door de gemeenschappelijke agenda kan een ritme ontstaan voor de gesprekken, verkenningen en besluiten. Maar vervolgens ook in een breder verband: de 11 puntenlijst helpt een nieuw perspectief op de toekomst van de diergaarde te formuleren. Daarmee wordt ook het vermogen tot 'herformatteren' tot uiting gebracht. Door het optreden van deze ambtenaar kan een nieuwe context ontstaan, waarin het discussiepunt gaandeweg wegbeweegt van het frame 'getroffen door bezuinigingen' en kantelt naar 'werken naar een verantwoorde toekomst'. Hiermee illustreert de coping met de bezuiniging door P. de onderscheiden insteek om een hoger belang aan te spreken om een aanvankelijk lastige situatie dragelijk te maken. In termen van Brummans (2010) lijkt sprake te zijn van 'frontstaging' van een nieuw frame 'verantwoordelijkheid'. We schrijven 'lijkt' omdat het gaat om onze 
interpretatie van het handelen en niet om een uitgesproken, bewuste strategie om de agenda te bepalen, afspraken top of mind te houden en rollen op scherp te stellen. Deze zorg om verantwoordelijkheid betrekt hij overigens om te beginnen op zichzelf. Hij markeert zelf zijn bezoek aan de opening van de nieuwe poort op de dag van de aanzegging van de bezuiniging als het 'sleutelmoment' in deze casus. Wegbewegen was toen geen optie:

- Nee, dan loop je weg voor je verantwoordelijkheid. Sterker nog, het werd door zowel de oude als de nieuwe directeur enorm gewaardeerd dat ik er was, dat de wethouder er ook was! Nee, in welke context dan ook, ik was ernaar toe gegaan. Tenzij stervende, maar goed, dan heb je een goede reden. M.[directeur diergaarde] zag mij toen hij op het podium stond om daar een toespraak te houden, en meteen dat de gelegenheid zich aandiende om zich even bij hem te vervoegen, ben ik op hem afgestapt, die behoefte had hij ook, en hebben we elkaar een hand gegeven.

We zien dit patroon ook bij het besluit om zelf nauw betrokken te zijn bij het project, hij neemt een voortrekkersrol:

- Blijdorp is een zodanig gezichtsbepalende voorziening, zo'n onderwerp is Chefsache. Een goede beleidsadviseur een tijdje vol in de wind zetten dat kan wel, maar op een gegeven moment word je toch omgeblazen en uit positie gespeeld.

Vervolgens vertaalt zich die focus op verantwoordelijkheid door in het contact met de gesprekspartners van de diergaarde. Een belangrijke troef hierbij is hierbij de zakelijke overeenstemming van beide directeuren op dit punt. Beiden tonen zich doordrongen van het hogere belang de diergaarde een gezonde toekomst te bezorgen. De combinatie van de drie stijlen - inleven, overeenkomen en herformuleren - zet zich door tot in de slotfase van de gesprekkenronde, tot waar we deze casus volgen. Dan moet een finale versie van het werkprogramma worden vastgesteld:

- Ja, powerplay is soms nodig, zoals toen we met die conclusies bezig waren. Dan is het: jij neemt je verantwoordelijkheid, ik neem mijn verantwoordelijkheid, we maken nog een keer een zin en die maken we samen, dan maken wij een deal. De rest van tafel doet even niet mee aan dat spelletje. Ja, kan het of kan het niet, die bezuinigingen? Met de kennis die we nu hebben, kan het. 


\subsubsection{Factoren in beeld}

Hoe oefenen de zes factoren invloed uit op het ambtelijk handelen in deze case?

We volgen de afzonderlijke factoren om het ambtelijk handelen scherper in kaart te brengen: wat maakt dat deze beleidsmaker in staat is om de mogelijke (re)acties te herkennen en hanteren?

Factor I: Persoonlijke hulpbronnen (de werking van extraversie, inschikkelijkheid, zorgvuldigheid, emotionele stabiliteit/autonomie en openheid/proactiviteit).

Op de dag van de bekendmaking van de bezuiniging, bezoekt hij de feestelijke opening van de hernieuwde poort. lemand die op een kritiek moment initiatief neemt getuigt van extraversie:

- Ik wist niet wat ik aan zou treffen, ik was niet bang, schaamde me ook niet, maar $i k$ voelde me wel onbestemd. Met gemengde gevoelens betreed je dat park. Ik kom gelukkig vrij snel T., de oude directeur tegen, daar ben ik meteen op afgestapt, die heb ik een hand gegeven, hadden we dat ook gehad, en toen was het ijs ook gebroken. Want, wat mensen soms doen is jou persoonlijk verantwoordelijk stellen daarvoor. Met hem heb ik ook eerder gesprekken gehad daarover indertijd, dat het wat het slechter ging, dat de subsidie minder zou gaan worden.

Uit het citaat spreekt ook terughoudendheid, dat wil zeggen dat P. zich bewust toont van de waarde die anderen aan de ontmoeting kunnen toekennen. Maar om te beginnen stapt hij op de ander af. Er is sprake van emotionele stabiliteit en vermogen om de druk te hanteren, zo kunnen we ook registreren. In een toelichting maakt $P$. duidelijk dat vaker sprake is van een spanning tussen openheid en beheersbaarheid. Volledige openheid tijdens de voorbereiding van een collegevoornemen kan niet, omdat je dan de Raad voor de voeten loopt, maar in een goede relatie houd je niet zomaar informatie achter. Heldere procesinformatie is dan wel mogelijk, zo maakt hij duidelijk:

- Wat we wel hebben gedaan is zoals het te doen gebruikelijk is, eerst winstwaarschuwingen afgegeven, schriftelijk, maar ook in gesprekken: 'Jullie komen hier niet ongeschonden uit', 'Het gaat om grote klappen die de gemeente krijgt, die de gemeente niet ongestraft kan opvangen. We zullen moeten ingrijpen, we zullen dus ook waar we kosten maken, kosten moeten reduceren'. [...].

Als de diergaarde met de gemeente aan tafel gaat zitten om aan de hand van de lijst van 11 punten in de hand 'de zachte landing' te bespreken, wordt snel duidelijk dat een voorgestelde deadline rauw op het dak van de diergaarde valt. Inschikkelijkheid wordt getoond. P. stelt voor

- 'een wat vagere aanduiding te gebruiken'. 
Factor II: professionele drijfveren ('roeping'ten opzichte van baan of carrière, beroepstrots, spel, publieke opgaven en betrokkenheid, gewaagde doelen en waarden).

P. heeft een passie voor publieke opgaven ontwikkeld en beschouwt zijn werk als een professie:

- Nou... je hebt je professie! Je professie is voor een groot deel gevormd door de kennis die je met je meedraagt, ervaringen die je hebt. Vanaf mijn 28e ben ik ambtenaar in een bestuurlijke omgeving, bij meerdere gemeenten. Dus je bent daar erg in opgegroeid, je hebt je daar kunnen ontwikkelen, en weten te handhaven, dus je kunt wel zeggen dat ik daar een antenne voor heb ontwikkeld. Het is 360 graden met de rug naar het midden, met je gezicht naar een krachtenveld, hoe zit dat krachtenveld in elkaar.

Wat telt voor deze beleidsmaker is helderheid: waar staat de overheid voor en waar anderen. Waarden zijn belangrijk: respect voorop en dat je in staat en bereid bent het samen eens te worden:

- Het aantal fokprogramma's, daar moet je als gemeente helemaal niets van willen weten. Anders dan dat het waarde heeft. En welke waarden zou je er aan toe kunnen kennen? Eén: dat de diergaarde bestaat, twee: de educatieve waarde die het voor de kinderen heeft in deze stad, daar hebben we de subsidie toen ook op gepinpoint.

Primair zien we hier een waardengedreven ambtenaar, dat wil zeggen dat hij respectvol wil streven naar het gedeelde belang:

- ... en dat betekent ook dat daar waar belangen niet gedeeld zijn, dat je elkaar wel respecteert. Als een tent in diepe rouw is, ga ik het niet lopen bevestigen. Maar tegelijk is de slechtste zin om zo'n zaaltje binnen te komen: 'Ja jongens er zijn ergere dingen'. Dan was ik gelijk de tent uitgeramd.

Bij de inzet zien we een streven naar professionele voldoening, die we als beroepstrots lezen:

- Waar ik wel van geniet is dat een college dan zo'n besluit neemt. Waar ik ook van geniet is het gezamenlijk optrekken naar een resultaat - daar kan ik dan wel van genieten ja. En waar ik ook van geniet is de sfeer aan tafel.

De metafoor 'spel' komt naar voren in deze casus, waarbij ook de doelgerichtheid naar voren komt, vooral in de betekenis van 'tegenspel':

- Ik hou wel van tegenspel, en daar zit bij mij ook echt iets van hoe komt het dat ik dit zo wil, waarom vind ik dit nou een hele goede zet en zij niet. Ik probeer wel te kijken of $i k$ me in die ander kan verplaatsen. Dan kun je zelf ook in je argumentatie en in je strategie daar rekening mee houden. 
Factor III: Ambtelijk besef (politiek-bestuurlijke sensitiviteit, weten hoe bureaucratische hazen lopen en beheersing van strategieën om 'systeemspanningen' te hanteren en partijen in stelling te brengen).

We herkennen de (drie) systeemgerelateerde spanningen die tussen beheersbaarheid en democratische context:

- Zorgvuldigheid is voor ons geen hol begrip. We hadden langdurige subsidierelaties, je moet altijd zorgvuldig handelen, maar ook vanwege de verdere procedures, als je het niet netjes doet, ga je later nat.

Bij een belangenafweging komt het er op aan individuele en algemene belangen te zien en op waarde te schatten:

- Je moet snappen dat als het woord Blijdorp in Rotterdam valt in termen van subsidiekorting, dat zoiets leeft in de harten van de Rotterdammers, links en rechts, dus ook in die van de Rotterdamse politici.

De spanning tussen vakinhoudelijkheid en bestuurlijke verantwoordelijkheid c.q. scoringsdrift zien we hier niet scherp naar voren komen. Beide oriëntaties sluiten eerder op elkaar aan:

- Het college vroeg mij: geeffacts and figures, hoe zit dat in elkaar? Toen kon ik melden hoe het er voor stond, er had eigenlijk al eerder een afbouwplan voor de subsidie gemaakt moeten worden, waar allerlei prestaties aanhangen, waarvan je je als gemeente afvraagt, moet ik daar nog wel wat mee te maken willen hebben.

Strategieën: in stelling brengen c.q. hanteren van de spanningen blijkt in deze casus te lokaliseren bij alle drie de arena's. Om te beginnen de bestuurlijke arena: het college moet goed geïnformeerd zijn en steeds in staat om de raad te laten zien wat er gebeurt, zo blijkt uit het citaat hierboven ook. Voor het hanteren van de bureaucratie is het belangrijk te weten wat mensen nodig hebben om in beweging te komen. En dan een zetje geven (de 'nudge' van Thaler en Sunstein (2007), wat vooral helpt als mensen wel willen maar niet kunnen). Als blijkt dat het bezorgen van ingrijpende kortingen nieuw is voor collega's bij de financiële afdeling van Bestuursdienst schieten P. en zijn medewerkers in de faciliterende rol. Er wordt:

- ... een draaiboek gemaakt, een standaardbrief gemaakt, enzovoort. Daar hebben we wel op moeten aandringen, want dat gevoel was er aanvankelijk niet.

Tot het in stelling brengen kan ook worden gerekend dat de maatschappelijke arena ruimte wordt gegund om weerstand te manifesteren:

- Tegelijkertijd dat is natuurlijk de functie van de directeur van Blijdorp en zeker de vorige, dat is die van een bekende Rotterdammer, voor de mensen die er werkten en de mensen die de diergaarde bezochten. Dus van M. werd ook verwacht, dat hij de barricades opging. En van mij werd verwacht dat ik loyaal besluiten van de gemeente voorbereid. En daar hebben we het ook over gehad. 
Bij het contact met de maatschappelijke arena in casu de diergaarde is duidelijk dat de leiding van de diergaarde gebrand is op een zakelijke bedrijfsvoering.

- Dus op zich zou je kunnen zeggen, en die stelling durf ik wel aan, dat het voornemen om de subsidie drastisch te korten, hem wel geholpen heeft om zijn organisatie te doordringen van het feit, de noodzaak, dat er gemoderniseerd, verzakelijkt moest worden.

Het gaat dan ook over de betekenis van de landing van de korting voor de wethouder. Die moet verantwoording kunnen afleggen, om te beginnen aan de Raad. Het is een voorbeeld van inlevingsvermogen in combinatie met een stevige kennis van de gemeentelijke mores:

- Je gaat de dingen toch opschrijven, omdat je met een verhaal moet komen. We hebben het echt vastgelegd om achteraf verantwoording te kunnen afleggen: is het raadsRekenkamer of enquêtecommissie -proof?

Factor IV: Sociale steun (werking van nabijheid, collega's, informatieve, emotionele en instrumentele steun en - intern en extern - gepercipieerde waardering van je handelen).

De nabijheid van instrumentele en informele steun komt in deze casus vooral tot uiting in het interne samenspel tussen P. en beleidsadviseur R. In de praktijk opereren ze als een tandem; verder is de kring van adviseurs beperkt. Naast geestverwantschap is sprake van aanvulling van kwaliteiten c.q. compensatie van tekortkomingen:

- $R$. is ook uit zo'n ambtelijke baarmoeder getrokken. We zijn allebei die ambtenarenzee in komen zwemmen. Dat maakt het werken met elkaar ook zo vreselijk makkelijk, dat je dat gevoel hebt en dat je niet uit hoeft te leggen. Er zit een hiërarchie tussen, maar dat is feitelijk onzin. Want hij zit er feitelijk veel dichter op dan ik. Uiteindelijk moet ik er iets van vinden, soms moet ik het even horen, maar ik heb er niets aan toe te voegen of af te voegen. We hebben dezelfde inschatting, denk ik, van waar we mee bezig waren.[...] Ik kan er goed over lullen, maar ik heb niet de tijd en zelfs niet het vermogen (dat laatste is niet getoetst), om dat goed op te schrijven en opdrachten die daaruit voortvloeien goed weg te zetten. lemand die je vertrouwt en op wie je kunt terugvallen is heel erg belangrijk - en in je eigen organisatie.

Informele en instrumentele steun kan ook in de interactie met de andere partij worden verkregen. P. waardeert de interactie met de collega van de diergaarde; die onderlinge band vertaalt zich door in andere functionele lagen aan beide kanten, zoals de wederzijdse controllers en andere ondersteuners. Beide managers helpen elkaar met het begrijpen van de beeldvorming in 'het andere kamp' en het aftasten van mogelijkheden en mores:

- Je mag iemand best adviseren hoe iemand het best zijn politieke lobby kan aanpakken, maar het hoe daar ga ik niet over.(...) Wie zijn dan die fractievoorzitters? Hij heeft van ons gewoon een lijst gekregen met namen. Ja, waarom zou je dat niet doen? 
Factor V: Zicht op resultaat (inzicht in impact, de keten van effecten van het eigen handelen en doorwerking naar einddoelgroepen. Concreetheid, snelheid en helderheid van feedback).

Uit de hiervoor aangehaalde waarnemingen ontlenen we een korte afstand tot resultaten en betekenissen voor relevante groeperingen, niet alleen buitenshuis:

- Zowel M. [directeur diergaarde. GR] als ik hebben veel gependeld. Gependeld in die zin van dat wij probeerden uit te leggen aan de wethouder en soms ook hier intern wat er aan de hand was bij Blijdorp. En M. pendelde van politiek-ambtelijke burelen naar zijn mensen om uit te leggen wat hier aan de hand was.

Er is daarbij sprake van zorg voor de focus van ambtenaren op de effecten van bestuurlijke beslissingen voor einddoelgroepen. P. signaleert aanvankelijk uiteenlopende oriëntaties als het gaat om de impact:

- [Controllers zijn] veel instrumenteler en technocratischer, het saldo moet op o uitkomen, en het zit nu op 100. Dat hoort bij hun functie. Daarom is ROTS [een eerdere bezuiniging, GR] mislukt, te technocratisch. Doordat wij dichter op de uitvoering zitten kun je meer politiek gevoel krijgen. Mensen die helemaal dicht op de uitvoering zitten hebben helemaal weinig gevoel, omdat ze er in de praktijk niks mee te maken hebben.

De concreetheid van de opdracht als variabele komt naar voren in de keuze voor het 11-puntenlijstje en het werken aan de hand van een voortschrijdend overzicht waarop de afspraken en de status van resultaten werden bijeengebracht. Hierdoor was steeds sprake van een betrekkelijk eenvoudige en gedeelde voorstelling van zaken.

Factor VI: Ruimte voor reflectie (koppeling tussen gedrag en leren, hernemen van beslissingen en coaching, programmatische aandacht).

Een interne werkgroep bezuinigingen wordt veel waarde wordt toegedicht als vraagbaak en terugvaloptie. Ook wordt aan het contact met de diergaardedirecteur een gemeenschappelijke reflectieve houding ontleend, zoals na afloop van een gesprek waarin enige wrijving in het gezelschap ontstond. Maar het is meer spontaan dan geprogrammeerd:

- En dan praat je eigenlijk, het klinkt wat blasé, als directeuren onder elkaar. Als professionals onder elkaar zeg je dat het soms lastig is om mensen te leiden, die gewoon de goede kant niet opwillen. [...] Ja, hij toetste toen vooral dingen. (...) Hoe je in de hele Rotterdamse politiek je staande houdt.

Eerdere ervaringen en getoond probleemoplossend vermogen helpen bij het bevorderen van een reflectieve houding. Zo deelden P. en de wethouder een eerdere ervaring met een groot bouwproject in de gemeente, waarbij ook lessen waren getrokken: 
- Wat ik daar van heb meegekregen is dat als een wethouder onvoldoende weet wat er gebeurt, hem of haar kan worden verweten dat hij niet voldoende stuurt.

Uit de reconstructie komt verder geen manifeste traditie van (programma's voor) leren en ontwikkelen naar voren.

7.4.4. Q-sort

Aan het slot van het gesprek krijgt de respondent enkele beweringen voorgelegd, met het verzoek deze te ordenen op een schaal van instemming tot afwijzing (figuur $7 \cdot 3 \cdot{ }^{12}$ ):

\begin{tabular}{|c|c|c|c|c|}
\hline Zeer mee oneens & & & & Zeer mee eens \\
\hline-2 & -1 & 0 & +1 & +2 \\
\hline \multirow[t]{3}{*}{$\begin{array}{l}\text { Dit hoort niet op } \\
\text { mijn bordje }\end{array}$} & $\begin{array}{l}\text { Hier zijn gelukkig } \\
\text { procedures en } \\
\text { commissies voor }\end{array}$ & $\begin{array}{l}\text { Weerstand maakt } \\
\text { nieuwsgierig }\end{array}$ & $\begin{array}{l}\text { Soms moet je } \\
\text { doorduwen }\end{array}$ & $\begin{array}{l}\text { Zoeken naar een } \\
\text { gedeeld belang of } \\
\text { waarde }\end{array}$ \\
\hline & $\begin{array}{l}\text { Er zijn ergere } \\
\text { dingen in de wereld }\end{array}$ & $\begin{array}{l}\text { We kunnen niet } \\
\text { bezig blijven }\end{array}$ & Wat kan wel & \\
\hline & & $\begin{array}{l}\text { Zonder bluf ben je } \\
\text { nergens }\end{array}$ & & \\
\hline
\end{tabular}

Figuur 7.3. Q-sort casus I

P. neemt als eerste het kaartje 'Weerstand maakt nieuwsgierig' ter hand.

Zegt: 'Meestal werkt dat wel zo bij mij, ja'. Legt het eerst helemaal rechts en schuift het dan naar het midden:

- Ik hou wel van tegenspel, en daar zit bij mij ook echt iets van hoe komt het dat ik dat zo wil, waarom vind ik dit nou een hele goede zet en zij niet. Ik probeer wel te kijken of ik me in die ander kan verplaatsen. Dan kun je zelf ook in je argumentatie en in je strategie daar rekening mee houden. En ja, 'We kunnen niet bezig blijven', ja op een gegeven moment is het een keer af, dat ongeduld.

Hij legt vervolgens snel de hierboven met blauw en groen gemerkte beweringen neer. 'Alles wat ik bij o heb gelegd zou ik ook in de +1-sfeer kunnen neerleggen'. Dan volgen de geel gemerkte kaartjes:

- 'Dit hoort niet op mijn bordje'? lets hoort in eerste instantie op mijn bordje en ik kijk vervolgens wel waar het heen moet'.

P. kijkt misprijzend bij de beweringen 'Hier zijn gelukkig commissies en procedures voor' en 'Er zijn ergere dingen in de wereld':

\footnotetext{
${ }^{12} \square$ = 'wegbewegen' $\square$ = 'meebewegen' $\square$ = 'tegenbewegen'. Zie voor een toelichting 7.3.
} 
- 'Ja, zeker in het begin heb ik dat ook wel eens gedacht. Ja, ik ben van relativeren, sommige mensen noemen me onverschillig, maar dat heb ik hier niet bij gevoeld. Omdat het gedeelde belang heel erg voorop stond (wijst op kaartje met de bewering hieromtrent, GR). Dat betekent ook dat daar waar belangen niet gedeeld zijn, je elkaar wel respecteert.

Neemt dan het kaartje 'Soms moet je doorduwen' ter hand:

- Ja, powerplay is soms nodig, zoals toen we met die conclusies bezig waren. Dan is het: jij neemt je verantwoordelijkheid, ik neem mijn verantwoordelijkheid, we maken nog een keer een zin en die maken we samen, dan maken wij een deal. De rest van tafel doet even niet mee aan dat spelletje. Ja, kan het of kan het niet, die bezuinigingen? Met de kennis die we nu hebben, kan het.

\subsubsection{Conclusie casestudy 'De zachte landing'}

De casestudy laat zien wat 'meebewegen' in essentie mogelijk maakt: persoonlijke hulpbronnen om contact te leggen en zo nodig door te pakken, professionele ambitie om meer te doen dan een klus te klaren en ambtelijk besef om de politiek, de bureaucratie en de maatschappelijke actoren te laten werken. De werking van die drie 'hefbomen' of beïnvloedende factoren komt in deze casestudy herkenbaar naar voren. Dat begint met een inschikkelijke houding en initiatiefrijke inzet. De beleidsmaker in deze casus zoekt de andere partij nadrukkelijk op en toont zich over de hele linie initiatiefnemer in het proces. Dat geldt voor de voorbereiding van de berichtgeving over de bezuinigingen in de gemeentelijke organisatie (zijn inzet op een draaiboek/protocol is voorloper van de gemeentebrede aanpak voor bekendmaking van de bezuinigingen), voor de toerusting van de wethouder, voor het afstappen op de dierentuindirecteur op de openingsdag, voor de introductie van de elfpuntenlijst, voor het gastheerschap van de bijeenkomsten en ook voor enkele stugge momenten bij het activeren van gemeentelijke onderdelen. P. verschaft hiermee voortdurend anderen een platform en mogelijkheden om te handelen. Die gestes blijven niet onbeantwoord. De initiatiefrijke inzet dempt niet alleen de teleurstelling over de bezuinigingen, ze maakt ook andere systeemgerelateerde zwakke punten verteerbaar. Dit geldt bijvoorbeeld voor de beperkte openheid die P. kan betrachten over de voorgenomen bezuiniging en het feit dat hij niet kan vooruitlopen op politieke en bestuurlijke besluitvorming. In de ontstane gemeenschappelijke werkruimte blijkt de werking van de besluitvorming transparant te kunnen worden gemaakt en kan weerstand in feite worden opgevangen. Wegbewegen is dus geen optie. P. meldt desgevraagd zijn aversie ervan, onder verwijzing naar zijn kijkt op de rol van de overheid en de betekenis van ambtenaren bij het voorbereiden en ondersteunen van bestuurders.

De gemeenschappelijke agenda ontstaat aanvankelijk door externe - politieke - druk: twee moties in de gemeenteraad dringen aan op 'een zachte landing' van de bezuiniging op de instellingssubsidie. Veel extrinsieke aansporing heeft deze ambtenaar - en ook de directeur van de diergaarde - echter niet nodig om dat moment te benutten. We zijn in deze casus getuige 
van een ambtenaar met verwantschap met de politiek-bestuurlijke arena, waardoor snel doorgepakt wordt als het gaat om signaleren van knelpunten, benoemen van de beïnvloedbare ruimte en adressering van oplossingsrichtingen. Of dit nu het overleg met de dierentuin of binnen de gemeentelijke organisatie betreft: steeds zien we een patroon terugkeren om de andere partij in het gezicht te zien en te (helpen) onderzoeken waar openingen zijn. Een gemeenschappelijke agenda met 11 punten werkt daarbij als een katalysator, waarvan ook de symbolische betekenis niet mag worden onderschat: een gemeenschappelijk makende interventie is het, die de partijen bindt. Het inlevingsvermogen en de tegelijk zakelijke houding van deze beleidsmaker helpt de meervoudige perspectieven op de kwestie te voorzien van één verbindende agenda. Die doet recht aan de uiteenlopende belangen, maar onder een gemeenschappelijke paraplu. Centraal daarin staat het nemen van verantwoordelijkheid voor de consequenties van een raadsbesluit. De focus op verantwoordelijkheid wordt een nieuw frame in de gesprekken. Van 'getroffen door bezuinigen' kantelt de gespreksinhoud. Het gaat steeds meer over het 'werken aan een verantwoorde toekomst'. Daarmee illustreert het handelen dragende kenmerken van de copingstrategie 'meebewegen'.

De dominantie van 'meebewegen' neemt niet weg dat we in deze case ook uitingen zien van de copingstrategie 'tegenbewegen'. Het onderscheid met deze strategie is minder scherp dan verondersteld bij ontwerp van het conceptueel model. Veeleer is sprake van een logische terugvaloptie, die kan worden aangegrepen op het moment dat de grenzen bereikt zijn van de trits stijlen uit de strategie 'meebewegen' ( inleven, overeenstemmen en herformuleren). Het is de second best optie. Op het moment dat de deadline van de voorbereidingen en de politieke verantwoording in zicht komt confronteert P. de leiding van de diergaarde met het hierboven aangehaalde point of no return. Hij stuurt dan krachtig op besluitvorming aan. Een tweede moment van tegenbewegen is aan de orde als in één van de overleggen waarbij P. niet aanwezig is, een deelnemer een eigen plan trekt en een verstoring van de gemeenschappelijke koers dreigt. P. grijpt dan in met de meest verstrekkende copingstijl die we onderscheiden - forceren - door een klemmend beroep op de diergaardedirecteur om de rijen te sluiten: overigens opnieuw een manifestatie van het verantwoordelijkheidsframe in optima forma. Beide voorbeelden maken duidelijk dat bij een sterke gemeenschappelijke basis en co-oriëntatie het zeer goed mogelijk is op vitale momenten teugels aan te halen.

De derde copingstrategie - 'wegbewegen' - wordt in deze casus niet manifest. We vinden in de case ondersteuning voor de stelling dat de kracht van de drie in hoofdstuk 6 als 'primair' aangemerkte factoren zo groot kan zijn, dat het - voor de hand liggende vluchtgedrag niet hoeft te worden aangesproken. De eerste drie invloedsfactoren versterken elkaar: persoonlijke hulpbronnen als empathie, initiatief en openheid worden in combinatie met een uitgesproken 'professionele ambitie' en een breed palet aan 'ambtelijk besef' ingezet. We zien P. voortdurend het initiatief houden, hij weet hoe de hazen lopen, hij kent wel in de organisatie een bruikbare bron en hij kan anderen in stelling brengen. Als inleven volgens G.H. Mead het vermogen inhoudt tot 'taking the role of the other' (1934) vinden we hiervoor in deze casestudy een bewijs. Daar komt bij dat op het functionele niveau de beide 
leidinggevenden gedrevenheid tonen om hun organisatie verder te brengen. Uit de aanpak blijkt nieuwsgierigheid, in combinatie met een kwetsbare opstelling. Er is in professionele en functionele zin sprake van verbondenheid. Hierdoor is ook sprake van ontvankelijkheid voor nieuwe zienswijzen en ontstaat vermogen om ook elkaar te helpen bij het vinden van intern draagvlak voor lastige opgaven.

Van de zes beïnvloedende factoren komen de eerste drie 'hefbomen' in deze casus dus krachtig naar voren. Daarmee bevestigen zij de veronderstelling in hoofdstuk 6 dat de trits 'persoonlijke hulpbronnen', 'professionele drijfveren' en 'ambtelijk besef' het mogelijk kan maken de andere drie factoren niet of minder aan te spreken. 'Sociale steun' vervult een bijrol, maar mag niet worden onderschat; in deze casus is onbetwist sprake van collegiale ondersteuning in de vorm van bevestiging en instrumentele support. P. weet zich verzekerd van goede ondersteuning bij de ambtelijke voorbereiding en follow-up van gesprekken in de persoon van een beleidsadviseur. Deze terugvaloptie hoeft niet zozeer te worden aangesproken om een zwakke eigenschap te compenseren of een mislukt optreden te herstellen; de support is vooral instrumenteel en informeel van aard. Wat de factor 'zicht op resultaat' betreft komt naar voren dat P. hecht aan contact met de einddoelgroepen. Pregnant blijkt de betekenis die hij aan deze factor toewijst bij de toelichting op het zendingswerk binnen de ambtelijke organisatie, vooral bij de gemeentelijke bestuursondersteuners. Hij onderstreept de betekenis van direct contact met einddoelgroepen. Zijn oog voor de doorwerking van bestuurlijke voornemens en besluiten leidt ook naar een initiërende rol bij de ambtelijke voorbereiding van de bezorging van bezuinigingen, het opstellen van draaiboeken etc. Minder uitgesproken zien we in deze casus de betekenis van de factor 'ruimte voor reflectie'. Daarnaar gevraagd relativeert P. de complexiteit van de opgave, en zegt: 'De mensen die elkaar nodig hebben, weten elkaar te vinden'. De laatste opmerking sluit ook aan op een eerdere vaststelling naar aanleiding van de interviews in de hoofdstukken 4 en 5 . Er is niet sprake van een openlijk beleden verleidingsstrategie, laat staan een trucje: een professional zoekt en vindt de beschikbare perspectieven en zet op basis van deelbare belangen vervolgstappen.

\subsection{Casestudy 2 - Een overtuigende opvang}

\subsubsection{Kroniek van het proces}

Voorjaar 2002 treedt een nieuw Rotterdams college van B\&W aan, bestaande uit CDA, VVD en Leefbaar Rotterdam. Het coalitieakkoord kondigt de sluiting aan van de 'tippelzone' aan de Keileweg. Daarmee kan een einde komen aan de jarenlange overlast in het gebied en kunnen de levensomstandigheden van de prostituees - vrijwel allen verslaafd aan drugs en/of drank - worden verbeterd. Het duurt bijna twee jaar voordat het college een brief aan de deelgemeenten stuurt met het verzoek om een opvangvoorziening te helpen vinden. Van meet af aan is duidelijk dat deelgemeenten niet staan te trappelen, maar wel bereid zijn mee te denken over mogelijke oplossingen. De stedelijke GGZ-instelling komt met een voorstel voor een pand aan de Veerlaan in de deelgemeente Feijenoord. Het pand bevindt 
zich op Katendrecht, een historisch beladen schiereiland, ook bekend als De Kaap. Van meet af aan stuit het voornemen op verzet. Als in juni 2004 een nieuw deelgemeentebestuur begint, kondigt het nieuwe dagelijks bestuur aan alternatieven te zoeken. Eind september ligt er een lijst met negen locaties. De verantwoordelijke wethouder en het stedelijke projectteam houden echter vast aan de eerdere voorkeur voor Katendrecht. De boot is aan als bekend wordt dat een woningbouwvereniging de betrokken panden aan de Veerlaan al heeft aangekocht. In december verharden de verhoudingen. Het deelgemeentebestuur onderstreept de kwetsbaarheid van Katendrecht, de beladen historie op prostitutiegebied en de risico's voor de verdere ontwikkeling van het gebied. Het dagelijks bestuur brengt twee voorkeuren elders in de deelgemeente in en verzoekt het stedelijke college van burgemeester en wethouders de haalbaarheid te onderzoeken van onder andere een pand aan de Oranjeboomstraat.

Eind januari 2005 melden $B \& W$ dat ze persisteren en de deelgemeentelijke bevoegdheden voor de vergunningenverlening in zullen trekken. Op 27 januari wordt de bevolking geïnformeerd en op 1 februari besluit het college definitief: het wordt Katendrecht. Feijenoord is overruled; het protest is niet van de lucht.

Het deelgemeentebestuur besluit dan een ultieme poging te doen om de impasse te doorbreken met voornoemd aanbod voor de locatie aan de Oranjeboomstraat. Het college omarmt de suggestie en - omgeven met de nodige cynische geluiden en commentaren in de media - draait haar voorstel terug; samen met de deelgemeente presenteert ze een doorbraak in de impasse: 'Katendrecht' is van de baan en de deelgemeente gaat de weg bereiden voor een nieuwe opvang. Op 16 februari belegt de deelgemeente een bewonersavond om de keuze voor de Oranjeboomstraat uit te leggen en begrip te verwerven voor de overwegingen. De avond in de plaatselijke Persoonshal wordt een pandemonium: een uitbundig toneel voor protesten en verwijten. De bewonersorganisatie voert aan niet goed gekend te zijn in de voorgenomen besluiten; uit de protesten komt ook naar voren dat men vindt dat er teveel vrouwen worden opgevangen en bovendien de rust in de wijk zal verdwijnen. De bewoners claimen de bijeenkomst. 'Niks deelgemeente, wij hebben deze hal afgehuurd', roept de voorzitter van de bewonersorganisatie in de microfoon (Rotterdams Dagblad, 17 februari 2005). Zeker vijfhonderd mensen zijn er binnen, cameraploegen en fotografen verdingen zich en deelraadsvoorzitter W. baant zich een weg naar voren. Aan echt spreken zal hij nauwelijks toekomen. 'We zijn bezig met een goede zaak, ik hoop u daarvan te kunnen overtuigen', probeert hij nog volgens het verslag in de krant. Joelende wijkbewoners snoeren hem de mond, bedreigingen en verwensingen vliegen door de zaal. De bereidheid om het college tegemoet te komen met een nieuwe locatie en daarbij ook nog een bedrag voor een noodkeet op tafel te leggen wordt als verraad afgedaan. 'We zijn geen stortplaats', roept een dame volgens het verslag in het Rotterdams Dagblad daags erna (17 februari 2005). Uiteindelijk zal de deelraadsvoorzitter onder politiebeveiliging worden afgevoerd. 'Ja, het was een rare film, waarin je helemaal niet meer zelf het gevoel hebt dat je daar nog de regie in hebt, maar dat je in een maalstroom van gebeurtenissen wordt meegezogen', zegt deze in het Rotterdams Dagblad van 18 februari 2005. 'Dit was wel het springende punt, het belangrijke moment voor jezelf. [...] Dit proces bracht me het besef bij dat ik de wijk iets aangedaan had, ook al wist ik dat het voor een deel komt 
door wat het gemeentebestuur eerst in de wijk Katendrecht de bewoners had aangedaan.[...] Het alternatief was wel een deelgemeentelijke keuze en daar voelde ik mij verantwoordelijk voor. En dan vervolgens - en dat vond ik wel een leermoment - hoe kan je nou proberen in het reine te komen met zo'n wijk'. Een paar dagen later neemt hij afstand door middel van een (al geplande) week vakantie. 'We moeten nu een adempauze inlassen. Er zal veel moeten worden geïnvesteerd om draagvlak te krijgen', zegt hij tegen de verslaggever van het Rotterdams Dagblad van 18 februari.

Het dagelijks bestuur besluit dan om een ronde te maken langs alle instellingen en groeperingen. W. kiest begin maart voor een aanpak van gesprekken in kleinere kring met eenieder die met de deelgemeente in gesprek wil treden. Hij introduceert een drietrapsraket: (1) eerst zorgen bespreken, vervolgens (2) oplossingsmogelijkheden verkennen en tenslotte (3) afspraken maken over wie welke actie kan ondernemen. Om het huisvestingsprobleem van 'de dames van de Keileweg' te kunnen tackelen worden vervolgens drie bijeenkomsten belegd. De ronde leidt naar een nieuw draagvlak voor de opvang van een beperkt aantal extippelaarsters. In juni gaat de deelraad akkoord met een programma voor de vestiging van het pand en volgde een officiële ondertekening door alle betrokken instellingen incluis de wethouder. Onderdeel van de aanpak is een 'compensatieprogramma': werkgelegenheid, scholingsactiviteiten, een opknapbeurt van de buurt. Ter ondersteuning van de gespreksronde werd met behulp van de Communicatieafdeling van de GGD een campagne opgezet.

Brieven en folders waren niet voldoende gebleken immers. In advertenties werden vragen van burgers aangegrepen voor uitleg, zoals 'Waarom sturen we ex-prostituees niet naar de Maasvlakte?' (Maasstad, 23 maart 2005). Een belangrijk uitgangspunt bij de campagne was dat het besluit over de opvang als zodanig niet ter discussie stond. Boodschap daarom, aldus een toelichting in dezelfde editie van 'Maasstad': 'niemand wil de dames van de Keileweg in zijn achtertuin, maar ik snap wel dat dit een adequate oplossing kan zijn'. De tippelzone aan de Keilweg sluit uiteindelijk iets eerder dan gepland: vanaf 14 september 2005 geldt een verbod op straatprostitutie, de opvanglocatie in Feijenoord opent de poorten.

Enkele maanden na afronding van de opgave keert W. terug naar de ambtelijke dienst. Hij wordt projectleider voor het programma 'Maatschappelijke opvang'. Doel: het vinden van opvangvoorzieningen voor daklozen in alle deelgemeenten. Hij benut de ervaringen uit Feijenoord bij de ontwikkeling van die opgave en het verwerven van draagvlak voor de nieuwe klus. Bij de start van de werkzaamheden wordt de communicatie met belanghebbenden nadrukkelijk geagendeerd. Lessen uit de ervaringen met de opvang van ex-prostituees worden meegewogen bij de nieuwe aanpak. Dit komt onder meer tot uiting in een keuze voor veel 1 op 1 communicatie, het erkennen van de eigen belangen en verwachtingen van deelnemers en ook maximale transparantie over processtappen, rollen en beschikbare ruimte voor onderhandeling (wat staat vast en wat niet). We betrekken observaties van W. over deze lessen bij de beschrijving van het ambtelijk handelen van de ambtenaar die deelraadsvoorzitter werd en weer terugging naar de ambtelijke dienst. Aan het begin van het programma worden deelraadbestuurders uitgenodigd voor een treffen in gebouw 'De Hille' in Feijenoord, ooit één 
van de mogelijke locaties voor de opvang van 'de dames van de Keileweg'. Boodschap van de wethouder en haar projectleider: gemeente en deelgemeenten gaan niet tegen elkaar maar met elkaar aan de slag om opvang te realiseren Tabel 7.8 vat deze kroniek feitelijk samen.

\section{Tabel 7.7. Feitenrelaas casestudy II}

\begin{tabular}{|c|c|}
\hline Feitenrelaas & \\
\hline Mei 2002 & Coalitieakkoord: beëindig Keileweg en vang prostituees elders in de stad op \\
\hline 6 februari 2004 & Brief college aan deelgemeenten met verzoek om zoeken opvanglocatie \\
\hline April 2004 & $\begin{array}{l}\text { Stedelijk voorstel voor pand aan de Veerlaan stuit op bezwaren bestuur } \\
\text { deelgemeente, diverse gesprekken deelgemeente en stedelijk bestuur }\end{array}$ \\
\hline September & Alternatieven voorgedragen door deelgemeente \\
\hline Oktober & $\begin{array}{l}\text { Panden aan de Veerlaan blijken reeds aangekocht door stedelijk projectteam, } \\
\text { bezwaar aangetekend, dreiging ontnemen bevoegdheden door wethouder Veilig }\end{array}$ \\
\hline November & $\begin{array}{l}\text { Overleg van deelgemeenten en stedelijk team over de opvang, alternatieven } \\
\text { ingebracht door deelgemeente maar wethouder persisteert }\end{array}$ \\
\hline December & $\begin{array}{l}\text { Deelgemeente biedt college van B\&W een DVD/tv-documentaire aan om } \\
\text { gevoeligheid van locatie Katendrecht te onderstrepen }\end{array}$ \\
\hline 27 januari 2005 & Voorgenomen keuze voor locatie lekt uit; Raadsbrief over gevolgde procedure \\
\hline 1 februari & Collegebesluit over Veerlaan (Katendrecht) \\
\hline 7 februari & $\begin{array}{l}\text { Deelgemeentevoorzitter belt burgemeester met herhaling alternatieve locatie } \\
\text { (Oranjeboomstraat) }\end{array}$ \\
\hline 10 februari & $\begin{array}{l}\text { College trekt besluit in: geen opvang op de Veerlaan. DB deelgemeente biedt } \\
\text { opvang in de Oranjeboomstraat aan, aldus wordt gemeld in persgesprek van } \\
\text { deelgemeente en gemeente }\end{array}$ \\
\hline 16 februari & Tumultueuze bewonersavond in de Persoonshal \\
\hline Maart & $\begin{array}{l}\text { Start ronde langs burgers en organisaties (drie bijeenkomsten), start } \\
\text { voorlichtingscampagne }\end{array}$ \\
\hline Juni & $\begin{array}{l}\text { Overeenstemming over convenant, kleinere omvang van de opvang en } \\
\text { compensatieprogramma }\end{array}$ \\
\hline Juli & Start bouw opvanglocatie \\
\hline Augustus & Oplevering opvang \\
\hline September & Opening opvang in Feijenoord en sluiting tippelzone \\
\hline Mei 2006 & $\begin{array}{l}\text { Deelraadsvoorzitter eindigt bestuurswerk en start als projectleider bij de GGD voor } \\
\text { het programma Maatschappelijke opvang }\end{array}$ \\
\hline
\end{tabular}




\subsubsection{Coping met opvang}

We volgen ook bij deze case de beschrijving van de copingstrategie 'meebewegen' uit het copingspectrum (samengevat in 7.2.). In welke mate spreekt uit de aanpak van deze beleidsmaker een of meer van de onderscheiden stijlen: 'inleven', 'overeenkomen' en 'herformuleren', met de bijbehorende gedragsvoorbeelden?

We vinden in de casus diverse tekenen van inleven in posities van anderen. W. is zelf eerst ambtenaar op het stadhuis geweest en ziet de collega's die daar nu zitten worstelen met de omgang met de deelgemeente, waar hij dan als deelgemeentebestuurder aantreedt:

- Voor mij was het in die zin ook wel een beetje een cultuurschok, dat ik dacht: ik heb vroeger aan de andere kant van de tafel gezeten, ging ik toen ook zo met de mensen om? Je kwam natuurlijk van de andere kant van de wereld en ineens voel je je gewoon een lulletje om het zo maar te zeggen. Je voelt je in alle opzichten niet serieus behandeld.

De massale bijeenkomst in de Persoonshal is voor hem het 'sleutelmoment' in de casus. Hij bekent dat er sprake was van een verrassing, een overweldigende ervaring, waar hij zich niet op had ingesteld, de inleving schoot hier dus tekort:

- Dat je ziet dat je een dag lang de opening van het NOS Journaal bent. Dat daar een schutterende voorzitter staat (...). Dat je moet afgevoerd worden door de politie. Wat ik zelf niet zo heb ervaren, maar van anderen achteraf hoorde, was dat er ook bedreiging en verwensingen naar mijn hoofd werden gesmeten. Je denkt: waar ben ik in godsnaam nou in terecht gekomen? (...) Ja, het was een rare film, waarin je helemaal niet meer zelf, het gevoel hebt dat je daar nog de regie in hebt, maar dat je in een maalstroom van gebeurtenissen...

Het voorval is een ingrijpend moment voor de ervaren gemeentelijke beleidsmaker. De impact is dusdanig, dat hij een andere benadering van de wijk bedenkt.

Dit gebeurt in de vorm van een drietrapsraket van gesprekken, die begint met ruimte bieden aan de zorg van de bewoners. De deelgemeente kan er niet om heen zich écht te verdiepen in wat mensen beweegt en daar moet je dus tijd voor nemen, benadrukt hij:

- Nou, het is de vlek benoemen (...). De woordjes ex-prostituee en prostituee liggen heel dicht bij elkaar. ledereen heeft ook het beeld op het netvlies staan van die uitgemergelde vrouwen op de Keileweg, die tientallen jaren verslaafd zijn, dan is het een beetje simpel om te denken van: je stopt ze eerst in een kliniek bij Bouman GGZ en even later, vallen ze daar nooit meer in terug. Dus dat is een hele reële zorg. Twee: we weten ook allemaal dat het te maken heeft met drugs. Dus dat zo'n voorziening een uitstraling heeft naar drugs, ja. Drie: Die vrouwen zijn niet op zichzelf. Zeker bij de Keileweg, daar zat een wereld van pooiers omheen. Dus ook, hoe houd je dat buiten de deur. Vier: Vervuiling. 
Vijf: Voorbeeldgedrag voor onze kinderen, opvoeden vanuit de situatie. Het is net een brainstorm, daarvan is het slecht als je in een eerste fase al gaat lopen afkappen. Nee, je respecteert alles, je respecteert alles wat ze zeggen. En in tweede instantie ga je het erover hebben: hoe reëel is dat nou allemaal.

Hij neemt de weerstand daarmee als een uitgangspunt voor het handelen, en zoekt naar mogelijkheden om aan te sluiten op beschikbare perspectieven en manifeste definities van de werkelijkheid. Daarmee komt de stijl van 'overeenkomen' uit de beschrijving van de copingstrategie 'meebewegen' direct in beeld: er komt ruimte voor twijfelen, ruimte en ordening. De stapsgewijze gespreksronde komt op tafel. Het begint met ruimte bieden aan wat er leeft:

- Eerste bijeenkomst: waar maken jullie je nou zorgen om? En daarna die tweede bijeenkomst: zet er nou eens naast wat kan je eraan doen om die dingen waarvan je denkt dat ze gaan gebeuren te bestrijden? En dan de derde bijeenkomst: afspraken. Het gevoelen, het leerpunt, dat je na wat je zo'n wijk aan hebt gedaan dat je weer met de wijk in het reine moet komen en toch ook richting stadsbestuur moet terug vechten. Dat had dan daarop betrekking dat we zeiden: het moet zo groot niet worden, kan-ie niet kleiner worden, 29 naar 21 vrouwen. En ook: dat geld dat we erin hebben gestoken, krijgen we dat ook terug? Jongens, ik ga voor jullie wijk dingen uit het vuur slepen bij de Coolsingel. Dat had ik zelf ook wel weer nodig in mijn gevoel om weer een beetje on speaking terms te komen met die wijk. Maar dat duurde wel een maand of vier, vijf....

We zien hoe hij stap voor stap resultaat boekt. Boodschap: ieder mag zijn zegje doen, maar we staan niet stil en zijn gericht op de oplossing. Consciëntieus zet hij in om mee te bewegen met de stadsbestuurders, gefocust op het algemeen belang en vooral op een moreel zuivere koers. Hij heeft een hoger belang in het vizier en vormt - herformuleren in termen van het stijlendrieluik van deze copingstrategie - alle inspanningen naar die focus. We kunnen hier van frontstaging spreken: het naar voren schuiven van een dominant frame ten koste van andere denkbare inkaderingen.

Bij W. draait alles om 'de inhoud van de zaak':

- ...want mij ging het puur en alleen om de inhoud van de zaak, ik had geen verdere politieke bijbedoelingen en ik wilde heel ver gaan om dat gedaan te krijgen. Het college had een nieuw feit nodig. Ik heb daaraan meegeholpen. Het was me veel waard. Achteraf dacht ik: misschien ben ik daar te ver in gegaan. Die draai maken en het college helpen... want het was geloof ik niet zo. Ik heb ook in die zin het spel maar beperkt meegespeeld. Dat ik wel duidelijk gemaakt heb dat het onderdeel van de toezegging, dat bod om mee te betalen, dat lag al in brieven van november, december vast. Althans, niet een bedrag, maar wel de bereidheid om mee te betalen, zij het dat dat bedrag nog niet geëxpliciteerd was.

Uit de beschrijvingen springt naar voren dat W. partijen in stelling kan brengen en daartoe op een flink doorzettingsvermogen kan terugvallen. Als het stadsbestuur wil 
terugkomen op het eerdere besluit in Katendrecht de opvang te realiseren, schuwt hij niet om te burgemeester en wethouders te helpen met een bestuurlijk alibi. Als je anderen mee wilt krijgen moet je voorstellen overnemen, zolang het de goede zaak - de inhoud - dient. Hij verklaart zijn publieke medewerking aan de verdediging van draai van het college:

- Omdat het mij zoveel waard was. Het was nogal niet een hele heftige voorgeschiedenis en ik beschouwde per saldo dat wij het gewonnen hadden, om het zo maar te zeggen. Want uiteindelijk was onze optie gekozen. En het college droop tussen aanhalingstekens af. Alleen, om de aftocht van het college een beetje te maskeren, wilde ik ze wel helpen en dus op die twee punten tegemoetkomen.

Dat patroon van anderen helpen om mee te werken in de door hem bedoelde richting herhaalt zich, als in de gesprekken in de deelgemeente naar voren komt dat verlaging van het aantal vrouwen in de opvang een rol kan spelen. Spelregels zijn er om gebruikt te worden...:

- Maar als ik nou die deelgemeenteraad wat scherpe moties laat aannemen, dat de verdere medewerking staat of valt met een kleiner aantal vrouwen in de opvang, dan ga ik natuurlijk weer met die moties onder mijn arm terug naar het gemeentebestuur. $J a$, zo werken die dingen. Dat spel, dat ging allemaal wel goed, ook samen met die deelgemeente. Dus dat kwam allemaal wel goed uit, dat werkte wel.

In de aanpak van deze beleidsmaker is het vinden van ruimte voor onderhandeling een belangrijk aspect van het proces. In die ruimte kunnen nieuwe mogelijkheden ontstaan of oude voorstellen rijpen. Zolang alle betrokkenen het hogere doel in de gaten te houden, is het niet nodig om je zin door te drukken. De toepassing van dit inzicht komt ook naar voren in zijn volgende baan. Hij gaat dan aan de slag als projectleider Maatschappelijke Opvang. In die functie neemt hij de zorg op zich voor een reeks aan opvangvoorzieningen voor daklozen in de stad. Daar is hij op dat moment harder nodig, verklaart hij de overstap. Over de aanpak:

- ... ik had een goede projectorganisatie die de uitvoering deed. Daar vond ik juist wel dat de kracht ervan was, en dat hoort bij een goede procesaanpak, dat je weliswaar weet waar je ongeveer qua richting uit wilt komen, maar dat je wel openstaat, ruimte laat, voor de inbreng van anderen. En dat je wel moet realiseren dat je, als het aan jou ligt bij wijze van spreken hier uitkomt, maar omdat je het met anderen doet, het ook denkbaar is dat je daar uitkomt, en dat je daar dus ruimte moet geven.(...). Vaak waren die oplossingen die wij dan hadden de goedkoopste, maar ja, met meer draagvlak dan kostte dat wat meer.

Bij deze nieuwe opdracht zien we dus copingstijlen terugkomen uit de eerdere ervaringen in deelgemeente Feijenoord. W. creëert openingen voor meedenken en zoekt oplossend vermogen bij partners. Bij het verbinden van algemene doelen aan individuele doelen zoekt hij overeenstemming over gemeenschappelijke spelregels, 
die nadrukkelijk inhoudelijke vertrekpunten beschrijven. En hij faciliteert het proces. Per deelgemeente komen er 'zoekgroepen', waarin gemeentelijke diensten, woningbouwcorporaties en ook de politie zitting hebben, onder regie van de deelgemeente. Per groep fungeert een stedelijke secretaris als aanjager.

Er komen enkele 'beginselen' waardoor het proces 'op zo'n objectief mogelijke manier' kan verlopen:

- Een: we willen netjes spreiden over de stad, waar dit soort voorzieningen de neiging heeft om altijd in bepaalde wijken terecht te komen. Dus iedereen doet mee. Ook Hoek van Holland, Pernis, iedereen krijgt zijn deel. In de verdeling - dat was ook zo'n principe - kijken we ook naar wat er al is in aan die soort voorzieningen en naar de Veiligheidsindex. En tenslotte ook de vraag hebben ze meegedaan aan voorzieningen voor de dames van de Keileweg. Dan hebben ze een plusje, anders hebben ze een achterstand. [...]. Daar heb ik al flink over nagedacht, er moet een goed beargumenteerd verhaal onder worden neergelegd.

\subsubsection{Factoren in beeld}

Wat heeft deze beleidsmaker in huis om mee te bewegen met de vermeende weerstand en om resultaat te boeken. We volgen de zes beïnvloedende factoren.

Factor I: Persoonlijke hulpbronnen (de werking van extraversie, inschikkelijkheid, zorgvuldigheid, emotionele stabiliteit/autonomie en openheid/proactiviteit).

Uit de casus spreekt een behoefte aan openheid en dat vraagt om mensen tegemoet te treden (proactiviteit), een goede relatie op te bouwen met relevante relaties:

- Het vorige DB zat in de loopgraven rondom de bewonersorganisaties, maar ik dacht: $i k$ wil een goede relatie met die organisaties opbouwen. Ik vind wel dat ik ze nodig heb, daar wil ik wel een goede relatie mee opbouwen.

We zien het koppel emotionele stabiliteit en waarden ook op andere momenten naar voren komen. Het is niet alleen belangrijk om zelf rustig te blijven, maar ook die rust over te brengen naar anderen. Zoals op de avond dat de gemeente haar aanvankelijke voornemen om de opvangvoorziening in Katendrecht te vestigen komt uitleggen.

Hij zit dan in de zaal als deelraadsvoorzitter:

- En ik zat er in die zaal wel rustig, voor mij was het natuurlijk wel een avond die verder wel goed verliep. Voor de inwoners van Katendrecht was ik wel even hun man om het zo te zeggen. De avond liep enigszins uit de hand. En ik heb toen juist gezegd: mensen, ik ben het er niet mee eens, maar geef ze wel de gelegenheid om hun verhaal af te maken.

Eerlijkheid is ook nodig over wie waarvoor verantwoordelijk is en realistische doelen nastreven. In een deelraadsvergadering meldt W. dat drugsgebruik in de nieuwe opvangvoorziening niet getolereerd zal worden en overlast zal worden afgestraft 
(Rotterdams Dagblad, 25 maart 2005). Moeten vrouwen niet zijn afgekickt voordat ze de voorziening binnenkomen? Hieruit spreekt ook aandacht voor zorgvuldigheid omtrent verwachtingen. En in huis-aan-huisblad Groot IJsselmonde meldt hij:

- "Nee, daarover moeten we eerlijk zijn"(...) "De vrouwen gaan allemaal eerst naar de kliniek met als doel af te kicken, maar dat zal zeker niet in alle gevallen lukken. Dat kun je ook niet verwachten, sommigen van hen zijn al twintig jaar verslaafd".

Factor II: professionele drijfveren ('roeping'ten opzichte van baan of carrière, beroepstrots, spel, publieke opgaven en betrokkenheid, gewaagde doelen en waarden).

Rotterdam motiveert, in het bijzonder publieke opgaven:

- Ik ben altijd wel een workaholic. Van huis uit meegekregen dat ik teveel eieren in een mandje doe. Er zitten veel werkeieren in. Ik heb nu wel een redelijk evenwicht tussen werken en genieten. [...], de jaren '9o, was ik dag en nacht met mijn werk bezig, schrijven en nadenken...maar nu. Maar wat bij mij een grote drijfveer is, is het publieke belang. Ik heb me altijd moeilijk kunnen voorstellen dat ik in het bedrijfsleven werken zou. En ik voel me altijd zeer verbonden met Rotterdam. Ik ben een geboren en getogen Rotterdammer. Bezig zijn met dingen van Rotterdammers, ik zou niet zonder kunnen.

Roeping is eerder aan de orde dan baan of carrière, dat is wel duidelijk. Daarbij zoekt hij het spel op. Als je het spel doorhebt, speel je het mee. Als het college het aanvankelijk voornemen om op Katendrecht de opvang te realiseren intrekt en de bereidheid van de deelraad als duveltje uit een doosje wordt gepresenteerd, klinkt in de media wantrouwen door. Een verslaggeefster registreert dat W. 'een slechte leugenaar' is (Rotterdams Dagblad, 12 februari 2005):

- Maar goed, ja, ik ben wat dat betreft ook een slechte toneelspeler, dus als het dan vervolgens in een bijeenkomst over gaat, ja, dan ga ik ook gekke bekken zitten trekken, en nee zitten schudden en zo. Ik kan dat ook niet volhouden. Ik kan mij dat krantenbericht nog wel herinneren. Het eindigde met de opmerking dat ik slecht kan liegen, en dat mijn vrouw daar gelukkig om moest zijn.

Daarbij etaleert hij een hoger doel, betrokkenheid van mensen is van belang. Hij onderstreept 'de participatiegedachte' als een vaandel voor het handelen. Dat is als een waarde, in die zin dat het als een moreel kompas fungeert:

- Representativiteit van samenstelling zegt mij iets minder, maar ik vind wel dat je een representatieve werkwijze moet hebben. In de manier waarop je tot een advies of standpunt komt, als een bewonersorganisatie zich open stelt voor allerlei opvattingen, bijvoorbeeld als je een standpunt bepaalt, dat je er dan ook een bewonersvergadering aan vooraf laat gaan, dan telt het voor mij ook wel. Het feit dat het weliswaar misschien geen mooie afspiegeling is van die wijken, dat kan je die bewonersorganisaties niet kwalijk nemen. Het feit dat anderen niet participeren, dat kan je de bewonersorganisaties niet kwalijk nemen. (...) Pieter Tops 
[bestuurskundige, GR] had het altijd over de vitale nieuwe coalities (...). Dus R. [voorzitter bewonersorganisatie, GR] had ik erin meegenomen, die had bij mij het beeld gevestigd dat dit overal een lastige discussie wordt, maar dat we er wel een zeker draagvlak voor hebben.

Factor III: Ambtelijk besef (politiek-bestuurlijke sensitiviteit, weten hoe bureaucratische hazen lopen en beheersing van strategieën om 'systeemspanningen'te hanteren en partijen in stelling te brengen)

De systeemspanningen liggen in deze casus wat gecompliceerd; de beleidsambtenaar is tijdelijk bestuurder. Hij herkent het samenkomen van de korte termijnfocus van de bestuurder en de lange termijn van de ambtenaar:

- Toen zei die topambtenaar: weet je wat, ik ga het sonderen bij de burgemeester, ik bel je er maandag over terug - of hij daar iets in ziet. Vervolgens belde hij: jij moet hem bellen vóór de collegevergadering van dinsdag met het zogenaamde aanbod. Dat is de grootst mogelijke onzin. Dus ik heb gewoon het spel meegespeeld, want ik was als een kind zo blij moet ik eerlijk zeggen, en dat is ook mijn gevoel.

De spanning tussen beheersbaarheid en democratische besluitvorming komt indringend naar voren door de gevoeligheid van de thematiek. Erkenning van de complexiteit speelt een belangrijke rol bij W., die onderkent geleerd te hebben van de vrucht die het bieden van ruimte - en het helpen benutten van die ruimte - heeft:

- Na de fase dat je de regie totaal kwijt was, daarna wel weer er meester van worden, ja en beheersbaarheid dat klinkt wat control-freakerig, niet in die vorm van beheersbaarheid maar dat het in grote lijnen wel allemaal te bezien valt en binnen marges voorspelbaar is.

Bezien we de strategieën c.q. het hanteren van spanningen dan zien we dus het vermogen om anderen in stelling te brengen. De drietrapsraket van bijeenkomsten na het debacle in de Persoonshal is er een voorbeeld van: zowel deelgemeente als samenleving krijgt hierdoor een platform. Hij is thuis in de gemeentelijke mores. Hij weet hoe de hazen lopen, kent de spanningen die de overheid als systeem met zich meebrengt en beweegt zich ogenschijnlijk lichtvoetig tussen de ambtelijke en bestuurlijke arena's. Bij de vertelling onderdrukt W. regelmatig binnenpretjes als hij gezette stappen herneemt. In het spel van geven en nemen komt het erop aan dat je een ander in positie kunt brengen door hem of haar te helpen bij het zien van alternatieven en het toerusten bij de presentatie hiervan:

- Ik ging mee in de wensen, ik weet niet waarom, of ik nou was meegetrokken of dat het een uitnodiging was, ik was natuurlijk al een man van de gemeente, en toen ontspon zich een gesprek en dat vond ik in die zin wel bizar dat ik dacht: er is toch een andere optie? Ik bracht twee punten naar voren: A, we willen eraan mee betalen, en $B$, natuurlijk is het zo dat wij altijd gezegd hebben dat wat tijdelijk is hier ook definitief 
wordt, en dat we daar ook voor garant staan. Dat waren voor hem een soort nieuwe feiten bijna.

W. vraagt hierbij aandacht voor de hygiëne van het samenspel tussen bestuur en samenleving, en om te beginnen ook binnenshuis. Eerlijkheid over rollen en verantwoordelijkheden is belangrijk:

- Ik heb later heel sterk (...) altijd geroepen: je kunt van deelgemeenten vinden wat je wilt, maar op het moment dat een deelgemeente coalities aangaat met bewonersorganisaties, dan kun je het als gemeentebestuur wel schudden. In die zin ben $i k$ van huis uit sowieso altijd wel een decentralist geweest, ook wel iemand die sterker op participatie is gericht, en dus in een proces verzeild was geraakt, waar alles op een manier gebeurde die eigenlijk indruist tegen de waarden waar je voor staat, om het maar zo te zeggen.

Alles draait bij deze ambtenaar om het aanspreken van mensen, luisteren naar wat hun beweegt en duidelijk maken van rollen en mogelijkheden. Bied mensen ruimte en laat het platform werken. Dan blijken de oplossingen soms klaar te liggen:

- De leidster van het kinderdagverblijf deed dat zó goed. Ik heb later ook wel eens gedacht: als zij een verhaal tegen had gehouden, dan was ik ook weggeweest. Want het werd door iedereen als argument gebruikt. Hoe kan je in godsnaam als bestuurder zo'n voorziening naast een kinderdagverblijf zetten? En daar zat een vrouw, dat zijn dan weer van die gouden krachten die er altijd wel zijn, die zei: die vrouwen moeten toch ook ergens zitten, dus ja, nou ja. Dus die bood mij ook wel dat podium. (...) En het was heel bepalend voor die avond, dat zij dus dat genuanceerde verhaal hield. Want anders was er een hele andere stemming ontstaan.

De crux schuilt in anderen in staat stellen regie over hun situatie te laten hebben en houden; die zienswijze werd toegepast bij het Maatschappelijk Opvangproject:

- Ze werkten allemaal mee. Maar ze hadden allemaal wel zelf de regie. Om de twee maanden zaten ze allemaal om de tafel bij de wethouder en dan vroeg ze: 'Hoe gaat het?' En daar legden ze - ook ten overstaan van elkaar - verantwoording af over de voortgang. Daarmee ontstond wel iets van een sfeer 'We hebben een gezamenlijke opgave', een mobiliseren van krachten.[...] Met die bestuurlijke sessies in het begin, juni een startbijeenkomst en eind augustus weer één, denk ik dat J. [wethouder] er wel in slaagde om bij de bestuurders gedaan te krijgen dat ze zeiden we hebben een gemeenschappelijk probleem, maar ook een kans met de middelen die er door het Rijk worden gegeven om de problematiek van de daklozen eens echt aan te pakken, en het gaat om een manier waar we echt geloof in hebben. Dat waren dingen die bij de deelgemeenten echt gingen ontstaan.

Feijenoord kwam in beweging nadat een gemeenschappelijke agenda was opgesteld: de drietrapsraket van zorgen bespreken, oplossingen definiëren en afspraken 
maken. Het vinden van passende taal en geschikte frames is in deze casus duidelijk af te tekenen. Als projectleider bij de GGD voor het vinden van ruim twintig opvangvoorzieningen voor dag- en thuislozen in de hele stad kiest hij opnieuw voor een start met enkele gemeenschappelijke vertrekpunten:

- We hadden het nog niet helemaal scherp, maar wel hoofdlijnen. En men zei:ja dat ziet er goed uit, en als we eind augustus die verdeling met elkaar rond hebben, dan hebben jullie - deelgemeenten - de regie bij het zoeken van locaties. Als het enigszins kan honoreren we jullie voorstellen.

Andere les wat de vormgeving betreft: beter dan zelf voor de troepen te gaan staan tijdens massale bijeenkomsten kun je netwerken mobiliseren:

- Wat we toen gedaan hebben is dat we ons hebben laten uitnodigen. De opbouwwerker had een hele goede relatie met de Peperklip en dat gebouw lag daar bijna pal naast, daar zat ook een vrouwenstudio. Die had nog zo wat andere relaties. We hadden ook van de deelgemeente een gebiedsmanager. Dat heette toen wat anders, maar goed, die hebben ook hun vertakkingen in de wijk. Die hadden we gezegd: wij willen een soort lange mars door alle instellingen gaan maken en ze allemaal bezoeken, om, wat niet gelukt is, want kijk die bijeenkomst in de Persoonshal was een groot drama (...) geen kans gekregen om een verhaal te houden.(...) Ik wilde proberen om overal dat verhaal te houden en in elke bijeenkomst. Dat had ik wel als idee: of er niet tenminste een paar mensen zijn, of een enkeling, die een tweede stap wil zetten om met elkaar aan dat convenant te werken....

Factor IV: Sociale steun (werking van nabijheid, collega's, informatieve, emotionele en instrumentele steun en - intern en extern - gepercipieerde waardering van je handelen).

Als het gaat om de beschikbaarheid van sociale steun noemt hij om te beginnen de directe collega's:

- ...ik had wel veel steun aan het bestuur, E. (dagelijks bestuurder] vooral, een gouden vent, echt ook scherp, jammer dat hij voor bestuur verder nooit door is gegaan. M. was van de VVD, ze steunde me door dik en dun. Daarnaast was er ook D. die me ook wel steunde, vanwege ziekte speelde ze een wat andere rol (...) Maar goed, we waren wel een team...

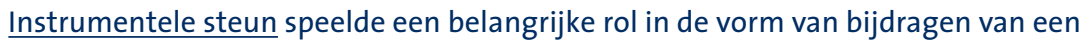
opbouwwerker en een communicatieadviseur. Ook hier zien we een patroon van gerichte inschakeling, geen toevallige contacten:

- Ik heb altijd veel gehad, en die heeft ook veel met mij meegedacht, aan T. [opbouwwerker]. Echt een eminente opbouwwerker vind ik, ook in andere processen. [...] Je kon hem sowieso opbellen, maar ook wel, meedenken... De wereld van T. was enerzijds opbouwwerker anderzijds bewonersorganisaties. Meedenken over hoe die bewonersorganisaties, hoe die toch een beetje mee te krijgen waren. Dat niet die hele 
wereld van de bewonersorganisaties over me heen zou vallen.[...]

- En dan is het wel goed dat je daar niet alleen zit, maar ook een communicatieman, een inhoudelijk deskundige van de GGD. Zodat de experts dan zeggen zus en zo, en je kaf van koren kunt scheiden, maar in eerste instantie neem je alle zorgen serieus. En je gaat met elkaar dat proces door.

Tot die steun behoort ook feedback van collega's en leidinggevenden:

- Bij mijn afscheid hadden we een etentje met de projectgroep en toen zei M. [directeur $G G D$ ]: jij gaat hier wel door het leven als de minzame potentaat. Daar heb ik wel over nagedacht. Aan de ene kant heeft het iets van vriendelijk over nadenken, maar anderzijds... wel op een gegeven moment gedreven aansturen waar je op wilt uitkomen. Dus die drive, ja, maar het is niet iets solistisch, wel het ontwerp heb ik een belangrijke rol gespeeld, maar in de uitwerking is het absoluut een collectieve prestatie.

Externe sociale steun vanuit de samenleving werkt ook als bekrachtiging en bemoediging. Wie goed doet, goed ontmoet:

- Er was een soort open dag, en toen zeiden mensen van Unilever: wij hebben ook een beetje na zitten denken nou, wij zouden het ook allemaal niet bedacht hebben maar ja, waar zijn wij nou goed in? Wij hebben heel veel koks want wij proberen voortdurend dingen uit. Zouden mensen van ons niet kookworkshops aan die vrouwen kunnen gaan geven? Toen dacht ik: nou, dat is nou een ideale vorm van dat sociale profijt dat je voortdurend probeert te organiseren. Dat soort dingen, dat zijn dan symbolen dat je denkt: uiteindelijk is het toch wel gaan werken.

Het perceived external prestige (waargenomen steun van de buitenwereld) is voor deze gedreven ambtenaar geen uitgesproken motivator. Jazeker, de media-aandacht over de bijeenkomst in de Persoonshal maakte indruk, maar om het telefoontje van de mediatrainer 's-anderendaags dat hij hem wel even zou kunnen helpen, moet hij vooral lachen.

Factor V: Zicht op resultaat (inzicht in impact, de keten van effecten van het eigen handelen en doorwerking naar einddoelgroepen. Concreetheid, snelheid en helderheid van feedback).

W. kiest er voor om de verantwoordelijke bestuurders van het stadsbestuur steeds te confronteren met impact van voornemens en beslissingen. Dat blijkt herhaaldelijk uit brieven die hij aan het gemeentebestuur stuurt: op 9 december, vergezeld van een recente tv-opname over het gebied:

- Katendrecht heeft [...] een spraakmakend verleden. Met die gevoelens en het rosse verleden is in het u voorgelegde besluit geen rekening gehouden. Evenmin met de kwetsbaarheid van het gebied, de moeilijk beheersbare veiligheidssituatie en de schade voor de toch al stagnerende vernieuwing van dit schiereiland. (...) De consequentie 
zal zijn dan Katendrecht veelvuldig en negatief in het nieuws komt [...] een negatieve uitwerking hebben op de grootschalige fysieke en sociale inspanningen die zowel in de bestaande als de te ontwikkelen delen van Katendrecht moeten worden geleverd.

Als hij een half jaar na afronding van zijn klus in Feijenoord gevraagd wordt om leiding te geven aan een programma om met deelgemeenten locaties voor maatschappelijke opvang te gaan zoeken helpt hij bij een eerste treffen concrete gevolgen te zien van keuzes:

- Dat heeft wel met respect te maken. Met tot het einde toe een gezaghebbende partij te blijven. Er zit ook wel iets in van geloofwaardigheid, en dat straalde ik ook uit denk ik: dat wat mij overkomen is met de Keileweg dat moet niet nog eens gebeuren. Dat wat mij is overkomen, daar te staan in die Persoonshal, dat is niet de manier waarop wij dat gaan doen. Tegelijkertijd wel duidelijk maken dat het wel om keuzes gaat waar ze verantwoordelijk voor zijn: jullie gaan erover, en jullie gaan het dadelijk ook vertellen en niet het stadsbestuur. Accepteren ze dat allemaal wel...

Helderheid over taak, territorium en rol streeft hij na, bijvoorbeeld als het gaat om interbestuurlijke verhoudingen, tussen de gemeente en de deelgemeenten:

- Ik heb later heel sterk - [...] ik was weer ambtenaar-altijd geroepen: je kunt van deelgemeenten vinden wat je wilt, maar op het moment dat een deelgemeente coalities aangaat met bewonersorganisaties, dan kun je het als gemeentebestuur wel schudden.

Factor VI: Ruimte voor reflectie (koppeling tussen gedrag en leren, hernemen van beslissingen en coaching, programmatische aandacht).

De koppeling tussen gedrag en leren ontstaat, zo wordt in deze casus, gevoed door een (dreigend) dieptepunt. Dan is sprake van ontvankelijkheid om te leren. Zoals het moment dat het college bakzeil heeft gehaald en in een nazit de wonden worden gelikt.

- Het bleek dat er grote onrust in de wijk was en ondertussen was er ook in de gemeenteraad een omslag dat er geen meerderheid in de Raad te krijgen, dat de Raad ook begon te denken: hoe heeft het college dit kunnen bedenken in Katendrecht? Hoe hebben ze zo dom kunnen zijn? Dat ontstond allemaal in die dagen, dus toen was voor T. als het ware ook al duidelijk dat dit dan de mogelijkheid was om eruit te komen. Toen zei hij: weet je wat, ik ga het sonderen bij de burgemeester, ik bel je er maandag over terug - of hij daar iets in ziet.

Sterker nog, je leert bij uistek van een tegenslag, zoals na de desastreus verlopen avond in de Persoonshal waar de deelgemeente steun voor de opvang verwachtte te oogsten:

- Oftewel, ik kwam daar ineens in een heel ander circus terecht. En we hadden dus totaal niet meer de regie. Dat was ook zo'n leermoment. Het was een proces, waarin 
je absoluut niet meer de regie hebt, dus helemaal overgenomen wordt door anderen, waarbij, en dat is ook zo'n leermoment, het zo is, dat alles wat ook maar tegen zo'n beslissing pleit, samenkomt op dat ene moment. Met hulp van J.[communicatieadviseur $G G D])$ hebben we later meer die benadering van segmentatie van doelgroepen gekozen, dit was tótáál het tegenovergestelde.

Bij de Rotterdamse School (opleidingscentrum van de gemeente) worden zijn ervaringen betrokken bij een interne cursus procesmanagement. Dit is op te vatten als vorming van institutioneel geheugen. Zodra W. als projectleider voor een nieuwe klus start, vormen de eerdere lessen uit de Keileweg ook het startpunt voor de interne communicatie. Hij kan aan de hand van ervaringen agenderen: laten zien dat de aanpak in Feijenoord aanvankelijk veeleer een 'projectaanpak' was - rechtlijnig en doelgericht - en dat hij op basis van de lessen meer oog voor een 'procesaanpak' is gaan krijgen. Een boek over procesmanagement van De Bruijn e.a. helpt dan de nieuwe aanpak te verklaren. In dat boek komen waarin waarden als respect en geloofwaardigheid op de voorgrond staan:

- Wat mij bij staat uit het boek is dat ergens wordt geschreven dat een goede procesaanpak 'kunst' is. Ik vond op een gegeven moment wel dat het allemaal goed doordacht was, goed in elkaar stak. Twee, waar ook wat in zat is het respect van partijen. Dat je alle partijen serieus moet nemen en in hun waarde moet laten. Wat ik consequent heb volgehouden, hoewel de verleiding heel groot was om ervan af te wijken, dat is dat als je hiervoor gekozen hebt, dan moet je ook niet toelaten dat een instelling langs komt en zegt: joh projectleider, ik heb me nou toch een mooie locatie op het oog, daar kan ik zo 40 daklozen kwijt. Dan zeg ik maar daar heb ik nu even geen boodschap aan. Als jij vindt dat je een goede locatie hebt, moet jij je melden bij die zoekgroep en inbrengen in dat proces. Ik ga met jou niet even een een-tweetje maken, dan verstoor je dat hele proces. (...)Er zit ook iets in van geloofwaardigheid, en dat straalde ik uit denk ik: wat mij overkomen is met de Keileweg moet niet nog eens gebeuren.

Wat de behoefte aan reflectie betreft: misschien komt er nog een eigen publicatie, meldt W. Voordat hij deelraadsvoorzitter was heeft hij zich gezet aan een boek over probleemmanagement:

- Ik ben geïnspireerd door anderen geweest. Ook een Engels boek over manieren van probleembehandeling. Toen ben ik ook ermee aan de slag gegaan, dacht dit biedt wel heel veel illustratie, maar misschien over twee jaar, hoewel: misschien ga ik dan wel een boerderijtje in Drenthe opknappen. 


\subsubsection{Q sort}

De ongemarkeerde en ongesorteerde reeks beweringen leidt naar de opstelling in figuur $7 \cdot 4 \cdot{ }^{13}$ :

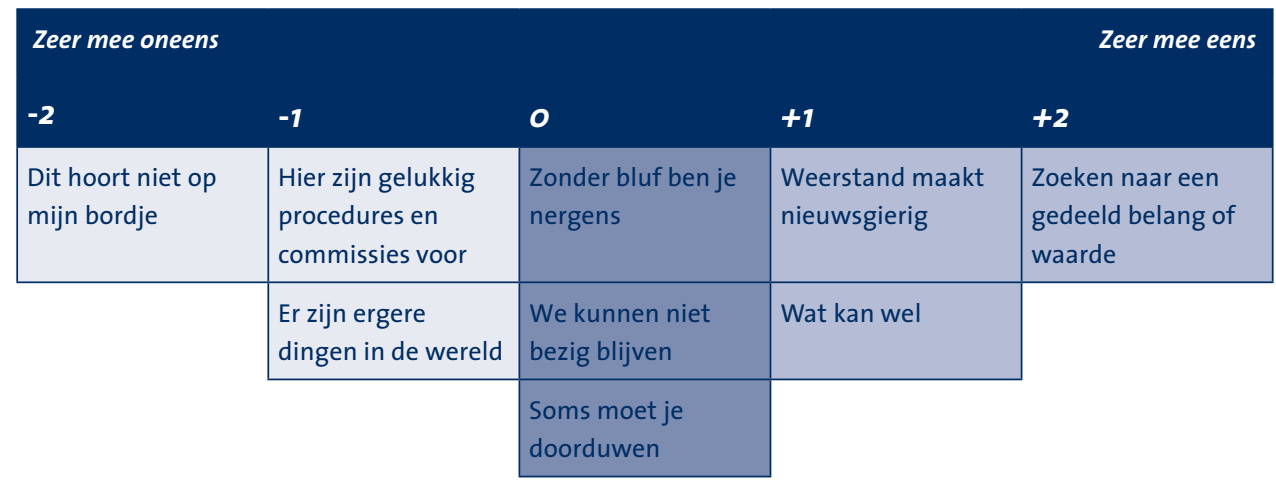

Figuur 7.4. Q-sort casestudy II

Commentaar van W. tijdens het ordenen van de beweringen:

- Kijk, 'zoeken naar gedeeld belang of waarde', dus altijd respect en het besef dat er niet één waarheid is en één waarde, en dat alles wel voor iets staat dat betekenis heeft. Dat is niet altijd jouw betekenis, maar ik heb wel een weerzin tegen mensen die zeggen dat als je de bestuurlijke organisatie zou veranderen dat de dingen dan veel makkelijker zouden gaan [...\} Een deelgemeente kan even lastig zijn als een randgemeente. Ze vertegenwoordigen allemaal een authentiek eigen belang of waarde.

- Ja, 'weerstand maakt nieuwsgierig'. Ik had het vandaag nog, waarom doet men dat. Erachter proberen te komen wat er zit en vandaar uit verder komend. Dat je een tegenstander tot bondgenoot kunt maken en als je daar goed op inspeelt, dat zo'n drive reëel kan zijn...

- 'We kunnen niet bezig blijven': ik ben een uitgesproken procesman, maar ik voel me niet een eeuwige polderaar. Het moet wel ergens toe leiden, het moet resultaat op leiden.

- 'Dat hoort niet op mijn bordje'? Nee, daar ben ik niet van. Dat kom je in de ambtenarij veel te veel tegen. Dat is een beperkt idee van probleemeigenaarschap. Ik instrueer de mensen hier op oogpunt van telefonische bereikbaarheid. Zorg dat mensen niet met een probleem blijven zitten. Ook al is het niet jouw probleem, het moet altijd wel verder geholpen worden.

- ...'Er zijn ergere dingen in de wereld'. Ja, een zekere mate van relativering, ja, maar dat zit bij mij toch meer aan de minkant dan aan de pluskant. Een zekere mate van relativering ja, maar ik wil toch wel bloedserieus bezig zijn met de opdracht.

\footnotetext{
${ }^{13} \square$ = 'wegbewegen' $\square$ = 'meebewegen' $\square$ = 'tegenbewegen'. Zie voor een toelichting 7.3 .
} 
- ...'Wat kan wel'? Je bedoelt daarmee te zeggen: naar een oplossing zoeken. Ja, nee, ja, nee, kijk, hier binnen, dat is natuurlijk wel grappig, ik houd de mensen hier altijd voor: [...] het beantwoorden van een juridische vraag is iets anders dan het oplossen van een probleem.[...] je kunt de juridische vraag beantwoorden of iemand wel of niet terecht een bevordering gekregen heeft, heb je wel een juridisch antwoord, is dat ja of nee, maar het achterliggende probleem is de verstoorde verhouding tussen die werkgever en die werknemer. Je zou hier veel meer bezig moeten zijn met: hoe kun je dat achterliggende probleem oplossen. Van mij is ook de uitdrukking hier: als je een bezwaarschrift krijgt ingediend, pak als eerste de telefoon en niet het wetboek. Dat je die bezwaarmakers gaat bellen: waarom heeft u dit bezwaarschrift nu zo opgesteld. Wat drijft u eigenlijk. Wat kan wel, ja dat zoeken naar.... erkennen van de ellende als basis is zo belangrijk. Dat moet je niet als de grote straatprijs willen verkopen....

\subsubsection{Conclusies case 'Een overtuigende opvang'}

We ontmoeten in deze casus een ambtenaar die de lastige situatie waarmee hij wordt geconfronteerd allesbehalve ontkent, wegwuift of anderszins 'wegbeweegt'. Veeleer is sprake van een wilskrachtige uiting van de copingcategorie 'meebewegen', hij is gericht op contact aangaan en oplossingen vinden. De drie dominante stijlen die we bij deze laatste categorie signaleerden kunnen moeiteloos worden geïdentificeerd in de casus. Het vermogen tot 'inleven' in de wensen en vooral de belangen van anderen helpt steeds een passende toon en tijdstip te vinden. Dit geldt bijvoorbeeld voor het college van B\&W, dat een houvast nodig heeft om een eerder afgekondigde koers af te breken. W. spreekt van een 'spel', waarvan hij geniet maar ook de grenzen ziet. Hij is transparant over zijn koers. Hieruit spreekt ook enige afstand, hij vervult - weloverwogen - een rol en getuigt daarmee van professionele distantie. Ook de stijlfiguur 'herformuleren' is te herkennen, als we focussen op het besluit van het dagelijks bestuur van de deelgemeente om na het 'drama' in de Persoonshal de drietrapsraket in gang te zetten: de tournee door de wijk met de opbouw zorgen verkennen, opties inventariseren en afspraken maken. Hij refereert hierbij openlijk aan hogere belangen. In de eerste plaats is dat een oplossing voor 'de meiden van de Keileweg' en ten tweede een passende, hernieuwde relatie met de bewoners - en zoekt daarbij naar mogelijkheden om 'overeen te komen'. De 'drietrapsraket' lijkt in zichzelf ook een illustratie van de drie stijlvormen te bevatten: eerst zorgen delen (= inleven), dan opties verkennen (= overeenkomen) en daarna afspraken maken (= herformuleren).

W. slaagt erin om een nieuwe, gemeenschappelijke definitie van de omgang met de kwestie te laten ontstaan: waarbij de drietrapsraket van bijeenkomsten die uiteindelijk naar een convenant (en realisatie van de opvang) leidt als een katalysator fungeert. Met de omarming van dat perspectief is de uitkomst van een gunstig, ontvankelijk klimaat voorzien Dit sturen op gemeenschappelijke afspraken fungeert als een hefboom in deze casus en zal ook als methodiek in een volgende opdracht die W. neemt worden doorgevoerd, maatstaf zijn. 
Zonder dat deelbelangen worden weggepoetst, richtinggevend is het te delen perspectief. Hij geeft dit ook expliciet aan als methode. Wegbewegen is in de casus geen optie, tenzij we de 'vaandelvlucht' tijdens de bijeenkomst in de Persoonshal hiervoor in aanmerking nemen; veeleer is hier echter sprake van een veiligheidsoverweging en reële inschatting van beïnvloedbare ruimte bij een massale dreiging. De ervaring hiermee levert W. overigens de les op bij hoge druk nimmer massale bijeenkomsten meer na te streven en op basis van een kleinere schaal te opereren, bij voorkeur 1 op 1 zoals hij aangeeft. Zelf noemt hij de tumultueuze bewonersavond in de Persoonshal het 'sleutelmoment' in de kwestie, het cruciale moment van inzicht. De herinnering aan de massa(medi)ale confrontatie vervaagt zodra de drietrapsraket met de bijeenkomsten duidelijk maakt dat ieder die dat wil zijn of haar zorgen kan uiten $(=1)$, mee kan denken over oplossingsrichtingen $(=2)$ en kan tekenen voor uitkomsten $(=3)$.

Deze drietrapsraket heeft ook een symbolische betekenis: het is de verbindende werkvorm voor de mensen die aan de nieuwe opvang werken. Bijeenkomen, op papier zetten en afkaarten: van de eerste sessie tot en met het convenant ligt er een proces waaraan de belangrijkste spelers zich weten te verbinden. W. realiseerde dit platform overwegend zelfstandig, maar kon wel degelijk terugvallen op enkele steunberen in de politiek en op communicatief gebied.

We zien ook in deze casus een uitgesproken frontstage frame. Alles draait om 'de inhoud van de zaak': een passende oplossing voor de meiden van de Keileweg. W. neemt waar dat hiervoor steun aanwezig is en dat die steun een humuslaag biedt voor de verdere ontwikkeling. Hij stelt vast dat de publieke steunbetuiging van de leidster van de naastgelegen kinderopvang op dit punt (dat de meiden toch ergens opgevangen moeten kunnen worden) een mogelijk onmisbare uiting van die steun is geweest. Het is een toonbeeld van 'compliance' zoals we die eerder beschreven aan de hand van de totstandkoming van de slagzin van de Belastingdienst: het fenomeen dat mensen ten aanzien van een vraagstuk beginselsteun hebben voor overheidsbemoeienis schraagt het bezorgen van lastige interventies. Zoals burgers ten aanzien van belasting betalen van mening zijn dat dit bij het burgerschap hoort, tonen de betrokken inwoners en ondernemers in Feijenoord in beginsel bereidheid om een oplossing te zoeken. Knellen doet de kwestie op een ander vlak en dat is de procedurele rechtvaardigheid (Van den Bos, 2009, 2011) die tentoon wordt gespreid. Zoals bij belastingbetalers sprake is van een behoefte aan een snelle en persoonlijke afdoening, hecht de buurt aan een zorgvuldige bejegening, en dus het horen van de zorgen, het meedenken over de opties en invloed op de oordeelsvorming. Op dit punt toont W. nieuwsgierigheid, gedrevenheid en eigenheid: hij voert bij voorkeur zelf de zoektocht aan en is gericht op korte lijnen en vooral ook: een zekere ingehoudenheid, bescheidenheid welhaast. Hij spreekt ook zorg uit over de tijd dat hij niet zelf bestuurder was: zag hij toen misschien de belangen 'aan de andere kant van de tafel' over het hoofd - of helemaal niet...?. Hieruit spreekt bewustzijn van macht. Hij toont zich op meerdere momenten bewust van de mogelijkheden op dit punt en schuwt doorzettingsmacht niet bij het handhaven van spelregels. Dan is sprake van 'tegenbewegen' in de zin dat hij - gewetensvol doorpakt en partijen met deadlines en eerdere afspraken confronteert. Het levert hem bij het afscheid van het maatschappelijk opvangproject de kwalificatie 'een minzame potentaat' op. 
Bezien we de zes invloedsfactoren, dan blijken de drie primaire beïnvloedende factoren stevig ontwikkeld te zijn. Qua persoonlijke hulpbronnen hebben we te maken met iemand die niet uitbundig, veeleer serieus en met professionele distantie, genegen is zich in anderen te verdiepen, contact te zoeken en een intrinsieke motivatie toont om 'de inhoud van de zaak' te dienen. Uit de bejegening van belanghebbenden spreekt aandacht en respect. $\mathrm{Hij}$ is niet uitgesproken extravert, maar ook niet beducht initiatief te nemen en zich kwetsbaar op te stellen. Vooral is sprake van autonomie. W. heeft inzicht en overzicht en kan daardoor 'vandaag' context geven én 'morgen' perspectief bieden, twee kernkwaliteiten van leiderschap (Seydel, 2008). Van de drie beïnvloedende factoren zien we vooral de combinatie van 'professionele ambitie' en 'ambtelijk besef' krachtig naar voren komen. Er moet sprake zijn van een diep gewortelde drijfveer om de publieke zaak in de stad, zijn stad te dienen. Dit blijkt uit de bereidheid om, ambtenaar zijnde, tijdelijk als deelraadsbestuurder op te treden voor een politieke partij, en daarna weer een ambtelijke status te hervatten. De inhoud van de zaak staat voorop... Het ambtelijk besef komt vooral tot uiting in de strategieën om anderen in stelling te brengen. Steeds weer zijn er situaties waarin hij de integriteit van personen waarneemt, monstert en dan handelt, of het nu gaat om het in stelling brengen van de burgemeester (die bij een lastig besluit kan worden geholpen), de bedrijfsleider van een kindercrèche (die haar zorgen toont over de positie van ex-prostituees zowel als de wijkveiligheid) of om de ex-prostituees (die gebruik maken van een opvanghuis als ze zich aan afspraken houden). Hij geeft aan 'de 'participatiegedachte' als een kompas te beschouwen en te weten hoe de hazen lopen. Jarenlange ervaring maakt dat sprake is van een uitgesproken verwantschap met politiek en stedelijke mogelijkheden). We nemen W. waar als een overheidsman, die, voorzien van kwalificaties die we bij die drie factoren rangschikken, in staat is om anderen in positie te brengen om in een door hem gewenste richting te bewegen: de politieke bestuurders die een vaandelvlucht nodig hebben, de ambtelijke voorbereiders van besluiten die context nodig hebben voor de argumenten en de instellingen in de buurt die willen weten waar het op staat en boter bij de vis verlangen.

De drie andere beïnvloedende factoren - 'sociale steun', 'zicht op resultaat' en 'ruimte voor reflectie' - spelen wel degelijk hun rol, maar op het tweede plan. Dat geldt zeker voor de eerste uit het drieluik: W. betrekt in zijn reconstructie de emotionele en instrumentele ondersteuning van medebestuurders, experts op het gebied van opbouwwerk en communicatie en ook het thuisfront. De betekenis van waardering van anderen komt niet (spontaan) naar voren. Ruimte voor reflectie is er in verscheidene vormen, niet in de laatste plaats aangeblazen door de impact van de gebeurtenis in de Persoonshal. W. krijgt hierna ongevraagd adviesdiensten aangereikt. De impact van de case nodigt uit tot bestudering aan hogescholen en W. krijgt ook platform binnen de gemeentelijke organisatie om (nieuwe) collega's te laten delen in de ervaringen. Bij de aanvang van de volgende opdracht binnen de gemeente - als projectleider Maatschappelijke Opvang - wordt besloten om de loutering van de Feijenoordervaring expliciet voor te houden aan de bestuurders van deelgemeenten, zodra die door de wethouder worden uitgenodigd om mee te werken aan de selectie van opvangvoorzieningen. 
W. krijgt hier kans om zijn ervaring als bestuurder en die van ambtenaar te verbinden en de weloverwogen zorg van het gemeentebestuur voor een zorgvuldig proces kracht bij te zetten.

De factor 'zicht op resultaat' komt minder scherp naar voren in deze casus, helder is wel dat de lichte ontvlambaarheid van het opvangdossier maakt dat uitvoeringseffecten eigenlijk steeds en snel in beeld komen. We hebben hier ook te maken met bestuurders en ambtenaren die bovenop de uitvoering beleid maken. De directe feedback in de Persoonshal vestigde bij W. nadrukkelijk de aandacht op persoonlijke communicatie, directe en systematische feedback en aandacht voor het inbouwen van checks and balances bij beleidsvorming. Het sleutelmoment en de ervaringen erna scherpt hem om partijen in beeld te houden, (rivaliserende) belangen en grenzen aan bereidheid te blijven zien en bijvoorbeeld compensaties te bespreken met partijen. Een door de wol geverfde ambtenaar kan meerdere ballen in de lucht houden, zo illustreert deze casus, namelijk een adequate infrastructuur realiseren, dialoog faciliteren, partijen bijeenbrengen en context bieden: daarmee maak je een behapbare voorstelling van een meervoudige werkelijkheid.

Tot slot zien we in deze case een betekenisvolle factor - of hefboom - die in het conceptueel model niet werd geïdentificeerd maar wel in de theoretische verkenning opdook: de invloed van een intense, ingrijpende ervaring. Weick (1995) wijst immers op de functie van een verstoring voor de het in gang zetten van het proces van betekenisverlening. Ook Czarniawska (1997) komt in haar studies naar het gebruik van narratieven in organisaties tot de vaststelling dat de intensiteit van een ingrijpende gebeurtenis vleugels kan geven aan iemands vermogen om te leren en tot handelen te komen. De persoonlijke ervaring van een schok - de confrontatie in de Persoonshal - fungeerde als een wake-up call, waarop W. achteraf per saldo met voldoening terugziet: reculer pour mieux sauter.

\subsection{Casestudy 3 - Een transparante bedding}

\subsubsection{Kroniek van het proces}

Eind februari 2009 krijgt A., projectleider van de dienst der Gemeentewerken van de gemeente Rotterdam de opdracht om de realisatie van watercompensatie voor de bouw van een parkeergarage in de deelgemeente Kralingen in goede banen te leiden. Op basis van zijn ervaring met ruimtelijke ordening ligt vrij snel een 'globale planning' op tafel.

Die gaat ervan uit dat in mei 2009 een afgerond 'inrichtingsplan' moet worden vastgesteld en vervolgens een reeks acties in gang kan worden gezet. Daarbij gaat het om o.a. het verleggen van kabels en leidingen, rioolwerkzaamheden, rooiwerk van bomen, flora- en faunaonderzoek, bodemonderzoek en bodemsanering (alles inclusief vergunningen). De planning mikt op afronding van alle werkzaamheden in juni 2010. De watercompensatie dient in april 2010 te zijn gerealiseerd. Gewoonlijk duurt een inrichtingsplanprocedure minstens een jaar, in plaats van de beschikbare luttele maanden. 
De opdrachtgever ('gebiedsmanager') denkt sneller door te kunnen pakken, zo klinkt door in een interne mail, waarin hij op 23 februari aan de deelgemeentelijke 'gebiedsprojectleider' preludeert op 'een leuke showcase (...) van goede samenwerking' tussen de betrokken diensten. Dat zijn naast onderdelen van Gemeentewerken, de dienst Stedenbouw en Volkshuisvesting ( $d S+V$ ), het Ontwikkelingsbedrijf (OBR) en de deelgemeente. In maart starten medewerkers van Gemeentewerken met het verzamelen van basisgegevens. Het is de projectleider duidelijk dat de gemeente met een meervoudig krachtenveld te maken heeft. Naast de gemeentelijke diensten zijn in beeld: de deelgemeente Kralingen-Crooswijk, waterleidingbedrijf Evides, Hoogheemraadschap Schieland, DCMR, volkstuinvereniging Nooitgedacht, belangenorganisatie De Bomenridders en omwonenden. Eerder onderzoek maakt ook duidelijk dat het plangebied vliegroutes van vleermuizen herbergt en dat er roofvogels en spechten voorkomen, maar dat ook de bodem sterk verontreinigd is. Oftewel, verschillende belangen dienen te worden meegewogen, die zowel infrastructuur, veiligheid, milieu, flora en fauna, recreatie als verkeer betreffen. Medio mei wordt een planteam gevormd uit de gemeentelijke diensten en de deelgemeente. Op 3 juni komt het team bijeen. In het verslag lezen we de inschatting 'dat de uitvoering veel aansturing nodig heeft'. Het is 3 juli als de projectleider zich terugtrekt met een collega om het krachtenveld nauwgezet in beeld te brengen. Deze collega volgde immers recent een cursus 'krachtenveldanalyse' en beschikt over software om direct in een beeldscherm een ordening te presenteren. De ordening onderscheidt de actoren naar hun rollen - leveranciers, gebruikers, opdrachtgevers en team - en hun houding: positief, negatief, neutraal of onbekend. Hierdoor kan snel en compact een uitgangssituatie in beeld worden gebracht. De bijeenkomst leidt naar een agenda met actiepunten voor de realisatie. Met een prioritering en accenten; welke partners doen er echt toe? Ook het relatiebeheer komt aan de orde: hoe matcht het team met de belangrijkste partners? Vanwege de inschatting van mogelijke gevoeligheden bij een van de externe partners besluit $A$. taken in het projectteam te herverdelen. De vroegtijdige focus op het krachtenveld helpt om te versnellen. Hij definieert de samenstelling van de krachtenveldanalyse als het 'sleutelmoment' in deze casus. Is voor de voorbereiding van een inrichtingsplan gewoonlijk meer dan een jaar nodig (en voor de technische voorbereiding van de realisatie van de inrichting 9 maanden of meer); snel en gericht aanspreken van de juiste partij kan tot een aanzienlijke versnelling leiden. In het planteam wordt op die basis snel zaken gedaan binnen de gemeente en met externe partijen. Die leiden naar de realisatie van de watercompensatie in het gebied.

Een belangrijk moment breekt aan als in augustus vraagtekens ontstaan over de definitie van de 'waterkwaliteit'. De vraag is: hoe kan de hoeveelheid te realiseren watercompensatie het beste worden berekend? Meerdere variabelen doen de ronde. Immers: hoe is de beschoeiing ter plekke, hoe berekenen we de diepte van de bodem en waar gaat straks hoe diep de spa de grond in? Het verslag van de planteamvergadering van 5 augustus rept van 'flauwe oevers', 'onderhoudsgrenzen', 'watergangen' en 'meetpunten' voor wat wel of niet kan worden aangemerkt als 'oppervlaktewater'. Begrippenkaders vallen niet samen. De projectleider maakt met behulp van een flip-over een tekening, op basis waarvan 
een gemeenschappelijke definitie wordt gevonden. Deze gedeelde werkelijkheid bindt de partijen en levert een aanzienlijke versnelling op voor het proces.

Ongeveer tegelijkertijd wordt een overleg gepland met het waterleidingbedrijf. Hoe kan het plan worden gerealiseerd op een manier die rekening houdt met de belangen van Evides. Kan een langdurige leidingenprocedure worden voorkomen of verkort? Normaalgesproken reageert Evides op een vastgesteld inrichtingsplan. Een vergunningprocedure en het inplannen van de werkzaamheden aan de leidingen kost ook ca. 9 maanden. Door goed overleg met het waterbedrijf kan het inrichtingsplan worden aangepast, zodanig dat de leidingen ongemoeid bleven en dat de ruimte voor beheer van het groen en van de leidingen van dezelfde strook grond gebruik konden maken, zonder dat de leiding teveel belast werd door zwaar verkeer. De volle negen maanden die voor een herinrichtingsplan op papier nodig worden geacht, zullen uiteindelijk niet nodig zijn.

Dan meldt in september de volkstuinvereniging zich met een onverwacht initiatief. Men wil een moestuin vestigen op de strook van de Groene Corridor. Op tafel ligt een plan voor 'de Heerlyckheit Nooit Gedacht, een lusthof met eetbare gewassen'. Voordat een projectplan wordt opgesteld willen de initiatiefnemers aan de hand van een 'informatieplan' hun kansen aftasten. Projectleider A. neemt aan de hand van een lijst criteria voor de bestemming van het gebied en aan de hand van de eigen doelstellingen van de Heerlyckheit het plan door met de initiatiefnemers. Op basis van inhoudelijke criteria zal dit plan sneuvelen. Het oogmerk van de Groene Corridor is primair 'watercompensatie', het gebied heeft een bijzondere functie voor flora en fauna - waaronder de betekenis als vlieggebied voor vleermuizen - en er is sprake van een sterk vervuilde staat van de bodem; voor de Heerlyckheit zijn extra voorzieningen nodig, en de toegang is verkeerskundig ook niet goed te regelen. De volkstuinvereniging zal een andere plek moeten zoeken.

In het vroege voorjaar van 2010 wordt de watercompensatie in de Groene Corridor gerealiseerd, een half jaar eerder dan bij een formele procedure. 'Hulde voor de snelle en fraaie renovatie; het resultaat mag er wezen', schrijft de voorzitter van de bewonersvereniging aan de deelgemeente op 2 april aan de voorzitter van de gemeente.

De procesmatige aanpak vertaalt zich in deze case in een betekenisvolle versnelling. Standaardtermijnen kunnen ingekort of overgeslagen worden. Tabel 7.8. vat de feiten samen: 
Tabel 7.8. Feitenrelaas casestudy III

\begin{tabular}{|c|c|c|c|}
\hline \multicolumn{4}{|l|}{ Feitenrelaas } \\
\hline & Werkelijk & Standaard & Plan (maart 2009) \\
\hline Collegebesluit bouw parkeergarage & Januari 2009 & & \\
\hline Zoeken projectleider en globale planning & Februari 2009 & Januari 2009 & \\
\hline Inventarisatie gegevens en knelpunten & April 2009 & (later) & Maart 2009 \\
\hline Start planteam & Mei 2009 & Mei 2009 & Maart 2009 \\
\hline $\begin{array}{l}\text { Tweegesprek krachtenveldanalyse en } \\
\text { bespreken relatiebeheer }\end{array}$ & 3 juli 2009 & & \\
\hline Flip-oversessie & Augustus 2009 & & \\
\hline Overleg Volkstuinvereniging & September 2009 & & \\
\hline Inrichtingsplan gereed & Oktober 2009 & Februari 2010 & Mei 2009 \\
\hline Start uitvoering & Februari 2010 & November 2010 & Juli 2010 \\
\hline Gereed fase 1 & April 2010 & & \\
\hline Pauze vanwege fauna & & $\begin{array}{l}\text { April-september } \\
\text { i.v.m. het broed- } \\
\text { seizoen }\end{array}$ & $\begin{array}{l}\text { Buiten } \\
\text { beschouwing }\end{array}$ \\
\hline Start fase 2 & Oktober 2010 & & \\
\hline Technisch gereed & December 2010 & April 2011 & November 2010 \\
\hline
\end{tabular}

\subsubsection{Coping met waterbelangen}

De ambtenaar in deze casestudy heeft als projectleider in eerste aanleg vooral met partijen met formele verantwoordelijkheden te maken. Deze functionele relaties vragen aandacht bij de vormgeving van de aanpak. Daarnaast spelen de belangen van het bestuur van een volkstuinvereniging en omwonende burgers en de wijkorganisatie een rol. De focus ligt echter op de functionele relaties in deze case. In welke mate is hier sprake van de copingstrategie 'meebewegen' en de daarbij geïdentificeerde dominante stijlen: inleven, overeenkomen en herformuleren?

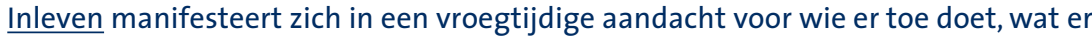
leeft en welke risico's op grond hiervan kunnen worden ingeschat. De rappe collegiale sessie met de krachtenveldanalyse fungeert als een katalysator. Maar we zien ook 
dat de ervaren projectleider het als vanzelfsprekend beschouwt de voorkeuren en belangen af te tasten en hier iets mee te doen. Het komt aan op:

- ... logisch denken. Wat is belangrijk voor de deelgemeente? Je kunt de beleidsstukken nakijken, maar ook zien hoe ze er inzitten. Want een deelgemeente zegt over het algemeen: geen gezeik en niet te veel geld uitgeven. En ze willen ook niet geconfronteerd worden met negatieve gevolgen, bijvoorbeeld een slechte beheerovereenkomst waardoor niet goed te beheren valt. Of een juridische procedure omdat in de voorbereiding iets niet goed gelopen is. Zorgen dat je bijvoorbeeld in deze wijk niet om half acht begint maar om acht uur, omdat de mensen in deze wijk de hoger opgeleiden zijn, die niet om half zeven naast hun bed staan. Simpele dingen.

Voor de totstandkoming van het inrichtingsplan zijn vele partijen nodig. A. kiest er nadrukkelijk voor gemeenschappelijk de verkenningen te maken en eventuele hobbels te bespreken. Daarmee bouwde hij expertise op en een profiel in de organisatie:

- In dit geval was ik de projectleider. Ik word ook wel eens in een adviesrol ingeschakeld - er is een probleem, kom er eens bij, hoe kunnen we partijen op een rijtje krijgen, is er nog financiering mogelijk, kunnen we het beter verkopen of communiceren of beter het probleem in beeld brengen - maar hier was ik de projectleider.

Op een rijtje krijgen... De tweede stijl - overeenkomen - uit het drieluik van de copingstrategie 'meebewegen' spreekt hem aan.

- Het zit soms in de procedure en soms in het contact; maar als je een goed gesprek voert dan komen de procedures vanzelf wel. Nu konden we op basis van voorlopig ontwerp voorstellen invoeren in plaats van veel later, met een uitgewerkt ontwerp in de vergunningenprocedure.

Hij 'weet' dat uit het contact nieuwe stappen naar voren kunnen komen:

- (...) Ja, er gebeurt meestal ook nog iets anders en dat is een soort saamhorigheidsgevoel: we zijn het over iets ingewikkelds eens geworden, wij kunnen samenwerken, wij begrijpen elkaar enzovoort.

Maar niet tegen elke prijs. Zelf kwalificeert A. zijn bejegening als 'genadeloos doelgericht met gevoel voor de omgeving'. Is hier sprake van forceren, een opleggen van een pandoer? Uit de benadering spreekt veeleer een neiging om experts in positie te brengen om van elkaar maximaal profijt te hebben. Als dat een extra vergadering vereist, dan moet dat, zo maakt hij duidelijk. Maar we pakken wel door als professionals:

- Ik ben over het algemeen vrij doelgericht, er moeten gewoon afspraken gemaakt worde. Maar ik zoek altijd naar mogelijkheden, naar opties, naar draagvlak, onderdeel daarvan is spreken we dezelfde taal, waar hebben we het over. Als je het ergens over eens wilt worden, moet je weten wat dat 'wat' is. Het type interventie is dan spontaan, de actie is wat je doen moet om er te komen. 
En:

- Ik heb natuurlijk ervaring opgedaan met bodemonderzoek en bodemsanering, dat zijn dingen die op het kritisch pad van een bouwproces zijn, dan moet je gewoon organiseren dat het onderzoek op tijd is gedaan, dat duidelijk is wat je gaat doen, dat de financiën op orde zijn, van die dingen.

Hiermee toont deze professional ook een dominant frame frontstage te positioneren en dat is 'vakmanschap'. Oftewel: als je professionals aanspreekt op hun kernkwaliteiten, kun je verder komen. Dan voer je een dialoog over de feiten:

- Ik geef mensen heel veel vrijheid, maar er zijn een paar dingen waar ik genadeloos op stuur en dat is het succes van het project ja of nee. Dus er zijn bepaalde dingen dan moet je je aan de regels houden, als dat mis gaat dan heb je een probleem, dat kan beteken dat je tot vannacht half drie moet werken van me, maar andere dingen mag je op jouw manier doen, want jij bent de deskundige. In allebei de gevallen luister ik naar advies, maar waar het uiteindelijk om gaat is het projectresultaat, daar worden we beiden op aangesproken. Tenzij we beiden tot de conclusie komen dat het een slecht project is, dat kan natuurlijk.

In de aanpak van A. vallen inleven in belangen en voorkeuren en aanspreken op professionaliteit op, waarbij hij streeft naar de verbinding tussen partijen.

Uiteindelijk bleek een gemeenschappelijke onzekerheid een belangrijke 'scharnierfunctie' te vervullen. Voor het verkrijgen van een vergunning was het nodig om een gemeenschappelijke beschrijving te maken van de hoeveelheid water bij de te realiseren watercompensatie. Eén mogelijkheid is dat de projectleider dan een voorstel laat maken en aan de vergadering van belanghebbende partijen in het planteam voorlegt. Mede dankzij een interventie van de projectondersteuner ontstond een andere aanpak:

- We hebben samen de vergunningvoorwaarden ontdekt, door eerst in de vergadering te spreken: hoe berekenen we die vierkante meters? Dat leidde al heel gauw tot iets waarvan de projectondersteuner dacht: ik begrijp er geen bal van. Ze was niet de enige, niemand begreep er wat van. Toen was het: hebben we het over de zelfde term, dus toen gingen we het even naar een hoger niveau tillen, het doel was watercompensatie, doel is dat je dat samen kunt vaststellen, doel is dat je aan bepaalde kwaliteit voldoet, doel is dat het robuust is in de zin van er staan allemaal bomen om heen, die verliezen blad, het maaiveld stijgt, het wateroppervlak wordt kleiner, wanneer doen we de meting, vandaag is het tienduizend vierkante meter, maar over vijf jaar zijn het er dan minder? Hoe rekenen we dan af? Wat is dus robuust en toen hebben we op het bord schetsen gemaakt: dus dan rekenen we dat wel mee en dat niet en dat voor 100 procent en dat voor 10 en zo kwamen we tot het aantal vierkante meters.

Op dit kritieke moment doet A. een interventie. Met de groep samen wordt een nieuwe schets gemaakt van de waterhoeveelheid: 
-We zijn aan een gemeenschappelijke taal gaan werken. Het Hoogheemraadschap, de Werf, het ontwikkelingsbedrijf...Niemand begreep elkaar, je zag de houdingen en je dacht: dit gaat niet goed. Dan moet je improviseren, je kijkt om je heen, denkt 'help' en er stond een flip-over. Is er ook een pen, ik geloof dat iemand de kamer uit is gerend en uit een la een stift heeft gehaald. Toen was het als we nou eens een doorsnede tekenen, dit tellen we mee, dit niet, eigenlijk waren we er in een kwartier wel uit. Een volgende keer in een sessie die tekening nog eens toegelicht, zijn we het hier over eens, die is ingescand en die is verkleind en toegevoegd aan de vergunning.

Hiermee openbaart zich in deze casus ook de tweede stijlfiguur van 'herformuleren'. A. verklaart:

- Het gaat ook over de taal, dat je over het onderwerp voldoende weet om met enig gezag te kunnen spreken of iemand de ruimte kunt geven om dat te doen. En het is nodig om de vaardigheid te hebben om partijen te kunnen bewerken, onderhandelen, perspectief schetsen, ik ben er niet zo bedreven in om dat te benoemen, maar om die dingen uit de kast te rukken nu hebben we dit nodig en nu dat.

De gezamenlijke definitie van de waterhoeveelheid was iets om trots op te zijn. De uitkomst gaf het projectteam vleugels. Voor A. ontstaat op enig moment gelegenheid om zich terug te trekken, zo vertelt hij:

- Op het moment dat ik wist dat het project loopt, heb ik er nauwelijks meer naar gekeken. Fietste ik er af en toe eens langs, vond ik ook dat ik niet meer bij de projectteamvergaderingen aanwezig hoefde te zijn. Dat kon de technisch projectleider doen.

Een oogje in het zeil volstaat dan. Hoewel, toen hij hoorde over een bodemverontreiniging bij een autosloperij, gingen de alarmbellen rinkelen bij deze ambachtsman:

- Dat is gut feeling, als ergens en autosloperij is geweest kan er van alles begraven zijn, asbestplaten, accu's, weet je niet (...) als je het echt aantreft, heb je vertraging. En dat is dan een gegeven en dan moet je er iets mee, dat betekent dat het kosten zijn, vertraging, pers erbij op een manier die je niet wil. Nee, pers mag overal zijn, maar dat de boodschap die naar buitenkomt niet overeenkomt met de werkelijkheid kunnen we niet hebben. Namelijk we hebben al heleboel onderzoek gedaan, we hebben niet lopen klootviolen, desondanks kun je nog iets aantreffen. Maar je wilt niet dat een Groene Corridor verbonden wordt met bodemverontreiniging, nee, smeerlapperij. We doen dat als gemeente netjes. 


\subsubsection{Factoren in beeld}

Welke betekenis hebben in deze casus de zes beïnvloedende factoren? Op basis van de reconstructie in gesprekken en bestudering van beleidsdocumenten stellen we vast in welke mate de factoren zich voordoen.

Factor I: Persoonlijke hulpbronnen (de werking van extraversie, inschikkelijkheid, zorgvuldigheid, emotionele stabiliteit/autonomie en openheid/proactiviteit).

Inschikkelijkheid is zichtbaar als hij zich verdiept in belangen en verwachtingen van de partijen aan tafel. Dan kijk je wat je voor een ander kunt betekenen. Zoals bij het waterleidingbedrijf:

- ... dan bedenken we: het is een grote waterleiding, dus ze moeten er altijd bij kunnen, dus we gaan dat faciliteren, welke methodes zijn er om dat te doen, 2 of 3 zeg maar, wat is onze voorkeursvariant, om die te bespreken, dit gaan we doen, we gaan jullie leiding niet kapot maken, maar bewaken dat het goed blijft en dat hadden we gedacht op die en die manier. We hadden die leiding al goed onderzocht, was er een goede gronddekking bijvoorbeeld, er was ook wat onderhoudsachterstand zagen we; dus we hadden hen ook wat te verwijten...

Hij toont het vermogen om te benoemen wat lastig ligt en een sfeer van openheid te creëren als blijkt dat een teamlid een remmende invloed kan hebben bij een cruciale partij. Dan moet je elkaar met open vizier tegemoet kunnen treden:

- Dus hebben we dat samen met hem besproken: er komt een andere technisch projectleider op, samen met hem in die sessie besproken. Hij kwam daar zelf al mee, dat wisten we overigens al, de samenwerking ingenieursbureau en de werf was precair, en we zagen samen in dat er een aantal mogelijkheden waren dat het zou escaleren de verkeerde kant op.

Uit het optreden spreekt ook emotionele stabiliteit. Hij realiseert zich een eigen pad te bewandelen binnen de organisatie:

- De manier waarop ik het invul is wel een persoonlijke stijl, want het is wat de dienst betreft niet gewoon. Binnen Gemeentewerken zijn we over het algemeen wat gestructureerder en formeler, in de zin van procedures volgen. Maar het is niet ongewoon dat je gewoon je opdracht gaat doen en daar gebruikt iedereen zijn sterkten en zwakten in.

Hij hecht aan zorgvuldigheid. Het project start met een sessie van twee uur waarin hij met een collega het krachtenveld in kaart brengt:

- We ordenden ze naar vier typen rollen: de gebruikers heb je, het team, dat het maakt en uitvoert, de leveranciers die vanuit vergunningen iets moeten of kunnen vinden en je hebt opdrachtgevers die vanuit hun rol iets kunnen vinden. Met kleuren ook kun je 
aangeven wie je als voorstanders of tegenstanders zijn, of mogelijk. (...) Het schept orde, het benoemen op de eerste plaats. Je hebt even orde nodig, dat was ook van belang om het opgeschreven te krijgen. Op zich was dat niet zo belangrijk - ik kan heel veel dingen onthouden en ik gedij heel goed in chaos - maar de praktijk is dat ik ongeveer drie dingen kan onthouden, waarop ik kan sturen. Dan maak je me om kwart voor vier wakker, dan weet ik dat ik dit of dat kan of moet doen. Dus zo konden we per partij aangeven wat de acties waren die we nodig hadden. En daarmee geef je richting aan je project.

Factor II: professionele drijfveren ('roeping'ten opzichte van baan of carrière, beroepstrots, spel, publieke opgaven en betrokkenheid, gewaagde doelen en waarden).

Hij heeft gekozen voor de publieke zaak. De noodzakelijke interactie met de omgeving motiveert om juist de overheid te dienen:

- ...bij een commercieel adviesbureau moet je ieder uur verantwoorden, een tijdlijst maken etc. De ruimte om met een project bezig te zijn is bij de overheid ruimer, er is meer aandacht voor de context. Daarom zijn we ook duurder en beter. We hebben wel eens een discussie met een opdrachtgever die zegt: wat zijn jullie engineering-kosten hoog. Dan zeg ik:'als u onder engineering verstaat dat we een tekening maken en een bestek en je zegt 50.000 en dan zijn we klaar, dat kan. Maar u vraagt ook dat wij gaan communiceren met de omgeving, dat wij vergunningen aanvragen en daarover de onderhandelingen doen, en als wij dat niet doen, moet een ander dat doen, dan wordt het ook betaald, maar het is nu op ons conto geschreven'. Sterker nog: wij worden soms gevraagd om een opdracht te schrijven terwijl het uw werk is. En u zegt tegen mij dat ik duur ben....'

Hoe complexer de publieke opgaven hoe leuker, er is sprake van nieuwsgierigheid naar nieuwe verbindingen, daaruit komt ook beroepstrots naar voren:

- Dat is je puzzeltje, je uitdaginkje, dat is leuk. (...) ik heb nu een ander project waar drie jaar een planteam op heeft gezeten en ik heb het overgenomen een paar weken geleden, ging toevallig ook over water, er was geen overeenkomst over de beheerskosten, daar is ongeveer een jaar over gesproken. Er bestaat geen buitenruimte op tekening die je niet beheert, er bestaat alleen een buitenruimte die functioneert en dus beheerd wordt. Ik heb geen overeenstemming, dus ik roep jullie nu bij elkaar en we gaan er uit komen in een hok. En binnen een uur waren we eruit. We hadden van tevoren wel een aantal varianten bedacht en opties, over die partij etc., en dan denk je na afloop waarom doen we er zo lang over.

Schaken is leuker als je op meerdere borden kunt spelen en de openingen ziet bij spelers, de gewaagde doelen zijn aan hem wel besteed en ook het spelelement komt naar voren. Hij verwacht dat ook bij andere spelers aan tafel:

- ...er zaten een paar mensen bij die denken alleen in problemen en niet in oplossingen 
en alleen oplossingen werken. Zo van: 'daar worden we voor betaald, dus daar gaan we naar toe.' Het vereist ook een bepaalde flexibiliteit van communicatie want het vereist verschillende talen spreken en dat is dat je de taal van verschillende partijen spreekt in de zin van wat zijn hun belangen, wat zijn hun verantwoordelijkheden, wat is het voor persoon, wat is hun mandaat, hoe zitten ze aan tafel ook. Ik denk dat ook van belang is dat je de vaktaal spreekt. Dat overtuigt (ze merken dat je weet waarover je het hebt); en dat is bij mij wel van belang.

- Als je een project doet, dan moet je weten wat de succesfactoren zijn en de faalkansen. Dat zijn de knoppen waaraan je kunt draaien.

Factor III: Ambtelijk besef (politiek-bestuurlijke sensitiviteit, weten hoe bureaucratische hazen lopen en beheersing van strategieën om 'systeemspanningen'te hanteren en partijen in stelling te brengen)

Van de systeemspanningen zien we de belangenafweging in relatie tot de rechtsstatelijkheid naar voren komen. Hij weegt regels en belangen op de hand:

- Eigenlijk was van tevoren al bekend dat er een grote tijdsdruk op stond. En dat betekent dat alle gebeurtenissen die tot vertragingen leiden, tot problemen leiden. Dus dat was een heel belangrijk ding om op te sturen. En dat kunnen dus processen en procedures zijn, daar kun je weinig aan doen want wettelijke procedures zijn wettelijke procedures, dus dan moet je zorgen dat je ze op tijd start, en dat kan zijn management van de omgeving van het project, dus alle betrokken die daar bij zijn, je projectteam enzovoort. (...) Bestuur, politiek etc., die zijn van belang, er is een club volkstuinders, die zijn erg belangrijk om te weten hoe ze in het project staan. En dat geldt ook voor diensten, want je kunt wel zeggen: de wettelijke procedure om een vergunning te verlenen is acht weken, dertien weken of wat dat dan ook zij, maar een deel is hoe lang ligt het op je bureau en een deel is ga je ook extra vragen stellen, is het wel duidelijk zo. Dan moet je van tevoren weten van die partijen of ze in de meewerkstand staan of niet, en waar dat je van afhankelijk bent.

Beheersbaarheid in een democratische context is de tweede systeemspanning die A. onderkent:

- Angst van de mensen [bij de deelgemeente, GR] was: 'Ho, dit is Kralingen Oost, die mensen schreeuwen altijd moord en brand, enzovoort, dus een communicatieplan volgens de participatieladder was nodig en daar heb ik toen een interventie opgedaan. Jongens ik ga nu met die omgeving communiceren, want straks staan er allemaal kranen in de achtertuin en dan weten die mensen nergens wat van. Dit moet besproken worden. Jullie zijn nog steeds bezig na te denken over een strategie enzovoorts, maar die tijd is voorbij, gáán! Daar schrokken ze van, toen moest ik op het deelgemeentekantoor komen, toen kon het wel, toen kon er een bespreking komen, met de bewoners van Kralingen en toen bleken die, mits goed gepresenteerd, heel ontvankelijk voor de oplossingen. 
De projectleider wil partijen'in stelling brengen', de spil in de strategieën die we onderkenden voor het hanteren van de systeemspanningen. Dat geldt ook voor de maatschappelijke groeperingen:

- Datzelfde gold voor de Bomenridders, de mensen van de volkstuinvereniging en die een heel leuk plan hadden, met wie ik ook in gesprek ben gegaan over hun plan en in dat gesprek bleek dat het leuke plan dat ze hadden helemaal niet haalbaar was. Wat er nu is gerealiseerd is, is een betere optie. Dat zijn allemaal politieke opties, waar je wel degelijk rekening mee moet houden. Dat heb ik dus gedaan vanaf het begin.

Steeds weer valt hij terug op inschattingen van mogelijke aanknopingpunten bij partijen. Je moet de complexiteit zien en de feiten filteren, dan kan een volgorde ontstaan voor denken en doen:

- Het enige verschil met dit project is dat het hier niet alleen om bodemverontreiniging gaat, maar ook om archeologie, om watervergunning, om flora en fauna, om etcetera. Het is hetzelfde ding, maar in meer dimensies, met meer partijen. En dan heb je ook nog met een proces te maken dat je moet realiseren met kritische succesfactoren als: iemand moet het betalen, dat doet hij alleen als er kwaliteit geleverd wordt en wat is dan kwaliteit? (...) Dus eigenlijk ga je eerst kijken: er moet water worden gegraven, dus daarmee begin je en je stelt je de vraag hoe is dat voor alle partijen die er een spaak in het wiel kunnen steken acceptabel of misschien zelfs aantrekkelijk?

Factor IV: Sociale steun (werking van nabijheid, collega's, informatieve, emotionele en instrumentele steun en - intern en extern - gepercipieerde waardering van je handelen).

De steun komt om te beginnen van het projectteam. Het is vooral ook de betekenis van informele en instrumentele steun voor elkaar die telt:

- Door te merken dat er aandacht is, werken mensen mee, zitten ze te praten, hoe is hun houding, zijn ze betrokken, dat zie je dus aan de verbale en de non-verbale communicatie en dan moet je mensen er bij trekken, want die en die is niet de eerste die wat zegt, maar hij moet wel erbij zijn dus eens aanspreken, een vraag stellen, even de pen uit handen geven, kun jij dat even uittekenen, daar weet jij meer van. Doe ik soms bewust, wat nodig is, en dat is niet door het als een soort alziende in te schatten. Als je het niet weet moet je het ook niet doen.

Alles valt of staat bij de alledaagse steun en ook persoonlijke aandacht voor elkaar:

- De projectondersteuner was heel belangrijk, het was haar eerste klus, ze was net in dienst, ontzettend leergierige meid, niet alleen maar briefjes schrijven, maar ze wilde alles weten. Voordat ze hier ging werken had ze een restaurant, ze weet ook al wat van management. Mensen kunnen meer dingen dan waar ze voor zijn ingeschakeld vanuit hun professionele rol. Als je dat benut bereik je meer, en werk je leuker. Dat heeft hier bij verschillende mensen zo gewerkt, en was heel effectief 
Wie goed doet, goed ontmoet, benadrukt A.:

- Wat wij in dit gesprek expliciet zitten te maken is voor een belangrijk deel een beetje intuïtief gebeurd, maar vooral die technisch projectleider heeft mij fantastisch geholpen om dit te doen. Dat was dus gewoon een gesprek met een collega. Collega-coaching... een medewerker coacht mij om explicieter bezig te zijn waar ik mee bezig ben. En dat is vaak waar het om gaat, dat je met een collega praat over je werk en dan krijg je een beter beeld, op de voorwaarde dat je niet wordt gezegd nu moet je dit doen of nu moet je dat doen, maar iemand die je dus goed in positie brengt. Daar ben ik hem zeer dankbaar voor. (...) Ik coach hem nu persoonlijk. Hij had een ontwikkelopgave op het gebied van communicatie, had een conflict met collega's, zowel met mensen onder hem als naast hem. Terwijl eigenlijk zijn bedoeling goed is, maar het kwam op een manier zijn mond uit die bij de klant en bij zijn collega's weerstand oplevert. Cursus gedaan over omgaan met weerstand en heb toen afgesproken met zijn leidinggevende dat $i k$ hem zou kunnen helpen bij toepassing. Hij doet het heel goed, staat zelfs heel hoog aangeschreven bij zijn collega's.

Factor V: Zicht op resultaat (inzicht in impact, de keten van effecten van het eigen handelen en doorwerking naar einddoelgroepen. Concreetheid, snelheid en helderheid van feedback).

Ingrijpen is één, vervolgens komt het aan op - helpen - zien van de effecten:

- Ik word ingehuurd om iets te doen, maar het moet ingepast worden in de omgeving en daar houd ik dus rekening mee. Probeer ik te pleasen? Feitelijk wel: ik probeer te voldoen aan de randvoorwaarden. Maar er zit ook een stukje verkoop bij. Letterlijk een beeld kunnen schetsen en mensen kunnen bewegen naar iets wat toch wel erg mooi is dat het er is. Daar is enige fantasie bij nodig. Het gaat over iets dat nog niet bestaat.

Niet onbelangrijk is dan partijen te helpen om zich in de betekenis van (re)acties bij anderen te verdiepen. Feed forward...:

- Als de corridor niet op tijd klaar komt, is er geen watercompensatie, kan formeel de bouw van de parkeergarage niet doorgaan en loopt gemeente een belangrijk project op gebied van verkeer en vervoer mis waarbij bovendien nog subsidie van de stadsregio aan verbonden is. En erger nog, vertraging, geld kwijt, parkeergarage - dat is geen goede combinatie in Rotterdam medio 2009... [waar zich een debacle aftekende bij de bouw van een parkeergarage onder het Museumpark, GR] (...) Dat is op stadhuisniveau. Op deelgemeenteniveau had ik gesprekken en vroeg ik toen ze met allerlei voorwaarden kwamen: hebben jullie dat stedelijk niveau wel in de gaten eigenlijk? Als jullie een beetje op de weerstands- of de vertragingsstoel gaan zitten, zijn ze jullie op het stadhuis erg dankbaar. Er zit een escalatieniveau in, dat de bevoegdheid van de deelgemeente aan de orde is. 
Factor VI: Ruimte voor reflectie (koppeling tussen gedrag en leren, hernemen van beslissingen en coaching, programmatische aandacht).

In de teams waarin hij werkt agendeert hij leren nadrukkelijk. De koppeling tussen gedrag en leren moet je onderhouden, en dat begint bij eigen voorbeeldgedrag, zo benadrukt hij:

- Zodra er routine ontstaat word ik slordig en kan ik het ook beter aan een ander geven. Er moet dynamiek zijn, uitdaging, iets van een puzzeltje zijn... (...) Maar ik ben nog lerend om dat goed te doen. En zien dat iets gebeurt en dat moet op een gegeven moment leiden tot bewuster inzetten, hetzij van tevoren, hetzij op het moment dat het zich voordoet weten, als dit niet werkt, nou dan doe ik gewoon dat.... Dat leren is leuk. Ik ben ook maar gewoon een aap met een banaan, op een gegeven moment komt er toch een banaan, het wordt uiteindelijk toch beloond, een simpele Skinneriaanse psychologie...(...)

Bewuste aandacht in de vorm van programma's is nuttig, maar het schiet er vaak bij in:

- Ja, die risicosessie is zoiets, dan doe je bewust dingen, een evaluatie, een echte aparte sessie, ik doe wel eens een interventie hoe gaat de samenwerking, laten we nou eens kijken wat we ervan vinden om even buiten het project te stappen en even op een ander niveau te bekijken, maar ik doe het niet vaak genoeg.

Het agenderen van leren is wat A. betreft dan ook een doel dat om onderhoud vraagt, met een focus op het leren nemen van risico's:

- Als je wilt leren moet je wel even stil staan bij dat je aan het leren bent. Leren moet zinvol zijn, het gaat erom dat je resultaten levert. Dan moet je wel de tijd nemen om stil te staan bij: wat doe ik. Als het daarom gaat, dat doe ik vrij vaak, maar vooral individuele gesprekken over houding, gedrag welke emotie hebben ze erbij, waarom vinden ze het moeilijk, zou het ook op een andere manier kunnen, meer 1 op 1.

Een tekenaar maakt een tekening en ik wil dat zijn werkwijze anders wordt.

Maar ik weet ook dat als ik zeg dat zijn houding anders moet, dat het dan niet effectief is. Ik wil met hem komen tot stappen naar tekeningen waar de opdrachtgever wat aan heeft. En dan ga je dus samen zitten kijken naar wat er gebeurt. Dan bespreek je dat een bepaalde aanpak van hem veiligheid geeft, terwijl ik in die fase van een project meer onzekerheid en het nemen van risico verwacht. Dat wordt wel onderwerp van gesprek, maar dan hebben we echt een paar stappen nodig: Dat heeft een keer een paar weken geduurd in een project. We hebben er toen een keer of drie bij stil gestaan hoe zijn werkwijze was, hoe hij zich er bij voelde, wat ik van hem verwachtte. Maar ik heb ook feedback gegeven: goh, jij leert wel snel, het is het nog niet, etcetera. Ik vind het heel belangrijk dat zo iemand uit zijn veilige hokje stapt en denkt: nou die boze wereld van onzekerheid, die durf ik wel aan, het valt best mee, mijn hoofd is er niet af. Dat soort gesprekken heb ik veel met die gasten. 


\subsubsection{Q-sort}

Aan het slot van het gesprek worden de negen beweringen voorgelegd, ongesorteerd en ongemarkeerd. Het leidt naar de ordening in figuur $7.5 .{ }^{14}$ :

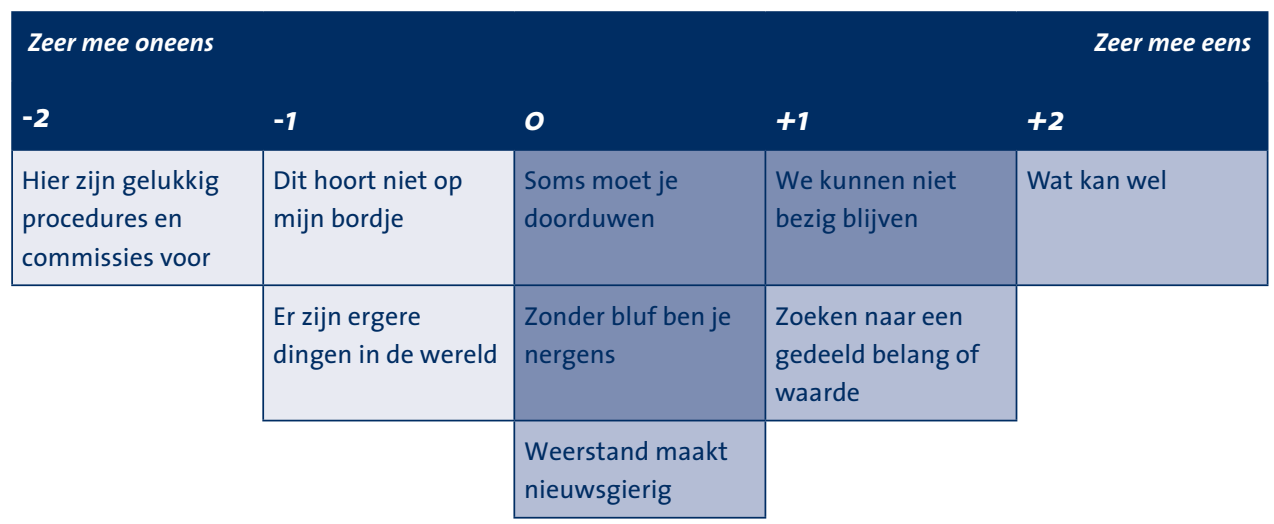

Figuur 7.5. Q-sort casus III.

Commentaar van A bij het ordenen van de beweringen:

- 'Oei, 'Dat hoort niet op mijn bordje' is niets voor mij.'

Hij concentreert zich direct op de beweringen die bij 'wegbewegen' zijn geïdentificeerd:

- 'Er zijn ergere dingen...'dat sowieso... Ik ben erg van het relativeren. Ik ben absoluut niet van de procedures dat is niet voor mij...Als je ze effectief kunt inzetten doen, en als je ze niet nodig hebt, nalaten.

Hij verlegt dan de blik naar de beweringen die we hebben opgesteld als onderdelen van 'meebewegen':

- 'Wat kan wel', dat...kansen grijpen, zoeken naar mogelijkheden. En: 'Soms moet je doorduwen', en 'We kunnen niet bezig blijven' dat zou ik weten....en, ach ja, we kunnen niet bezig blijven... Die zet ik wel heel hoog. Als je het hebt over afpellen van verantwoordelijkheden, dit is je fatale datum en zo, dus daarom heb ik wel wat met 'We kunnen niet bezig blijven'ja.

- Als er gedeelde belangen zijn te vinden, dan is het mooi, maar als het te lang duurt... Ik heb eerder wel eens een ervaring gehad met Communicatie, toen moesten er heel veel bewonersbrieven geschreven worden, toen moest ik pas op de plaats maken, en toen heb ik gezegd: flikker op ga niet aan mijn kop lopen janken, dat is de 'afdeling procedures' en ook haantjesgedrag 'nu kom jij aan mijn project', iedereen mag zich ermee bemoeien, schoonmaakster, wethouder, voorlichter, maar niet als ik een rituele tekst krijg voorgeschoteld.

\footnotetext{
${ }^{14} \square$ = 'wegbewegen' $\square=$ 'meebewegen'
} $=$ 'tegenbewegen'. Zie voor een toelichting 7.3. 


\subsubsection{Conclusies case 'Een stevige bedding'}

Wie met meerdere partijen te maken heeft en met uiteenlopende belangen, doet er goed aan die partijen in stelling te brengen om hun eigen doelen te halen; de erkenning van eigen perspectieven (of: agenda's) opent de weg naar een gemeenschappelijke agenda, een deelbaar doel. Deze conclusie aan het slot van deze casus zou zo ontleend kunnen worden aan enkele studies naar grote projecten zoals de aanleg van de ze Maasvlakte (De Bruijn e.a., 2007, Pauly, 2001). In deze casus is de projectleider immers gericht op het vergaren van kennis over agenda's, voorkeuren en werkwijzen en op het verkennen van mogelijkheden om individuele en collectieve wensen te benutten. De schaal is anders dan bij genoemde grote projecten, maar we zien inzichten die bij complexe en meervoudige opgaven onafhankelijk van de schaal bruikbaar zijn. Zoals: belast partijen niet met meer opgaven dan nodig is, bind partijen op een belang waar ze het wel over eens zijn en breng partijen in stelling met gerichte voorzetten, die er voor hen toedoen. In de casus blijkt sprake van een overlap en een afhankelijkheid in taken. Zoek dan naar een positieve samenwerkingssfeer, is de boodschap van de projectleider. Niet in de trant van: 'eerst moet jij dit en dan pas doe ik dat'. Maar: 'we moeten daar naartoe, hoe helpen we elkaar, hoe lopen we elkaar niet in de weg'. In deze casus had de projectleider te maken met potentiële hobbels vanwege de belangen van een waterleidingbedrijf, een volkstuinvereniging en meerdere ambtelijke diensten. Hij slaagde erin 'gemeenschappelijk te maken', te communiceren dus, en deed dat met een redelijk straffe hand. 'Je werkt mee of niet' staat op de ongeschreven uitnodiging van een beleidsmaker die een uiterste poging zal doen om die medewerking te bevorderen. Het vermogen het krachtenveld goed in kaart te brengen kent hij veel betekenis toe; de eerste samenstelling van de krachtenveldanalyse is wat hem betreft het 'sleutelmoment' bij deze ambtelijke opgave.

Op het 'copingspectrum' wegbewegen - meebewegen - tegenbewegen kan de aanpak van projectleider A. worden gepositioneerd als een illustratie van 'meebewegen'. Van vluchten of duiken is geen sprake en van forceren alleen op detailniveau (waaronder de besluitvorming over de fietsroute). We hebben hier te maken met iemand die doorwaadbare plaatsen helpt zoeken - en vinden. De projectleider legt er eer mee in om mee te bewegen met geluiden van belanghebbenden. Zodra de plaatselijke volkstuinvereniging aankondigt een 'lusthof' aan de Groene Corridor te willen vestigen, nodigt hij hen uit om met hun plannen op de proppen te komen. In het gesprek wordt het voorstel getoetst aan al vastgestelde criteria voor het gebied en de eigen doelen van het plan. Hij luistert, vertraagt en helpt de perspectieven te concretiseren. Op grond van de verkenning stelt het bestuur van de volkstuinvereniging vast dat het voorstel niet gerealiseerd kan worden.

Het beschreven proces voor het realiseren van watercompensatie vanwege de aanleg van een parkeergarage elders in de wijk Kralingen, toont vooral hoe het expliciteren van twijfels en het zoeken van gemeenschappelijke taal en ruimte kan mobiliseren. Deze dynamiek zien we als in een beslissend stadium onduidelijkheid blijkt te bestaan over de definitie van het begrip' waterkwaliteit'. De onduidelijkheid werd aangegrepen om een gemeenschappelijke definitie te formuleren. De tekening die in een sessie van het planteam op de flip-over verscheen 
werkte zoals een katalysator in een chemisch proces: een verbinding te maken en een proces te versnellen. Na een gedeeld beeld van het krachtenveld bij de aanvang van het project realiseerde projectleider A. met deze flip-overactie opnieuw een gedeeld begrippenkader en deze beide interventies verschaften de betrokkenen een gemeenschappelijke energie. De tekening op de flip-over is een symbool voor het gemeenschappelijk besef.

Het vermogen om mensen hun inbreng te laten leveren en beelden van de werkelijkheid te delen en nieuwe gedeelde beelden te definiëren kan worden teruggebracht op de werking van de beïnvloedende factoren. Zo bieden persoonlijke hulpbronnen houvast: hier is sprake van inschikkelijkheid, openheid, zorgvuldigheid en een stabiele inzet. Deze beleidsmaker weet wat hij wil en kan. A. karakteriseert zelf zijn stijl als 'genadeloos doelgericht met gevoel voor de omgeving'. Professionele ambitie werkt als een verzachter in dit proces: zijn gerichtheid op de inhoud, resultaat wordt met grote passie voor de publieke zaak gebracht. Hij is een ingenieur van het kaliber 'hard op de inhoud en zacht op de relatie'. Ook het ambtelijk besef helpt om tijdig de relevantie van tegengeluiden en de werking van procedures voor de ruimtelijke inrichting op hun waarde te schatten. En dan proactief door te pakken. Ook actuele kennis van politieke en bestuurlijke agenda's, risico's, voorkeuren en werkwijzen weeft hij ogenschijnlijk achteloos in. Hier staat iemand die de politiek, de bureaucratie en maatschappelijke actoren in stelling kan brengen. Hij schenkt vertrouwen en gaat daarin zover, dat hij zichzelf langzaam buiten beeld brengt en terugtrekt in een faciliterende rol als expert-op-afroep. Als frontstage frame kunnen we bij deze casus spreken van 'vakmanschap' en meer specifiek over de betekenis van 'dialoog over de feiten'. Na zich stevig vergewist te hebben van wie er toe doen, waar voorkeuren, allergieën en belangen zitten, zoekt A. de gemeenschappelijkheid in definities van processtappen en leidende begrippen als 'waterkwaliteit'. Vakmensen kun je op inhoud aanspreken en binden.

De ruime mate van beschikbaarheid van deze drie basale beïnvloedende factoren maakt dat in de casus de andere drie typen factoren minder gewicht hoeft te worden toegekend. Sociale steun is er, onder meer in de vorm van de directe collega, die (krachtenveld) kennis wil delen en als vaktechnische vraagbaak beschikbaar blijft, maar ook de ondersteuner die als een hofnar vragen blijft stellen om de zaak te kunnen volgen: de waarde van de frisse blik. We zien echter primair een zelfstandig opererende beleidsmaker. Het netwerk van belanghebbenden dat hij om zich heen spant zorgt voor het behoud van zicht op resultaat, dat is van belang voor de momenten dat hij onverhoopt zelf geen overzicht zou hebben, het biedt hem ook ruimte om als projectleider voortijdig terug te treden en op afstand de voortgang te volgen. Ruimte voor reflectie etaleert hij nadrukkelijk als een belangrijk thema, door de eigen ervaring als casuïstiek in te brengen in collegiale ontmoetingen en initiatief te nemen voor het doorvertellen en toetsen van lessen met ruimtelijke inrichtingsplannen zoals in deze casus. Investeren in leren en expliciteren van aannames en gedragingen vraagt onderhoud, benadrukt A., waarbij hij wijst op het onbewuste karakter van veel gedragingen. Het leren kan er gemakkelijk bij inschieten, daarom moet je regelmatig 'er samen voor gaan zitten'. Uit de casus blijkt niet hoe de omgeving hem hiertoe in staat stelt, het is welhaast een onderdeel 
van de primaire set beïnvloedende factoren: een persoonlijke hulpbron in combinatie met professionele ambitie, roeping en wil om er het beste van te maken.

\subsection{Conclusies casestudies}

De centrale vraag in dit onderzoek luidde: hoe komen beleidsambtenaren bij vermeende weerstand succesvol tot de copingstrategie 'meebewegen'? Twee specifieke onderzoeksvragen richten de beantwoording op de copingstrategie respectievelijk de zes beïnvloedende factoren.

7.7.1. Deelvraag 1: Hoe manifesteert de copingstrategie 'meebewegen'zich ten opzichte van de optie om weg- en tegen te bewegen?

Uit de drie casussen spreekt een prompte houding als het gaat om de mogelijkheid om te vluchten: wegbewegen is kennelijk geen optie. Er is een uitgesproken wil aanwezig om een taak uit te oefenen en het daarvoor noodzakelijke contact aan te gaan. P. stelt schertsend, dat hij alleen dood een alibi kan hebben om verantwoordelijkheid te ontlopen. Hij beroept zich op die verantwoordelijkheid als ambtenaar om een bestuurlijk besluit na te helpen komen. W. haalt ook de legitimiteit van politieke besluitvorming aan om de geloofwaardigheid van de overheid te benadrukken. A. wijst op vakinhoudelijke drive en noemt ook nieuwsgierigheid als motivatie. De strategische optie 'wegbewegen' is wel bekend, maar als handelingsoptie is ze niet in Frage; wat maakt deze afwijzing bij deze drie functionarissen zo manifest? De drie primaire beïnvloedende factoren bieden houvast. Bij alle drie functionarissen is sprake van krachtige persoonlijke hulpbronnen: empathie, een extraverte instelling, emotionele stabiliteit en intellectuele autonomie. Die persoonlijke bagage zorgt voor een stevige fundering. De professionele ambitie (factor twee) in combinatie met kennis van en ervaring met ambtelijke processen (factor drie) versterkt dat fundament. De combinatie helpt om niet alleen wegbewegen uit te sluiten, maar de mogelijke weerstand juist op te willen zoeken en andere spelers en andere mogelijkheden te gebruiken, of het nu gaat om informeren, motiveren of in stelling brengen. Hiermee wordt de betekenis van de drie als primair genoemde hulpbronnen onderstreept: ze maken dat een ambtenaar 'beroepstrots' heeft en die trots maakt dat je bij tegenwind niet afbuigt, maar juist zeilen bijzet om 'vol overtuiging' koers te kiezen. Wegbewegen is duidelijk niet aan de drie gevolgde ambtenaren besteed.

\section{Tegenbewegen is een terugvaloptie}

Aan de andere kant van het 'copingspectrum' staat de optie om bij weerstand de confrontatie aan te gaan en een van de geïdentificeerde stijlen te kiezen: een doorbraak forceren, doordrukken of intimideren. Deze tweede strategische optie ligt genuanceerder dan de vluchtstrategie. Uit de casestudies kan niet worden opgemaakt dat deze handelingsoptie wordt afgewezen; in alle drie de cases is sprake van persistent gedrag om ervoor te zorgen dat de klad er niet in komt, zodra het eigen dominante frame wordt geraakt. Bij P. is het talmen over de formulering van een zin in een concluderend document aanleiding om door te drukken: 'Jij neemt je verantwoordelijkheid, ik neem mijn verantwoordelijkheid, we maken nog een 
keer de zin en die maken we samen, dan maken wij een deal. De rest van de tafel doet even niet mee aan het spelletje', zegt hij tegen de dierentuindirecteur. Bij W. zijn er herhaaldelijk momenten dat hij zelf de pen of de telefoon pakt: 'Ik ben geen eeuwige polderaar. Het moet wel ergens toe leiden, het moet resultaat op leveren', zegt hij, steeds gefocust op de inhoud van de zaak. Dat geldt ook voor een strenge houding bij het naleven van regels door de toekomstige bewoonsters van de opvangvoorziening. Tijdens de afronding van een volgend project wordt hem de kwalificatie toegevoegd 'een minzame potentaat' te zijn. Projectleider A. is vooral gevoelig als buitenstaanders procedurele interventies plaatsen: 'ga niet aan mijn kop janken, dat is de afdeling procedures' (...) iedereen mag zich ermee bemoeien, schoonmaakster, wethouder, voorlichter, maar niet als ik een rituele tekst krijg voorgelegd'. Hij geeft zich een kwalificatie, waarin doorzettingsmacht de overhand heeft: 'genadeloos doelgericht met gevoel voor de omgeving'. Tegenbewegen is geen primaire strategie; bij mogelijke weerstand confronteer je pas in een tweede instantie. De optie wordt van stal gehaald als het niet lukt 'gemeenschappelijk te maken' (tot een overeenstemming te komen op basis van beschikbare kennis van perspectieven). Een bevorderende factor hierbij is het oordeel dat de andere partij iets aan te rekenen valt. In de drie besproken cases komt tegenbewegen in beeld zodra de ambtenaar het vertrouwen dreigt te verliezen in de competentie van anderen om een beslissing te nemen. A. is bereid om iemand die iets niet snapt even apart te nemen en te coachen, maar uiteindelijk mogen we niet uit de tijd lopen. W. wil investeren in meedenken over opties om de opvang te realiseren, maar verwacht uiteindelijk commitment aan het hogere (overheids) doel of algemeen belang. En P. verliest geduld als in het andere kamp een loopje wordt genomen met zijn mensen en de 'spelregels' (mores). Verwonderlijk is het niet: de betrokken ambtenaren terug kunnen vallen op een stevige set persoonlijke hulpbronnen, waaronder intellectuele autonomie en emotionele stabiliteit. Wie sterk in zijn schoenen staat, is voor geen kleintje vervaard. Het is juist het ambtelijk besef en in het bijzonder de wens om anderen in stelling te brengen en ruimte te creëren, wat meebewegen preferabel maakt. Tegenbewegen, de tweede optie, komt in beeld als de allergie van de autonome en nieuwsgierige 'overheidsman' wordt geraakt. Bewustzijn hiervan kan helpen er adequaat mee om te gaan, anders is het een achilleshiel: een kwetsbaar punt voor iedere betrokken, zelfstandige beleidsmaker.

\section{Meebewegen is het bindmiddel vinden: inhoud}

Wat maakt meebewegen met de weerstand heilzaam? Er zijn meer perspectieven op een vraagstuk mogelijk, zodra die meervoudige perspectieven worden (h)erkend is het vinden van een - nieuwe - gedeelde werkelijkheid mogelijk. Die - deelbare - werkelijkheid is mogelijk bij een basale wil van betrokkenen om een oplossing te vinden (compliance). $\mathrm{Er}$ is reden aan te nemen dat die wil bij gesprekspartners van de overheid aanwezig kan zijn, en in ieder geval het verdient geëxploreerd te worden. Deze wil om zich te voegen - compliance - hangt samen met een grondhouding ten opzichte van overheid; burgers (en ondernemers) zijn in beginsel gefocust op procedurele rechtvaardigheid (Van den Bos, 2011). Bij die basale en soms ronduit kwetsbare bereidheid spelen erkenning en bejegening een hoofdrol. Belangrijker dan de inhoudelijke kwestie (respectievelijk bezuiniging, huisvesting van ex-prostituees en 
watercompensatie) is de vraag of er behoefte is aan procedureel houvast. De sleutel schuilt daarmee in rechtvaardigheid of eerlijkheid. Mensen kunnen beperkingen accepteren, maar ze moeten voelen dat de beperking redelijk, voor iedereen gelijk en terecht is. Zowel weerstand als dissonantie zijn krachtige prikkels. Het is aannemelijk om weerstand te zien als een speciaal soort dissonantie. Weerstand heeft echter één afwijkende eigenschap. Mensen ervaren weerstand als iemand anders hen iets aandoet (oneerlijke beperking). Dissonantie echter wordt gevoeld als mensen zelf iets inconsistents doen (Brehm \& Weintraub, 1977).

De beleidsmaker slaagt erin om deze basale wil of grondtoon aan te boren zodra en zolang hij dus op het' wrijvingspunt' van het eerlijke of rechtvaardige contact maakt en hieraan een als relevant te beoordelen perspectief weet te verbinden. Gevraagd: een passend 'frame' (denkkader) voor het nieuwe, deelbare perspectief. In een minimalistische voorstelling van zaken: onze drie beleidsmakers slagen erin om het met belanghebbenden ergens over eens te worden. Er is sprake van betekenisverlening die naast (niet per se in plaats van) de eigen werkelijkheid een nieuw perspectief helpt te nestelen. Je zorgt dat iets bindt. Dat is om te beginnen een inhoudelijke aangelegenheid, maar vervolgens speelt ook symboliek een rol. Brummans et al. (2008) spreken van front stage framing: in een complexe situatie schuif je bepaalde thema's (argumenten, zienswijzen) naar voren (of naar de achtergrond), waardoor een nieuwe zienswijze mogelijk is, zonder dat bestaande, mogelijk strijdige perspectieven verdwijnen. Gabriel (2000) ontleende aan onderzoek naar narratieven in organisaties een set dominante stijlmiddelen, te weten het gebruik van een motief, het nemen van verantwoordelijkheid, het bieden van kwaliteit, een causale relatie, eenheid of uitsluiting en agency (vert.: opwekken tot actie). Uit het ambtelijk handelen van P. kan zo een dominante focus op 'verantwoordelijkheid' worden afgeleid. Hij noemt het begrip expliciet als hem gevraagd wordt naar beweegredenen om initiatief te nemen, om niet weg te bewegen of om sturing te geven. Hij betrekt dat op zichzelf, maar neemt ook anderen de maat aan de hand van dit stijlmiddel. Zoals wanneer het gaat om het in positie brengen van de wethouder om verantwoording af te kunnen leggen en bij het uitleggen van wat hij van de tegenspelers bij de dierentuin verwacht: laat ieder vanuit zijn verantwoordelijkheid handelen. Bij hem is 'verantwoordelijkheid' het front stage frame, dat sterker wordt dan andere denkbare frames zoals 'emotie' (aan de hand van slachtofferschap van bezuinigingen bijvoorbeeld) of 'kwaliteit' (deugdelijke invoering van een democratisch besluit). Het aanspreken van verantwoordelijkheid mobiliseerde partijen om het gemeenschappelijk werkblad ten volle te gebruiken en 'wegbewegen' af te wenden en 'tegenbewegen' tot een minimum te beperken.

Bij W. is het 'motief' leidend als frame, en dat motief is het dienen van de inhoud, de goede zaak. Dit frame beweegt naar de voorgrond en drukt alle andere mogelijke invalshoeken naar de achtergrond. Voor 'de goede (publieke) zaak' kan het ook nodig zijn - even - een spel mee te spelen; zolang je er transparant over bent, is sprake van een flexibel werkterrein. Het doel heiligt in dit geval de middelen. Dat heeft alles te maken met de bij W. (en overigens in mindere mate ook bij de anderen waarneembare) sterk ontwikkelde opvatting over wat de overheid vermag, waardoor 'rechtvaardigheid' en 'meedoen' naar voren komen als pregnante 
thema's. Verwantschap met of lidmaatschap van een politieke partij speelt hierbij een rol en ook een bij zichzelf herkende nieuwsgierigheid voor complexe processen, zelfstudie, het verzorgen van lessen en een (nog niet afgemaakt) boek.

Als dominant frame komt bij A. 'kwaliteit' naar voren, meer specifiek: de kwaliteit van de vakman. Op de voorgrond speelt zich wat $A$. betreft het gesprek af hoe een beoogde voorziening deugdelijk en verantwoord kan worden gerealiseerd. De kwalitatieve inzet is niet gespeend van lol. Hij geniet van het spel. Hier staat een vakman die geniet van het professionele gooi- en smijtwerk, die een slimme procesgang nastreeft en die ruimte biedt aan andere vaktechnische inzichten en ervaringen. Hij stapt er aan het einde van het project ook letterlijk voor opzij: anderen kunnen het project afmaken. Hij heeft geen behoefte aan glorie over zijn persoon; de klus is goed geklaard. Bij de reconstructie laat hij op zijn computer enkele mooie foto's zien van het gebied. Dat je werk enkele fraaie winterlandschappen oplevert is meegenomen, maar het is niet de kern van de zaak.

\section{Meebewegen is binden: ook op vorm}

Bij het ambtelijk handelen presenteerden de drie respondenten niet alleen aan de hand van inhoudelijke troeven (zoals herbenoeming van interpretatiekaders) overeenstemming en daarmee draagvlak voor een verandering. Een bejegening waaruit eerlijkheid (rechtvaardigheid) spreekt in combinatie met een relevante duiding van het perspectief verschaffen interactie een basis. Ze slaagden er alle drie ook in om qua vorm mensen aan zich te binden: er ontstond een gemeenschappelijk beeld, dat als een 'gezamenlijke werkruimte' fungeerde. Dit verwijst naar de betekenis van symboliek. In alle drie de gevallen hangt het vermogen om niet te hoeven tegenbewegen of wegbewegen samen met de creatie van een gedeelde voorstelling van zaken. Er is dan sprake van co-oriëntatie (Habermas, 1970): de bereidheid om gezamenlijk aan de slag te gaan. De gedeelde voorstelling van zaken werkt als een gemeenschappelijke horizon waaraan partijen zich moeilijk kunnen onttrekken, weet Van Osch (2003): als overeenstemming wordt bereikt over de manier van communiceren, is de uitkomst gelegitimeerd. Een gemeenschappelijke werkelijkheid ontstaat. Symbolische daden helpen om een nieuwe, gedeelde context te vinden waaraan perspectief gekoppeld is, een grondslag voor leiderschap (Seydel, 2008). Achtereenvolgens zijn dat in de casussen een gezamenlijke agenda (11 puntenlijstje voor de zachte landing van een bezuiniging), een bijeenkomstenreeks (drietrapsraket om van zorgen via oplossingsrichtingen naar afspraken te komen) en een tekening op een flip-over (om een definitie van waterkwaliteit te verkrijgen). Er was een concreet benoembaar houvast, waaraan mensen zich konden verbinden. P. lanceert het '11-puntenlijstje' en daarmee beschikken gemeente en diergaarde over een gemeenschappelijke agenda. Het akkoord over deze gezamenlijke opgaven, het ritme van tweewekelijkse gesprekken en de verslaglegging in de vorm van een groeidiamant, fungeert als een bindmiddel. Het steeds weer terugkerende en aanvullende lijstje is het gedeelde werkblad. $\mathrm{Bij}$ W. is dat werkblad de ronde door de wijk die als drietrapsraket is opgebouwd: eerst ruimte voor de zorgen, dan de oplossingen bespreken en dan afspraken maken. De negatieve sfeer die was ontstaan rond de in de Persoonshal wordt doorbroken met een open uitnodiging, een 
gezamenlijke agenda en een gedeelde uitkomst. De bijeenkomstenreeks fungeert als symbool, het verschaft houvast en biedt uitzicht op de toekomst. In de derde casus ontstaat ook een gemeenschappelijke werkruimte op het moment dat partijen zoeken naar een definitie van 'waterkwaliteit': als A. voor de flip-over gaat staan en met het gezelschap de lokale situatie in kaart brengt komt in co-creatie een gemeenschappelijk beeld op tafel. Dat beeld activeert als een gezamenlijk product, het helpt de complexiteit accuraat en eenvoudig te presenteren. Ook dat schept een band. Deze gedeelde werkruimten met hun inhoudelijke en symbolische componenten binden meningen, ze binden de partijen en helpen ook de complexiteit te reduceren. Er is sprake van een basale bereidheid - in alle casussen - om er samen uit te komen. Mensen zijn niet tegen verandering, maar veranderen stuit op weerstand en aandacht voor die weerstand is het begin van bereidheid om andere wegen in te slaan. Sennett (2008) spreekt van de professionele kwaliteit om te kunnen 'herformatteren': het vermogen om een oorspronkelijk 'format' of basisinstelling te herbezien en zich te hernemen: 'o, zit dat zo'.

\section{Een opeenvolgende trits}

In de beschrijving van de copingstrategie 'meebewegen' worden drie stijlmiddelen onderscheiden: inleven, overeenkomen en herformuleren. De casestudies laten zien dat dit drieluik als een volgtijdelijke reeks kan worden gezien. Samengevat: wie kan inleven, creëert ruimte voor overeenstemming en in die nieuwe context kunnen nieuwe perspectieven en een opgave worden geherformuleerd. De beschreven casuïstiek biedt houvast om deze tritsen af te tekenen. Het inleven in de denkbare reacties op de subsidiekorting (casus 1) gaat bij de verantwoordelijke beleidsmaker in de casus van de diergaarde gepaard met een actief contact met betrokkenen. Door de aard van dat contact is het mogelijk perspectieven op de toekomst uit te wisselen en een inventarisatie te maken van kansrijke verbeterprogramma's. De interactie levert naast (niet in plaats van) dialoog over de bezuiniging een minstens zo waardevol discours op over een toekomstbestendige ontwikkeling van de topattractie.

Bij realisatie van de opvang van ex-prostituees (casus 2) brengt een schokkende ervaring met publiek verzet een versnelling en een verdieping aan in de inleving in de publieke zorgen. De beleidsmaker voorziet de stroom aan zorgen van een bedding en een perspectief, waardoor beelden kunnen worden uitgewisseld over condities waaronder de opvang mogelijk kan zijn. De gesprekkenreeks is van vitale betekenis voor de inhoudelijke overeenkomst in de vorm van een convenant, waarna de weg naar realisatie van de opvang mogelijk is. Ook in de derde casus zien we dat het naar de voorgrond halen van een gemeenschappelijke opgave - de bepaling van de gewenste waterkwaliteit aan de hand van een tekening op een flip-over - volgt op een systematisch georganiseerde maar in de uitvoering ingehouden en rustige kennismaking met belangen, mores en voorkeuren. De gemeenschappelijke labeling van een gemeenschappelijke kernvraag opende deuren naar commitment.

Deze opbouw vertoont verwantschap met enkele ordeningen voor gedragingen in andere werkvelden. Zo presenteert econoom Nooteboom (2004) bij zijn beschrijving van de transactiekostentheorie de opbouw 'contact - contract - control'. Deze opbouw heeft betrekking op het verloop van zakelijke transacties. Handhaving (in control zijn) staat of valt bij 
een overeenstemming (contract) en voor overeenstemming is 'contact' nodig: een geslaagde kennismaking. Sociaal psycholoog Marra gebruikte deze opbouw in feite ook in een verhandeling over het verloop van communicatie in crisissituaties. Hij heeft hierbij gewezen op de samenhang tussen de benadering van een ander, een overdracht of mandaat en het verwerven van instemming. Dit is door hem samengebald met 'relatie - vertrouwen commitment' (Gutteling, 1999). De systematiek kan ook worden herkend in de bedrijfsstrategie die olieconcern Shell presenteerde na de bekritiseerde afzinking van de Brent Spar: 'DialogueDecide-Deliver' (Rothermund, 1998).

Deze drieluiken zetten de gekozen volgtijdelijke opbouw bij de copingstrategie 'meebewegen' kracht bij. In schema ontstaat dan een copingsdrieluik (tabel 7.9.):

Tabel 7.9. Copingsdrieluik

\begin{tabular}{|l|l|l|l|}
\hline Nooteboom (2004) & Marra (1998) & Shell (1998) & Rijnja (2011) \\
\hline Contact & Relatie & Dialogue & Inleven \\
\hline Contract & Vertrouwen & Decide & Overeenkomen \\
\hline Control & Commitment & Deliver & Herformuleren \\
\hline
\end{tabular}

De uitwisseling is geen trucje

Wederkerigheid speelt bij de vormen van gemeenschappelijk maken een belangrijke rol. In alle drie de casussen is sprake van een 'geschenk' door de betrokken ambtenaar aan andere partijen: het 11-punten lijstje, de drietrapsraket en de flip-overtekening zijn een gebaar dat uitlokt tot interactie, een ruilen van kennis, standpunten en argumenten. In iedere casus zijn bovendien momenten aan te wijzen waarop de beleidsmaker een extra investering doet in de relatie. P. biedt hulp van andere gemeentelijke onderdelen aan om kennis over andere typen arbeidsvoorwaarden te onderzoeken, mantelcontracten aan te spreken of investeringen door te rekenen. W. klimt op cruciale momenten zelf in de pen om brieven te schrijven en de juiste toon te treffen voor berichtgeving. A. biedt de volkstuinvereniging aan om de plannen door te rekenen en te toetsen op haalbaarheid. Wie geeft, ontvangt. Zodra dat een trucje is, wordt het doorzien als een poging tot apaiseren, verhullen of om de hete brij heen draaien. Juist in combinatie met een eerlijke bejegening, ruimte voor het expliciteren van twijfel en het toelaten van meervoudige perspectieven is een wederkerig gebaar betekenisvol. Er is per saldo sprake van een uitwisseling die veeleer kan worden verstaan als het faciliteren van de weerstand dan het afwenden of tegengaan ervan. 


\subsubsection{Deelvraag 2: Hoe oefenen de zes factoren invloed uit op de ambtelijke taxatie bij}

(vermeende) weerstand - ieder voor zich en in samenhang?

Uit de casestudies komen krachtige 'meebewegers' naar voren. De beleidsmakers treden de kans op weerstand tegemoet, teneinde in de ontmoetingen met anderen openingen te vinden voor een acceptabele, dragelijke overdracht van lastige boodschappen. In de vorige paragraaf is al een verwijzing gemaakt naar de betekenis van toeleverende bronnen voor het ambtelijk handelen; in deze paragraaf volgen conclusies ten aanzien van de werking van de zes beïnvloedende factoren.

\section{De ambtelijke schraag: persoonlijkheid, ambitie en ambtelijk besef}

Bij de eerste factor uit de reeks primaire hulpbronnen - 'persoonlijke hulpbronnen' - lichten extraversie, inschikkelijkheid en proactieve openheid het meest duidelijk op. Voorbeelden zijn het afstappen op de door de bezuiniging getroffen directie in de eerste casus, de hang van W. naar open relaties en participatie van bewoners en hun organisaties en, in de derde casus, het aanspreken van collega's en externe gesprekspartners op hun vakmanschap (of het tekortschieten daarin). Het feit dat alle drie met een belangrijke vorminterventie komen (respectievelijk een gemeenschappelijke agenda, een drietrapsraket van bijeenkomsten en een tekening op een flip-over) illustreert de betekenis van proactiviteit, in combinatie met een adequaat ambtelijk besef: je weet hoe je partijen in stelling kunt brengen. Wat ook opvalt, is het vermogen om twijfel toe te laten en daarbij niet te gaan jakkeren. In de woorden van Sennett (2008) gaat het dan om het identificeren met de weerstand (zoek de kleine meegevende elementen op) en Ury (aangehaald in Giebels \& Eeuwema, 2005) spreekt van de kunst om naast anderen te gaan staan. In alle drie de casussen zijn momenten aan te wijzen dat sprake is van vertraging om mensen gelegenheid te geven in te voegen en, zoals dat in Rotterdam heet, 'het been bij te trekken'. De openheid over twijfels, dilemma's en oplossingsrichtingen draagt bij aan de beoordeling van het gedrag van de ambtenaar in termen als 'eerlijk', 'rechtvaardig' of 'gezaghebbend'. De drie beleidsmakers tonen een vermogen tot inschikkelijkheid, zonder dat sprake is van serviliteit of overdreven dienstbaarheid. Ury signaleerde bij zijn onderzoek naar omgang met conflicten de neiging om bij wat we hier meebewegen noemen het anderen steeds lastiger te maken om nee te zeggen. In het optreden van onze drie ambtenaren zagen we die houding ook terug: P. hecht aan duidelijkheid bij afronding van de gesprekken, W. verlangt dat mensen niet terug willen blijven komen op eerdere stappen en $\mathrm{A}$. maakt de ernst van afspraken aan zijn gesprekspartners duidelijk.

\section{Dunne lijn professionele ambitie en ambtelijk besef}

De casussen tonen functionarissen met idealen en een weloverwogen keuze voor en blijk van besef van de werking van de publieke zaak. De factoren 'professionele ambitie' en 'ambtelijk besef' komen in combinaties tot uiting en de scheidslijn tussen beide factoren is eigenlijk dun. De ambities hebben immers bij uitstek betrekking op de publieke zaak en een aan gretigheid grenzende nieuwsgierigheid van drie professionals om een opgave naar een goed einde te brengen. Daarbij is wel sprake van enkele accenten. Bij de compensatie van de wateronttrekking in Kralingen is sprake van vooral vaktechnische belangstelling om 
vraagstukken van meerdere kanten te bekijken. Bij de realisatie van de opvang in deelgemeente Feijenoord speelt maatschappelijk engagement: in welke context krijgt beleid gestalte, zo blijkt uit aandacht voor de sociaal-culturele belasting van de geschiedenis van prostitutie in Katendrecht. In de eerste casus ligt het accent op de bedrijfsvoering in een politiek-bestuurlijke omgeving. In de drie casussen leidt stevige kennis van hoe de hazen lopen in de bestuurlijke, maatschappelijke en bureaucratische arena's tot vindingrijke uitkomsten. Met dat inzicht kun je steeds weer mensen in stelling brengen en daarmee anderen belangrijke zetten latten doen. Professionele ambitie en ambtelijk besef liggen dicht tegen elkaar aan. Ze vormen op hun beurt de ambtelijke instelling, die gevoegd bij de persoonlijke instelling in feite als belangrijkste factoren uit onze casestudies naar voren komen. Een sterke ambtelijke instelling, gevoegd bij een sterke persoonlijke instelling maakt het verschil.

De drie casestudies maken duidelijk dat voor beleidsmakers die opteren voor meebewegen met de weerstand - ook al is dat niet bewust - de vluchtoptie in ieder geval niet aan de orde is. Immers, als je geraakt bent door de publieke zaak en je staat sterk in je schoenen, gaat je nieuwsgierigheid met je aan de haal, zo leren de casestudies en ook enkele interviews in de hoofdstukken 4 en 5 . Je wilt contact leggen en dus zoek je 'de ander' op, verken je zienswijzen en laat je je verrassen door de doorwaadbare plaatsen die in die nieuwe ordening van perspectieven besloten ligt. Daar wil je desnoods voor vechten, waarmee de derde copingstrategie - tegenbewegen - als terugvaloptie beschikbaar is. Die is vooral aan de orde als je persoonlijk minder sterk voor de dag kunt komen. Dat is iets anders dan ambtelijk even tekort schieten in je kennis en vaardigheden; want ook dan kan de terugvaloptie bij onvermogen om mee te bewegen een risico vormen. Als de persoonlijke drive (boosheid bijvoorbeeld) het ambtelijke besef overvleugelt, kun je doorslaan. Zijn ambtelijk besef noch persoonlijke hulpbronnen toereikend, dan rest vluchten: wegbewegen van de vermeende botsende belangen. De gecombineerde kwaliteit van de persoonlijkheid - gevoed door hulpbronnen als extraversie, inschikkelijkheid, zorgvuldigheid, openheid en emotionele stabiliteit - en 'ambtelijkheid' - gevoed door professionele ambitie en besef van hoe de hazen lopen onder de drie spanningsbogen en partijen in stelling kunnen worden gebracht - maakt het verschil. Wie 'persoonlijkheid' aan 'ambtelijkheid' paart kan als het ware niet anders dan de vermeende weerstand opzoeken. In schema (tabel 7.10):

Tabel 7.10. Invloed van factoren op coping

\begin{tabular}{l|l|l|} 
& \multicolumn{2}{|c}{$\begin{array}{c}\text { Ambtelijkheid } \\
\text { P }\end{array}$} \\
\hline Persoonlijkheid & + Meebewegen & Doorslaan \\
\hline & - Tegenbewegen & Wegbewegen \\
\hline
\end{tabular}




\section{Sociale steun: de terugvaloptie}

Het tweede drietal van beïnvloedende factoren werd voorafgaand aan het onderzoek als 'secundair' aangemerkt: steunberen die kunnen worden aangesproken als de eerste drie zwak ontwikkeld zijn. De casussen bevestigen dat de eerste drie een zwaarder gewicht in de schaal leggen. Hun soortelijk gewicht bepaalt de mate waarin 'de tweede rang' wordt aangesproken. Van de drie secundaire factoren is vooral instrumentele steun van betekenis, zo blijkt uit de casussen. Zo kan W., terugvallen op enkele experts en bestuurlijke relaties; hij benadrukt ook de betekenis van deze terugvalopties als hem voor de voeten geworpen wordt dat hij goed zelfstandig lastige opgaven kan oplossen. Uit de beschrijvingen komt naar voren dat het vooral functionele contacten zijn die worden genoemd en niet steun die kan worden toegeschreven aan leidinggevenden. De ambtenaar die met de kop in de wind de weerstand pareert noemt niet direct schouders om uit te rusten of verhaal te halen; P. verwijst desgevraagd naar zijn naast beleidsadviseur en directieteam als het gaat om feedback en tips bij kritische momenten. A. noemt de mensen die zijn dagelijks werk faciliteren, naast directe collega's en kamergenoten zijn dat functionele relaties en dat kunnen zowel vakinhoudelijke als ondersteunende medewerkers zijn. Eigenlijk kunnen ze het best alleen en zijn zij het die anderen tot steun zijn, context verschaffen en helpen om opties en perspectieven in beeld te brengen en te houden. Ook hier laat de combinatie van autonomie, initiatief en kennis van hoe de hazen lopen zich gelden: er is sprake van ambtelijk leiderschap. Daarnaar gevraagd blijkt de beeldvorming in de buitenwereld - perceived external prestige - geen bijzondere rol te spelen. Berichtgeving in de media speelt bij de eerste twee casussen een rol, maar overtreffen niet de persoonlijke ervaringen. In eerdere interviews (hoofdstuk 4 en 5 ) bleek dat beleidsambtenaren meer op eigen kompas varen dan op die van andere opiniemakers. Zowel P. als W. noemt expliciet de relatieve betekenis van artikelen in de media voor hun eigen oordeelsvorming. Vantevoren niet ingeschat maar in de casussen I en II nadrukkelijk geëtaleerd is de betekenis van bekrachtiging door 'de ander'. Zo noemt P. meermalen de invloed van zijn evenknie bij de diergaarde en benoemt W. de ervaren steun van een crècheleidster en de support die hij krijgt van een in het gebied gevestigde voedingsmiddelenfabrikant: de aanpak leverde bijval op.

\section{Zicht op resultaat}

Uit de drie casussen komt naar voren dat deze 'meebewegende' ambtenaren alle drie in enige mate verbonden zijn met de einddoelgroepen en het eindresultaat van hun handelen. Voor W. zijn dat bewoners en (hulpverleners achter) de vrouwen van de Keileweg, voor A. partners die de organisaties vertegenwoordigen die moeten meewerken aan de watercompensatie en bij P. zijn dat de leiding van de diergaarde zowel als bestuurlijke voorlieden. Alle drie zitten ze dicht op de werkvloer en is er volgens hun uitspraken sprake van snelle feedback op hun handelen, en dus mogelijkheden om bij te sturen of te interveniëren. Hier is sprake van een relatie met de factor 'ambtelijk besef': ambtenaren die aandacht hebben voor de drie arena's - politiek bestuur, de bureaucratie en het publiek - zorgen eerder dat ze zicht hebben en houden op de uitvoering en effecten van beslissingen. Meer dan bij de rijksoverheid is de correctietoets op ambtelijk handelen binnen handbereik. Ook deze 'hefboom' hoeft echter niet echt aangesproken te worden om de ambtenaren aan te zetten 
tot meebewegen met de mogelijke weerstand, hij is in hun functioneren (zie de beschrijving van de eerste drie factoren) al ingebakken... Vastgesteld kan worden dat de prompte correctie van burgers en hun organisaties op beleidsvoornemens, besluiten en uitvoering bij gemeenten sneller en concreter is dan bij overheid die meer op afstand staat zoals provincies of het rijk. In een beschrijving van het gemeentelijk optreden na een schietincident op het Rotterdamse Oleanderplein (Gemeente Rotterdam, 2010) lezen we hoe beleidsmakers zelf brieven bezorgden, deuren langsgingen, present waren, luisterden en aanspreekbaar waren en bleven. Rijksambtenaren hebben vaker hulpstructuren nodig, wat ook blijkt uit de populariteit van werkelijkheidsvervangende presentaties van het publiek, zoals studies over burgerschapsstijlen, ijkpersonen en persona's. Wie ver van de werkelijkheid afstaat, maakt een verbeelding. Direct contact met einddoelgroepen bevordert het zicht op meerdere perspectieven (in plaats van de eigen visie en het eigen handelen); persoonlijke contacten bieden meer uitzicht op gemeenschappelijke uitkomsten dan massale bijeenkomsten. Schaal telt mee. Dit thema leent zich dus voor verder onderzoek, waaronder vergelijking tussen bestuurslagen op het punt van zicht op resultaat (impact).

\section{Ruimte voor reflectie}

De veronderstelling dat reflectie helpt en ook onderhoud behoeft, kan bij alle drie de gesprekspartners op steun rekenen. Was in de vraagstelling vooral rekening gehouden met beleidsmakers als ontvangers van toerusting, uit de reconstructies komt een genuanceerd beeld naar voren. Dit blijkt het meest pregnant in de tweede casus. Op basis van zijn ervaringen met de communicatie met bewoners en hun organisaties in Feijenoord - met als sleutelmoment de bewonersopstand in de Persoonshal - trekt W. eerst zelf lessen. Op basis daarvan schoeit hij de procesaanpak op een andere leest. Na afronding van zijn werkzaamheden besluit hij bij de aanvang van een nieuwe opgave de lessen uit een vorige baan actief in te brengen - zowel aan anderen in ambtelijke cursussen als in de eigen nieuwe praktijk. Dit patroon sluit aan bij onderzoek van Weggeman (2007) dat de klassieke stadia van leren - leerling wordt gezel en gezel wordt meester - zich kan herhalen. De meester wordt weer leerling en gezel. W. verhaalt over de wijze waarop hij lessen uit de deelgemeente Feijenoord overdraagt aan nieuwe medewerkers en ook hoe de lessen worden ingezet als strategische interventie bij de start van zijn volgende project: ten overstaan van een gezelschap van deelgemeentebestuurders krijgt hij als oud-bestuurder de vloer om op te biechten hoe het niet moet en hoe wel, als het om samenspel tussen gemeente en deelgemeenten gaat. A. vertelt hoe hij anderen coacht, bij hem is faciliteren een tweede natuur. Door anderen te ondersteunen wordt hij ook zelf wijzer, krijgt hij ook zelf feedback, zo maakt hij duidelijk. Uit zijn toelichting blijkt ook dat investeren in leren idealiter wordt aangeboden, maar vaker afhangt van de beschikbaarheid van anderen die in mensen willen investeren. Of dus het ontbreken hieraan. 


\subsection{Tot slot: reflectie}

Meebewegen helpt; de casestudies bieden onmiskenbaar inzicht in de werking van de als voorkeur aangemerkte copingstrategie. Wie extravert, vriendelijk en open (vermeende) weerstand tegemoet treedt en weet hoe de hazen lopen en anderen in beweging kunnen en willen komen, kan een aanvankelijk als negatief geconnoteerde houding helpen ombuigen naar nieuwe perspectieven. Daarbij helpt de nabijheid van collega's, een lerende omgeving en een snelle terugkoppeling op gedrag, maar dat is op de tweede hand: een succesvolle meebeweger is hier niet van afhankelijk. Met deze karakteristiek kan de vrucht van de gevalsbeschrijvingen in dit hoofdstuk worden samengevat.

\section{Intense ervaringen}

Daarbij zijn nieuwe bevindingen opgedaan. Zoals de opeenvolgende werking van de drie stijlen 'inleven', 'overeenkomen' en 'herformuleren' (tabel 7.11.), de gesignaleerde samenhang tussen persoonlijke en professionele hulpbronnen (tabel 7.12) en de relatieve kracht van primaire hulpbronnen ten opzichte van de als secundair gekwalificeerde factoren sociale steun, ruimte voor reflectie en zicht op resultaat. De casestudies hebben ook als nieuwe beïnvloedende factor de hefboomwerking van een intense ervaring aangelicht. Zowel in de eerste als de twee casus wijzen de beleidsmakers dit als 'sleutelmoment' (critical incident) aan in hun casus. Bij W. is dat de confrontatie met het verzet in de Persoonshal. Dit moment had een ontwapenende uitwerking. Bij P. blijkt dit intense moment samen te hangen met de impact van de ontmoeting met de directeur, de voormalige directeur en de medewerkers bij het betreden van de diergaarde op de dag dat de opening van een vernieuwd poortgebouw samenvalt met de mededeling van de subsidiekorting. Ook dan is er sprake van een schokkende ervaring, waarin hij zich op zichzelf voelt teruggeworpen: 'Ik sloop haast naar de Rivièrahal, waar die bijeenkomst was. Ik wist dus niet wat ik aan zou treffen, ik was niet bang, schaamde me ook niet, maar ik voelde me wel onbestemd'. Hij stapt op de vroegere directeur af: 'hadden we dat ook gehad, en toen was het ijs ook gebroken. Want, wat mensen soms doen is jou persoonlijk verantwoordelijk stellen daarvoor'. Ook hij schetst de ervaring als 'sleutelmoment' in de casus: 'Op dat moment wordt iets heel persoonlijk, daar sta je tegenover mensen tegenover je, de mensen met wie je samenwerkt'. De kracht van deze intense ervaring raakt aan wat Weick als startpunt van betekenisverlening identificeert (1995): een verstoring van een evenwicht. Ook andere auteurs wijzen op de betekenis van de ingrijpende ervaring voor het leren. In 'Een levensregel voor beginners' schrijft Derkse (2008) over de beginselen van de leer van Benedictus: 'De leider dient ook 'beproefd' te zijn in de zin dat zijn karakter (Grieks voor stempel of 'kras') met vallen en opstaan tot rijping is gekomen. Een boy wonder met uitsluitend successen op zijn conto moeten we zeker gelukwensen, maar of deze een goede leider zal zijn?' De koppeling met de persoonlijke hulpbronnen is hier evident: wat heb je per saldo in huis om te bewegen en een nieuwe 'losse koppeling' te maken waardoor sprake is van 'leren en ontwikkelen' (Boonstra \& Van Staveren, 2006). Socioloog Sennett spreekt van 'heilzame mislukkingen' (2008); op 26 juni 2011 hield hij de Premselalezing, waarin hij het omgaan met weerstand in een overspannen samenleving besprak. 'Geconfronteerd met een 
moeilijk moment, een beproeving, weet het lichaam zichzelf te kalmeren. Over het algemeen betreden we als we nieuwsgierig worden, een opgeschorte toestand, we zitten in het moment en houden ons in en reflecteren in plaats van onszelf vooruit te dwingen'. De amateurcellist Sennett verwees hierbij naar de reactie op potentieel moeilijke momenten in het muziekspel. Dan 'moet (je) leren om niet de duim van de linkerhand onder de hals van de cello te duwen; als hij gespannen is en de hals meer vastgrijpt dan aanraakt, wordt de linkerhand stijf; we leren dat te doen door te experimenteren met het geheel loslaten van de duim bij het uitvoeren van moeilijke passages. (...) Als hij op een vakkundige manier werkt met weerstand, en niet vecht tegen de aanwezigheid van het probleem, kan de artiest of de wetenschapper naar buiten keren in plaats van naar binnen, en in contact treden met de wereld in haar ruwheid, hardheid en moeilijkheid'

\section{Onbewust bekwaam?}

In het volgende (slot)hoofdstuk maak ik de balans op. Vooruitlopend hierop vraag ik aandacht voor een repeterend fenomeen in de verkenningen en onderzoeken. Bij de confrontatie van de respondenten met de uitkomsten van de casestudies tekende ik immers opnieuw op dat sprake is van overwegend onbewuste gedragingen. Dit roept de vraag op in hoeverre sprake is van een keuze voor een of meer copingstrategieën. In welke mate zijn impliciete keuzes immers over te dragen en bespreekbaar te maken? De 'ruimte voor reflectie' komt als beïnvloedende factor in geen van de cases manifest naar voren; de ondervraagde beleidsmakers tonen daartoe uitgenodigd echter belangstelling voor aanscherping van kennis, inzichten en vaardigheden. Ook onderstrepen ze de betekenis van overdracht, systematisch zelfs. Maar ondertussen rust succesvol ambtelijk handelen op onbewuste inzichten en ervaringen. De respondenten zijn 'onbewust bekwaam' in de karakteristieke ordening van Kolb: er is in ruime mate sprake van impliciete kennis van de politiek-bestuurlijke context. De geïnterviewden tonen zich vooral bewust van de noodzaak om te weten hoe de bestuurlijke en politieke mores zijn. Dit kwam ook in eerdere deelonderzoeken (hoofdstuk 4 en 5) naar voren. Die intrigerende mixture van onbewuste en bewuste, persoonlijke en ambtelijke nieuwsgierigheid hebben we eerder in deze paragraaf een schraag van de ambtelijke vindingrijkheid genoemd. Die mixture vraagt om verdere exploratie. Wat betekent het als wat Karssing een 'seculiere roeping' noemt het succes feitelijk drijft? Wat als je geen onverschrokken passie bezit om gemeenschappelijke waarden te articuleren en anderen in hun kracht te zetten? Veelzeggend detail is dat de respondenten bij de confrontatie met de resultaten van de studies geneigd zijn tot relativering; ontkend wordt er niet wat wordt beschreven, maar laten we vooral hun slagkracht niet overdrijven. Naast Hollandse nuchterheid spreekt hieruit ook professionele distantie. De geïdentificeerde front frames zetten deze houding kracht bij: het gaat om respectievelijk verantwoordelijkheid, de inhoud van de zaak en vakmanschap.

\section{Onderzoeksaanpak}

Tot slot de onderzoeksaanpak. In paragraaf 7.3. heb ik de beperkingen aangegeven van kwalitatief onderzoek en casestudies met een kleine omvang (small-N). 
Daarbij is de betwijfelde generaliseerbaarheid of overdraagbaarheid aangeroerd.

Op basis van de uitkomsten vind ik steun voor de uitleg van Tsoukas (2003) dat verfijning van inzicht in de werking van gedragingen niet per se afhankelijk is van een bepaalde omvang van onderzoeksobjecten. Ik heb mij geconcentreerd op de vraag of relevante kenmerken (van respondenten of van situaties, zie criteria in paragraaf 7.3.) in de onderzoeksgroep vertegenwoordigd zijn en ik heb aan de hand van de ordening van data vastgesteld dat in voldoende mate sprake was van toetsbaarheid van de factoren en indicatoren. Daarnaast heb ik aandacht geschonken aan de presentatie van data en interpretatie (Boeije, 2005). Om die reden heb ik gekozen voor een systematische presentatie van citaten aan de hand van de geordende copingstrategieën, factoren en indicatoren. Hiermee is er naar gestreefd om gegevens zo veel mogelijk concreet en in hun 'rijke', betekenisvolle vorm weer te geven. Dit wordt ook aangeduid als thick description: een verhalende, veelomvattende en gedetailleerde manier van beschrijven (Boeije, 2005). Citaten hebben in kwalitatieve rapportages daarmee een overeenkomstige functie als tabellen in kwantitatief onderzoek: ze maken duidelijk dat de gegevens er echt zijn. Er is daarmee geen aanwijzing om de toegevoegde waarde van een vierde of vijfde case op te voeren; dat neemt niet weg dat nieuwe casestudies kunnen helpen aan een scherpere aftekening van de werking van beïnvloedende factoren bij de coping met vermeende weerstand. Dit laatste geldt ook voor een discutabele keuze bij het ontwerp van het onderzoek. Deze keuze - om uitsluitend cases te onderzoeken waarbij op voorhand indicaties aanwezig waren dat de betrokken beleidsambtenaar erin was geslaagd om weerstand te hanteren - blijft voor discussie vatbaar. Ze kan ook als beperkend worden opgevat. Gezien de doelstelling van dit onderzoek is echter nadrukkelijk geen 'contramal' geplaatst bij de 'meebeweeg'-strategie. Ik ben nadrukkelijk niet op zoek geweest naar tegenvoorbeelden, of - om het met wetenschapsfilosoof Popper te zeggen - heb niet geprobeerd de analyse te falsificeren (Schafer, 2005). Het onderzoek richt zich op onderbouwing van een succesvolle benadering van overheidseigen situaties, waarbij sprake is van vermeende weerstand. Een enkelvoudige conclusie dat al doende in dit onderzoek vooral bewijsvoering is geoogst voor een voorgestelde voorkeursstrategie, zou de bevindingen dan ook geen recht doen. Daarvoor hebben de casestudies teveel nuanceringen opgeleverd. Hierdoor kunnen gewichten worden toegekend aan de diverse factoren en kan ik verbanden aanwijzen tussen de onderscheidende factoren en enkele nieuwe mechanismen identificeren die bijdragen aan het vermogen van beleidsmakers om bij lastige opgaven doorwaadbare plaatsen te gebruiken. Dit neemt niet weg dat als een interessante optie voor vervolgonderzoek wenkt om verstorende factoren in kaart te brengen en deze in de praktijk te onderzoeken. 


\section{Conclusies en slotbeschouwing}

Weg van de meeste weerstand 15

\subsection{Inleiding}

Drie vragen vormden de vertrekstaat bij de start van de zoektocht die in dit proefschrift centraal staat. Welke betekenis heeft de context 'overheid'voor de beslissingen die beleidsambtenaren nemen over het contact met het publiek? Welke mogelijkheden heeft de beleidsambtenaar om de specifieke context te herkennen en te hanteren bij het contact over omstreden beslissingen? Welke lessen kunnen worden ontleend aan de kennis over de beoordeling van beleidsambtenaren van kritiek op overheidshandelen en de gedragingen die hiervan het gevolg zijn? Zes conclusies verbind ik aan de voorgaande verkenningen en onderzoeken. Enkele aanbevelingen sluiten dit hoofdstuk af. Niet de zoektocht. De ontdekking van de verscheidenheid die (vermeende) weerstand biedt werpt daarvoor te veel uitnodigende zoeklichten vooruit.

Even terug naar het openingsbeeld in hoofdstuk 1: een ambtenaar mag een bezuiniging of anderszins negatief geladen boodschap bezorgen en krabt zich achter de oren. De studies van de theorie en de praktijk leren dat de orenkrabberij niet ingegeven hoeft te zijn door tobberigheid. Bepaald niet zelfs; groot is de kans dat we hier te maken hebben met één van de personen die in de cases en interviews figureren: 'geroepen' functionarissen, die gericht zijn op het helpen zien van perspectieven op probleemoplossing en het in stelling brengen van maatschappelijke, politieke en ambtelijke partijen. Opdat meer partijen meer doelen kunnen realiseren en toch sprake kan zijn van een gemeenschappelijke basis van begrip. In de verkenningen en onderzoeken hebben we het vizier gericht op de invloed van de overheidscontext op werk, de mogelijkheden van weerstand en de betekenis van persoonlijke bagage, ambtelijk besef en gereedschappen van beleidsmakers. Daarbij is herhaaldelijk vastgesteld dat veelal kennis, vaardigheden en houdingen onbewust aanwezig zijn en onberedeneerd worden aangesproken. Ambtenaren hebben meer vindingrijkheid onder de leden dan ze zelf weten.

\subsection{De betekenis van overheid als context van werk (vraag 1)}

Drie conclusies over de betekenis van de context.

Conclusie 1. Beleidsmakers bij de overheid ontmoeten onvermijdelijk spanningen, die niet vragen om enkelvoudige oplossingen.

15 Deze slagzin is niet origineel. In oktober 2011 bleek dat FrieslandCampina het product Vifit aanprijst met 'Lang leve de weg van de meeste weerstand' en brachten de Heideroosjes een lied uit met de zelfde titel. 
De context van de beleidsambtenaar is in hoofdstuk 2 uitgewerkt aan de hand van een verkenning van het eigene van de overheid. Dit eigene is gekoppeld aan het onvermogen van vrije krachten in de samenleving om individu-overstijgende problemen op te lossen. Daarbij hoort een 'systeem' waarin openbare meerderheidsbesluiten worden genomen om in het algemeen belang de problemen te verhelpen. Deel van dat systeem is dat burgers volksvertegenwoordigers mandateren, die op hun beurt de dagelijkse voorbereiding en uitvoering functioneel toedelen aan daarvoor vrijgestelde ambtenaren. In onze representatieve democratie hebben we die gezaghebbende besluiten en interventies met checks and balances omgeven om de macht een tegenmacht te verschaffen en per saldo voor een legitieme basis te zorgen. Zijderveld (2011) heeft het omstreden karakter dat de overheid dientengevolge kenmerkt, gekarakteriseerd met 'opschorten van legaliteit' en daarbij de samenhang tussen legaliteit en legitimiteit aangelicht. De overheid zal niet alleen op ordentelijke wijze via de wetgevende macht de omstreden besluiten van goedkeuring moeten voorzien en in werking zien te zetten; ze zal er ook voor moeten zorgdragen dat die besluiten door burgers en bestuurders merendeels gedragen, goedgekeurd en nagevolgd worden. Steeds weer. De cultuursocioloog deed zijn uitspraak najaar 2011 naar aanleiding van het Kamerdebat over de verblijfsvergunning van een jonge minderjarige asielzoeker Mauro. Het is een voorbeeld van de lastige beleidsopgaven waarmee beleidsmakers van doen kunnen hebben.

Een wandeling onder een arcatuur van drie bogen. Die metafoor dient in hoofdstuk 5 voor de duiding van het conglomeraat van spanningen waarmee een beleidsambtenaar te maken heeft. Die spanningen zijn samengebald in een drietal 'spanningsbogen' omdat ze uitersten verbinden: a) ruimte voor belangenafweging ten opzichte van grondslagen van rechtsstatelijkheid, b) ijveren voor beheersbaarheid in een democratische en dus lastig stuurbare context en c) streven naar vakmanschap onder de verantwoordelijkheid van (leken) bestuurders. Onder die spanningsbogen zijn ambtenaren met bestuurders in gesprek over de snelheid van resultaten en de beheersbaarheid van problemen. Ambtenaren zijn er met burgers in de weer over de verdeling van schaarse voorzieningen en vormen van zeggenschap. Interbestuurlijke vuurtjes wakkeren er aan en doven weer. Steeds weer zijn beleidsambtenaren in staat om onder die spannende bogen passende arrangementen te bedenken, voor te bereiden en uit te voeren. Dat doen ze vooral, aldus de vrucht van het in hoofdstuk 5 gepresenteerde onderzoek naar de omgang met systeemspanningen, door bestuurders, burgers (en hun organisaties) en andere ambtelijke geledingen in stelling te brengen. Dat is: het bieden van publieke en politieke platforms en het verbinden van mensen, middelen en mogelijkheden. De identificeerbare ambtelijke strategieën verraden een niet onschuldige inspanning binnen ambtelijke muren: juist in het vermogen bureaucratie te laten werken liggen zowel handige doorbraken als hardnekkig blokkades besloten. Beleidsambtenaren doen aldus aan 'contextcreatie'. Resultaat: het onverminderd omstreden systeem overheid kan gedijen en spanningen tussen legaliteit en legitimiteit, korte termijn en lange termijn, scoringsdrift en duurzame relaties en zorgvuldigheid en openbaarheid kunnen worden gehanteerd. Al doende staan deze beleidsmakers niet zelden in een spagaat (Teisman, 2009) en met de bereidheid daartoe ontstaat een mogelijkheid om meer lagen in vraagstukken te zien, meer belangen te 
zien onder standpunten ook en voorbij enkelvoudige oplossingen te denken, durven en doen. Denk niet dat dit contre coeur gebeurt: $\mathrm{HBO}$ - en WO-afgestudeerden wegen het problematische karakter van de overheid mee bij hun beroepskeuze, blijkt steevast uit onderzoek (BZK, 2008, Niessen \& Karssing, 2008). De herkenning en vooral ook erkenning van deze onvervreemdbare 'systeemspanningen' is het vertrekpunt voor ambtelijk handelen. Waar macht is, is nu eenmaal tegenmacht en wie er beroepshalve mee te maken heeft, kan in feite niet onder de werking hiervan uit. 'Resistance is what opposes power, not simply diametrically but transversally, opposing by going off in a different direction...Acts of refusal indeed typically involve power themselves, even the most passive responses (Thomas \& Hardy, 2011). Wie beleidsmaker is bij de overheid, ontmoet uiteenlopende partijen en belangen. De weerspannige context is voortdurend onderwerp van gesprek, studie en reflectie. Meer dan menigeen in de buitenwereld vermoedt, maar ook meer dan in de eigen kring van toegewijde overheidsfunctionarissen bewust wordt ervaren.

Conclusie 2. In de spanningsvolle context van de overheid is weerstand geen blinde muur, maar een wand van mogelijkheden.

De overheid vraagt om problemen. Deze, toegegeven, wat populistisch aandoende karakteristiek helpt om in te zoomen op het fenomeen van de weerstand. In hoofdstuk 3 kwam bij de verkenning van dit thema naar voren dat weerstand erbij hoort in een arbeidscontext van spanningen en strijd om schaarse middelen en discutabele waarden. Daarbij is duidelijk geworden dat de inschatting van de ontmoeting van weerstandgeladen situaties eenvoudig kán leiden naar vluchtgedrag: afhouden, afkeren en andere negatieve reacties. Maar de interviews met rijksambtenaren en gemeentelijke beleidsmakers laten zien dat wegbewegen van de weerstand allesbehalve favoriet is, in denken noch doen. Integendeel, juist bij de overheid met haar ingebakken problematische karakter, openbare strijd en uiteenlopende belangen wijzen de waarnemingen van beleidsmakers naar een andere karakteristiek van weerstand. Uit de interviews en case studies komt naar voren dat beleidsmakers weerstand niet bepaald benaderen als een blinde muur, maar als een wand van mogelijkheden. Weerstand is in de context van overheid een meervoudig perspectief op de werkelijkheid; als het een muur is, dan één vol open deurtjes, die zich als in adventskalenders geraffineerd aan het oog onttrekken.

Deze opvatting over weerstand lijkt strijdig met tal van studies en publicaties, waarin de houding van burgers ten opzichte van de overheid - soms op het gretige af als negatief wordt uitgelegd. Zie hiervoor hoofdstuk 2: publieke houdingen hebben een negatieve connotatie, begrippen als 'kloof', 'verzet' en 'cynisme' worden bij voorkeur als afwijzingen gepresenteerd. Een dergelijke verenging van de weerstand tot een enkelvoudige werkelijkheid - als zijnde een obstakel - past bij de stroming New Public Management en de bijbehorende opgeklopte hoge verwachtingen van de overheid. De dempende invloed van de hausse aan maakbaarheidsidealen werd in hoofdstuk 5 gerelativeerd - alsof de overheid 
niet mag teleurstellen en zelf als Grote Oplosser voor de dag moet komen! Als antwoord op dergelijk overspannen management van verwachtingen (er zijn adviesbureaus die zichzelf afficheren met de discipline 'perceptiemanagement') doopte ik in de inleiding mijn studie 'deceptiemanagement' (Rijnja, 2007). Deze karakteristiek sloot aan op de aanname dat beleidsmakers handiger moeten zien om te gaan met de waaier aan kritiek: pakkender, compacter, anders, lolliger, etc. informatie overbrengen. De theoretische verkenningen en deelonderzoeken leiden echter naar een genuanceerder boodschap: erken het omstreden karakter van de overheid en maak de teleurstelbaarheid zichtbaar, handelbaar, draagbaar. Lichten boven de korenmaat. In de (h)erkenning van de gerede kans op publieke teleurstelling liggen immers openingen besloten voor het vinden van gemeenschappelijke perspectieven. In het tegenovergestelde gedrag - afwimpeling of ontkenning - gedijt de ophef, zo bleek in 2010 uit de omgang met CO2-opslag in de gemeente Barendrecht. Cuppen maakte uit onderzoek op dat tegenstanders zich 'ingraven' als ze op één hoop worden geveegd en, als een eenheid en repeterend te horen krijgen dat het $\mathrm{CO}_{2}$-project een noodzakelijke stap is om de klimaatdoelstellingen te halen (Bos, 2011). Het is veelbetekenend dat energieconcern - en partner in $\mathrm{CO}_{2}$-opslag - Shell deze ervaring recent meemaakte, ruim tien jaar na het debacle rond de afzinking van de container Brent Spar. De publieke weerzin tegen de voorgenomen dumping van de container in zee leidde toen immers tot een kentering in de bedrijfsstrategie. Er moest eerder en beter geluisterd worden, oordeelde toenmalig topman Herkströter; in plaats van Decide - Announce - Defend (DAD) zou voortaan Dialogue - Decide - Deliver (DDD) de leidraad zijn (Rothermund, 1998). Het voorbeeld leert dat de problemen met weerstand niet exclusief aan de overheid zijn voorbehouden; wel komen ze daar bij uitstek naar voren als gevolg van de gesignaleerde systeemspanningen. Beheersbaar, besloten en behapbaar is overheidshandelen nu eenmaal zelden.

De casestudies (hoofdstuk 7) en interviews (hoofdstuk 4 en 5) hebben diverse voorbeelden getoond van publieksgroepen die vragen om erkenning van een eigen standpunt en, meer specifiek, erkenning van twijfel. Knowles en Linn (2004) hebben het fenomeen van de meervoudige perspectieven eerder uitgewerkt in de context van reorganisaties: zij registreerden dat medewerkers bij een voorgestelde verandering afwisselend voor en tegen het voornemen kunnen zijn: 'In this regard, research shows that people who voluntary undertake to quit smoking still have strong positive and negative beliefs and feelings about doing so (Petty \& Cacioppo, 1996), and people with high-quality employment relationships have both positive and negative views toward change (Kim \& Rousseau, 2006)'. Het kan dan zijn dat iemand van binnen voorstander is, maar en public tegenstand biedt. Ford, Ford en d'Amelio (2008) stelden vast dat die wisselende houdingen juist als bereidheid kunnen worden uitgelegd: 'When we agree to deal with resistance in terms of publicly observable phenomena, we do not need to hypothesize recipient feelings of injustice, betrayal, and violations of trust. Rather, we can overtly inquire about such perceptions directly and, thus, bring old hurts, angers, or assumptions out of the hidden background and into the light of a dialogue for closure, resolution, or inclusion in agent sensemaking (Isaacs, 1993)'. In de cases blijkt aan meervoudige perspectieven geen gebrek te bestaan. Bij de case van de dierentuin doet, naast bezuinigingen, een zakelijke bedrijfsvoering 
als perspectief ertoe. Bij de realisatie van de opvang voor ex-prostituees is ook sprake van een pleidooi voor een gezonde toekomst van een kansarme groep. Ook spelen in deze case publieke verwachtingen op het gebied van veiligheid, gebiedsimago én erkenning van zeggenschap bij de wijkontwikkeling een rol (hoofdstuk 7).

Weerstand komt uit de verkenningen en onderzoeken naar voren als een zoekende houding naar een uitweg (wat iets anders is dan een uitgang...) en de vraag is, of en hoe de overheid die houding wil en kan herkennen, erkennen en verkennen. In hoofdstuk 4 wordt verslag gedaan van een onderzoek onder beleidsambtenaren naar hun betekenisverlening aan werk. Hieruit komt naar voren dat beleidsambtenaren bewust kiezen voor het oppakken van heikele kwesties en de politieke spanningen niet schuwen. Ze merken daarbij op dat de procesmatige kanten en in het bijzonder de interactie met belanghebbenden steeds meer tijd en aandacht vragen. Zoals ook sociaal psycholoog Van den Bos recent vaststelde (2011) laat de praktijk zien dat het niet altijd eenvoudig is de betekenis van het tegenspel in te schatten: is sprake van wantrouwen of van onzekerheid? In het tweede geval - een grote meerderheid volgens Van den Bos - zijn twijfelaars op zoek naar procedurele informatie en werken feitelijke argumenten onnodig als een gif; vervang de distributieve rechtvaardigheid (uitkomsten communiceren) door procedurele rechtvaardigheid (procesgang communiceren), luidt het devies van Van den Bos. In het onderzoek naar de omgang met systeemspanningen (hoofdstuk 5) komen beleidsmakers naar voren die volgens deze lijn - opnieuw: onbewust - investeren in procesinformatie. Habermas spreekt in dit kader van co-oriëntatie (1970): als mensen het eens zijn over de manier van communiceren is de uitkomst gelegitimeerd. De Nationale Ombudsman laat niet na op dit aambeeld te hameren (getuige onder meer de jaarverslagen over 2009 en 2010): in de bejegening ligt een kans om weerstand te geleiden, en omgekeerd dreigt bij slordige omgang cynisme te ontstaan en een lage motivatie en commitment.

Legitimering van een (mogelijke) verandering is dus belangrijker dan wat ook. Tomala en Petty (2004) hebben onderzoek gedaan naar de waardering voor het benoemen van lastige opgaven: 'Not talking about or acknowledging resistance may actually exacerbate it. Building on the approach-avoidance theory of persuasion they contend that a persuasive message raises both accepting consideration and counteractive resistance and that acknowledging resistance, labeling it as such, and overtly identifying its role in change have the paradoxical effect of defusing its power'. Uit oogpunt van beeldvorming is sprake van een paradox: omdat veel mensen twijfelen is er ruimte nodig om te vertwijfelen, maar juist die 'twijfelruimte' bezorgt de overheid een beeld van trage en inefficiënte besluitvorming.

In hoofdstuk 6 is bij het ontwerp van het conceptueel model (voor de ideaaltypische omgang van beleidsmakers met (vermeende) weerstand) een belangrijke onderlegger voor het welslagen van die procesmatige, communicatieve benadering van beleid geïdentificeerd. Namelijk dat er sprake is van een basale bereidheid bij Nederlanders om de overheid taken toe te vertrouwen. Ook in hoofdstuk 2, bij de bespreking van onderzoeken naar vertrouwen van burgers in politiek en bestuur, is deze grondtoon van instemming gemarkeerd. 
Een deel van de hiervoor gesignaleerde twijfelachtige houding van publieksgroepen is terug te voeren op compliance: men is weliswaar bereid om zich te voegen, maar weet niet hoe. De ontdekking van deze basale bereidheid is onder meer onderwerp van jarenlang onderzoek door de Belastingdienst. In 1992 werd al gepeild wat de publieke houdingen zijn over het betalen van belasting; hieruit kwam naar voren dat grosso modo Nederlanders belasting betalen als onderdeel van het burgerschap beschouwen. Men is niet zozeer tegen het betalen van belasting, maar wel tegen de - ingewikkelde - wijze waarop aan die publieke plicht moet worden voldaan. De Belastingdienst beantwoordde die weerstand passend door een nog steeds voortschrijdende vereenvoudiging van formulieren, procedures en toegankelijke werkprocessen. In de slagzin wordt de weerstand en het gevonden perspectief verwoord: 'Leuker kunnen we het niet maken. Wel makkelijker'. Hier beweegt overheid mee met de weerstand en voorziet ze het publiek van 'rechtvaardigheidsinformatie'. Het welslagen van dergelijke interventies kan niet los gezien worden van de culturele context: er is een oerHollandse behoefte het samen eens te worden, elkaar op te zoeken, draagvlak te verwerven. Hofstede (1999) ent die basishouding onder meer op een 'lage machtsafstand': staat en straat zijn niet ver van elkaar verwijderd in tegenstelling tot landen met een traditioneel grote machtsafstand als Frankrijk. Dit blijkt ook uit de traditie van de overlegeconomie, het zogeheten polderdenken, de gidsfunctie van Nederland op het vlak van internationaal recht en de snelle worteling van mediation als fenomeen. In ons land is er bereidheid te onderzoeken waar je het wel over eens bent, wat ook de populariteit van positieve psychologie en appreciative inquiry (vertaald met 'waarderend organiseren') in ons land kan verklaren. De casestudies in hoofdstuk 7 zijn hier in feite ook voorbeelden van.

Weerstand komt in deze studie naar voren als kenmerk van een mogelijk broze, maar ondertussen gewortelde betrokkenheid van burgers bij 'hun' overheid. Er is sprake van een wezenlijk en wederzijds engagement, zowel aan de kant van de samenleving als de overheid. De op zijn zachtst gezegd niet-afwijzende grondtoon in de relatie tussen overheid en samenleving kan erkend, herkend en verkend worden - en dan deuren openen. Zolang twijfel wordt (h)erkend. Dit is de context waarin de overheidswerker weerstand en dus wat we overheidsbereidheid kunnen noemen, ontmoet. En die tegemoet treedt - of niet. We weten nu nog beter, wat het vermag als je wantrouwen en twijfel door elkaar haalt, te laat of te weinig of te massaal contact zoekt, feitelijke argumenten boven procedurele rechtvaardigheid verkiest... Mijn onderzoeken laten tekortkomingen zien, maar vooral voorbeelden van vindingrijkheid om de onlosmakelijke spanningen te tonen bij het beheersen van complexe vraagstukken, het pendelen tussen voorkeuren van bewindslieden, gedeputeerden of wethouders en burgers of maatschappelijke organisaties en het bieden van platforms aan partijen om samen een probleem van alle kanten te bekijken of oplossingsrichtingen te verkennen.

Conclusie 3. De onvermijdelijke ontmoeting met weerstand wakkert een inclusieve benadering van communicatieve aandacht binnen de overheid aan. 
Er is onmiskenbaar sprake van een toegenomen en nog steeds toenemende aandacht voor het communicatief handelen van (overheids)organisaties. De karakteristiek van Van Ruler (2003) biedt houvast. Ze schetst de ontwikkeling van de beroepsuitoefening in de communicatiesector aan de hand van de focus op een informatiemodel (middelenmanagement), via een dominantie van een overredingsmodel (imagomanagement) en een intermediair model (relatiemanagement) naar een behoefte aan reflectie (reflectief model, identiteitsmanagement). We stellen vast dat verantwoordelijke actoren voor primaire processen van wilsvorming, besluitvorming en uitvoering binnen de overheid zich die reflectieve arbeid steeds meer toe-eigenen. Ik plaats deze krachtige ontwikkeling nadrukkelijk in het licht van de hiervoor geschetste onvermijdelijke onvervreemdbare zorg voor kritiek, conflict, weerzin en twijfel. 'Communicatie' wordt in de context van de overheid steeds minder als een gescheiden bezigheid van een daartoe vrij te stellen discipline beschouwd: de communicatie van organisaties hangt samen met de wijze waarop mensen in en om de primaire processen van een organisatie betekenis geven aan informatie. Vanuit diverse wetenschappen wordt dit vuurtje aangewakkerd, voor wat betreft de overheid voorop de bestuurskunde (procesmanagement) en communicatiewetenschappen, waarbij diverse overlappende oriëntaties ontstaan, zoals onder vlaggen als omgevings-, proces-, stakeholdersen netwerkmanagement. Dit leidt ertoe dat naast de communicatiediscipline de rol van bestuurders, beleidsmakers, partners, (eind)doelgroepen en ook de media aandacht vragen - en die krijgen. Deze bredere blik op het communiceren van organisaties past bij de belangstelling voor een contextuele benadering van vraagstukken. Contextuele communicatie staat dan voor het meewegen van de invloed van de omgeving van waaruit mensen handelen bij de verklaring van hun gedragingen, zoals de werking van emotie, vertrouwen, bindingen, sociale druk en eigen effectiviteit (Rijnja, Seydel \& Zuure, 2009a en b). Het vraagstuk van weerstand tegen overheidsbemoeienis is tegen die achtergrond ook contextueel onderzocht: wie doen er toe, welke belangen, verwachtingen en rollen oefenen invloed uit en hoe hanteert een ambtelijke professional de (al dan niet bewuste) kennis van die context? Daarbij heb ik de blik steeds geworpen in de richting van één categorie actoren: beleidsambtenaren en hún communicatieve vermogens.

De communicatieve impact van het omstreden karakter van de overheid op het verrichten van werk is groot. Dit is terug te brengen op meerdere factoren, bleek in hoofdstuk 2. De openbaarheid van tegenstellingen en de zichtbaarheid van strijdende partijen spelen een rol en eisen hun tol. Waar conflicten zijn, zijn media. Journalisten zullen als 'wekhonden en waakhonden' (Nijhof, 1985) conflicten opsporen, aanlichten en uitvergroten. Voormalig parlementariër Schutte (2002) weet dat Thorbecke bij het ontwerp van onze gedecentraliseerde eenheidsstaat in 1848 de media die rol ook welbewust toebedacht. De bedoelde strijd die overheid heet vraagt publiek - en krijgt het ook. Het uitdijende netwerk van media voltrekt zich echter steeds minder langs herkenbare lijnen, zoals de zuilen van weleer gemeenschappelijk maakten. Kranten, omroepen en maatschappelijke organisaties waren immers dusdanig verweven dat sprake kon zijn van herkenbare en beheersbare informatiestromen, althans beter herkenbaar en beheersbaar dan in de grenzeloze, open en snelle netwerken van deze tijd. Waarin allerhande vanzelfsprekende en traceerbare verbindingen tussen volk, 
vertegenwoordigers en versterkers plaatsmaken voor kortstondige, wisselende en vooral veelsoortige associaties. 'In de oude omgeving was de informatie die mensen kregen geordend en geoormerkt naar wat paste bij het maatschappelijk krachtenveld. Leiders konden hun boodschap kwijt en hadden via het maatschappelijk krachtenveld waartoe ze behoorden controle op hoe informatie overkwam. Dit gaf een voorspelbaarheid en overzichtelijkheid. De informatie die nu, midden in het informatietijdperk over ons wordt uitgestort, is in omvang verveelvoudigd en niet meer geoormerkt naar het krachtenveld. Ze is veel diffuser geworden. De diffuse informatie en het gebrek aan herkenning maken dat een gerucht kan leiden tot een negatieve kracht die het momentum kan doen omslaan', vatte de econoom Boot (2011) de situatie recent samen. Ondertussen kan geen manager of beleidsverantwoordelijke om fuzzy structures heen. Hij kan beter de knopen in het netwerk leren zien.

De conflictueuze aard van overheidsbemoeienis, gevoegd bij de losse maatschappelijke koppelingen en de snelle en openbare uitvergrotingen in allerhande media, leidt naar andere infrastructuren en interacties. Kennis van die veranderingen is relevant voor de wijze waarop beleidsmakers hun interventies overwegen, voorbereiden en maken. In termen van de metafoor van het gezelschapsspel schuift de ganzenbordspeler van weleer - die aan de hand van voorschrijvende spelregels het lineaire spel kon bijbenen - nu aan een tafel waar het bord, kaartjes en stukken voor 'Risk' zijn uitgestald; meervoudige, interactieve spelregels dagen uit om met vrije hand en slimme combinaties en coalities de winst binnen te halen. Net als een rotonde een ander beroep doet op de automobilist dan het kruispunt met stoplichten, vraagt het klassieke systeem waarin gezaghebbende toedeling van waarden plaatsvindt in de moderne tijd nieuwe gedragingen en capaciteiten van de deelnemers. Immers, luidde de conclusie na de verkenning van het eigene van de overheid, niet zozeer is de kerntaak van de overheid veranderd - de gezaghebbende toedeling van waarden -en ook niet de basisfuncties van de overheid - het garanderen van een basisbestaan, de zorg om veiligheid en het tegengaan van marktimperfecties blijven corebusiness - maar wel de wijze waarop taken worden uitgeoefend. Beleid is communicatief in de zin dat het vermogen om relaties aan te wenden voorwaardenscheppend is geworden voor het succesvol voorschrijven van regels of treffen van voorzieningen. Communicatie komt niet na de vorming van beleid, beleidsvorming is de resultante van communicatie. Dat vraagt vroegtijdig oog voor woorden, beelden, timing en toonzetting bij zowel het peilen van opinies, het bezorgen van boodschappen als het organiseren van terugkoppelingen. Wie niet weet wat er leeft, kan niet zorgen dat het beleid werkt ${ }^{16}$.

De internationale financiële malaise plaatst anno 2012 de verdeling van schaarse middelen in een extra 'spannend' daglicht. De druk van bezuinigingen is onontkoombaar bij degenen die belast zijn met de dagelijkse verantwoording van het openbaar bestuur en beantwoording van de vraag waar de overheid zich nu weer mee bemoeit. Ambtenaren dus, de voorbereiders en uitvoerders van bestuurlijke besluiten, die hun weg vinden onder

\footnotetext{
${ }^{16}$ Met een knipoog naar de slogan die het ministerie van BZK tot 2010 voerde: 'Weet wat er leeft, zorgt dat het werkt'
} 
de drie systeemspanningsbogen in drie strijdende arena's: politiek bestuur, samenleving en bureaucratie. In die context is de overheid een andere werkgever dan een private organisatie. Gemeen hebben overheid en bedrijf de klant-dienstverlener relatie, de gerichtheid op overwegend enkelvoudige - transacties van diensten. Vervolgens kent de overheid ook de relatie staatsburger-schaarsteverdeler, kiezer-gekozene en onderdaan-handhaver. Met dus alle bijbehorende arena's en hun spanningen. Net als de burger vervult de beleidsmaker zelden alle rollen tegelijk, maar hij of zij zal zich wel bewust moeten zijn van de verwachtingen en opvattingen die bij rollen horen (Van Gisteren, 2010). In hoofdstuk 4 heb ik vastgesteld dat de toenemende interacties en de negatieve publieksreacties steeds meer aandacht en vernuft vragen, maar niet bepaald de lust van het ambtelijk metier ontnemen. Integendeel. Uit onderzoek naar de work meaning van de beleidsmaker kwam eerder gretigheid en nieuwsgierigheid naar voren, als het gaat om het aanpakken van als 'onmogelijk' gekwalificeerde opgaven, om het in stelling brengen van bestuurders en politici en om het smeden van slimme coalities met maatschappelijke partijen. De metafoor van het spel komt in de interviews veelvuldig naar voren, soms om geraffineerde trucs aan te halen, maar meestal om duidelijk te maken dat 'powering and puzzling' (Heclo, 1974) eigenlijk de reden is van de keuze voor een ambtelijke beleidsfunctie. In zowel hoofdstuk 4 en hoofdstuk 7 spreken beleidsmakers letterlijk van kunst om ogenschijnlijk onverenigbare wensen van politiek en samenleving te verknopen. Overheid is de kunst van het probleemoplossend vermogen, en daar kies je voor. Langs die weg komt de verdieping van procesmatige aspecten en communicatief handelen tot een krachtige ontwikkeling.

Uit de publicaties over en uitspraken van beleidsmakers spreekt een stilzwijgende erkenning van het problematische karakter van de overheid en dus de noodzaak te investeren in communicatie c.q. processen. Ik gebruik 'stilzwijgend', omdat de negatieve connotatie van overheid als zodanig niet of slechts luchtig wordt benoemd. ledere beleidsambtenaar kent wel een ambtenarengrap (zie hoofdstuk 4 voor een impressie), maar zowel in het onderzoek naar de betekenis van werk als dat in hoofdstuk 5 naar herkenning en hantering van systeemspanningen komt naar voren dat de waargenomen meningen van anderen over de overheid (perceived external prestige) er nauwelijks toe doen. Ja, de oordelen zijn bekend, maar nee, je laat je er door niet door ringeloren. Als er al van een waargenomen extern oordeel sprake is dan geldt dit primair de percepties van opvattingen van einddoelgroepen, zo bleek uit het work meaning onderzoek. In dit onderzoek werden uitsluitend rijksambtenaren ondervraagd, die daarbij te kennen gaven dat direct contact met belanghebbenden groot verschil kan uitmaken voor het definiëren van een probleem, oplossingsrichtingen en rollen van overheid, burgers en organisaties. Hun feedback is van belang, vooral bij negatieve interventies biedt snelle terugkoppeling immers mogelijkheden voor bijsturing van voornemens. Wat er vooral toe doet is het perceived internal prestige, zo bleek uit de interviews over de werkbeleving (hoofdstuk 4): hoe neem je waar dat collega's, leidinggevenden en bestuurders denken over jouw werk. Met als bijzondere bevinding dat in als 'lastig' te kwalificeren situaties minder de inhoudelijke kennis en vaardigheden van die collega's ertoe doen als de beschikbaarheid van mensen met empathische vermogens: luisteraars. Ten aanzien van de steun in eigen kring werden kanttekeningen geplaatst bij laatdunkende uitspraken over ambtenaren door 
politici in verkiezingstijd (onderzoeksperiode 2009 - 2010): juist binnen eigen kring wordt waardering verwacht, trots gezocht en bij voorkeur gedeeld. Fritz (1990) wees op de betekenis van de erkenning van wat hij noemt 'structurele spanning'. Professionals bind je op basis van hun passie en dat is in de eerste plaats een gemeenschappelijk gewaagd doel. Dat brengt geheid spanning met zich mee en die moet erkend en gedeeld worden. Het tweede element van die spanning is bij Fritz een eerlijke blik op de huidige realiteit: laat zien dat je niet alles kan, of van alles niet kan. De erkenning van het nu en het straks (perspectief) maken het dus problematisch én spannend, lastig én uitdagend om ambtenaar te zijn. Deze casestudies en interviews ontbloten een toenemende kennis, bereidheid en capaciteit om communicatief te denken, durven en doen.

\subsection{Ambtelijke vindingrijkheid: herkennen en hanteren van de specifieke context} (vraag 2)

Het vermogen om weerstand op te vangen is in hoofdstuk 7 gemunt als 'meebewegen'. Deze 'copingstrategie' bevindt zich tussen 'wegbewegen' (vluchten) en 'tegenbewegen' (vechten). Daarbij zijn zes beïnvloedende factoren geïdentificeerd. Zij bevorderen dat beleidsmakers de weerstand opzoeken of voortijdig herkennen. Hieruit volgen twee conclusies.

Conclusie 4. De combinatie van persoonlijkheid en ambtelijkheid maakt het beleidsmakers mogelijk om weerstand te herkennen en te hanteren.

Drie factoren maken dat beleidsmakers bij vermeende weerstand een taxatie maken om niet weg of tegen te bewegen, maar juist een communicatieve confrontatie ('comfrontatie') aan te gaan: persoonlijke hulpbronnen (extraversie, vriendelijkheid, zorgvuldigheid, intellectuele autonomie en openheid), professionele ambitie ('seculiere roeping') en ambtelijk besef (kennis van de (drie) systeemspanningen en beheersing van de (vijf) strategieën om anderen in stelling te brengen, zoals uitgewerkt in hoofdstuk 5). In hoofdstuk 7 heb ik op basis van de casestudies geconcludeerd dat dit drieluik kan worden samengebracht tot twee factoren. 'Professionele ambitie' en 'ambtelijk besef' vertonen immers een grote verwantschap; de ambitie om de publieke zaak te dienen en de toe-eigening van kennis en vaardigheden over hoe de hazen lopen schurken in de praktijk heel dicht tegen elkaar. Ik heb deze samengestelde factor 'ambtelijkheid' gedoopt. In hoofdstuk 7 heb ik in beeld gebracht hoe een sterke score op beide terreinen als een hefboom het vermogen tot meebewegen in gang zet; bij een geringe capaciteit op het vlak van de persoonlijke hulpbronnen of de ambtelijkheid bestaat eerder de neiging om tegen te bewegen. Hoe zwakker de bagage op beide fronten is, hoe groter de kans ook dat de beleidsmaker wegbeweegt en vlucht in rituelen of vermijdgedrag toont. In de case studies is overigens alleen aandacht besteed aan het vermogen tot meebewegen; tegen- en wegbewegen zijn hierbij niet onderzocht, anders dan dat kon worden vastgesteld dat hiertoe in geringe mate respectievelijk niet een neiging toe aanwezig was. 
De voornoemde typologie van persoonlijkheid en ambtelijkheid leent zich voor verder onderzoek; Neelen en Strijp (2007) hebben een tentatieve verkenning gemaakt van basisoriëntaties van beleidsmakers. Is de beleidsambtenaar gericht op de effecten van interventies voor burgers, behartiging van politieke belangen, organisationele (managerial) doelen of juist op de eigen professie en het vakmanschap; we herkennen hier ook de driehoek van arena's die onder meer werd toegelicht in hoofdstuk 2. Deze 'tweede-orde'- informatie kan bij verder onderzoek naar de ambtelijke vindingrijkheid bij het omgaan met weerstanden van betekenis zijn ${ }^{17}$. De samenhang van persoonlijke en professionele aspecten intrigeert immers. Noorderhaven (1995) maakte uit onderzoek onder ambtelijke 'beslissers' op dat besluiten overwegend worden genomen op basis van 'intuitive judgement', waaarvan hij stelt: 'The set of decision rules internalizes by an individual. These decision rules are uncodified and unconscious'. Rationaliteit en intuïtie versterken elkaar dus. De Meere (2003) neemt waar dat in cursussen zienderogen meer tijd uitgaat naar de wijze waarop kennis en ervaring samengaan en vooral ervaringen aandacht krijgen om te kunnen begrijpen waarom de hazen lopen zoals ze lopen, beslissingen worden voorbereid als ze worden voorbereid en zo verder. Kingdon (1984) wees al op de betekenis van beleidsmakers als makelaars, bij wie persoonlijke en beroepsmatige vaardigheden samenkomen. Scholten (2009) haalt het samenkomen van persoonlijke en professionele karakteristieken ook naar voren in zijn studie van 'daring decisions', waarin hij beleidsmakers 'policy entrepreneurs' noemt, die complexiteit en afhankelijkheden omarmen, risico's durven nemen en netwerken kunnen bewegen. Hij haalt Williams (2002) aan die degenen bij wie individuele en beleidsmatige vaardigheden samenballen karakteriseert als 'boundary spanners': 'individuals that have a pivotal role in the management of interorganizational relationships'.

Ten opzichte van het 'koningskoppel' persoonlijkheid \& ambtelijkheid komen de drie andere - en als secundair gepositioneerde - beïnvloedende factoren minder krachtig uit de onderzoeken naar voren. Dat wil zeggen: de tweede trits uit het conceptueel model blijkt in de casestudies vooral als terugvaloptie een betekenisvolle rol te spelen. Dat geldt nog het minst voor de 'sociale steun' van directe collega's, die door velen als terugvaloptie wordt geroemd; het geldt vooral voor de toegekende waarde aan 'ruimte voor reflectie' (leren en ontwikkelen) en 'zicht op resultaat' (hoe dichter met je neus op de effecten, hoe krachtiger de invloed van anderen). Deze factoren kunnen (momenten waarop sprake is van) zwak ontwikkeld ambtelijk besef en/of ontoereikende persoonlijke bagage versterken. Het zijn hulptroepen. De betekenis van deze competenties voor de training en vorming van beleidsmakers komt bij de beantwoording van de derde hoofdvraag in paragraaf 8.4. terug.

Conclusie 5. 'Meebewegers' volgen een karakteristieke opbouw bij hun 'comfrontatie'

\footnotetext{
17 Zoals bijvoorbeeld ook het onderzoek naar 'beroepsbeelden' van beleidsambtenaren door M. Jeliazkova en R. Hoppe, gepubliceerd in Beleidswetenschap 1996/2, 124-153, waarin vijf dominante rolopvattingen worden onderscheiden: procesregisseurs, beleidsfilosofen, advocaten, neo-weberianen en experts.
} 
Op basis van de drie casestudies concludeerde ik dat de drie stijlen binnen de copingstrategie 'meebewegen' - inleven, overeenstemmen en herformuleren - volgtijdelijk kunnen worden gezien (zie paragraaf 7.7.1.). Zonder 'herformulering' van perspectieven geen uitweg, zonder basale bereidheid c.q. 'overeenstemming' geen herformulering en zonder 'inleven' geen zicht op overeenkomstigheden. Op grond van de casestudies komt de drieslag 'inleven - overeenkomen - herformuleren' echter te grof over: ook tussenliggende stappen zijn aan de oppervlakte gekomen, waardoor de weg van het meebewegen met weerstand fijnmaziger geduid kan worden. Bij het identificeren van de ambtelijke mogelijkheden om weerstand tegemoet te treden komt als een eerste stap het vermogen naar voren om het negatieve aspect ruimte te bieden. Dat kan door het bevestigen van (tegen-)argumenten, het benoemen van tegenstellingen of het uitvergroten van de vlek. Vindplaatsen voor deze benadering zijn er in diverse werkvelden, zoals het in hoofdstuk 7 beschreven honoreren van verzet in de jezuïetenmethode (Geul, 1999), de toelating van de schok en de woede bij de verwerking van berichten over levensbeëindiging (Kubler-Ross, 1996) en het opzoeken van lichamelijke draaipunten bij judo. Kern van de benaderingen is dat in de bevestiging van het negatieve de sleutel ligt voor het realiseren van werkelijk contact. Waarvan men zich op voorhand vaak niet bewust is; Vermaak (2009) spreekt daarom van het 'vertragen op het impliciete'. Het komt dan aan op het duiden van het 'nu', de actuele context, waarbij niet alleen de feiten, maar ook en vooral de bejegening er toe doet. Met verwijzing naar Aristoteles gaat het dan om krachtige presentie op zowel het vlak van ethos (eerlijkheid, geloofwaardigheid), pathos (begeestering, passie) als logos (feiten op een rij). Aarts (2009) noemt met verwijzing naar Scharmer (2010) de betekenis van werkelijk luisteren als vaardigheid; dat is niet zozeer 'downloaden' (zoeken naar wat je zelf al vindt) of 'informatief luisteren' (willen horen wat je nog niet wist), maar 'empathisch luisteren' (denken vanuit het perspectief van de ander). Zij onderscheidt bij haar fasering als summum van inlevingsvermogen 'generatief luisteren' (verschillende vormen afwisselen). Het zich welbewust inleven in de ander, het opzoeken van de twijfel en het verkennen van opties is in vele beroepsgroepen met 'necessary evils' en 'dirty work' (hoofdstuk 3) aanwezig. In de medische sector (NRC 29 oktober 2011) wordt artsen (in opleiding) geleerd om te luisteren en 'sorry' te zeggen. Angst dat een verzekeraar niet vergoedt weerhield hen ervan. Een verzekeraar (!) heeft een gedragscode helpen opstellen met onder meer de wenk: 'Erken de fout. Zeg sorry'. De code maakt deel uit van een 'veiligheidsmanagementsysteem'. Dit is er gekomen op initiatief van het ministerie van Volksgezondheid, Welzijn en Sport (VWS) en ontleend aan ervaringen in weer twee andere sectoren: luchtvaart en kernenergie. De initiërende verzekeraar wist in korte tijd $70 \%$ van de ziekenhuizen mee te krijgen. Diverse aanvullingen zijn van de grond gekomen. Zo leren verpleegkundigen in het Sint Lucas Andreas Ziekenhuis Amsterdam in het programma Speak Up om makkelijker een specialist aan te spreken en te corrigeren. $\mathrm{Na}$ (ast) luisteren komt het aan op aanspreken.

Wie erin slaagt om - aansprekend - contact te maken, komt aan tafel. Dat maakt het mogelijk 'het impliciete te expliciteren': de twijfel, de weerzin, de aarzeling, de kritiek of wat dies meer zij. Het is van wezenlijke betekenis om het negatieve niet alleen te omarmen, maar 
te voorzien van een perspectief, leerde hoofdstuk 7. In de slagzin 'Leuker kunnen we het niet maken. Wel makkelijker' betekent de eerste zin weinig zonder de tweede. Welke perspectieven zijn beschikbaar en welke zijn deelbaar, waar kunnen we het over eens worden? In hoofdstuk 7 is de communicatie van het projectbureau voor de aanleg van de Noord-Zuidlijn aangehaald. $\mathrm{Na}$ aanvankelijke vlucht- en vechtbewegingen naar aanleiding van de weerstand tegen de aanleg van de tunnels koos men voor het openlijk tonen van de weerstand op de website (in de vorm van open doorgifte van berichten op Twitter, Facebook, Flickr en de filmpjes Youtube) en het proactief melden van misstanden. Deze prompte openheid werd gekoppeld aan perspectieven over de voortgang. Het probleemoplossend vermogen bij schade en onderbrekingen werd gepresenteerd door de werkers op de vloer in filmpjes, posters, advertenties en persbezoeken. Het primaire proces communiceert. De projectleiding registreert een kentering plaatsvinden in de publieke beoordeling van de weerstand; projectleider Sheerazi wijst op de betekenis van erkenning van de actuele moeite die mensen hebben met de overlast en de schade (Sheerazi, 2011). Veelbetekenend blijkt hierbij het vermogen te zijn om de belangen onder de standpunten te zien. Wat mensen zeggen verwoordt niet per se wat ze bedoelen, waar ze naar verlangen. Daarvoor zijn diverse vormen van inventarisatie en analyse van actoren en hun belangen en argumenten mogelijk, zoals de krachtenveldanalyse in de case van de watercompensatie (hoofdstuk 8) liet zien. Daarbij is gewezen op misverstanden die kunnen ontstaan, zodra de ene partij argumenteert over (abstracte) visies en de ander over (concrete) uitkomsten. Zoals de oproep om gastvrij ex-prostituees te ontvangen stuitte op angst voor veiligheid en daling van huizenprijzen. Deze stap naar verbinding leidt naar overeenstemming als eenieder die ertoe doet zich gehoord en serieus genomen weet en dat men het ergens over eens is geworden. Deze simpel ogende gecursiveerde woordenreeks verwijst naar de kern van wat communicatie als functie vermag (communicare = gemeenschappelijk maken). Er is sprake van gemeenschappelijke contextcreatie als partijen het eens worden over de definitie van het nu (actuele situatie, betwijfeld) en het perspectief (de manier waarop en de gedeelde inhoud). Dan is sprake van wat in het conceptueel model 'in stelling brengen van anderen' noemen. Het contact heeft geleid naar de bereidheid en het vermogen om op basis van meervoudige perspectieven een of meer gemeenschappelijke perspectieven te formuleren en hierover afspraken te maken. Er is dan sprake van 'accommoderen'. Dat kan in de vorm van een voorstel of een tegenaanbod ('counteroffer'), maar van wezenlijker betekenis is dat sprake is van erkenning, zekerheid over informatie en uitzicht, een perspectief. Tjeenk Willink raakte de paradoxale drang naar consensus en strijd in zijn Machiavellilezing in 1995: 'In Nederland geven we elkaar de ruimte. We kennen geen blijvende overwinaars en geen blijvende verliezers. Luisteren en overleg horen bij onze cultuur. Evenwicht en samenspraak zijn kernbegrippen. Maar zonder tegenwicht geen evenwicht en zonder tegenspraak geen samenspraak. Dat tegenwicht en die tegenspraak zie ik nu te weinig'.

De casestudies laten zien dat bij het zoeken en vervolgens vinden van de overeenstemming een symbolische handeling voor een versnelling kan zorgen. Zoals de flipover met de tekening van de waterhoeveelheid, maar het kan ook een ontmoeting op een ander dan vertrouwd terrein zijn. Het is niet alleen een kwestie van vorm; in de praktijk is sprake van een pakkend beeld of begrip, de kwestie wordt geherformuleerd of anders 'gelabeld' 
of 'geframed'. Bij het formuleren van het nieuwe en deelbare perspectief is sprake van wat Brummans e.a. (2008, zie hoofdstuk 7) frontstage framing noemen. De gesprekspartners 'accommoderen' dan naar het nieuwe samenhangende beeld 'not through conflict, but through the negotiation of mutually sensible meanings' (Dobosz-Bourne \& Jankokwski, 2006). In een negatieve uitleg kan dat dus ook het label 'conflict' of 'weerstand' zijn. 'In other words, resistance only exists if change agents label the actions of change recipients as such; and a tendency to do so precipitously of unthinkingly may hinder the change effort'. En dan?

Wie bij vermeende weerstand zich weet in te leven en ruimte weet te creëren voor beschikbare perspectieven en dus alternatieven, heeft de voorwaarden geschapen voor het maken van nieuwe verbindingen en vinden van nieuwe perspectieven. De overeenstemming daarover kan tot een herformulering van de aanvankelijke standpunten of zienswijzen leiden, bleek bij de wijziging van het discours over de bezuinigingen op de diergaarde naar een dialoog over toekomstbestendige bedrijfsvoering. De case is na dat moment niet langer gevolgd. In feite is het loslaten ook aan de orde in de casussen. Na de realisatie van het convenant beschouwde de tijdelijke deelraadsvoorzitter zijn taak als volbracht. In de casus van de watercompensatie droeg de projectleider ook voortijdig dagelijkse taken aan andere teamleden over. Het is een patroon wat in de analyse van heldenverhalen veelvuldig wordt aangehaald: de held verlaat vaak vlak voor het vieren van de overwinning het toneel om weer beschikbaar te zijn voor nieuwe opgaven ${ }^{18}$.

De aldus verkregen opbouw van 'meebewegen' leidt naar een opbouw met vijf stappen voor de ideaaltypische ontwikkeling van 'meebewegen', de weg waarlangs de beleidsmakers communicatie confrontaties ('comfrontaties') aangaat. Dit 'comfrontatiemodel' kent vijf fasen (tabel 8.2.):

I. Weerstand. Bij de ontmoeting van (vermeende) weerstand komt het aan op inleven. Vertragen is dan de belangrijkste activiteit. Opbrengst die de beleidsmaker oogst is erkenning en de bereidheid om met elkaar verder in zee te gaan.

II. Twijfel over wat men moet loslaten of moet ondernemen vraagt om ruimte. Twijfel te expliciteren is van belang, wat in bereidheid kan resulteren om met elkaar in gesprek te gaan of te blijven.

III. Toenadering is nodig van wie ertoe doet, gehoord en gezien kan worden. De (nieuwe) verbinding kan mensen in stelling brengen om een zoekproces helpen vormgeven. Dan is sprake van cocreatie.

IV. Perspectief gloort. Aan beschikbare in- en uitzichten in deze fase geen gebrek. Nu komt het aan op richting. Een symbolische interventie, het op de voorgrond of juist naar achteren schuiven van perspectieven biedt een nieuw perspectief.

\footnotetext{
${ }^{18}$ Bij mythische en bijbelse verhalen zien we de held vroegtijdig afscheid nemen, waarna volgelingen mogen zorgdragen voor consolidatie.
} 
V. Inbedding. Het vervolg is 'in the eye of the beholder'. Dat vraagt om los te laten, over te dragen en dus te vertrouwen. In deze fase zien vertrekt de beleidsmaker als initiator.

Tabel 8.1. Comfrontatiemodel

\begin{tabular}{|l|l|l|l|l|l|}
\hline Kenmerk & Weerstand & $\begin{array}{l}\text { II } \\
\text { Twijfel }\end{array}$ & $\begin{array}{l}\text { III } \\
\text { Toenadering }\end{array}$ & $\begin{array}{l}\text { IV } \\
\text { Perspectief }\end{array}$ & $\begin{array}{l}\text { V } \\
\text { Inbedding }\end{array}$ \\
\hline Activiteit & Vertragen & Vertwijfelen & Verbinden & Vertalen & Verlaten \\
\hline Resultaat & Bereidheid & Begrip & Cocreatie & Handelen & Bestendiging \\
\hline Competentie & $\begin{array}{l}\text { Inleven en } \\
\text { luisteren }\end{array}$ & $\begin{array}{l}\text { Ruimte bieden } \\
\text { en bevragen }\end{array}$ & $\begin{array}{l}\text { In stelling } \\
\text { brengen }\end{array}$ & $\begin{array}{l}\text { Framing en } \\
\text { organiseren }\end{array}$ & $\begin{array}{l}\text { Vertrouwen } \\
\text { geven }\end{array}$ \\
\hline
\end{tabular}

De casestudies illustreren deze ideaaltypische opbouw. Tabel 8.2. vat deze toepassing samen:

Tabel 8.2. Cases in Comfrontatiemodel

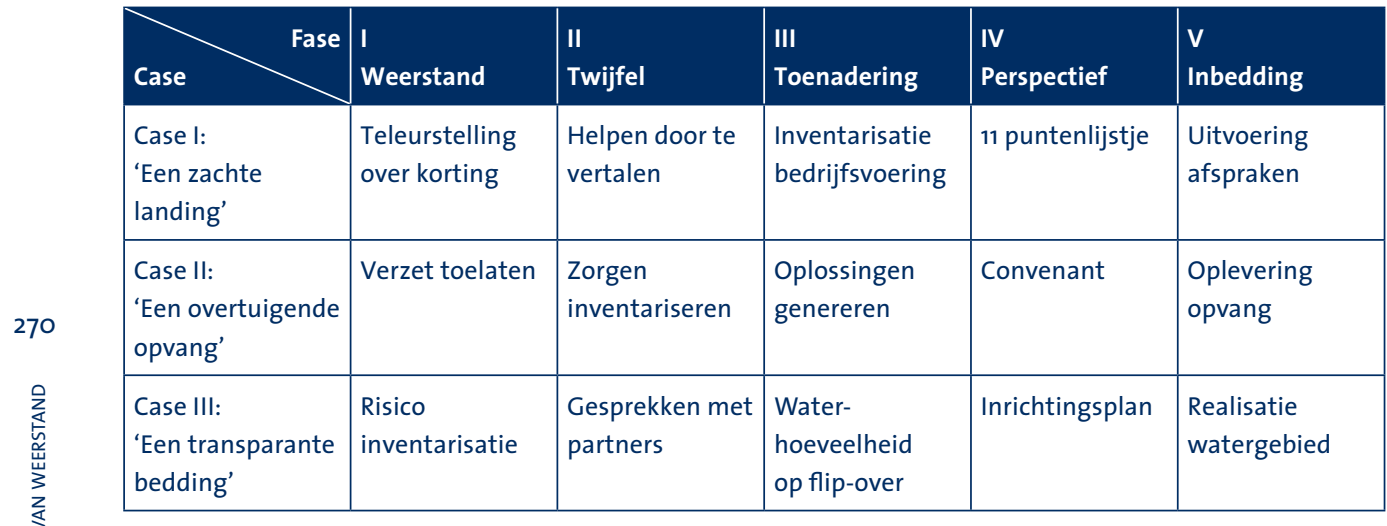

'Meebewegen' ontvouwt zich langs de lijnen van deze uitleg niet als een trukendoos. Er is sprake van een proces, waarin van meet af aan het vermogen om contact te maken voor een fundering zorgt. Daarbij komen enkele competenties in beeld, die de beleidsmaker helpen om de ideaaltypische stappen te zetten en daarbij benodigde acties in gang te zetten. Op die ambtelijke toerusting focust de derde centrale onderzoeksvraag. 


\subsection{Toerusting voor weerstand: competenties van beleidsmakers (vraag 3)}

Aan bestek, bouwmaterialen en gereedschap geen gebrek. Een bonte reeks aan kennis, vaardigheden, gereedschappen en inzichten blijkt voorhanden. Het is duidelijk dat kennis van de ambtelijke mores en verbeeldingskracht belangrijke bouwstenen zijn. (Schok) ervaringen kunnen ook bijdragen aan het vermogen om in te spelen op verstoringen. In de casestudies in hoofdstuk 7 zijn voorts over de zes beïnvloedende factoren - persoonlijke hulpbronnen, professionele ambitie, ambtelijk besef, sociale steun, ruimte voor reflectie en zicht op resultaat - uitspraken te vinden voor de betekenis van kwaliteiten als empathie, intellectuele autonomie, openheid en de aandacht voor reflectie in organisaties. In de ordening van het comfrontatiemodel (tabel 8.1.) zijn tenslotte vijf eenheden van competenties naar voren geschoven, te weten zich inleven \& vragen stellen, ruimte bieden \& luisteren, in stelling brengen, framing \& organiseren en vertrouwen geven. Daarbij komt uit de onderzoeken in hoofdstukken 4,5 en 7 naar voren dat sprake is van tacit knowledge: impliciete, achteraf vaak desgevraagd wel herkende inzichten en vaardigheden.

Het begrip 'competenties' zucht onder het imago 'containerbegrip' en behoeft dus toelichting. Hoewel er eerdere vindplaatsen van deze krachtterm mogelijk zijn, wordt Taylor honderd jaar geleden de eer gegund als eerste de relatie tussen vakbekwaamheid en effectieve arbeid te hebben onderkend. Hij positioneerde competenties als maatstaven om mensen te werven, ontwikkelen en evalueren zodat ze een hogere productie in de beschikbare tijd konden leveren. De in de vorige alinea samengevatte waaier van zienswijzen illustreert de brede interpretatie van het begrip competenties. In de uiteenlopende interpretatie van het begrip kan worden uitgegaan van competentie als a) toegepaste wetenschappelijke kennis (zoals in de medische wereld favoriet is), b) de persoonlijke set kennis, vaardigheden, houdingen in specifieke werksettings $\mathrm{c}$ ) de tacit knowledge in bepaalde disciplines of $d$ ) de bestudering van hoe professionals spreken over hun werk? Sandberg en Pinnington (2009) die deze varianten aanhalen, signaleren een afnemende neiging om competenties aan de hand van statische gegevens (zoals kennis en vaardigheden) te beschouwen. De belangstelling neemt toe voor een contextuele benadering, ook van leren en ontwikkelen dus. Het komt er dus op aan het competente handelen van een persoon of beroepsgroep te bezien vanuit de betekenis die deze persoon of categorie toekent aan de praxis, de werkervaring. Competentie is dan samen te vatten als 'doorleefde ervaring'.

Deze invalshoek sluit aan op aanwijzingen in hoofdstuk 3. Voor een goed begrip van professionele gedragingen en idem dito selectie van interventies, is het relevant om te focussen op de fase waarin iemands vakontwikkeling zich bevindt en de persoonlijke basisoriëntatie qua leren en ontwikkelen. Die opvatting ontleenden we aan de ordening van Lynn (1986) van professionals naar beginners, technologen, professionals en master practicioners en Weggeman's (2007) bewerking van de leercyclus van Kolb. Weggeman verbindt aan de professionele ontwikkeling van ervaren via observeren en conceptvorming naar experimenteren een onderscheid naar basishoudingen, die hij dromers, denkers, beslissers en doeners noemt. 
Beide opvattingen stellen de ervaring centraal en dat sluit aan waarnemingen in de casestudiss. Zo is op basis van de cases (hoofdstuk 7) vast te stellen dat we eerder met 'professionals' en 'master practicioners' dan met 'beginners' en 'technologen' van doen hebben en eerder 'beslissers' en 'doeners' aan het werk zien dan 'denkers' en 'dromers'. Deze indelingen zijn hulpmiddelen om de complexe praktijk van het ervaringsleren te duiden, bevestigen Weggeman (2007) en Vermaak (2006). Elke leerstijl is legitiem en er is in de praktijk vaak sprake van snelle cycli, waardoor de meester van vandaag de leerling van morgen kan zijn, zoals de beleidsmaker in de casus van de watercompensatie zelf onder woorden brengt (hoofdstuk 7). 'Sociale steun' is de eerste uit het tweede drieluik van beïnvloedbare factoren. Bij meebewegen komt het in de eerste plaats aan op persoonlijkheid - de kwaliteit van de persoonlijke hulpbronnen - en ambtelijkheid: het beschikken over professionele ambitie en ambtelijk besef. Maar daarnaar gevraagd worden de sleutelfiguren en steunberen in de omgeving moeiteloos aangewezen. We hebben hier niet met solisten te maken, maar wel met mensen die zelfstandig verantwoordelijkheid kunnen nemen. Daarbij registreerden we nog twee opvallende patronen. Een: naast de directe collegiale omgeving komt naar voren dat vooral de interactie met personen van wie de weerstand kan worden verwacht van betekenis is. De vermeende tegenstanders blijken dan kompanen, zoals in de casus van de opvang van ex-prostituees bleek toen bewoners werden aangesproken op wat ze wel wilden. Twee: voor de ogenschijnlijk logische optie om op de sociale omgeving terug te kunnen vallen bij lastige opgaven is inhoudelijke kennis van zaken van collega's geen voorwaarde om als steunbeer te fungeren. Vooral hun beschikbaarheid en inlevingsvermogen telt: kunnen ze écht luisteren en de beren op de weg helpen benoemen?

Sandberg en Pinnington (2009) hebben aan het uitgangspunt van ervaring als fundament voor leren een relevante analyse toegevoegd. In hun eerder aangehaalde studie over vakbekwaamheid stellen ze vast dat competenties ten onrechte alternerend worden gedefinieerd, dus als óf toegepaste wetenschappelijke kennis óf ongrijpbare vaardigheden (tacit knowledge) óf een reeks af te perken beschrijvingen van vaardigheden, houdingen en persoonlijke eigenschappen. Deze benadering kan worden opgevat als een ondersteuning voor een contextuele benadering: niet zozeer de waaier aan kennis en vaardigheden, maar het praktiseren van ervaringen en acties ontbloot de kern van professionele competenties. In de contextuele benadering zullen competenties steeds in een relationeel perspectief moeten worden bezien: bij wat iemand voorneemt, doet of achteraf overweegt gaat het dan om wat hij of zij in een ontmoeting met anderen voor elkaar krijgt: 'a collectively developed understanding of joint enterprise, mutual engagement in the sense of established norms of interaction, and a shared repertoire of communal resources such as laguage, routines, stories and tools'.

De auteurs grijpen Heidegger's existentiële ontologie aan om de essentie van competenties te zoeken in de betrokkenheid ('involvement') van een professional met zijn werk: '(...) what Heidegger highlights through his existential ontology s that our way of being comes before the subject-object distinction, because it is our way of being that enables us to understand ourselves as particular subjects and objects. Een competentie is dan een existentiële aangelegenheid, a way of being, hoe jij betekenis geeft aan werk. Daarin vormen vier elementen de 'competentiebasis': 1) zelfkennis, 2) besef van de essentie van het werk, 3) vaardigheden in de 
interactie met anderen en 4) beschikbare gereedschappen zoals kennis en hulpmiddelen. Deze analyse van competenties bevestigt de eerdere vaststelling dat juist in de combinatie van 'persoonlijkheid' en 'ambtelijkheid' (zie tabel 8.1.) de sleutel ligt verborgen voor het vermogen om de copingstrategie 'meebewegen' te manifesteren. Wat we doen en 'leveren' is primair gedefinieerd door hoe beschikbare kennis, vaardigheden en hulpmiddelen betekenis krijgen in de relaties met anderen. Dit leidt naar een zesde conclusie:

Conclusie 6. Vier competenties schragen het ambtelijke vermogen om meebewegen te leren en te leven.

De voorgaande beschouwing leidt naar een conclusie over de kerncompetenties voor de copingstrategie 'meebewegen' oftewel bij de werking van het comfrontatiemodel (tabel 8.2.). Ik breng hierbij de waaier aan zienswijzen, kenniselementen, vaardigheden en houdingen terug tot vier elementen. De competente beleidsmaker is in staat tot 1) Helpen zien van meervoudige perspectieven op een (voorgenomen) bemoeienis van de overheid, 2) In stelling brengen van relevante partners om hun eigen en gemeenschappelijke doelen te realiseren, 3) Vormgeven van gemeenschappelijke perspectieven en 4) Overdragen van lessen uit ervaringen met weerstand, twijfel, toenadering en hervonden perspectief. Per competentie kunnen specifieke elementen worden benoemd, zoals de benodigde kennis, vaardigheden, hulpmiddelen en werkvragen die de way of being van Sandberg en Pinnington kunnen versterken.

\section{(1) Helpen zien van meervoudige perspectieven op een (voorgenomen) bemoeienis van de} overheid

Weerstand is geen blinde muur, maar een wand vol betekenissen (conclusie 2).

De beleidsmaker die de betekenissen herkent, kan doorbraken helpen maken in situaties waarin tegenspel als negatief wordt gepercipieerd. Uit de interviews bleek hoe ambtenaren bij bestuurders, collega's en externe partners in staat waren openingen te vinden. Door het uitwisselen van meerdere standpunten, argumenten en ideeën ontstaat spanning in de werkelijkheidsbeelden en de basisassumpties van deelnemers aan de dialoog. Dit biedt mogelijkheden voor het betwijfelen van de basisassumpties en geeft ruime voor de wijziging ervan en voor het ontwikkelen van nieuwe werkelijkheidsbeelden (Elving \& Boonstra, 2009). Voor het helpen zien is contact een vereiste; de ontmoeting met de ander is een voorwaarde voor het scheppen van een klimaat waarin zienswijzen kunnen worden getoond, uitgewisseld en onderzocht. Bij het contact moet ruimte zijn voor negatieve verwachtingen, ervaringen en standpunten en de authenticiteit van die presentie kan het verschil maken. Het vermogen om te vertragen is daarbij van vitaal belang: kan twijfel worden geëxpliciteerd? Ook de kwaliteit van luisteren is hierbij aangehaald, om te onderstrepen dat het doorzien van standpunten (op onderliggende belangen of eerdere ervaringen bijvoorbeeld) meer vraagt dan alleen een bereidwillig oor. Het vereist ook de kwaliteit om eigen agenda's op te schorten of in de wacht te zetten. Contact kan dan de opmaat zijn naar 'contract', dat wil zeggen dat dialoog over perspectieven nieuwe inzichten en vergezichten kan opleveren. In hoofdstuk 5 (onderzoek 
systeemspanningen) zien we voorbeelden van ambtelijk inlevingsvermogen aan de voet staan van een (her)formulering van voornemens en standpunten. Tijdig aan tafel zitten bij beslissers, voorsorteren op agenda's van politici en tijdige inventarisatie van belangen en voorkeuren zijn daarbij belangrijke troeven. Ken je krachtenveld.

Qua gereedschap komen hulpmiddelen van pas, die bijdragen aan het bewustzijn van eigen hulpbronnen als extraversie, initiatief, openheid en intellectuele autonomie. In literatuur en op internet is een veelheid aan testen te vinden die de toepassing van deze competentie binnen handbereik brengen. Diagnosemodellen voor risico's, krachtenveld, argumentatie, belangen en standpunten zijn beschikbaar voor het ordenen van kennis en houdingen die aan perspectieven ten grondslag liggen. In onze onderzoeken hebben we hier de rol van de directe werkomgeving gezien: bestuurders en collega-ambtenaren kunnen helpen kwesties van meerdere kanten te zien. Wie onder aanhoudende spanningsbogen (hoofdstuk 5) zijn of haar weg moet vinden, kan niet anders dan tegendelen gaan zien, getuige ook de arbeidsmarktcampagne 'Het Rijk. Als je verder denkt' waarmee aan de hand van puzzelstukjes tegendelen van maatschappelijke opgaven als appetizers werden opgedist.

(2) In stelling brengen van relevante partners om hun eigen en gemeenschappelijke doelen te realiseren

Kennis van de bestuurlijke/politieke, maatschappelijke en ambtelijke arena's en hun mores helpt om te voorzien welke zetten spelers kunnen doen en te begrijpen waarom in specifieke situaties gedragingen voorkomen. In stelling brengen betekent vooral: ruimte vinden en die ruimte helpen vullen. Dat kan een (publicitair) platform zijn om twijfels, voornemens of uitkomsten te presenteren en toetsen, het kan ook het fourneren van gesprekspartners inhouden om naar een achterban tekst en uitleg te geven over (voorgenomen) handelingen bij een spannende interactie. Uit de cases en interviews komt de betekenis naar voren van korte lijnen met partijen en directe feedbackmogelijkheden. In de praktijk blijkt immers dat maatschappelijke actoren vooroordelen hebben over de mate waarin de overheid bereid en in staat zijn tot cocreatie, coproductie en mogelijk ook gezamenlijke beslissingen. Een belangrijk begin is echter het kennen en erkennen van agenda's en mores. Voor de bureaucratie komen dan andere elementen in beeld dan politieke bestuurders of belangenorganisaties. Vertrouwdheid met de geschetste arcatuur van spanningsbogen is een vereiste. Wallage (Academie voor Overheidscommunicatie, 2011): 'Als je een beroep doet op experts uit de samenleving gaan die meeleven en meedenken, en wordt de uitkomst ook meer geaccepteerd (...) Een goed voorbeeld vind ik de Zuiderzeespoorlijn. Daar zijn door Rijkswaterstaat met de burgemeesters langs het traject hele goede gesprekken gevoerd en duidelijke afspraken gemaakt over de opbrengsten van de gronden en het investeren van gelden in de spoorlijn'.

Qua gereedschap helpt kennis van kwesties, gebruiken en voorkeuren, waarbij ook de onder (1) genoemde diagnosemodellen uitkomst kunnen bieden. Netwerkvaardigheden zijn 
van betekenis om vanuit een relatie met de belanghebbenden te kunnen handelen; wie als het er op aan komt tabula rasa moet beginnen heeft in de termen van Nooteboom (2004) hoge transactiekosten. De eerder genoemde persoonlijke eigenschappen die samenhangen met inlevingsvermogen komen ook hier weer in beeld.

(3) Vormgeven van gemeenschappelijke perspectieven

Bij het gemeenschappelijk maken van de perspectieven kunnen nieuwe betekenissen een nieuw zicht op de gepercipieerde werkelijkheid geven. Dat kan in vele vormen gestalte krijgen. Inhoudelijke frames of interpretatiekaders kunnen helpen om een (nieuw) beeld te helpen karakteriseren. Ook de vorm van de perspectiefwisseling is relevant. Dat kunnen praktische hulpmiddelen als flip-overs zijn alsook pakkende illustraties, verbeeldingen, metaforen of ruimtelijke ordeningen. Zo kan de vergadering op een afwijkende locatie of het in gang zetten van een bijeenkomstenreeks ook als vormgeving van een perspectief dienen. Dat hoeft teleurstelling niet per se weg te nemen, maar kan haar wel dempen, in die zin dat begrip en bereidheid ontstaat voor verantwoordelijkheden en mogelijkheden van partijen.

Qua gereedschap is kennis van framing, vormgeving van ontmoetingen (incluis protocol) en regie van debatten en andere bijeenkomsten in de voorbeelden in onze onderzoeken genoemd. Ook reclametechnieken voor het trekken van aandacht, oproepen van nieuwsgierigheid en likeability komen als gereedschappen van pas. Het vermogen tot het vormgeven van ontmoetingen is niet iedereen gegeven, maar de onderkenning ervan is al een begin. En aan wenken geen gebrek, zoals protocolpionier De Groot (2008) menigeen bijbracht: hoe je mensen ontvangt, tegemoet treedt, laat staan of zitten, met elkaar in verbinding brengt of aan hun lot over laat, kan het verschil maken tussen de spreekwoordelijke blinde muur en de wand vol mogelijkheden.

(4) Overdragen van lessen uit ervaringen met weerstand, twijfel, toenadering en hervonden perspectief

In het vermogen tot delen van ervaringen liggen veel mogelijkheden besloten om anderen te binden, ervaringen te verdiepen en over te dragen. In de interviews en cases is naar voren gekomen dat ruimte voor reflectie kan bijdragen aan een lerende organisatie, dat wil zeggen dat bereidheid bestaat om lastige situaties te benoemen en op juiste waarde te schatten. Hierbij is het relevant kennis te dragen van de ontwikkelingsfase waarin jezelf en anderen zich bevinden; zelfkennis en kennis van de omgeving kan helpen om gericht aan te sluiten in plaats van ongericht zendingswerk te verrichten. Diverse respondenten hebben het belang onderstreept van bespreking van schokkende ervaringen; wie als meester een ervaring achter de rug heeft met een lastige boodschap, kan als leerling bereid zijn om ondervraagd te worden en impliciete kennis en aannames boven tafel te brengen. 
Qua gereedschap komen intervisie en andere reconstructietechnieken in aanmerking voor de vakman. Het systematisch en gezamenlijk hernemen van keuzes bij ontwerp en uitvoering van projecten helpt de organisatie mee te laten leren van zowel fouten als geslaagde missies. Hiertoe kunnen ook tussentijdse interventies worden gerekend zoals de 'zwartkijksessies' waartoe de ambtelijke leiding van het Ministerie van VWS naar verluidt besloot tijdens de invoering van het nieuwe zorgstelsel (De Bruijn e.a., 2007). Voormalig Secretaris-generaal Van der Steenhoven van het ministerie van Onderwijs, Cultuur en Wetenschap (OCW) pleitte in bijeenkomsten regelmatig voor 'tegendenken': systematische feedback en van buiten naar binnen kijken helpt de kans op verrassingen te verkleinen. Dergelijke voorzieningen helpen om impliciete kennis te expliciteren en niet alleen op een individueel niveau. Ook de betekenis van de organisatiecultuur en hierin dominante patronen kunnen op tafel komen. Een waaier van beschikbare testen voor persoonlijke vaardigheden kan ook voor deze competentie betekenis hebben.

\subsection{Tot slot: van wie is de overheidscommunicatie?}

Tijdens de beantwoording van de centrale onderzoeksvragen zijn nieuwe vragen opgeworpen. Bedoeld en onbedoeld. Sommigen slopen al eerder tussen de regels door of sluimerden al vanaf het begin. Eén vraag kan niet buiten beschouwing blijven als een communicatieprofessional zich verdiept in de biotoop van beleidsmakers: van wie is de overheidscommunicatie?

\section{Uniek voor de overheid?}

Voordat ik me aan de beantwoording waag stel ik vast dat meer vragen aandacht verdienen. Zoals: hoe uniek is dit betoog voor overheidsdienaren? Steeds meer bedrijven hebben toch ook met publieke verantwoording te maken, ook zij ontmoeten toch publieke weerstand? Jazeker, de voorbeelden van Shell en de gebeurtenissen bij Brent Spar (1989) en de CO2opslag in Barendrecht (2010) werden aangehaald bij de duiding van omgang met omstreden kwesties en kritische doelgroepen. Niet alleen de overheid heeft te maken met weerstand van publiek, ook private organisaties krijgen bij ingrepen (in woon- en leefgebieden) te maken met de patronen die in deze studie worden opgedist. Wie de schoen past, trekke hem aan: daar waar gegevens uit deze studie bruikbaar zijn voor niet-overheidsorganisaties kunnen ze naar hartelust worden aangewend. De op meer plaatsen aangehaalde wezenstrek van de overheid om besluiten te nemen over zaken waar vrije krachten in de samenleving zelf niet over kunnen of willen oordelen, maakt de gerede kans op ongemak, rumoer of verzet bij de overheid aanmerkelijk groter dan bij bedrijven. Enkele andere kenmerken versterken de relevantie om juist in de publieke sector te investeren in het omgaan met weerstand. Zo kan de overheid nu eenmaal minder snel achter gesloten deuren interventies voorbereiden of uitvoeren. Tegenover openheid - als mentaliteit - staat openbaarheid als plicht voor de overheid en recht van de burger: een onder meer bij de Wet openbaarheid van bestuur (Wob) verankerde grondslag bepaalt dat overheidshandelen openbaar is, tenzij enkele uitzonderingsbepalingen 
van kracht zijn. Mede door de controlerende rol van de media in het algemeen en de trits snelheid, openheid en schaal die de sociale media karakteriseren zijn de mogelijkheden om openheid af te houden afgenomen en om openheid af te dwingen steeds grote. De copingstrategieën die in de overheidscontext zijn uitgewerkt lenen zich voor onderzoek bij bedrijven. Bedrijfsleven en overheid groeien op meerdere terreinen door marktwerking en liberalisering meer naar elkaar toe. Dit leidt naar de conclusie dat niet zozeer qua problemen/ opgaven sprake is van verschillen als wel qua context ${ }^{19}$.

De systeemgerelateerde spanningen maken de kans op de ontmoeting van weerstand groter dan in een willekeurig bedrijf. Een nadere verkenning van verschillen en overeenkomsten op dit vlak is aan te bevelen. Mogelijk draagt dergelijk onderzoek bij aan een toetsbare beschrijving van de ambtelijke vindingrijkheid. Als pendant van de Emotionele Quotiënt (EQ) zou de karakterisering van een Ambtelijke Quotiënt (AO) kunnen bijdragen aan de zichtbaarheid van de vermogens in de openbare sector om contactueel sterk voor de dag te komen. We hopen dat deze dissertatie hiervoor bruikbare bouwstenen bevat. Klassieke schotten tussen 'publiek' en 'privaat' vervagen en dat leidt ook tot nieuwe combinaties op wetenschappelijk gebied. Gaandeweg dit proefschrift viel het op dat over de omgang met weerstand vaak de organisatieleer (en verwante disciplines als veranderkunde) wordt aangegrepen voor empirie en verklaring en onderbouwing van zienswijzen. Dit proefschrift bood ruimte om kruisbestuiving toe te laten uit grensgebieden en bij grenspaaltjes van vakgebieden niet (alleen) stil te staan.

\section{Hoe bewegen vijf generaties mee?}

Als het gaat over grenzen vraagt ook leeftijd aandacht. Voordat ik aan de hoofdvraag van deze slotparagraaf toekom, verstout ik mij nog één hartekreet. Aanleiding is het afstudeeronderzoek van Bosman (2009) naar work meaning. Daarin brachten jongere rijksambtenaren vaker het belang van hun werk voor de maatschappij dan oudere collega's. Vaker ook gaven jongere ambtenaren aan dat ze het beleid dat de overheid voert willen kunnen uitleggen aan familie of vrienden. En vaker ook dan ouderen bekenden ze een terugkoppeling te geven aan de minister of de directie waarneer ze het niet eens zijn met een bepaald beleid. Veel oudere respondenten legden zich er bij neer dat je soms beleid uit te moeten voeren waar je zelf niet (helemaal) achter staat ${ }^{20}$. Bontekoning (2007) wees er op dat binnen tien jaar vijf generaties de werkvloer delen. De nu oudste generatie (de protestgeneratie) is dan geheel verdwenen uit de rijksdienst. De eerste vertegenwoordigers van de jongste generatie (screenagers, geboren 1985-2000) stromen nu al binnen. Daarmee verdwijnt een generatie voor wie de waarden van status, positie, consensus en zelfontplooiing hoog scoren.

\footnotetext{
19 Zoals Ron Niessen krachtig de ambtelijke status verdedigde door er op te wijzen dat een ambtenaar niet zozeer een ander type medewerker is maar de overheid een ander type werkgever (Niessen, 2011).

${ }^{20}$ Uit het onderzoek kan niet worden opgemaakt of de verschil alleen samenhangen met leeftijd of (ook) met het aantal jaren ervaring binnen de overheid.
} 
De nieuw binnenkomende generatie houdt zich minder aan oude grenzen, is gericht op interactief ontwikkelen en streeft niet zozeer naar consensus maar hanteert veel meer een praktijk van leven en laten leven. De verschillen tussen opeenvolgende generaties brengen nieuwe zienswijzen, eigen invullingen van idealen en drijfveren met zich mee. Dat is van alle tijden. Nu gaan nieuwe ontwikkelingen op het gebied van werken aandacht vragen: telewerken, elektronische diensten, nieuwe interactieve vormen. De diversiteit binnen het personeelsbestand zal toenemen want met de nieuwe generaties neemt de diversiteit toe: meer vrouwen, meer (sub)culturen bijvoorbeeld. De generatie X (geboren 1955-1970) bezet ondertussen nu de meeste leidinggevende posten in organisaties. Vervolgvraag: welke invloed heeft het samenkomen van meer generaties voor het vermogen tot meebewegen met (vermeende) weerstand?

\section{Van wie is de overheidscommunicatie?}

Aan deze voorzetten voor vervolgonderzoek voeg ik tot slot de prangende vraag toe naar het eigenaarschap van de (overheids)communicatie. De beschrijvingen in de verkenningen en onderzoeken maken een verschuiving duidelijk, die niet meer afgedaan kan worden als een interessant uitstapje. Wat lange tijd het aandachtsgebied van louter een stafafdeling was, wordt in toenemende mate het domein van degenen die het primaire proces van de beleidsvorming organiseren. De nog steeds groeiende aandacht voor communicatieve/ procesmatige aspecten van organisatie en beleid onderstreept de trend naar inclusieve communicatie. Kennis van en inzicht in procesmanagement, omgaan met (de kans op) weerstand lijkt te belangrijk om aan communicatieprofessionals alleen over te laten. De geïnterviewden bij de rijksoverheid en de casestudies bieden illustraties van de wassende stroom aan ervaringen, inzichten en gereedschappen. 'Beleid' claimt 'communicatie'. Dit vertaalt zich ook in nieuwe opleidingen op communicatief gebied en inbedding van communicatieve elementen in trainingen en cursussen voor beleidsmakers.

De wassende stroom kan deels op het conto worden bijgeschreven van de communicatiediscipline zelf. De belangstelling voor het programma 'Factor C' (bewustwording van communicatief handelen voor beleidsmakers vanuit de communicatiediscipline) getuigt hiervan. Bij de rijksoverheid en inmiddels ook diverse gemeenten en provincies leiden cursussen en andere handreikingen naar een steeds diepere indaling van communicatie in beleidstrajecten (zie www.rijksoverheid.nl). De tien jaar geleden door de Commissie Toekomst Overheidscommunicatie aangeblazen - en door onder meer de Academie voor Overheidscommunicatie verder uitgewerkte - bewustwording en kennisoverdracht mag er zijn. 'Factor C' richt zich direct op het bewust maken van beleidsmakers op het terrein van krachtenveld/netwerkanalyse, identificeren van frames en formuleren van kernboodschappen en de omzetting van deze kennis en inzichten in communicatieve beleidsplanning (en dus niet in gescheiden communicatieplannen). Indirect richt het programma zich op toerusting van de communicatiediscipline voor het toerusten van hun beleidscollega's. De aangereikte competenties in paragraaf 8.4. en de lessen uit de cases en interviews kunnen ook worden opgevat als een aansporing voor communicatieafdelingen om van die toerustende taak nog 
meer werk te maken. Om nog meer de blik naar binnen te richten in plaats van de veel bepleite externe oriëntatie. Stelling: laat communicatieafdelingen minder zélf als boodschappers fungeren en zich toeleggen op de vorming en ondersteuning van werkers in primaire processen bij hun communicatief handelen.

'De nieuwe communicatieadviseur is de aanjager van dit proces tussen departement en omgeving, zij of hij is de coach van de beleidsmaker, kan helpen met kernboodschappen rondom de probleemstelling, wanneer het beleid nog niet staat'. Aldus Pieter Idenburg, directeur Communicatie van het ministerie van Sociale Zaken en Werkgelegenheid (Academie voor Overheidscommunicatie, 2011). Maar in hoeverre wordt deze interne aanjaagfunctie erkend en omarmd? Middel (2002) nam bij zijn start als lector Overheidscommunicatie aan de Hogeschool Utrecht een behoefte waar aan een krachtiger dienstverlening door de communicatiediscipline ten aanzien van 1) informeren (van binnen naar buiten); sturen op informatieoverdracht en 2) consulteren (van buiten naar binnen); sturen op gemeenschappelijke probleemanalyse en oplossingsbepaling. In een onder zijn leiding verschenen Trendonderzoek Overheidscommunicatie (Middel, 2004) meldden interne opdrachtgevers (beleidsmakers en leidinggevenden) de 'contactuele vaardigheden' als belangrijkste competentie van communicatieprofessionals te zien, met op de tweede plaats 'analytisch vermogen'. In dit onderzoek klonk de zorg door of de communicatiediscipline in staat is om beleidsmakers afdoende bij te staan bij het verder ontwikkelen van de omgang met communicatieve interventies. Anders gezegd: wie staat in voor de vorming van meebewegers?

In dit proefschrift staat de vraag centraal hoe beleidsmakers weerstand kunnen ontmoeten, tegemoet kunnen treden en kunnen hanteren. Daarbij is dit handelen gedefinieerd als communicatief handelen (hoofdstuk 3 ) en in het licht geplaatst van houdingen van de media (hoofdstuk 2) en de interne en externe gepercipieerde beeldvorming (hoofdstuk 4). De vraag naar de functie van de communicatiediscipline is buiten beschouwing gelaten. Ze leent zich voor vervolgstudie. Vraag: welke functie heeft de communicatiediscipline bij de versterking van het communicatief handelen van beleidsmakers? Bestuurskundige Geul (2001) noemde overheidscommunicatie een 'halve professie': de sociale component is wel voldoende ontwikkeld (het kent onder meer een enigszins hechte beroepsgroep), maar de inhoudelijke component niet. Coops (2010) meent dat de discipline die 'zo afwijkend en bijzonder niet is (...) alleen wat eerder in de kijker [loopt]' de competentie durf ontbeert. Hij signaleert dat 'er te weinig gezaghebbende 'communicanten' rond lopen die het vak verdedigen, presenteren, verder brengen, bekritiseren en verantwoorden'. 'Lenigheid is geboden. Maar een rechte rug ook'. Elving en Boonstra (2009) signaleren dat de rol van communicatieadviseurs vooral van het type strategie afhangt. Dat wil zeggen, bij overtuigings- en beïnvloedingsstrategieën in organisaties worden communicatieadviseurs eerder 'ingezet' als boodschappers en uitvoerders van campagnes, terwijl bij een relationele strategie (gericht op bereiken en bewegen van netwerken), een afstemmingsstrategie (focus op ontwerp van processen) en interactieve strategie (dialoog bevorderen) communicatieadviseurs juist afstemming, samenwerking en dialoog kunnen helpen organiseren en faciliteren. 
Communicatie zal steeds minder het alleenrecht zijn van die ene discipline, wat niet wegneemt dat de discipline vanuit de rijke vijver aan kennis en kunde waarde kan toevoegen aan de beleidspraktijk. Maar dan dus minder door taken over te nemen als wel de (beleids) organisatie te faciliteren bij het werven en versterken van het communicatieve handelen. Daarbij kan de communicatiediscipline een bijdrage leveren aan het reflecteren op dat handelen. Deze slotparagraaf biedt ruimte om een eerder met Bikker geuit (Bikker \& Rijnja, 2007) pleidooi voor 'communisprudentie' kracht bij te zetten. Zoals juristen gezaghebbende uitspraken over interpretatie van wetgeving laten doen en deze jurisprudentie opnemen in de populaire uitgaven van wet- en regelgeving, wint ook het openbaar bestuur aan professioneel gewicht als de prudente omgang met lastige opgaven wordt beschreven en besproken. Beschrijf dus de communicatieve beleidsvorming systematisch en vraag een college van wijze mensen om uitspraken te doen over de aannames, keuzes en uitkomsten. Een levendige 'moresprudentie' (Karssing, 2007) draagt bij aan herkenbaarheid van een vakgebied, een transparante uitvoering ervan bovendien aan een gezaghebbend imago van de toch steeds weer bekritiseerde rol van de overheid. Dus wie weet wat hier voor mooie gevolgen nog uit kunnen voortvloeien. Dertig jaar na de invoering van de Wet openbaarheid van bestuur (Wob) is het geen luxe de maatstaven voor publieke sturing van informatie in het licht van de actuele context van beleidsvorming te herwaarderen.

In 1987 bracht een tekst op een stadhuis een proces in werking. Waarom afficheert een gemeente zich met een verontschuldiging, was de reactie van een startende voorlichter bij lezing van 'Ne Jupiter Quidem Omnibus' op de gevel. Zoals zo vaak vertelt de buitenkant maar de helft van het verhaal. Of nog minder. Vijfentwintig jaar ervaring binnen uiteenlopende overheidshuizen helpt om door muren heen te kijken (en ook te breken) en nieuwe perspectieven te zien. Wat heet, het helpt om onverschrokken te genieten van wat zich in tweede instantie als een wand van mogelijkheden voordoet. Omdat het eerste oordeel meestal fout is, precies zoals Chiel Galjaard beweerde: louter omdat je met de eerste inval niet genoegen moet nemen. De tweede slag is een daalder waard: overheid, gun jezelf de kans om de context te herkennen en de eigen kracht meer te benutten. De ambtelijke kracht, die helpt om het eigene van de overheid te begrijpen en weerstand, lees: meervoudige perspectieven, aan te spreken. De nieuwe conceptualisering van weerstand nodigt uit om verder uitgepakt te worden. De geïnterviewde beleidsmakers in dit proefschrift staan model voor een wassende stroom aan ervaringen en inzichten. Weerstand hoort erbij en je kunt er van genieten. Ik zou het van de daken willen schreeuwen. Hoeft niet, zegt de gastheer in de hal van het Rotterdamse stadhuis, als ik hem vertel over het opschrift van het oude Haagse stadhuis. Hij neemt me mee naar buiten en wijst vanaf het bordes naar een basreliëf. We zien een afbeelding van een man, die een vel ophoudt met de letters U.P.N.O. .'Ultra Posse Nemo Obligatur'staat voor 'Tot meer dan hij kan wordt niemand gedwongen', weet hij. Lange leve de mensen die deuren openen naar meervoudige perspectieven. 


\section{Verantwoording}

Paragraaf 1.2. is een uitwerking van een eerste verkenning van het onderzoeksthema, die verscheen als artikel in het tijdschrift Comma (Rijnja, 2007). Met het essay 'Deceptiemanagement: Hoe gebruikt u uw teleurstelling?' heb ik het voornemen voor een promotieonderzoek binnen de overheidsector kenbaar gemaakt. Een waaier aan reacties op het artikel leidde begin 2008 tot een eerste onderzoeksvoorstel met een uitgewerkte probleemstelling en onderzoeksvragen.

Paragraaf 2.2. is voor een belangrijk deel gebaseerd op een essay (Rijnja \& Klinkers, 2011) voor het Centrum voor arbeidsverhoudingen overheidspersoneel (CAOP) ten behoeve van een bundel over het eigene van de overheid ('Waarden maken de overheid', 2011).

In het onderzoek in hoofdstuk 4 werd gebruik gemaakt van data die verkregen werden tijdens de afstudeerstage van Anouk Bosman in het kader van de master communicatiewetenschap aan de Universiteit Twente (Bosman, 2009). Onder mijn leiding werd het afstudeeronderzoek verricht bij de Academie voor Overheidscommunicatie van het ministerie van Algemene Zaken.

In 2009 heb ik samen met Hans Wilmink van de directie Kennis van het ministerie van Binnenlandse Zaken en Koninkrijksrelaties (BZK) het onderzoek naar de omgang met systeemspanningen opgezet en uitgevoerd (hoofdstuk 5). Dit onderzoek verscheen als brochure bij het ministerie onder de titel 'Beroep: beleidsambtenaar - over ambtelijk besef en professioneel lef' (Rijnja \& Wilmink, 2010). Voor het gebruik van de onderzoeken in hoofdstukken 4 en 5 geldt dat op basis van de oorspronkelijke data een definitieve selectie en ordening van de informatie heeft plaatsgevonden. 


\section{Bijlage I: Onderzoeksaanpak Work meaning}

\section{Onderzoeksprotocol}

I. Achtergrondgegevens respondent

Geslacht: man/vrouw

Leeftijd: jaar

Werkzaam bij:

Functie:

Aantal jaren werkzaam binnen de overheid:

Aantal jaren werkzaam binnen deze functie:

Hoeveel uur per week werkzaam:

Leidinggevende positie? Zo ja, hoeveel mensen?

II. Gegevens over het werk

Ik zou u graag eerst wat algemene vragen over uw werk willen stellen:

- Kunt u beschrijven wat uw functie inhoudt?

- Kunt u vertellen hoe de afgelopen werkweek er voor u heeft uitgezien?

- Is deze week representatief voor hoe uw werkweek er normaal uitziet? Wat is er anders?

- Is er een voorwerp in deze kamer dat centraal staat voor uw werkbeleving?

- Is er een vast ritueel dat u elke dag uitvoert en dat centraal staat voor de beleving van uw werk?

- Welke onderdelen van uw baan vindt u leuk? En waarom?

- Welke onderdelen van uw baan vindt u minder leuk? En waarom?

- Wat is de grootste uitdaging in uw werk? En waarom? Hoe gaat u met deze uitdaging om?

- Hoe belangrijk is deze baan in uw leven? En de organisatie? En de afdeling?

III. Interacties op het werk

Tijdens mijn studie en in de literatuur die ik ter voorbereiding gelezen heb, komt vaak naar voren dat de interacties die mensen tijdens hun werk hebben bepalend zijn voor de beleving van hun werk. Ik ga u daarom nu wat vragen stellen over de interacties die u tijdens uw werk heeft.

- Welke contacten heeft u zoal gedurende uw werk?

- Wat zijn voor u de belangrijkste contacten? En waarom?

- Kunt u een situatie beschrijven waarbij u contact had met iemand en waarbij de communicatie op een zodanige manier plaatsvond dat het $u$ energie gaf of juist 
ontnam?

- Met wie had u dit contact?

- Wat gebeurde er?

- Waarom gebeurde dit?

- Was de communicatie plezierig of onplezierig?

- Wat betekende dit voor de beleving van uw werk?

- Wat betekende dit voor de manier waarop u uw werkzaamheden verder oppakte?

- Verliep dit contact in andere situaties op dezelfde manier?

- Als u terugkijkt, had u de situatie dan anders aangepakt?

- Waren er andere mogelijkheden of was er maar één mogelijkheid?

- Kunt u nog een andere situatie beschrijven? Zie vorige punten.

\section{Beeld buitenstaanders}

Ik wil het nu graag hebben over het beeld dat buitenstaanders van uw werk hebben. In de literatuur komt terug dat het beeld dat buitenstaanders van uw werk hebben van invloed kan zijn op hoe u zelf tegen uw werk aankijkt. Ik ga u daarom een aantal vragen stellen over het beeld van buitenstaanders van uw werk hebben. Stel dat u op een feestje bent en u vertelt over uw werk.

- Wat vertelt u dan?

- Waarom vertelt u juist dit?

- Hoe reageren mensen op uw verhaal?

- Hoe voelt u zich wanneer u vertelt over uw werk?

- Wat is volgens $u$ het algemene beeld dat mensen hebben van de overheid?

- Waarom denkt u dat mensen dit beeld hebben?

- Klopt dit met uw eigen beeld van de overheid?

- Houdt u zich veel bezig met hoe anderen over de overheid denken? / Maakt u zich druk over

- hoe anderen over de overheid denken (Laatste vraag alleen stellen als er een negatief beeld van de overheid uit voorgaande vragen naar voren komt.)

- Hoe gaat u hiermee om?

- Zou u andere mensen aanraden om voor de overheid te gaan werken?

\section{Communicatie beleid}

In mijn onderzoek wil ik ook meenemen hoe beleidsambtenaren omgaan met het communiceren van beleid en welke rol de reactie van het publiek hierbij speelt. Ik ga u daarom een aantal vragen stellen over het opstellen van beleid.

- Kunt u een situatie noemen waarbij u bezig was met de communicatie van beleid en waarbij u achteraf dacht, dit had ik anders aan moeten pakken? 
- Bent u tijdens het opstellen van beleid bezig met de impact die dit heeft op het publiek?

- Wanneer bent u hiermee bezig?

- Wat gebeurt er op zo'n moment?

- Wat levert het op?

- Wat is effectief?

- Welke invloed heeft dit op de wijze waarop u het beleid communiceert?

VI. Verdiepingsvragen bij negatieve publieksreacties

- Hebt u moeite met het communiceren van beleid dat veel negatieve publieksreacties met zich mee zal brengen?

- Houdt u hier in de voorbereidingen rekening mee?

- Probeert u op deze publiekreacties in te spelen? Zo ja, hoe? Zo nee, waarom niet?

- Wat doen deze negatieve publiekreacties met uw werkbeleving?

- Hoe communiceert u beleid dat veel negatieve publieksreacties met zich mee brengt?

\section{Codeerschema}

\begin{tabular}{|c|c|}
\hline \multirow{3}{*}{$\begin{array}{l}\text { Work meaning (welke betekenis geven ambtenaren } \\
\text { aan hun werk? }\end{array}$} & Job meaning (Taken en activiteiten) \\
\hline & Role meaning (Rol in de sociale structuur) \\
\hline & $\begin{array}{l}\text { Self meaning (Karakteristieken die iemand aan } \\
\text { zichzelf toekent door zijn werk) }\end{array}$ \\
\hline \multirow{2}{*}{$\begin{array}{l}\text { Interacties op het werk (Welke interacties hebben } \\
\text { invloed op de work meaning) }\end{array}$} & Positieve interacties \\
\hline & Negatieve interacties \\
\hline $\begin{array}{l}\text { Perceived external prestige (Hoe denken } \\
\text { medewerkers dat buitenstaanders tegen de } \\
\text { organisatie aankijken?) }\end{array}$ & \\
\hline \multirow{3}{*}{$\begin{array}{l}\text { Job crafting (Veranderingen aanbrengen in baan die } \\
\text { buiten de formele functiebeschrijving vallen) }\end{array}$} & Taak crafting \\
\hline & Cognitieve crafting \\
\hline & Relationele crafting \\
\hline
\end{tabular}




\section{Bijlage II: Onderzoeksaanpak Systeemspanningen}

\section{Onderzoeksprotocol}

In het onderstaande interviewraster ('grid') zijn (9) 'systeemspanningen' uitgewerkt naar rolopvattingen en gedragingen, en voorzien van een startvraag. In de interviews werd aan de hand van de vragen in dit raster geïnventariseerd of en hoe de respondenten spanningen herkennen en hanteren.

\begin{tabular}{|c|c|c|c|c|}
\hline $\begin{array}{l}\text { Systeem- } \\
\text { spanningen (1) }\end{array}$ & Ambtelijke rol (2) & Persoonlijke rol (3) & Gedragingen (4) & Startvragen (5) \\
\hline $\begin{array}{l}\frac{\text { Taak omstreden, }}{\text { algemeen versus }} \\
\text { individueel belang } \\
\text { (I) }\end{array}$ & $\begin{array}{l}\text { Doel bemoeienis } \\
\text { en proces helder } \\
\text { maken }\end{array}$ & $\begin{array}{l}\text { Wat vind ik echt } \\
\text { zelf? }\end{array}$ & $\begin{array}{l}\text { Conflicten mijden, } \\
\text { doelen verbergen }\end{array}$ & $\begin{array}{l}\text { Waarom bemoeit } \mathrm{u} \\
\text { zich met thema } \mathrm{X} \text { ? }\end{array}$ \\
\hline $\begin{array}{l}\frac{\text { Hoge }}{\text { verwachtingen en }} \\
\text { beperkt draagvlak } \\
\text { (II) }\end{array}$ & $\begin{array}{l}\text { Hoe communiceren } \\
\text { we ook slechte } \\
\text { boodschappen? }\end{array}$ & $\begin{array}{l}\text { Word ik } \\
\text { gewaardeerd, en } \\
\text { door wie? }\end{array}$ & $\begin{array}{l}\text { Mystificeren, } \\
\text { verbergen van } \\
\text { bedoelingen, } \\
\text { spanning ontlopen, } \\
\text { monitoren }\end{array}$ & $\begin{array}{l}\text { Hoe weet } u \text { dat } u \\
\text { goed zit? }\end{array}$ \\
\hline $\begin{array}{l}\text { Beperkte } \\
\text { beheersbaarheid } \\
\text { en complexe } \\
\text { processen } \\
\text { (III) }\end{array}$ & $\begin{array}{l}\text { Keuze voor } \\
\text { interventies, } \\
\text { alternatieven } \\
\text { en resultaten } \\
\text { (beleidstheorie) }\end{array}$ & $\begin{array}{l}\text { Ben ik wel nuttig, } \\
\text { draag ik wel } \\
\text { bij, waar haal } \\
\text { ik het vandaan } \\
\text { (opleiding)? }\end{array}$ & $\begin{array}{l}\text { Kunstmatige } \\
\text { controle, } \\
\text { bureaucratisme, } \\
\text { prestatie- } \\
\text { vertekening } \\
\text { (NPM- reflex) }\end{array}$ & $\begin{array}{l}\text { Welke relaties } \\
\text { doen er toe en wat } \\
\text { bepaalt interventies } \\
\text { met wie en voor } \\
\text { wie? }\end{array}$ \\
\hline $\begin{array}{l}\text { Efficiency en } \\
\text { maatschappelijk } \\
\frac{\text { commitment }}{(\text { IV) }}\end{array}$ & $\begin{array}{l}\text { Keuzes voor } \\
\text { betrokkenheid en } \\
\text { verantwoording }\end{array}$ & $\begin{array}{l}\text { Welke zichtbare } \\
\text { mijlpalen heb ik } \\
\text { nodig? }\end{array}$ & $\begin{array}{l}\text { Verantwoorden, } \\
\text { procesinterventies, } \\
\text { doordrukken }\end{array}$ & $\begin{array}{l}\text { Wat beschouwt u } \\
\text { als resultaat? } \\
\text { Ruimte voor } \\
\text { discours }\end{array}$ \\
\hline $\begin{array}{l}\text { Democratisch } \\
\text { verkregen macht } \\
\text { en maatschappelijk } \\
\text { commitment } \\
\text { (V) }\end{array}$ & $\begin{array}{l}\text { Expliciteren van } \\
\text { politieke grondslag }\end{array}$ & $\begin{array}{l}\text { Vind ik mijn eigen } \\
\text { morele standaarden } \\
\text { terug (waarden en } \\
\text { normen)? } \\
\text { Is het moreel } \\
\text { acceptabel als } 51 \% \\
\text { (meerderheid) een } \\
\text { voorstel steunt? }\end{array}$ & Ontkenning & $\begin{array}{l}\text { Hoe gaat/ } \\
\text { ging u om met } \\
\text { (omstreden) } \\
\text { politieke besluiten? }\end{array}$ \\
\hline $\begin{array}{l}\text { Open(baar)heid } \\
\text { en zelfbinding } \\
\underline{\text { (rechtsstatelijkheid) }} \\
\underline{\text { VI }}\end{array}$ & $\begin{array}{l}\text { Openbaarheid, } \\
\text { verantwoording }\end{array}$ & $\begin{array}{l}\text { Is dit een eerlijk, } \\
\text { oprecht en correct } \\
\text { overheidsoptreden? } \\
\text { Kan ik het zelf } \\
\text { rechtvaardigen? }\end{array}$ & $\begin{array}{l}\text { Geen slechte } \\
\text { boodschappen, } \\
\text { mystificeren }\end{array}$ & $\begin{array}{l}\text { Welke rol speelt de } \\
\text { relatie met burgers/ } \\
\text { veld in uw werk }\end{array}$ \\
\hline
\end{tabular}




\begin{tabular}{|c|c|c|c|c|}
\hline $\begin{array}{l}\text { Systeem- } \\
\text { spanningen (1) }\end{array}$ & Ambtelijke rol (2) & Persoonlijke rol (3) & Gedragingen (4) & Startvragen (5) \\
\hline $\begin{array}{l}\text { Lekenbestuurder } \\
\text { en ambtelijke } \\
\text { professional } \\
\text { (VII) }\end{array}$ & $\begin{array}{l}\text { Objectieve } \\
\text { mogelijkheden/ } \\
\text { alternatieven } \\
\text { expliciteren } \\
\text { (beleidstheorie?) }\end{array}$ & $\begin{array}{l}\text { Kan ik mijn kunnen } \\
\text { hier kwijt? }\end{array}$ & $\begin{array}{l}\text { Tunnelvisies, } \\
\text { eenzijdig } \\
\text { opschrijven wat } \\
\text { politiek verlangd } \\
\text { wordt, cynisme }\end{array}$ & $\begin{array}{l}\text { Hoe hebt u het } \\
\text { contact met uw } \\
\text { bewindspersoon } \\
\text { georganiseerd? } \\
\text { Ruimte voor } \\
\text { discours vanwege } \\
\text { politieke leiding, } \\
\text { expliciet of impliciet } \\
\text { gegeven? }\end{array}$ \\
\hline$\frac{\text { Korte en }}{\text { lange termijn }}$ & $\begin{array}{l}\text { Consistenties en } \\
\text { inconsistenties } \\
\text { blootleggen }\end{array}$ & $\begin{array}{l}\text { Krijg ik de ruimte } \\
\text { om dit bloot te } \\
\text { leggen? }\end{array}$ & $\begin{array}{l}\text { Conflict mijden, } \\
\text { spanning ontwijken, } \\
\text { confronteren, } \\
\text { argumenteren }\end{array}$ & $\begin{array}{l}\text { Stelling: politici } \\
\text { streven naar } \\
\text { korte termijn, } \\
\text { ambtenaren naar } \\
\text { de lange. } \\
\text { Een issue in uw } \\
\text { werk? }\end{array}$ \\
\hline $\begin{array}{l}\text { Ondergeschiktheid } \\
\text { en eigen verant- } \\
\text { woordelijkheid } \\
\text { (IX) }\end{array}$ & $\begin{array}{l}\text { Binnen eigen } \\
\text { verantwoordelijk- } \\
\text { heid werken }\end{array}$ & $\begin{array}{l}\text { In hoeverre ben ik } \\
\text { verantwoordelijk } \\
\text { (technisch en } \\
\text { moreel/ethisch)? }\end{array}$ & $\begin{array}{l}\text { Verantwoordelijk- } \\
\text { heid afdwingen, } \\
\text { ontkennen, steun } \\
\text { zoeken }\end{array}$ & $\begin{array}{l}\text { Hoe bent u } \\
\text { omgegaan met } \\
\text { de ambtelijke } \\
\text { hiërarchie? } \\
\text { Ruimte voor } \\
\text { discours van } \\
\text { ambtelijke leiding, } \\
\text { impliciet of expliciet } \\
\text { gegeven? }\end{array}$ \\
\hline
\end{tabular}

\section{Codeerschema}

Bij het coderen van de transcripties bleek de indeling naar 9 kenmerken te fijnmazig. Vervolgens zijn de 9 stappen teruggebracht naar 3 systeemspanningen waarbij opnieuw is getoetst op de genoemde factoren. Tussen haakjes staan de voornoemde 9 systeemspanningen:

\begin{tabular}{|l|l|l|l|}
\hline Systeem- spanningen (1) & Ambtelijke rol (2) & Persoonlijke rol (3) & Gedragingen (4) \\
\hline $\begin{array}{c}\text { A. Belangenafweging in het besef van } \\
\text { rechtsstatelijkheid (I, II en VI) }\end{array}$ & & & \\
\hline $\begin{array}{c}\text { B. Beheersbaarheid in democratische } \\
\text { context (III, V en VI) }\end{array}$ & & & \\
\hline $\begin{array}{l}\text { C. Vakmanschap onder ministeriele } \\
\text { verantwoordelijkheid (VII, VIII en IX) }\end{array}$ & & & \\
\hline
\end{tabular}




\section{Bijlage III: Onderzoeksaanpak Casestudies}

\section{Protocol onderzoek}

I. Introductie

Aanleiding en aanpak onderzoek.

II. Sleutelmoment

a. Wat ziet $u$ als hét sleutelmoment bij deze opdracht? Neem ons mee naar dat moment.

b. Wat maakt dit moment tot een sleutelmoment?

c. Wie deden ertoe en in welke rol (krachtenveld)?

d. Hoe luidde de opdracht?

e. Waarom was u erbij betrokken?

f. Hoe was het moment ontstaan?

g. Wat maakt dit sleutelmoment zo betekenisvol?

III. De taxatie

a. Wilt u een schets geven van handelingen die u heeft ondernomen?

b. Welke keuzes lagen voor?

c. Welke overwegingen waren bepalend bij deze keuzes?

d. Wie betrok u bij deze keuzes? Welke rol speelden collega's

e. Welke rol speelden belangen in dezen

f. In welke mate bent u uit geweest op beheersbaarheid

g. Hoe omschrijft u een goede ambtelijke beslissing? En toegepast in deze casus?

h. Hoe creëerde u feedback op uw handelingen? Hoe wist u dat u op de goede weg zat? Welke manieren heeft $u$ benut voor het registreren van effecten? 
i. Waar hebt u taken bij anderen gelaten, gegeven of overgedragen? Wat stuurde uw keuzes hierbij?

j. Wat waren sterke momenten? - wat maakte deze momenten sterk, en wie?

k. Wat waren lastige momenten? - wat maakte deze momenten lastig, en wie?

IV. De reflectie

a. Wat had u nooit uit handen gegeven? (loopbaanankers)?

b. Wat karakteriseert uw manier van behandeling van deze opdracht?

c. Wat maakt deze opgave onderscheidend ten opzichte van eerdere opgaven?

d. Wie zijn belangrijk voor u geweest bij het klaren van deze klus? In welke rol?

e. Wat is de betekenis van deze ervaring voor andere werkzaamheden? Waaruit blijkt dat?

f. Wat betekent werk voor $u$ ?

V. Q-sort

Zie toelichting onder 2.

VI. Afronding 


\section{Aanpak Q-sort}

Bij de selectie van de cases is een veronderstelling uitgesproken van dominantie van 'meebewegen'. Aan de hand van de O-sort wordt een evaluatie uitgevoerd. Aan het slot van het gesprek wordt vastgesteld in welke mate sprake is van coping. Daarbij zijn de volgende beweringen gebruikt:

\begin{tabular}{|l|l|l|}
\hline Copingcategorie & Bewering & Nummer \\
\hline Wegbewegen & Dit hoort niet op mijn bordje & $\mathrm{I}$ \\
& Er zijn ergere dingen in de wereld & $\mathrm{II}$ \\
& Hier zijn gelukkig procedures en commissies voor & $\mathrm{III}$ \\
\hline \multirow{2}{*}{ Meebewegen } & Weerstand maakt nieuwsgierig & IV \\
& Wat kan wel? & V \\
& Zoeken naar een gedeeld belang of waarde & VI \\
\hline \multirow{2}{*}{ Tegenbewegen } & Zonder bluf ben je nergens & VII \\
& Soms moet je doorduwen & VIII \\
& We kunnen niet bezig blijven & IX \\
\hline
\end{tabular}

Werkwijze: aan het slot van het interview werd de respondent uitgenodigd om de beweringen te rangschikken op een schaal van zeer eens naar zeer oneens. Bovendien zijn aan de hand van de transcripties van de interviews en door bestudering van onderliggende documenten (beleidsbrieven, knipsels) copingstrategien gemarkeerd. Dat gebeurde aan de hand van de volgende coderingstabel:

\begin{tabular}{|l|l|l|l|}
\hline Copingstrategie & $\begin{array}{l}\text { Corresponderende } \\
\text { Q-sortkaart }\end{array}$ & Gedragsvoorbeeld & Code \\
\hline Wegbewegen & Q-sort I, II, III & $\begin{array}{l}\text { Afschuiven, opschalen (I), wegwuiven, } \\
\text { grapjes maken (II), ritualiseren (III) }\end{array}$ & \\
\hline Meebewegen & Q-sort IV, V, VI & $\begin{array}{l}\text { Inleven, twijfel expliciteren, vertragen } \\
\text { (IV), herformuleren, energie aanboren (V), } \\
\text { overeenkomstig belang of waarde vinden } \\
\text { (VI) }\end{array}$ & $\square$ \\
\hline Tegenbewegen & Q-sort VII, VIII, IX & $\begin{array}{l}\text { Intimideren (VII), emotioneel beroep (VIII), } \\
\text { Doordrukken (IX) }\end{array}$ & $\square$ \\
\hline
\end{tabular}




\section{Scoreformulier interviews}

De transcripties van de interviews worden per casus gescoord op het voorkomen van de variabelen. Deze werkwijze passen we ook toe op de documenten. Naast de manifestatie van factoren (hoe komen ze voor; tekstmarkering) is de interferentie onderzocht: hoe spelen de factoren op elkaar in, versterken ze elkaar (analyse achteraf), alsook dominantie: welke factoren wegen per saldo het zwaarste mee:

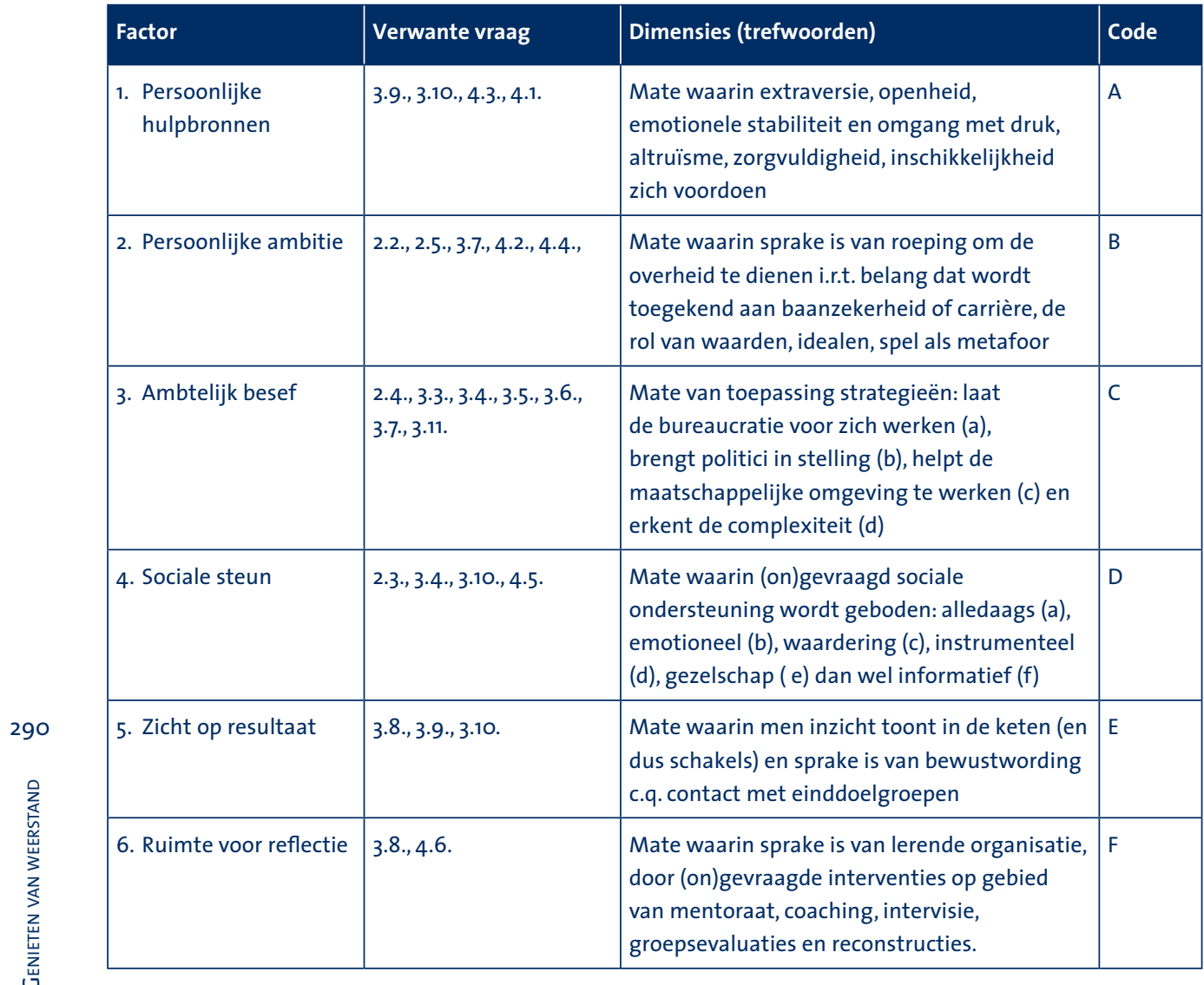




\section{Literatuur}

Aarts, N. (2009). Een gesprek zonder einde, over strategische communicatie in een voortdurend veranderende omgeving. Inaugurele rede. Amsterdam: UVA.

Aarts, N. (2011). Communicatie begint met luisteren. Toespraak. Nieuwjaarsreceptie van de communicatiesector van de gemeente Rotterdam, 9 januari 2011.

Academie voor Overheidscommunicatie (2011). Werkboek Open en Bloot, congres voor rijksambtenaren 10 november 2011. Den Haag: Ministerie van Algemene Zaken, dienst Publiek en Communicatie.

Akkerman, T. (2006). Politiek vertrouwen. Wat staat er op het spel? In: Korsten A. en P. de Goede, Bouwen aan vertrouwen in het openbaar bestuur. Den Haag: Elsevier Overheid.

Ajzen, I. (2002). Perceived behavioral control, self-efficacy, locus of control, and the theory of planned behavior. Journal of Applied Social Psychology, 32, 665-683.

Alberts, A. (1986). Inleiding tot de kennis van de ambtenaar. Amsterdam: Veen.

Algemene Rekenkamer (2003). Tussen beleid en uitvoering, lessen uit recent onderzoek van de Algemene Rekenkamer. Den Haag.

Allewijn, D. (2007). Met de overheid om tafel, vertrouwen in de overheid als centraal thema in mediation. Den Haag: Sdu.

Almond, G. \& Verba, S. (1963). The Civic Culture. Princeton: Princeton University Press.

Amelink, H. (2010). Neem filosofie niet te ernstig. Interview met Renée van Riessen. NRC Handelsblad, 18 december 2010, p. 4-5.

Ankersmit, F. (2009). De tien plagen van de staat, de bedrijfsmatige overheid gewogen. Amsterdam: Van Gennep.

Ashforth, B. E. \& Kreiner, G. E. (1999). 'How can you do it?’'Dirty work and the challenge of constructing a positive identity. Academy of Management Review, 24, 413-434.

Ashforth, B.E. \& Kreiner, G. E. (2002). Normalizing emotion in organizations: making the Extraordinary seem ordinary. Human Resource Management Review, 12, 215-235.

Ashforth, B. E., Kreiner, G. E., Clark, M. A. \& Fugate, M. (2007), Normalizing Dirty Work: Managerial Tactics for Countering Occupational Taint, Academy of Management Review, 50, 149-174.

Ashforth, B. E. \& Mael, F. (1989). Social identity theory and the organization. Academy of Management Review, 14, 20-39. 
Bagozzi, R. (2003) Positive and negative emotions in organizations, in K. S. Cameron, Dutton, J. E. and Quinn, R. E. (Eds.) Positive Organizational Scholarship. 176-193. San Francisco Berrett-Koehler.

Balkenende, J.P. (2006). Vanuit waarden werken aan vertrouwen. Toespraak. Festival der Bestuurskunde, 16 februari 2006.

Balzac, de, H. (1841). Fysiologie van de ambtenaar. Den Bosch: Voltaire.

Battjes, H. \& Vermeulen, B. (2007). Constitutionele klassiekers. Nijmegen, Aequi Libri.

Bartels, G. C. (1998). Het wiel uitvinden: gedragsverandering als wisselwerking tussen persoon, gedrag en omgeving. In Bartels, G.,W. Nelissen en H. Ruelle (1998). De transactionele overheid; communicatie als instrument: zes thema's in de overheidsvoorlichting, pp. 245-261. Alphen aan den Rijn: Kluwer.

Baumeister, R. F., et al. (1998). Ego-depletion: is the active self a limited resource? Journal of Personality and Social Psychology. 74. 1251-1265.

Becker, J. \& Dekker, P. (2005), Beeld van beleid en politiek. In: De sociale staat van Nederland 2005, pp. 328-362. Den Haag: Sociaal en Cultureel Planbureau.

Becking, K. (2011). 'Grand design': een onderzoek naar processen van normalisering en decentralisering in de arbeidsverhoudingen voor overheidspersoneel in de periode 1990-2000. Den Haag: CAOP.

Bekker, R. (2009a). Liaisons dangereuses, enige beschouwingen over de arbeidsverhoudingen bij de overheid, met name tussen politici en ambtenaren. Oratie. Leiden: CAOP.

Bekker, R. (2009b). Een grenzeloze overheid vraagt grenzeloze ambtenaren. Toespraak. Buluitreiking Public Sector MBA van Nyenrode Business Universiteit op 17 december. www.caop.nl.

Bekker, R. (2010a). Over heckrunderen, politici en ambtenaren. Toespraak. Afscheid Secretaris-generaal Vernieuwing Rijksdienst op 29 juni. Den Haag: BZK.

Bekker, R. (2010b). Toespraak. ICT congres van de overheid, 'Collaborate today, maximize the public value tomorrow' op 13 oktober. www.caop.nl.

Bekker, R. (2011). Haalt de overheid 2050? In: Het eigene van de overheid. Input voor het debat over de rol van de overheid, pp. 53-66. Den Haag: CAOP.

Bekkers, V., Beunders, H., Edwards, A. en Moody, R. (2009). De virtuele lont in het kruitvat. Welke rol spelen de oude en nieuwe media in de micromobilisatie van burgers en hun strijd om politieke aandacht? Den Haag: Boom.

Bellah, R. (1985). Habits of the heart. Berkeley: University of California Press. 
Bennis, W. G., Benne, K. D. en Chin, R. (1985). The planning of change. Holt, Rinehart and Winston, New York.

Berg, H., (1999). Systeemkenmerken overheid maken dat ambtenaar niet zichzelf kan zijn.

Management \& Bestuur, juli, 10-11. Den Haag, Sdu.

Berg, H. (2008). De eigen aard van de overheid. Delft: Eburon.

Berlo, D. (2008). Ambtenaar 2.0, nieuwe ideeën en praktische tips om te werken in overheid 2.0.

Den Haag: LNV.

Bernlef, J., Fens, K. \& K. Schippers (1986). Inleiding tot de kennis van A. Alberts. Amsterdam: Veen.

Bierens de Haan, J.. (1943), Politeia, groote mannen over staat en maatschappij. Amsterdam: Elsevier.

Bikker H. \& Rijnja, G. (2006). Lessen van het grondwetreferendum. Comma 3, 6-7. Den Haag: Sdu.

Zie ook: www.communisprudentie.nl.

Blauw Research (2007). Zelfverwezenlijking op de Arbeidsmarkt, een onderzoek naar de aantrekkingskracht van de overheid als werkgever en de rol van arbeidsvoorwaarden als stuurmiddel, Rotterdam.

Blom, Ph. (2010). Het verdorven genootschap. De vergeten radicalen van de Verlichting.

Amsterdam: de Bezige Bij.

Boer, R. de (2011). Gevoel voor draagvlak, alleen dialoog met burgers verschaft benodigde steun, De ingenieur 17 december, 20-21.

Boeije, H. (2005). Analyseren in kwalitatief onderzoek. Denken en doen. Amsterdam: Boom onderwijs

Bok, M. de, (2010). Van abdicatie tot zetelroof, begrippen uit het staatsrecht verklaard door Max de Bok.

Den Haag: BZK.

Bontekoning, A. (2007). Generaties in organisaties, een onderzoek naar generatieverschillen en de effectendaarvan op de ontwikkeling van organisaties. Proefschrift. www.aartbontekoning.com.

Boom, H. \& Metze, M. (1997). Slag om de Betuweroute, het spel langs de lijn. Amsterdam: Balans.

Boonstra, J. (2000). Lopen over water. Inaugurele rede. Amsterdam: UVA.

Boot, A. (2011). Diffuse informatie en gebrek aan verankering vormen de bijl aan de wortel van goed leiderschap, essay in Het Financieele Dagblad 10 september 2011, p. 27.

Bos, J. (2007). Discourseanalyse, communicatie op de werkvloer. Bussum: Coutinho. 
Bos, J. (2011). Een tweede 'Barendrecht' is de angstdroom van schaliegaslobby. Interview met onderzoekster Cuppen. Het Financieele Dagblad, 15 oktober, p. 8.

Bos, K. van den (2000). Omgaan met onzekerheid, het belang van rechtvaardigheid in organisaties, Gedrag en organisatie, 13, 249-259.

Bos K. van den (2009). Rechtvaardigheid en onzekerheid, in: W.L. Tiemeijer e.a. De menselijke beslisser, over de psychologie van keuze en gedrag, pp. 89-114. Amsterdam: Amsterdam University Press.

Bos, K. van den (2011). De overheid kan efficiënter en effectiever functioneren door na te gaan wat burgers daadwerkelijk drijft, Pionierskrant ministerie van BZK, 6-7. BZK: Den Haag.

Bos, R. ten (2003), Spookrijders, een reflectie over de onschuld van desorganisatie. Inaugurele rede bij de aanvaarding van het ambt van hoogleraar filosofie in het bijzonder van de bedrijfswetenschappen aan de Katholieke Universiteit Nijmegen op 13 februari.

Bosman, A. (2009). Workmeaning van de rijksambtenaar, een studie naar de betekenis die rijksambtenaren aan hun werk verlenen en de consequenties hiervan voor hun leerbehoeften. Afstudeerscriptie Master Communication Studies. Enschede: Universiteit Twente.

Botton, A. de (2009). Ode aan de arbeid. Amsterdam: Atlas.

Bouman, M, Van Tol, C., Rijnja, G. en De Regt, W. (2009). Gebundelde inspiratie, leefstijlcampagnes in de schijnwerpers. Den Haag: ZonMw.

Breed, K. (2007). Bestuurscultuur en strategie, een onderzoek naar de cognitieve kaart van topambtenaren. Den Haag: ROI.

Breeman, G. (2006). Cultivating Trust, how do public policies become trusted. Rotterdam: Optima Grafische communicatie.

Brehm, J., \& Weintraub, M. (1977). Physical barriers and psychological reactance: 2-year-olds response to threats to freedom. Journal of Personality and Social Psychology, 35, 830-836.

Brenninkmeijer, A. (2008). 'De overheid is te hard tegen burgers'. Interview. De Volkskrant,19 maart 2008, p.3.

Brenninkmeijer, A. (2009). 'Reageren is iets anders dan regeren'. Column. PM op 11 september 2009, p.16.

Brenninkmeijer, A. (2009). Excuus! Column. Opportuun, 5, 2009, p.17.

Brink, G. van den, Jansen, T. \& Kole, J. (2009). Beroepstrots als programma. Pleidooi voor een republikeinse besturingsfilosofie. In: Beroepstrots. Een ongekende kracht, zelfde redacteuren). Amsterdam: Boom. 
Bruijn H., Ten Heuvelhof, E. en In 't Veld, R. (2002). Procesmanagement, over procesontwerp en besluitvorming: Amsterdam: Academic Service.

Bruijn, de, H., Ten Heuvelhof, E., Van Mill, B. \& Visser, H. (2007). Invoering van een nieuw zorgstelsel. Bestuurlijke strategieën en communicatie. Den Haag: Elsevier Gezondheidszorg.

Bruijn, H. (2010). Geert Wilders in debat. Over de framing en reframing van een politieke boodschap. Den Haag: Lemma.

Bruijne, P. de \& Rijnja, G. (2007). Van reparatie naar preparatie, communicatie voor beleidsmakers. C, 4, 4-6. Den Haag: Sdu.

Brummans, B. H. J. M., Putnam, L. L., Gray, B., Hanke, R., Lewicki, R. J. \& Wiethoff, C. (2008). Making Sense of Intractable Multiparty Conflict: A Study of Framing in Four Environmental Disputes. Communication Monographs, 75, 25-51.

Buber, M. (2007). Dialogisch leven. Utrecht: Bijleveld.

Buuren van, A. (2006). Competente besluitvorming. Den Haag: Boom Lemma.

Buurma, H. (2001). Marketing van overheidsbeleid. Utrecht: Lemma.

CAOP (2006). Advies van de Raad voor het Overheidspersoneelsbeleid over Normalisatie Rechtspositie Overheidspersoneel. CAOP: Den Haag.

CAOP (2011). Het eigene van de overheid I (input voor debat) en II (Vervolgpublicatie naar aanleiding van het debat). CAOP: Den Haag.

Caluwé, L. de \&. Vermaak, H. (2002). Leren veranderen, een handboek voor de veranderkundige. Alphen aan den Rijn: Kluwer.

Caplan, M. (2002). Winnen door verliezen, Weg van mislukking. Deventer: Ankh-Hermes.

Carmeli, A. (2005). Perceived external prestige, affective commitment and citizenship behaviors. Organization Studies, 26, 443-464.

Cartwright, S. \& Holmes, N. (2006). The meaning of work: the challenge of regaining employee engagement and reducing cynicism. Human Resource Management Review, 16, 199-208.

Cialdini, R. (2006). Invloed - theorie en praktijk, de zes geheimen van het overtuigen. Den Haag: Sdu.

Clarke, S. \& Hoggett, P. (2009) (ed.), Researching beneath the surface. London: Karnac books. 
Cloke, K. (2006). Ten reasons we get stuck in conflict. Ongepubliceerd paper. Eerder verschenen in: Into the heart of conflict. Janis Publishers.

Commissie Toekomst Overheidscommunicatie (2001), In dienst van de democratie.

Eindrapport van de staatscommissie. Den Haag: Sdu.

Commissie van Onderzoek Besluitvorming Irak (2010), Boom: Amsterdam.

Compas, B. E., Connor-Smith, J. K., Saltzman, H., Harding Thomsen A. \& Waldsworth, M. E. (2001).

Coping with stress during childhood and adolescence: problems, progress, and potential in theory and research, Psychological bulletin 127, 87-127.

Coops, R. \& Rijnja, G. (2001a). Een nieuwsgierige, conceptuele luisterpost, interview met VNG-hoofddirecteur prof.dr. J.Th.J. van den Berg, Management in overheidsorganisaties, 34. H1380 1-9. Alphen aan den Rijn: Kluwer.

Coops, R. \& Rijnja, G. (2001b). De overheid heeft het altijd gedaan. Alphen aan den Rijn: Samson.

Coops, R. (2010). De heilige integraal. Bijdrage afscheidssymposium Guido Rijnja ‘De schreef van het vak. Morele dilemma's in de driehoek bestuur, politiek en communicatie op 1 november 2010. www.schuttelaar.nl.

Czarniawska, B. (1997). Narrating the organization, dramas of institutional identity. Chicago: The Chicago University Press.

Dam, van, A. (2009). De kunst van het falen. Amsterdam: Ambo.

Dekker, P. (2006). Politiek cynisme. Driebergen: Stichting Synthesis.

Dekker, P. (2006). Individuele achtergronden van ontbrekend vertrouwen in de regering. In: Korsten A. en P. de Goede, Bouwen aan vertrouwen in het openbaar bestuur, pp. 45-6o. Den Haag: Elsevier Overheid.

Dekker, P., Halman, L. \& Van der Meer, T. (2006). Ontwikkelingen in politiek vertrouwen in Europa, 1981-2004, in Korsten, A. \& De Goede, P. (red.). Bouwen aan vertrouwen in het openbaar bestuur, diagnoses en remedies, pp. 61-78. Den Haag: Elsevier Overheid.

Dennett, D. (2007). De evolutie van de vrije wil. Amsterdam: Olympus.

Derks, S., (2005). Ramp-zalig, een onderzoek naar critical incidents binnen de Gemeente Enschede.

Afstudeerscriptie voor de opleiding Communication Studies. Enschede: Universiteit Twente.

Derkse, W. Een levensregel voor beginners, Benedictijnse spiritualiteit voor het dagelijks leven. Tielt: Lannoo.

Derksen, W. (1996) Lokaal bestuur. Den Haag: Vuga. 
Deutsch, K. (1966). The nerves of government, models of political communication and control. New York: The free press.

Dinten, van, W. (2002). Met gevoel voor realiteit, over herkennen van betekenis bij organiseren. Delft: Eburon.

Dixon, N. (1994). The organisational learning cycle, how we can learn collectively. London: McGraw-Hill.

Dutton, J. E. , Dukerich, J. M. \& Harquail, C. V. (1994). Organizational images and member identification. Administrative Science Quarterly, 39, 239-263.

Duyndam, J. \& Poorthuis, M. (2005). Levinas, kopstukken filosofie, Rotterdam: Lemniscaat.

Dijk, W. \& Zeelenberg, M. (2002). Investigating the appraisal patterns of regret and disappointment. Motivation and Emotion, 26, 321-331.

Dijk, W. \& Zeelenberg, M. (2002). What do we talk about when we talk about disappointment? Distinguishing outcome-related disappointment from person-related disappointment. Cognition and Emotion, 16, 787-807.

Dijkstra, T., Van der Laan, D. \& Rijnja, G. (2010). Collegacoaching bij de overheid, tien jaar Intercoach, Den Haag: BZK.

Dijksterhuis, A. (2007). Het slimme onbewuste. Amsterdam: Bert Bakker.

Easton, D. (1965). A systems analysis of political life. Chicago: The University of Chicago Press.

Eberg, J. (2004), Van verwantschap naar verbondenheid: overheidscommunicatie en bestuurskunde.

Cahier 36. Faculteit Communicatie en Journalistiek, Hogeschool van Utrecht

Eidelson, R. J. \& Eidelson, J. I. (2003). Dangerous ideas: five beliefs that propel groups towards conflict. American Psychologist, 58, 182-192.

Eisenhardt, K. M. (1989). Building theories from case study research. Academy of Management Review, 14, 532-550.

Elchardus, M. (2002). De Dramademocratie. Tielt: Lannoo.

Elchardus, M. \& Smits, W. (2002), Anatomie en oorzaken van het wantrouwen. Brussel: VUB-Press.

Elias, N. (1982). Het civilisatieproces. Utrecht: Het Spectrum.

Elsbach, K. D. \& Bhattacharya, C. B. (2001). Defining who you are by what you're not: organizational disidentification and the National Rifle Association. Organization Science, 12, 393-413. 
Elving, W. J. L. \& Boonstra, J. J. (2009). Veranderkunst, een wetenschappelijke inleiding: denkbeelden over organisaties, veranderingen en de rol van communicatie. In Brouwer, W., Van Dongen, D., Haarhuis, M., De Regt, A., Schra, R. \& Verhoef, J. (red.), Veranderkunst: communicatiemanagement in praktisch perspectief, pp. 21-42. Assen: Van Gorcum.

Endedijk, B. en Van Steenbergen, E. (2011). Dokter mag niet falen, NRC Handelsblad, 29 oktober 2011, pp. 12 - 13.

Ester, P., Vinken, H., Van Raaij, F. \& Van Dun, L. (2004). Identiteit en imago van overheid en bedrijfsleven als werkgever. Resultaten van een publiekssurvey onder de Nederlandse beroepsbevolking. Sociale Wetenschappen, 1, 15-40.

Euwema, M. \& Wild, U. (2006). Vuurhaarden, pyromanen en brandweermannen, omgaan met conflicten op het werk. Zaltbommel: Thema.

Evers, F. \& Susskind, L. (2006). Het kan wel, bestuurlijk onderhandelen voor een duurzaam resultaat. Haarlem: MGMC.

Eysink Smeets, M., (2008). Public Reassurance in een symbolische, snibbige en slapeloze samenleving. Lectorale rede, Hogeschool INHolland.

Fairhurst, G. \& Star, R. (1996). The art of Framing. San Francisco: Jossey-Bass.

Februari, M. (2009). Mislukken, falen, van je paard vallen en weer opstaan. Column. De Volkskrant, 10 januari 2009, p.3.

Februari, M. (2011). Op een ambtenaar moet je kunnen vertrouwen. Column. NRC Handelsblad, 31 oktober 2011, p. 14

Festinger, L. (1957) A theory of cognitive dissonance. Stanford, CA: Stanford University Press.

Fields, L. \& Prinz, R. J. (1997). Coping and adjustment during childhood and adolescence, Clinical Psychology Review, 17, 937-976.

Figée, E. (red.) (2001). Op de tast: je vraagt een lantarenpaal en je krijgt een integraal veiligheid. Den Haag: VNG Uitgeverij.

Fiol, C. M. (1994). Consensus, diversity, and learning in organizations. Organization Science 5, 403-420.

Flyvbjerg, B. (2006). Five misunderstandings about case-study research. Qualitive Inquiry, 12, 219-245.

Foqué, R. (2006). De actualiteit van Montesquieu's constitutionalisme. Ongepubliceerd paper. 
Ford, J. D. \& Ford, L. (1995). The role of conversations in producing intentional change in organizations, Academy of Management Review, 1995, 20, 541-570.

Ford, J. D. (1999). Organizational change as shifting conversations, Journal of Organizational Change Management, 12, 480-550.

Ford, J. D., Ford, L. W. \& McNamara, R. (2001). Resistance and the backgrounds conversations of change, Journal of Organizational Change Management, 15, 105-121.

Ford, J. D. , Ford, L. W. \& D’Amelio, A. (2008). Resistance to change: the rest of the story, Academy of Management Review 2008, 33, 362-377.

Frank, M.G., \& Gilovich, T. (1988). The dark side of self and social perception, black uniforms and aggression in professional sports. Journal of Personality and Social Psychology, 54, 74-85.

Franzen, G. (2008). Motivatie, denken over drijfveren sinds Darwin. Amsterdam: Boom.

Freidson, E (1994). Professionalism reborn. Theory, prophecy and policy. Chicago: University of Chicago Press.

Frequin, M. (2006). Ja minister, nee minister, over het samenspel van ministers, staatssecretarissen en topambtenaren. Den Haag: Sdu.

Frijda, N. (2005). De emoties. Amsterdam: Bert Bakker.

Frissen P. H. A. (1996), De virtuele staat: politiek, bestuur,technologie: een postmodern verhaal. Schoonhoven: Academic Service, Economie en Bedrijfskunde 1996.

Frissen, P. H. A. (2009). Gevaar verplicht, over de noodzaak van aristocratische politiek. Amsterdam: Van Gennep.

Fukuyama, F. (1995). Trust, the social virtues and the creation of prosperity. New York: Free Press.

Fukuyama, F. (2010). De oorsprong van onze politiek, van de prehistorie tot de Verlichting. Amsterdam: Uitgeverij Contact.

Fuld, M. (2003). Impressie van vernieuwingen bij het Rijk, verslag van het onderzoek. www.xpin/materiaal.

Fuller, J. B., Hester, K., Barnett, T., Frey, L., Relyea, B. \& Beu, D. (2006). Perceived external prestige and internal respect: new insights into the organizational identification process. Human Relations, 59, 815-846.

Fombrun, C. \& Van Riel, C. (2004), Fame \& Fortune, how successful companies build winning reputations. New York: Prentice hall. 
Gabriel, Y. (2000). Storytelling in organisations, facts figures and fictions. Oxford: Oxford University Press

Galjaard, C. (1999). Wie bekommert zich om de overheid? Utrecht: Lemma.

Galjaard, C. (1997). Overheidscommunicatie, de binnenkant van het vak. Utrecht: Lemma.

Galjee, W. \& Lazaron, N. (2009). Op weg naar werk met zin. Manager zou verschil moeten maken, essay in Het Financieele Dagblad, 29 augustus 2009.

Gardner, H. (2002). Learning from extraordinary minds. In M. Ferrari (Ed.), The pursuit of excellence through education. Mahwah, NJ: Lawrence Erlbaum.

Gardiner, P. (2001). Kierkegaard. Rotterdam: Lemniscaat.

Gehrels, C., Möhring, H., Verwey T. \& G. Kwikkers (2004). Verantwoord verleiden in beleidsprocessen, het communicatiespectrum. Assen: Van Gorcum.

Gelb, M. (1999). Denken als Leonardo da Vinci. Baarn: De Kern.

Gemeente Rotterdam (2010). De methodiek van het Oleanderplein. Rotterdam: Deelgemeente Feijenoord i.s.m. Directie Veilig.

Geul, A. (1998). Beleidsconstructie, coproductie en communicatie, zes beproefde methodieken van beleidsontwikkeling. Utrecht: Lemma.

Geul, A. (2001), Communicatie bij beleid en beleidscommunicatie, in: B. Dewez e.a. (red.), Overheidscommunicatie - De nieuwe wereld achter Postbus 51, pp. 57-75.Amsterdam: Boom,

Geul, A. (2010). De kunst van het autorijden, over beleidsadviseurs en andere professionals. Den Haag: Boom Lemma.

Guevara, K., \& Ord, J. (1996). The search for meaning in a changing work context. Futures, 28, 709-722.

Giebels, E. en Eeuwema, M. (2006). Conflictmanagement, analyse, diagnostiek en interventie. Houten: Wolters-Noordhoff.

Gisteren, R. van (2001). De wisselende relaties van overheid en burger, in: Je vraagt een lantarenpaal en krijgt een integraal veiligheidsbeleid, E. Figee (red.), pp. 47-60. Den Haag: VNG uitgeverij.

Gisteren, R. van (2010). Overheidscommunicatie versus burgercommunicatie, en hoe men iets dichter langs elkaar heen zou kunnen praten. Essay. www.hclc.nl. 
Gladwell, M. (2001). Het beslissende moment, hoe je net verschil kunt maken. Amsterdam: Contact Point.

Glimmerveen, M. (2007). Van training naar transfer, hoe haal je meer uitopleidingen.

In: Communicatief beleid: van cursus tot cultuur, RVD Platformreeks 8, 2007, 75-82. Den Haag: Sdu.

Godin, S. (2008). Tribes, we need you to lead us. London: Piatkus.

Goldstein, N, Martin, S. \& Cialdini, R. (2007). Overtuigingskracht, 50 geheimen van de psychologie van het beïnvloeden. Amsterdam: Uitgeverij Nieuwezijds.

Goleman, D. (1996). Emotional Intelligence. New York: Bantam books.

Gotsi, M., Andropoulos, C., Lewis, M. \& Ingram, A. (2010). Managing creatives, paradoxical approaches to identity regulation, Human relations Online First, 10, doc. 10.1177, pp. 1-25.

Graaf, H. van de \& Hoppe, R. (1996). Beleid en politiek, een inleiding tot de beleidswetenschap en de beleidskunde. Bussum: Coutinho.

Gradus, R. (2009). Burgers zijn goedkoper dan ambtenaren. Opinieartikel. De Volkskrant, 30 december 2009, p. 13.

Gramsbergen-Hoogland, Y. H., Deveer, M. A. J. \& Leezenberg, M. G.(2005). Persoonlijke kwaliteit, inzicht, oefening en ontwikkeling van competenties. Groningen: Wolters Noordhoff.

Gray, P. (2003). Psychology, fourth edition. New York: Worth publishers.

Greimas, A.J. (1988) Maupassant, the semiotics of text. Amsterdam: Benjamins.

Groot, H. de (2008). Protocol, vormgeven van bijeenkomsten. Den Haag: Sdu.

Gunsteren, van, H. (2006). Vertrouwen in democratie. Amsterdam: Van Gennep.

Habermas, J. (1970). Towards a theory of communication competence. Inquiry, 13, 360-375.

Habermas, J. (1984). The theory of communicative action; volume one, reason and the rationalization of society. London: Heineman.

Hackman, J. R. \& Oldham, G. R. (1980). Work Redesign. Massachusetts: Addison-Wesley.

Hajer, M. (2009). Authoritative governance, policy making in the age of mediatization, Oxford: Oxford University Press. 
Hallinan, J. (2009). Uitglijers, waarom we fouten maken en hoe we ze kunnen voorkomen. Scriptum.

Hanson, E., Educational administration and organizational behavior. Boston: Allyn and Bacon.

Hardin, R. (2006). Trust. Cambridge: Polity Press.

Heclo, H. (1974). Modern social policies in Britain and Sweden: from relief to income maintenance.

New Haven: Yale University Press

Heese, R. van (2009). 'Het mag wel wat flexibeler', interview met Roel Bekker bij oratie. Trouw 4 februari 2009 , Amsterdam.

Heldeman, J. (2009). Het geheim van Den Haag. Amsterdam: Contact.

Hermans, H. (2006). Dialoog en misverstand, leven met de toenemende bevolking van onze innerlijke ruimte. Soest: Nelissen.

Hermanns, J. (1998). Waar geen wil is, is een argument. Ulvenhout: Co-Act Consult.

Hertogh, M. (2002). De levende rechtsstaat, een ander perspectief op recht en openbaar bestuur.

Utrecht: Lemma.

Hofman, J. (2007). Blik op de rijksoverheid. Nijmegen: Ars Aequi Libri.

Hoggett, P. (2006), Conflict, ambivalence, and the contested purpose of public organizations, Human Relations February, 59: 175-194.

Hofstede, G. (1991). Allemaal andersdenkenden, omgaan met cultuurverschillen. Amsterdam: Contact.

Holland, G. van (2008). Verliezen is een zonde in onze samenleving, het mentale leed van topsporters moet veel meer aandacht krijgen. NRC Handelsblad 23 augustus 2008, p.7.

Holtslag, J.W. (2011). Weet wat er leeft, zorg dat het werkt. In: Het eigene van de overheid input voor het debat over de rol van de overheid. Den Haag: CAOP.

Hoogerwerf, A. (1995). Politiek als evenwichtskunst, dilemma's rond overheid en markt.

Alphen aan den Rijn: Samsom H.D. Tjeenk Willink.

Horn, T. (1998). Waar geen wil is, is een argument, over de weerbarstige weg van organisatieverandering, in: Waar geen wil is, is een argument, pp 21-42. Ulvenhout: Co-Act.

Horn, L. ten (2009). Psychologische aspecten van de organisatie. Alphen aan den Rijn: Kluwer. 
Houwaart, D. (1995). Notities van een ambtenaar. Kampen: Kok.

Houston. D. J. (2000). Public-service motivation. A multivariate case, in: Journal of Public Administration Research \& Theory, 4, 713-728.

Huibregtsen M. (red.) (2009). De publieke zaak, inspiratie voor een nieuwe dynamiek in de samenleving. Amsterdam: Business Contact.

Huizinga, J. $(1938,2008)$ Homo Ludens, proeve eener bepaling van het spel-element der cultuur. Amsterdam: Amsterdam University Press.

Huttner,H., Renckstorf, K. \& Wester, F. (1995). Onderzoekstypen in de communicatiewetenschap. Houten/Dieghem: Bohn, Stafleu Van Loghum.

Huurman, G. (2007). Ruzie in de tent, wat nu? Conflictenbundel, Den Haag: Ministerie van Justitie.

Inglehart, R. (1999), Postmodenization erodes respect for authority, but increases support for democracy, in P. Norris (ed), Critical citizens. Oxford: Oxford University Press.

Illia L. \& Lurati F. (2006). Stakeholders Perspectives on Organizational Identity: Searching for a Relationship Approach. Corporate Reputation Review, 8.

Jagt, R. van der (2004), Het verhaal van de onderneming, in: Rijnja, G. en Van der Jagt, R. Storytelling, de kracht van verhalen in communicatie, pp. 29-38. Alphen aan den Rijn: Kluwer.

Johnson, S. (2010). Houd me vast, zeven gesprekken voor een hechte(re) relatie. Utrecht: Kosmos.

Jong, M.J. de (1997). Grootmeesters van de Sociologie. Amsterdam: Boom.

Jong, P. de \& Kim Berg, I. (2010). De kracht van oplossingen, handwijzer voor oplossingsgerichte gesprekstherapie. Amsterdam: Pearson.

Karssing, E. (2006). Integriteit in de beroepspraktijk. Dissertatie. Rotterdam: Erasmus Universiteit Rotterdam.

Keij, J. (1993). Eenvoudig gezegd, Levinas. Kampen: Agora.

Kettl, D. F. 1988. Government by Proxy: (Mis)Managing Federal Programs. Washington, DC: CQ Press.

Kernberg, O. F. (1975). Borderline conditions and pathological narcissism. New Jersey: Jason Aronson, Inc.

Kirlin, J. J. (1984), A political perspective. In: T. Miller (ed.). Public sector performance: a conceptual turning point, pp. 164-165. Baltimore/London: John Hopkins University. 
Kingdon, J. (1984). Agendas, alternatives and public policies. New York: HarperCollins.

Klarenbeek, A. (2009), Het aan de orde stellen van risico's door crisismakelaars. Paper voor dissertatie.

Klamer, A., (2009). It's the society, stupid, in: Bruijn, de, W. De Publieke Zaak, inspiratie voor een nieuwe dynamiek in de samenleving. Amsterdam: Business Contact.

Kleinnijenhuis, J., Oegema, J., Ridder, de, J. A., Hoof, van, A. M. J., \& Vliegenthart, R. (2003). De puinhopen van het nieuws. De rol van de media bij de Tweede Kamer verkiezingen van 2002. Alphen aan den Rijn: Kluwer.

Klinkers, L. (2009). Nota vernieuwing Rijksdienst (6): Het bijzondere van het ambtenaarschap.

Column. www.klinkers.info.

Klinkers, L. \& Van Vliet, L. (red.) (2010). Uit de koker van. Praktijken van verkokering en ontkokering. Den Haag: Raad voor Maatschappelijke Ontwikkeling en Vereniging van Overheidsmanagement.

Klooster, P. M. ten, Visser, M. \& De Jong, M. D. T. (2008). Comparing two image research instruments: the $q$ sort method versus the Likert attitude questionnaire. Food quality and Preference, 19, 511-518.

Kloosterboer, P. (2005). Voor de verandering, over leidinggeven aan organisatieverandering. Amsterdam: Academic Service.

Knies, E. \& Leisink, P. (2008). Wie wil er nou voor de overheid werken? Bestuurswetenschappen, 62, 12-35.

Knight, G., MacNeill, M. \& Donelly, P. (2005). The disappointment games, narratives of Olympic failure in Canada and New Zealand, International Review for the sociologist of sport, 40, 25-51.

Korsten, A. (2005). Deliberatieve beleidsanalyse en politiek als vorming van discourscoalities.

Paper. www.arnokorsten.nl.

Korsten, A. \& De Goede, P. (red.) (2006). Bouwen aan vertrouwen in het openbaar bestuur, diagnoses en remedies. Den Haag: Elsevier Overheid

Korsten A. en P. de Goede (2007). Dalend vertrouwen in de (rijks)overheid: verklaringen op een rij, paper voor werkconferentie The Netherlands Institute of Government.

Korsten, A. (2009). Leiderschap: boorputten slaan in de onderstroom. Paper. www.arnokorsten.nl.

Korsten, A. Mensgerichte organisaties. Wat zijn people processsing organisations? Paper. www.arnokorsten.nl.

Kotter, J. \& Whitehead, L. (2010). De kunst van overtuigen, draagvlak en betrokkenheid creëren.

Amsterdam: Business Contact. 
Kreiner, G. E., Clark, M. A. \& Fugate, M. (2007). Normalizing dirty work: managerial tactics for countering occupational taint, Academy of Management Journal, 50, 149 - 174.

Kübler-Ross, E. (1969). Lessen voor levenden. Amsterdam: Ambo.

Kuijken, W. (2008). Galjaardlezing van de secretaris-generaal van het ministerie van Verkeer en Waterstaat, gehouden in Utrecht op 4 november. www.logeion.nl.

Lazarus, R. S. \& Folkman, S. (1987). Transactional theory and research on emotions and coping.

European Journal of personality 1, 141-169.

Lendering, J. (2005). Polderdenken, de wortels van de Nederlandse overlegcultuur. Amsterdam: Arbeiderspers.

Levinas, E.(2005). Over de ontsnapping, voorafgegaan door: Enkele beschouwingen over het hitlerisme. Kampen: Agorareeks.

Lewin, K. (1951). Field Theory in Social Science. New York: Harper and Row.

Lieshout, van, M., Aarts, N. \& Van Woerkum, C. (2006). De straat is van ons allemaal! Een studie naar conflicten in publieke ruimte en de rol van de overheid. Wageningen University reeks.

Lincoln, Y. S. \& Guba, E. G. (1985). Naturalistic inquiry. Thousand Oaks, CA: Sage.

Lindblom, C. (1979) Still Muddling, Not Yet Through. Public Administration Review, 39, 517-526.

Lippitt, R., Watson, J. \& Westley, B. (1958). The Dynamics of Planned Change. New York:

Harcourt, Brace and World

Lipsky, M. (1980). Street-level bureaucracy: dilemma's of the individual in public services. New York: Russel Sage foundation.

Lunt, F. (2009). Words that work, it's not what you say, it's what people hear. New York: Hyperion books.

Lynn, G., (1986). Levels of development for OD Consultants; moving from self-acceptance to mastery, $O D$ Practicioner, 2, 1986, 14-16.

Lyons, S. T., Duxbury, L. E. \& Higgins, C. A. (2006). A comparison of the values and commitment of private sector, public sector, and parapublic sector employees, in: Public Administration Review, 4, 605-617.

Machiavelli, N. (1992). The prince. Dover publications. 
Masselink, R. e.a. (2008). Waarderend organiseren, appreciative inquiry: co-creatie van duurzame verandering. Amsterdam: Gelling Publishing.

Matsier, N. (2005). Het achtenveertigste uur. Roman. Amsterdam: De Bezige Bij.

Maurer,R. (1996), Using resistance to build support for change. Journal for Quality and Participation, 19, 56-64.

Maxwell, J. A. (1998). Designing a qualitative study. In L. Bickman \& D. J. Rog (Eds.), Handbook of applied social research methods, 69-100. Thousand Oaks: Sage.

Meer, F. M. van der \& C. F. van den Berg (2011). De groei en daling van het aantal ambtenaren: een kwestie van appels en peren. In: R. Bekker e.a., De Staat van de ambtelijke dienst; hoe staan de ambtenaren er in 2011 voor?, pp. 16-24. Den Haag: CAOP.

Meere, F. de. (2003). Actoren in het wetgevingsproces: over de rol van persoonlijke factoren bij de totstandkoming van wetgeving. In: Houtman, D., Steijn, B. \& Van Male, J. (red). Cultuur telt: sociologische opstellen voor Leo d'Anjou, pp. 75-86. Maastricht: Shaker Publishing.

Meiden, A. van (2003). Inleiding tijdens jaarcongres van de Vereniging voor Overheidscommunicatie in Enschede.

Mens, M., Mul,M. \& Van den Kieboom, J. (2010). Investeren in samen werken, impressies van een leeronderzoek. Den Haag: Rijksadvies.

Mercier, P. (2007). Nachttrein naar Lissabon. Roman. Amsterdam: Wereldbibliotheek.

Merron, K. (1993). Let's bury the term resistance. Organization Development Journal, 11, 77-86.

Metselaar, E. E. \& Cozijnsen, A. J. (1997). Van weerstand naar veranderingsbereidheid

over willen, moeten en kunnen veranderen. Heemstede: Holland Business Publications.

Mertens, F. J. H. (1996). Vriendelijk conserveren en krachtig optreden: over vakmanschap in de beleidsadvisering. Oratie. Erasmus Universiteit Rotterdam.

Mertens, F., Pieterman, R., Schuyt, C. \& De Vries, G. (2003). Pech moet weg, Amsterdam: Salomé.

Metze, M., (2010). Veranderend getij, Rijkswaterstaat in crisis. Amsterdam: Balans.

Meuleman, L. \& In 't Veld, R. (2009). De governance van lange-termijnbesluiten. www. rmno.nl.

Michaels, D., (2008). Doubt is their product, how industry's assault on science threatens your health.

New York: Oxford University Press 
Middel, R. (2002). Daar hebben we toch communicatie voor, een beschouwing over de toegevoegde waarde van een discipline. Openbare les bij de aanvaarding van het lectoraat Overheidscommunicatie. Utrecht: Hogeschool van Utrecht, reeks Lectori Salutem.

Middel, R. (2004), Sprekend de bestuurder. Eerste meting trendonderzoek overheidscommunicatie. Faculteit Communicatie en Journalistiek, Hogeschool van Utrecht.

Miles, M. B. \& Huberman, A. M. (1994). Qualitative Data Analysis, an expanded sourcebook. Thousand Oaks: Sage. Ministerie van BZK (2005). Andere overheid in het buitenland, internationale vergelijking van veranderprocessen bij de centrale overheid. Den Haag: Ministerie van BZK.

Ministerie van BZK (2008). Brief over de bijzondere rechtspositie van de ambtenaar aan de Tweede Kamer der Staten-Generaal d.d. 30 oktober 2008.

Ministerie van BZK (2008). Stroomversnelling, waaier voor loopbaanadviseurs van beleidsmedewerkers.

Ministerie van BZK (2010). Trendnota arbeidszaken Overheid 2010.

Ministerie van BZK (2011). Hoezo luistert de overheid (niet)? Burgerperspectieven op overheidsresponsiviteit.

Ministerie van Financiën, Belastingdienst (2011). Beleidsplan communicatie 2011/2015. Den Haag: DGBel/CKC.

Miyake, K., (1991). In: G. Hatano \& Inagaki, K. Sharing cognition through collective comprehension activity. In: L. B. Resnik, Levine, J.M. and Teasley, S. D. (eds.), Perspectives on socially shared cognitions, 331-348. American Psychological Association, Washington.

Miyata, H. \& Kai, I., (2009). Reconsidering evaluation criteria for scientific adequacy in health care research: an integrative framework of quantitative and qualititative criteria. http:/creative commons.org/licenses/by/2.0, $64-75$.

Moeskops, O (2004). Terugkerende patronen in veranderingsprocessen, een psychodynamisch perspectief. $M O, 3,26-49$.

Moeskops, O. (2006). Het vermogen om te verdragen, een psychoanalytisch perspectief op diagnose en interventie in veranderingsprocessen. $M O, 1,25-39$.

Möhring, H., Gehrels, C., Plug, P. en In 't Veld, R. (2002). Beladen begrippen, vertrouwen en loyaliteit in het openbaar bestuur. Utrecht: Berenschot Fundatie.

Molinsky, A., \& J. Margolis 2005. Necessary evils and interpersonal sensitivity in organizations.

Academy of Management Review, 30, 245-268. 
Molinsky, A. L., \& Margolis, J. D. (2008). Navigating the bind of necessary evils: psychological engagement and the production of interpersonally sensitive behavior. Academy of Management Journal, 51, 847-872.

Mors, E. ter (2009). Dealing with information about complex issues, The role of source perceptions.

Dissertatie. Leiden: Kurt Lewin instituut

Nathans, H. (1992), Adviseren als tweede beroep, resultaat bereiken als adviseur. Alphen aan den Rijn: Kluwer.

Nationale Ombudsman (2005). De burger is een mens, 25 jaar Nationale Ombudsman, en jaarverslagen $2007-2011$.

Nauta, F. (2008). Het innovatieplatform, innoveren in het centrum van de macht. Amsterdam: Academic Service

Neelen, G. \& Strijp, P. (2007). Daar doe ik het voor, rolopvattingen van ambtenaren. Utrecht: Publiek Domein.

Nelis, J. (2009). Eerste stap op weg naar een loopbaanbeleid voor beleidsmedewerkers, resultaten van een praktijkgericht onderzoek. Den Haag: ministerie van BZK.

Nelissen, N. (1989). Dynamiek bij de inzet van instrumenten voor milieubeleid. In: G. Bartels e.a., De transactionele overheid, pp. 21-37. Alphen aan den Rijn: Kluwer.

Newton, K. (2000), Confidence in Public Institutions: faith, culture or performance. In: Pharr, S. J. \& Putnam, R. (eds), Disaffected Democracies, pp. 52-73. Princeton: Princeton University Press.

Niessen, C. R., e.a. (1989). Ambtenue. Drie speciale uitgaven bij het 175 jarig bestaan van het ministerie van Binnenlandse Zaken, Den Haag.

Niessen, C. R. (2001). Vluchten kan niet meer, iets over beleids- en beheersproblemen en hun oplossing. Inaugurele rede. Den Haag: CAOP.

Niessen, C. R. (2003). Ambtenaar in de overheidsorganisatie. Studiepocket staats- en bestuursrecht nr. 42. Deventer: Kluwer.

Niessen, C. R. (2011). Eigen aard is eerbied waard. In: Het eigene van de overheid, input voor het debat over de rol van de overheid, pp.149-156. Den Haag: CAOP.

Niessen C. R. \& Karssing, E. (2008). Geroepen om het algemeen belang te dienen, ambtenaren, integriteit en beroepstrots. Den Haag: CAOP.

Nieuwenkamp, R. (2001). De prijs van het politieke primaat, wederzijds vertrouwen en loyaliteit in de verhouding tussen bewindspersonen en ambtelijke top. Dissertatie. Delft: Eburon.

Nijhoff, D. J. (2002). Wat beweegt professionals? Motieven bij loopbaankeuzen. Amsterdam: Academic Service. 
Noordergraaf, M., Van der Steen, M. \& Frissen, P. (2010), De crisis van het vertrouwen en het vertrouwen na de crisis, de risico's van het vertrouwen op vertrouwen. Den Haag: Ministerie van BZK.

Noorderhaven, N. G. (1995), Strategic decision making. Workingham: Addison-Wesley.

Nooteboom, B. (2002). Vertrouwen, vormen, grondslagen, gebruik en gebreken van vertrouwen. Amsterdam: Academic Service.

Osch, D. van (2003). Co-oriëntatie, truc of troef, symmetrische communicatie als managementinstrument. Alphen aan den Rijn: Kluwer.

Ouwekerk, R. (2001). De trotse ambtenaar. Noordwijk: De Baak.

Paardekooper B. \& Schillemans, T. (2004). Verhalen uit het vooronder, ambtenaren over de overheid. Den Haag: Sdu.

Parsons, T., \& Bales, R. F. (1955). Family socialization and interaction process. Glencoe: The Free Press.

Patton, M. . (1990). Qualitative evaluation and research methods. Sage Publications.

Pauly, S. (2001). Ambiguïteit in het spel, de casus PolyVinylChloride. Dissertatie. Delft: Eburon.

Pessers, D. (2006). Goede en kwade trouw in het openbaar bestuur. Lezing voor de Raad voor het Openbaar Bestuur op 12 september 2006 in Den Haag.

Pleij, H. (2007). Erasmus en het poldermodel. Essay. Amsterdam: Bert Bakker.

Pligt, J. van der, Koomen, W. \& Van Harreveld, F. (2007). Bestraffen, belonen en beïnvloeden. Utrecht: Centrum voor criminaliteitspreventie.

Pol, B., Swankhuisen, C. \& Van Vendeloo, P. (2007). Nieuwe aanpak in overheidscommunicatie, mythen, misstanden en mogelijkheden. Bussum: Coutinho.

Pol, B. (2008). Tussen professoren en professionals. Openbare les. Utrecht: Hogeschool Utrecht.

Poiesz, T. (1999). Gedragsmanagement, waarom mensen zich (niet) gedragen. Wormer: Inmerc.

Pollit, C. \& Bouckaert, G. (2004). Public management reform. A comparative analysis. Oxford: Oxford University Press.

Pratt, M. G. \& Ashforth, B. E. (2003). Fostering meaningfulness in working and at work. In: K. S. Cameron, Dutton, J. E. \& Quinn, R. E. Positive organizational scholarship: foundations of a new discipline, 309-328. Berrett-Koehler, San Francisco. 
Prein, H. (2001).Trainingsboek conflicthantering en mediation. Houten: Bohn, Stafleu Van Loghum.

D. Pruitt \& Kim, S. H. (2004), Social Conflict: Escalation, Stalemate, and settlement. New York: McGraw-Hill.

Putnam,R. (1993). Making democracy work, Princeton University Press, Princeton, 1993.

Quinn, R. W. \& Dutton, J. E. (2005). Coordination as energy in conversation. Academy of Management Review, $30,36-57$.

Raad voor het Openbaar Bestuur (2005). Over de staat van de democratie, pleidooi voor herkenbare en aanspreekbare politiek. Den Haag: ROB.

Raad voor het Openbaar Bestuur (2010). Vertrouwen op democratie. Den Haag: ROB.

Raad van State (2008, 2009, 2010). Jaarverslagen, in het bijzonder inleidingen vice-voorzitter, Den Haag.

Ramzy, A. (2002). Lezing over storytelling voor De Baak, studiecentrum VNONCW, Noordwijk.

Rebel, H. J. (2000). Communicatiebeleid en communicatiestrategie. Amsterdam: Boom.

Remarque, P. (2010). 'Obama: ik heb fouten gemaakt', openingsartikel De Volkskrant op 21 januari 2010.

Repelaer van Driel, O. A. (2002). Towards a profitable Reputation Quotient for Governmental and Not-for-profit organizations. Master thesis. Erasmus Universiteit Rotterdam.

Reijnders, E. (2006). Interne communicatie voor de professional, naar een interactievisie. Assen: Van Gorcum.

Ridder, J. A. de, Kleinnijenhuis, J. en Scholten, O. (2008). Politieke kennis en effecten van nieuws,

Tijdschrift voor Communicatiewetenschap, 36, 204-224.

Ringeling, A. (2004). Het imago van de overheid. Den Haag: Elsevier Overheid.

Ritzen, J. (1998). De minister, een handboek. Amsterdam: Bert Bakker.

Robbins, S. P. \& Judge, T. A. (2008). Gedrag in organisaties. Amsterdam: Pearson.

Rogers, E. (1995). Diffusion of Innovations. New York: Free Press.

Rooij, H. van (2009). Diensten en dreigementen, de boodschappen van de Belastingdienst. Beleidsnotitie.

Den Haag: DG Belastingdienst/CKC.

Rooy, P. van (2009). Nederland boven water, praktijkboek gebiedsontwikkeling. Habiform/NIROV. 
Rosenthal, U., Docters van Leeuwen, A., Van Eeten, M. \& Van Twist, M. (2001). Ambtelijke vertellingen, over verschijnselen die niet onbenoemd mogen blijven. Amsterdam: Boom.

Rothstein, B. (2002). Social capital in the democratic state, in R. D. Putnam (ed.), Democracies in flux. Oxford: Oxford University Press.

Rousseau, D. M. (1989). New hire perspectives of their own and their employer's obligations: A study of psychological contracts, in Journal of Organisational Behaviour 11, 389-400.

Ruler, A.A. van (2003). Communicatiemanagement: van kwantiteit naar kwaliteit. Over professionalisering van het management van organisationele communicatie. Oratie. Enschede: Universiteit Twente.

Rutgers, M. (2011). Het torentje van de overheid. In: Het eigene van de overheid, input voor het debat over de rol van de overheid, pp. 137-146. Den Haag: CAOP.

RVD Communicatiereeks 1 (2004). Communicatie in het hart van beleid en 8 (2007) Communicatief beleid: van cursus tot cultuur. Den Haag: Sdu.

Rijkenberg, J.(2005). Concepting, het managen van concept-merken in het communicatiegeoriënteerde tijdperk. Den Haag: Bzztoh.

Rijn, J. van (2010). De eeuw van het debat, de ontwikkeling van het publieke debat in Nederland 1800-1920. Dissertatie. Amsterdam: Wereldbibliotheek.

Rijnja, G. \& Klinkers, L. (2011). Waarden maken de overheid, in: Het eigene van de overheid, input voor het debat over de rol van de overheid, pp. 15-51. Den Haag: CAOP.

Rijnja, G. \& Meuleman, L. (2004). Maken we beleid begrijpelijk of begrijpelijk beleid? De verplaatsing van communicatie, RVD Platformreeks 4, 28-43. Den Haag: Sdu

Rijnja, G. (2005). Imago verbeteren? Vergeet de resultaten, Comma, 2, 24-25. Den Haag: Sdu.

Rijnja, G. (2007). 'Deceptiemanagement: Hoe gebruikt u uw teleurstelling vandaag?' C, 2, 8-10.

Den Haag: Logeion.

Rijnja, G., Seydel, E. \& Zuure, J. (2009a). Instrumenten zoeken orkest, de omslag naar contextuele communicatie, RVD Platformreeks 11, 5-10. Den Haag: Sdu.

Rijnja, G., Seydel, E. \& Zuure, J. (2009b). Communiceren vanuit de context: Naar effectievere overheidscommunicatie. In: Tiemeijer, W. L., Thomas, C. \& Prast, H. (red.), De menselijke beslisser, 2009, pp. 185-209. Amsterdam: Amsterdam University Press. 
Rijnja, G. \& Wilmink, H. (2010). Beroep: beleidsambtenaar, over ambtelijk besef en professioneel lef. Den Haag: BZK.

Rijnja, G. \& De Witte, V. (2007). De kracht van de kernboodschap. Opvallen, overkomen en overnemen. Alphen aan den Rijn: Kluwer.

Sandberg, J. \& Pinnington, A. H. (2009). Professional competence as ways of being: an existential ontological perspective. Journal of Management Studies 46/7, 1138-1170.

Savater, F. (1998). Goed samen leven. Politiek voor mensen van morgen. Utrecht: Bijleveld.

Schafer, L (2005). Popper, kopstukken filosofie. Rotterdam: Lemniscaat.

Scharpf, F. W. (1999). Governing in Europe: Effective and democratic? Oxford: Oxford University Press.

Schalkwijk, L. (2011). 'De overheid is heel slecht in toegeven van fouten', Nationale Ombudsman Brenninkmeijer begint strijdvaardig aan tweede termijn. Interview in AD op zaterdag 2 april 2011, p. 2.

Schama, S. (1989). Overvloed en onbehagen; de Nederlandse cultuur in de Gouden Eeuw.

Amsterdam: Uitgeverij Contact.

Scharmer, C. O. (2010), Theorie U, leiding vanuit de toekomst die zich aandient. Zeist: Christofoor.

Schendelen, M. van. (1989). Toegepaste Politicologie. Leiden: Stenfert Kroese.

Schein, E. (2001). Loopbaan ankers, ontdek je werkelijke waarden. Amsterdam: Academic Service.

Scholten, P. (2009). Daring decisions and representative municipal democracy: an exploration within the new river management in the Netherlands. The Innovation Journal: The Public Innovation Journal, 14, 1-15.

Schoofs, M. \& Nelissen, P. W. M. (2008). Reputaties van overheidsorganisaties: een situationele benadering, Tijdschrift voor Communicatiewetenschap, 26. 170-186.

Schultz von Thun, F. (2003). Hoe bedoelt u: een psychologische analyse van menselijke communicatie. Groningen: Wolters-Noordhoff.

Schutte, G. J. (2002). De gewetensfunctie van het parlement'.Thorbecke-lezing, Den Haag.

Schuyt, C. (2003). Wees precies, vindingrijk en speels, dertien praktische nieuwe deugden om direct te beoefenen, opiniebijdrage in NRC Handelsblad van 2 november 2003, p. 7.

Scott, J. (1998). Seeing like a state, How certain schemes to improve the human condition have failed. New York: Yale. 
Scott-Morgan, P. (2001). De ongeschreven regels van het spel, beheers en vernietig de verborgen regels en verwijder de barrières die organisatieveranderingen in de weg staan. Groningen: Boekwerk.

Sears, D. O., \& Kosterman, R. (1994). Political persuasion. In S. Shavitt \& T. Brock (Eds.), Persuasion: Psychological Insights and Perspectives, 251-278. Boston: Allyn \& Bacon.

Seibert, S. E., Kraimer, M. L. \& Crant, J. M. (2001), What do proactive people do? A longitudinal model linking proactive personality and career success, Personal Psychology, 58, 1, 1- 21.

Seligman, A. (1997). The problem of trust. Princeton: Princeton University Press.

Sennett, R. (2008). De ambachtsman, De mens als maker. Amsterdam: Meulenhoff.

Sennett, R. (2010). De mens als werk in uitvoering. Spinozalezing 2010. Uitgesproken op 24 november in Amsterdam en verkort verschenen in de Groene Amsterdammer van 25 november 2010.

Sennet, R. (2011). Geen contact meer. Premselalezing 2011. Uitgesproken op 26 juni in Amsterdam en verkort verschenen in de Groene Amsterdammer van 7 juli 2011, p. 32-35.

Seydel, E. (2008). Crisis nee...chapeau, column in Magazine nationale veiligheid en crisisbeheersing, april, 3. Den Haag: Ministerie van BZK.

Sheerazi, A. (2011) De mens voor de machine. De herpositionering van een project in de problemen. Powerpointpresentatie. Amsterdam: projectbureau Noord/Zuidlijn.

Simon, H. (1966). De besluitvorming in de organisatie. Amsterdam: De Bussy.

Smidts, A., Pruyn, A. T. H. \& Van Riel, C. B. M. (2001). The impact of employee communication and perceived external prestige on organizational identification. Academy of Management journal, 44, 1051-1062.

Sonderen, E. van (1993). Het meten van de sociale steun met de Sociale Steun Lijst - Interacties en Sociale Steun Lijst - Discrepanties. Groningen: Noordelijk Centrum voor Gezondheidsvraagstukken.

Spaan, J. (1941). De glorie van het ambacht. Amsterdam: Querido.

Spiering, H. (1996). Een volk van praters, interview met W. Frijhoff. NRC Handelsblad, 3 augustus 1996, Z-bijlage, 2-3.

Staub, E. (1989). The roots of evil: The origins of genocide and other group violence. New York: Cambridge University Press.

Staveren, van A. \& Boonstra, J. (2007). Langzaam, zo snel als ze konden. Communicatie in het hart van beleid als 
organisatieverandering. Platform, 8, 28-33.

Steen, M. van der, Van der Spek, J. en Van Twist, M. (2010). Figureren in het verhaal van de ander, over gezagsdragers in beeld. Den Haag: NSOB.

Steijn, B. (2003), HRM, arbeidssatisfactie en de publieke sector, in: Bestuurswetenschappen, 4, 289-307.

Steijn, B. (2009), Over de competenties van de 'nieuwe' ambtenaar, in: Rijksambtenaren van de toekomst, pp.30-45. Den Haag: Ministerie van BZK.

Stroebe, W., Stroebe, M. S., Abakoumkin, G. \& Schut, H. (1996). The role of loneliness and social support in adjustment to loss: A test of attachment versus stress theory. Journal of personality and social psychology, 6 , 1241-1249.

Swanborn, P. G. (2005). Methoden van sociaal-wetenschappelijk onderzoek. Amsterdam: Boom.

Swieringa, J. en Jansen, J. (2006). Gedoe komt er toch, zin en onzin over organisatieverandering. Utrecht: Scriptum.

Teisman, G. (1992). Complexe besluitvorming: een pluricentrisch perspectief op besluitvorming over ruimtelijke investeringen. 's-Gravenhage: VUGA.

Teisman, G. (2009). Inspiratiecollege voor het ministerie van Binnenlandse Zaken en Koninkrijksrelaties op 23 juni. www.ambtenaarzo.nl.

314 Terkel, S. (1972). Working. New York: The New Press.

Thomas, R., Sargent, D. L. \& Hardy, C. (2011). Managing organizational change: negotiating meaning and power-resistance relations. Organization Science, 22, 22-41.

Thomas R. \& Hardy, C. (2011). Reframing resistance to organizational change, Scandinavian Journal of Management 27, 322-331.

Thompson, P. \& Alvesson, M. (2005). Bureaucracy at work, misunderstandings and mixed blessings. In: P. du Gay (ed.), The values of bureaucracy, pp. 89-113. Oxford University Press.

Tiemeijer, W. L., Thomas, C. \& Prast, H. (red.) (2009). De menselijke beslisser, over de psychologie van keuze en gedrag. Amsterdam: Amsterdam University Press.

Tiemeijer, W. L., (2010). Hoe mensen keuzes maken, de psychologie van het beslissen. Amsterdam: Amsterdam University Press. 
Tjeenk Willink, H. (2009). Democratie en wetenschap in de toekomst, in het bijzonder met betrekking tot de organisatie van de publieke sector. Lezing tijdens het congres Towards Knowledge Democracy op 27 augustus.

Tonkens, E. (2008). Herwaardering van professionals, maar hoe? ROB-lezing. Den Haag: ROB.

Toonen, Th. (1987). Denken over binnenlands bestuur. Dissertatie. Rotterdam: Erasmus Universiteit Rotterdam.

Tops, P (1999). Moderne regenten, over lokale democratie. Amsterdam: Contact.

Tops, P. (2010). Gedrag en gezag, over de gezagspositie van de politie. Apeldoorn: Politieacademie.

Trommel, W. (2009). Gulzig bestuur. Inaugurele rede bij de aanvaarding van het hoogleraarschap beleids- en bestuurswetenschappen aan de Vrije Universiteit Amsterdam.

Trompenaars, F. (2007). Creativiteit en innovatie, geïnspireerd door John Cleese. Amsterdam:

Uitgeverij Nieuw Amsterdam.

Tropman, J. E. (1981). New strategic perspectives on social policy. Pergamon Press.

Tsoukas, H. (2009). Craving for generality and Small-N-studies: A Wittgensteinian appraoch towards the epistemology of the particular in organization and management studies, in: Ed. Buchanan, D. A. \& Bryman, A The Sage handbook of organizational research methods, 285-301. Thousand Oaks.

Tsoukas, H. \& Knudsen, C. (2003). The Oxford handbook of organization theory, meta-theoretical perspectives. Oxford University Press: Oxford.

Twist, M. J. W. van (1994), Verbale vernieuwing, aantekeningen over de kunst van bestuurskunde. Dissertatie. Den Haag: Vuga.

Twist, M. J. W. van (2010). Over (on)macht en (on)behagen in de beleidsadvisering, inaugurele rede, Den Haag, Lemma.

Twist, M. J. W. van (2011). Marktwerking en de rol van de overheid. In: Het eigene van de overheid, input voor het debat over de rol van de overheid, pp. 101-126. Den Haag: CAOP.

Tyler, T. \& Lind, E. (1992). A relational model of authority in groups, in M.P. Zanna (red.), Advances in experimental social psychology, vol. 25, 115-191. San Diego: Academic Press.

Veld, R. J. in ‘t (1995), Spelen met vuur. Den Haag: Vuga.

Veld, R. J. in 't (2007). De vloek van het succes, over de ontwikkeling van democratie. Inaugurele rede als lector. Hogeschool InHolland, Amsterdam. 
Veld, R. J. in 't (2009). Willens en wetens, de rollen van kennis over milieu en natuur in beleidsprocessen. Den Haag: RMNO.

Ven, van der, N. (2007). Schaamte en verandering. Denken over organisatieverandering in het licht van de filosofie van Emmanuel Levinas. Kampen: Klement.

Vergouwen en Overduin (2011). Zelftest omgaan met weerstanden, vo.upnet.nl.

Verborg, F. (2010). Leiding geven aan weerstand, effectief inspelen op de verwaarloosde dimensie. www.npi.eru.

Vermaak, H. (2009). Plezier beleven aan taaie vraagstukken, werkingsmechanismen van vernieuwing en weerbarstigheid. Alphen aan den Rijn: Kluwer.

Van de Vliert, E. \& Euwema, M. (1994). Agreeableness and activeness as components of conflict behaviors, Joumal of Personality and Social Psychology, 66, 674-687.

Vonk, R. (red.) (2003). Cognitieve sociale psychologie, psychologie van het dagelijks denken en doen. Utrecht: Lemma.

Vooren, I., (2009).Voetballer mag moeite hebben met zijn rol, interview met sportpsycholoog Keizer, Trouw, 30 januari, p. 15.

Vries, de, J. \& Van Dam, M. (1998). Politiek-bestuurlijk management, een blik achter de gouden muur. Alphen aan den Rijn: Samsom.

316 Vries, K. de (2007). 'De overheid houdt niet van haar mensen'. In: Binnenlands Bestuur, 4 mei. Alphen aan den Rijn: Kluwer.

Vries, K. de (2007). Over ambtenaren en politiek. Rede bij de Raad voor het Openbaar Bestuur op 7 juni.

Vuisje, B. (2008). 'In vijf maanden kabinet drie keer op m'n donder'. Interview met Pieter Winsemius in Binnenlands Bestuur van 21 maart 2008, 12, 9-11.

Vuuren, M. van \& Dorenbosch, L. (2011). Mooi werk. Naar een betere baan zonder weg te gaan. Handboek job crafting. Amsterdam: Boom.

Wagemans, M. (1998). Geregeld mis. Delft: Eburon.

Wal, van der, Z. (2006). Kernwaarden in Openbaar Bestuur en Bedrijfsleven. Een overzicht van de meest genoemde organisatiewaarden in bestuurskundige en bedrijfskundige literatuur, gedragscodes en onderzoek. Beleidswetenschap 20 (2): pp. 48-63. 
Wallage, J. (2005). Lang leve de ambtenaar. Amsterdam: Bert Bakker.

Walle, van der, S. (2006). Zullen beter werkende overheidsdiensten bijdragen tot vertrouwensherstel?

In: Korsten A. \& De Goede, P. Bouwen aan vertrouwen in het openbaar bestuur, pp. 125-138.

Den Haag: Elsevier Overheid.

Walsh, K. \& Gordon, J. R. (2008). Creating an individual work identity. Human Resource

Management Review, 18, 46-61.

Watson, P. (2005). Ideeën, de ontwikkeling van het menselijk denken. Houten: Spectrum.

Weggeman, M. (2008). Leidinggeven aan professionals niet doen, over kenniswerkers, vakmanschap en innovatie. Schiedam: Scriptum.

Weick, K. E. (1995). Sensemaking in organizations. London: Sage Publications

Weick, K. E. (1999). Sensemaking as an Organizational Dimension of Global Change.

In D. L. Cooperrider \& J. Dutton (Eds.), Organizational Dimensions of Global Change , 39-56.

Weick, K. E., Sutcliffe, K. M. \& Obstfeld, D. (2005). Organizing and the process of sensemaking. Organization Science, 16, 409-421.

Wessel, M. van (2008), Ontevreden over het functioneren van de democratie...maar hoe moet het dan wel... Den Haag: Ministerie van BZK.

Westen, D., (2007), The political brain, the role of emotion in deciding the fate of the nation. New York: Public Affairs.

Wester, F. (1991). Strategieën voor kwalitatief onderzoek. Muiderberg: Coutinho.

Wieringa, S (2011), Communiceren tegen de argwaan, praten over issues met burgers die je niet vertrouwen. www.bdrp.nl.

Wilson, J., (1989). Bureaucracy: what government agencies do and why they do it. New York: Basic books.

Winsemius, P., Gast in eigen huis.Beschouwingen over milieumanagement. Samsom: Alphen aan den Rijn.

Winsemius, P. (1990), Speel nooit een uitwedstrijd. Topprestaties in sport en management. Utrecht: Veen.

Wirschell, A. (red.) (2008), Canon van de Nederlandse ambtenaar. Den Haag: ROI. 
Woerkum, C. M. J. van (2000). Overheid en communicatie. Bijlagen 'In dienst van de democratie', eindrapport Commissie Toekomst Overheidscommunicatie. Den Haag: Sdu.

WRR (2005), Vertrouwen in de buurt. Amsterdam: Amsterdam University Press.

WRR (2006), Lerende overheid, een pleidooi voor probleemgerichte politiek.

Amsterdam: Amsterdam University Press.

WRR (2011), Het gezicht van de publieke zaak, openbaar bestuur onder ogen.

Amsterdam: Amsterdam University Press.

Wrzesniewski, A., McCauley, C. R. , Rozin, P. \& Schwartz B. (1997). Jobs, careers and callings: people's relations to their work. Journal of Research in Personality, 31, 21-33.

Wrzesniewski, A. \& Dutton, J. E. (2001). Crafting a job: revisioning employees as active crafters of their work. Academy of Management Review, 26 , 179-201.

Wrzesniewski, A., Dutton, J. E. \& Debebe, G. (2003). Interpersonal sensemaking and the meaning of work. Research in Organizational Behavior, 25, 93-135.

Xiao, H. \& Smith, S. L. J. (2006). Case studies in tourism research: a state-of-the-art analysis. Tourism management 27, 738-749.

Yin, R. K. (1984). Case Study Research: Design and Methods. Sage Publications, Newbury Park.

Wuthnow, R. (2002). Bridging the privileged and the marginalized? In: R.D. Putnam (ed.), Democracies in flux. Oxford: Oxford University Press.

Zalm, G (2009). De romantische boekhouder. Amsterdam: Balans

Zanal, Z. (2007), Casestudy as a research method, Jurnal Kemanusiaan 9,

Zeelenberg, M., Van Dijk, W. W., Manstead, A. S. R. \& J. van der Pligt (1998). The Experience of Regret and Disappointment, Cognition and emotion, 12, 221-230.

Zeelenberg, M., \& Pieters, R. (2006). Feeling is for doing: A pragmatic approach to the study of emotions in economic behavior. In D. DeCremer, Zeelenberg, M. \& Murnighan, J. K. (Eds.), Social psychology and economics, pp. 117-137. Mahwah, NJ: Erlbaum.

Zimbardo, P. (2010), Het Lucifer Effect, hoe gewone mensen zich laten verleiden tot het kwaad. Amsterdam: Lemniscaat. 
Zwijze-Koning, K. H. \& De Jong, M. D. T. (2005). The critical incident technique as a communication audit tool, a study into the quality of organizational communication. Journal of Organizational Behavior, 1-61.

Zijderveld, A. (2009). Van taboe tot schuldgevoel, de mens komt slecht los van zijn schaamte. Essay. Het Financieele Dagblad, 30 mei, p. 17.

Zijderveld, A. (2009) Generalisaties zijn nodig en riskant. Column. Het Financieele Dagblad, 14 november. p. 17.

Zijderveld, A. (2011). Legaal en legitiem. Column. Het Financieele Dagblad, 5 november, p. 17. 


\section{Samenvatting}

Wie bij de overheid beleid maakt, heeft een grote kans weerstand te ontmoeten bij degenen voor wie het beleid bedoeld is en zelfs bij degenen voor wie dit beleid helemaal niet bedoeld is. De omgang met dit fenomeen staat centraal in dit proefschrift. De studie is geboren uit de verwondering van een voorlichter/communicatieadviseur die zich vaak als een 'beleidsreparateur' gesteld zag voor de vraag of een voorbereide maatregel, voorziening of dienst zodanig gepresenteerd kan worden dat teleurstelling wordt voorkomen, ergernis wordt weggenomen of conflicten worden afgewend. Maar waarom het paard achter de wagen spannen? In plaats van beleid begrijpelijk maken kun je begrijpelijk beleid maken. Deze studie is gestoeld op praktijkervaring als communicatieadviseur bij de overheid en betrokkenheid bij het opleiden van beleidsmakers om communicatief te denken en doen. Bij die advisering en scholing kwamen naast communicatiekundige inzichten ook beleids- en bestuurswetenschappen steeds meer in het vakmatige vizier. Communicatie is anno 2012 niet meer de pejoratief van een af te zonderen discipline of afdeling, wat niet wegneemt dat op de communicatieberoepsgroep een indringend beroep wordt gedaan om bij te dragen aan een procesmatige (of beter: procesrijke) voorbereiding en landing van overheidsbeleid.

Kritiek op overheidsinterventies is van alle tijden en raakt een breed spectrum: de aanleiding, de werkwijze, de organisatie, de deskundigheid, de gezichten en de uitkomst. Aan verklaringen voor het falen, teleurstellen of tekortschieten van de overheid bestaat geen gebrek. Zo biedt de sociale psychologie vele verklaringen voor het uitvergroten van negativiteit, het wegbewegen van afwijzingen, het toewijzen van schuld en het imploderen bij tegenspel. Ook studies over politiek en sociaal vertrouwen, bejegening van burgers en mediaberichtgeving leveren volop argumenten over het aanhoudende tegenvallende oordeel over de prestaties van de overheid. Deze en andere verklaringen leiden in hoofdstuk 1 naar de probleemstelling dat de beleidsambtenaar werkt in een onvervreemdbaar omstreden context met een vaak negatieve connotatie, waarin bewuste en onbewuste verwachtingen, verplichte en onverplichte relaties en gevraagde en ongevraagde interventies bij uitstek neerdalen op de ambtelijke beleidsmaker. Diens inzichten en vaardigheden om weerstand te herkennen en hanteren wenken vervolgens als relevante troeven om de teleurstelbaarheid van overheidsbemoeienis te beteugelen. De probleemstelling leidt naar drie centrale onderzoeksvragen: 1) welke betekenis heeft de context 'overheid' voor de beslissingen die beleidsambtenaren nemen over het contact met het publiek, (2) welke mogelijkheden heeft de beleidsambtenaar om de specifieke context te herkennen en te hanteren bij het contact over omstreden beslissingen en (3) welke lessen kunnen worden ontleend aan de kennis over de beoordeling van beleidsambtenaren van kritiek op overheidshandelen en de gedragingen die hiervan het gevolg zijn. Het proefschrift bestaat uit drie delen. Na twee theoretische verkenningen volgt een empirisch deel met twee praktijkonderzoeken. In het derde deel wordt een conceptueel model gepresenteerd, waarvan de werking aan de hand van casestudies wordt onderzocht. 


\section{A. Theoretische verkenningen: overheid, werk en weerstand}

De twee verkenningen in het eerste deel verduidelijken de kernthema's overheid, werk en weerstand. Hoofdstuk 2 stelt de vraag naar het eigene van de overheid. Over dat eigene bestaat een wezenlijke, gemeenschappelijke notie: er is in de samenleving een basaal begrip voor de instandhouding van een systeem voor taken die vrije krachten in de samenleving te boven gaan. Zoals het waarborgen van de rechtsorde, het garanderen van een basisbestaan en het tegengaan van onvolkomenheden in de vrije markt. Ophef ontstaat als het gaat om de manier waarop die taken worden overgenomen of overgedragen en vooral ook wie daarbij welke rol krijgt, vraagt of opeist. We schetsen de ontwikkeling hiervan aan de hand van een kleine canon van de overheid. Specialisaties, uitbouw, verzelfstandiging en nieuwe netwerken dwingen een overheid af die vroegtijdig, evenwichtig en openbaar problemen articuleert en de vraag helpt beantwoorden wie waarvoor verantwoordelijk is. Daarmee krijgen we de werkers binnen de overheid op de korrel. Wat en wie zijn bepalend voor hun werkomgeving? Vanzelfsprekend komen dan politici in beeld, die immers tekenen voor de tegenstellingen over de toedeling van schaarse waarden en middelen. Overheidsbemoeienis is a priori omstreden en (h)erkenning hiervan is wezenlijk voor iedereen die met de overheid te maken heeft. De beleidsambtenaar - de vrijgestelde dienstverlener van de gekozen of benoemde bestuurder - komt dan in dat strijdperk naar voren als 'verschilmaker'. We positioneren deze verbindende schakel in een context van drie arena's: politiek bestuur, samenleving en bureaucratie. In die context tekenen systeemspanningen het werk van de ambtenaar, zoals het samenkomen van individuele belangen en algemeen belang, beperkte beheersbaarheid en grote (verkiezings) beloften en lange termijnontwerpen en korte termijn scoringsdriften. Dit raakt niet voor alle ruim 400.000 ambtenaren die ons land kent in gelijke mate. Voor velen geldt dat zij ervoor tekenen dat deze spanningen resulteren in door een meerderheid gedragen besluiten over de toedeling van macht, de (verplichte) levering van diensten en de organisatie van toegankelijkheid, dialoog en interactie (ook bekend als: communicatie).

Hoofdstuk 3 zoomt verder in op het thema werk. We staan in het bijzonder stil bij werk, waarbij noodzakelijk kwaad moet worden toegepast of waar sprake is van gedurfde besluiten. In de tweede verkenning ontwikkelen we het fenomeen werk om de relatie van werk en weerstand in beeld te brengen. Het belang van werk verschilt van mens tot mens, maar wie - bewust of onbewust - zich geroepen voelt om professioneel een bepaald doel te behalen, is zoals blijkt uit onderzoek vaker geneigd grenzen op te zoeken en als het even kan te verleggen, dan iemand die uitgaat van louter een baan of van een carrière. Op de betekenisverlening aan werk (workmeaning) oefenen meerdere factoren invloed uit. Zoals persoonlijke eigenschappen als extraversie, opvattingen over vakmanschap, sociale vaardigheden, de identificatie met de (beeldvorming over) de organisatie en de professionele context: welke waarde kent wie toe aan het maken van fouten en reflecteren op het eigen handelen? Deze factoren beïnvloeden de mate waarin een koppeling plaatsvinden tussen opvattingen en gedrag, een opgave die in een diffuse samenleving onder forse (financiële) druk er allesbehalve lichter op wordt. 
Wat betekent werk voor het ontmoeten van weerstand? Kritiek, ongemak en tegenspel zijn immers niet uitsluitend voorbehouden aan werken bij de overheid, maar komen in arbeid op een pregnante manier tot uiting. Weerstand is een verzamelbegrip, met alle risico's van onnauwkeurigheid van dien. Aan vooral de organisatiekunde ontlenen we het inzicht dat een negatieve uitleg van het begrip geen recht doet aan de onderliggende bereidheid van mensen om oplossingen na te streven. We definiëren weerstand daarom als 'een verzameling uiteenlopende ideeën over hoe de organisatie er uit moet gaan zien', in de wetenschap dat sprake is van veel onbewuste en onberedeneerde processen. Een ontleding van het fenomeen weerstand maakt duidelijk dat onduidelijkheid van verwachtingen en opvattingen, het raken aan bronbelangen als nieuwsgierigheid en nabijheid en de beschikbaarheid van ervaring een rol opeisen. De erkenning van die perspectieven, verwachtingen en belangen komt naar voren als een belangrijke troef van degenen die weerstand ontmoeten en dat geldt ook voor de betekenis van hieraan te koppelen perspectief. Erkenning én perspectief schragen de aanpak van weerstand, zo wordt duidelijk. Ervaringen met beroepsgebonden weerstand in onder andere de gezondheidszorg en op het gebied van veiligheid maken duidelijk dat rechtvaardigheid een belangrijke waarde vertegenwoordigt, met het accent op bejegening (procedurele rechtvaardigheid). Voor wat betreft de overheidsrelaties is een belangrijke grondslag compliance: veel mensen accepteren dat bepaalde taken uit handen moeten worden gegeven; overheid hoort erbij. Maar zoals bij iedere transactie verwachten ze in ruil voor die basale bereidheid een wederkerige relatie: een passende, pakkende bejegening van iemand die niet om de hete brij heen draait. Met die wetenschap koppelde de Belastingdienst ooit de burgerlijke erkenning van een last aan een handreiking om er zo snel mogelijk van af te komen: 'Leuker kunnen we het niet maken. Wel makkelijker'. De slagzin spoot slagroom op de taart. Niet alleen de treffende combinatie van erkenning en perspectief telde immers, maar vooral het toegankelijke formulier en dito dienstverlening. Communicatief beleid is beleid dat zichzelf uitlegt. Met die wetenschap kunnen meer overheidsfunctionarissen weerstand in een ander daglicht helpen zetten door de weerstand niet uit de weg te gaan, maar juist op te zoeken en de meervoudige perspectieven te (h)erkennen.

\section{B. Empirisch deel: werkbeleving en systeemspanningen onderzocht}

In hoofdstuk 4 komen overheidsdienaren aan het woord. Hoe verlenen zij betekenis aan hun arbeid? Interviews met 32 rijksambtenaren werpen licht op de context van het werk, de relaties met anderen en de betekenis van beeldvorming. De workmeaning van de beleidsambtenaar steunt naast de betekenis die aan concrete taken en de hieraan ontleende positie, op wat het werk iemand over zichzelf leert. Daarbij zijn de interacties op en vanuit het werk betekenisvol, maar ook de gepercipieerde beeldvorming: wat betekenen andermans opvattingen voor je? De interviews maken om te beginnen het belang van directe collega's duidelijk. Deze interne contacten worden duidelijk meer gewicht toegekend dan de interactie met het publiek en/of organisaties. We onderzochten positieve en negatieve werkervaringen. Positieve interacties kenmerken zich door - snel - resultaat, vermogen om tegenstrijdige belangen samen te brengen en waardering voor geleverde inspanningen. 
Bij negatieve interacties komt beeldvorming rap naar voren. Het negatieve beeld bij buitenstaanders van de overheid en de ambtenaar draagt bij aan een bepaalde weerstand die ambtenaren ervaren, waarbij geringe voorkennis bij buitenstaanders en een niet altijd begrepen achterdocht bij belangenorganisaties ten opzichte van overheidsbemoeienis als verklaringen naar voren komen. Ook de focus van de media op negatieve gebeurtenissen wordt veelvuldig als reden genoemd. Veel ondervraagde ambtenaren geven aan moeite te hebben om soepel met deze 'signalen van weerstand' om te gaan. Ook geven sommige ambtenaren aan dat het lastig is om in te schatten welke ruimte ze hebben, bijvoorbeeld in welke fase ze in de openbaarheid kunnen treden met hun beleid. Tegenover de nadelen van het waargenomen negatieve beeld bij anderen staat de ervaring dat spanningen bij het werk horen en ook deel uitmaakten van de overweging om juist bij de overheid te gaan werken. De invloed van de beeldvorming wordt over het algemeen dan ook niet hoog geschat; er is veel relativering, naast de genoemde redenen komt dit ook door het ervaren besef dat de overheid er als zodanig toe doet. Uit de omgang met de ervaren druk komt vindingrijkheid naar voren in de vorm van het nemen van ruimte en het zoeken van afwisseling; ook wordt vaak de metafoor 'spel' gebruikt. Dat blijkt ook uit de luchtige betekenisverlening aan grapjes en vooroordelen over ambtenaren en hun gedrag. De waargenomen steun van collega's wordt vaak opgevoerd als relevante terugvaloptie in lastige situaties.

Hoofdstuk 5 presenteert de resultaten van onderzoek naar de omgang met de overheidseigen context. Er is sprake van specifieke 'systeemspanningen' door het samenkomen van meervoudige belangen - vanuit de publieke, bureaucratische en politieke arena's en enkele specifieke kenmerken van de overheid. Hoe komen de bijzondere kenmerken van de overheid tot uiting in het dagelijks werk van de beleidsambtenaar en hoe gaat de beleidsambtenaar met die spanningen om? In dit onderzoek zijn negen beleidsmakers ondervraagd. Hun werkbeschrijvingen worden uitgelegd als een wandeling onder een arcatuur van drie spanningsbogen: (1) belangenafweging in het besef van rechtsstatelijkheid, (2) beheersbaarheid in democratische context en (3) vakmanschap onder bestuurlijke verantwoordelijkheid. Met dit drieluik zijn de contextuele spanningen van het maken van beleid bij de overheid nader geduid. Daarbij zijn vervolgens vijf strategieën geidentificeerd die duidelijk maken hoe de ambtenaar situaties hanteert waarin deze spanningen zich voordoen: (I) Gebruik de bureaucratie, zonder je er buiten te plaatsen, (II) Breng de politiek in stelling, zonder door te schieten, (III) Help de maatschappelijke omgeving te werken, zonder het politiek primaat te vergeten, (IV) Erken de complexiteit, zonder eigen verantwoordelijkheid te schuwen en (V) Neem het heft in eigen hand, zonder beginselen van behoorlijk bestuur uit het oog te verliezen. De verhalen maken duidelijk hoe beleidsambtenaren steeds weer proberen juist niet af te haken of zich af te schermen en ook in het beperkt beheersbare werk zelf de spil willen en kunnen blijven. De negen respondenten vertellen in feite een verhaal van actieve, oplossingsgerichte ambtenaren. Beleidsambtenaren zijn gedreven door resultaten - in de wetenschap dat die lange adem en de nodige relativering vragen -, waardering - die begint in de binnenring van collega's en leidinggevenden - en probleemoplossend vermogen: je bent gefocust op het vinden van verbindingen, gemeenschappelijke oriëntaties en belangen. 


\section{Conceptueel model: de coping van meebewegers}

Bij het oplossen van lastige opgaven en de ontmoeting van tegenspel staan de beleidsmaker meer 'copingstrategieën' ten dienste. Hoofdstuk 6 beschrijft de ambtelijke taxatie van kansrijke coping met de nieuwe situaties. Vooral in de sociaal-pedagogische zorg, bij conflicthantering en in de context van organisatieverandering zijn hiermee betekenisvolle inzichten en ervaringen opgedaan. Er is sprake van een 'copingspectrum', met aan de ene kant de taxatie 'weg te bewegen' van de weerstand en aan de andere kant 'tegenbewegen' om weerstand te breken en verandering te forceren. Tussen deze uitersten van 'vluchten' en 'vechten' in ligt een middenweg, die we 'meebewegen' noemen. Deze copingstrategie veronderstelt het willen en kunnen aangaan van een wederkerig contact, waarin enkele werkende elementen oplichten. Zoals: geduld en aanpassing (Sennett), twijfel en vertraging (Vermaak) eerlijkheid en waardigheid (Levinas), bescherming van verschillen (Brummans) en meervoudige perspectieven (Merron). Vanuit dat contact kunnen volgende stappen worden gezet, waarbij 'inleven', 'overeenkomen' en 'herformuleren' als dominante stijlen zijn geïdentificeerd. Het conceptueel model dat in dit hoofdstuk wordt neergelegd beschrijft de ideaaltypische bagage van de beleidsmaker om aan de copingstrategie 'meebewegen' gestalte te kunnen geven. Hierbij fungeren zes beïnvloedende factoren als 'hefbomen'. Daarbij worden drie als 'primair' geïdentificeerd: (1) persoonlijke hulpbronnen als extraversie en openheid, (2) professionele drijfveren (een 'seculiere roeping') en (3) ambtelijk besef (weten hoe de hazen lopen). Een tweede trits 'secundaire factoren' kan bij zwakke ontwikkeling van de eerste drie als krachtige aanjager fungeren: (4) sociale steun (van om te beginnen collega's), (5) zicht op resultaat (afstand tot de impact van het handelen) en (6) ruimte voor reflectie (een lerende omgeving).

Drie casestudies brengen in hoofdstuk 7 de werking van het conceptueel model tot

leven. Bij de bekendmaking van een bezuiniging op de gemeentelijke subsidie aan de plaatselijke dierentuin blijkt een beleidsmaker tot 'meebewegen' in staat vanwege een combinatie van openheid, ondersteuning en persistentie. Het honoreren van de instellingsbehoefte aan verzakelijking van de bedrijfsvoering en een gefaseerd en gedoseerd proces dragen ertoe bij dat een vermeende weerstand vervaagt ten gunste van een toekomstbestendige organisatie. In een tweede casestudy blijkt hoe het expliciteren van twijfels, en vinden van overeenstemming over condities letterlijk en figuurlijk ruimte creëert voor een aanvankelijk omstreden opvang van ex-prostituees. De onverschrokken inzet voor de uitkomst in combinatie met een zorgvuldige opbouw helpen hier om een nieuw perspectief te genereren. De 'meebeweger' in deze casus paart evenals in de eerste casus een stevige score op persoonlijke hulpbronnen aan ambtelijk besef, waarbij de eerder geïdentificeerde ambtelijke strategieën stuk voor stuk tot bloei kunnen komen. In de derde casus komt bij 'meebewegen' de geïdentificeerde trits inleven - overeenkomen - herformuleren krachtig naar voren. Bij de totstandkoming van een in richtingsplan (met het oog op compensatie van wateronttrekking vanwege de bouw van een parkeergarage) komt opnieuw de versterkende kracht van persoonlijke en ambtelijke hulpbronnen naar voren. Op basis hiervan luidt de conclusie dat deze trits stijlen als opbouw 
dienst doen en als zodanig dus verder ontwikkeld kunnen worden. Bij alle drie de casussen blijken voorts de drie secundaire factoren op de achtergrond een rol te spelen, herkenbaar maar duidelijk minder manifest. De betekenis van een intense ervaring (schok) wordt aan de factorenset toegevoegd. Dit onderzoek biedt steun voor de werking van de copingstrategie 'meebewegen' en de conclusie dat 'wegbewegen' bij aanwezigheid van de drie primaire factoren geen optie is en tegenbewegen een functie kan vervullen om op terug te vallen, als handhaving van afspraken in het geding is. De casestudies laten zien dat bij het zoeken en vervolgens vinden van de overeenstemming een symbolische handeling voor een versnelling kan zorgen. De flip-over met de tekening van de waterhoeveelheid, maar het kan ook een ontmoeting op een ander dan vertrouwd terrein zijn. Het is niet alleen een kwestie van vorm; in de praktijk is sprake van een pakkend beeld of begrip, de kwestie wordt geherformuleerd of anders 'gelabeld' of 'geframed'. Bij het formuleren van het nieuwe en deelbare perspectief kan frontstage framing deuren openen.

Zes conclusies bieden in hoofdstuk 8 een balans voor de verkenningen en onderzoeken. De verkenningen en onderzoeken hebben een bundel licht geworpen op de invloed van de context, het eigene van de weerstand en de betekenis van persoonlijke bagage, ambtelijk besef en de gereedschappen bij de ambtelijke omgang hiermee. Daarbij is vastgesteld dat veel kennis, vaardigheden en houdingen onbewust aanwezig is en onberedeneerd wordt aangesproken. Ambtenaren hebben meer vindingrijkheid onder de leden dan ze zelf weten en dat is een eerste aanwijzing voor verder onderzoek. Ik doe dat vanuit het besef (conclusie 1) dat beleidsmakers bij de overheid onvermijdelijk spanningen ontmoeten, die niet met enkelvoudige oplossingen zijn te verhelpen. Ten aanzien van het fenomeen weerstand stel ik vast (conclusie 2 ) dat in de spanningsvolle context van de overheid weerstand geen blinde muur is, maar een wand van mogelijkheden. Er is sprake van een actieve expressie van wat mensen willen, die verstaan moet worden als een meervoudig perspectief met stevige wortels is in een basale bereidheid om de overheid te laten doen wat de samenleving zelf niet kan. De aandacht hiervoor maakt een zo krachtige ontwikkeling door dat (conclusie 3) dat niet de vraag of beleidsmakers de inclusieve benadering van de communicatieve aandacht omarmen aan de orde is, maar hoe, met daarbij de prikkelende vraag hoe communicatieafdelingen gegund wordt deze indaling verder gestalte te geven. Over de benodigde bagage van de beleidsmaker luidt de conclusie (4) dat de combinatie van persoonlijke hulpbronnen en ambtelijk besef en ambitie ('ambtelijkheid') het beleidsmakers mogelijk maakt om (vermeende) weerstand te herkennen en te hanteren; vooral om een samenspel aan te gaan. Er is sprake van een grote geneigdheid tot een communicatieve confrontatie ('comfrontatie') zodra persoonlijke hulpbronnen (extraversie, vriendelijkheid, zorgvuldigheid, intellectuele autonomie en openheid), professionele ambitie ('seculiere roeping') en ambtelijk besef (kennis van de (drie) systeemspanningen en beheersing van de (vijf) strategieën om anderen in stelling te brengen) beschikbaar zijn. Die 'meebewegers' volgen (conclusie 5) een karakteristieke opbouw, zo maken de interviews en casestudies duidelijk. In het 'comfrontatie-model' hebben we deze volgtijdelijkheid samengebald. Deze fasering maakt duidelijk hoe achtereenvolgens herkenning 
van de weerstand, erkenning van de twijfel, faciliteren van de toenadering, expliciteren van een gedeeld perspectief naar realisatie ('inbedding') leiden.

Voor de verdere ontwikkeling van ambtelijke professionaliteit worden (conclusie 6) vier competenties naar voren geschoven: (I) Helpen zien van meervoudige perspectieven op een (voorgenomen) bemoeienis van de overheid, (II) In stelling brengen van relevante partners om hun eigen en gemeenschappelijke doelen te realiseren, (III) Vormgeven van gemeenschappelijke perspectieven en (IV) Overdragen van lessen uit ervaringen met weerstand, twijfel, toenadering en hervonden perspectief. Per competentie worden suggesties gedaan voor praktijkgereedschap. Daarbij wordt een pleidooi gehouden voor de vorming van 'communisprudentie': de systematische evaluatie van 'best' én 'bad' practices.

Met de beantwoording van de centrale onderzoeksvragen zijn nieuwe vragen opgeworpen. Tot slot worden enkele thema's voor vervolgonderzoek naar voren geschoven. Zoals de vraag of het comfrontatiemodel zich ook voor toepassing bij bedrijven leent. Dit is aan de orde, als we bedenken dat steeds meer ondernemingen met verwante situaties te maken hebben als het gaat om het herkennen en hanteren van meervoudige perspectieven. Ook de betekenis van generaties is enkele malen als thema naar voren gekomen bij het beschrijven van het vermogen om in te spelen op perspectieven en het vinden van gedeelde zienswijzen. Met binnenkort vijf generaties op de werkvloer is dat geen luxe. Tot slot werpen we de vraag op: 'Van wie is de overheidscommunicatie?'. Nu niet louter de communicatiediscipline kan en zal worden aangesproken voor het verwezenlijken van het communicatief handelen van de overheidsorganisatie vraagt deze vraag indringend aandacht. Zijn beleidsmakers zelf in staat en in gelegenheid om kennis en ervaring over de omgang met weerstand aan te spreken of zullen communicatieadviseurs hen daarbij ondersteunen? De verwachtingen over deze toegevoegde waarde van de communicatiesector zijn niet onverdeeld hooggespannen. Met het bewustwordingsprogramma 'Factor C' heeft de communicatieprofessie laten zien dat zij tot toerusting in staat is, maar meer disciplines werpen zich op de toerusting van beleidsmakers, van agendering tot reflectie op praktijkervaringen. 


\section{Summary}

Anyone who develops policy in the government is very likely to meet opposition from those for whom the policy is intended, and even from those for whom this policy is not intended at all. This thesis focuses on dealing with this phenomenon. The study originated in the amazement of a spokesperson/communications advisor who, as a 'policy repairer', was often asked whether a planned measure, provision or service could be presented in a way that would prevent disappointment, allay irritation or avoid conflict. But why put the horse behind the cart? Rather than make policy understandable, you can make understandable policy. This study is based on practical experience as a communications advisor for the government and involvement in training policy-makers to think and act communicatively. Besides insight into communication, in these advisory and training roles, policy science and public administration also became increasingly important. In 2012, communication is no longer the pejorative of an isolated discipline or department, which does not detract from the fact that communications professionals are urgently required to contribute to process-related (or better: process-rich) planning and landing of government policy.

Criticism of government interventions belongs to all eras and relates to a broad spectrum: the reason, the method, the organisation, the expertise, the faces and the results. There are plenty of explanations for the failure, disappointment or ineffectiveness of the government. Thus social psychology produces numerous explanations for magnifying negativity, distancing oneself from rejections, attributing guilt and implosion in the case of defence. Studies about political and social trust, treatment of citizens and media communication also generate many arguments focusing on the persistence of negative opinions about government performance. In Chapter 1 , these and other explanations result in the formulation of the problem that the policy officer works in an inalienably controversial context with an often negative connotation, in which conscious and subconscious expectations, obligatory and non-obligatory relations and requested and non-requested interventions all tend to descend on the government policy-maker. His insights and skills in recognising and handling resistance are then required as relevant trumps with which to curb disappointment with government intervention. The problem definition produces three central research questions: 1) what is the significance of the 'government' context for the decisions taken by policy officers regarding contact with the public, (2) what options are open to the policy officer for recognising and handling the specific context in contacts relating to controversial decisions and (3) what lessons can be learned from knowledge about the evaluation of policy officers regarding criticism of government actions and the resulting behaviour? The thesis consists of three parts. Two theoretical studies are followed by an empirical part containing two practical studies. In the third part, a conceptual model is presented and examined on the basis of case studies. 


\section{A. Theoretical studies: government, work and resistance}

The two studies in the first part explain the key themes government, work and resistance. Chapter 2 explores what constitutes the government. There is a real, communal idea about what government is: society has a fundamental understanding about upholding a system for tasks which are beyond free forces in society. Such as maintaining law and order, safeguarding a basic existence and tackling imperfections in the free market. Conflict arises about the way in which these tasks are assumed or transferred, and in particular about who is given, requests or claims which role. We outline the development of this process based on a small canon of the government. Specialisations, expansion, privatisation and new networks force a government which publically and at an early stage articulates problems in a balanced way and helps to answer the question who is responsible for what. We thus fix the spotlight on the workers within government. What and who determine their working environment? Politicians naturally come into the frame; they are the ones who are responsible for the differences of opinion about the allocation of scarce values and resources. Government intervention is disputed a priori and recognition and acknowledgement of this is essential for everyone involved with the government. In that arena, the policy officer - the exempt service-provider of the elected or appointed administration - then emerges as 'someone who can make a difference'. We position this connecting link in a context of three arenas: political administration, society and bureaucracy. In that context, system tensions define the work of the civil servant, such as the converging of individual interests and the general interest, limited control and big (election) promises, long-term designs and short-term scoring campaigns. This does not affect all the 400,000 civil servants in our country equally. Many accept that these tensions result in majority-based decisions regarding the allocation of power, the (mandatory) provision of services and the organisation of accessibility, dialogue and interaction (also known as: communication).

Chapter 3 looks further at the theme of work. In particular, we reflect on work situations whereby either the necessary evil must be applied or bold decisions taken. In the second study, we develop the phenomenon of work in order to illustrate the relationship between work and resistance. The importance of work varies from person to person, but research has shown that anyone who-consciously or subconsciously - feels called to professionally achieve a certain goal is more likely to seek the boundaries and if possible extend them than someone who merely wants a job or a career. Several factors influence work meaning. Such as personal characteristics like extraversion, ideas about craftsmanship, social skills, identification with (image-forming of) the organisation and the professional context: what value does who attribute to making errors and reflecting on their own actions? These factors affect the extent to which a link is made between ideas and behaviour, which in a diffuse society under tremendous (financial) pressure does not get any easier.

What does work mean for meeting resistance? Criticism, unease and opposition are not only reserved for working for the government, but are inherent to all forms of labour. 
Resistance is a collective term, involving all possible inaccuracies. It is largely from organisational studies that we derive the insight that a negative explanation of the term does not do justice to people's underlying willingness to find solutions. We therefore define resistance as 'a collection of different ideas about what the organisation should look like', in the knowledge that this involves many subconscious and irrational processes. An analysis of the phenomenon resistance reveals that lack of clarity about expectations and ideas, source interests like curiosity and proximity and the availability of experience, play a role.

The acknowledgement of these perspectives, expectations and interests also emerges as an important trump for those confronted with that resistance and this also applies to the meaning of any linked perspective. Recognition and perspective support the approach to resistance, this much is clear. Experiences with professionally-related resistance in the health service and with regard to security, among others, show that justice represents an important value, with the emphasis on treatment (procedural justice). With regard to government relations, an important basis is compliance: many people accept that certain tasks must be outsourced; government is necessary. But as in every transaction, in exchange for that basic willingness, they expect a reciprocal relationship: suitable, effective treatment of someone who tells it as it is. With that knowledge, the Dutch Tax and Customs Administration once linked civil recognition of a burden to an offer of support to get it sorted as soon as possible: 'We can't make it nicer. But we can make it easier'. The slogan was the icing on the cake. Not just the apt combination of recognition and perspective was important, but especially the accessible form and service. Communicative policy is policy which explains itself. Bearing that in mind, more government officials can help to put resistance in a new light by not avoiding it but rather by seeking it out and by recognising and acknowledging the multiple perspectives.

\section{B. Empirical part: examination of work perception and system tensions}

Chapter 4 focuses on government officials. How do they give meaning to their work? Interviews with 32 national government civil servants shed light on the context of their work, their relationships with others and the significance of image forming. The work meaning of the policy officer is based on what the work teaches someone about himself, besides the meaning ascribed to concrete tasks and the position derived from them. The interactions at and resulting from work are meaningful, but so is the perceived image forming: how do other people's ideas affect you? First of all, the interviews reveal the importance of colleagues at work. More weight is clearly given to these internal contacts than contacts with the public and/or organisations. We studied positive and negative work experiences. Positive interactions are characterised by fast - results, ability to combine conflicting interests and appreciation for the efforts made. In negative interactions, image forming is quick to emerge. The negative image which outsiders have of government and civil servants contributes to a certain resistance which civil servants experience. Explanations for this include lack of knowledge among outsiders and a not always understood suspicion among lobby groups towards government intervention. The focus of the media on negative events is also frequently given as a reason. Many of the civil servants interviewed said they had difficulty dealing with these 'signs of resistance'. Some of the civil 
servants also indicated that they found it difficult to estimate their room for manoeuvre, for example at which stage they could announce their policy. However, although there are disadvantages related to their perceived negative image among others, there is the realisation that tensions are part of the work and the decision to work for the government.

The influence of image forming is not generally highly estimated therefore. There is a great deal of rationalisation, besides the reasons mentioned also due to the realisation that the government matters. Handling pressure produces inventiveness in the form of creating room for manoeuvre and seeking variety; the metaphor 'game' is also often used. This is also apparent from the light-hearted response to jokes and prejudices about civil servants and their behaviour. The perceived support from colleagues is often regarded as a relevant fall-back option in difficult situations.

Chapter 5 presents the results of research relating to dealing with the government's own context. Here there are specific 'system tensions' resulting from the convergence of multiple interests - from the public, bureaucratic and political arenas - and various specific characteristics of the government. How are the special characteristics of the government expressed in the daily work of the policy officer and how does he deal with those tensions? In this research, nine policy officers were interviewed. Their work descriptions are explained as a walk under an arcade with three arches: (1) consideration of interests in the realisation of constitutionalism, (2) manageability in a democratic context and (3) craftsmanship under administrative responsibility. With this triptych, the contextual tensions of making policy in government are further discussed. Five strategies are then derived which show how the civil servant deals with situations in which these tensions occur: (I) Use the bureaucracy, without placing yourself outside it, (II) Bring in the weight of politics without going too far, (III) Help the social environment to work, without forgetting the political primate, (IV) Recognise the complexity, without shying from our own responsibility and (V) Stay in control, without losing sight of the principles of proper management. The stories reveal how policy officers always try not to quit or protect themselves and are willing and able to play a pivotal role in the limited manageable work. In fact, the nine respondents tell a story of an active, solution-oriented civil servant. Civil servants are driven by results, in the knowledge that they require patience and the necessary rationalisation; appreciation, which starts in the inner circle of colleagues and managers, and problem-solving capacity: focused on finding connections, communal orientations and interests.

\section{Conceptual model: the coping empathisers}

When solving difficult problems and meeting opposition, the policy-maker has several 'coping strategies'. Chapter 6 describes the official appraisal of promising coping strategies in the new situations. Significant insights and experiences have been acquired here, particularly in socio-pedagogic care, conflict management and organisational change. There is a 'coping spectrum', with the appraisal 'distancing' from the resistance on the one hand and on the other hand 'countering' to break resistance and force change. Between these two extremes of 'flight' 
and 'fight' is a middle way, which we call 'empathising'. This coping strategy presupposed the willingness and ability to enter into a reciprocal contact, in which several working elements are highlighted. Such as: patience and adjustment (Sennett), doubt and delay (Vermaak), honesty and dignity (Levinas), protection of differences (Brummans) and multiple perspectives (Merron). From that contact, the following steps can be taken, whereby 'empathy', 'agreement' and 'reformulation' are identified as dominant styles. The conceptual model defined in this chapter describes the ideal typical baggage of the policy-maker in order to substantiate the 'empathising' coping strategy. Here, six influencing factors act as 'levers'. Three are identified as 'primary': (1) personal aids like extraversion and openness, (2) professional motivations (a 'secular calling') and (3) political realisation (know how the system works). A second series of three 'secondary factors' can provide a powerful boost if the first three are only weakly developed: (4) social support (starting with colleagues), (5) view of results (distance to the impact of action) and (6) space for reflection (a learning environment).

In Chapter 7, three case studies bring the working of the conceptual model to life. When announcing cutbacks in the municipal subsidy for Rotterdam Zoo, a policy-maker proves his ability to 'empathise' due to a combination of openness, support and persistence. Honouring the organisation's need for streamlining the business operations and a phased and gradual process mean that supposed resistance fades in favour of a future-proof organisation. A second case study shows how expressing doubts and finding agreement about conditions literally and figuratively creates room for an initially controversial scheme for ex-prostitutes. The undaunted efforts for the result in combination with a careful structure help generate a new perspective here. As in the first case study, the 'empathiser' in this case also links a good score for personal resources to political realisation, whereby the previously identified political strategies can each flourish. In the third case study, in 'empathising' the three identified steps - empathy - agreement - reformulation - strongly emerge. In producing a development plan, the reinforcing power of personal and official resources again converge. On this basis, the conclusion is that these three styles provide the structure and as such can be further developed. In all three cases, the three secondary factors also appear to play a role in the background, recognisable but clearly less prominent. The meaning of an intense experience (shock) is added to the factor set. This research supports the effectiveness of the coping strategy 'empathising' and the conclusion that, with the presence of the three primary factors, 'distancing' is not an option while countering can fulfil a fall-back function, if compliance with agreements is involved. The case studies show that when looking for and then finding agreement, a symbolic act can accelerate matters. Examples are meaning of a flip-over with a drawing of the water volume in the third casestudy and the creation of a meeting somewhere other than the familiar terrain. It is not only a question of form; in practice we talk about a gripping image or term, the question is reformulated or 'labelled' or 'framed' differently. When formulating the new and shared perspective, front stage framing can open doors. 
In Chapter 8, six conclusions provide a balance for the explorations and research. The explorations and research have highlighted the influence of the context, the characteristics of resistance and the meaning of personal baggage, political realisation and the tools required by the civil servant. It has also been established that lots of knowledge, skills and attitudes are subconsciously present and used in an irrational way. Civil servants possess more inventiveness than they realise and this is an initial pointer for further research. This is based on the realisation (conclusion 1) that policy-makers in government are inevitably confronted with tensions, which cannot be resolved with easy solutions. With regard to the phenomenon resistance, I conclude (conclusion 2) that in the tense context of government, resistance is not a blind wall, but a wall of opportunity. There is an active expression of what people want, which must be understood as a multiple perspective with strong roots in a basic willingness to leave to government what society cannot do itself. Attention to this is undergoing such strong development that (conclusion 3 ) it is not about whether policy-makers embrace the inclusive approach of communicative attention, but how, with the interesting question of how communications departments may give this engagement further form. With regard to the necessary baggage of the policy-maker, the conclusion (4) is that the combination of personal resources and political realisation and ambition ('officialdom') makes it possible for policymakers to recognise and deal with (supposed) resistance; in particular to embark on concerted action. There is a great tendency towards communicative confrontation ('comfrontation') as soon as personal resources (extraversion, friendly attitude, care, intellectual autonomy and openness), professional ambition ('secular calling') and political realisation (knowledge of the (three) system tensions and control of the (five) strategies to bring others to bear) are available. These 'empathisers' follow (conclusion 5) a characteristic structure, as is revealed by the interviews and case studies. In the 'comfrontation model', we have combined these consecutively. This phasing shows how recognising resistance, acknowledging doubt, facilitating overtures, and defining a shared perspective lead to embedding.

For the further development of political professionalism (conclusion 6), four competencies come to the fore: (I) Help see multiple perspectives regarding (planned) government intervention, (II) Bring relevant partners to bear in order to realise their own and communal objectives, (III) Shape communal perspectives and (IV) Communicate lessons from experience with resistance, doubt, overtures and rediscovered perspective. For each competence, suggestions are made for practical tools. In doing so, an appeal is made for the creation of 'communisprudence': the systematic evaluation of best and bad practices.

By answering the central research questions, new questions are generated. Finally, several themes for subsequent research are proposed. Such as the question whether the comfrontation model can also be applied to businesses. This is a possibility, when we consider that more and more companies are confronted with similar situations when it comes to recognising and applying multiple perspectives. The significance of generations also appeared as a theme several times when describing the ability to respond to perspectives and find shared outlooks. This will be essential in the near future when we have five generations 
on the work floor. 'From whom is the government communication?' Now that not merely the communication discipline can and will be used for the communicative actions of the government organisation, this question demands urgent attention. Are policy-makers themselves able and in a position to use knowledge and experience about dealing with resistance or will they receive support from communication advisors? The expectations about this added value of the communication sector are not altogether high. With the awareness programme 'Factor C', the communication profession has shown that it is able to equip policymakers, but more disciplines are making demands of the equipment of policy-makers, from putting subjects on the agenda to practical experiences. 


\section{Curriculum Vitae}

Guido Rijnja (1960) is in Amsterdam geboren. In 1982 is hij afgestudeerd aan de Haagse Hogeschool met een scriptie over de opkomst van communicatie in de non profit sector ('Welzijnswerkers hebben voorlichting nodig'), wat leidde tot het Netwerk voorlichters in de welzijnssector (later omgedoopt in 'Netwerk communicatie in de nonprofitsector') en de publicatie 'Voorlichting in het welzijnswerk - ervaringen en adviezen' (Guido Rijnja (red.), 1984, De Horstink, Amersfoort). In 1982 trad hij in dienst van de Vereniging van Gehandicaptenorganisaties Rotterdam (VGR); hierna volgde de overstap naar de Gemeentesecretarie van 's-Gravenhage, waar hij bestuursvoorlichter was. Daarna volgde communicatiefuncties bij het Nederlands Bureau voor Toerisme (hoofd Corporate Communicatie), de gemeente Rotterdam (bestuursvoorlichter), de Vereniging van Nederlandse Gemeenten (VNG, adviseur overheidscommunicatie), de ministeries van Binnenlandse Zaken en Justitie (communicatieadviseur en plv. directeur (wnd.), de Hogeschool Utrecht (adjunctdirecteur HEAO Communicatie) en het ministerie van Algemene Zaken (kennisadviseur Academie voor Overheidscommunicatie). Thans werkzaam als communicatiemanager bij de Bestuursdienst van de gemeente Rotterdam.

Hij publiceerde onder meer over het overheidsimago ('De overheid heeft het altijd gedaan', 2000, met Robbert Coops), naamgeving in de publieke sector ('Aangenaam kennis te maken/naamgeving als publieke troef', 2003, Hogeschool Utrecht), storytelling ('Storytelling - de kracht van verhalen in communicatie', 2004, met Ron van der Jagt), kernboodschappen ('De kracht van de kernboodschap', 2008, met Vera de Witte), leefstijlcampagnes ('Gebundelde inspiratie', 2008, met Martine Bouman e.a.), communicatie als beleidsinstrument ('Instrumenten zoeken orkest', 2008 in de RVD-Platformreeks en 'Communiceren vanuit de context: naar effectievere overheidscommunicatie', 2009, voor de WRR, beide publicaties samen met Erwin Seydel en Jasper Zuure), coaching ('Collega-coaching bij de over overheid - tien jaar Intercoach', 2010 met Dymph van der Laan en Tieneke Dijkstra) en het eigene van de overheid ('Waarden maken de overheid', 2010, met Leon Klinkers en 'Onvervreemdbaar overheid - op zoek naar het eigene', 2011) en ambtelijk leiderschap ('Van bolwerken naar netwerken, over ambtelijk leiderschap in nieuwe associaties', CAOP). Hij is erelid van Logeion, beroepsvereniging voor communicatie en juryvoorzitter van de Galjaardprijs, 'voor de beste staaltjes overheidscommunicatie'.

Contact: guido@rijnja.com, Meloenstraat 85, 2564 TC Den Haag. 


\section{Colofon}

Dit is een uitgave in eigen beheer: guido@rijnja.com

Druk: Gildeprint, Enschede

Boekverzorging en omslag: Ron Meijer, hAAI, Rotterdam

Den Haag, april 2012

ISBN 978-90-365-3354-6 



\title{
Stellingen
}

Bij het proefschrift

\section{Genieten VAN WEerstand}

\author{
Guido Rijnja, 27 april 2012
}

1. Weerstand is een gegeven voor wie de overheid dient (dit proefschrift)

2. Ambtelijk besef is een belangrijke factor voor het begrijpen van weerstand, maar zonder sterke persoonlijke hulpbronnen heb je er niet zo veel aan (dit proefschrift)

3. Sociale steun van collega's is niet afhankelijk van hun inhoudelijke verwantschap met de opgaven waarmee een beleidsmaker van doen heeft (dit proefschrift)

4. Vertragen wordt ten on rechte gezien als een brevet van beleidsmatig onvermogen (dit proefschrift)

5. Beleidsmakers en burgers zijn zich allebei nauwelijks bewust van hun basale bereidheid om overheidsbemoeienis te aanvaarden (dit proefschrift)

6. Voor de overheid en voor proefschriften geldt dat het proces belangrijker is dan het resultaat

7. De betekenis van zure appels wordt schromelijk onderschat (Vitamine C verhoogt de weerstand)

8. De hype rond twittergedichtjes ('twijmpjes') over Delft-Zuid in het voorjaar van 2011 bewijst de eerste marketingwet van Ries en Trout

9. De schamele communicatie over de woekerpolis maakt duidelijk dat in plaats van vroegtijdige aandacht voor begrijpelijke producten, levensverzekeraars liever achteraf producten begrijpelijk maken (op kosten van de verzekerden)

10. Wie niet vertrouwt op een goed verzet kan in geen enkele koers voldoende weerstand bieden 

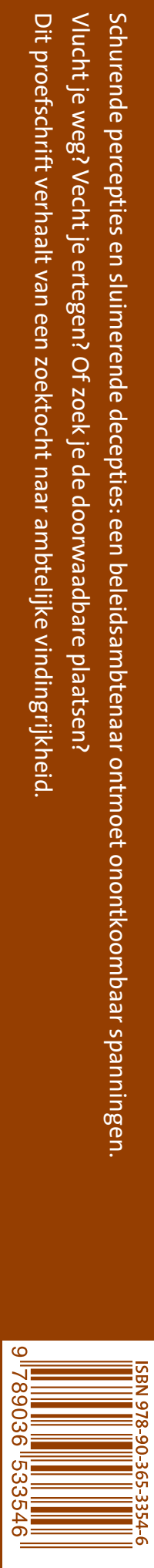